\title{
ABUSO DE SITUAÇÕES JURÍDICAS PROCESSUAIS NO CÓDIGO DE PROCESSO CIVIL
}

Dissertação apresentada ao Curso de Pós-Graduação em Direito Processual da Faculdade de Direito da Universidade de São Paulo como requisito parcial para a obtenção do título de Mestre.

Orientador: Professor Associado Dr. Antonio Carlos Marcato. 


\section{ABUSO DE SITUAÇÕES JURÍDICAS PROCESSUAIS NO CÓDIGO DE PROCESSO CIVIL}

Dissertação apresentada ao Curso de Pós-Graduação em Direito Processual da Faculdade de Direito da Universidade de São Paulo como requisito parcial para a obtenção do título de Mestre.

\section{Comissão Examinadora}

Prof. Associado Dr. Antonio Carlos Marcato Faculdade de Direito da USP

São Paulo, de 2013. 
Às minhas avós, Jandira e Luzia (“in memoriam") e a Deus. 


\section{AGRADECIMENTOS}

Ao Professor Associado Dr. Antonio Carlos Marcato, por ter aceitado me orientar, mesmo diante dos seus inúmeros compromissos profissionais, e por tudo o que me ensinou sobre processo civil desde quando eu cursava o segundo ano da graduação na Faculdade de Direito do Largo de São Francisco.

Ao meu pai, Manuel Soares Ferreira Carradita, pelo apoio total e irrestrito à minha pesquisa, pelas conversas a respeito dos assuntos controvertidos do trabalho, nas quais tentava me passar um pouco de sua vasta experiência jurídica, como desembargador, professor e ex-advogado, bem como pela ajuda na revisão da dissertação.

À minha mãe, Carolina Aparecida Galvão Santoro Carradita, pelo empenho em me ajudar nas horas difíceis, pelos inestimáveis conselhos que só uma pesquisadora experiente poderia dar, pelo constante incentivo às minhas pesquisas e pelo auxílio na revisão do trabalho.

Ao meu querido irmão, Alexandre Santoro Carradita, sempre prestativo e me dando apoio, incentivo e conselhos.

À Ivana, por compreender minha ausência, pelas palavras de apoio nos momentos difíceis e pela paciência diante dos meus "surtos" de mau humor ao longo da pesquisa.

A André Lucenti Estevam, pela amizade desde os bancos da faculdade e pela ajuda na obtenção de obras essenciais para o desenvolvimento da dissertação.

Ao amigo e professor Dr. Fabrizzio Matteucci Vicente, por tudo o que me ensinou na graduação e no mestrado e por todos os valiosos conselhos que me deu ao longo da pesquisa. 
"Certo que jamais se conseguirá banir dos tribunais o abuso do direito, velho como o próprio direito, e, paradoxalmente, imortal como este.

Todavia, há que se esforçar ao menos por diminuílo, reduzi-lo a proporções menos maléficas, não receando encará-lo frontalmente, nem deixando de reprimi-lo severamente, como, até aqui, vem sendo a atitude suicida predominante" (CASTRO FILHO, José Olímpio de. Abuso do Direito no Processo Civil. $2^{\mathrm{a}}$ ed. Rio de Janeiro: Forense, 1960, p. 214). 


\section{RESUMO}

Este trabalho visa a realizar uma análise sistemática das diversas normas do Código de Processo Civil que tratam do abuso de situações jurídicas processuais. O tratamento desse tema é dividido em quatro partes. Em primeiro lugar, analisa-se a teoria geral do abuso do processo, que abrange a evolução histórica do abuso processual, a adoção da teoria do abuso do direito oriunda do Direito privado, os fundamentos da prevenção e da repressão dos comportamentos abusivos, os elementos essenciais que caracterizam o abuso do processo (objeto, sujeitos e requisitos do ato processual abusivo) e a discussão acerca da ilicitude do ato processual abusivo. Em seguida, considerando os elementos caracterizadores do abuso do processo, são identificadas e estudadas as hipóteses de abuso de situações jurídicas processuais previstas no Código de Processo Civil brasileiro. A terceira seção deste trabalho é dedicada às consequências jurídicas do abuso do processo e a algumas questões referentes à aplicação de sanções. Finalmente, na quarta parte, procede-se ao exame dos mecanismos destinados a prevenir o abuso de situações jurídicas processuais.

Palavras-chave: Abuso do processo. Princípio da boa-fé. Princípio da cooperação. Dever de veracidade. Dever de lealdade processual. Dever de prontidão. Dever de utilidade. Litigância de má-fé. 


\begin{abstract}
This work aims to do a systematic analysis of the different norms of the Brazilian Civil Procedure Code that deals with the abuse of procedural rights. The treatment of this subject is divided into four sections. In the first place, it analyses the general theory of abuse of process, which includes the historical evolution of abuse of process, the adoption of the theory of abuse of rights from civil law, the foundations of prevention and repression of abusive behaviors, the essential elements that characterize the abuse of process (its object, its subjects and the requisites of the abusive procedural act) and the discussion about the unlawfulness of the abusive procedural act. Subsequently, considering the distinguishing elements of abuse of process, it identifies and studies the "fattispecies" of abuse of procedural rights contained in the Brazilian Civil Procedure Code. The third section of this work is dedicated to the legal consequences of abuse of process and to some questions related to the application of sanctions. Finally, in the fourth section, it examines the legal devices aimed at preventing abuse of procedural rights.
\end{abstract}

Key words: Abuse of process. Principle of good faith. Principle of cooperation. Duty to tell the truth. Duty of procedural fairness. Duty of promptness. Duty of usefulness. Vexatious and frivolous litigation. 


\section{SUMÁRIO}

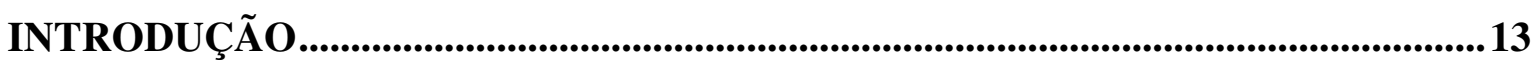

1 TEORIA GERAL DO ABUSO DO PROCESSO .......................................................17

1.1 A teoria do abuso do direito oriunda do Direito privado ............................................. 17

1.2 Breve histórico do abuso do processo e adoção, no âmbito processual, da teoria do abuso do direito.

1.2.1 Análise crítica da corrente doutrinária que nega a adoção da teoria do abuso do direito .43

1.3 Fundamentos da prevenção e da repressão do abuso do processo. 47

1.3.1 O princípio da inafastabilidade do controle jurisdicional (art. $5^{\circ}, \mathrm{XXXV}$, da CF).47

1.3.2 A garantia da razoável duração do processo (art. 5, LXXVIII, da CF) .................49

1.3.3 As garantias da igualdade e da ampla defesa (art. 5', "caput" e LV, da CF) .........55

1.3.4 $\mathrm{O}$ respeito às finalidades institucionais do processo.............................................58

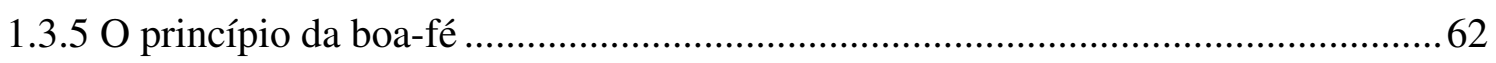

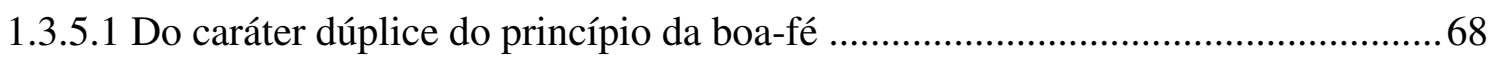

1.3.5.2 Conflito entre a garantia do contraditório e o princípio da boa-fé? ......................70

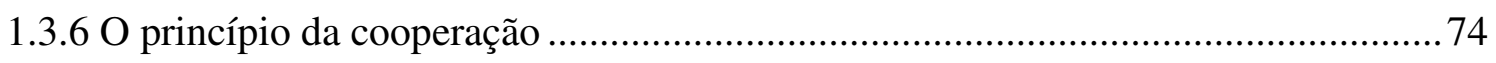

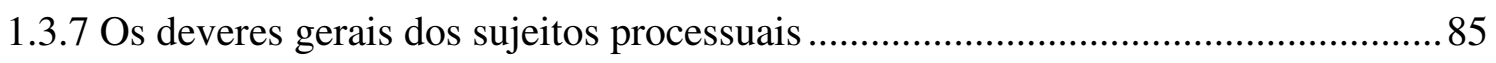

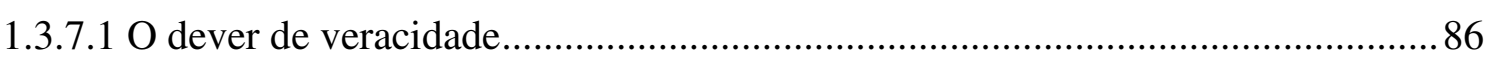

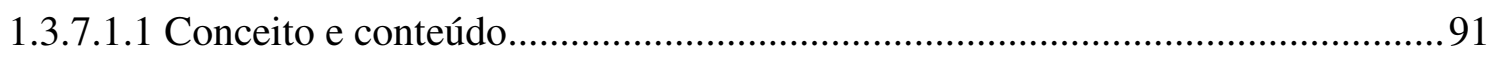

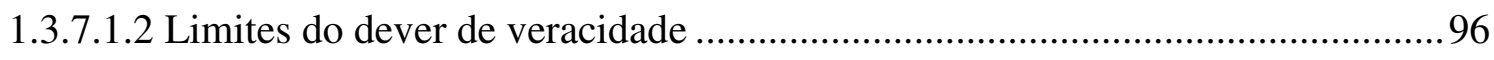

1.3.7.1.3 Conflito entre o princípio dispositivo e o dever de veracidade?..................... 106

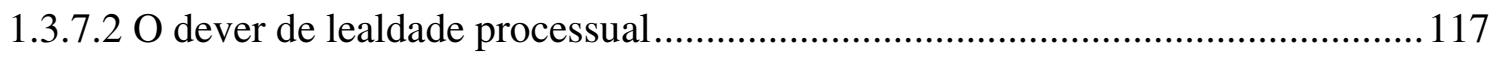

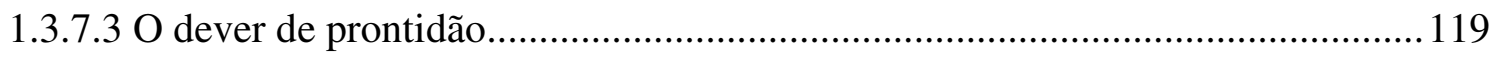

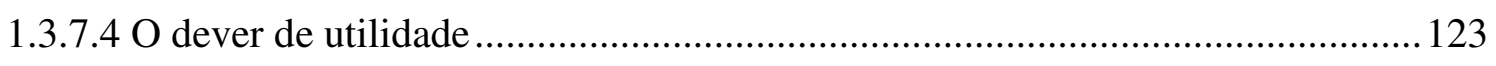

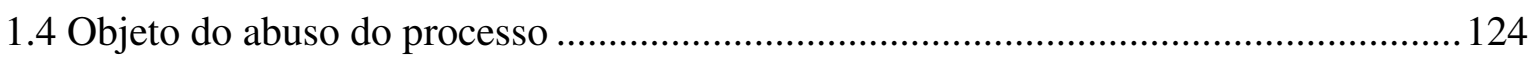

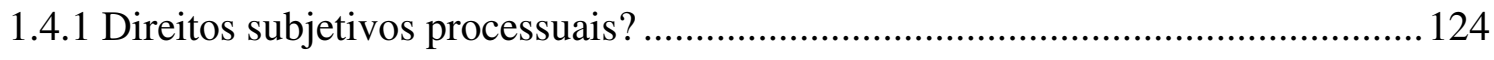

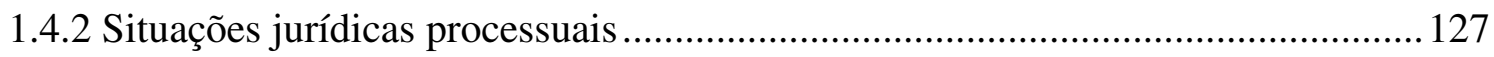

1.4.3 Abuso do processo em sentido estrito e abuso de instrumentos processuais

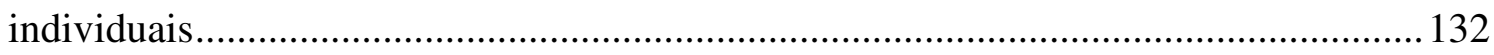


1.4.3.1 O abuso do processo em sentido estrito e as garantias fundamentais de acesso à justiça e de ampla defesa 134

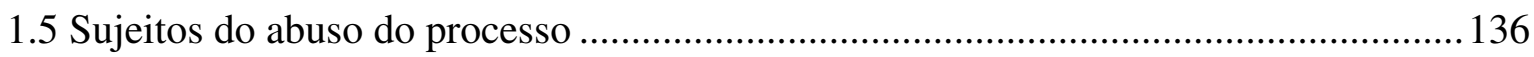

1.6 Requisitos para classificar um ato processual como abusivo .................................... 142

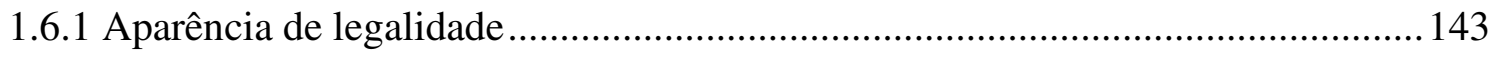

1.6.1.1 Comportamentos processuais que não podem ser considerados abuso do processo por falta de aparência de legalidade. 144

1.6.2 Exercício da situação jurídica processual com desvio de finalidade, para atingir escopo ilícito ou ilegítimo

1.6.2.1 Comportamentos processuais que não podem ser considerados abuso do processo por falta de desvio de finalidade. 152

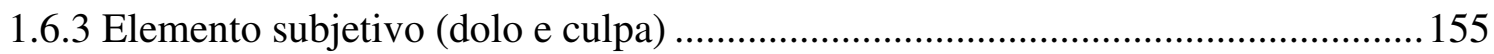

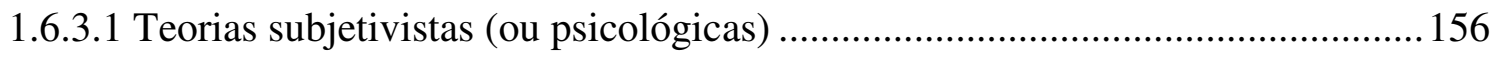

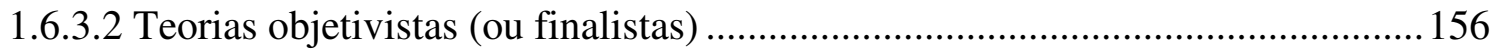

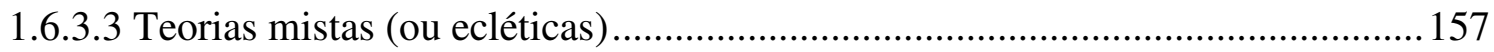

1.6.3.4 Da prescindibilidade do dolo e da culpa no abuso do processo......................... 160

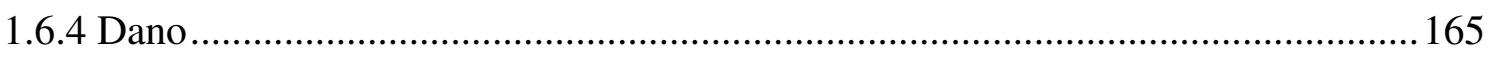

1.7 Circunstâncias que não configuram requisitos do ato processual abusivo ................... 167

1.8 Ato processual abusivo como espécie do gênero "fatos jurídicos processuais lato sensu ilícitos".

\section{HIPÓTESES DE ABUSO DO PROCESSO PREVISTAS NO CÓdIGO DE

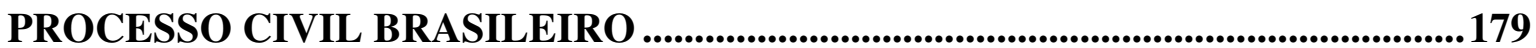

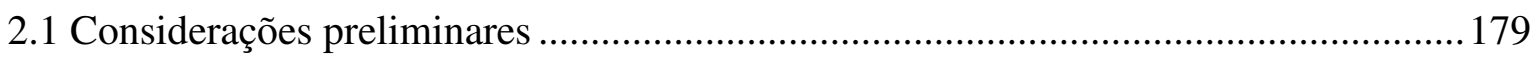

2.2 Abuso do processo ou de poder processual mediante a dedução de pretensão ou de defesa contra texto expresso de lei ou fato incontroverso (art. 17, I, do CPC) .................. 180

2.3 Utilização do processo para conseguir objetivo ilegal (art. 17, III, do CPC) .............. 185

2.4 Utilização do processo como instrumento para simulação .......................................... 188

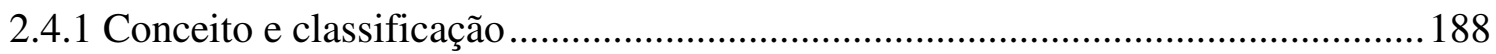

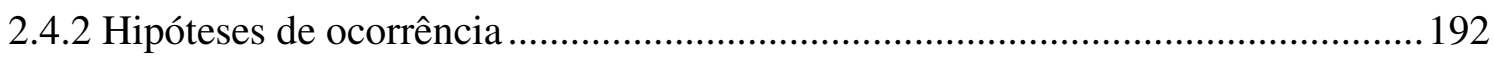

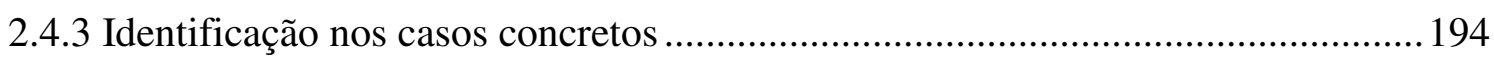

2.5 Violação do dever de veracidade (arts. 17, II; e 233 do CPC) .................................... 199

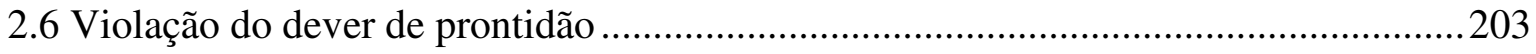

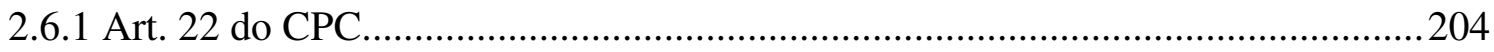


2.6.2 Art. $113, \S 1^{\circ}$, do CPC

2.7 Abuso do poder de nomear à autoria (art. 69 do CPC)

2.8 Utilização de poderes e faculdades processuais para opor resistência injustificada ao andamento do processo (arts. 17, IV, do CPC).

2.9 Utilização de poderes e faculdades processuais de modo temerário (art. 17, V, do CPC)

2.10 Abuso do poder de provocar incidentes no processo (arts. 17, VI, do CPC) .222

2.11 Abuso do poder de recorrer 225

2.11.1 Características gerais do abuso recursal e hipóteses previstas no CPC 225

2.11.2 Art. 17, VII, do CPC 228

2.11.3 Art. 538, parágrafo único, do CPC 233

2.11.3.1 Reincidência em abuso do poder de opor embargos de declaração 235

2.11.4 Art. 557, § $2^{\circ}$, do CPC 237

2.12 Abuso do processo da rescisória (art. 488, II, do CPC). 239

2.13 Utilização de poderes e faculdades processuais para opor-se maliciosamente à execução (art. 600, II, do CPC)

2.14 Abuso do poder de opor embargos do devedor (art. 740, parágrafo único, do CPC) 244

2.15 Abuso do poder de se arrepender da arrematação de bem imóvel de incapaz (art. 701, $\S 2^{\circ}$, do CPC) 250

2.16 Abuso do poder de opor embargos à execução de segunda fase (art. 746, § $3^{\circ}$, do $\mathrm{CPC})$ 257

2.17 Abuso de poder-dever por magistrado. 260

2.18 Abuso de poder-dever por auxiliar da justiça 265

3 CONSEQUÊNCIAS JURÍDICAS DO ABUSO DO PROCESSO 270

3.1 Reparação de perdas e danos

3.1.1 Responsabilidade das partes pelo ressarcimento de perdas e danos decorrentes de litigância de má-fé .273

3.1.1.1 Natureza jurídica da responsabilidade 275

3.1.1.2 Amplitude do dever de indenizar. 276

3.1.1.3 Montante da indenização 281

3.1.1.4 Sujeitos passivo e ativo da obrigação de indenizar. 282

3.1.1.5 Cominação do dever de indenizar e cobrança da quantia devida 285 
3.1.1.6 Possibilidade de pleitear a indenização por meio de demanda autônoma

3.1.2 Responsabilidade do réu pelo ressarcimento das perdas e danos decorrentes de abuso do poder de nomear à autoria

3.1.4 Responsabilidade do juiz pelo ressarcimento das perdas e danos decorrentes da prática de abuso processual.

3.1.5 Responsabilidade dos auxiliares da justiça pelo ressarcimento das perdas e danos decorrentes da prática de abuso processual

3.2.1 Aspectos gerais 305

3.2.2 Destino do montante da multa 310

3.2.3 Cominação da multa e cobrança da quantia devida 313

3.2.4 Peculiaridades da multa por abuso do processo da rescisória 317

3.3 Pagamento da multa como pressuposto objetivo de admissibilidade de recursos posteriores

3.4 Obrigação de arcar com o custo do processo (despesas processuais e honorários advocatícios) 325

3.5 Antecipação de tutela (art. 273, II, do CPC) 334

3.6 Prolação de sentença que obste ao objetivo das partes de praticar ato simulado ou de conseguir fim ilícito por meio do processo (art. 129 do CPC) 343

3.7 Cabimento de ação rescisória 346

3.8 Relativização da coisa julgada material 360

3.9 Nulidade do ato processual 371

3.10 Remoção do inventariante 374

3.11 Questões referentes à aplicação das sanções 376

3.11.1 Necessidade de respeito ao contraditório. 377

3.11.2 Aplicação de sanções por tribunal e respeito ao duplo grau de jurisdição 379

3.11.3 Possibilidade de cumulação e "non bis in idem" 382

3.11.4 Dever de motivação das decisões que reprimem condutas processuais abusivas e impossibilidade de punição fora dos limites permitidos pela lei 384

3.11.5 Da condenação do advogado ao ressarcimento das perdas e danos e ao pagamento de multa. 
5 CONCLUSÃO

.415

REFERÊNCIAS BIBLIOGRÁFICAS......................................................................424 


\section{INTRODUÇÃO}

Nos anos de 1994, 1995, 2001 e 2002, o Código de Processo Civil foi alterado por diversas leis, visando ao aprimoramento do trinômio qualidade-tempestividade-efetividade. O que o movimento de reforma da legislação processual civil almejava era um processo mais efetivo, que conseguisse outorgar, em um lapso razoável de tempo, a tutela jurisdicional àquele que tivesse razão. Com esse mesmo desiderato, houve a Reforma do Poder Judiciário, por meio da Emenda Constitucional n $n^{\circ}$ 45, de 08 de dezembro de 2004. Mais recentemente, várias leis modificaram o ordenamento jurídico nacional (v.g., Leis $\mathrm{n}^{\text {os }}$ 11.232/05, 11.276/06, 11.277/06, 11.418/06, 11.419/06 e 11.672/08), evidenciando a preocupação do Poder Legislativo em conferir maior celeridade e efetividade aos processos.

Todavia, não bastam alterações procedimentais para que o Poder Judiciário brasileiro consiga conceder tutelas jurisdicionais efetivas e tempestivas ao grande número de demandas que lhe são apresentadas. A reforma pela qual o Código de Processo Civil brasileiro passou nos últimos anos pode ser inócua, caso não haja uma mudança na atitude das partes e dos magistrados no sentido de evitar a prática do abuso de situações jurídicas processuais.

Cintra, Dinamarco e Grinover ${ }^{1}$ prelecionam que a concretização do objetivo de dar maior efetividade ao processo, como meio de acesso à justiça, depende menos das mudanças legislativas que da postura mental dos operadores do sistema. Pregam os autores a indispensabilidade da "consciência de que o processo não é mero instrumento técnico a serviço da ordem jurídica, mas, acima de tudo, um poderoso instrumento ético destinado a servir à sociedade e ao Estado".

Essa realidade foi constatada pelo Ministro Mauro Campbell Marques, do Superior Tribunal de Justiça, que assim se manifestou em seu voto como relator no julgamento dos Embargos de Declaração no REsp nº 949.166/RS (DJe 28/11/2008):

Em tempos de severas críticas ao Código de Processo Civil brasileiro, é preciso pontuar que pouco ou nada adiantará qualquer mudança legislativa destinada a dar agilidade na apreciação dos processos se não houver uma revolução na maneira de encarar a missão dos Tribunais Superiores e do Supremo Tribunal Federal.

Enquanto reinar a crença de que esses Tribunais podem ser acionados para funcionarem como obstáculos dos quais as partes lançam mão para prejudicar o andamento dos feitos, será constante, no dia-a-dia, o desrespeito à Constituição.

\footnotetext{
${ }^{1}$ Teoria Geral do Processo, p. 47.
} 
Como se não bastasse, as conseqüências não param aí: aos olhos do povo, essa desobediência é fomentada pelo Judiciário, e não combatida por ele; aos olhos do cidadão, os juízes passam a ser inimigos, e não engrenagens de uma máquina construída unicamente para servi-los.

$\mathrm{O}$ ministro chegou à seguinte conclusão: enquanto as partes não modificam o seu comportamento, os magistrados não podem ficar inertes. É preciso que o juiz utilize os instrumentos que o sistema processual brasileiro já lhe oferece para coibir as condutas processuais abusivas.

O que se infere dessas manifestações da doutrina e da jurisprudência é a atualidade e a importância do estudo do abuso de situações jurídicas processuais, com o escopo de permitir o oferecimento de uma tutela jurisdicional efetiva, célere e que respeite preceitos éticos, dando concretude ao que determina a Constituição Federal nos artigos $5^{\circ}$, XXXV e LXXVIII, e 37, “caput”.

Incrementa ainda mais a relevância do tema a constatação, feita por Castro Filho ${ }^{2}$, de que contribuem para a timidez dos juízes em aplicar as normas sancionadoras de condutas processuais abusivas: (a) a falta de precisão dos conceitos gerais de abuso do direito, advindos do Direito substantivo, cuja caracterização é quase sempre controvertida; e (b) a imprecisão da doutrina quanto à manifestação do instituto no processo civil.

Definitivamente, o abuso do processo não é um assunto inédito. É farta a bibliografia específica a respeito da litigância de má-fé, do abuso do direito de defesa e da responsabilidade processual, contribuindo para a elucidação desse tema. Porém, poucos trabalhos se destinam à análise sistemática do abuso processual. Aqueles que o fazem privilegiam o estudo dos fundamentos da teoria geral do abuso do processo e analisam apenas algumas projeções e manifestações dessa teoria no processo civil, reputadas mais importantes. Percebe-se, assim, que a doutrina nacional ainda não se preocupou em tentar sistematizar as normas do atual Código de Processo Civil que preveem hipóteses abusivas e que cominam consequências jurídicas para o sujeito processual que as pratica. Também se constata uma lacuna bibliográfica a respeito das normas destinadas a prevenir comportamentos processuais ímprobos.

Ante o exposto, o objetivo precípuo deste trabalho é contribuir para a definição do contorno do abuso na seara processual por meio da análise sistemática das diversas normas

\footnotetext{
${ }^{2}$ Abuso do Direito no Processo Civil, pp. 13-14 e 116-117.
} 
do Código de Processo Civil que tratam do abuso de situações jurídicas processuais, afastando do estudo a legislação extravagante ${ }^{3}$.

A abordagem desse tema será dividida em quatro partes. Em primeiro lugar, é necessário analisar a teoria geral do abuso do processo, que abrange a evolução histórica do abuso processual, a recepção da teoria do abuso do direito oriunda do Direito privado, os fundamentos da prevenção e da repressão dos comportamentos abusivos, os elementos essenciais que caracterizam o abuso do processo (objeto, sujeitos e requisitos do ato processual abusivo) e a discussão acerca da ilicitude do ato processual abusivo (capítulo 1). Em seguida, cumpre estudar as hipóteses abusivas previstas no Código de Processo Civil brasileiro (capítulo 2). A terceira seção deste trabalho será dedicada às consequências jurídicas do abuso do processo e a algumas questões referentes à aplicação de sanções (capítulo 3). Finalmente, na última parte, proceder-se-á ao exame dos mecanismos que o legislador prevê atualmente para prevenir o abuso processual (capítulo 4).

Deve-se ressaltar que a ordem dos capítulos não foi estabelecida para indicar a relevância das normas tratadas em cada um deles. Assim, o fato de os dispositivos que previnem o abuso processual serem estudados no capítulo 4 não significa que eles tenham menos importância que os instrumentos de repressão tratados no capítulo 3. Pelo contrário, como se verá no momento apropriado, os remédios processuais de prevenção de condutas abusivas podem impedir a incidência das normas repressivas, pois - como o próprio nome indica - a sua aplicação diminui e até mesmo obsta a eficácia deletéria da improbidade processual. Optou-se por abordar a prevenção do abuso do processo no último capítulo, depois do estudo das consequências jurídicas do instituto, apenas porque a gravidade destas dá destaque à premência daquela.

A metodologia a ser empregada no desenvolvimento desses assuntos envolve, principalmente, o método dialético, já que serão analisadas e discutidas diferentes propostas doutrinárias e jurisprudenciais em face de cada problema; o método indutivo, pois, mediante o estudo de casos concretos, intentar-se-á formular possíveis soluções para as questões doutrinárias; e o método dedutivo, uma vez que se buscará em princípios já assentados a resolução de certos problemas concretos. Serão igualmente utilizados os métodos comparatístico (análise de como a legislação, a doutrina e a jurisprudência estrangeiras lidam com os problemas levantados) e histórico (pesquisa do tema em leis

\footnotetext{
${ }^{3}$ Por conseguinte, não serão examinadas no presente estudo as normas acerca do abuso processual que estejam previstas em atos normativos distintos do Código de Processo Civil (v.g., o art. 13 da Lei $\mathrm{n}^{\circ}$ 4.717/65; o art. 17 da Lei $n^{\circ}$ 7.347/85; os arts. $1^{\circ}$, I, “ $n$ ”, e 25 da Lei Complementar n' 64/90; o art. 25 da Lei n $12.016 / 09$; o art. 14, § 11, da CF etc.).
} 
processuais brasileiras já revogadas, notadamente o Regulamento $\mathrm{n}^{\circ} 737$ de 1850 , o Decreto n 3.084 de 1898, os Códigos de Processo dos Estados e o Código de Processo Civil de 1939). Sempre que possível, haverá a análise da maneira como o Projeto de Lei $\mathrm{n}^{\circ}$ 8.046/2010, que versa sobre o novo Código de Processo Civil, em trâmite no Congresso Nacional, trata do tema escolhido. 


\section{TEORIA GERAL DO ABUSO DO PROCESSO}

\subsection{A teoria do abuso do direito oriunda do Direito privado}

Apesar de alguns autores sustentarem que a origem da teoria do abuso do direito repousa no Direito romano ${ }^{4}$, a maior parte da doutrina - com a qual concordamos - alega que a originalidade dessa teoria encontra-se na França e na Bélgica, entre meados do século XIX e o princípio do século $\mathrm{XX}^{5}$.

\footnotetext{
${ }^{4}$ Algumas fórmulas do Direito romano isentavam o titular do direito de responsabilidade por qualquer dano decorrente do seu exercício, tais como: "nullus videtur dolo facere, qui suo iure utitur" (Gaio, D. 50.17.55); "[...] an non facit dolo qui iure perpetuo utitur?" (Paulo, D. 19.1.42.pr.); "[...] Quia dolo malo non videtur habere, qui suo iure utitur" (Ulpiano D. 43.29.3.2); e "Non videtur vim facere, qui iure suo utitur et ordinaria actione expeditur" (Paulo, D. 50.17.155.1-2) (MENEZES CORDEIRO, Da Boa Fé do Direito Civil, p. 672 e nt. 50). Infere-se de todos esses textos que, em Roma, o proprietário podia atuar como lhe aprouvesse dentro do seu imóvel, ainda que a sua conduta causasse dano a outrem (RICCOBONO; RICCOBONO JR., Emulazione (Diritto Romano), in Novissimo Digesto Italiano, vol. VI, p. 520). É em limitações aos referidos brocardos romanos que alguns doutrinadores identificam as raízes históricas do abuso do direito.

Abra-se, aqui, um parêntese para observar que os romanos não empregavam as palavras "abusus" e "abuti" no sentido de "mau uso" ou "uso reprovável". Abdo (O Abuso do Processo, p. 17) esclarece que tais palavras significavam "uso intenso", "aproveitamento completo da coisa", "uso que consome, exaure definitivamente a res", em consonância com o teor das fórmulas supracitadas. É nesse sentido que se deve entender a expressão "ius utendi et abutendi", ou seja, direito de usar a coisa e de consumi-la ao máximo. Não se trata do direito de fazer mau uso do bem. A autora também leciona que a atual acepção de "abuso" é de origem medieval, tendo sido concebida por tratadistas e glosadores do direito comum e do direito canônico.

Retomando-se o raciocínio, a doutrina compilou dois métodos utilizados para restringir o poder absoluto do titular do direito: (a) mediante regras gerais que limitavam o exercício de direitos subjetivos, como os brocardos "summum ius summa iniuria" (Cícero); "non omne quod licet honestum est" e "malitis non est indulgendum" (Celso, D. 6.1.38); (b) de forma casuística, por meio de institutos específicos, notadamente a "aemulatio", a "exceptio doli" e as relações de vizinhança, utilizadas para gerar limitações ao direito de propriedade, impostas pela necessidade de uma convivência pacífica (MENEZES CORDEIRO, Da Boa Fé do Direito Civil, pp. 672-673). Stoco (Abuso do Direito e Má-Fé Processual - aspectos doutrinários, p. 60) e Limongi França (Responsabilidade Civil e Abuso de Direito, in Revista do Advogado, $\mathrm{n}^{\circ}$ 19, p. 42), por exemplo, defendem o advento da teoria do abuso do direito no Direito romano e fazem menção ao primeiro desses métodos.

Todavia, a tese de que o berço da teoria do abuso do direito repousa em Roma não é aceita pacificamente no âmbito doutrinário. De acordo com Menezes Cordeiro (Da Boa Fé do Direito Civil, pp. 672-673 e nt. 57), os brocardos romanos com conteúdo genérico supracitados não podem ser apontados como fonte dessa teoria porque o Direito romano era avesso a teorizações gerais, de modo que não poderia conceber o abuso do direito como uma categoria onipresente, expressa em princípios gerais. Isso só foi possível quando a ciência do Direito adquiriu o pensamento sistemático moderno, o que ocorreu apenas no século XVII, com Hobbes. O mesmo autor também se empenha em negar que a raiz da teoria do abuso do direito conhecida atualmente se encontre na proibição de atos emulativos, na "exceptio doli" e na regulação dos conflitos de vizinhança, no Direito romano e no Direito medieval. Para ele, esses três institutos jurídicos específicos não podem ser apontados como antecedentes do abuso do direito, pois obedecem a técnicas próprias e seguem princípios diferentes. Não seria correto, portanto, dos pontos de vista dogmático e histórico, reconduzi-los a uma teoria geral do abuso do direito (MENEZES CORDEIRO, Da Boa Fé do Direito Civil, pp. 673-677).

${ }_{5}^{5}$ Dentre os doutrinadores que pensam assim, estão: Menezes Cordeiro (Da Boa Fé do Direito Civil, pp. 677 e 683), Ascensão (A Desconstrução do Abuso do Direito, in Revista de Direito do Tribunal de Justiça do Estado do Rio de Janeiro, $\mathrm{n}^{\circ}$ 66, p. 62), Albuquerque (Responsabilidade Processual por Litigância de Má Fé, Abuso de Direito e Responsabilidade Civil em Virtude de Actos Praticados no Processo, p. 82) e Falco (La Buona Fede e l'Abuso del Diritto: principi, fattispecie e casistica, p. 378).
} 
No século XIX, vigoravam o individualismo e o positivismo na Europa, de modo que os direitos eram vistos como absolutos, incontrastáveis. A concepção absolutista (ou atômica) dos direitos subjetivos - então adotada - estatuía que nenhum direito subjetivo dependia de outro, nem ofendia qualquer outro direito. Com fins didáticos, Pontes de Miranda $^{6}$ recorre a elementos de geometria e descreve tal teoria como sendo aquela que concebia os direitos subjetivos como linhas que nunca se atravessavam ou se cortavam. Apenas a lei, em casos excepcionais, fazia alguma limitação dos direitos, retraindo-os. A regra "nemo iniuria facit qui iure suo utitur" traduz bem a tese esposada por essa corrente doutrinária ${ }^{7}$.

$\mathrm{O}$ art. 544 do Código Civil de Napoleão, de 1.808, foi elaborado à luz dessa concepção: "A propriedade é o direito de gozar e de dispor das coisas da maneira mais absoluta, desde que não se faça um uso proibido pelas leis ou pelos regulamentos" (tradução nossa).

$\mathrm{Na}$ França, esse modo absoluto de exercer o direito de propriedade deu ensejo a uma série de danos patrimoniais e morais. Os autores que tratam do tema "abuso do direito" mencionam sempre dois exemplos dessa época que são paradigmáticos. O primeiro é o do indivíduo que ergueu uma falsa chaminé em seu imóvel com o intuito de impedir que uma das janelas do prédio de seu vizinho recebesse a incidência da luz do sol. O outro é o do proprietário de um imóvel que construiu nele uma série de espigões de ferro tão somente com o fim de danificar dirigíveis que seu vizinho construía ${ }^{8}$.

Essas situações conflituosas não tardaram a ensejar o ajuizamento de demandas judiciais. As primeiras decisões francesas que trataram do que hoje se conhece como "abuso do direito" foram prolatadas logo no início da vigência do Código Napoleão, em $1.808^{10}$.

\footnotetext{
${ }^{6}$ Tratado de Direito Privado, t. LIII, p. 67.

${ }^{7}$ PONTES DE MIRANDA, Tratado de Direito Privado, t. LIII, p. 68.

${ }^{8}$ VINCENZI, A Boa-Fé no Processo Civil, p. 145; BARBOSA MOREIRA, Abuso do Direito, in Revista Trimestral de Direito Civil, vol. 13, p. 99; MENEZES CORDEIRO, Litigância de Má-Fé, Abuso do Direito de Ação e Culpa "in Agendo", p. 78.

${ }^{9}$ Inicialmente, não se utilizava a expressão "abuso do direito". Ela foi concebida depois, por Laurent, e passou a ser encontrada também na jurisprudência a partir da CassFr 10-Jun. - 1902, D1902, 1, 454-456 (455, $1^{a}$ col.) (MENEZES CORDEIRO, Da Boa Fé do Direito Civil, pp. 670-671 e nt. 40; MENEZES CORDEIRO, Litigância de Má-Fé, Abuso do Direito de Ação e Culpa "in Agendo", p. 78; ALBUQUERQUE, Responsabilidade Processual por Litigância de Má Fé, Abuso de Direito e Responsabilidade Civil em Virtude de Actos Praticados no Processo, p. 82).

${ }^{10}$ Exemplificativamente, podem ser mencionadas as seguintes decisões, em ordem cronológica (MENEZES CORDEIRO, Da Boa Fé do Direito Civil, p. 671):

a) C. Imp. Metz, 10-Nov.-1808, S 1821, 2, 154: condenou o proprietário de uma oficina de chapéus que gerava vapores desagradáveis à vizinhança;
} 
Para dar resposta a esses litígios, os tribunais franceses precisaram admitir que os direitos subjetivos são relativos, superando a concepção absolutista. Persistindo na analogia entre direitos e linhas, proposta por Pontes de Miranda, pode-se afirmar que a concepção relativa dos direitos subjetivos aceita que eles têm crises e hostilidades entre si. Topam uns nos outros, cruzam-se e molestam-se. Desse modo, quando uma pessoa exerce um direito seu, ainda que dentro de seus limites, ela pode lesar direitos de outrem ${ }^{11}$. Na França, a relatividade dos direitos proveio do reconhecimento de que o ordenamento jurídico prevê os direitos subjetivos tendo em vista uma certa finalidade social, que Josserand chama de "espírito do direito"12. Constatou-se que o titular de um direito subjetivado - ou de qualquer situação jurídica subjetiva - deve, ao exercê-lo, respeitar as finalidades sociais que permeiam as normas que o regem. Toda vez que um indivíduo exerce uma situação jurídica de maneira incompatível com a sua destinação social, econômica, política ou ética, ocorre o abuso ${ }^{13}$. Assim, seguindo ainda a terminologia de Josserand, o abuso do direito foi concebido como uma sanção à violação do "espírito do direito" $" 14$.

Percebe-se que, na verdade, o "abuso do direito" nada mais é do que uma fórmula tradicional utilizada para exprimir a ideia do exercício disfuncional de situações jurídicas, ou seja, do exercício concreto de uma situação jurídica que, apesar de ser correto em si,

b) C. Imp. Metz, 16-Ago.-1820, S. 1821, 2, 155: condenou o construtor de um forno que, por não ter tomado as devidas precauções, prejudicava seu vizinho;

c) C. Imp. Colmar, 2-Mai.-1855, D 1856, 2, 9-10: condenou o proprietário de um imóvel que nele construiu uma falsa chaminé com o intuito de impedir a entrada de luz solar em uma janela de seu vizinho;

d) C. Imp. Lyon, 18-Abr.-1856, D 1856, 2, 199-200: condenou o proprietário de um imóvel que bombeava água de seu próprio poço para um rio, visando a baixar o nível de água no poço do seu vizinho;

e) C. Imp. Colmar, 25-Jul.-1861, S 1861, 2, 578: condenou um indivíduo que realizou perfurações no seu prédio sem o devido cuidado, o que ocasionou desabamentos no prédio vizinho;

f) C. Ap. Paris, 2-Dez.-1871, D 1873, 2, 185: condenou o proprietário que promoveu batuque e algazarra em seu imóvel para espantar a caça do prédio vizinho;

g) Compiègne, 19-Fev.-1913, D 1913, 2, 181 e CassFr 3-Ag.-1915, D 1917, 1, 79: famoso julgado que condenou o proprietário que ergueu em seu imóvel um dispositivo dotado de espigões de ferro, destinado a danificar dirigíveis que seu vizinho construía.

${ }^{11}$ PONTES DE MIRANDA, Tratado de Direito Privado, t. LIII, pp. 67-68.

12 "[...] em definitivo, toda essa teoria do abuso constitui a consagração e a sanção do espírito de que são animadas nossas diferentes prerrogativas, cuja perfeita observação ela pretende assegurar; graças a ela [a teoria do abuso], os direitos se realizam, não em uma direção qualquer, mas em um ambiente social, em função de sua missão e em conformidade com seus princípios gerais, que são, como dissemos, subjacentes à legalidade e que constituem, em seu conjunto, um direito natural de conteúdo variável, como uma superlegalidade. Cada uma de nossas faculdades tende a um fim que é determinado pelo espírito da instituição: é a teoria do abuso que os mantêm no caminho correto, que os impede de se afastarem e que os conduz, assim, de uma impulsão certa até o objetivo a ser atendido" (tradução nossa) (JOSSERAND, De l'Esprit des Droits et de leur Relativité - théorie dite de l'abus des droits, pp. 387-388).

${ }^{13}$ CASTRO FILHO, Abuso do Direito no Processo Civil, p. 21.

${ }^{14}$ Daí o entendimento de Josserand (De l'Esprit des Droits et de leur Relativité - théorie dite de l'abus des droits, p. 388) de que o "espírito dos direitos", a relatividade dos direitos e o abuso dos direitos são conceitos conexos. 
não é admitido pelo Direito porque entra em confronto com o sistema jurídico na sua globalidade ${ }^{15}$.

A doutrina reputa natural e coerente, do ponto de vista sociológico, que a teoria do abuso do direito tenha surgido no contexto retratado, uma vez que, entre o fim do século XIX e o início do século XX, houve uma forte influência de valores éticos e sociais em todas as áreas do ordenamento jurídico, tanto no Direito público quanto no privado ${ }^{16}$. No âmbito do Direito administrativo, por exemplo, surgiu a categoria do "desvio de poder". Já na seara privatística, ocorreu a submissão dos negócios jurídicos aos padrões da boa-fé e a intervenção do Estado nas relações privadas para proteger os contratantes considerados mais fracos ${ }^{17}$.

Sob a ótica da ciência do Direito, Menezes Cordeiro ${ }^{18}$ aponta dois fatores que determinaram o nascimento da teoria do abuso do direito na França, nesse momento histórico:

a) a jussubjetivização. O autor explica que, até a Idade Média, não houve necessidade de se desenvolver uma justificativa científica para a repressão do abuso do direito (ou seja, uma teoria geral do abuso do direito) porque os remédios jurídicos excepcionais que eram então utilizados para o combate às condutas abusivas encontravam respaldo nos valores sociais da época, especialmente nos valores religiosos, de tipo humanístico-cristão. Todavia, o conceito de "direito subjetivo" passou por um refinamento científico permanente e foi elevado ao "status" de categoria fundamental do Direito privado, fenômeno esse batizado de “jussubjetivismo". Ante a elaboração de um entendimento científico do direito subjetivo, conectado com ideias de absolutização, tornou-se necessária a cientificidade também do abuso do direito. Foi, portanto, no contexto do jussubjetivismo que se propôs a ideia de firmar limitações aos comportamentos dos sujeitos por meio dos direitos próprios de cada um ${ }^{19}{ }^{20}$; e

\footnotetext{
${ }^{15}$ MENEZES CORDEIRO, Litigância de Má-Fé, Abuso do Direito de Ação e Culpa "in Agendo”, pp. 75 e 113-114; BRAGA NETTO, Teoria dos Ilícitos Civis, pp. 118-120.

${ }^{16}$ THEODORO JÚNIOR, Boa-Fé e Processo: princípios éticos na repressão à litigância de má-fé - papel do juiz, in MARINONI (coord.), Estudos de Direito Processual Civil - homenagem ao professor Egas Dirceu Moniz de Aragão, p. 637.

${ }^{17}$ BARRETO, O Dirigismo na Vida dos Contratos, in Revista Forense, vol. 77, p. 255.

${ }^{18}$ Da Boa Fé do Direito Civil, pp. 683-684.

${ }^{19}$ MENEZES CORDEIRO, Da Boa Fé do Direito Civil, p. 674.

${ }^{20}$ Pontes de Miranda (Tratado de Direito Privado, t. LIII, p. 63) afirma que a relatividade dos direitos subjetivos e a teoria do abuso do direito são consequências (e não uma reação) do individualismo e do absolutismo. Para ele, a doutrina do abuso do direito constitui uma "teoria (individualista) das relações entre direitos individuais" (destaque no original).
} 
b) a segunda sistemática. Nos séculos XVII e XVIII, os jusnaturalistas e os jusracionalistas enxergavam a razão como a principal fonte das regras jurídicas e pretendiam deduzir todo o Direito de algumas proposições que consideravam básicas e corretas. Conceberam, assim, a sistemática central ou segunda sistemática ${ }^{21}$. Diferentemente da chamada "primeira sistemática" (a sistemática dos humanistas ${ }^{22}$ ), que foi empírica, periférica (partia de elementos exteriores dispersos para chegar à estrutura), sem um pensamento sistemático (o conjunto de leis vigentes não tinha unidade e coerência $)^{23}$, a principal característica da segunda sistemática foi a centralização. Ela se desenvolveu de modo unitário e metódico, a partir de alguns princípios firmados com vista ao sistema ${ }^{24}$. Quem deu início à segunda sistemática foi Hobbes, ao introduzir nas ciências humanas estruturas mentais embasadas na lógica cartesiana (caracterizada pela superioridade do pensamento unitário, que parte de uma base bem determinada e é conduzido por um só critério) e no mecanicismo galileano (que consiste em entender " $a$ priori" os pressupostos mecânicos dos movimentos dos corpos) ${ }^{25}$. O principal (mas não o único) responsável pela implantação da segunda sistemática no Direito privado foi Pufendorf, no século XVII ${ }^{26}$. Graças à segunda sistemática, elaborou-se um conceito de abuso do direito alicerçado em princípios teóricos gerais e abstratos.

\footnotetext{
${ }^{21}$ MENEZES CORDEIRO, Litigância de Má-Fé, Abuso do Direito de Ação e Culpa “in Agendo", p. 145.

${ }^{22} \mathrm{O}$ humanismo foi um fenômeno cultural complexo, que consistiu em uma projeção do renascimento nas ciências humanas. Teve raízes na Idade Média e floresceu na Itália, a partir do século XIV, expandindo-se, em seguida, para a França e outros países (MENEZES CORDEIRO, Da Boa Fé do Direito Civil, pp. 189-190 e 196).

Os humanistas apresentavam as seguintes características (MENEZES CORDEIRO, Da Boa Fé do Direito Civil, pp. 190-193):

a) entendiam que o universo tinha por foco o homem. Isso os levou à defesa da liberdade em vários campos (v.g., no campo religioso, a Reforma; no campo político, a evolução constitucional na Inglaterra e nos Países Baixos etc.);

b) tomavam por modelo a Antiguidade, sem mediações. No âmbito jurídico, os humanistas se debruçavam diretamente sobre as fontes romanas e se opunham à ciência jurídica medieval e aos autores da compilação justinianeia. Seu objetivo era alcançar a verdadeira ciência jurídica romana e, por isso, criticavam muito as interpolações;

c) quando buscavam o Direito romano clássico puro, os humanistas não queriam uma "ressurreição" da antiguidade, mas, sim, uma renovação metodológica do presente. O que eles tinham em vista com o estudo do Direito romano clássico era criticar o método pedagógico da escolástica anterior (caracterizado por memorizações e pelo estudo de sutilezas isoladas) e propor o estudo de ideias gerais perpétuas. Sob a influência filosófica de Platão, buscavam distinguir o acidental do essencial.

A principal consequência de tudo isso no âmbito jurídico foi a assimilação da ideia kantiana de sistema, entendido como um conjunto de conhecimentos ordenado segundo princípios (MENEZES CORDEIRO, Da Boa Fé do Direito Civil, pp. 193 e 194).

${ }^{23}$ MENEZES CORDEIRO, Da Boa Fé do Direito Civil, pp. 195-196 e 217.

${ }^{24}$ MENEZES CORDEIRO, Da Boa Fé do Direito Civil, p. 219.

${ }^{25}$ MENEZES CORDEIRO, Da Boa Fé do Direito Civil, pp. 218-219.

${ }^{26}$ MENEZES CORDEIRO, Da Boa Fé do Direito Civil, pp. 219-220.
} 
Do espaço jurídico francês, o abuso do direito estendeu-se ao alemão, onde a repressão dos atos abusivos teve uma feição qualitativamente diferente ${ }^{27}$.

Na Pandectística do século XIX (terceira sistemática), os tribunais e doutrinadores alemães buscaram no "Corpus Iuris Civilis" e no Direito comum as soluções para as práticas abusivas $^{28}$.

Inicialmente, os alemães elegeram duas vias principais para lidar com as práticas abusivas:

a) a da "exceptio doli", que, desde o Direito romano comum, podia ser de dois tipos: (1) a "exceptio doli specialis" (ou "praeteriti"), por meio da qual o réu impugnava a base jurídica do que se pleiteava em juízo, alegando que o autor tinha atuado com dolo ${ }^{29}$ no momento em que a situação jurídica substantiva levada a juízo se formara; e (2) a "exceptio doli generalis" (ou "presentis"), que permitia ao réu contrapor-se à ação do autor, sustentando que este tinha incorrido em dolo no momento da discussão da causa. Com o passar do tempo, a primeira espécie de "exceptio doli" evolveu para a doutrina dos vícios na formação e exteriorização da vontade e para a "culpa in contrahendo". Já a "exceptio doli generalis" foi empregada na Alemanha, no fim do século XIX, como técnica para deter os atos de abuso do direito; e

b) a da chicana, que tinha dois sentidos: (1) exercício do direito para prejudicar outrem (sentido amplo); e (2) exercício do direito sem interesse próprio para prejudicar outrem (sentido estrito). No § 226 do BGB, o legislador alemão adotou uma visão bastante restritiva de chicana: "O exercício de um direito é inadmissível quando ele só possa ter por escopo infligir um dano a outrem".

Os pandectistas alemães desistiram de utilizar a "exceptio doli generalis" como técnica para precisar o fenômeno do abuso do direito em razão de sua vagueza, sendo ela substituída por esquemas mais precisos.

A atenção voltou-se, então, para a proibição da chicana. Apontavam-se duas vantagens em empregar o $§ 226$ do BGB na repressão das práticas abusivas: (a) como esse dispositivo foi inserido na parte geral do Código, ele era aplicável a todo o Direito privado, e não só à propriedade e aos conflitos de vizinhança; (b) era puramente objetivo, de modo

\footnotetext{
${ }^{27}$ MENEZES CORDEIRO, Da Boa Fé do Direito Civil, pp. 685-686.

${ }^{28}$ MENEZES CORDEIRO, Da Boa Fé do Direito Civil, pp. 686-687.

29 Entendido, aqui, como "dolus malus", ou seja, como manobra ardilosa empregada com a intenção ou consciência de induzir ou manter alguém em erro (MENEZES CORDEIRO, Da Boa Fé do Direito Civil, p. 720).
} 
que a sua incidência não exigia culpa ou qualquer outro elemento subjetivo por parte do titular do direito.

Porém, o referido dispositivo legal tinha um defeito: seu campo de incidência era muito pequeno. Exigia que o exercício inadmissível tivesse como escopo apenas e tão somente infligir danos. Ocorre que um comportamento abusivo pode ser movido por um número ilimitado de escopos, dentre eles algum ou alguns não-danosos. É bastante difícil imaginar, fora do âmbito acadêmico, o exercício de um direito que só possa ter como escopo gerar prejuízos a terceiras pessoas. A doutrina (v.g., Hölder, Bode, Endemann e Von Zahn) tentou alargar o campo de aplicação do $§ 226$, afirmando que só o escopo principal é que deveria ser o de prejudicar, porém essa tese não prosperou e o dispositivo foi muito pouco aplicado. Considera-se que a proibição da chicana falhou por insuficiência científico-sistemática.

Diante da ruína prática e teórica da proibição da chicana, buscou-se reprimir o exercício inadmissível de direitos com base na cláusula dos bons costumes, prevista no $\S$ 826 do BGB: "Aquele que, de uma forma que atente contra os bons costumes, inflija dolosamente um dano a outrem, fica obrigado à indenização do dano". Inicialmente, a doutrina justapôs esse dispositivo ao § 226. Em seguida, houve uma tentativa de repartir áreas de influência entre os dois preceitos. Por fim, o $\S 826$ passou a ser utilizado para suprir as insuficiências da proibição da chicana (§ 226).

Acontece que o $§ 826$ do BGB também não se mostrou insuscetível de críticas. Em primeiro lugar, esse dispositivo tinha o dolo como requisito de incidência, o que fazia com que não abrangesse atos negligentes, nem aqueles em que o dolo fosse indemonstrável. Ademais, só previa o dever de indenizar, e não a obrigação de cessar a prática abusiva. Por fim, a doutrina vinculava o conceito de "bons costumes" ao de Moral e, sob influência do neokantismo jurídico, não elaborou estudos no sentido de dar tratamento científico ao tema, para que fosse concretizado o preceito.

Como o recurso ao $\S 826$ do BGB também se mostrou insuficiente no combate ao exercício inadmissível de direitos, a doutrina procurou um novo espeque legal e encontrouo no $\S 242$ do BGB, que prevê a boa-fé: "O devedor está obrigado a executar a prestação tal como o exige a boa-fé, com consideração dos costumes do tráfego". O uso da boa-fé como fundamento da repressão do exercício inadmissível de direitos trouxe três vantagens principais:

a) trata-se de um princípio geral de Direito, sendo suficientemente vasto para controlar o exercício de todos os direitos privados; 
b) é positivo, ou seja, prescreve condutas, não prevendo apenas o dever de indenizar; e

c) é objetivo, dispensando o dolo e a negligência.

Em síntese, percebe-se que, na doutrina germânica, o abuso do direito evoluiu da proibição da chicana para a conformidade com os bons costumes e, finalmente, para o respeito à boa-fé ${ }^{30}$.

Esse desenvolvimento não se deu mediante o aprofundamento doutrinário de um conceito central de abuso, ou seja, de um conceito construído em torno de princípios teóricos gerais, a partir do qual se deduzem distintas aplicações, como ocorreu na França. Pelo contrário, seu ponto de partida foi a análise de casos concretos, à luz de normas e princípios jurídicos. Em primeiro lugar, houve uma sedimentação jurisprudencial e doutrinária de situações tipicamente abusivas, cuja repressão era baseada nos bons costumes e na boa-fé. Depois de um desenvolvimento setorial, em face de questões concretas, passou-se a falar em exercício inadmissível de direitos, fundado na boa-fé. Só quando já havia uma experiência jurisprudencial consagrada é que teve início a elaboração de uma teoria jurídica do abuso do direito ${ }^{31}$.

Cumpre tratar, sucintamente, nesta breve introdução à teoria do abuso do direito, dos principais grupos de situações típicas a partir dos quais se desenvolveu o abuso do direito na Alemanha, notadamente: o "venire contra factum proprium", a inalegabilidade formal, a "suppressio", o "tu quoque" e o desequilíbrio no exercício das situações jurídicas ${ }^{32}$.

$\mathrm{O}$ "venire contra factum proprium" consiste na prática de um ato que contraria o comportamento anterior do agente. Menezes Cordeiro ${ }^{33}$ explica que esse tipo de ato abusivo exige duas condutas da mesma pessoa, ambas lícitas em si, diferidas no tempo, sendo que a primeira (o "factum proprium") é contraditada pela segunda (o "venire"), que pode ser tanto uma ação ("venire" positivo), quanto uma omissão ("venire" negativo).

\footnotetext{
${ }^{30}$ Acerca dessa evolução histórica do abuso do direito na Alemanha, consultar: MENEZES CORDEIRO, Da Boa Fé do Direito Civil, pp. 687-694; MENEZES CORDEIRO, Do Abuso do Direito: estado das questões e perspectivas, in Revista da Ordem dos Advogados, vol. 65, n 02, pp. 334-335 e 339-341; MENEZES CORDEIRO, Litigância de Má-Fé, Abuso do Direito de Ação e Culpa “in Agendo”, pp. 76-77 e 80-82.

${ }^{31}$ MENEZES CORDEIRO, Da Boa Fé do Direito Civil, pp. 694-695.

32 Para uma visão mais detalhada das hipóteses de exercício típico abusivo, consultar: MENEZES CORDEIRO, Litigância de Má-Fé, Abuso do Direito de Ação e Culpa “in Agendo”, pp. 91-105; MENEZES CORDEIRO, Do Abuso do Direito: estado das questões e perspectivas, in Revista da Ordem dos Advogados, vol. $65, \mathrm{n}^{\circ} 02$, pp. $348-362$.

${ }^{33}$ Litigância de Má-Fé, Abuso do Direito de Ação e Culpa “in Agendo”, p. 92.
} 
Com relação à fundamentação teórica da proibição do "venire contra factum proprium", existem duas correntes: (a) as doutrinas da confiança, que afirmam que o "venire" é proibido quando entra em contradição com uma situação de confiança legítima criada pelo "factum proprium"; e (b) as doutrinas negociais, segundo as quais o "venire" viola um vínculo negocial que foi gerado pelo agente ao praticar o "factum proprium". Atualmente, predominam as doutrinas da confiança ${ }^{34}$.

O princípio da confiança implica a proteção das pessoas que, legitimamente, tenham sido levadas a acreditar na manutenção de um certo estado de coisas. Segundo Menezes Cordeiro ${ }^{35}$, a tutela da confiança é embasada na boa-fé e depende de quatro pressupostos: (a) uma situação de confiança conforme com o ordenamento jurídico, manifestada na boa-fé subjetiva e ética do agente que, sem violar deveres de cuidado, ignore estar lesando situações jurídicas alheias; (b) uma justificação para essa confiança, fundada em elementos objetivos que sejam capazes, em abstrato, de provocar uma crença plausível; (c) um investimento de confiança, ou seja, a realização de atividades jurídicas fundadas na crença consubstanciada; e (d) a imputação da situação de confiança criada à pessoa que vai ser atingida pela proteção dada ao confiante. O autor lusitano observa que é irrelevante para a tutela da confiança a falta de alguma ou algumas dessas proposições, desde que as demais tenham intensidade suficiente para, valorativamente, compensar a ausência, dentro da lógica de um sistema móvel.

A inalegabilidade formal impede que uma pessoa que tenha dado ensejo a uma nulidade formal tire proveito do negócio inválido enquanto lhe convier, postergando a alegação do vício para o momento em que o fim do vínculo negocial lhe for mais vantajoso. O sistema jurídico veda essa espécie de "venire contra factum proprium" por considerá-la uma violação grosseira da confiança. De acordo com Menezes Cordeiro ${ }^{36}$, a inalegabilidade exige, além dos quatro supracitados pressupostos da tutela da confiança, aplicáveis normalmente para o "venire contra factum proprium", mais outros três requisitos: (a) devem estar em jogo apenas interesses das partes envolvidas no negócio, sem afetar interesses de terceiros de boa-fé; (b) a situação de confiança deve ser censuravelmente imputável à pessoa a ser responsabilizada; (c) o investimento de confiança deve ser sensível, sendo dificilmente assegurado por outra via. Mantém-se, aqui,

\footnotetext{
${ }^{34}$ Nesse sentido: MENEZES CORDEIRO, Litigância de Má-Fé, Abuso do Direito de Ação e Culpa "in Agendo”, p. 93; MARTINS-COSTA, A Boa-Fé no Direito Privado: sistema e tópica no processo obrigacional, pp. 466 e 470-471.

${ }^{35}$ Litigância de Má-Fé, Abuso do Direito de Ação e Culpa “in Agendo”, pp. 93-94.

${ }^{36}$ Litigância de Má-Fé, Abuso do Direito de Ação e Culpa “in Agendo”, p. 98.
} 
a possibilidade de faltar algum ou alguns desses requisitos, dentro da já mencionada lógica de um sistema móvel.

A "suppressio" (supressão) impede o exercício de uma posição jurídica que não tenha sido exercida em certas circunstâncias e por certo lapso de tempo. Menezes Cordeiro $^{37}$ enuncia os seguintes pressupostos dessa situação típica de abuso: (a) nãoexercício prolongado de uma situação jurídica; (b) por tempo suficiente para gerar no beneficiário uma situação de confiança, no sentido de que não mais haveria o exercício; (c) uma justificação para essa confiança; (d) a imputação da confiança ao não-exercente. Trata-se, no fundo, de uma espécie de "venire contra factum proprium" em que o "factum proprium" é a inação do titular da posição jurídica.

“Tu quoque" (“também tu!”) teria sido a expressão proferida por Júlio César, em tom de espanto e crítica, quando, no momento de seu assassinato, percebeu que seu próprio filho adotivo, Bruto, se encontrava entre as pessoas que tinham planejado sua morte. No âmbito jurídico, ela é empregada para exprimir a máxima segundo a qual a pessoa que tiver violado uma norma jurídica não pode, em seguida: (a) tirar proveito da situação jurídica decorrente do ilícito; (b) exercer a situação jurídica violada; ou (c) exigir de outrem o acatamento da situação já violada. Nesses casos, se se exigisse da contraparte um comportamento equivalente ao que seria devido se a parte não tivesse violado a situação jurídica, seriam contrariados valores materiais, ético-jurídicos, que o ordenamento jurídico visa a efetivar (a chamada "materialidade subjacente"). Observe-se, contudo, que, com o intuito de evitar a inobservância generalizada do ordenamento jurídico, a aplicação do " $t u$ quoque" deve ser limitada às partes envolvidas.

Por fim, o desequilíbrio no exercício das situações jurídicas é uma hipótese residual e extensa de exercício abusivo típico, que abrange vários subtipos, dentre eles: (a) o exercício danoso inútil; (b) a exigência do que, logo em seguida, deva ser restituído (“dolo agit qui petit quod statim redditurus est"); e (d) a desproporção grave entre o benefício do titular da situação jurídica que é exercida e o sacrifício imposto por ele a outrem. Em todos esses casos, o exercício da situação jurídica, que é formalmente lícito, atenta contra valores fundamentais do sistema jurídico.

Menezes Cordeiro ${ }^{38}$ alerta que essa regulação típica dos comportamentos abusivos não pode ser confundida com uma tentativa de classificação, já que existem situações abusivas atípicas, além de ocorrências desfocadas em relação aos núcleos duros das

\footnotetext{
${ }^{37}$ Litigância de Má-Fé, Abuso do Direito de Ação e Culpa "in Agendo”, p. 100.
}

${ }^{38}$ Litigância de Má-Fé, Abuso do Direito de Ação e Culpa “in Agendo”, p. 91. 
diversas situações típicas supramencionadas e de ocorrências de sobreposição parcial (ou seja, algumas vezes, um mesmo ato pode ser objeto de mais de uma das regulações típicas enunciadas).

A teoria do abuso do direito, ora apresentada de forma sucinta, foi originalmente concebida no âmbito dos direitos subjetivos patrimoniais, notadamente dos direitos reais. Aos poucos, o seu campo de aplicação foi alargado pela doutrina, pelos tribunais e também pelos legisladores, passando a abranger praticamente todas as matérias do Direito privado: as relações de Direito de família, de Direito empresarial, de Direito do consumidor, os direitos da personalidade $\operatorname{etc}^{39}$. A incidência do instituto atinge também outras áreas, como

${ }^{39} \mathrm{Na}$ seara privada, o legislador brasileiro reprime condutas abusivas tanto no Código Civil quanto no Código de Defesa do Consumidor.

$\mathrm{O}$ art. 187 do CC caracteriza como abusiva a conduta que preencha estes requisitos (MIRAGEM, Abuso do Direito: ilicitude objetiva no direito privado brasileiro, in Revista dos Tribunais, vol. 842, p. 28):

a) consista no exercício de um direito próprio; e

b) viole um dos seguintes limites objetivos: a finalidade econômica e social do próprio direito, a boa-fé ou os bons costumes. Segundo Barbosa Moreira (Abuso do Direito, in Revista Trimestral de Direito Civil, vol. 13, p. 105), essa enumeração é alternativa, não cumulativa, logo, o titular do direito só precisa violar uma das categorias enunciadas no art. 187 do CC para que haja abuso.

Nem sempre o ato abusivo gera dano (MIRAGEM, Abuso do Direito: ilicitude objetiva no direito privado brasileiro, in Revista dos Tribunais, vol. 842, pp. 26 e 37; ASCENSÃO, A Desconstrução do Abuso do Direito, in Revista de Direito do Tribunal de Justiça do Estado do Rio de Janeiro, $\mathrm{n}^{\circ}$ 66, pp. 78; BARBOSA MOREIRA, Abuso do Direito, in Revista Trimestral de Direito Civil, vol. 13, p. 108). Quando ele é danoso, o seu autor responde civilmente com base no art. 927 do CC. Outra consequência jurídica que pode advir da prática abusiva é a desconsideração da personalidade jurídica, prevista no art. 50 do CC (MIRAGEM, Abuso do Direito: ilicitude objetiva no direito privado brasileiro, in Revista dos Tribunais, vol. 842, pp. 28 e 37).

É preciso abrir um parêntese para deixar claro que nem todos os estudiosos do Direito civil vinculam o art. 187 do CC à teoria do abuso do direito. Martins-Costa (A Ilicitude Derivada do Exercício Contraditório de um Direito: o renascer do venire contra factum proprium. In Revista Forense, vol. 376, pp. 109-129, nov./dez. 2004, pp. 122 e 124) entende que art. 187 do CC não consagra a doutrina do abuso do direito, mas, sim, o "exercício inadmissível de posição jurídica". A autora parte do pressuposto de que o exercício inadmissível de posição jurídica prescinde da culpa como elemento do seu suporte fático, enquanto o abuso do direito tem como um de seus elementos a culpa ou o dolo. Outro autor que segue essa mesma linha de pensamento é Ascensão (A Desconstrução do Abuso do Direito, in Revista de Direito do Tribunal de Justiça do Estado do Rio de Janeiro, n 66, pp. 79 e 81-82), para quem o art. 187 do CC também não prevê o abuso do direito. De acordo com o jurista, esse dispositivo apenas reune três categorias independentes, que não são recondutíveis a uma categoria comum: os atos contrários à boa-fé, os contrários aos bons costumes e os contrários ao fim econômico ou social dos direitos. A junção dessas três figuras no mesmo artigo é meramente casual, no seu entender. Para ele, essas figuras não têm princípios nem regimes próprios e apenas apresentam três elementos comuns: (a) a irregularidade no exercício de um direito; (b) o fato de essa irregularidade ser objetiva, independente do estado de espírito do agente; e (c) a necessidade de se realizar uma análise valorativa para a caracterização da irregularidade. O autor aduz que nem mesmo o texto do art. 187 do CC utiliza a expressão "abuso do direito", o que, segundo ele, reforça a sua tese.

Há ainda outra hipótese de abuso do direito contida no Código Civil: o art. 1.228, $\S 2^{\circ}$, que veda que os proprietários de imóveis pratiquem atos emulativos (ou chicaneiros) (BARBOSA MOREIRA, Abuso do Direito, in Revista Trimestral de Direito Civil, vol. 13, pp. 107-108; ASCENSÃO, A Desconstrução do Abuso do Direito, in Revista de Direito do Tribunal de Justiça do Estado do Rio de Janeiro, nº 66, p. 81).

O Código de Defesa do Consumidor também sanciona diversas práticas abusivas, porém o fundamento é diferente do adotado pelo art. 187 do CC. Este assume como limites para caracterizar o ato abusivo a finalidade econômica e social do direito, a boa-fé e os bons costumes. Já o CDC leva em consideração, na caracterização do abuso, principalmente a desigualdade entre fornecedor e consumidor, em decorrência da vulnerabilidade deste, ficando em segundo plano as considerações acerca do princípio da boa-fé. Segundo a legislação consumerista, há abuso quando o fornecedor usa sua superioridade técnica para impor 
o Direito do trabalho, o Direito administrativo, o Direito concorrencial, o Direito internacional $e t c^{40}$. Hoje, a proibição do abuso do direito configura um postulado da ordem jurídica inteira, sendo encontrada em todas as disciplinas e especialidades do Direito 414243 44 .

circunstâncias desfavoráveis ao consumidor (MIRAGEM, Abuso do Direito: ilicitude objetiva no direito privado brasileiro, in Revista dos Tribunais, vol. 842, pp. 13, 36 e 38-39).

Quatro situações abusivas são expressamente previstas no CDC (MIRAGEM, Abuso do Direito: ilicitude objetiva no direito privado brasileiro, in Revista dos Tribunais, vol. 842, pp. 38 e 40-43):

a) as cláusulas contratuais abusivas (art. 51 da Lei $n^{\circ}$ 8.078/90). Também aqui há divergência doutrinária. Ascensão (A Desconstrução do Abuso do Direito, in Revista de Direito do Tribunal de Justiça do Estado do Rio de Janeiro, $\mathrm{n}^{\circ}$ 66, p. 66) entende que as cláusulas abusivas não se relacionam com a teoria do abuso do direito porque elas se referem à formação do contrato, ao exercício da faculdade de contratar, e não ao exercício de direitos;

b) a publicidade abusiva (art. 37 da Lei $\left.n^{\circ} 8.078 / 90\right)$;

c) as práticas comerciais abusivas (art. 39 da Lei $n^{\circ} 8.078 / 90$ ); e

d) o abuso da personalidade jurídica (art. 28 da Lei $n^{\circ} 8.078 / 90$ ).

Percebe-se que todos esses dispositivos do CDC somente punem o fornecedor, nunca o consumidor. Isso confirma a teoria supramencionada de que a Lei ${ }^{\circ} 8.078 / 90$ considera principalmente a vulnerabilidade do consumidor para reprimir os atos abusivos (MIRAGEM, Abuso do Direito: ilicitude objetiva no direito privado brasileiro, in Revista dos Tribunais, vol. 842, p. 36).

${ }^{40}$ A prevenção e a repressão de algumas condutas abusivas são objeto de previsões normativas do Direito comunitário e do Direito internacional. De acordo com Catalano (L'Abuso del Processo, p. 19), as noções de abuso do direito contidas no art. 54 da Carta dos direitos fundamentais da União Europeia e no art. 17 da Convenção europeia dos direitos do homem nada mais são do que uma fusão entre o tradicional conceito privatístico de abuso e a recente concepção de "Wehrhaft Demokratie" (democracia capaz de se defender), elaborada pela doutrina internacionalista.

${ }^{41}$ Acerca do campo de abrangência da teoria do abuso do direito, consultar: STOCO, Abuso do Direito e MáFé Processual - aspectos doutrinários, pp. 62-65; CASTRO FILHO, Abuso do Direito no Processo Civil, p. 21.

${ }^{42} \mathrm{Na}$ verdade, a evolução da teoria do abuso do direito não se deu assim, de maneira linear, sem qualquer percalço. Os seus defensores tiveram que digladiar com diversos autores que insistiam em negar a existência do instituto do abuso do direito.

Um dos seus opositores mais conhecidos foi Planiol (Traité Élémentaire de Droit Civil, $2^{\circ}$ tomo, p. 284), para quem a expressão "uso abusivo dos direitos" é uma logomaquia, pois se a pessoa usa o seu direito, o seu ato é lícito; quando ele é ilícito, é que a pessoa ultrapassou seu direito e agiu sem direito. Esse doutrinador nega que o abuso do direito seja uma categoria distinta do ato ilícito. Ele parte do pressuposto de que um ato só pode ser conforme ao direito ou contrário a ele, não havendo um "tertium genus". Como o ato abusivo não é, na sua opinião, o exercício de um direito, pois "o direito cessa onde o abuso começa", então ele só pode ser um ato ilícito.

Em resposta, Josserand (Relatividad y Abuso de los Derechos, in Del Abuso de los Derechos y Otros Ensayos, pp. 23-25) alega que a contradição alardeada é apenas aparente e que ela se dissipa se se considerar que a palavra "direito" possui duas acepções muito diferentes:

a) direito objetivo (ou juridicidade), que é o ordenamento jurídico como um todo;

b) direito subjetivo, que é uma prerrogativa determinada.

$\mathrm{O}$ ato abusivo é aquele realizado em virtude de um direito subjetivo, mas que contraria outras normas do ordenamento jurídico (direito objetivo). Em outras palavras, não é o direito, em sentido objetivo, que é abusivo, mas sim o exercício do direito substantivado. Nesse mesmo sentido: CASTRO FILHO, Abuso do Direito no Processo Civil, p. 21.

${ }^{43}$ Apesar de sua ampla aplicação atual, parte da doutrina enuncia a progressiva decadência da teoria do abuso do direito no âmbito do Direito privado. A respeito desse tema, consultar: MENEZES CORDEIRO, Da Boa Fé do Direito Civil, pp. 697-707.

${ }^{44}$ Catalano (L'Abuso del Processo, pp. 3 e 16) alerta que, se, por um lado, essa contínua expansão do abuso a novos ramos do Direito demonstra a vitalidade dessa categoria jurídica; por outro, aumenta a margem de indeterminação do instituto e, ao mesmo tempo, faz crescer as reservas que a doutrina suscita com relação ao uso de um conceito cuja pertinência à ciência jurídica é contestada. 


\subsection{Breve histórico do abuso do processo e adoção, no âmbito processual, da teoria do abuso do direito}

A prática do abuso processual é um problema bastante antigo, que atormentava os operadores do direito e os legisladores muitos séculos antes do advento da moderna teoria do abuso do direito examinada no item anterior.

A ideia de prevenir e reprimir comportamentos processuais ímprobos estava presente já no período das "legis actiones" do processo civil romano ${ }^{45}$. Nessa época, havia o "sacramentum", que era a pena que o litigante devia ao Estado caso não demonstrasse, na fase "apud iudicem" da "actio sacramenti", o direito que houvesse afirmado diante do magistrado na fase "in iure" o sucumbente suportava independentemente de ter agido de modo temerário ou chicaneiro ao ajuizar a ação (no caso do autor) ou ao resistir a ela (caso fosse o réu o sucumbente). A mera sucumbência era suficiente para que se presumisse a temeridade e o dolo da parte. $\mathrm{O}$ litigante vencedor, todavia, não era beneficiado com a aplicação dessa sanção, uma vez que o "sacramentum" era destinado aos sacerdotes ou ao erário ${ }^{47} 48$. Na "legis actio per manus

\footnotetext{
${ }^{45}$ Contra, entendendo que não havia repressão do abuso do processo nesse período: CASTRO FILHO, Abuso do Direito no Processo Civil, pp. 41-42.

${ }^{46}$ De acordo com Gaio (Institutas, Livro IV, § 12), havia cinco ações da lei: (a) a "actio sacramenti"; (b) a "iudicis postulatio"; (c) a "condictio"; (d) a "manus iniectio"; e (e) a "pignoris capio". As três primeiras eram ações de conhecimento, que visavam a declarar a existência, ou não, de um direito ou a proceder a uma divisão. Já a "manus iniectio" e a "pignoris capio" tinham natureza executiva (AZEVEDO; TUCCI, Lições de História do Processo Civil Romano, p. 52).

Em regra, as ações da lei se submetiam ao "ordo iudiciorum priuatorum", ou seja, seu procedimento era dividido em duas fases: a primeira diante do magistrado ("in iure") e a segunda, do juiz popular ("apud iudicem"). A única exceção era a "legis actio per pignoris capionem" (MOREIRA ALVES, Direito Romano, vol. 1, p. 193).

47 Acerca da "actio sacramenti" e do "sacramentum", consultar: MOREIRA ALVES, Direito Romano, vol. 1, pp. 196-199; AZEVEDO; TUCCI, Lições de História do Processo Civil Romano, pp. 63-66; CHIOVENDA, La Condanna nelle Spese Giudiziali, § 14, pp. 13-14; AMIRANTE, Giuramento (Diritto Romano), in Novissimo Digesto Italiano, vol. VII, p. 938; SOBRINHO, Dever de Veracidade das Partes no Processo Civil, pp. 11-13.

${ }^{48}$ Ainda no sistema das ações da lei, os jurisconsultos criaram o processo "per sponsionem", utilizado para reivindicar coisas. Nele, o réu realizava uma "sponsio", por meio da qual prometia formalmente pagar certa importância ao autor, caso ficasse provado que a coisa que ele possuía não era sua. Na sentença, o "iudex" tinha que determinar se o autor podia, ou não, reclamar o pagamento da "sponsio" e, com isso, decidia quem era o verdadeiro proprietário da coisa, ainda que de maneira indireta (MOREIRA ALVES, Direito Romano, vol. 1, pp. 198-199).

Em tese, poder-se-ia dizer que o dever que o réu-vencido tinha de pagar a quantia prometida no processo "per sponsionem" era outra forma de sancionar a atuação processual temerária, ao lado da perda do "sacramentum". Porém, na prática, a quantia prometida era, geralmente, insignificante e nem mesmo era paga ao autor quando ele se sagrava vencedor. A doutrina explica que, no processo "per sponsionem", a "sponsio" não era utilizada como um meio de aquisição, mas sim como um meio de provocar um processo. Tratava-se, assim, de um "simulacro processual" (SOHM, Instituciones de Derecho Privado Romano: historia y sistema, p. 624; MOREIRA ALVES, Direito Romano, vol. 1, p. 199, nt. 38).
} 
iniectionem" existia também um mecanismo de repressão ao abuso processual. A "manus iniectio" era a ação executória por excelência no sistema das ações da lei e só podia ser utilizada para a execução de quantia certa. O devedor que tivesse confessado o débito "in iure" ou que tivesse sido condenado ao seu pagamento tinha que cumprir a obrigação dentro de 30 dias (“dies iusti”). Decorrido esse prazo sem o adimplemento do débito, o credor conduzia o devedor à presença do magistrado, segurava uma parte do seu corpo e pronunciava uma fórmula solene para possibilitar o início da execução ${ }^{49}$. Feito isso, o devedor tinha três opções: (a) pagar a dívida; (b) apresentar um "uindex”, que contestasse, em seu lugar, a legitimidade do processo de execução (v.g., alegando que a sentença era nula ou que a obrigação já estava extinta); ou (c) restar inerte, dando continuidade à execução. Caso o devedor realizasse a segunda conduta, ele era liberado da execução, mas instaurava-se um novo processo de cognição para verificar a veracidade da alegação do "uindex", podendo este ser condenado a pagar o dobro da dívida originária se ficasse constatado que era mentira ("condemnatio rei in duplum") ${ }^{50}$. Esse risco patrimonial a que estava sujeito o "uindex" fez com que a sua atuação não fosse muito frequente ${ }^{51} 52$.

No período do sistema formulário, foram criados diversos institutos processuais esparsos para refrear as condutas desleais e punir eventuais abusos praticados pelos sujeitos do processo. Os romanos estabeleceram que o juiz que favorecesse uma das partes ou agisse com manifesta "imprudentia" ou com dolo (“dolo malo") estava sujeito a ser condenado a ressarcir todo o prejuízo que houvesse provocado, por meio da "actio contra iudicem qui litem sua fecerit" (ação contra juiz que fez sua a lide) (Gaio, Institutas, Livro

Portanto, se, por um lado, o pagamento do valor do "sacramentum" ao Estado pode ser considerado como um instrumento de repressão do abuso do processo no período das "legis actiones", já que a mera sucumbência presumia a temeridade e o dolo (injusto objetivo); do outro, o mesmo não pode ser afirmado com relação à "sponsio", uma vez que o valor prometido era insignificante e o seu pagamento ao autor-vencedor, muitas vezes, nem mesmo ocorria, pois se tratava apenas de um meio indireto de dirimir o litígio acerca da titularidade da coisa.

${ }^{49}$ Segundo Moreira Alves (Direito Romano, vol. 1, p. 202, nt. 60), a fórmula tinha o seguinte conteúdo:

"Porque tu me deves por julgamento (ou por condenação) dez mil sestércios, e não pagaste, lanço sobre ti a mão por causa dos dez mil sestércios".

50 Depois da Lei das XII Tábuas, as hipóteses de cabimento da "manus iniectio" foram ampliadas, sendo utilizada para a cobrança de créditos referidos em certas leis, mesmo sem haver julgamento nem "confessio in iure", e seus efeitos foram abrandados (v.g., passou-se a admitir que o réu se defendesse pessoalmente em alguns casos, sem ter que recorrer ao "uindex"; nos fins da República, proibiu-se o credor de matar ou vender o devedor inadimplente como escravo, podendo apenas obrigá-lo a pagar a dívida com trabalho).

${ }^{51}$ DINAMARCO, A Execução na Teoria Geral do Direito Processual Civil, p. 16.

52 Acerca da "legis actio per manus iniectionem", consultar: MOREIRA ALVES, Direito Romano, vol. 1, pp. 201-204; AZEVEDO; TUCCI, Lições de História do Processo Civil Romano, pp. 68-70; LONGO, Esecuzione Forzata (Diritto Romano), in Novissimo Digesto Italiano, vol. VI, pp. 714-716; VOCI, Esecuzione Forzata (Diritto Romano), in Enciclopedia del Diritto, vol. XV, pp. 422-423; DINAMARCO, A Execução na Teoria Geral do Direito Processual Civil, pp. 12-19; GROSSMANN, O Dever de Veracidade no Processo Civil (exposição de direito comparado), in Revista Forense, vol. 101, p. 280. 
IV, § 52; Ulpiano, D., 5.1.15.1, “libro XXI ad edictum") ${ }^{53}$. Também havia normas acerca de comportamentos abusivos dos litigantes: (a) na "actio certae creditae pecuniae" e na "actio de pecunia constituta", exigia-se que as partes jurassem "sponsiones" para evitar processos sem fundamento (Gaio, Institutas, Livro IV, $\S 171)^{54}$; (b) nas ações "iudicati”, “depensi" (de quantia paga), de dano injusto e de legados "per damnationem", se o réu discutisse sem fundamento, resistindo injustificadamente à pretensão do autor, ele era condenado a pagar o dobro da quantia originalmente devida (Gaio, Institutas, Livro IV, § $171)^{55}$; (c) a parte autora que tivesse conduta processual maliciosa podia ser punida por meio das ações de malícia ("iudicium calumniae") e contrária ("contrarium iudicium") (Gaio, Institutas, Livro IV, $\S § 174$ a 179 e 181) ${ }^{56}$; (d) o litigante temerário podia sofrer a pena de infâmia (Gaio, Institutas, Livro IV, § 182) ${ }^{57}$ etc. Existia, outrossim, a preocupação com a prevenção do abuso do processo, mediante o "iusiurandum calumniae", na dúplice articulação "non calumniae causa infitias ire" e "non calumniae causa agere"58. Nas hipóteses em que não era possível a "sponsio", nem a condenação em dobro, podia-se exigir do réu o juramento de não contestar maliciosamente ("non calumniae causa infitias ire"), se desde o início a ação fosse simples (Gaio, Institutas, Livro IV, § 172).

\footnotetext{
53 AZEVEDO; TUCCI, Lições de História do Processo Civil Romano, p. 130.

${ }^{54} \mathrm{Na}$ "actio certae creditae pecuniae", o réu, por meio da "sponsio tertiae partis", prometia pagar ao autor o montante de um terço do valor da ação se fosse vencido. Em contrapartida, o autor realizava a "restipulatio tertiae partis", pela qual se comprometia a pagar ao réu quantia referente a um terço do valor da ação, caso sucumbisse. Ao final, o que fosse vencido era obrigado a pagar a quantia prometida ao vencedor.

O mesmo ocorria na ação "constituta pecunia", com a peculiaridade de que o montante que as partes se obrigavam a pagar no caso de sua respectiva sucumbência era de metade do valor da ação.

Acerca desse tema, consultar: SOBRINHO, Dever de Veracidade das Partes no Processo Civil, p. 13; MOREIRA ALVES, Direito Romano, vol. 1, p. 201, nt. 53; SCIALOJA, Procedimiento Civil Romano, § 36, p. 278.

55 Acerca desse tema, consultar: SOBRINHO, Dever de Veracidade das Partes no Processo Civil, p. 13; SCIALOJA, Procedimiento Civil Romano, § 36, pp. 276-278; MOREIRA ALVES, Direito Romano, vol. 1, pp. 225 e 226-227; AZEVEDO; TUCCI, Lições de História do Processo Civil Romano, pp. 128 e 132-133; BONIFACIO, Infitiatio, in Novissimo Digesto Italiano, vol. VIII, pp. 655-656; BONIFACIO, Revocatio in Duplum, in Novissimo Digesto Italiano, vol. XV, pp. 820-821; LONGO, Esecuzione Forzata (Diritto Romano), in Novissimo Digesto Italiano, vol. VI, p. 718; VOCI, Esecuzione Forzata (Diritto Romano), in Enciclopedia del Diritto, vol. XV, p. 424.

56 Acerca do "iudicium calumniae" e do "contrarium iudicium", consultar: SOBRINHO, Dever de Veracidade das Partes no Processo Civil, pp. 13-14; CHIOVENDA, La Condanna nelle Spese Giudiziali, § 15, pp. 14-15; SCIALOJA, Procedimiento Civil Romano, § 36, pp. 280 e 281-282.

57 CASTRO FILHO, Abuso do Direito no Processo Civil, p. 42, nt. 5; SCIALOJA, Procedimiento Civil Romano, § 36, p. 283.

Acerca da pena de infâmia no Direito romano, consultar: MOREIRA ALVES, Direito Romano, vol. 1, pp. 118-119; BRASIELLO, Infamia (Diritto Romano), in Novissimo Digesto Italiano, vol. VIII, pp. 641-643; MAZZACANE, Infamia (Diritto Romano e Intermedio), in Enciclopedia del Diritto, vol. XXI, pp. 382-385; AZEVEDO; TUCCI, Lições de História do Processo Civil Romano, p. 131.

${ }^{58}$ De acordo com Chiovenda (La Condanna nelle Spese Giudiziali, § 15, p. 14), o "iusiurandum calumniae" ("non calumniae causa se infitias ire" - "non calumniae causa agere") não era realmente uma pena, mas sim um remédio preventivo de ações e exceções abusivas.
} 
Analogamente, o réu também podia exigir que o autor jurasse não estar agindo com intuito doloso ("non calumniae causa agere") (Gaio, Institutas, Livro IV, § 176)

$\mathrm{Na}$ passagem do sistema formulário para a "cognitio extraordinaria", e ao longo deste último período, houve a paulatina supressão da "sponsio tertiae partis", da "restipulatio tertiae partis", do "iudicium calumniae" e do "contrarium iudicium" 60 . Por outro lado, foram amplamente desenvolvidos outros instrumentos para prevenir e reprimir condutas ímprobas dos sujeitos processuais. Dentre eles, o "iusiurandum calumniae", que consistia em um juramento, feito após a alegação e a resposta ("narratio" e "contradictio"), em que os litigantes e seus tutores, curadores e advogados declaravam, perante as Escrituras, que acreditavam defender um direito e que não estavam atuando em juízo com espírito chicaneiro. Caso o réu se recusasse a prestar o juramento, ele ficava na posição de "confessus" e era julgado como tal. Também na fase probatória as partes prestavam um "iusiurandum calumniae", notadamente nas hipóteses de produção de prova documental, com o fim de assegurar que elas não atuavam com intuito protelatório ${ }^{61}$. No sistema extraordinário, o litigante considerado temerário podia ser condenado ao ressarcimento das despesas processuais da parte vencedora ${ }^{62}$. Havia também sanções por

59 Acerca do "iusiurandum calumniae", consultar: SOBRINHO, Dever de Veracidade das Partes no Processo Civil, pp. 14-15; AZEVEDO; TUCCI, Lições de História do Processo Civil Romano, p. 130; AMIRANTE, Giuramento (Diritto Romano), in Novissimo Digesto Italiano, vol. VII, p. 942; GROSSMANN, O Dever de Veracidade no Processo Civil (exposição de direito comparado), in Revista Forense, vol. 101, p. 280.

${ }^{60}$ SOBRINHO, Dever de Veracidade das Partes no Processo Civil, p. 15; CHIOVENDA, La Condanna nelle Spese Giudiziali, $\S 17$, p. 16.

O seguinte trecho do $\S 1^{\circ}$ do Título XVI do Livro IV das Institutas de Justiniano trata especificamente do "iudicium calumniae": "[...] Todas essas formalidades foram criadas para substituir a antiga ação de calúnia, caída em desuso, porque punia o autor com a pena da décima parte do valor da causa, pena que, entretanto, nunca vimos aplicada. Em lugar dela, introduzimos o juramento de que falamos, e a obrigação, que tem a parte da má-fé, de pagar à outra parte perdas e danos, além das custas" (CRETELLA JR.; CRETELLA, Institutas do Imperador Justiniano, pp. 273-274).

${ }^{61}$ Acerca do "iusiurandum calumniae" na "cognitio extraordinaria", consultar: MOREIRA ALVES, Direito Romano, vol. 1, p. 248; SOBRINHO, Dever de Veracidade das Partes no Processo Civil, pp. 15-20.

${ }^{62}$ Chiovenda (La Condanna nelle Spese Giudiziali, $\S \S 24-26$, pp. 28-32) ensina que, em regra, o vencedor e o vencido deviam arcar com suas respectivas despesas. As exceções constavam de dois textos legais do imperador Ulpiano (Lei 79, D. "de iudiciis", 5, I. - Ulp., lib. V, “de off. proc.”; e Lei I, § I, D. "de vac. et exc. mun. ”, 50, 5. - Ulp., lib. II, “opin.”), que estatuíam que o autor sucumbente e temerário devia ser condenado a reembolsar as despesas e danos sofridos pelo vencedor. No caso de sucumbência do réu, não havia tal sanção.

A possibilidade de o réu sucumbente e temerário também ser condenado a ressarcir as despesas da parte vencedora foi prevista, pela primeira vez, em uma lei de Valentiniano e Valente (L. I, C. Th. "de fructibus et litis expensis", 4, 18 (I) Valentinianus et Valens A. A. Olybrio Pf. U.) (CHIOVENDA, La Condanna nelle Spese Giudiziali, § 32, pp. 41-42).

Leone (L. 32 (33), § 8, C. “de episcopis et clericis", I, 3. "Leo et Ant. AA. Erythrio pp.”) estabeleceu como privilégio dos eclesiásticos a condenação nas despesas independentemente do requisito da "temeritas". Bastava que a demanda fosse considerada injusta e ilegítima, independentemente do ânimo da parte vencida, para que esta fosse condenada a ressarcir os clérigos das despesas processuais. Não obstante isso, o intuito do 
condutas ilegais, manifestamente infundadas e protelatórias praticadas em sede recursal, tanto pelo magistrado, quanto pelas partes. Por exemplo, o juiz recorrido não podia recusar-se a receber a "appellatio", a não ser que ela fosse ilegal. Se houvesse recusa do recebimento do recurso, o recorrente podia dirigir-se diretamente ao juiz superior. Caso este entendesse que a apelação deveria ter sido recebida, punia o juiz recorrido; caso contrário, sancionava o apelante. Eram previstas também punições para o caso de o recurso ser julgado improcedente: no período de Constantino, o apelante rico era condenado à pena de desterro por dois anos, além de ter a metade de seus bens confiscada; se fosse pobre, era forçado a trabalhar por dois anos nas minas. Posteriormente, Justiniano conferiu ao juiz o poder de fixar uma sanção moderada ao apelante considerado temerário. No procedimento da "appellatio more consultationem", criada pelos imperadores Diocleciano e Constantino, cabível contra decisões de juízes de grau superior, existiam penas pela prática de condutas protelatórias do feito: (a) se o apelante não exigisse, no prazo legal, a "opinio" do magistrado, nem apresentasse as suas razões recursais ("preces refutatoriae"), seu recurso era considerado deserto e tinha fim a suspensão da execução do julgado impugnado (C. Th. 11.30.14, a. 327); (b) se o juiz cuja decisão havia sido inpugnada e seus funcionários não

legislador continuava sendo a repressão da "temeritas" (CHIOVENDA, La Condanna nelle Spese Giudiziali, $\S 38$, pp. 47-48).

Foi Zanone o responsável por alterar radicalmente as regras sobre a condenação nas despesas do processo romano. Por meio da L. 5 C. "de fruct. et. lit. exp." 7, 51, ele estabeleceu de maneira geral, pela primeira vez, a condenação do sucumbente pura e simplesmente (CHIOVENDA, La Condanna nelle Spese Giudiziali, § 39, pp. 49-50). Com isso, qualquer sucumbente, autor ou réu, de boa ou má-fé, em qualquer tipo de demanda, era condenado nas despesas (CHIOVENDA, La Condanna nelle Spese Giudiziali, § 72, p. 77). Caso o juiz constatasse que o sucumbente tinha atuado com má-fé no processo, devia somar à condenação nas despesas uma pena no valor de um décimo destas, a qual beneficiava o erário público. Em casos excepcionais, era possível que uma parte do valor dessa punição fosse destinada ao vencedor a título de ressarcimento dos danos. Por outro lado, se o magistrado ficasse convencido de que o sucumbente agira de boa-fé, podia excepcionalmente isentá-lo das despesas em alguns casos (CHIOVENDA, La Condanna nelle Spese Giudiziali, § 43, pp. 53-54). Percebe-se que, mesmo quando o Direito romano passou a condenar o vencido nas custas em razão apenas do fato objetivo da sucumbência, continuaram existindo punições aplicáveis ao litigante temerário (CASTRO FILHO, Abuso do Direito no Processo Civil, p. 44).

Posteriormente, Justiniano legislou bastante acerca da condenação nas despesas, porém sem inovações substanciais (CHIOVENDA, La Condanna nelle Spese Giudiziali, § 50, p. 59; § 57, pp. 65-66).

Todavia, cumpre observar que Cordopatri (L'Abuso del Processo e la Condanna alle Spese, in Rivista Trimestrale di Diritto e Procedura Civile, v. 59, $\mathrm{n}^{\circ}$ 1, pp. 254-257) não concorda com essa tese de Chiovenda, que busca no Direito romano o fundamento histórico da regra da condenação ao ressarcimento das despesas processuais fundada no mero fato objetivo da sucumbência. Segundo o autor, a tratadística alemã - embasada nas conclusões dos glosadores, dos comentadores (ou pós-glosadores) e da Escola Culta ensina que a condenação ao ressarcimento das despesas não era uma consequência automática da sucumbência. Ela podia e devia advir: da "temeraria citatio", ou da "contumacia", ou do "retardatus processus", ou então da "victoria" de uma das partes. Ressalta que este último pressuposto da condenação nas despesas não era entendido como uma expressão simétrica e contrária da sucumbência em sentido objetivo, mas sim como um indício evidente da "malitia" da parte vencida, que deduziu em juízo uma "lis calumniosa" ou meramente "colposa".

A opinião de Cordopatri tem sido endossada por alguns autores, como, por exemplo: ALBUQUERQUE, Responsabilidade Processual por Litigância de Má Fé, Abuso de Direito e Responsabilidade Civil em Virtude de Actos Praticados no Processo, p. 15, nt. 15; p. 17, nt. 26; p. 28, nt. 81; e p. 33, nt. 85. 
remetessem os autos do recurso ao tribunal imperial dentro do prazo de 20 dias, eram obrigados a pagar montante correspondente ao objeto do litígio, a título de multa $(\mathrm{C}$. Th. 11.30.8 $)^{63}$. Foram mantidas, nesse período da história do Direito romano, a condenação em dobro (Justiniano, Institutas, Livro IV, Título XVI, $\S 1^{\circ}$ ) e a pena de infâmia (Justiniano, Institutas, Livro IV, Título XVI, $\left.\S 2^{\circ}\right)^{64}$.

$\mathrm{O}$ esforço contra a improbidade processual estava igualmente presente no antigo Direito germânico, durante a baixa Idade Média. Ao formular sua demanda perante a Assembleia, que era o órgão julgador, o autor devia realizar um juramento de boa-fé e de verdade. Por meio desse juramento, ele assegurava estar atuando em juízo de boa-fé, de acordo com a verdade e o justo, invocando Deus para garantir a retidão de sua intenção. No Direito longobardo, o juramento denominava-se "sacramentum de asto"65. Como a demanda formulada pelo autor tinha como fundamento a culpa do réu, este, caso fosse inocente, se sentia pessoalmente ofendido. Diante disso, e com o intuito de se purificar, o demandado também realizava um juramento, geralmente acompanhado de conjuradores, tomando a divindade como testemunha de sua não-culpa. Se o réu não realizasse o juramento de purificação, ele era considerado confesso, perdendo a ação ${ }^{66}$.

O processo itálico romano-canônico ${ }^{67}$, nos primórdios do século XI, restaurou o juramento de calúnia (“calumniae iuramentum") ${ }^{68}$. Utilizou, outrossim, a condenação ao pagamento de despesas processuais como forma de sancionar o abuso do processo. Durante os séculos XII, XIII e XIV, a condenação do vencido nas despesas era a regra geral no processo romano-canônico. Porém, se a parte sucumbente tivesse justa causa para litigar, ela não era condenada a pagar despesas. Tratava-se da teoria da "iusta causa litigandi”, que, na prática, tinha mais incidência que a regra geral de condenação do vencido. Essa exceção era formada por dois $\operatorname{conceitos}^{69}$ : (a) se se constatasse, na demanda, um conjunto de circunstâncias que excluísse a má-fé do vencido ou que demonstrasse uma

${ }^{63}$ Acerca dessas sanções decorrentes da prática de abuso do poder de recorrer no Direito romano, consultar: MOREIRA ALVES, Direito Romano, vol. 1, p. 252; AZEVEDO; TUCCI, Lições de História do Processo Civil Romano, pp. 172-173.

${ }^{64}$ Para uma análise pormenorizada do abuso do processo no Direito romano, consultar: BUZZACCHI, L'Abuso del Processo nel Diritto Romano, "passim".

${ }^{65}$ SOBRINHO, Dever de Veracidade das Partes no Processo Civil, p. 35.

${ }^{66}$ SOBRINHO, Dever de Veracidade das Partes no Processo Civil, pp. 26-27; AMIRANTE, Giuramento (Diritto Intermedio), in Novissimo Digesto Italiano, vol. VII, p. 943.

${ }^{67}$ Inicialmente, a Igreja possuía apenas jurisdição eclesiástica. Em seguida, começou a estendê-la também a particulares, notadamente nas "causas mistas" (v.g., questões matrimoniais, de estado de família, dotais testamentárias etc.). Daí surgiu um processo itálico romano-canônico, decorrente da contribuição do Direito romano reestudado, aliada à jurisprudência da alta Itália influenciada pelo Direito germânico (SOBRINHO, Dever de Veracidade das Partes no Processo Civil, p. 38)

${ }^{68}$ SOBRINHO, Dever de Veracidade das Partes no Processo Civil, p. 36.

${ }^{69}$ CHIOVENDA, La Condanna nelle Spese Giudiziali, § 111, pp. 113-114. 
razão plausível para ele litigar, gerando uma presunção de boa-fé, ele não podia ser condenado nas despesas; (b) entendia-se também que a parte tinha sempre o direito de litigar, ou seja, que ela podia defender aquilo que acreditava ser o seu direito até o fim do processo. Desse modo, sendo lícita a discussão do direito, ela não podia ser sancionada, se vencida, mediante a condenação ao pagamento das despesas. Todavia, esse direito de litigar não era considerado absoluto, de modo que, quando faltava uma causa plausível para a parte vencida litigar, entendia-se que ela tinha abusado do processo, sendo responsabilizada pelas despesas. A teoria da "iusta causa litigandi" também era aplicada na seara recursal, porém com maior rigor. Se a sentença fosse confirmada com base nos mesmos fundamentos da decisão atacada, o apelante era condenado nas despesas ${ }^{70}$.

Nesse período, houve uma discussão acerca da eficácia do "iuramentum calumniae" com relação à condenação a pagar despesas. Alguns autores (a maioria canonistas) defendiam que, após prestar esse juramento, o litigante não podia mais ser condenado ao pagamento das despesas porque se presumia que ele litigava de boa-fé. Contudo, essa isenção da parte que prestava o juramento também possuía muitos opositores, dentre eles: Bartolo, Baldo e Abate Palermitano. Eles fundavam sua argumentação na distinção entre "calumnia" propriamente dita e "temeritas", sendo que a primeira teria por conteúdo o dolo, ou seja, a consciência do erro, enquanto a segunda consistiria na leviandade ou negligência. Afirmavam que o "iuramentum calumniae" destinava-se a reprimir a "calumnia" propriamente dita, enquanto que a condenação nas despesas era condicionada apenas à "temeritas". Com base nisso, concluíam que o "iuramentum calumniae" não podia escusar alguém de pagar as despesas decorrentes da sucumbência. Essa dissensão na doutrina perdurou enquanto o referido juramento foi admitido pelo Direito ${ }^{71}$.

O processo romano-canônico informou o Direito estatutário italiano, levando muitos estatutos a aplicarem o "iuramentum calumniae", ainda que de maneira reduzida ${ }^{72}$. Houve outros juramentos ligados ao de calúnia, resultantes da experiência jurídica do processo canônico, tais como: o "iuramentum de veritate dicenda" nas "causae spiritualibus"; o "iuramentum appelatorium"; o "iuramentum revisiorium"; e o

\footnotetext{
${ }^{70}$ CHIOVENDA, La Condanna nelle Spese Giudiziali, § 114, p. 116.

${ }^{71}$ CHIOVENDA, La Condanna nelle Spese Giudiziali, § 113, pp. 115-116.

${ }^{72}$ Os estatutos de Casale e de Genova, por exemplo, admitiam-no se houvesse requerimento. O estatuto de Bologna restringiu-o apenas a algumas causas. O de Milano limitou o seu âmbito de aplicação aos estrangeiros. No estatuto de Novara, determinadas pessoas eram dispensadas de prestar o juramento. Por outro lado, outros estatutos não admitiram o juramento de calúnia. É o caso dos estatutos de Como, Bari, Moncalieri e Brescia, que suprimiram esse instituto jurídico. Com isso, o juramento de calúnia foi paulatinamente perdendo o valor.
} 
"iuramentum malitiae", que se destinava à prevenção da chicana de certos atos processuais particulares ${ }^{73}$.

Notadamente a partir de 1.495 , ocorreu a recepção do processo romano-canônico também no Direito germânico, contribuindo para a formação do chamado "processo cameral”. Juntamente com essa recepção, foram acolhidos tanto o juramento de calúnia geral, quanto o especial (destinado a impedir a chicana em atos processuais particulares) ${ }^{74}$.

No Direito lusitano, é possível encontrar a preocupação do legislador com o problema do abuso do processo já em suas primeiras fontes, os forais ${ }^{75}$. Dentre os meios de prova neles previstos estavam os juramentos dos litigantes e de pessoas mais ou menos estranhas à causa, os quais eram utilizados para provar a existência, ou não, de qualquer fato relacionado à demanda. Eram eles a jura de malícia, o "outorgamento" ou "firma", a "manquadra" e a "compurgação" (ou "conjuramento") ${ }^{76}$. Todos se fundamentavam em um princípio moral: o temor que as pessoas tinham de mentir aos homens e a Deus, o que era algo muito grave em uma época de crenças robustas ${ }^{77}$.

Mais tarde, os legisladores afonsinos, manuelinos e filipinos também se preocuparam com a veracidade no processo, ao disciplinarem o juramento de calúnia (Ordenações Afonsinas, Livro III, Título XXXIX; Ordenações Manuelinas, Livro III, Título XXIX; e Ordenações Filipinas, Livro III, Título XLIII), por meio do qual se prometia "litigar de boa-fé, e abster-se de toda tergiversação, e fraude" "78. À época, considerava-se que esse instituto pertencia menos aos modos de prova que às fórmulas do juízo. Eram previstos dois tipos de juramento de calúnia: (a) um geral, que era universal para todo o feito, sendo prestado logo após a contestação, de ofício ou a requerimento de qualquer litigante (Ordenações Afonsinas, Livro III, Título XXXIX, pr.; Ordenações Manuelinas, Livro III, Título XXIX, pr.; Ordenações Filipinas, Livro III, Título XLIII, pr.); e (b) outro especial, que dizia respeito a certo e determinado ato e era prestado em

\footnotetext{
${ }^{73}$ SOBRINHO, Dever de Veracidade das Partes no Processo Civil, pp. 38-40; CHIOVENDA, La Condanna nelle Spese Giudiziali, $\S 120$, pp. 122-123; GROSSMANN, O Dever de Veracidade no Processo Civil (exposição de direito comparado), in Revista Forense, vol. 101, p. 281.

${ }^{74}$ SOBRINHO, Dever de Veracidade das Partes no Processo Civil, pp. 42-46.

${ }^{75}$ De acordo com os ensinamentos de Azevedo e Tucci (Lições de História do Processo Civil Lusitano, p. 31 ), os forais continham o direito consuetudinário que era vigente nas aldeias que os detinham, direito esse de origem e estrutura germânicas

${ }^{76}$ Acerca desses juramentos previstos nos forais, consultar: HERCULANO, História de Portugal: desde o começo da monarchia até o fim do reinado de Affonso III, tomo IV, pp. 362-371; SOBRINHO, Dever de Veracidade das Partes no Processo Civil, pp. 52-57 e 60; MERÊA, Resumo de História do Direito Português, pp. 107-108.

${ }^{77}$ HERCULANO, História de Portugal: desde o começo da monarchia até o fim do reinado de Affonso III, tomo IV, p. 359; LOBÃO, Segundas Linhas sobre o Processo Civil, Parte I, p. 574.

${ }^{78}$ Esse conceito é adotado por Pereira e Sousa (Primeiras Linhas sobre o Processo Civil, tomo I, § CCXLVII, nt. 521, p. 214) e Ramalho (Praxe Brasileira, § 193, pp. 300-301).
} 
qualquer momento do feito, inclusive antes da contestação (Ordenações Afonsinas, Livro III, Título XXXIX , § 1º; Ordenações Manuelinas, Livro III, Título XXIX, § 1º $1^{\mathrm{a}}$ parte; Ordenações Filipinas, Livro III, Título XLIII, $\S 1^{\circ}$ ). Este último também era conhecido como "juramento de malícia". Era necessário uma das partes requerer ao juiz que a outra realizasse o juramento de calúnia especial, podendo, porém, o juiz determinar a sua realização de ofício em alguns casos. As partes e seus tutores e curadores não eram as únicas pessoas legitimadas a realizar juramentos de calúnia (geral e particular). Era possível requerer que os procuradores das partes também prestassem o juramento em seu próprio nome (Ordenações Afonsinas, Livro III, Título XXXIX, $\S 2^{\circ}$ e $\S 4^{\circ}$; Ordenações Manuelinas, Livro III, Título XXIX, $\S 1^{\circ}, 2^{a}$ parte, e $\S 3^{\circ}$; Ordenações Filipinas, Livro III, Título XLIII, $\S 2^{\circ}$ e $\S 4^{\mathrm{o}^{79}}$ ). Havia a previsão de sanções para a parte que se recusasse a jurar sem justa razão. Se fosse o autor, perdia toda a ação; se fosse o réu, presumia-se que havia confessado todos os fatos alegados pelo demandante (Ordenações Afonsinas, Livro III, Título XXXIX, pr., parte final; Ordenações Manuelinas, Livro III, Título XXIX, pr., parte final; Ordenações Filipinas, Livro III, Título XLIII, pr., parte final). Lobão ${ }^{80}$ afirma que a parte podia purgar a contumácia realizando o juramento antes do advento da sentença que cominava a pena. Já a falta de juramento por parte do procurador, do tutor, do síndico, do ecônomo, ou de outro administrador, não prejudicava a parte ${ }^{81}$.

Segundo Luso Soares ${ }^{82}$, o juramento de calúnia incorporado pelas Ordenações caiu em descrédito porque as pessoas juravam que eram litigantes probos, dando garantia disso, com o fim de mentirem impunemente depois. Nas palavras do autor, foi "um remédio que voltou contra si, envenenada, a arma que ingenuamente erguera em prol da verdade".

A doutrina dá destaque a outros dispositivos das Ordenações destinados a prevenir e punir o abuso do direito no processo $^{83}$ : (a) dependendo da malícia do vencido, ele podia

\footnotetext{
${ }^{79}$ Não obstante a existência e vigência de tais normas, Lobão (Collecção de Dissertações e Tractados Varios em Supplemento ás Segundas Linhas sobre o Processo Civil e ás Notas a Elles Relativas, Tractado VII, § 22, p. 266) afirma que, na prática, não estava em uso o $\S 2^{\circ}$ do Título XLIII do Livro III das Ordenações Filipinas.

${ }^{80}$ Collecção de Dissertações e Tractados Varios em Supplemento ás Segundas Linhas sobre o Processo Civil e ás Notas a Elles Relativas, Tractado VII, $\S \S 6^{\circ}$ e $7^{\circ}$, p. 257.

${ }^{81}$ Acerca do juramento de calúnia nas Ordenações, consultar: SOBRINHO, Dever de Veracidade das Partes no Processo Civil, pp 58-60; PEREIRA E SOUSA, Primeiras Linhas sobre o Processo Civil, tomo I, § CCXLVII e nt. 521, pp. 214-216; LOBÃO, Collecção de Dissertações e Tractados Varios em Supplemento ás Segundas Linhas sobre o Processo Civil e ás Notas a Elles Relativas, Tractado VII, pp. 251-269; RAMALHO, Praxe Brasileira, § 193, pp. 300-302; RIBAS, Consolidação das Leis do Processo Civil Commentada pelo Conselheiro Dr. Antonio Joaquim Ribas com a Colloboração de seu Filho Dr. Julio A. Ribas, vol. I, commentario CCLXXXVIII, pp. 313-315; CASTRO FILHO, Abuso do Direito no Processo Civil, pp. 77-78.

${ }^{82}$ A Responsabilidade Processual Civil, p. 204, nt. 438.

${ }^{83}$ CASTRO FILHO, Abuso do Direito no Processo Civil, pp. 73-76 e 77-78.
} 
ser condenado ao pagamento das custas em dobro ou tresdobro e, se não fossem encontrados bens suficientes para satisfazer o crédito decorrente dessa condenação, podia ter o seu direito de liberdade suprimido, pagando a dívida na cadeia (Ordenações Afonsinas, Livro III, Título LXX, $\S \S 3^{\circ}$ e $4^{\circ}$; Ordenações Manuelinas, Livro III, Título LI, $\S 4^{\text {o }}$; Ordenações Filipinas, Livro III, Título LXVII, $\S 1^{\text {o }}$ ); (b) se se demandasse, maliciosamente, em juízo débito maior que o devido, o autor era condenado a pagar custas em tresdobro na parte em que o réu fosse vencedor, enquanto o réu tinha que pagar somente custas singelas referentes à parte do mérito em que tivesse sido condenado (Ordenações Afonsinas, Livro III, Título XXXII, pr. e $\S 1^{\text {}}$; Ordenações Manuelinas, Livro III, Título XXV, pr.; Ordenações Filipinas, Livro III, Título XXXIV, pr.); (c) se se cobrasse, maliciosamente, em juízo dívida já paga, o autor era condenado a pagar ao réu o dobro do que já tivesse recebido e, nas Ordenações Manuelinas e Filipinas, também era condenado nas custas em dobro (Ordenações Afonsinas, Livro III, Título XXXIV, $\S 1^{\text {o }}$; Ordenações Manuelinas, Livro III, Título XXVII, pr.; Ordenações Filipinas, Livro III, Título XXXVI, pr.); (d) se, em uma ação real, o réu negasse ao juiz que estava na posse da coisa, mas o autor provasse o contrário, aquele perdia a posse (Ordenações Afonsinas, Livro III, Título XXVI, $\S 1^{\circ}$, e Título CXXVII; Ordenações Filipinas, Livro III, Título XL, pr.); (e) no chamamento à autoria, se o convocado demonstrasse a legitimidade do seu direito sobre a coisa reivindicada, o réu principal era absolvido e o autor tinha que lhe pagar o valor da coisa em dobro, além de ser condenado nas custas em dobro ou tresdobro, dependendo de sua malícia (Ordenações Afonsinas, Livro III, Título XLI, § 1º; Ordenações Manuelinas, Livro III, Título XXXI, § 1º; Ordenações Filipinas, Livro III, Título XLIV, § $1^{\circ}$ ); (f) a parte que quisesse nomear à autoria devia jurar que não estava agindo maliciosamente, nem para prolongar o feito, caso contrário o seu pedido de nomeação à autoria não era recebido (Ordenações Afonsinas, Livro III, Título XL, pr.; Ordenações Manuelinas, Livro III, Título XXX, pr.; Ordenações Filipinas, Livro III, Título XLV, $\S 1^{\circ}$ ); (g) a apresentação, em juízo, de documento falso era sancionada (Ordenações Afonsinas, Livro III, Título LXV, $\S \S 3^{\circ}$ e $4^{\text {o }}$; Ordenações Manuelinas, Livro III, Título XLVI, $\S 4^{\text {o }}$; Ordenações Filipinas, Livro III, Título LX, $\S 4^{\circ}$ ); (h) a parte que alegasse que o documento apresentado por sua adversária era falso, mas não conseguisse provar isso, também sofria sanção (Ordenações Afonsinas, Livro III, Título LXV, § 9º Ordenações Manuelinas, Livro III, Título XLVI, § 5; Ordenações Filipinas, Livro III, Título LX, § 5º; (i) o vencido que atrasasse a execução por meio de embargos, ou que fizesse com que a execução não acabasse dentro do prazo de três meses por culpa sua, era punido com pena de prisão até a 
satisfação do direito do vencedor da demanda (Ordenações Filipinas, Livro III, Título LXXXVI, § 18); (j) o advogado que opusesse embargos de matéria velha e que já tivesse sido tratada no feito principal, dilatando a duração do processo, sofria sanção pecuniária, além de ter suas atividades suspensas pelo tempo que o juiz entendesse ser suficiente em cada caso concreto (Ordenações Filipinas, Livro III, Título LXXXVII, § 10); etc.

O Livro III das Ordenações Filipinas regeu amplamente o processo civil brasileiro até a promulgação do Regulamento $\mathrm{n}^{\circ} 737$, em 1.850, que passou a regular as causas comerciais, permanecendo os processos sobre questões civis regidos pela legislação lusitana. Em 1.890, o Decreto no 763 estatuiu que o referido Regulamento devia ser observado no processo das causas cíveis em geral, com algumas exceções ${ }^{84}$.

De acordo com a doutrina brasileira da segunda metade do século XIX, o juramento de calúnia geral, previsto nas Ordenações, foi abolido pelo art. 10 da "Disposição Provisória acerca da administração da Justiça Civil”, anexa ao Código de Processo Criminal do Império, de 29 de novembro de 1.832. O juramento particular continuou sendo prestado em alguns casos, como, por exemplo, para reforma de termos, vista para embargos de terceiro, bem como em outras situações em que não podia haver prova, exceto o juramento da própria parte ${ }^{85}$.

Durante o Império e nos primórdios da República, o ordenamento jurídico brasileiro previa apenas algumas sanções a condutas processuais temerárias, ainda de maneira fragmentária, demonstrando um mínimo de preocupação com a malícia dos sujeitos do processo. Elas estavam presentes, por exemplo, no Regulamento $\mathrm{n}^{\mathrm{o}} 737$ de $1.850^{86}$ e no Decreto $\mathrm{n}^{\mathrm{o}} 3.084$ de 1.898 (consolidação das leis referentes à Justiça Federal $)^{87}$.

${ }^{84}$ SOBRINHO, Dever de Veracidade das Partes no Processo Civil, pp. 61-62.

${ }^{85}$ É o que afirmam: RIBAS, Consolidação das Leis do Processo Civil Commentada pelo Conselheiro Dr. Antonio Joaquim Ribas com a Colloboração de seu Filho Dr. Julio A. Ribas, vol. I, commentario CCLXXXVIII, p. 315; e RAMALHO, Praxe Brasileira, § 193, p. 301 e p. 302, nt. "c".

${ }^{86}$ Exemplos de disposições que demonstravam preocupação com a malícia processual: na exceção de suspeição do juiz, quando o excipiente fosse vencido, ele era condenado nas custas em tresdobro e em multa (arts. 87 e 94); se o embargo ou arresto fosse requerido com má-fé, o embargado tinha o direito de pedir, mediante a ação competente, as perdas e danos que lhe resultassem da medida (art. 337) (CASTRO FILHO, Abuso do Direito no Processo Civil, p. 80).

${ }^{87}$ Esse ato normativo regulava o processo na justiça federal e previa as seguintes situações de abuso do processo: faculdade de o embargado pedir perdas e danos, mediante ação própria, quando o arresto ou embargo fosse requerido de má-fé (art. 127); custas em tresdobro quando a exceção de suspeição fosse rejeitada (art. 187, § $8^{\circ}$ ); custas em dobro se a oposição fosse rejeitada (art. 227); reversão ao Tesouro das multas impostas como penas disciplinares (art. 281); na ação executiva por aluguéis, quando o réu provasse já haver pago o aluguel, no todo ou em parte, o autor devia pagar custas em tresdobro (art. 435); se o executado escondesse bens à penhora, era condenado à pena de prisão de até um ano (art. 524); custas de retardamento pelo oferecimento de artigos cujo fim não fosse a absolvição ou a condenação do réu e que não fossem recebidos ou que, se recebidos, não fossem julgados provados (art. 763); custas em tresdobro ou em 
Nos Códigos dos Estados, que vigoraram no período de autonomia estadual para legislar sobre processo, também era possível encontrar dispositivos versando sobre o abuso de situações jurídicas processuais. Podem ser citados como exemplos ${ }^{88}$ : o Código de Minas Gerais (Lei $\left.n^{\circ} 830 / 1.922\right)^{89}$, o de São Paulo (Lei $\left.n^{\circ} 2.421 / 1.930\right)^{90}$, o da Bahia (Lei $n^{\text {o }}$ $1.121 / 1.915)^{91}$, o do Rio Grande do Sul (Decreto $\left.n^{\circ} 65 / 1.908\right)^{92}$, o de Pernambuco (Ato $n^{\circ}$ 907/1.924) ${ }^{93}$, o do Rio de Janeiro (Lei n $\left.{ }^{\text {o }} 1.580 / 1.919\right)^{94}$ e o do Distrito Federal (Decreto ${ }^{\text {o }}$ $16.752 / 1.924)^{95}$.

dobro ao autor que pedisse mais do que lhe fosse devido, ou que pedisse antes do vencimento ou implemento da condição (art. 764); obrigação de restituição em dobro ao que demandasse por dívida já paga (art. 764, § $2^{\circ}$ ); e, se houvesse malícia do vencido, este podia ser condenado nas custas em dobro ou tresdobro (art. 765) (CASTRO FILHO, Abuso do Direito no Processo Civil, pp. 80-81).

${ }^{88}$ CASTRO FILHO, Abuso do Direito no Processo Civil, pp. 81-83.

${ }^{89}$ Exemplos: imposição de multa de $5 \$ 000$ a $100 \$ 000$ ao excipiente que fosse vencido na exceção de suspeição do juiz (art. 196); custas em dobro ao réu que nomeasse à autoria pessoa que não possuísse a coisa em seu nome (art. 227); custas de retardamento em dobro ao opoente vencido (art. 236); quando o arresto fosse requerido de má-fé, o arrestado tinha o direito de pedir a indenização de perdas e interesses mediante ação própria (art. 402), o que também se aplicava ao sequestro (art. 426) e à detenção pessoal, quando esta fosse requerida culposa ou dolosamente, acarretando ao requerente também a condenação das custas em décuplo (art. 438); ao arguente de falsidade que agisse com dolo ou sem guardar as precauções ordinárias eram impostas custas em décuplo (art. 538); multa de $100 \$ 000$ ao advogado que interpusesse agravo claramente incabível (art. 1.486).

${ }_{90}$ Podem ser mencionadas as seguintes medidas repressivas de abusos: condenação ao pagamento de custas em tresdobro de quem nomeasse à autoria pessoa ilegítima (art. 76); responsabilidade do credor requerente do arresto (art. 372).

${ }^{91}$ Reprimia as seguintes práticas abusivas: se o autor propusesse a ação e prosseguisse nela, sendo que a outra parte, desde o princípio, concordasse com a sua pretensão, ele era condenado nas custas (art. 50); o embargado ou arrestado que fosse requerido de má-fé tinha o direito de pedir as perdas e danos mediante a ação competente (art. 942).

${ }^{92}$ Estatuía que o demandante da exceção de suspeição devia ser condenado a perder a caução prestada (100\$000 para suspeição de desembargador e $50 \$ 000$ para suspeição de juiz), bem como a pagar as custas do retardamento (art. 182).

${ }^{93}$ Previa os seguintes preceitos sancionadores do abuso de situações jurídicas processuais, dentre outros: custas de retardamento em dobro ao réu que nomeasse à autoria pessoa que não possuísse a coisa em seu nome (art. 408); custas em dobro se a arguição de falsidade fosse rejeitada liminarmente, elevando-se ao décuplo se o arguente tivesse agido com dolo ou propósito de retardar o andamento da causa (art. 435); se o arresto fosse requerido de má-fé, o arrestado tinha direito de pedir a indenização de perdas e danos, mediante a ação competente (art. 829), regra essa que também valia para o sequestro (art. 834) e para a detenção pessoal (art. 846) etc.

${ }_{94}$ Além de outros dispositivos, continha as seguintes regras gerais: se houvesse malícia da parte do vencido, ele podia ser condenado, ao arbítrio do juiz, a pagar custas em dobro ou em tresdobro (art. 471); de acordo com o art. 2.371, ainda quando não estivesse expressamente estatuído nas normas processuais, o erro, o dolo, a fraude e a simulação podiam ser arguidos pela pessoa lesada ou prejudicada, observados os arts. 97 e 104 do Código Civil de 1916.

${ }^{95}$ A título exemplificativo, podem ser citados os seguintes dispositivos: aplicava-se a pena de confesso se o depoimento pessoal da parte fosse requerido e ela não fosse encontrada no lugar indicado ou se se recusasse a depor (art. 88); condenação ao pagamento de multa de 1:000\$000 se a arguição de suspeição do juiz fosse recusada ou condenação ao pagamento das custas em dobro quando a exceção fosse rejeitada liminarmente (art. 122, $\S \S 1^{\circ} \mathrm{e} 4^{\circ}$ ); custas em tresdobro ao que nomeasse à autoria pessoa que não possuísse a coisa em seu nome (art. 155); custas de retardamento em dobro ao opoente que decaísse da oposição (art. 167); contagem das multas impostas ao litigante de má-fé como custas (art. 290); o arguente de falsidade que agisse de má-fé era condenado nas custas em tresdobro (art. 453); era imposta multa de $100 \$ 000$ ao advogado que interpusesse agravo fora dos casos expressos na lei (art. 1.140); se o arresto fosse requerido de má-fé, o arrestado tinha direito à indenização dos prejuízos e interesses (art. 397), o que também se aplicava ao sequestro (art. 402); pena de prisão à parte que não obedecesse à exibição judicial deferida (art. 428). 
$\mathrm{O}$ abuso de situações jurídicas processuais somente recebeu tratamento sistematizado no Código de Processo Civil nacional (Decreto-lei $\mathrm{n}^{\mathrm{o}}$ 1.608/39). O legislador, ao elaborá-lo, houve por bem tratar do tema em vários dispositivos esparsos ${ }^{96} \mathrm{e}$ dedicar os artigos $3^{\circ}$ e 63 à fixação do seu conceito e de suas consequências ${ }^{97}$, atuando como "normas gerais repressoras" 98 . Segundo a doutrina que estudou esse diploma legislativo, as modalidades de abuso processual nele previstas eram: (a) o dolo, que se subdividia em dolo substancial e instrumental; (b) a temeridade; (c) a fraude, que abrangia o processo aparente e o processo simulado; (d) a emulação; (e) o capricho; (f) o erro grosseiro; (g) a violência; (h) a protelação da lide; (i) a falta ao dever de dizer a verdade; e (j) a situação intermediária do poder de disposição do processo. As três primeiras espécies são consideradas oriundas do direito material, enquanto as demais são típicas do processo $^{99}$.

O atual Código de Processo Civil também versa sobre a matéria em inúmeros dispositivos, tais como os artigos 14; 16 a 18; 22; 129; 273, II; 267, § $3^{\circ}$; 485, III; 488, II; 538, parágrafo único; 557, § 2º 600 e 601 etc., os quais serão estudados de maneira mais minuciosa nos capítulos 2 e 3 "infra".

Sendo o abuso do processo um problema "velho como o próprio direito, e, paradoxalmente, imortal como este" ${ }^{" 100}$, é natural a existência dos supracitados atos normativos preventivos e sancionadores de comportamentos processuais ímprobos,

\footnotetext{
${ }^{96}$ Seguindo os ensinamentos de Castro Filho (Abuso do Direito no Processo Civil, p. 85, nt. 60), merecem destaque os seguintes artigos do Código de Processo Civil de 1939: 17; 23; 36; 48; 59; 61; 62; 65; 77; 100; $115 ; 117 ; 120 ; 131 ; 160 ; 166, \S 2^{\mathrm{o}} ; 179 ; 182, \S 1^{\mathrm{o}} ; 186 ; 189 ; 201 ; 218 ; 219, \mathrm{n}^{\mathrm{o}}$ II $; 220\left(3^{\mathrm{o}}\right) ; 221 ; 224 ; 229$ e $\S$; $231 ; 238 ; 243 ; 252 ; 266 ; 277 ; 372 ; 385 ; 474 ; 476 ; 688 ; 712 ; 780 ; 817 ; 895 ; 920, \S$ 3; e 924 .

${ }^{97}$ Esses dispositivos estatuíam o seguinte:

“Art. $3^{\circ}$ Responderá por perdas e danos a parte que intentar demanda por espírito de emulação, mero capricho, ou erro grosseiro.

Parágrafo único. O abuso de direito verificar-se-á, por igual, no exercício dos meios de defesa, quando o réu opuser, maliciosamente, resistência injustificada ao andamento do processo";

“Art. 63. Sem prejuízo do disposto no art. $3^{\circ}$, a parte vencida, que tiver alterado, intencionalmente, a verdade, ou se houver conduzido de modo temerário no curso da lide, provocando incidentes manifestamente infundados, será condenada a reembolsar à vencedora as custas do processo e os honorários do advogado. $\S 1^{\circ}$ Quando, não obstante vencedora, a parte se tiver conduzido de modo temerário em qualquer incidente ou ato do processo, o juiz deverá condená-la a pagar à parte contrária as despesas a que houver dado causa.

$\S 2^{\circ}$ Quando a parte, vencedora ou vencida, tiver procedido com dolo, fraude, violência ou simulação, será condenada a pagar o décuplo das custas.

$\S 3^{\circ}$ Se a temeridade ou malícia for imputável ao procurador o juiz levará o caso ao conhecimento do Conselho local da Ordem dos Advogados do Brasil, sem prejuízo do disposto no parágrafo anterior".

${ }^{98}$ CASTRO FILHO, Abuso do Direito no Processo Civil, p. 84.

99 CASTRO FILHO, Abuso do Direito no Processo Civil, pp. 87-88. Endossam esse entendimento: THEODORO JÚNIOR, Abuso de Direito Processual no Ordenamento Jurídico Brasileiro, in Revista Forense, v. 344, pp. 43-44; STOCO, Abuso do Direito e Má-Fé Processual - aspectos doutrinários, p. 64.

${ }^{100}$ CASTRO FILHO, Abuso do Direito no Processo Civil, p. 214.
} 
elaborados desde o Direito romano e a Idade Média ${ }^{101}$. Acontece que, até o surgimento e consolidação da teoria do abuso do direito, no âmbito do Direito privado, esses textos legais eram analisados separada e desordenadamente, como se não houvesse nada em comum entre eles. Foi a moderna teoria do abuso do direito que forneceu o esquema dogmático necessário para ordenar as hipóteses de abuso processual que já eram previstas no ordenamento jurídico e identificadas pela jurisprudência ${ }^{102}$. Logo, a teoria do abuso processual deve ser vista como uma derivação da teoria do abuso do direito, ou seja, como uma adaptação desta às peculiaridades do processo ${ }^{103} 104$.

${ }^{101}$ É o que constata Bonumá (Direito Processual Civil, vol. I, p. 511):

"As medidas de repressão contra os litigantes temerários já se encontravam no direito romano e abundavam no processo das Ordenações do Reino. É, portanto, um problema velho de muitos séculos".

${ }^{102}$ CATALANO, L'Abuso del Processo, pp. 19-20.

${ }^{103}$ Vários autores defendem que a teoria do abuso do processo foi transplantada do Direito civil, tais como: ABDO, O Abuso do Processo, p. 26; OLIVEIRA, Litigância de Má-Fé, pp. 25-34; STOCO, Abuso do Direito e Má-Fé Processual - aspectos doutrinários, pp. 64-65; THEODORO JÚNIOR, Boa-Fé e Processo: princípios éticos na repressão à litigância de má-fé - papel do juiz, in MARINONI (coord.), Estudos de Direito Processual Civil - homenagem ao professor Egas Dirceu Moniz de Aragão, p. 643; THEODORO JÚNIOR, Abuso de Direito Processual no Ordenamento Jurídico Brasileiro, in Revista Forense, v. 344, p. 51; CASTRO FILHO, Abuso do Direito no Processo Civil, p. 31; PONTES DE MIRANDA, Comentários ao Código de Processo Civil, tomo I, p. 384; OTEIZA, Abuso de los Derechos Procesales en América Latina, in BARBOSA MOREIRA (coord.), Abuso dos Direitos Processuais, pp. 15-18 e 31; LUCAS SOSA, Abuso de Derechos Procesales, in BARBOSA MOREIRA (coord.), Abuso dos Direitos Processuais, pp. 41 e 67-68; MENEZES CORDEIRO, Litigância de Má-Fé, Abuso do Direito de Ação e Culpa "in Agendo", p. 77; DONDI, Abuse of Procedural Rights: regional report for Italy and France, in TARUFFO (ed.), Abuse of Procedural Rights: comparative standards of procedural fairness, pp. 109-110 e 114; TAELMAN, Abuse of Procedural Rights: regional report for Belgium-The Netherlands, in TARUFFO (ed.), Abuse of Procedural Rights: comparative standards of procedural fairness, p. 125; FALCO, La Buona Fede e l'Abuso del Diritto: principi, fattispecie e casistica, pp. 25, 26 e 504.

${ }^{104}$ Diante disso, não se pode concordar com Catalano (L'Abuso del Processo, pp. 9-26), que defende a autonomia conceitual da noção de abuso do processo em relação ao abuso do direito. A doutrinadora sustenta esse entendimento com base nos seguintes argumentos:

a) a origem e a função histórica do abuso do direito e do abuso do processo são distintas. A autora observa que, no Direito romano clássico, não se conhecia a noção de abuso do direito como categoria dogmática geral, nem havia uma nítida noção de "emulatio", a qual foi elaborada completamente apenas no Direito intermédio. Em contrapartida, no processo civil romano, já eram conhecidos conceitos gerais de abuso processual (como a noção de "temeritas"), bem como eram utilizados remédios de repressão e prevenção da improbidade processual;

b) apesar de os conceitos gerais de abuso processual e de abuso do direito se apoiarem em uma idêntica intuição empírica e obedecerem aos mesmos postulados de justiça substancial, eles possuem uma diversidade de "ratio" decorrente da diferença entre situações subjetivas substanciais e situações subjetivas processuais;

c) o quadro sancionatório aplicável às situações de abuso processual é distinto do aplicável aos casos de abuso do direito;

d) as regras que sancionam o abuso processual são autônomas em relação às normas gerais que vedam o abuso do direito, tanto nos ordenamento jurídicos nacionais, quanto nas normas internacionais (e.g., de um lado, o art. 17 da Convenção Europeia dos Direitos do Homem contém proibição do abuso dos direitos nela estatuídos; do outro, o art. 35 da mesma Convenção trata especificamente do exercício abusivo do direito de recorrer à Corte Europeia dos Direitos do Homem, sancionando-o com a não-recepção do recurso);

e) a autonomia do abuso do processo em relação ao abuso do direito é confirmada pelo Direito inglês, no qual aquele é um tema amplamente discutido e desenvolvido, enquanto este não é difundido;

f) as escalas de valores empregadas para reconhecer as hipóteses de abuso nos âmbitos da autonomia privada e do processo são diferentes. Isso se reflete nos critérios que são utilizados para imputar o comportamento abusivo ao seu autor: adota-se a teoria objetiva ao tratar do abuso do direito, mas prefere-se a concepção subjetiva na conceituação do abuso processual; e 
É importante observar que a "importação" da teoria do abuso do direito não pode ser feita às cegas. Em primeiro lugar, devem-se identificar quais garantias e princípios inerentes ao Direito processual lhe dão espeque. Em seguida, é preciso adaptar a teoria do abuso às peculiaridades da relação jurídica processual, que, como é sabido, possui objeto, sujeitos e pressupostos distintos dos da relação jurídica de direito substancial. Feito isso, cumpre identificar os elementos essenciais do abuso do processo. Os próximos itens deste capítulo destinam-se a essa tarefa de adaptação da teoria do abuso do direito ao processo e de delimitação do conceito de abuso processual. Mas, antes disso, é necessário fazer uma breve análise crítica da corrente doutrinária que se recusa a admitir a adoção da teoria do abuso do direito pelo Direito processual.

\subsubsection{Análise crítica da corrente doutrinária que nega a adoção da teoria do abuso do direito}

g) por fim, a autora afirma que a autonomia da noção de abuso processual reflete-se na propensão que a corrente doutrinária italiana que nega a existência do abuso do direito tem de acolher a categoria técnicojurídica do abuso do processo.

"Data venia", não parece correto afirmar que a noção de abuso do processo tem autonomia em relação à teoria do abuso do direito pelas seguintes razões:

a) no Direito romano, havia realmente diversas normas de prevenção e repressão do abuso do processo. Porém, diferentemente do que afirma Catalano, os romanos eram avessos a teorizações gerais (MENEZES CORDEIRO, Da Boa Fé do Direito Civil, pp. 672-673), logo, não se pode afirmar que eles conceberam o abuso do processo como uma categoria expressa em princípios gerais. Além disso, da mesma forma como a elaboração de um conceito científico de direito subjetivo (jussubjetivização), ligado a ideias de absolutização, foi necessário para o desenvolvimento da teoria do abuso do direito na seara privada, a criação da teoria do abuso de situações jurídicas processuais também dependeu da emancipação científica e dogmática do processso civil e dos estudos a respeito das situações jurídicas processuais, o que somente teve início na segunda metade do século XIX;

b) não é cientificamente seguro embasar a existência de conceitos gerais de abuso processual na noção de "temeritas", uma vez que a doutrina nem mesmo consegue definir ao certo o sentido dessa palavra no Direito romano (acerca das teorias sobre a noção de "temeritas", consultar: CHIOVENDA, La Condanna nelle Spese Giudiziali, $\S \S 26$ e 27, pp. 32-33);

c) o fato de as hipóteses de abuso do direito e de abuso do processo estarem previstas em textos legais distintos não é motivo suficiente para defender a autonomia do segundo conceito em relação ao primeiro. No Direito brasileiro, o abuso do direito contra consumidores está previsto em lei especial (a Lei $\mathrm{n}^{\mathrm{o}}$ 8.078/90) e nem por isso é tido como um instituto diverso do regulado pelo art. 187 do CC;

d) a própria Catalano (L'Abuso del Processo, pp. 25-26) explica a razão pela qual o abuso do direito não é um assunto amplamente desenvolvido no Direito inglês. Segundo ela, a teoria do abuso do direito não se mostrou necessária por causa da existência do instituto do "tort de nuisance", destinado a resolver conflitos entre proprietários de bens imóveis no Direito inglês, função essa que, como já foi visto anteriormente, ensejou a elaboração daquela teoria na França e na Bélgica.

$\mathrm{Na}$ realidade, a teoria do abuso processual deve ser vista como uma adaptação da teoria do abuso do direito às peculiaridades do processo, o que justifica o fato de ela possuir fundamentos, sujeitos, objeto, requisitos e sanções próprios. Aliás, Castro Filho (Abuso do Direito no Processo Civil, p. 15) já havia notado que, apesar de o abuso do processo advir da teoria do abuso do direito, há diferenças entre os dois institutos:

"Ora, no processo civil, até aqui, vêm sendo geralmente invocadas, para a caracterização do abuso do direito, as mesmas noções gerais elaboradas pelo direito privado, quando, na realidade, aqui, o problema oferece aspectos ou feições singulares que tornam possível, senão exigem, ao nosso ver, tratamento diverso". 
Apesar de a maioria dos doutrinadores contemporâneos sustentar que a teoria do abuso do direito se aplica ao processo civil, ainda é possível encontrar vozes contrárias a esse entendimento.

É o caso de Méndez, que desaprova a existência de normas preventivas e repressivas do abuso do processo, pois, segundo ele, existe o risco de essa questão ser tratada de maneira desproporcional, autoritária ${ }^{105}$. Em sua obra, é possível identificar três linhas de argumentação ${ }^{106}$ :

a) diante da proibição da autotutela nos Estados civilizados, a única forma lícita de o cidadão satisfazer uma pretensão legítima é por meio do ajuizamento de demanda perante o Poder Judiciário, exceto em casos excepcionais. O poder de ajuizar demandas precisa ser amplo, caso contrário os cidadãos não conseguiriam fazer valer todos os seus direitos. No entanto, na opinião do doutrinador, o autoritário sistema de prevenção e repressão do abuso do processo restringe a liberdade do cidadão de recorrer ao Judiciário, pois transforma o processo, que contém em si a luta por direitos, em uma "disputa bemeducada, sem discórdia e com abundância de saudações" (tradução nossa);

b) os ordenamentos jurídicos contemporâneos reconhecem uma série de direitos fundamentais e princípios aplicáveis ao processo (v.g., imutabilidade da coisa julgada, julgamento pelo juiz natural etc.). Quando um litigante alega a violação de um deles, o debate processual acerca dessa questão naturalmente enseja o dispêndio de tempo e de atividades das partes e do órgão jurisdicional. De acordo com Méndez, o autoritário sistema de prevenção e repressão do abuso processual associa a invocação desses direitos fundamentais e princípios processuais ao intuito protelatório ou ao desvio da questão principal do processo e considera o cidadão a causa da lentidão e excesso de serviço do Judiciário;

c) o ordenamento jurídico não confere direitos, nem impõe obrigações, aos sujeitos processuais; ele apenas atribui às partes expectativas e ônus, de acordo com o sistema contraditório. A maneira como essas situações jurídicas são exercidas é um problema que, na opinião do doutrinador, concerne apenas às partes. Para Méndez, a única consequência para a não-observância de uma norma processual deve ser, em princípio, a preclusão, sendo desproporcional a lei que prescreve condutas ou atividades processuais e fixa sanções às partes que não as cumprem. Diz que "uma dose de estratégia, que é realmente

\footnotetext{
105 Abuse of Procedural Rights? Spain and Portugal, in TARUFFO (ed.), Abuse of Procedural Rights: comparative standards of procedural fairness, p. 181.

${ }^{106}$ MÉNDEZ, Abuse of Procedural Rights? Spain and Portugal, in TARUFFO (ed.), Abuse of Procedural Rights: comparative standards of procedural fairness, pp. 187-190.
} 
um elemento do princípio do contraditório, não é incompatível com o sistema processual" (tradução nossa). Na sua opinião, uma norma geral prevendo a boa-fé seria o suficiente para lidar com as condutas processuais abusivas.

Na verdade, a teoria do abuso do processo não limita o acesso ao Poder Judiciário, como alega Méndez. Pelo contrário, seu objetivo é prevenir e sancionar comportamentos que impeçam o cidadão de obter uma tutela jurisdicional efetiva e que dificultem a realização das finalidades institucionais do processo (itens 1.3.1 e 1.3.4 "infra").

O jurista espanhol também se engana ao relacionar a prevenção e a repressão do abuso do processo com a limitação do poder de pleitear a observância de um direito fundamental ou de um princípio processual. O exercício de uma situação jurídica processual só é considerado abusivo se ficar constatado o desvio de finalidade (item 1.6.2 “infra"). Logo, a invocação de um direito fundamental ou de um princípio processual não pode ser sancionada, ainda que provoque atraso na prestação da tutela jurisdicional, a não ser que seja feita com o fim de atingir finalidade ilícita ou ilegítima.

Por fim, levando em consideração o ordenamento jurídico nacional, não é possível negar que os sujeitos do processo são titulares de deveres (como o de veracidade, de lealdade, de prontidão e os decorrentes do princípio da cooperação - itens 1.3 .6 e 1.3.7 "infra") e que a violação de alguns deles enseja a aplicação de sanções, o que põe por terra o terceiro argumento de Méndez.

A teoria do abuso do processo também encontra alguma resistência no Brasil. Vincenzi ${ }^{107}$, por exemplo, não admite a incorporação da teoria do abuso do direto pelo ordenamento processual brasileiro, alegando dois motivos principais:

a) a aplicação da teoria do abuso do direito é muito tortuosa e complexa para ser envolvida em um procedimento judicial;

b) essa teoria foi assimilada à responsabilidade civil, de modo que ela acarreta apenas a imposição do dever de indenizar a parte prejudicada por perdas e danos.

A autora afirma que os deveres do art. 14 do CPC, a litigância de má-fé (arts. 16-18 do CPC) e os atos atentatórios à dignidade da Justiça (arts. 600 e 601 do CPC) são institutos jurídicos que não podem ser equiparados e critica quem pretende tratá-los como espécies de abuso do processo. Segundo ela, na seara processual, o abuso do direito só foi consagrado no art. $3^{\circ}$ do CPC $39^{108}$ e, atualmente, no art. 273, II, do CPC ${ }^{109} 110$.

\footnotetext{
${ }^{107}$ A Boa-Fé no Processo Civil, p. 177.

108 “Art. $3^{\circ}$ Responderá por perdas e danos a parte que intentar demanda por espírito de emulação, mero capricho, ou erro grosseiro.
} 
Ocorre que nenhum desses argumentos parece proceder. A alegação de que a teoria do abuso do direito não poderia ser utilizada por ser excessivamente intrincada não se mantém porque a proposta que a doutrinadora faz para substituí-la apresenta idêntico grau de complexidade. Vincenzi não defende a impunidade das condutas que a maioria dos autores trata como abuso do processo. Ela as denomina como "exercício inadmissível de posições jurídicas processuais" e fundamenta a sua repressão no princípio geral da boa-fé objetiva $^{111}$. Segundo a autora, esse princípio rege o ordenamento jurídico processual brasileiro e os deveres previstos no art. 14 do CPC são corolários do mesmo ${ }^{112}$. Na prática, essa tese alcança o mesmo resultado que a dos defensores da incorporação da teoria do abuso do direito ao processo civil. A única distinção entre as duas correntes doutrinárias é a terminologia: enquanto uma engloba as condutas processuais ímprobas no gênero "abuso do processo", a outra prefere denominá-las "exercício inadmissível de posições jurídicas processuais".

Além disso, quando Vincenzi assevera que a teoria do abuso do direito foi assimilada à responsabilidade civil, ela parece desconsiderar as diversas outras consequências advindas do abuso do processo, como a incidência de multas, a obrigação de arcar com o custo financeiro do processo, a antecipação de tutela etc $^{113}$. Até mesmo no Direito privado, o dever de indenizar não é considerado o único efeito jurídico do abuso do direito, dada a possibilidade de ele servir de fundamento também para a desconsideração da personalidade jurídica (art. 50 do CC) ${ }^{114}$.

Conclui-se, portanto, que não há qualquer óbice à adoção, na seara processual, da teoria do abuso do direito, elaborada originalmente pelos estudiosos do direito de propriedade.

Parágrafo único. O abuso de direito verificar-se-á, por igual, no exercício dos meios de defesa, quando o réu opuser, maliciosamente, resistência injustificada ao andamento do processo" (destaque nosso).

109 “Art. 273. O juiz poderá, a requerimento da parte, antecipar, total ou parcialmente, os efeitos da tutela pretendida no pedido inicial, desde que, existindo prova inequívoca, se convença da verossimilhança da alegação e:

$[\ldots]$

II - fique caracterizado o abuso de direito de defesa ou o manifesto propósito protelatório do réu" (destaque nosso).

${ }^{110}$ VINCENZI, A Boa-Fé no Processo Civil, pp. 92 e 95, nt. 53.

${ }^{111}$ VINCENZI, A Boa-Fé no Processo Civil, pp. 24, 167-172 e 176.

112 VINCENZI, A Boa-Fé no Processo Civil, p. 98.

113 O capítulo 3 "infra" é dedicado ao estudo mais aprofundado das consequências jurídicas do abuso do processo.

${ }^{114}$ Acerca do abuso do direito no Direito privado, consultar a nota 39 "supra". 
É lícito até mesmo afirmar que o processo civil é um campo mais vasto para as condutas abusivas que o Direito privado, uma vez que ${ }^{115}$ :

a) via de regra, o processo se forma quando não existe mais harmonia de vontades entre as partes e desenvolve-se como uma luta de interesses, em que cada litigante busca a vitória, ainda que à custa do sacrifício do direito alheio;

b) a prestação da tutela jurisdicional exige o dispêndio de tempo na realização de providências indispensáveis para o julgamento da demanda e de seus incidentes, o que dá ensejo a condutas processuais procrastinatórias.

\subsection{Fundamentos da prevenção e da repressão do abuso do processo}

No ordenamento jurídico brasileiro, a farta previsão legislativa de medidas preventivas e de sanções ao abuso de situações jurídicas processuais encontra sete ordens de fundamentos: (a) o princípio da inafastabilidade do controle jurisdicional (art. $5^{\circ}$, XXXV, da CF); (b) a garantia da razoável duração do processo (art. $5^{\circ}$, LXXVIII, da CF); (c) as garantias da igualdade e da ampla defesa (art. $5^{\circ}$, "caput" e LV, da CF); (d) o respeito às finalidades institucionais do processo; (e) o princípio da boa-fé; (f) o princípio da cooperação; e (g) os deveres gerais dos sujeitos processuais (deveres de veracidade, de lealdade, de prontidão e de utilidade).

\subsubsection{O princípio da inafastabilidade do controle jurisdicional (art. $5^{\circ}, \mathrm{XXXV}$, da CF)}

Originalmente, entendia-se que o art. $5^{\circ}, \mathrm{XXXV}$, da CF previa tão somente a garantia da ação, que assegura o acesso ao Poder Judiciário a todo cidadão que sofra uma lesão, ou ameaça de lesão, a um direito seu, bem como o julgamento de sua pretensão ${ }^{116}$.

A doutrina mais recente sustenta que esse dispositivo constitucional tem um conteúdo ainda maior, trazendo em seu bojo o direito a um acesso efetivo à justiça. Entende-se que o chamado "princípio da inafastabilidade do controle jurisdicional" estatui que as pretensões devem ser aceitas em juízo, processadas e julgadas e que a tutela deve ser oferecida pelo órgão jurisdicional de maneira efetiva e tempestiva, respeitadas as regras

\footnotetext{
${ }^{115}$ CASTRO FILHO, Abuso do Direito no Processo Civil, pp. 31-32.

${ }^{116}$ Pretende-se incluir essa garantia expressamente no novo Código de Processo Civil, visto que o art. $3^{\circ}$ do Projeto de Lei $\mathrm{n}^{\circ}$ 8.046/2010 estatui o seguinte: "Não se excluirá da apreciação jurisdicional ameaça ou lesão a direito, ressalvados os litígios voluntariamente submetidos à solução arbitral, na forma da lei".
} 
técnicas do processo e a ordem constitucional ${ }^{117}$. Em outras palavras, não basta o acesso formal aos órgãos jurisdicionais; é preciso que a tutela jurisdicional seja concedida do modo mais justo e no menor espaço de tempo possível (resultado substancialmente justo $)^{118}$.

Nesse sentido, afirma-se que o acesso à justiça, como direito fundamental, compreende dois sentidos: (a) em sentido formal, garante a todos, sem qualquer tipo de discriminação, o acesso livre e em igualdade de condições ao órgão competente para tutelar os direitos subjetivos materiais lesados ou ameaçados; (b) em sentido substancial, assegura que todo e qualquer procedimento desenvolvido em juízo, após o adequado contraditório, deve proporcionar provimentos jurisdicionais justos, adequados e efetivos, aptos a atuar o direito material objeto do processo ${ }^{119}$.

Trata-se de entendimento influenciado pela interpretação que os doutrinadores italianos dão ao art. $24, \S 1^{\circ}$, da Constituição da Itália ("Todos podem agir em juízo para a tutela dos próprios direitos e interesses legítimos" - tradução nossa). Comoglio, Ferri e Taruffo $^{120}$ ensinam que o conteúdo desse dispositivo constitucional possui dois aspectos:

a) negativo: estabelece que a pessoa que age em juízo não tem qualquer certeza préconstituída, nem mesmo algum grau pré-constituído de probabilidade, de sucesso efetivo na demanda promovida, ou seja, a Constituição não assegura à parte, "a priori" a pronúncia de um provimento jurisdicional que acolha sua demanda;

b) positivo: assegura a cada litigante, "ex ante", a possibilidade efetiva (1) de realizar todas as atividades processuais tecnicamente mais idôneas a fazer valer os direitos ou interesses pleiteados; e (2) de obter, no caso de o provimento jurisdicional de mérito lhe ser favorável, uma forma de tutela adequada à satisfação da sua variável necessidade de tutela, salvaguardando, assim, a relação de adequação entre as exigências de tutela do sujeito que demanda em juízo e as formas de tutela disponíveis no ordenamento jurídico.

Pode-se afirmar, em resumo, que a ação em sentido constitucional não é um mero "direito ao processo", mas sim um "direito a uma tutela efetiva" ${ }^{121}$. De fato, em um Estado Democrático de Dirieto, não faria sentido entender que a Constituição garante ao cidadão

\footnotetext{
${ }^{117}$ DINAMARCO, Instituições de Direito Processual Civil, vol. I, § 79, p. 204; MARINONI, Garantia da Tempestividade da Tutela Jurisdicional e Duplo Grau de Jurisdição, in CRUZ E TUCCI (coord.), Garantias Constitucionais do Processo Civil - homenagem aos 10 anos da Constituição Federal de 1988, p. 218.

${ }^{118}$ LUCON, Abuso do Exercício do Direito de Recorrer, in NERY JÚNIOR; ALVIM WAMBIER (coords.), Aspectos Polêmicos e Atuais dos Recursos Cíveis e de Outras Formas de Impugnação às Decisões Judiciais, p. 879.

${ }^{119}$ THEODORO JÚNIOR, Direito Fundamental à Duração Razoável do Processo, p. 7.

${ }^{120}$ Lezioni sul Processo Civile, pp. 65-66.

${ }^{121}$ COMOGLIO; FERRI; TARUFFO, Lezioni sul Processo Civile, p. 64.
} 
apenas o direito a uma simples resposta do órgão jurisdicional, independentemente de ser ela efetiva e tempestiva, pois isso não seria suficiente para garantir os demais direitos. $\mathrm{O}$ direito de acesso efetivo à justiça é que merece o "status" de direito fundamental, uma vez que é ele o garantidor de todos os demais direitos substantivos ${ }^{122}$. Cappelletti e Garth ${ }^{123}$ têm razão ao considerarem o direito de acesso efetivo à justiça como o requisito fundamental de um sistema jurídico moderno e igualitário, que pretenda não só proclamar, mas também garantir os direitos de todos.

Uma vez fixado o teor da garantia constitucional contida no inciso XXXV do art. $5^{\circ}$ da $\mathrm{CF}$, é possível constatar que as condutas processuais abusivas contrariam-na frontalmente.

Em primeiro lugar, porque elas comprometem a outorga de uma tutela jurisdicional efetiva, visto que o litigante ímprobo utiliza os instrumentos processuais de maneira destorcida, dificultando que o processo alcance os fins próprios para os quais foi instituído ${ }^{124}$, o que será mais bem estudado no item 1.3.4 "infra".

Em segundo lugar, porque alguns atos processuais abusivos são praticados com intuito protelatório e eles são capazes de atrasar a entrega da prestação jurisdicional a ponto de torná-la inútil para o vencedor da demanda, ocorrendo denegação de justiça e, consequentemente, patente transgressão ao princípio da inafastabilidade do controle jurisdicional $^{125}$.

\subsubsection{A garantia da razoável duração do processo (art. $5^{\circ}$, LXXVIII, da CF)}

A Emenda Constitucional n ${ }^{\circ} 45 / 04$ inseriu o inciso LXXVIII no art. $5^{\circ}$ da CF, prevendo a garantia da razoável duração do processo, nos seguintes termos: "a todos, no âmbito judicial e administrativo, são assegurados a razoável duração do processo e os

\footnotetext{
122 Nesse sentido: MARINONI, Garantia da Tempestividade da Tutela Jurisdicional e Duplo Grau de Jurisdição, in CRUZ E TUCCI (coord.), Garantias Constitucionais do Processo Civil - homenagem aos 10 anos da Constituição Federal de 1988, p. 218.

${ }^{123}$ Acesso à Justiça, p. 12.

${ }^{124}$ PICÓ I JUNOY, El Principio de la Buena Fe Procesal y su Fundamento Constitucional, in Revista de Processo, n 196, pp. 154-156; MÉNDEZ, Abuse of Procedural Rights? Spain and Portugal, in TARUFFO (ed.), Abuse of Procedural Rights: comparative standards of procedural fairness, p. 181.

${ }^{125}$ LUCON, Abuso do Exercício do Direito de Recorrer, in NERY JÚNIOR; ALVIM WAMBIER (coords.), Aspectos Polêmicos e Atuais dos Recursos Cíveis e de Outras Formas de Impugnação às Decisões Judiciais, pp. 877-879; GRINOVER, Abuso do Processo e Resistência às Ordens Judiciárias: o contempt of court, in $A$ Marcha do Processo, pp. 62-63; THEODORO JÚNIOR, Abuso de Direito Processual no Ordenamento Jurídico Brasileiro, in Revista Forense, v. 344, pp. 53-54.
} 
meios que garantam a celeridade de sua tramitação"126. Como todas as normas que definem direitos e garantias fundamentais, esse dispositivo constitucional tem aplicação imediata (art. $5^{\circ}, \S 1^{\circ}$, da CF).

Contudo, mesmo antes do advento da Emenda Constitucional $n^{\circ} 45 / 04$, a doutrina já reconhecia a existência da garantia da duração razoável do processo civil no ordenamento jurídico brasileiro. Alguns juristas entendem que ela sempre esteve implícita na garantia do devido processo legal (art. $5^{\circ}$, LIV, da CF $)^{127}$. Afirmam que o devido processo legal consiste em um conjunto de garantias constitucionais indispensáveis ao correto exercício da jurisdição, pois asseguram às partes a atuação de suas faculdades e poderes processuais, sendo uma delas a garantia da prestação jurisdicional sem dilações indevidas, já que tutela tardia não é verdadeira tutela. Outros autores preferem deduzir a garantia da razoável duração do processo do princípio na inafastabilidade da jurisdição $\left(\text { art. } 5^{\circ}, \mathrm{XXXV} \text {, da } \mathrm{CF}\right)^{128}$. Conforme já se afirmou anteriormente, esse princípio assegura não só o acesso ao Poder Judiciário a todo cidadão que sofra uma lesão, ou ameaça de lesão, a um direito seu, mas também a efetividade da tutela jurisdicional, respeitadas as regras técnicas do processo e as normas constitucionais. Dado que um dos fatores que contribuem para a efetividade da tutela jurisdicional é a sua tempestividade, parte da doutrina anuncia que a duração razoável do processo é um desdobramento do princípio na inafastabilidade da jurisdição.

No âmbito supranacional, o art. 8.1 da Convenção Americana sobre Direitos Humanos (Pacto de San José da Costa Rica), assinada em 22 de novembro de 1969, estatui que: "Toda pessoa terá o direito de ser ouvida, com as devidas garantias e dentro de um prazo razoável, por um juiz ou Tribunal competente, independente e imparcial, estabelecido anteriormente por lei, na apuração de qualquer acusação penal formulada contra ela, ou na determinação de seus direitos e obrigações de caráter civil, trabalhista, fiscal ou de qualquer outra natureza". Essa norma integra o ordenamento jurídico brasileiro desde novembro de $1992^{129}$ e, segundo a jurisprudência do Supremo Tribunal

\footnotetext{
${ }^{126}$ Caso o Projeto de Lei $n^{\circ} 8.046 / 2010$ seja aprovado nos termos atuais, essa garantia passará a constar expressamente do novo Código de Processo Civil:

"Art. $4^{\circ}$ As partes têm direito de obter em prazo razoável a solução integral da lide, incluída a atividade satisfativa".

${ }^{127}$ Nesse sentido: THEODORO JÚNIOR, Direito Fundamental à Duração Razoável do Processo, pp. $10 \mathrm{e}$ 12; CRUZ E TUCCI, Duração Razoável do Processo (Art. 5', LXXVIII, da Constituição Federal), in MARTINS; JOBIM (coords.), O Processo na Constituição, pp. 322-324, 336-337 e 341-342.

${ }^{128}$ Nesse sentido: NERY JUNIOR, Princípios do Processo na Constituição Federal: processo civil, penal e administrativo, p. 311.

${ }^{129}$ No Brasil, o Pacto de San José da Costa Rica foi aprovado pelo Decreto Legislativo $n^{\circ} 27$, de 25 de setembro de 1992, e promulgado pelo Decreto nº 678, de 6 de novembro de 1992.
} 
Federal, possui "status" supralegal ${ }^{130}$. O Estado brasileiro já foi até mesmo condenado pela Corte Interamericana de Direitos Humanos, em 2006, por violar o direito de acesso à justiça entendido como direito à pronta prestação jurisdicional, além de outros direitos protegidos pelo Pacto de San José da Costa Rica, como o direito à vida e o direito à integridade física $^{131}$.

As expressões "razoável duração do processo" e "dentro de um prazo razoável”, contidas nos atos normativos supracitados, são conceitos jurídicos indeterminados e abertos, de modo que não existe uma norma que fixe, de forma objetiva, o instante em que a duração de um processo deixa de ser razoável ${ }^{132}$.

Para determinar esse momento, o aplicador do direito não pode levar em consideração apenas o valor da celeridade processual. É preciso ponderar também o princípio da segurança jurídica, que exige um lapso temporal razoável para a tramitação do processo em conformidade com a Constituição Federal e as leis processuais ${ }^{133}$.

De fato, a prática dos atos do procedimento tendentes a outorgar a prestação jurisdicional definitiva a quem tem razão demanda um certo tempo. Trata-se de uma perda de tempo natural, fisiológica, que pode ter várias origens, dentre elas: o grande número de recursos e remédios que o ordenamento jurídico prevê para a impugnação dos atos decisórios; a demora no julgamento desses recursos e remédios; o efeito suspensivo dos recursos; a desvalorização das decisões de primeiro grau; a duração da instrução probatória etc ${ }^{134}$. Assim sendo, se o tempo despendido em um determinado processo, ainda que longo, for aquele estabelecido pela Constituição e pelas leis para o caso concreto, não há

\footnotetext{
${ }^{130}$ STF, Tribunal Pleno, RE 349.703/RS, Rel. Min. Carlos Britto, DJe-104 DIVULG 04-06-2009 PUBLIC 05-06-2009; STF, $1^{\text {a }}$ Turma, HC 94.523/SP, Rel. Min. Carlos Britto, DJe-048 DIVULG 12-03-2009 PUBLIC 13-03-2009; STF, $1^{\text {a }}$ Turma, HC 94.013/SP, Rel. Min. Carlos Britto, DJe-048 DIVULG 12-032009 PUBLIC 13-03-2009; STF, 2a Turma, RE 404.276 AgR/MG, Rel. Min. Cezar Peluso, DJe-071 DIVULG 16-04-2009 PUBLIC 17-04-2009.

${ }^{131}$ Corte IDH. Caso Ximenes Lopes versus Brasil. Sentença de 4 de julho de 2006. Série C, no 149, par. 192 a 206 e 247.

${ }^{132}$ Exceto no âmbito da Justiça Eleitoral, nos processos que possam resultar em perda de mandato eletivo, tendo em vista o diposto no art. 97-A da Lei no 9.504/97:

"Art. 97-A. Nos termos do inciso LXXVIII do art. 5o da Constituição Federal, considera-se duração razoável do processo que possa resultar em perda de mandato eletivo o período máximo de 1 (um) ano, contado da sua apresentação à Justiça Eleitoral.

$\S 1^{o}$ A duração do processo de que trata o caput abrange a tramitação em todas as instâncias da Justiça Eleitoral.

$\S 2^{o}$ Vencido o prazo de que trata o caput, será aplicável o disposto no art. 97, sem prejuízo de representação ao Conselho Nacional de Justiça".

${ }^{133}$ CRUZ E TUCCI, Duração Razoável do Processo (Art. $5^{\circ}$, LXXVIII, da Constituição Federal), in MARTINS; JOBIM (coords.), O Processo na Constituição, pp. 324.

${ }^{134}$ LUCON, Abuso do Exercício do Direito de Recorrer, in NERY JÚNIOR; ALVIM WAMBIER (coords.), Aspectos Polêmicos e Atuais dos Recursos Cíveis e de Outras Formas de Impugnação às Decisões Judiciais, p. 878.
} 
desrespeito ao princípio da duração razoável. Nesse caso, a parte deve-se conformar com os inconvenientes da demora natural do provimento jurisdicional, mesmo que isso a deixe aborrecida e angustiada $^{135}$. A busca da celeridade e da duração razoável do processo não pode ser feita a qualquer custo, violando outros valores constitucionais e processuais indispensáveis ao Estado Democrático de Direito, como o contraditório, a ampla defesa, a igualdade entre os litigantes, o juiz imparcial, o juiz natural, a inadmissibilidade das provas ilícitas e ilegítimas $e t c^{136}$. Somente no caso de o processo durar muito mais tempo do que o exigido para a observância do devido processo constitucional e legal é que se pode cogitar se houve, ou não, alguma violação ao direito fundamental contemplado no art. $5^{\circ}$, LXXVIII, da $\mathrm{CF}^{137}$.

A Corte Europeia dos Direitos do Homem, ao interpretar o art. $6^{\circ}, \S 1^{\circ}$, da Convenção Europeia para Salvaguarda dos Direitos do Homem e das Liberdades Fundamentais, de 1950, estabeleceu três critérios objetivos para apreciar o tempo razoável de duração de um determinado processo, os quais podem ser utilizados como parâmetro na interpretação e aplicação do art. 5, LXXVIII, da CF, já que equilibram os referidos postulados da celeridade processual e da segurança jurídica ${ }^{138}$. São eles ${ }^{139}$ :

a) a complexidade do caso. O Poder Judiciário deve proferir a decisão final de mérito num lapso de tempo que seja compatível com a natureza e a complexidade do

\footnotetext{
135 Obviamente, se a espera pela sentença puder inutilizar a efetivação da tutela merecida pelo titular do direito lesado ou ameaçado, este pode pleitear a antecipação da tutela para afastar o perigo de dano iminente. Porém, como salienta Theodoro Júnior (Direito Fundamental à Duração Razoável do Processo, pp. 3-4 e 22), o combate ao perigo da demora natural do processo, feito por meio das tutelas de urgência, não se confunde com a repressão à duração excessiva do processo, que se dá por meio da responsabilidade civil objetiva do Estado (art. 37, $\S 6^{\circ}$, da CF). Trata-se de fenômenos distintos.

${ }^{136}$ NERY JUNIOR, Princípios do Processo na Constituição Federal: processo civil, penal e administrativo, pp. 315 e 318.

${ }_{137}$ THEODORO JÚNIOR, Direito Fundamental à Duração Razoável do Processo, pp. 13 e 15.

${ }^{138}$ Esses mesmos critérios são adotados pela Corte Interamericana de Direitos Humanos na interpretação do art. 8.1 da Convenção Americana sobre Direitos Humanos (Corte IDH. Caso Baldeón García. Sentença de 6 de abril de 2006. Série C, $n^{\circ} 147$, par. 151; Corte IDH. Caso López Álvarez. Sentença de $1^{\circ}$ de fevereiro de 2006. Série C, $\mathrm{n}^{\circ}$ 141, par. 132; Corte IDH. Caso do Massacre de Pueblo Bello. Sentença de 31 de janeiro de 2006. Série C, nº 140, par. 171; Corte IDH. Caso Ximenes Lopes. Sentença de 4 de julho de 2006. Série C, $\mathrm{n}^{\circ}$ 149, par. 196).

Eles também constam da "Legge Pinto" italiana (Lei no 89/01), que prevê o dever de o Estado italiano reparar os danos morais e materiais causados aos cidadãos pela duração exagerada dos seus processos. Estatui o art. $2^{\circ}, \S 2^{\circ}$, do referido ato normativo:

"2. Na verificação da violação, o juiz considera a complexidade do caso e, em relação à mesma, o comportamento das partes e do juiz do procedimento, bem como o de qualquer outra autoridade chamada a cooperar com eles ou a, de qualquer maneira, contribuir para a sua definição" (tradução nossa).

139 THEODORO JÚNIOR, Direito Fundamental à Duração Razoável do Processo, p. 12; CRUZ E TUCCI, Duração Razoável do Processo (Art. 5 , LXXVIII, da Constituição Federal), in MARTINS; JOBIM (coords.), O Processo na Constituição, pp. 326-327; NERY JUNIOR, Princípios do Processo na Constituição Federal: processo civil, penal e administrativo, pp. 315-316 e nt. 665; BERALDO, O Comportamento dos Sujeitos Processuais como Obstáculo à Razoável Duração do Processo, pp. 36-44.
} 
objeto litigioso $^{140}$. Na avaliação da complexidade do caso, deve-se levar em consideração tanto elementos fáticos (v.g., a importância da controvérsia; a quantidade de pedidos; o número de litigantes; a quantidade de testemunhas ouvidas; a quantidade de documentos examinados; a necessidade de realizar perícia ou até perícia complexa, que abranja mais de uma área de conhecimento específico; a qualidade das partes etc.), quanto elementos jurídicos (e.g., questões inéditas na doutrina, que demandam estudo aprofundado do assunto; questões controversas na doutrina e na jurisprudência; questões sobre constitucionalidade de lei ou ato normativo; necessidade de resolver dificuldades jurídicas particulares etc.);

b) o comportamento dos litigantes e de seus procuradores. São taxadas de indevidas apenas as demoras proporcionadas pela inércia, pura e simples, do órgão jurisdicional; por outro lado, as dilações decorrentes do exercício regular de direitos e poderes processuais pelas partes (v.g., poder de recorrer, poder de suscitar incidentes, poder de revogar a procuração do atual advogado e conceder procuração a outro etc.) são consideradas aceitáveis;

c) a atuação do órgão jurisdicional. Segundo Theodoro Júnior ${ }^{141}$, a duração nãorazoável do processo ocorre sempre que: (1) o juiz e seus auxiliares não respeitam os prazos legais; (2) o órgão jurisdicional não policia o comportamento das partes, permitindo que provas e diligências inúteis e tumultuárias sejam praticadas impunemente; (3) o juiz anula tardiamente o processo, acarretando sua onerosa repetição, quando era possível sanar o defeito no nascedouro; (4) o magistrado realiza audiência de instrução e julgamento quando o caso é de julgamento antecipado da lide, ou comete outro tipo de afastamento desarrazoado do procedimento traçado pela lei processual. O excesso de trabalho dos órgãos do Poder Judiciário, o número excessivo de processos, a quantidade insuficiente de juízes ou de servidores só são justificativas aceitáveis da duração exagerada do processo quando forem causas de crise passageira. No caso de crise estrutural do Poder Judiciário, elas não são consideradas uma justificativa plausível para a lentidão na prestação da tutela jurisdicional $^{142}$, uma vez que o Estado tem o dever constitucional de prestar o serviço judiciário em conformidade com os direitos fundamentais e de maneira eficiente (art. 37, "caput", da CF), sendo obrigado aparelhar-se adequadamente, com recursos materiais e

${ }^{140}$ CRUZ E TUCCI, Duração Razoável do Processo (Art. 5º LXXVIII, da Constituição Federal), in MARTINS; JOBIM (coords.), O Processo na Constituição, pp. 324 e 325.

${ }_{141}^{14}$ Direito Fundamental à Duração Razoável do Processo, pp. 13, 16-17 e 18.

${ }^{142}$ NERY JUNIOR, Princípios do Processo na Constituição Federal: processo civil, penal e administrativo, p. 316 . 
humanos, para se desincumbir desse mister ${ }^{143}$. Cruz e Tucci ${ }^{144}$ pondera que, diante da profunda diferença de "performance" dos órgãos jurisdicionais das diversas regiões do Brasil, a aferição do "prazo razoável" deve ser diferenciada de Estado para Estado, tanto no âmbito da Justiça Estadual, quanto no da Justiça Federal.

Beraldo $^{145}$ enfatiza que a garantia da razoável duração do processo impõe obrigações: (a) ao Poder Executivo, de dotar o Poder Judiciário de meios materiais e humanos suficientes para atender de forma minimamente satisfatória todas as demandas ${ }^{146}$; (b) ao Poder Legislativo, de criar as leis processuais necessárias para agilizar a marcha do processo $^{147}$; (c) a todos os sujeitos processuais, de atuarem de forma leal e conforme as regras processuais de conduta, abstendo-se de praticar atos procrastinatórios. Estas últimas obrigações é que interessam ao presente estudo.

De fato, algumas condutas processuais abusivas são praticadas ao arrepio da nova garantia individual prevista no inciso LXXVIII do art. $5^{\circ}$ da CF, uma vez que visam a dilatar o tempo necessário para a obtenção da tutela jurisdicional, configurando uma demora patológica do processo ${ }^{148}$. É o que ocorre, por exemplo, nos casos de interposição de recurso com intuito manifestamente protelatório (arts. 17, VII; e 538, parágrafo único, do CPC), bem como na oposição de embargos do devedor (art. 740, parágrafo único, do $\mathrm{CPC}$ ) ou de embargos à execução de segunda fase (art. 746, $\S 3^{\circ}$, do CPC) manifestamente protelatórios.

${ }^{143}$ THEODORO JÚNIOR, Direito Fundamental à Duração Razoável do Processo, pp. 13-14, 19 e 21-22.

144 CRUZ E TUCCI, Duração Razoável do Processo (Art. 5º LXXVIII, da Constituição Federal), in MARTINS; JOBIM (coords.), O Processo na Constituição, pp. 340-341.

145 O Dever de Cooperação no Processo Civil, in Revista de Processo, no 198, pp. 455-456; $O$ Comportamento dos Sujeitos Processuais como Obstáculo à Razoável Duração do Processo, pp. 35-36.

${ }_{146}$ Nesse sentido, a Emenda Constitucional no 45/04 acrescentou no art. 93 da CF o inciso XIII, com a seguinte redação: "o número de juízes na unidade jurisdicional será proporcional à efetiva demanda judicial e à respectiva população".

${ }^{147}$ É o que consta expressamente do art. $7^{\circ}$ da Emenda Constitucional no 45/04:

“Art. $7^{\circ}$ O Congresso Nacional instalará, imediatamente após a promulgação desta Emenda Constitucional, comissão especial mista, destinada a elaborar, em cento e oitenta dias, os projetos de lei necessários à regulamentação da matéria nela tratada, bem como promover alterações na legislação federal objetivando tornar mais amplo o acesso à Justiça e mais célere a prestação jurisdicional".

Falco (La Buona Fede e l'Abuso del Diritto: principi, fattispecie e casistica, p. 501) observa que, após a constitucionalização do princípio da razoável duração do processo, o legislador ordinário ficou fortemente vinculado à adoção de instrumentos processuais que não só não retardem a conclusão de cada processo individual, mas que também acelerem, dentro do possível, a conclusão de todos os processos.

${ }^{148}$ TARUFFO, General Report, in TARUFFO (ed.), Abuse of Procedural Rights: comparative standards of procedural fairness, pp. 14-15; VINCENZI, A Boa-Fé no Processo Civil, pp. 110-112; ABDO, O Abuso do Processo, pp. 124-125; LUCON, Abuso do Exercício do Direito de Recorrer, in NERY JÚNIOR; ALVIM WAMBIER (coords.), Aspectos Polêmicos e Atuais dos Recursos Cíveis e de Outras Formas de Impugnação às Decisões Judiciais, pp. 877-879; PICÓ I JUNOY, El Principio de la Buena Fe Procesal y su Fundamento Constitucional, in Revista de Processo, $\mathrm{n}^{\circ}$ 196, pp 157-159; OTEIZA, Abuso de los Derechos Procesales en América Latina, in BARBOSA MOREIRA (coord.), Abuso dos Direitos Processuais, pp. 18-19; LUCAS SOSA, Abuso de Derechos Procesales, in BARBOSA MOREIRA (coord.), Abuso dos Direitos Processuais, p. 44. 
O Código de Processo Civil incumbe o Estado-juiz de velar pela rápida solução do litígio, devendo ele prevenir e, se for o caso, punir a eventual prática desses atos processuais abusivos (art. 125, II e III, do CPC).

\subsubsection{As garantias da igualdade e da ampla defesa (art. $5^{\circ}$, “caput” e LV, da CF)}

A democracia, entendida como governo do povo, pelo povo e para o povo, tem como um de seus valores fundantes a igualdade substancial. Segundo Afonso da Silva ${ }^{149}$, a democracia é o "regime de garantia geral para a realização dos direitos fundamentais do homem", notadamente dos direitos econômicos e sociais, pois sem eles os direitos individuais não se concretizam realmente. Sendo os direitos econômicos e sociais direitos igualitários, o constitucionalista brasileiro afirma que a democracia constitui um instrumento de realização da igualdade substancial no plano prático.

$\mathrm{O}$ art. 5', "caput", da CF prevê a igualdade jurídico-formal ao estabelecer que “todos são iguais perante a lei, sem distinção de qualquer natureza [...]". Esse tipo de igualdade visa apenas a abolir os privilégios, isenções pessoais e regalias de classe. Do ponto de vista histórico e político, tem suas raízes na reação da burguesia contra as desigualdades oriundas do regime feudal, tendo como fundamento a ideologia liberal e uma visão individualista do homem. Isolada, a igualdade formal pode incrementar as desigualdades e propiciar injustiça, uma vez que propõe a incidência da lei geral, abstrata e impessoal em todos igualmente, levando em conta apenas a igualdade dos indivíduos, sem considerar o fato de que os seres humanos já nascem desiguais. Entretanto, a Constituição também contém normas que buscam a igualização dos desiguais, constituindo, assim, reais promessas de busca da isonomia material. São exemplos disso os seguintes dispositivos constitucionais, dentre outros: o art. $3^{\mathrm{o}}$, III, $2^{\mathrm{a}}$ parte, e IV ("Constituem objetivos fundamentais da República Federativa do Brasil: [...] III - [...] reduzir as desigualdades sociais e regionais; IV - promover o bem de todos, sem preconceitos de origem, raça, sexo, cor, idade e quaisquer outras formas de discriminação"); o art. 7, XXX ("proibição de diferença de salários, de exercício de funções e de critério de admissão por motivo de sexo, idade, cor ou estado civil") e XXXI ("proibição de qualquer discriminação no tocante a salário e critérios de admissão do trabalhador portador de deficiência”); o art. 196 (“A saúde é direito de todos e dever do Estado, garantido mediante políticas sociais e

${ }^{149}$ Curso de Direito Constitucional Positivo, pp. 131-132. 
econômicas que visem à redução do risco de doença e de outros agravos e ao acesso universal e igualitário às ações e serviços para sua promoção, proteção e recuperação") da $\mathrm{CF}^{150}$.

Como o processo civil moderno é considerado um "microcosmos" em relação ao Estado democrático, a igualdade também é vista como um valor de primeira grandeza na seara processual, assumindo a conotação de "princípio da igualdade das partes"151 (ou "princípio da paridade entre as partes" ${ }^{\text {152 }}$ ). Segundo Afonso da Silva ${ }^{153}$, esse princípio é um corolário da igualdade perante a lei, como garantia constitucional indissoluvelmente ligada à democracia.

A importância da aplicação do princípio da isonomia no processo é patente. Somente com o respeito à garantia de que as partes litigam em igualdade de condições é que se tem a razoável certeza de que o provimento jurisdicional não é resultado da astúcia ou da superioridade econômica de uma das partes em detrimento da outra, mas sim fruto de um debate jurídico igual. Logo, é correto afirmar que o cumprimento dos escopos do processo depende da observância desse princípio, visto que, sem ele, corre-se grande risco de oferecer tutela jurisdicional a quem efetivamente não tenha razão ${ }^{154}$.

A igualdade das partes perante o órgão jurisdicional possui duas dimensões ${ }^{155}$ :

a) dimensão estática: determina que o legislador e o magistrado não criem desigualdades entre as partes. Há uma equiparação dos litigantes no que se refere à titularidade e fruição de poderes, faculdades e direitos, assim como à sujeição a deveres e ônus, assegurando a todos as mesmas possibilidades de obter um provimento jurisdicional favorável. Nesse aspecto, o princípio da igualdade consubstancia uma limitação ao legislador, que, ao elaborar a lei, deve reger situações idênticas com disposições iguais, atribuindo-lhes os mesmos ônus e as mesmas vantagens. Constitui, por outro lado, uma regra de interpretação para o juiz, que deve aplicar a lei de acordo com os critérios nela constantes, ficando proibido de interpretá-la de modo a criar distinções entre situações iguais ${ }^{156}$;

\footnotetext{
${ }^{150}$ AFONSO DA SILVA, Curso de Direito Constitucional Positivo, pp. 211-212 e 213-215; PORTANOVA, Princípios do Processo Civil, pp. 36, 38-39.

${ }^{151}$ DINAMARCO, Instituições de Direito Processual Civil, vol. I, § 82, p. 213.

${ }^{152}$ PORTANOVA, Princípios do Processo Civil, p. 41.

${ }^{153}$ Curso de Direito Constitucional Positivo, p. 218.

154 Nesse sentido: PORTANOVA, Princípios do Processo Civil, pp. $42-43$ e 47; BEDAQUE, Poderes Instrutórios do Juiz, pp. 101-102.

${ }^{155}$ PORTANOVA, Princípios do Processo Civil, p. 34; DINAMARCO, Instituições de Direito Processual Civil, vol. I, § 82, pp. 213-214.

${ }^{156}$ AFONSO DA SILVA, Curso de Direito Constitucional Positivo, pp. 215-216 e 218.
} 
b) dimensão dinâmica: estatui que o legislador e o magistrado devem neutralizar as desigualdades substanciais que porventura existam entre as partes, dando tratamento formalmente desigual aos desiguais, na medida das suas desigualdades. Diz respeito às desigualdades substanciais resultantes de fatores externos ao processo, como a pobreza, a desinformação e as carências culturais e psicossociais. São manifestações dessa faceta da isonomia entre as partes, dentre outras: a promessa constitucional e legal de assistência jurídica integral e gratuita aos necessitados (arts. 50, LXXIV; e 134 da CF; Lei n $^{\circ}$ 1.060/50); a prioridade de tramitação, em todas as instâncias, dos procedimentos judiciais de interesse de idosos ou pessoas portadoras de doença grave (arts. 1.211-A a 1.211-C do CPC; art. 71 da Lei $\left.n^{\circ} 10.741 / 03\right)$; a prerrogativa de foro da mulher nas ações de separação judicial e de divórcio (art. 100, I, do CPC); os poderes instrutórios do juiz (art. 130 do CPC) ${ }^{157}$.

Ambas dimensões encontram-se previstas no art. 125, I, do CPC, que atribui ao juiz o poder-dever de "assegurar às partes igualdade de tratamento" 158 . Dinamarco ${ }^{159}$ leciona que esse dispositivo inclui entre os deveres primários do magistrado a prática e a preservação da igualdade entre as partes, de modo que ele é obrigado não só a agir com igualdade em relação a todos os litigantes, mas também a neutralizar desigualdades.

O mandamento da isonomia das partes relaciona-se intimamente com outros princípios, como o da imparcialidade do juiz ${ }^{160}$. Isso porque o juiz parcial é propenso a buscar o favorecimento de uma das partes, comprometendo o tratamento isonômico dos litigantes, o qual é necessário para que o processo possa oferecer tutela jurisdicional a quem efetivamente tenha razão ${ }^{161}$.

Outro tema muito próximo do princípio da isonomia é a garantia da ampla defesa (art. $5^{\circ}, \mathrm{LV}$, da $\mathrm{CF}$ ), pois a paridade entre as partes implica igualdade nas oportunidades de participar do processo, empregando livremente os instrumentos processuais disponíveis com o objetivo de convencer o juiz a proferir julgamento favorável ${ }^{162}$. Como dizem

\footnotetext{
157 Acerca desta última manifestação da faceta dinâmica do princípio da igualdade processual, consultar: BEDAQUE, Poderes Instrutórios do Juiz, pp. 97-107; PORTANOVA, Princípios do Processo Civil, pp. 43, 44 e $46-47$.

${ }^{158}$ O projeto do novo Código de Processo Civil (Projeto de Lei $\mathrm{n}^{\mathrm{o}}$ 8.046/2010) menciona expressamenteo princípio da igualdade das partes em seu art. $7^{\circ}$ : " $E$ assegurada às partes paridade de tratamento em relação ao exercício de direitos e faculdades processuais, aos meios de defesa, aos ônus, aos deveres e à aplicação de sanções processuais, competindo ao juiz velar pelo efetivo contraditório".

${ }^{159}$ Instituições de Direito Processual Civil, vol. I, § 82, p. 213.

${ }^{160}$ PORTANOVA, Princípios do Processo Civil, p. 41.

161 DINAMARCO, Instituições de Direito Processual Civil, vol. I, § 82, p. 214; AFONSO DA SILVA, Curso de Direito Constitucional Positivo, pp. 218-219.

${ }^{162}$ DINAMARCO, Instituições de Direito Processual Civil, vol. I, § 82, pp. 214-215.
} 
Comoglio, Ferri e Taruffo ${ }^{163}$, a defesa, considerada como um direito e uma garantia de conteúdo efetivo, consagra formas adequadas de colaboração dinâmica das partes no curso de todo o processo, de modo que seja sempre concedida a elas, sobre bases paritárias, uma possibilidade efetiva de influir na formação da convicção do juiz a respeito da decisão da demanda ${ }^{164}$. Assim, o art. $5^{\circ}, \mathrm{LV}$, da $\mathrm{CF}$, ao prever a ampla defesa como direito fundamental, assegura aos litigantes a paridade de armas processuais de ataque e defesa ${ }^{165}$, abrangendo: (a) o direito de deduzirem alegações adequadas, que efetivamente sejam aptas a fazer valer sua pretensão ou defesa no processo judicial; (b) o direito de provarem essas mesmas alegações; e (c) sobrevindo decisão adversa, o direito de interporem o recurso cabível para o caso ${ }^{166}$.

Ocorre que, em algumas situações, a atuação abusiva de um litigante é dirigida a tolher o direito constitucional de ampla defesa da parte contrária, o que acaba culminando em uma ruptura do equilíbrio de interesses que o ordenamento jurídico processual estabelece para fazer respeitar a plena igualdade de tratamento entre as partes. É o caso, por exemplo, do demandante que, dolosamente, descumpre o ônus de instruir a petição inicial com os documentos indispensáveis à propositura da demanda e introduz nos autos, extemporaneamente, alguma prova documental pré-constituída. Essa conduta ímproba desrespeita o dever de prontidão, como se verá no item 1.3.7.3 “infra”, e também contraria os direitos constitucionais de ampla defesa e de igualdade das partes, uma vez que prejudica gravemente a estratégia defensiva do demandado, que constrói toda sua argumentação fática e jurídica com base nos documentos que constam dos autos no momento em que formula sua defesa ${ }^{167}$.

\subsubsection{O respeito às finalidades institucionais do processo}

A história do processo civil já passou por três fases metodológicas ${ }^{168}$ :

\footnotetext{
163 Lezioni sul Processo Civile, p. 71.

${ }^{164}$ Nesse sentido, na doutrina nacional: PORTANOVA, Princípios do Processo Civil, p. 127.

${ }^{165}$ Comoglio, Ferri e Taruffo (Lezioni sul Processo Civile, p. 72) mencionam a igualdade substancial das partes como um dos requisitos que asseguram a efetividade mínima do contraditório e da ampla defesa.

${ }^{166}$ NERY JUNIOR, Princípios do Processo na Constituição Federal: processo civil, penal e administrativo, p. 244.

${ }_{167}$ PICÓ I JUNOY, El Principio de la Buena Fe Procesal y su Fundamento Constitucional, in Revista de Processo, nº 196, pp. 156-157.

168 DINAMARCO, Instituições de Direito Processual Civil, vol. I, § 98, pp. 259-262; CINTRA; DINAMARCO; GRINOVER, Teoria Geral do Processo, pp. 44-47.
} 
a) período de sincretismo: o sistema processual não tinha autonomia, pois era encarado como um simples capítulo do Direito privado. O processo era confundido com o procedimento e era definido como uma mera sucessão de atos, sem que se mencionasse a existência da relação jurídica entre os sujeitos processuais, nem a conveniência política do contraditório. A ação era entendida como um direito adjetivo, ou seja, como algo inerente ao direito subjetivo material (teoria imanentista da ação); era o próprio direito subjetivo material que, após ser lesado, recebia forças para que seu titular comparecesse em juízo para ter seu dano reparado. Não se pode afirmar que havia, nesse período, uma ciência do processo civil porquanto os conhecimentos eram empíricos, não havia princípios, nem conceitos próprios e nem mesmo um método;

b) período autonomista (ou conceitual): teve início em 1.868, com a obra "Teoria dos pressupostos processuais e das exceções dilatórias", na qual Oskar Von Bülow defendeu a existência de uma relação jurídica especial entre os sujeitos processuais e a distinguiu da relação jurídica substancial litigiosa, em razão dos seus sujeitos (o juiz, o autor e o réu), do seu objeto (os provimentos jurisdicionais) e dos seus pressupostos (os pressupostos processuais). A partir de então, o Direito processual ganhou autonomia e foi elevado à categoria de ciência, uma vez que passou a ter seu próprio método e seu objeto material, que eram as categorias jurídico-processuais, ou seja, a jurisdição, a ação, a defesa e o processo. Em seguida, os doutrinadores identificaram os elementos caracterizadores da ação (partes, causa de pedir e pedido), elaboraram a teoria das condições da ação e dos pressupostos processuais, formularam princípios e também desenvolveram estudos acerca do objeto do processo. Ocorre que o empenho dos estudiosos dessa época em desvincular o processo do Direito material resultou numa teorização do processo como técnica justificável em si e por si, minimizando-se quase por completo a função reservada ao processo no plano da atuação do direito material violado ${ }^{169}$;

c) período instrumentalista (ou teleológico): começou em meados do século XX, quando alguns autores (dentre eles, Mauro Cappelletti e Vittorio Denti) propuseram a adoção de um método de estudo do processo civil que desse importância aos resultados da prestação da atividade jurisdicional na vida das pessoas. Esse modo de pensar o processo civil levou a doutrina processual contemporânea a superar o dogma da natureza exclusivamente técnica do processo, entendido como mero instrumento do direito material, e a reconhecer que ele possui também escopos metajurídicos.

${ }^{169}$ THEODORO JÚNIOR, Direito Fundamental à Duração Razoável do Processo, pp. 4-5. 
De acordo com a visão instrumentalista do processo, hoje vigente, o processo tem três finalidades institucionais ${ }^{170}$, quais sejam:

a) o seu escopo social, que abrange:

1) o intuito de pacificar pessoas por meio da eliminação de conflitos com justiça. Parte-se da constatação de que as insatisfações são estados psíquicos inevitáveis na vida dos indivíduos. Elas comprometem a felicidade das pessoas e possuem a tendência de se multiplicarem, promovendo a desagregação social. Por causa disso, o Estado tem a missão e o dever de eliminar esses estados de insatisfação. Obviamente, não é possível satisfazer a todos, uma vez que a satisfação de um dos sujeitos em conflito necessariamente implica a contrariedade dos interesses do outro. Porém, para o litigante é preferível a decepção derivada da derrota na demanda a continuar sofrendo em decorrência da indefinição de sua relação jurídica com o vencedor; e

2) o fim de educar as pessoas para a defesa de seus próprios direitos e para o respeito aos direitos alheios. A esse respeito, Dinamarco ${ }^{171}$ ensina: "Onde a Justiça funciona mal, transgressores não a temem e lesados pouco esperam dela";

b) os seus escopos políticos, que são três:

1) o de contribuir para a estabilidade das instituições políticas. $O$ ordenamento jurídico é uma projeção positivada do poder estatal. Então, quando o Poder Judiciário aplica os preceitos legais na solução das demandas jurisdicionais, generalizando o respeito à lei, ele reafirma a autoridade do próprio Estado;

2) o de permitir a participação dos cidadãos na vida e nos destinos do Estado. Essa participação política se dá por meio de alguns instrumentos legais, como a ação popular, a ação direta de inconstitucionalidade (art. 5, LVIII; c/c art. 102, I, “ $a$ ”, e art. 103 da CF) e as ouvidorias de justiça (art. 103-B, $\S 7^{\circ}$, da CF); e

3) o de preservar o valor liberdade, por meio da proteção dos indivíduos e das entidades em que se agrupam contra os desmandos do Estado. O ordenamento jurídico prevê diversos meios para possibilitar a reação a abusos do Estado: o "habeas corpus", o mandado de segurança, o mandado de injunção, o "habeas data" etc.; e

c) o seu escopo jurídico, que é o de atuar a vontade concreta do direito (teoria dualista $\left.^{172}\right)$.

\footnotetext{
${ }^{170}$ DINAMARCO, Instituições de Direito Processual Civil, vol. I, §§ 47-51, pp. 129-140.

${ }^{171}$ Instituições de Direito Processual Civil, vol. I, § 49, p. 133.

${ }^{172}$ Quando se discute o objetivo do processo perante a ordem jurídica, duas teorias metodológicas digladiamse (DINAMARCO, Instituições de Direito Processual Civil, vol. I, §§ 47 e 51, pp. 129-130 e 136-137):
} 
A problemática do abuso de situações jurídicas processuais revela-se totalmente contrária à realização da instrumentalidade do processo $^{173}$, uma vez que solapa cada um dos três escopos supracitados.

O escopo social de pacificar os litigantes com justiça fica prejudicado quando se verifica que, em muitos casos, o abuso de situações jurídicas processuais causa a demora na outorga da prestação jurisdicional, o que aumenta o desgaste financeiro e psicológico das partes e pressiona aquelas que são menos resistentes a abandonar a causa ou a aceitar acordos por valores inferiores àqueles a que teriam direito ${ }^{174}$. Com isso, também fica comprometido o escopo de atuar a vontade concreta do direito (escopo jurídico do processo) ${ }^{175}$.

Quando o litigante ímprobo desrespeita o dever de dizer a verdade, igualmente obsta a concretização do escopo jurídico do processo, pois impede que o magistrado realize a subsunção da situação fática que efetivamente ocorreu à norma jurídica ${ }^{176}$.

Ademais, as práticas abusivas estimulam as pessoas a inadimplirem suas obrigações, uma vez que os devedores confessos sabem que é economicamente muito mais vantajoso esperar uma decisão judicial desfavorável, a ser prolatada em um processo que pode ser retardado o máximo possível por meio de atos abusivos, do que realizar a

a) a teoria unitária do ordenamento jurídico: parte do pressuposto de que o direito material positivo é insuficiente para reger as situações conflitivas concretas (ou seja, para compor a lide). O direito material e o processual compõem uma só unidade e não há direitos nem obrigações antes da sentença, uma vez que a norma que rege cada conflito só pode-se considerar perfeita e acabada com a prolação da decisão. Desse modo, a função do juiz é a de completar o trabalho do legislador, formando a norma do caso concreto e, assim, criando direitos e obrigações entre as partes;

b) a teoria dualista do ordenamento jurídico: considera que os ordenamentos jurídicos de países de origem romano-germânica se dividem em dois planos, o substancial e o processual. Sempre que ocorre na vida concreta os fatos previstos no suporte fático da norma (ou hipótese de incidência), esta incide automaticamente, produzindo os efeitos previstos em seu preceito (ou disposição). Assim, o surgimento de direitos e obrigações depende apenas da observância, no mundo fático, dos fatos narrados no antecedente da norma e da consequente incidência desta. O juiz não cria normas jurídicas substanciais, de modo que a jurisdição tem o escopo apenas de atuar a vontade concreta da lei.

Ao tratar desse assunto, Dinamarco (Instituições de Direito Processual Civil, vol. I, § 51, pp. 137-140) constata que, na realidade, a maior parte dos direitos e obrigações nascem, desenvolvem-se, modificam-se e extinguem-se sem que haja qualquer intervenção jurisdicional. Cumprir as obrigações e respeitar direitos constitui a "vida fisiológica" dos direitos, enquanto os descumprimentos e as transgressões são a "patologia". Para o autor, o único bem jurídico que os pronunciamentos judiciais acrescentam à situação jurídica material é a segurança jurídica, para evitar novos questionamentos a respeito do assunto.

Diante disso, o jurista chega à conclusão de que a segunda corrente (a de que o escopo jurídico do processo é a atuação da vontade concreta do direito) está correta, pois as sentenças de mérito apenas revelam direitos e obrigações, mas nunca os criam. Isso também vale para as sentenças constitutivas porque a nova situação jurídica material preexiste à sentença que a cria. Quando a sentença de mérito não é adimplida voluntariamente pelo obrigado, a execução forçada garante que o direito do credor seja satisfeito no mundo da realidade.

${ }^{173}$ ABDO, O Abuso do Processo, pp. 82-86.

${ }^{174}$ Nesse sentido: CASTRO FILHO, Abuso do Direito no Processo Civil, p. 213.

${ }^{175}$ PUOLI, Os Poderes do Juiz e as Reformas da Lei Processual Civil Brasileira, pp. 190-191.

${ }^{176}$ CASTRO FILHO, Abuso do Direito no Processo Civil, pp. 102 e 131. 
prestação pontualmente ${ }^{177}$. Essa mentalidade desleal se mostra manifestamente incompatível com o outro escopo social do processo - o de educar as pessoas para que respeitem os direitos alheios -, bem como com o escopo político de contribuir para a estabilidade das instituições.

Portanto, para que seja possível alcançar os escopos sociais, políticos e jurídico aventados pela doutrina processual instrumentalista, é de suma importância que haja a prevenção do abuso de situações jurídicas processuais, bem como a repressão dos atos abusivos que eventualmente forem praticados.

\subsubsection{O princípio da boa-fé}

No Direito romano, a boa-fé era utilizada como um recurso técnico para suprir lacunas e corrigir injustiças decorrentes do extremo formalismo do primitivo "ius civile". O conceito de "bona fides" apresentava duas facetas: (a) era um complexo de regras sociais definidoras de certa ética (critério objetivo); e (b) era também a consciência individual de proceder de maneira proba (critério subjetivo) ${ }^{178}$.

Posteriormente, operou-se uma maior subjetivização da "bona fides", que deixou de constituir um complexo de imperativos de conduta, o qual foi absorvido pelo Direito, passando a significar apenas a convicção de atuar de maneira proba, sem prejudicar terceiros. O seu contrário passou a ser, então, a "mala fides", a "scientia". O Direito canônico influenciou bastante no atingimento dessa subjetivização, a qual foi mais sedimentada pelo individualismo liberal do século $\mathrm{XIX}^{179}$.

O princípio da boa-fé possui estrutura tipicamente civil. Mas, nos ordenamentos jurídicos modernos, ele tem sido empregado tanto nos domínios do direito material, quanto nos do direito processual ${ }^{180}$. Inicialmente, a jurisprudência alemã se mostrou refratária à sujeição do processo ao princípio da boa-fé. O esforço dos doutrinadores do início do século XX para defender a autonomia do processo civil com relação ao Direito substantivo

\footnotetext{
177 Nesse sentido: LUCON, Abuso do Exercício do Direito de Recorrer, in NERY JÚNIOR; ALVIM WAMBIER (coords.), Aspectos Polêmicos e Atuais dos Recursos Cíveis e de Outras Formas de Impugnação às Decisões Judiciais, p. 877; DORIA, A Litigância de Má-Fé e a Aplicação de Multas, in MARINONI (coord.), Estudos de Direito Processual Civil - homenagem ao professor Egas Dirceu Moniz de Aragão, p. 650 .

${ }^{178}$ LUSO SOARES, A Responsabilidade Processual Civil, pp. 151-152.

${ }^{179}$ LUSO SOARES, A Responsabilidade Processual Civil, pp. 152-153.

${ }^{180}$ LUSO SOARES, A Responsabilidade Processual Civil, p. 151.
} 
prejudicou o movimento de aplicação do $§ 242$ do BGB ao processo civil ${ }^{181}$. Apesar disso, é possível encontrar algumas decisões e opiniões doutrinárias alemãs desse mesmo período histórico que já aplicavam o princípio da boa-fé no campo processual ${ }^{182}$. Nos dias de hoje, os legisladores incluem previsões explícitas do princípio da boa-fé em diversas legislações processuais nacionais $^{183}{ }^{184}$, visando a evitar qualquer discussão acerca de sua vigência no respectivo ordenamento jurídico.

Mesmo assim, algumas vozes ainda se mostram contrárias ao princípio da boa-fé processual. Existe uma doutrina denominada "garantismo processual" (ou "neoprivatismo processual"), que se propõe a proteger o cidadão dos abusos do Estado, especificamente do aumento dos poderes do juiz no processo. Trata-se do ramo processual da teoria do garantismo, proposta por Luigi Ferrajoli ${ }^{185}$. Para uma parte dos seguidores dessa doutrina, a imposição da boa-fé no comportamento dos sujeitos processuais é uma manifestação do

181 ALBUQUERQUE, Responsabilidade Processual por Litigância de Má Fé, Abuso de Direito e Responsabilidade Civil em Virtude de Actos Praticados no Processo, pp. 69-74; HESS, Abuse of Procedure in Germany and Austria, in TARUFFO (ed.), Abuse of Procedural Rights: comparative standards of procedural fairness, pp. 154-155.

${ }^{182}$ MENEZES CORDEIRO, Litigância de Má-Fé, Abuso do Direito de Ação e Culpa “in Agendo", pp. 125127.

${ }^{183}$ Por exemplo: o art. 14, II, do CPC (“Art. 14. São deveres das partes e de todos aqueles que de qualquer forma participam do processo: [...] II - proceder com lealdade e boa-fé"); os arts. $5^{\circ}$ e 63 do CPC uruguaio (Artigo 5o. Boa-fé e lealdade processual-As partes, seus representantes ou assistentes e, em geral, todos os partícipes do proceso, ajustarão sua conduta à dignidade da Justiça, ao respeito que se devem os litigantes e à lealdade e boa-fé [...]"; "Artigo 63. Requisitos dos atos processuais - Além dos requisitos que em cada caso se estabeleçam, os atos deverão ser lícitos, pertinentes e úteis. Haverão de ser realizados com veracidade e boa-fé e ter por causa um interesse legítimo" - tradução nossa); o art. 34, 5, "d", do CPC argentino ("Artigo 34 - São deveres dos juízes: [...] 5. Dirigir o procedimento, devendo, dentro dos limites expressamente estabelecidos neste Código: [...] d) prevenir e sancionar todo ato contrário ao dever de lealdade, probidade e boa-fê" - tradução nossa); o art. 266-A do CPC português ("Artigo 266"-A (DEVER DE BOA FÉ PROCESSUAL) As partes devem agir de boa fé e observar os deveres de cooperação resultantes do preceituado no artigo anterior"); o art. 247.1 da "Ley de Enjuiciamiento Civil" da Espanha (“Art. 247.1. Os intervenientes em todo tipo de processo deverão ajustar-se, em suas atuações, às regras da boa-fé" - tradução nossa); e os arts. 11.1 e 542.2 da "Ley Orgánica del Poder Judicial" também da Espanha (“Art. 11.1. Em todo tipo de procedimento respeitar-se-ão as regras da boa-fé. [...]”; “Art. 542.2. Em sua atuação perante os juízos e tribunais, os advogados são livres e independentes, sujeitar-se-ão ao princípio da boa-fé, gozarão dos direitos inerentes à dignidade de sua função e serão amparados por aqueles em sua liberdade de expressão e defesa" - tradução nossa).

${ }^{184}$ Cumpre destacar que o princípio da boa-fé processual não foi positivado apenas recentemente. Segundo Picó i Junoy (El Principio de la Buena Fe Procesal y su Fundamento Constitucional, in Revista de Processo, $\mathrm{n}^{\circ}$ 196, p. 133), Oteiza (Abuso de los Derechos Procesales en América Latina, in BARBOSA MOREIRA (coord.), Abuso dos Direitos Processuais, p. 11) e Landoni Sosa (El Abuso de los Derechos Procesales, in BARBOSA MOREIRA (coord.), Abuso dos Direitos Processuais, p. 132), a formulação normativa desse princípio ocorreu séculos antes da promulgação dos atuais códigos de processo civil, podendo ser encontrada, por exemplo, na "Ordenanza de Buenos Aires", dada por Real Cédula de Carlos IV, em Aranjuez, em 30 de janeiro de 1794 , cujo artigo $5^{\circ}$ estatuía que "nos juízos se há de proceder sempre com estilo claro, verdade sabida e boa-fé guardada" (tradução nossa).

${ }^{185}$ DIDIER JUNIOR, Os Três Modelos de Direito Processual: inquisitivo, dispositivo e cooperativo, in Revista de Processo, no 198, pp. 217-218. 
ativismo judicial próprio de estados autoritários ${ }^{186}$. É o que pensa, por exemplo, Montero Aroca $^{187}$. Na opinião desse jurista, o princípio da boa-fé processual e a ideia de que o processo é o meio para que as partes colaborem com o órgão judicial no descobrimento da verdade material e na realização do direito objetivo proclamado na lei só podem ser compreendidos em um contexto ideológico autoritário, fascista ou comunista, em que o Estado negue ao cidadão o direito de lutar pelo que crê ser seu direito subjetivo, ante um terceiro imparcial, e o direito de fazê-lo com todas as armas que o ordenamento jurídico põe à sua disposição. O jurista espanhol nega a existência de um princípio processual de boa-fé e de um dever de as partes e seus advogados atuarem no processo conforme a boafé, mas, por outro lado, reconhece que o art. 247 da "Ley de Enjuiciamiento Civil" impõe aos intervenientes no processo o dever de não atuar com má-fé ${ }^{188}$.

Os partidários dessa corrente doutrinária encabeçada por Montero Aroca parecem estar enganados, uma vez que o princípio da boa-fé processual coaduna-se mais com o processo liberal que com o processo autoritário, já que contribui para a proteção dos direitos e garantias fundamentais dos litigantes ao impor ao juiz uma atuação tolerante, colaborativa, e, às partes, um comportamento leal ${ }^{189}$. Na verdade, o reconhecimento do princípio da boa-fé no âmbito do processo não se vincula a alguma ideologia política determinada, mas sim à percepção da natureza pública do processo e ao intento de lograr a máxima eficácia do processo civil, devendo-se respeitar sempre as garantias constitucionais. Ou seja, trata-se de uma questão predominantemente técnica, e não política. Caso contrário, não seria possível encontrar o princípio da boa-fé positivado em diversos Códigos de Processo Civil modernos de Estados totalmente democráticos (como os do Brasil e de Portugal), nem se poderia admitir que legislações processuais de sistemas políticos ditatoriais o omitissem (como a "Ley de Procedimiento Civil, Administrativo y Laboral" cubana, de 1977) ${ }^{190}$.

\footnotetext{
${ }^{186}$ Saliente-se que nem todos os autores que seguem a denominada corrente garantista do processo seguem esse entendimento. Segundo Picó i Junoy (El Principio de la Buena Fe Procesal y su Fundamento Constitucional, in Revista de Processo, $\mathrm{n}^{\circ}$ 196, p. 137, nt. 11, e pp. 161-162), há quem participe desse movimento doutrinário, mas reconheça a plena vigência do princípio da boa-fé processual.

${ }^{187}$ Ideología y Proceso Civil. Su Reflejo en la "Buena Fe Procesal", in CONRADI (coord.), El Abuso del Proceso: mala fe y fraude de ley procesal, pp. 251-319.

${ }^{188}$ Com razão, Picó i Junoy (El Principio de la Buena Fe Procesal y su Fundamento Constitucional, in Revista de Processo, $\mathrm{n}^{\circ}$ 196, p. 136) argumenta que, se o bom é o contrário do mau, não há diferença entre o dever genérico de atuar com boa-fé processual e a proibição genérica de agir com má-fé processual.

189 Nesse sentido é a opinião de Didier Junior (Os Três Modelos de Direito Processual: inquisitivo, dispositivo e cooperativo, in Revista de Processo, $\mathrm{n}^{\circ}$ 198, p. 218).

${ }^{190}$ PICÓ I JUNOY, El Principio de la Buena Fe Procesal y su Fundamento Constitucional, in Revista de Processo, nº 196, pp. 137-141 e 161.
} 
Ressalvadas as manifestações doutrinárias supramencionadas, o fato é que a maior parte dos juristas contemporâneos, nacionais e estrangeiros, aceitam a aplicação do princípio da boa-fé na seara processual ${ }^{191}$. Isso se reflete nos diversos projetos doutrinários de harmonização internacional do processo civil, como os "Principles of Transnational Civil Procedure", aprovados pelo "American Law Institute" e pela "Unidroit" em 2005, e o "Código Procesal Civil Modelo para Iberoamérica", de 1998, que preveem explicitamente a observância da boa-fé no processo ${ }^{192}$.

Afirma-se que o processo civil foi o primeiro setor extracivil no qual a boa-fé se impôs, por meio de um processo de transposição facilitado por sua natureza instrumental perante o Direito civil ${ }^{193}$.

A favor da existência de um princípio processual da boa-fé, argumenta-se que, se em suas relações privadas as pessoas devem comportar-se segundo a boa-fé (como determinam os arts. 113; 187; e 422 do CC), há ainda maior razão para atuarem dessa forma em juízo, já que praticam os atos processuais perante o magistrado, que representa a autoridade do Estado. Não faz sentido defender que uma conduta ilícita se torna lícita quando é praticada perante o juiz ${ }^{194}$. Além do mais, como se salientou no item 1.3.4 "supra", a boa-fé configura uma condição essencial para que o processo alcance seus escopos. Se as partes não procederem honestamente, o objetivo estatal de realizar a justa composição dos litígios por meio do processo fica frustrado ${ }^{195}$. Daí a doutrina afirmar que

191 Nesse sentido: ALBUQUERQUE, Responsabilidade Processual por Litigância de Má Fé, Abuso de Direito e Responsabilidade Civil em Virtude de Actos Praticados no Processo, p. 68; MENEZES CORDEIRO, Litigância de Má-Fé, Abuso do Direito de Ação e Culpa “in Agendo”, pp. 125 e 127; MITIDIERO, Colaboração no Processo Civil: pressupostos sociais, lógicos e éticos, pp 95-97; RIBEIRO, O Sobreprincípio da Boa-Fé Processual como Decorrência do Comportamento da Parte em Juízo, in Revista Forense, vol. 381, pp. 59-70; PICÓ I JUNOY, El Principio de la Buena Fe Procesal y su Fundamento Constitucional, in Revista de Processo, $\mathrm{n}^{\circ}$ 196, pp. 132-136, passim; LOZANO, La Buena Fe Procesal y el Ejercicio de la Abogacía, in CONRADI (coord.), El Abuso del Proceso: mala fe y fraude de ley procesal, p. 110; TAELMAN, Abuse of Procedural Rights: regional report for Belgium-The Netherlands, in TARUFFO (ed.), Abuse of Procedural Rights: comparative standards of procedural fairness, pp. 127-128 e 132.

${ }^{192}$ O $11^{\circ}$ "Principle of Transnational Civil Procedure" trata dos deveres das partes e de seus advogados. O seu $1^{\circ}$ parágrafo estatui que "as partes e seus advogados devem atuar de boa-fé em suas relações com o tribunal e com as outras partes" (tradução nossa).

O "Codigo Procesal Civil Modelo para Iberoamerica" estabelece que "as partes, seus representantes ou assistente e, em geral, todos os partícipes do proceso, ajustarão sua conduta à dignidade da Justiça, ao respeito que se devem os litigantes e à lealdade e boa-fé" (art. $5^{\circ}$ ) e que os atos processuais "haverão de ser realizados com veracidade e boa-fé e ter por causa um interesse legítimo (art. 73) (tradução nossa).

${ }^{193}$ MENEZES CORDEIRO, Litigância de Má-Fé, Abuso do Direito de Ação e Culpa "in Agendo”, p. 125; ALBUQUERQUE, Responsabilidade Processual por Litigância de Má Fé, Abuso de Direito e Responsabilidade Civil em Virtude de Actos Praticados no Processo, pp. 68-69.

${ }^{194}$ Nesse sentido: LENT, Diritto Processuale Civile Tedesco, $1^{\mathrm{a}}$ parte, p. 106; PICÓ I JUNOY, El Principio de la Buena Fe Procesal y su Fundamento Constitucional, in Revista de Processo, $\mathrm{n}^{\circ}$ 196, pp. 138-139; CHIOVENDA, Principios de Derecho Procesal Civil, tomo II, p. 211.

${ }^{195}$ LUSO SOARES, A Responsabilidade Processual Civil, p. 164. 
a boa-fé processual é um reflexo da publicização do processo civil ${ }^{196}$. Como diz Picó i Junoy ${ }^{197}$, "uma vez superada a visão bélica ou agonística do processo, este se configura como um modo mais civilizado e pacífico de resolução de conflitos, no qual a intervenção das partes deve estar presidida pela boa-fê" (tradução nossa) ${ }^{198}$.

No ordenamento jurídico brasileiro, o princípio da boa-fé encontra-se positivado no art. 14, II, do CPC, que prevê o dever de "proceder com lealdade e boa-fê"199 200 . Além desse dispositivo legal, estão distribuídos pelo Código de Processo Civil diversos preceitos

${ }^{196}$ Nesse sentido: OLIVEIRA, Litigância de Má-Fé, p. 59; OTEIZA, Abuso de los Derechos Procesales en
América Latina, in BARBOSA MOREIRA (coord.), Abuso dos Direitos Processuais, p. 17; LANDONI
SOSA, El Abuso de los Derechos Procesales, in BARBOSA MOREIRA (coord.), Abuso dos Direitos
Processuais, pp. 132 e 150 .
É o que se infere, outrossim, dos seguintes excertos dos itens 5 e 17 da Exposição de Motivos do Código de
Processo Civil de 1973, elaborada pelo então Ministro da Justiça Alfredo Buzaid:
"O processo civil é um instrumento que o Estado põe à disposição dos litigantes, a fim de administrar
justiça. Não se destina a simples definição de direitos na luta privada entre os contendores. Atua, como já
observara BETTI, não no interesse de uma ou de outra parte, mas por meio do interesse de ambos. O
interesse das partes não é senão um meio, que serve para conseguir a finalidade do processo na medida em
que dá lugar àquele impulso destinado a satisfazer o interesse público da atuação da lei na composiçao dos
conflitos. A aspiração de cada uma das partes é a de ter razão: a finalidade do processo é a de dar razão a
quem efetivamente a tem. Ora, dar razão a quem a tem é, na realidade, não um interesse privado das partes, quem efetivamente a tem. Ora, dar razão a quem

$[\ldots]$

"Posto que o processo civil seja, de sua índole, eminentemente dialético, é reprovável que as partes se sirvam dele, faltando ao dever, da verdade, agindo com deslealdade e empregando artifícios fraudulentos; porque tal conduta não se compadece com a dignidade de um instrumento que o Estado põe à disposição dos contendores para atuação do direito e realização da justiça. Tendo em conta estas razões ético-jurídicas, definiu o projeto como dever das partes: a) expor os fatos em juízo conforme a verdade; b) proceder com lealdade e boa-fé; c) não formular pretensão, nem alegar defesa, cientes de que são destituídas de fundamento; d) não produzir provas, nem praticar atos inúteis ou desnecessários à declaração ou defesa do direito (art. 17)".

${ }^{197}$ El Principio de la Buena Fe Procesal y su Fundamento Constitucional, in Revista de Processo, $\mathrm{n}^{\circ}$ 196, p. 160.

${ }^{198}$ Na opinião de Ribeiro (O Sobreprincípio da Boa-Fé Processual como Decorrência do Comportamento da Parte em Juízo, in Revista Forense, vol. 381, pp. 61-62), o fato de o princípio da boa-fé ser um reflexo da publicização do processo civil, necessário para a atuação do Direito material e a realização da justiça, faz dele um sobreprincípio do ordenamento jurídico, que se sobrepõe e condiciona os demais princípios (inclusive aqueles previstos na Constituição Federal, como o direito de ação e o contraditório).

${ }^{199}$ Luso Soares (A Responsabilidade Processual Civil, pp. 162-165) assegura que a boa-fé é mais que um dever, configurando um elemento constitutivo do conceito de processo e uma condição essencial para que este alcance suas finalidades. Para ele, não é correto afirmar a existência de um "dever de boa-fé".

Ocorre que, como já se afirmou, a conduta em conformidade com a boa-fé encontra-se prevista como um dever das partes no art. 14, II, do CPC. Nesse aspecto, parece que o legislador brasileiro seguiu a orientação de Cunha (O Dolo e o Direito Judiciário Civil, pp. 18-19), que, já em 1936, ensinava que o concurso da boafé, além de ser um princípio orientador de toda a atividade processual, deve ser entendido como um verdadeiro dever, uma obrigação dos sujeitos do processo, uma vez que a atividade processual ímproba de uma parte prejudica mais o Estado que a parte adversária. Segundo o autor, a conduta processual contrária à boa-fé deve ser sancionada pelo Estado porque diminui potencialmente a força coativa estatal, que é o elemento principal para a vida e a segurança do direito. No mesmo sentido, Oliveira (Litigância de Má-Fé, p. 57) não identifica nenhum óbice à previsão do princípio da boa-fé como um dever. Pelo contrário, a autora afirma que isso reforça a aplicabilidade desse princípio e o seu respeito pelos sujeitos processuais, já que se atribui sanção ao seu descumprimento.

${ }^{200}$ O Projeto de Lei $n^{\circ} 8.046 / 2010$, em trâmite no Congresso Nacional, que versa sobre o novo Código de Processo Civil, prevê o mesmo dever no art. 80, II. 
éticos e deontológicos, corolários do princípio da boa-fé processual, como, por exemplo, os arts. 15, 17, 18, 31, 133, 135, 144, 147, 153, 193, 600, 601 etc. A violação de qualquer um deles configura ilícito processual ${ }^{201}$ e acarreta sanções predeterminadas na lei ("nulla poena sine lege").

Consoante o "caput" do art. 14 do CPC, estão sujeitos ao dever (e princípio) da boa-fé "todos aqueles que de qualquer forma participam do processo", ou seja: as partes, todos os possíveis intervenientes, seus advogados ${ }^{202}$, a Fazenda Pública, os membros do Ministério Público, os juízes ${ }^{203}$, os auxiliares da Justiça, as testemunhas etc $^{204}{ }^{205}$. Aliás, com relação a estes últimos (Fazenda Pública, Ministério Público, Magistratura e auxiliares da Justiça), a violação ao dever de boa-fé consiste, não só em um ato ilícito processual, mas também em um ato inconstitucional, uma vez que a Constituição Federal lhes impõe o dever de agir com probidade, segundo o princípio da moralidade administrativa (art. 37, "caput", da CF).

Na opinião de Luso Soares ${ }^{206}$, o legislador, ao regular o processo contencioso, faz uso de remissão delimitativa ao conceito de boa-fé, uma vez que atribui às partes o poder de impulso processual, porém veda os pedidos ilegais, a articulação de fatos inverídicos, o requerimento de diligências meramente dilatórias etc. Percebe-se, assim, que a boa-fé limita os poderes dos sujeitos processuais. Além disso, como a boa-fé é essencial para que o processo alcance os seus escopos, o mesmo jurista assevera que existe uma remissão impositiva a ela na seara processual. Ou seja, a boa-fé é impositiva a todo o processo.

\footnotetext{
${ }^{201}$ CINTRA; DINAMARCO; GRINOVER, Teoria Geral do Processo, p. 73.

${ }^{202}$ Não há dúvida de que os advogados devem respeitar o dever de boa-fé. O título do Capítulo II do Título II, do Livro I do Código de Processo Civil corrobora essa tese, pois estatui que os artigos nele contidos, inclusive o art. 14, que prevê o dever de "proceder com lealdade e boa-fé", tratam "dos deveres das partes $\boldsymbol{e}$ dos seus procuradores" (destaque nosso). Além disso, o art. $2^{\circ}$, parágrafo único, II, do Código de Ética e Disciplina da OAB enfatiza que o advogado deve "atuar com destemor, independência, honestidade, decoro, veracidade, lealdade, dignidade e boa-fé" (destaque nosso).

${ }^{203}$ Nesse sentido: MITIDIERO, Colaboração no Processo Civil: pressupostos sociais, lógicos e éticos, pp. 95-97; BAPTISTA DA SILVA, Comentários ao Código de Processo Civil, vol. 1, p. 104.

204 THEODORO JÚNIOR, Abuso de Direito Processual no Ordenamento Jurídico Brasileiro, in Revista Forense, v. 344, p. 46; DINAMARCO, Instituições de Direito Processual Civil, vol. II, § 528, p. 266; CINTRA; DINAMARCO; GRINOVER, Teoria Geral do Processo, pp. 73 e 74.

${ }^{205}$ Segundo Picó i Junoy (El Principio de la Buena Fe Procesal y su Fundamento Constitucional, in Revista de Processo, $\mathrm{n}^{\circ}$ 196, pp. 135 e 160) e Lozano (La Buena Fe Procesal y el Ejercicio de la Abogacía, in CONRADI (coord.), El Abuso del Proceso: mala fe y fraude de ley procesal, pp. 111-112), na Espanha, o âmbito de aplicação do princípio da boa-fé processual, previsto no art. 247 da "Ley de Enjuiciamiento Civil", é também bastante amplo, afetando as partes, os advogados, os procuradores, as testemunhas, os peritos, enfim, todo interveniente no processo.

Landoni Sosa (El Abuso de los Derechos Procesales, in BARBOSA MOREIRA (coord.), Abuso dos Direitos Processuais, p. 136) e Oteiza (Abuso de los Derechos Procesales en América Latina, in BARBOSA MOREIRA (coord.), Abuso dos Direitos Processuais, pp. 9 e 11) afirmam o mesmo com relação aos arts. $5^{\circ}$ e 63 do CPC uruguaio e aos arts. $5^{\circ}$ e 73 do "Codigo Procesal Civil Modelo para Iberoamerica".

${ }^{206}$ LUSO SOARES, A Responsabilidade Processual Civil, pp. 155-156.
} 


\subsubsection{Do caráter dúplice do princípio da boa-fé}

No âmbito do Direito obrigacional, a doutrina reconhece duas vertentes da boa$\mathrm{fe}^{-207}$ :

a) a boa-fé objetiva: é uma norma de comportamento leal, fundada na honestidade, na lealdade, na probidade e na consideração para com os interesses do "alter" (especificamente, na consideração para com as expectativas que a própria conduta cria, legitimamente, nos demais sujeitos da relação). Trata-se de um modelo objetivo de conduta social, sendo que cada indivíduo deve ajustar o seu comportamento a esse "standard" jurídico, atuando como atuaria um homem honesto, leal e probo. O seu conteúdo não pode ser rigidamente fixado, devendo o intérprete levar em consideração os fatores concretos do caso, como o "status" pessoal e cultural dos envolvidos. A boa-fé objetiva desempenha três funções técnicas específicas, que se evidenciam em cada relação contratual considerada concretamente: (1) a de cânone hermenêutico-integrativo do contrato, impelindo o juiz a tornar concreto o mandamento de respeito recíproco à confiança legítima da outra parte contratante, de modo a impedir que o contrato atinja finalidade diferente daquela para a qual foi celebrado; (2) a de norma de criação de deveres jurídicos instrumentais, também chamados de anexos ou laterais (v.g., deveres de cuidado, previdência e segurança, deveres de aviso e esclarecimento, deveres de informação, dever de prestar contas, deveres de colaboração e cooperação, deveres de proteção e cuidado com a pessoa e o patrimônio da contraparte, deveres de omissão e de segredo etc.), os quais se dirigem a ambas partes contratantes, tendo em vista a satisfação do fim contratual; e (3) a de norma de limitação ao exercício de direitos subjetivos, abrangendo, por exemplo, a teoria do adimplemento substancial, a regra do "tu quoque" e a proibição do "venire contra factum proprium"; e

b) a boa-fé subjetiva: é o convencimento individual da parte de que procede em conformidade com o direito. Normalmente, concretiza-se na crença errônea, ainda que escusável, acerca da existência do próprio direito, ou na ignorância de se estar lesando direito alheio, ou ainda na vinculação egoística à literalidade do pactuado. É qualificada como "subjetiva" porque a sua aplicação exige que o intérprete considere a intenção do sujeito da relação jurídica, o seu estado psicológico. Contrapõe-se à má-fé, que é a intenção de lesar outrem.

${ }^{207}$ MARTINS-COSTA, A Boa-Fé no Direito Privado: sistema e tópica no processo obrigacional, pp. 411 413 e $427-472$. 
A mesma dualidade existente no Direito civil entre boa-fé objetiva e subjetiva pode ser encontrada também no âmbito processual ${ }^{208}$ :

a) a boa-fé objetiva no processo gera o dever de as partes agirem com lealdade e cooperarem entre si e com o juiz no exercício justo da atividade jurisdicional, com o fim de obter um provimento o mais próximo possível da verdade processual ${ }^{209}$. Ela está prevista no art. 14, II, do CPC e serve de fundamento para as diversas normas que previnem e sancionam o abuso de situações jurídicas processuais (v.g., arts. 16-18; 129; 600-601 do CPC etc.);

b) a boa-fé subjetiva consiste na presunção de probidade e honestidade das partes na prática dos atos processuais. Em outras palavras, ela cria a presunção relativa de que há um comportamento leal e cooperativo dos litigantes no processo ${ }^{210}$. Contrapõe-se à má-fé e ao dolo processual, que não se presumem. Seu fundamento legal também é o inciso II do art. 14 do CPC. São exemplos de sua aplicação no processo civil: (1) a presunção relativa de veracidade da declaração de pobreza para que incida a Lei no 1.060/50; (2) a presunção relativa de correção do valor da causa indicado na petição inicial; e, (3) no processo de execução, presumem-se verdadeiras as alegações do autor com relação ao "quantum debeatur". O princípio da boa-fé subjetiva acelera o procedimento e confere maior eficácia aos provimentos jurisdicionais. Além disso, configura uma garantia contra a má aplicação da teoria do abuso do processo porque impede que o magistrado enxergue em cada comportamento das partes a intenção de prejudicar ou de mentir, transformando o processo em um instrumento de iniquidade, de surpresa e de maldade. Cumpre ao juiz evitar o abuso do processo e, caso isso não seja possível, sancionar as condutas ímprobas perpetradas pelas partes. Todavia, não se pode permitir o exagero nessa atividade repressora ${ }^{211}$.

Portanto, é possível afirmar que o princípio da boa-fé processual possui duas finalidades: (a) fundamento da prevenção e da repressão do abuso do processo (boa-fé

\footnotetext{
${ }^{208}$ VINCENZI, A Boa-Fé no Processo Civil, pp. 24, 167-172 e 177.

É o que também ensina Luso Soares (A Responsabilidade Processual Civil, p. 154). Para o autor, a boa-fé objetiva processual consiste em "regra de comportamento conforme os preceitos legais que estatuem deveres de comportamento processual", enquanto a boa-fé subjetiva processual é a "situação jurídica em que se encontra o sujeito que actua com observância daqueles deveres".

${ }^{209}$ Picó i Junoy (El Principio de la Buena Fe Procesal y su Fundamento Constitucional, in Revista de Processo, no 196, pp. 143 e 161) conceitua boa-fé processual como a "conduta exigível de toda pessoa, no marco de um processo, por ser socialmente admitida como correta" (tradução nossa)

${ }^{210}$ Fazem referência a essa presunção relativa de boa-fé dos litigantes: OLIVEIRA, Litigância de Má-Fé, p. 56; PONTES DE MIRANDA, Comentários ao Código de Processo Civil, tomo I, p. 385.

${ }^{211}$ Esse risco de exagero por parte dos juízes na aplicação da teoria do abuso processual vem sendo alertado há muito tempo, como se percebe, por exemplo, na obra de Castro Filho (Abuso do Direito no Processo Civil, p. 215).
} 
objetiva); e (b) garantia de que o magistrado não exerça com excesso de autoridade sua função preventiva e repressiva de condutas processuais abusivas (boa-fé subjetiva).

\subsubsection{Conflito entre a garantia do contraditório e o princípio da boa-fé?}

O princípio da inafastabilidade do controle jurisdicional (art. $5^{\circ}, \mathrm{XXXV}$, da $\mathrm{CF}$ ) assegura o direito ao devido processo constitucional, ou seja, garante o acesso ao instrumento de solução de controvérsias que é o processo tal como concebido pela Constituição Federal. Dentre as garantias constitucionais inerentes ao modelo processual brasileiro encontra-se a do contraditório ${ }^{212}$.

Essa garantia constitucional, prevista no inciso LV do art. $5^{\circ}$ da $\mathrm{CF}$, destina-se a proporcionar ampla participação dos sujeitos processuais nos atos preparatórios do provimento jurisdicional final, possibilitando, assim, que cada um deles influencie no resultado do processo. Ela apresenta dupla destinação ${ }^{213}$ :

a) aplica-se às partes, de modo que a lei deve instituir meios para que elas participem no processo e o juiz deve disponibilizar-lhes esses meios. A participação franqueada aos litigantes é tríplice, abrangendo oportunidades para participar pedindo, participar alegando e participar provando. A garantia do contraditório destinada às partes é formada por dois elementos: (1) ciência bilateral obrigatória, mediante citação ou intimação, já que a efetividade da participação dos litigantes depende do conhecimento do ato processual a ser atacado; e (2) reação possível ao ato desfavorável praticado pela parte contrária ou pelo juiz; e

b) aplica-se ao próprio juiz, que deve participar ativamente da preparação do julgamento, exercendo ele mesmo o contraditório. Trata-se de verdadeiro dever de participação, já que o juiz não tem faculdades no processo, mas apenas poderes e deveres. A participação que a garantia do contraditório impõe ao magistrado consiste em atos: (1) de direção do processo, que é exercida mediante o impulso oficial (art. 262, parte final, do CPC) e a atividade de saneamento (art. 331, $\S 3^{\circ}$, do CPC); (2) de prova (diversos dispositivos do Código de Processo Civil atribuem ao juiz o poder-dever de ter iniciativa

\footnotetext{
${ }^{212}$ BEDAQUE, Os Elementos Objetivos da Demanda Examinados à Luz do Contraditório, in CRUZ E TUCCI; BEDAQUE, Causa de Pedir e Pedido no Processo Civil: questões polêmicas, pp. 19-20.

${ }^{213}$ DINAMARCO, Instituições de Direito Processual Civil, vol. I, §§ 84-85, pp. 220-224; e $\S 88$, pp. 226231; CINTRA; DINAMARCO; GRINOVER, Teoria Geral do Processo, pp. 57-59; BEDAQUE, Os Elementos Objetivos da Demanda Examinados à Luz do Contraditório, in CRUZ E TUCCI; BEDAQUE, Causa de Pedir e Pedido no Processo Civil: questões polêmicas, pp. 20-23; NERY JUNIOR, Princípios do Processo na Constituição Federal: processo civil, penal e administrativo, pp. 205-207.
} 
probatória em certos casos e em alguma medida, como os arts. 33, 342 e 399); e (3) de diálogo (v.g., tentativa de conciliar as partes, esclarecimento sobre a distribuição do ônus da prova, advertência da necessidade de provar melhor, incitação das partes para que se manifestem sobre possível extinção do processo com fundamento na falta de alguma condição da ação não alegada pelo réu etc.).

Em um Estado democrático de direito, o exercício do poder só é legítimo quando preparado por atos idôneos praticados segundo a Constituição e a lei (devido processo legal), com a participação dos sujeitos interessados. Como é a garantia do contraditório que proporciona a oportunidade de participação dos interessados no processo, ela é considerada um fator de legitimação dos atos de poder praticados pelo órgão jurisdicional ${ }^{214} 215$.

Além de legitimar atos estatais decisórios por meio da participação dos interessados, a garantia do contraditório tem outras finalidades no sistema jurídico processual. Por exemplo, o diálogo que se desenvolve, ao longo do processo, entre as partes e o juiz contribui para que a decisão seja mais aperfeiçoada, pois permite um juízo mais aberto e ponderado ${ }^{216}$. Yarshell ${ }^{217}$ acrescenta outra utilidade: no contexto da prova pré-constituída, o contraditório funciona como fator determinante da conduta processual responsável das partes porque possibilita que os interessados conheçam previamente fatos relevantes relacionados à situação substancial controvertida, permitindo que eles formem sua própria convicção e, com base nela, ingressem em juízo, ou resistam a dada pretensão, ou então pratiquem atos de autocomposição. Além disso, a doutrina processual discute se o efetivo contraditório entre as partes também contribui, ou não, para a proteção da boa-fé processual.

Na opinião de Carnelutti ${ }^{218}$, o contraditório constitui a melhor defesa contra a improbidade no processo. O autor ensina que os poderes atribuídos pelo ordenamento jurídico ao magistrado não são tão eficazes no combate aos atos de má-fé de uma das partes quanto a astúcia da parte adversária. Analogamente, Comoglio, Ferri e Taruffo 219 dizem que a contraposição dinâmica entre as partes, decorrente do contraditório, destina-se

\footnotetext{
${ }^{214}$ DINAMARCO, Instituições de Direito Processual Civil, vol. I, § 85, pp. 220-221.

${ }^{215}$ É oportuno observar que, se o exercício do poder estatal não impõe qualquer restrição à esfera jurídica de quem quer que seja, não é necessária ou útil a observância da garantia do contraditório. Daí a afirmação de que o art. 285-A do CPC não contraria o direito do réu ao contraditório, já que este não pode obter nenhum resultado juridicamente superior à total improcedência da demanda, por mais e melhores argumentos que possa apresentar ao órgão judicial (YARSHELL, Antecipação da Prova sem o Requisito da Urgência e Direito Autônomo à Prova, pp. 166-167).

${ }^{216}$ YARSHELL, Antecipação da Prova sem o Requisito da Urgência e Direito Autônomo à Prova, p. 166.

${ }^{217}$ Antecipação da Prova sem o Requisito da Urgência e Direito Autônomo à Prova, pp. 170-172.

${ }^{218}$ Contro il Processo Fraudolento, in Studi di Diritto Processuale, vol. II, p. 26.

${ }^{219}$ Lezioni sul Processo Civile, p. 68.
} 
à obtenção de fins superiores, dentre os quais está "a exigência de uma autoregulamentação interna das forças processuais, com um controle bilateral e recíproco dos riscos de 'abuso' dos instrumentos processuais à disposição das partes” (tradução nossa).

Lois Estévez ${ }^{220}$, porém, não parece compartilhar desse entendimento. Ao tratar dos elementos jurídicos que fundamentam a ilicitude do processo fraudulento, o autor sustenta que dentre eles não se encontra o princípio da boa-fé processual. Um dos argumentos que ele usa para defender sua tese consiste em afirmar que, não obstante esse princípio seja, teoricamente, suficiente para embasar a ilicitude da fraude, na prática, ele perde grande parte de seu valor porque é inevitavelmente relativizado pelo princípio do contraditório. Segundo o autor, como é inerente ao contraditório a defesa de teses antagônicas pelas partes (ainda que sejam apenas divergências de pontos de vista), e como a verdade é uma só, algum dos sujeitos processuais necessariamente falta com a verdade. Diante disso, conclui que a boa-fé é uma aspiração do processo, embora seja inexequível se considerada em termos absolutos 221 .

A conclusão a que este autor chega não se mostra inteiramente correta, uma vez que ele parte de premissas errôneas. De fato, a verdade objetiva é uma só. Entretanto, as alegações das partes no processo não são feitas com base nela e sim em um conhecimento subjetivo parcial da verdade, já que cada um a conhece à sua maneira ${ }^{222}$. O princípio da boa-fé não obriga os sujeitos processuais a atuarem em juízo em consonância com a verdade objetiva, mas sim com as respectivas verdades subjetivas. Desse modo, é possível que as alegações das partes sejam contraditórias entre si, porém ambas estejam de acordo com o princípio da boa-fé, pois traduzem as suas verdades pessoais ${ }^{223}$. Por causa disso, o princípio da boa-fé não é em nada relativizado pelo princípio do contraditório.

Deve-se ter em mente também que um dos corolários do princípio da boa-fé no processo civil é o princípio da cooperação e que esse princípio informa e qualifica o

\footnotetext{
${ }^{220}$ Teoria del Fraude en el Proceso Civil, pp. 68-70.

${ }^{221}$ Loiz Estévez (Teoria del Fraude en el Proceso Civil, pp. 70-71) restringe sua pesquisa ao Direito positivo, encontrando dois caminhos para demonstrar objetivamente a ilicitude da fraude processual:

a) do ponto de vista do Direito material, cada caso concreto de fraude processual configura uma infração indireta da norma que os sujeitos processuais querem burlar;

b) do ponto de vista do Direito processual, a fraude configura uma utilização anormal do processo, seja porque impede que o processo como um todo alcance o seu escopo de garantir a vigência e a eficácia da ordem jurídica material, seja porque o seu perpetrador deixa de cumprir alguma norma processual específica, referente à concreta determinação do curso e do modo como uma pretensão deve ser pleiteada em juízo.

${ }^{222}$ BARROS, A Busca da Verdade no Processo Penal, p. 30.

${ }^{223}$ LUSO SOARES, A Responsabilidade Processual Civil, pp. 161-162.
} 
contraditório $^{224}$. Como se verá de forma mais detalhada no item 1.3.6 "infra", as partes participam do contraditório processual como sujeitos em cooperação. Elas cooperam com o juiz no exercício da função jurisdicional, oferecendo meios de prova, propondo interpretações legislativas, desenvolvendo conceitos doutrinários, apresentando precedentes dos tribunais etc., sempre com o intuito de obter um provimento jurisdicional favorável $^{225}$. Logicamente, a mentira a respeito dos fatos relevantes para a demanda não pode ser considerada uma dessas atividades de cooperação interessada. Caso contrário, ao invés de colaborarem com a atividade do magistrado, as partes estariam dificultando o exercício justo da atividade jurisdicional.

Em resumo, o efetivo contraditório entre as partes contribui, sim, para a concretização da boa-fé processual.

No entanto, a recíproca nem sempre é verdadeira, pois, se o princípio da boa-fé for elevado a níveis extremos, ele pode prejudicar a efetividade das garantias constitucionais do contraditório e da ampla defesa. Dinamarco ${ }^{226}$ menciona duas situações em que o órgão jurisdicional radicalizou exigências de lealdade, em detrimento do contraditório e da ampla defesa. No primeiro caso, o tribunal condenou por litigância de má-fé uma parte que interpôs agravo de instrumento antes de ser apreciado o pedido de reconsideração que ela tinha feito da mesma decisão recorrida. O juízo não levou em consideração que, se a parte não interpusesse o recurso no prazo contado a partir da decisão (e não da resposta ao requerimento de reconsideração), ocorreria preclusão temporal do poder de recorrer. No segundo, o juiz condenou uma das partes por litigância de má-fé e atribuiu crime de desobediência aos seus advogados porque estes incluíram no instrumento de um recurso de agravo documentos que ele tinha mandado desentranhar dos autos principais, os quais haviam sido exibidos juntamente com as razões de apelação.

Por conseguinte, diante das situações concretas, o magistrado deve usar a razoabilidade, evitando a repressão de condutas das partes que revelem apenas astúcia ou espírito de luta, sem contrariar a boa-fé, sob pena de fazer tábula rasa da garantia contida no art. $5^{\circ}, \mathrm{LV}$, da CF.

\footnotetext{
${ }^{224}$ DIDIER JUNIOR, O Princípio da Cooperação: uma apresentação, in Revista de Processo, nº 127, pp. 7677 .

${ }^{225}$ DINAMARCO, Instituições de Direito Processual Civil, vol. II, § 521, p. 255; GRINOVER, Abuso do Processo e Resistência às Ordens Judiciárias: o contempt of court, in A Marcha do Processo, p. 62; YARSHELL, Antecipação da Prova sem o Requisito da Urgência e Direito Autônomo à Prova, p. 163.

${ }^{226}$ Instituições de Direito Processual Civil, vol. II, § 528-A, pp. 274-275.
} 


\subsubsection{O princípio da cooperação}

A doutrina processual contemporânea reconhece a existência do chamado "princípio da cooperação" (ou da colaboração), que prega uma nova organização da participação do juiz e das partes no processo civil, promovendo um equilíbrio entre as posições jurídicas de todos os sujeitos processuais ${ }^{227}$.

A ideia de cooperação implica o fortalecimento dos poderes das partes, que passam a ter uma participação mais ativa e leal no processo de formação da decisão, aliado à atribuição de um papel ativo, porém não-autoritário, ao órgão jurisdicional ${ }^{228}$. Concebese o processo como uma verdadeira "comunhão de trabalho", em que cada participante exerce suas próprias funções, mas todos têm o objetivo comum de alcançar a justiça no caso concreto, de uma maneira ágil e eficaz ${ }^{229}$.

Grasso $^{230}$ explica que a colaboração não se confunde com a mera sucessão temporal de atividades dos sujeitos processuais, ordenadas segundo um critério de pressuposição (ou seja, não se pode inferir a existência do princípio da cooperação, por exemplo, do fato de a parte não poder ver aplicada a lei sem que haja o provimento judicial e de o juiz não poder aplicar a lei sem que haja a provocação da parte). Para que exista verdadeira colaboração, segundo os ensinamentos desse jurista italiano, é necessário que uma pluralidade de sujeitos atue contemporaneamente e de comum acordo para conseguir um resultado de síntese, que não poderia ser alcançado por um indivíduo isolado. Sendo assim, somente se toda a matéria litigiosa, fática e jurídica, for submetida às atividades do autor, do réu e do juiz, em concurso, nos limites das respectivas atribuições, antes da prolação do provimento jurisdicional, é que o resultado do processo de cognição pode ser considerado o produto de uma colaboração processual total.

O princípio da cooperação encontra-se positivado em diversas legislações estrangeiras, como a alemã $\tilde{a}^{231}$, a francesa ${ }^{232}$, a portuguesa ${ }^{233}$ e a italiana ${ }^{234} 235$. No

\footnotetext{
${ }^{227}$ MITIDIERO, Colaboração no Processo Civil como Prêt-à-Porter? Um Convite ao Diálogo para Lenio Streck, in Revista de Processo, no 194, pp. 57 e 62.

${ }^{228}$ ALVARO DE OLIVEIRA, Poderes do Juiz e Visão Cooperativa do Processo, in Revista da AJURIS, $\mathrm{n}^{\circ}$ 90, p. 62.

${ }^{229}$ DIDIER JUNIOR, O Princípio da Cooperação: uma apresentação, in Revista de Processo, $\mathrm{n}^{\circ}$ 127, p. 76; MITIDIERO, Colaboração no Processo Civil: pressupostos sociais, lógicos e éticos, pp. 102-103.

${ }^{230}$ La Collaborazione nel Processo Civile, in Rivista di Diritto Processuale, vol. XXI, pp. 584-587.

${ }^{231}$ O $§ 139$ da ZPO Alemã estatui o seguinte:

"§ 139 (Dever de esclarecimento judicial)

I - O presidente deve fazer com que as partes se pronunciem de forma íntegra sobre os fatos relevantes $e$ efetuar as petições pertinentes, em especial completar também dados insuficientes dos fatos invocados e
} 
ordenamento jurídico brasileiro, ele é fundado nos princípios do devido processo legal (art. $5^{\circ}$, LIV, da CF), da boa-fé processual (art. 14, II, do CPC), do contraditório (art. $5^{\circ}, \mathrm{LV}$, da $\mathrm{CF})^{236}$ e da duração razoável do processo (art. $5^{\circ}$, LXXVIII, da CF) ${ }^{237}$ juntos $^{238}$.

indicar os meios de prova. Com esse objeto, sempre que seja necessário, discutirá o assunto e o litígio com as partes e fará perguntas sobre o aspecto fático e jurídico do conflito.

II - O presidente deve chamar a atenção sobre as considerações que imperam em vista dos pontos a ter em conta de ofício.

III - Se assim se requer, deve permitir estabelecer perguntas a cada membro do tribunal" (tradução nossa, baseada na versão em espanhol: ENCINAS; MÍGUEZ, Código Procesal Civil Alemán, p. 52).

${ }^{232}$ Determina o art. 16 do CPC francês:

"O juiz deve, em todas as circunstâncias, fazer observar e observar ele mesmo o princípio do contraditório.

Ele não pode levar em consideração, em sua decisão, os meios, as explicações e os documentos invocados ou produzidos pelas partes, a não ser que estas tenham sido capazes de debatê-los em contraditório.

Ele não pode fundar sua decisão em meios de direito que ele tenha considerado de ofício sem ter, previamente, convidado as partes a apresentar suas observações" (tradução nossa).

${ }^{233} \mathrm{O}$ princípio da cooperação consta dos arts. $3^{\circ}, \mathrm{n}^{\circ} 3$; e 266 do CPC português:

“ARTIGO 3. ${ }^{\circ}$ (Necessidade do pedido e da contradição)

[...]

3. O juiz deve observar e fazer cumprir, ao longo de todo o processo, o princípio do contraditório, não lhe sendo lícito, salvo caso de manifesta desnecessidade, decidir questões de direito ou de facto, mesmo que de conhecimento oficioso, sem que as partes tenham tido a possibilidade de sobre elas se pronunciarem [...]";

"ARTIGO 266. (Princípio da cooperação)

1. Na condução e intervenção no processo, devem os magistrados, os mandatários judiciais e as próprias partes cooperar entre si, concorrendo para se obter, com brevidade e eficácia, a justa composição do litígio.

2. O juiz pode, em qualquer altura do processo, ouvir as partes, seus representantes ou mandatários judiciais, convidando-os a fornecer os esclarecimentos sobre a matéria de facto ou de direito que se afigurem pertinentes e dando-se conhecimento à outra parte dos resultados da diligência.

3. As pessoas referidas no número anterior são obrigadas a comparecer sempre que para isso forem notificadas e a prestar os esclarecimentos que lhes forem pedidos, sem prejuízo do disposto no $n^{\circ} 3$ do artigo 519..

4. Sempre que alguma das partes alegue justificadamente dificuldade séria em obter documento ou informação que condicione o eficaz exercício de faculdade ou o cumprimento de ónus ou dever processual, deve o juiz, sempre que possível, providenciar pela remoção do obstáculo".

${ }^{234} \mathrm{O}$ art. $101, \S 2^{\circ}$, do CPC italiano estabelece o seguinte:

“Art. 101 (Princípio do contraditório)

$[\ldots]$

Se cogita pôr como fundamento da decisão uma questão considerada de ofício, o juiz reserva a decisão, atribuindo às partes, sob pena de nulidade, um prazo, não inferior a vinte dias e não superior a quarenta dias a contar da comunicação, para o depósito, na secretaria, de memoriais contendo observações sobre a mesma questão" (tradução nossa).

${ }^{235}$ DIDIER JUNIOR, O Princípio da Cooperação: uma apresentação, in Revista de Processo, $\mathrm{n}^{\circ}$ 127, pp. 7576 e pp. 77-78, nts. 7, 9 e 10; DIDIER JUNIOR, Os Três Modelos de Direito Processual: inquisitivo, dispositivo e cooperativo, in Revista de Processo, n 198, pp. 221-224, nts. 30, 33 e 34.

${ }^{236}$ DIDIER JUNIOR, Os Três Modelos de Direito Processual: inquisitivo, dispositivo e cooperativo, in Revista de Processo, no 198 , pp. 218-219.

${ }^{237}$ BERALDO, O Dever de Cooperação no Processo Civil, in Revista de Processo, no ${ }^{\circ}$ 198, pp. 455-456.

${ }^{238}$ O Código de Processo Civil projetado (Projeto de Lei $\mathrm{n}^{\circ}$ 8.046/2010) dedica diversos dispositivos ao tratamento do princípio da cooperação, destacando-se os arts. $5^{\circ}$ e $8^{\circ}$ :

"Art. $5^{\circ}$ As partes têm direito de participar ativamente do processo, cooperando com o juiz e fornecendo-lhe subsídios para que profira decisões, realize atos executivos ou determine a prática de medidas de urgência"; "Art. $8^{\circ}$ As partes e seus procuradores têm o dever de contribuir para a rápida solução da lide, colaborando com o juiz para a identificação das questões de fato e de direito e abstendo-se de provocar incidentes desnecessários e procrastinatórios".

Segundo Marinoni e Mitidiero (O Projeto do CPC: crítica e propostas, p. 72), "é possível afirmar sem qualquer dúvida que o modelo de processo civil proposto pelo Projeto é indubitavelmente um modelo de processo civil cooperativo" (destaques no original). 
Mitidiero $^{239}$ ensina que o modelo cooperativo de processo civil é estruturado a partir de pressupostos culturais que podem ser enfocados sob o ângulo social, lógico e ético.

Sob a ótica social, parte-se da ideia de que o ordenamento jurídico concebe o Estado tendo como referencial a atual sociedade cooperativa. Na sociedade hodierna, o indivíduo, a sociedade civil e o Estado atuam coordenadamente para a obtenção de proveito mútuo. Essa necessidade de participação forma a base da democracia contemporânea. Daí a Constituição Federal estatuir que a República Federativa do Brasil constitui-se em Estado Democrático de Direito (art. 1', “caput"), fundamentado na dignidade da pessoa humana (art. $1^{\circ}$, III), que tem como um de seus objetivos fundamentais a construção de uma sociedade livre, justa e solidária (art. $3^{\circ}$, I). Essas características colaborativas que a sociedade imprime no Estado, por meio das normas constitucionais, repercutem nas posições ocupadas pelos participantes do processo: para que o processo seja organizado de forma justa, capaz de alcançar decisões justas, os sujeitos processuais têm de ter posições jurídicas equilibradas ao longo do procedimento, que permitam uma condução isonômica, democrática, do processo.

Do ponto de vista da lógica utilizada para a resolução dos conflitos, o modelo de processo civil pautado pela cooperação tem como pressuposto o reconhecimento do caráter problemático do Direito. A tomada de consciência da problematicidade do Direito ocorreu no início da segunda metade do século XX, quando os conflitos de valores se tornaram mais agudos e prementes e os conceitos jurídicos ficaram mais imprecisos e elásticos, dado o emprego frequente de princípios, conceitos jurídicos indeterminados e juízos de equidade na legislação. Esse fenômeno reabilitou a feição argumentativa do Direito e iniciou o resgate da dimensão retórica e dialética do processo $^{240}$. Compreende-se o Direito não mais como algo totalmente pré-dado pela legislação, mas sim como um problema para cuja solução é relevante o aporte argumentativo que as partes levam ao processo; em outras palavras, reconhece-se o Direito cada vez mais como "juris prudentia", e não apenas como "scientia juris". A compreensão problemática do Direito incrementa os poderes das partes relativos à valoração do material jurídico da causa e fortalece o direito ao contraditório,

Acerca do princípio da cooperação no projeto do novo Código de Processo Civil, consultar: BONICIO, Ensaio sobre o Dever de Colaboração das Partes Previsto no Projeto do Novo Código de Processo Civil Brasileiro, in Revista de Processo, $\mathrm{n}^{\circ}$ 190, pp. 210-230.

${ }^{239}$ MITIDIERO, Colaboração no Processo Civil: pressupostos sociais, lógicos e éticos, pp. 63; 71-77; 90-94; 95-97; 99-100; 102-103; MITIDIERO, Colaboração no Processo Civil como Prêt-à-Porter? Um Convite ao Diálogo para Lenio Streck, in Revista de Processo, no 194, pp. 59-61.

${ }^{240}$ ALVARO DE OLIVEIRA, Poderes do Juiz e Visão Cooperativa do Processo, in Revista da AJURIS, $\mathrm{n}^{\circ}$ 90, pp. 61-62. 
que passa a ser entendido como um direito a influenciar efetivamente o órgão jurisdicional acerca das questões do processo, sejam elas fáticas, jurídicas ou mistas, materiais ou processuais. Adota-se, assim, a lógica dialética e o contraditório assume um papel de destaque no formalismo processual, viabilizando o diálogo e a cooperação entre os sujeitos do processo e forçando a uma melhor distribuição das posições jurídicas das partes e do órgão jurisdicional no processo.

Por fim, na perspectiva da ética, o processo pautado pela cooperação pressupõe a obtenção da verdade para a prestação da tutela jurisdicional adequada e justa em cada caso concreto. A persecução da verdade é considerada tarefa não só das partes, mas também do juiz (art. 131 do CPC), na medida de seus interesses. Além disso, ainda na seara da ética, esse modelo processual exige das partes e do Estado-juiz a observância tanto da boa-fé subjetiva, quanto da boa-fé objetiva.

De acordo com Mitidiero ${ }^{241}$, o modelo processual cooperativo deve ser encarado como o resultado da superação histórica e cultural dos modelos de processo isonômico (ou paritário), caracterizado pela relação de paridade entre as partes e o Estado-juiz, e de processo assimétrico (ou hierárquico), em que o Estado-juiz é alocado acima das partes. Outros autores preferem vê-lo como uma superação dos modelos de processo dispositivo (ou "adversarial") e de processo inquisitivo (ou "inquisitorial") ${ }^{242}$. Há ainda quem entenda que se trata de uma superação cultural dos modelos processuais civis liberal, socialista e de Franz Klein ${ }^{243}$.

Para a obtenção de um processo leal e cooperativo, diversos deveres comportamentais são imputados às partes e ao órgão jurisdicional. As condutas que transgridem tais deveres, obstaculizando o ideal de transformar o processo em uma “comunidade de trabalho", devem ser consideradas ilícitas ${ }^{244}$.

Dentre os deveres atribuídos às partes encontram-se ${ }^{245}$ :

241 Colaboração no Processo Civil: pressupostos sociais, lógicos e éticos, pp. 63-103; Colaboração no Processo Civil como Prêt-à-Porter? Um Convite ao Diálogo para Lenio Streck, in Revista de Processo, $\mathrm{n}^{\circ}$ 194, p. 58.

242 DIDIER JUNIOR, Os Três Modelos de Direito Processual: inquisitivo, dispositivo e cooperativo, in Revista de Processo, ${ }^{\circ}$ 198, pp. 213-220; GRASSO, La Collaborazione nel Processo Civile, in Rivista di Diritto Processuale, vol. XXI, pp. 596-598.

${ }^{243}$ ALVARO DE OLIVEIRA, Poderes do Juiz e Visão Cooperativa do Processo, in Revista da AJURIS, $\mathrm{n}^{\circ}$ 90, pp. 56-65.

${ }^{244}$ DIDIER JUNIOR, Os Três Modelos de Direito Processual: inquisitivo, dispositivo e cooperativo, in Revista de Processo, no 198, pp. 220-221 e 225.

${ }^{245}$ DIDIER JUNIOR, Os Três Modelos de Direito Processual: inquisitivo, dispositivo e cooperativo, in Revista de Processo, n 198, p. 221. 
a) o dever de esclarecimento: o demandante deve deduzir sua pretensão com clareza e coerência, caso contrário sua petição é considerada inepta (art. 295, I e parágrafo único, do CPC). Os deveres das partes previstos nos arts. 339 (dever de colaborar com o Poder Judiciário para o descobrimento da verdade), 340 (dever de comparecer em juízo, respondendo ao que lhe for interrogado; dever de se submeter à inspeção judicial; e dever de praticar o ato que lhe for determinado), 355 (dever de exibir documento ou coisa que se ache em seu poder) 381 e 382 do CPC (dever de exibir, total ou parcialmente, livros e documentos) derivam deste dever, uma vez que ajudam o juiz a esclarecer pontos duvidosos ou controvertidos da causa;

b) o dever de lealdade: as partes devem atuar em juízo com lealdade (art. 14, II, do CPC), abstendo-se de cometer atos de litigância de má-fé (art. 17 do CPC); e

c) o dever de proteção: a parte não pode lesar a parte adversária, sob pena de ter de ressarcir-lhe as perdas e danos (arts. 475-O, I; 574; e 881 do CPC).

$\mathrm{Na}$ opinião de Mitidiero e Marinoni ${ }^{246}$, não existe colaboração entre as partes, uma vez que elas atuam em juízo movidas por diferentes interesses no que concerne ao resultado do julgamento da demanda. Para eles, a colaboração que é devida no processo civil é apenas do juiz para com as partes. Salientam que a própria estrutura adversarial inerente ao processo contencioso repele a ideia de colaboração entre as partes, o que não implicaria, no seu modo de ver, o reconhecimento do processo civil como um ambiente livre dos deveres de boa-fé e lealdade.

"Venia concessa", parece ser preferível o entendimento contrário, de que existe, sim, um dever de colaboração recíproco entre as partes. De acordo com o atual enfoque instrumentalista do processo civil, uma das finalidades precípuas do processo é promover a justa composição dos litígios, mediante a atuação da vontade concreta do Direito substancial. Logo, não obstante as partes atuem em juízo tentando satisfazer seus próprios interesses, elas têm o dever de cooperar entre si e com o órgão jurisdicional para poderem alcançar o objetivo comum de obter um provimento jurisdicional justo, célere e eficaz. Essa cooperação recíproca das partes é eminentemente processual, não tendo nada a ver com o teor favorável ou desfavorável do provimento jurisdicional. Isso porque o dever que o litigante tem de cooperar com o seu adversário para o bom desenvolvimento do processo não implica a obrigação de abrir mão do direito ou da situação jurídica material

${ }^{246}$ O Projeto do CPC: crítica e propostas, p. 73; MITIDIERO, Colaboração no Processo Civil como Prêt-àPorter? Um Convite ao Diálogo para Lenio Streck, in Revista de Processo, nº 194, p. 62. 
controvertida $^{247}$. Um exemplo talvez elucide melhor essa asserção: quando o demandado atua em conformidade com o dever de veracidade (art. 14, II, do CPC) e confirma os fatos narrados na petição inicial, tornando-os incontroversos, ele coopera com a outra parte e com o juiz para a obtenção de uma decisão de mérito justa e em consonância com a garantia constitucional da duração razoável do processo. Entretanto, isso não significa, necessariamente, que a sentença de mérito lhe será desfavorável, já que pode alegar em sua defesa a ocorrência de prescrição da pretensão obrigacional oriunda dos acontecimentos descritos pelo autor e por ele corroborados, ou então a existência de alguma outra defesa de mérito indireta apta a ensejar a improcedência da demanda inicial. É oportuno salientar que, em Portugal, o parágrafo $1^{\circ}$ do art. 266 do CPC menciona expressamente o dever de colaboração recíproco entre os litigantes: "na condução e intervenção no processo, devem os magistrados, os mandatários judiciais e as próprias partes cooperar entre si, concorrendo para se obter, com brevidade e eficácia, a justa composição do litígio" (destaque nosso).

O dever de colaboração das partes não é absoluto. Ele é excepcionalmente atenuado pelo próprio legislador, em respeito à defesa legítima da esfera privada, de certos valores morais e de outros interesses relevantes ${ }^{248}$. Consoante o art. 347 do CPC, a parte não é obrigada a se manifestar sobre fatos criminosos ou torpes que lhe tenham sido imputados, nem sobre fatos a cujo respeito, por estado ou profissão, deva guardar segredo. A doutrina afirma que esse dispositivo não contém rol taxativo, de modo que o juiz pode reconhecer outros motivos graves que justifiquem a dispensa do dever de colaborar (por exemplo, a parte não pode ser obrigada a se manifestar sobre fato criminoso ou torpe imputado a pessoa de sua família, nem sobre fatos que lhe tenham causado algum trauma psicológico, como acidentes ou crimes de que tenha sido vítima ${ }^{249}$. As limitações do dever de colaboração previstas no art. 347 do CPC só não se aplicam às ações de filiação, de separação, de divórcio e de anulação de casamento (art. 347, parágrafo único, do CPC). No mesmo sentido, o art. 363 do CPC dispensa a parte de exibir documento ou coisa em juízo sempre que: (a) disser respeito a negócios da própria vida da família; (b) a sua apresentação puder violar dever de honra; (c) a publicidade do documento resultar em desonra à parte, ou a seus parentes consanguíneos ou afins até o terceiro grau, ou ainda se

\footnotetext{
${ }^{247}$ BERALDO, O Dever de Cooperação no Processo Civil, in Revista de Processo, no 198 , pp. 458-461.

248 TABOSA PESSOA, Comentários ao art. 339 do CPC, in MARCATO (coord.), Código de Processo Civil Interpretado, p. 1083; TABOSA PESSOA, Comentários ao art. 363 do CPC, in MARCATO (coord.), Código de Processo Civil Interpretado, p. 1165.

${ }^{249}$ TABOSA PESSOA, Comentários ao art. 347 do CPC, in MARCATO (coord.), Código de Processo Civil Interpretado, pp. 1107-1108.
} 
representar perigo de ação penal; (d) a exibição acarretar a divulgação de fatos a cujo respeito, por estado ou profissão, deva guardar segredo; ou (e) houver algum outro motivo grave que, segundo o prudente arbítrio do juiz, justifique a recusa da exibição. Se o motivo disser respeito apenas a uma parte do conteúdo do documento, deve-se extrair uma suma da outra parte para ser apresentada em juízo (art. 363, parágrafo único, do CPC).

Quanto ao juiz, o princípio da cooperação concretiza-se por meio das seguintes regras, que devem ser seguidas na condução do processo ${ }^{250}$ :

a) dever de lealdade: assim como as partes, o magistrado também deve agir em juízo com lealdade;

b) dever de esclarecimento: se o órgão jurisdicional tem alguma dúvida acerca das alegações, pedidos ou posições das partes em juízo, ele deve esclarecer-se junto delas. O objetivo é evitar decisões tomadas com base em percepções equivocadas ou apressadas. No cumprimento desse dever, o juiz pode, por exemplo, pedir esclarecimentos ao demandante se constatar obscuridade do pedido ou da causa de pedir, esquivando-se de indeferir a petição inicial desde logo; pode interrogar as partes sobre os fatos da causa (art. 342 do CPC); se estiver em dúvida sobre o preenchimento de algum requisito processual de validade, pode pedir esclarecimentos para a parte envolvida, ao invés de extinguir o processo sem julgar o mérito etc. $\mathrm{O}$ dever judicial de esclarecimento abrange também o dever de o juiz esclarecer os seus próprios pronunciamentos para as partes, por meio do julgamento de embargos de declaração (art. 535, I, do CPC), o que é uma decorrência do dever constitucional de motivar todas as decisões (art. 93, IX, da CF);

c) dever de prevenção: o órgão jurisdicional deve prevenir as partes do risco de os seus pedidos serem frustrados pelo uso inadequado do processo. Fá-lo apontando as deficiências das postulações e dando aos litigantes oportunidades para que possam suprilas. Esse dever impede o juiz de não-conhecer de determinado pedido em razão de defeito processual sanável, sem antes ter dado oportunidade para a parte saná-lo. A doutrina explica que, em razão do dever de prevenção, o órgão jurisdicional tem o dever: de sugerir a explicitação de pedidos pouco claros (v.g., solicitar a especificação de um pedido indeterminado); de fazer referência ao caráter lacunar da exposição dos fatos relevantes

\footnotetext{
${ }^{250}$ Mitidiero (Colaboração no Processo Civil: pressupostos sociais, lógicos e éticos, pp. 75-76; Colaboração no Processo Civil como Prêt-à-Porter? Um Convite ao Diálogo para Lenio Streck, in Revista de Processo, $\mathrm{n}^{\circ}$ 194, p. 63) cita os deveres de esclarecimento, de prevenção, de consulta e de auxílio do juiz para com os litigantes.

Já Didier Junior (O Princípio da Cooperação: uma apresentação, in Revista de Processo, no 127, pp. 77-79; Os Três Modelos de Direito Processual: inquisitivo, dispositivo e cooperativo, in Revista de Processo, $\mathrm{n}^{\circ}$ 198, pp. 221-224) menciona os deveres de lealdade, de esclarecimento, de consulta e de prevenção como aspectos do princípio da cooperação na esfera jurídica do magistrado.
} 
que fundamentam a demanda; de solicitar a adequação do pedido formulado à situação concreta; e de sugerir uma certa atuação pela parte (e.g., esclarecer se a parte desistiu do depoimento de uma testemunha indicada ou se apenas não se lembrou da mesma; convidar a parte a provocar a intervenção de um terceiro). No direito positivo brasileiro, o dever de prevenção se manifesta no art. 284 do CPC, que assegura ao demandante o poder de emendar a petição inicial, caso o magistrado considere que falta algum requisito nela. Não se pode indeferir a petição inicial sem que se dê a oportunidade de correção do defeito. Outro exemplo é a regra que consta do art. 295, V, do CPC, segundo a qual, nos casos de escolha equivocada do tipo de procedimento, a petição inicial não pode ser indeferida sem que o magistrado intime previamente o demandante e indique qual o procedimento aplicável, dando-lhe prazo para que tome as providências que reputar necessárias. Analogamente, nos casos em que o magistrado constata a falta de interesse de agir, na modalidade interesse-adequação, ele não pode reconhecer a carência de ação sem antes indicar qual o tipo de providência jurisdicional adequada e oferecer oportunidade de corrigir o defeito $^{251}$;

d) dever de consulta: o órgão jurisdicional deve consultar as partes antes de decidir sobre qualquer questão, seja ela de fato ou de direito, de natureza processual (v.g., art. 267, $\S 3^{\circ}$, do CPC) ou material (arts. 269, IV; $219, \S 5^{\circ}$; e 295 , IV, do CPC). Esse dever se aplica mesmo às questões que o juiz deve conhecer de ofício ${ }^{252} 253$. Trata-se de

\footnotetext{
${ }^{251}$ O dever de prevenção está previsto no Código de Processo Civil projetado (Projeto de Lei no 8.046/2010): "Art. 291. Antes de proferir sentença sem resolução de mérito, o juiz deverá conceder à parte oportunidade para, se possivel, corrigir o vício";

"Art. 893. As questões preliminares suscitadas no julgamento serão solucionadas antes do mérito, deste não se conhecendo se incompatível com a decisão.

$\S 1^{\circ}$ Verificada a ocorrência de nulidade sanável, o relator deverá determinar a realização ou a renovação do ato processual, no próprio tribunal ou em primeiro grau, intimadas as partes; cumprida a diligência, sempre que possível, prosseguirá o julgamento do recurso".

${ }^{252}$ Nesse sentido: BEDAQUE, Os Elementos Objetivos da Demanda Examinados à Luz do Contraditório, in CRUZ E TUCCI; BEDAQUE, Causa de Pedir e Pedido no Processo Civil: questões polêmicas, pp. 38-42; GRASSO, La Collaborazione nel Processo Civile, in Rivista di Diritto Processuale, vol. XXI, pp. 591 e 608609.

${ }^{253}$ O Projeto de Lei $n^{\circ} 8.046 / 2010$, em trâmite no Congresso Nacional, que versa sobre o novo Código de Processo Civil, trata expressamente desse dever:

"Art. 10. O juiz não pode decidir, em grau algum de jurisdição, com base em fundamento a respeito do qual não se tenha dado às partes oportunidade de se manifestar, ainda que se trate de matéria sobre a qual tenha que decidir de ofício.

Parágrafo único. O disposto no caput não se aplica aos casos de tutela de urgência e nas hipóteses do art. 307";

"Art. 474. Haverá resolução de mérito quando:

[...]

Parágrafo único. Ressalvada a hipótese do $\$ 1^{\circ}$ do art. 307, a prescrição e a decadência não serão decretadas sem que antes seja dada às partes oportunidade de se manifestar";
} 
manifestação da garantia do contraditório, que assegura aos litigantes o poder de influenciar o juiz a respeito do rumo a ser dado à causa. É possível avistar a aplicação desse dever no art. 296 do CPC, que autoriza a retratação do magistrado após a interposição de apelação contra a sentença que indeferiu a petição inicial, visto que confere ao demandante a oportunidade de tentar alterar a convicção do magistrado acerca da questão conhecida "ex officio", sobre a qual não teve a oportunidade de manifestar-se anteriormente; e

e) dever de auxílio: o órgão jurisdicional deve auxiliar as partes a superarem eventuais obstáculos no exercício de direitos ou faculdades ou no cumprimento de ônus ou deveres processuais. São exemplos de concretização desse dever: o poder-dever do juiz de mandar o executado indicar bens à penhora (art. 652, § $3^{\circ}$, do CPC); e o poder-dever de ordenar que a parte exiba documento ou coisa que se encontre em seu poder (art. 355 do CPC). Como o efetivo adimplemento desse dever depende, muitas vezes, de determinado comportamento de uma das partes, o magistrado tem o poder-dever de aplicar multa punitiva ao litigante recalcitrante, que viola o dever de obediência ao juízo (art. 14, parágrafo único, do CPC) e frustra, indiretamente, a possibilidade de colaboração em favor da parte contrária ${ }^{254}$.

Cumprindo esses deveres, o magistrado exerce um duplo papel no processo cooperativo: é isonômico na condução do processo, no diálogo com as partes, e é assimétrico quando impõe suas decisões. Ele mantém sua tarefa de dirigir o processo, mas o faz de maneira dialogada, colhendo a impressão das partes a respeito dos fatos e da valoração jurídica da causa. Isso assegura aos litigantes uma maior participação na condução do processo, dada a possibilidade de influenciarem o juiz na tomada de suas decisões. Desse modo, o julgador deixa de ser um mero fiscal de regras e espectador do "duelo" das partes e adota a posição de agente-colaborador do processo, participando ativamente do contraditório ao longo de todo o procedimento ${ }^{255}$. Apenas no momento da

"Art. 480. Se, depois da propositura da ação, algum fato constitutivo, modificativo ou extintivo do direito influir no julgamento da lide, caberá ao juiz tomá-lo em consideração, de ofício ou a requerimento da parte, no momento de proferir a sentença.

Parágrafo único. Se constatar de ofício o fato novo, o juiz ouvirá as partes sobre ele antes de decidir";

"Art. 880. Extingue-se a execução quando:

$[\ldots]$

Parágrafo único. Na hipótese de prescrição intercorrente, deverá o juiz, antes de extinguir a execução, ouvir as partes, no prazo comum de cinco dias".

${ }^{254}$ MITIDIERO, Colaboração no Processo Civil como Prêt-à-Porter? Um Convite ao Diálogo para Lenio Streck, in Revista de Processo, $\mathrm{n}^{\circ}$ 194, pp. 64-65.

${ }^{255}$ MITIDIERO, Colaboração no Processo Civil: pressupostos sociais, lógicos e éticos, pp. 72-75; 102; MITIDIERO, Colaboração no Processo Civil como Prêt-à-Porter? Um Convite ao Diálogo para Lenio 
decisão é que o Estado-juiz assume posição assimétrica em relação às partes, uma vez que o ato de decidir e impor sua decisão é manifestação do poder estatal, o qual é exclusivo do órgão jurisdicional ${ }^{256}$.

A obediência ao princípio da cooperação, mediante o cumprimento dos deveres supracitados, contribui para uma maior efetividade do processo, uma vez que impede ou pelo menos dificulta a decretação de nulidades processuais, bem como a prolação de juízos de inadmissibilidade ${ }^{257}$.

Por outro lado, o juiz que não atende aos seus deveres de cooperação viola o direito fundamental ao processo justo (art. $5^{\circ}, \mathrm{LIV}$, da CF), podendo ser responsabilizado se o seu comportamento omissivo gerar danos (art. 133, II e parágrafo único, do CPC), notadamente nos casos de descumprimento dos deveres de esclarecimento, de diálogo e de prevenção, cuja observância independe de qualquer conduta da parte contrária à que se beneficia da colaboração ${ }^{258}$.

Se o princípio da cooperação deve orientar os comportamentos processuais das partes e dos órgãos judiciais, com muito mais razão ele deve servir de padrão de comportamento para os auxiliares da justiça. Estes auxiliam os magistrados no exercício da

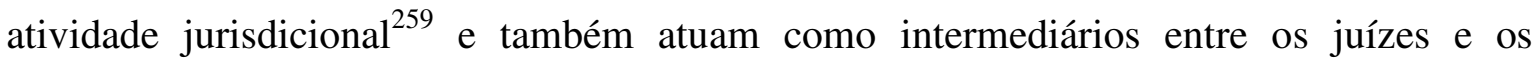

Streck, in Revista de Processo, $\mathrm{n}^{\circ}$ 194, p. 61; DIDIER JUNIOR, O Princípio da Cooperação: uma apresentação, in Revista de Processo, $\mathrm{n}^{\circ}$ 127, p. 76; DIDIER JUNIOR, Os Três Modelos de Direito Processual: inquisitivo, dispositivo e cooperativo, in Revista de Processo, no 198, p. 219.

${ }^{256}$ MITIDIERO, Colaboração no Processo Civil: pressupostos sociais, lógicos e éticos, pp. 76-77; DIDIER JUNIOR, Os Três Modelos de Direito Processual: inquisitivo, dispositivo e cooperativo, in Revista de Processo, $\mathrm{n}^{\circ} 198$, p. 220.

${ }^{257}$ DIDIER JUNIOR, O Princípio da Cooperação: uma apresentação, in Revista de Processo, no ${ }^{\circ}$ 127, p. 77.

${ }^{258}$ MITIDIERO, Colaboração no Processo Civil como Prêt-à-Porter? Um Convite ao Diálogo para Lenio Streck, in Revista de Processo, $\mathrm{n}^{\circ}$ 194, pp. 64-65.

${ }^{259}$ A efetividade e a qualidade do exercício da jurisdição dependem da prática de uma série de atividades de apoio, tais como: documentação processual (redução a escrito dos atos realizados oralmente em audiência); movimentação processual (passagens dos autos de processos do cartório ao juiz, às partes ou aos peritos etc. e vice-versa, ou do relator à secretaria do tribunal para envio ao revisor); comunicação processual (citações, intimações, editais para conhecimento geral); pregão das audiências ou das sessões dos tribunais; efetivação de medidas constritivas de bens ou pessoas (penhoras, arrestos, sequestros, buscas-e-apreensões etc.); depósito e administração de bens constritos; realização de exames técnicos para a descoberta de circunstâncias fáticas indispensáveis para o julgamento da demanda; perícias e arbitramentos; contas e partilhas; conhecimento de línguas estrangeiras para compreender documentos e depoimentos; distribuição de feitos (processos novos, recursos); documentação de atos dos sujeitos processuais; certificação de atos processuais não-escritos e do conteúdo dos autos; conservação e guarda de autos de processos; diligências externas; administração do espólio, da falência ou da recuperação judicial etc. (DINAMARCO, Instituições de Direito Processual Civil, vol. I, § 338, pp. 661-662; e § 346, pp. 671-672; DINAMARCO, Instituições de Direito Processual Civil, vol. II, § 515, p. 248).

Seria humanamente impossível atribuir ao magistrado a realização de todas essas atividades necessárias ao julgamento das pretensões dos litigantes, desde o início até o fim de todos os processos. Por causa disso, a lei prevê que ele deve ser auxiliado por diversas pessoas especializadas, os auxiliares da justiça, os quais compõem o juízo. Segundo Barbi (Comentários ao Código de Processo Civil, vol. I, § 761, p. 447), o juízo mais simples que se pode imaginar deve contar, pelo menos, com um juiz, para ordenar e decidir, um 
jurisdicionados, acudindo às necessidades dos advogados, das partes, das testemunhas etc. Constituem, assim, instrumentos indispensáveis para a boa administração da justiça, necessários à expedita definição e efetivação de direitos, logo também devem agir de acordo com o princípio da cooperação. Para os auxiliares da justiça, o dever de cooperação acarreta as seguintes regras: (a) dever de urbanidade nas relações com as partes e seus mandatários (previsto no art. 116, XI, da Lei ${ }^{\circ}$ 8.112/90, que rege os servidores públicos civis da União); (b) dever de não praticar atos inúteis (inferido do disposto no art. 29 do CPC); (c) dever de assegurar a autuação e a regular tramitação dos processos pendentes, sob a dependência funcional do juiz (abrangido pelo dever de "exercer com zelo $e$ dedicação as atribuições do cargo", contido no inciso I do art. 116 da Lei no 8.112/90); (d) dever de cumprir os prazos previstos na lei ou fixados pelo juiz (arts. 144, I; e 146 do CPC); (e) dever de executar as decisões judiciais e de realizar as diligências necessárias a tal fim (arts. 141, II; e 143, I e II, do CPC e art. 116, IV, da Lei n 8.112/90); (f) dever de praticar oficiosamente os atos de que a lei os encarrega diretamente (arts. 141 e 143 do CPC e art. 116, I, da Lei $\mathrm{n}^{\circ}$ 8.112/90); (g) dever de facultar, nos termos da lei, a consulta ou vista de autos de processos judiciais (art. 141, IV, “ $b$ ”, c/c art. 155, parágrafo único, do CPC); (h) dever de dar certidão de qualquer ato ou termo do processo (art. 141, V, c/c art. 155, parágrafo único, do CPC); (i) dever de auxiliar o juiz em tudo que for necessário para o bom desempenho da função jurisdicional etc. ${ }^{260}$

Por fim, deve-se sublinhar que até mesmo pessoas que não são sujeitos do processo estão adstritas ao dever de cooperação ${ }^{261}$. Como a atividade jurisdicional é realizada não apenas no interesse dos próprios litigantes, mas também do Estado e da sociedade como um todo, é necessário que todos colaborem, na medida do possível, com o Poder Judiciário, independentemente do seu envolvimento pessoal no litígio e da perspectiva de obtenção de algum benefício direto do processo ${ }^{262}$. É o que estatuem os arts. 339 ("Ninguém se exime do dever de colaborar com o Poder Judiciário para o descobrimento da verdade"), 341 ("Compete ao terceiro, em relação a qualquer pleito: Iinformar ao juiz os fatos e as circunstâncias, de que tenha conhecimento; II - exibir coisa

escrivão, para documentar, e um oficial de justiça, para praticar os atos que precisam ser feitos fora do local de trabalho do magistrado.

Deve-se salientar que os auxiliares da justiça não exercem a jurisdição, que é sempre exclusiva dos magistrados. O que eles praticam são apenas funções judiciárias (DINAMARCO, Instituições de Direito Processual Civil, vol. II, § 514, p. 247).

${ }^{260}$ GERALDES, Temas da Reforma do Processo Civil, vol. I, pp. 91-93.

${ }^{261}$ GERALDES, Temas da Reforma do Processo Civil, vol. I, p. 88, nt. 121, e p. 92.

${ }^{262}$ TABOSA PESSOA, Comentários ao art. 339 do CPC, in MARCATO (coord.), Código de Processo Civil Interpretado, p. 1082. 
ou documento, que esteja em seu poder") e 399 do CPC (“O juiz requisitará às repartições públicas em qualquer tempo ou grau de jurisdição: I - as certidões necessárias à prova das alegações das partes; II - os procedimentos administrativos nas causas em que forem interessados a União, o Estado, o Município, ou as respectivas entidades da administração indireta [...]”).

Entretanto, se até o dever de cooperação das partes é relativo, não seria coerente exigir que os indivíduos estranhos ao processo colaborassem ilimitadamente com o Poder Judiciário. Assim, os motivos que justificam a recusa em exibir documento ou coisa previstos no art. 363 do CPC, fundados no resguardo da esfera individual, de certos valores morais e de outros interesses importantes, são válidos também para os terceiros. Analogamente, o art. 406 do CPC e o art. 229 do CC estabelecem que o terceiro pode-se negar a depor sobre: (a) fato que o exponha, ou o seu cônjuge, ou seu parente em grau sucessível, ou ainda algum amigo íntimo, a perigo de vida, de demanda, ou de dano patrimonial imediato; (b) fato a cujo respeito, por estado ou profissão, deva guardar sigilo; e (c) fato a que não possa responder sem desonra própria, de seu cônjuge, parente em grau sucessível, ou amigo íntimo. De acordo com Tabosa Pessoa ${ }^{263}$, o fato de o terceiro ser desvinculado dos interesses em disputa no processo acarreta duas consequências: (a) ele é naturalmente menos sujeito ao dever de colaborar com o Poder Judiciário, de modo que sua participação deve-se resumir ao estritamente necessário à resolução do caso concreto; e (b) tem uma maior possibilidade de se opor ao fornecimento de determinadas informações de cunho pessoal. Sendo assim, pode-se exigir que o terceiro informe o que sabe, ou exiba documentos que possui, a respeito dos litigantes, mas, em princípio, ele não pode ser indagado a respeito de si próprio e de seus interesses diretos.

\subsubsection{Os deveres gerais dos sujeitos processuais}

Os deveres a que os sujeitos do processo estão submetidos podem ser divididos em duas grandes classes ${ }^{264}$ :

a) os deveres gerais, que vinculam toda e qualquer pessoa que atue no processo (juízes, partes, intervenientes, advogados, auxiliares da justiça); e

\footnotetext{
${ }^{263}$ Comentários ao art. 339 do CPC, in MARCATO (coord.), Código de Processo Civil Interpretado, p. 1083; Comentários ao art. 341 do CPC, in MARCATO (coord.), Código de Processo Civil Interpretado, p. 1087; Comentários ao art. 406 do CPC, in MARCATO (coord.), Código de Processo Civil Interpretado, p. 1306.

${ }^{264}$ LUSO SOARES, A Responsabilidade Processual Civil, pp. 165-189.
} 
b) os deveres específicos, que são de titularidade apenas das pessoas investidas na categoria ou na função em atenção à qual o dever foi estabelecido pela lei.

Luso Soares $^{265}$ ensina que existem quatro espécies de deveres gerais:

1) o dever de veracidade;

2) o dever de lealdade;

3) o dever de prontidão; e

4) o dever de utilidade.

Consoante o mesmo doutrinador, o somatório de todos esses deveres constitui o chamado "dever de probidade", que é considerado um sinônimo "defeituoso" do princípio da boa-fé $\mathrm{e}^{266267}$.

É necessário tratar pormenorizadamente de cada um dos deveres gerais enunciados por Luso Soares, dada a sua importância para o tema da improbidade processual e, consequentemente, para a compreensão do problema do abuso do processo.

\subsubsection{O dever de veracidade}

A busca da verdade não configura um dever natural do ser humano. Ocorre que, em algumas circunstâncias, as pessoas impõem a si mesmas e aos outros membros da sociedade a obrigação de descobrir a verdade. Desse modo, é possível encontrar o dever de veracidade em diversos subsistemas sociais ${ }^{268}$ :

a) nas religiões, existem juramentos de verdade a Deus ou aos Deuses, variando as punições decorrentes de seu descumprimento;

b) nos sistemas morais, há o dever ético, quer perante si mesmo, quer perante o grupo social;

\footnotetext{
${ }^{265}$ A Responsabilidade Processual Civil, p. 165.

${ }^{266}$ Nas palavras do autor:

"É certo que os autores falam ainda, muito reiteradamente, no dever de probidade. Só que este, para mim, não é mais de que o complexo ou somatório de todos os restantes, e como tal, não passa de constituir uma designação defeituosa do princípio da boa fé. Quem falta à verdade não é litigante probo; aquele que litiga deslealmente não o é também; quem procrastina no processo age improbamente; e o que comete inutilidades desorientantes, disfarçantes, etc., etc., do mesmo passo actua de forma que não se dirá proba - o que tudo, afinal, significa que não há propriamente um dever de probidade" (destaque no original) (LUSO SOARES, A Responsabilidade Processual Civil, p. 166).

${ }^{267}$ Trata-se de entendimento análogo ao de Barbi (Comentários ao Código de Processo Civil, vol. I, § 154, p. 121), para quem os deveres de expor os fatos em juízo conforme a verdade (art. 14, I, do CPC) e de não formular pretensões, ou alegar defesas, ciente de que são destituídas de fundamento (art. 14, III, do CPC) são meras particularizações do princípio de lealdade (art. 14, II, do CPC).

${ }^{268}$ PONTES DE MIRANDA, Comentários ao Código de Processo Civil, tomo IV, p. 382.
} 
c) na economia, a exigência da qualidade e da quantidade levou ao dever econômico de veracidade;

d) no âmbito político, a mentira é considerada traição ao grupo, apesar de a repercussão da verdade poder ser prejudicial a certos membros ou à sua permanência no poder;

e) na arte, o dever de veracidade acarreta a repulsa à reprodução e à imitação;

f) na ciência, o objetivo do cientista é descobrir enunciados verdadeiros.

Diante dessas inúmeras manifestações da presença do dever de veracidade na sociedade, o Direito não poderia ser diferente, principalmente se se considerar que o sistema jurídico não é isolado dos demais subsistemas supracitados. O dever de dizer a verdade pode ser considerado um exemplo das influências que os subsistemas sociais exercem uns sobre os outros ${ }^{269}$.

Quando o Código de Processo Civil de 1939 era vigente, parte da doutrina nacional já reconhecia a existência desse dever ${ }^{270}$. Hoje, o dever de expor os fatos em juízo conforme a verdade consta expressamente dos arts. 14, I; 17, II; e 339 do CPC 271272273.

${ }^{269}$ É o que se infere do seguinte trecho da obra de Buzaid:

"[...] por tradição imemorial na História do universo, se impôs sempre aos homens o dizerem a verdade como uma obrigação e se condenou sempre a mentira como uma manifestação torpe. Não se trata de um dever moral destituído de sanção. É um imperativo legal, que atende à condição da própria existência dos homens em sociedade. Por isso ele figura na legislação dos povos civilizados" (Processo e Verdade no Direito Brasileiro, in Revista de Processo, $\mathrm{n}^{\circ}$ 47, p. 98).

${ }^{270}$ É o caso de Castro Filho (Abuso do Direito no Processo Civil, pp. 102-109).

Porém, nem todos os doutrinadores pensavam assim. Tratando do tema quando ainda era vigente o Código de 1939, Bonumá (Direito Processual Civil. vol. I. São Paulo: Saraiva e Cia., 1946, pp. 512-514) sustenta que o dever de as partes dizerem a verdade, inclusive nos casos em que essa verdade as prejudica, é apenas moral, e não jurídico. Na opinião do autor, do ponto de vista jurídico, a finalidade do processo não é assegurar o descobrimento da verdade, mas sim dirimir os litígios com justiça, por meio da aplicação, ao caso concreto, da norma jurídica abstrata. Para isso, as partes têm a liberdade de alegar as razões de fato e de direito que fundamentam suas pretensões e de produzir as provas que julgam oportunas e convenientes para demonstrálas. Ao juiz, por sua vez, resta apenas aplicar o direito consagrado na lei à demanda delimitada pelas partes, gerando certeza jurídica, mas sem necessariamente coincidir com a verdade. Assim, desde que as partes não ajam com dolo, ou malícia, produzindo prejuízo desnecessário à parte contrária, o juiz não pode punir eventuais violações do dever de veracidade. Como sustenta que o referido dever tem apenas natureza moral, Bonumá afirma que os atos contrários a ele também geram consequências de foro íntimo, que refletem apenas indiretamente no processo $(v . g$., a partir do momento em que um litigante prova que o outro mentiu ou ocultou a verdade, o magistrado passa a ser mais rigoroso na apreciação da pretensão da parte inescrupulosa).

${ }^{271}$ YARSHELL, Antecipação da Prova sem o Requisito da Urgência e Direito Autônomo à Prova, p. 155.

${ }^{272}$ Pontes de Miranda (Comentários ao Código de Processo Civil, tomo IV, pp. 388-389) ensina que, ainda que não houvesse previsão legal expressa do dever de veracidade, não se poderia negar que ele faz parte do ordenamento jurídico, pois se trata de um princípio implícito no Direito moderno. O autor salienta que o dever de veracidade é pré-processual, pois consiste em um elemento da tutela jurídica: o Estado só consegue cumprir a promessa de prestar a tutela jurisdicional se as partes, os interessados e o juiz cumprirem o dever de veracidade. Se houver mentira, não ocorre a correta aplicação das normas jurídicas e há injustiça.

Analogamente, Couture (El Deber de las Partes de Decir la Verdad, in Estudios de Derecho Procesal Civil, t. III, pp. 249-250) preleciona que existe um princípio ínsito em todo o processo civil, independente da 
Consoante a atual visão instrumentalista do processo civil, o respeito ao dever de veracidade é um dos requisitos essenciais para que o processo atinja o seu escopo jurídico, que nada mais é do que a atuação da vontade concreta do direito substancial. De fato, para que a lei seja aplicada corretamente, é necessário que o juiz faça a subsunção da situação fática que efetivamente ocorreu à norma jurídica. Logo, existe um vínculo muito forte entre a reconstituição histórica dos fatos alegados pelos litigantes e a prestação jurisdicional justa ${ }^{274}$.

Um reflexo da importância que a doutrina processual civil contemporânea atribui à busca da verdade consiste na superação do entendimento de que o processo civil amolda-se à aplicação do princípio da verdade formal, enquanto que o processo penal é regido pelo princípio da verdade material. Juntamente com o fenômeno da publicização do Direito processual civil, houve um incremento dos poderes de intervenção "ex officio" do juiz durante a instrução do processo, com o intuito de permitir que ele possa diligenciar no sentido de descobrir a verdade, garantindo, assim, a efetivação da justiça e a paz social (v.g., arts. 130; 342; 355; 440 do CPC). Isso afastou o processo civil do princípio da verdade formal - segundo o qual o juiz não está obrigado a diligenciar de ofício com o objetivo de descobrir a verdade, contentando-se com as provas trazidas aos autos pelas partes -, e o aproximou do princípio da verdade real - que confere ao juiz o poder-dever de não se contentar com as provas que lhe são apresentadas pelas partes, senão quando são as melhores que se possam ter em concreto, e atribui-lhe poderes de iniciativa probatória para que possa velar pela conformidade da postulação das partes com a verdade ${ }^{275}$.

Não obstante a veracidade das alegações das partes seja imprescindível para o correto exercício da função jurisdicional, não se pode incluir a busca da verdade entre as

existência de texto legal expresso, que determina que as partes devem dizer a verdade, pois o processo é a realização da justiça e nenhuma justiça pode-se apoiar na mentira.

${ }^{273}$ Se o Projeto de Lei $n^{\circ} 8.046 / 2010$ for aprovado, sancionado e publicado com sua redação atual, tais normas constarão dos seguintes dispositivos:

"Art. 80. São deveres das partes, de seus procuradores, e de todos aqueles que de qualquer forma participam do processo: I - expor os fatos em juízo conforme a verdade";

"Art. 83. Considera-se litigante de má-fé aquele que: [...] II - alterar a verdade dos fatos";

"Art. 364. Ninguém se exime do dever de colaborar com o Poder Judiciário para o descobrimento da verdade".

${ }^{274}$ DINAMARCO, A Instrumentalidade do Processo, pp. 274-277; CASTRO FILHO, Abuso do Direito no Processo Civil, pp. 102 e 131; FERNANDES DE SOUZA, Abuso de Direito Processual - uma teoria pragmática, p. 146; BARROS, A Busca da Verdade no Processo Penal, p. 31; MARQUES, Instituições de Direito Processual Civil, vol. 3, p. 322; BEDAQUE, Poderes Instrutórios do Juiz, p. 107.

${ }^{275}$ BARROS, A Busca da Verdade no Processo Penal, pp. 34-44; FERNANDES DE SOUZA, Abuso de Direito Processual - uma teoria pragmática, pp. 159-160 e nts. 151 e 152. 
finalidades institucionais do processo e dizer que o juiz só deva decidir quando a tiver encontrado $^{276}$.

Em primeiro lugar, porque a verdade - entendida como a conformidade da noção ideológica com a realidade -, assim como a certeza - que é a crença na percepção dessa conformidade $^{277}$-, são conceitos absolutos, que dificilmente são atingidos no processo ou fora dele $\mathrm{e}^{278}$. Se o objetivo do processo fosse alcançar essa verdade, haveria sério comprometimento da exigência social da rápida solução dos litígios, visto que a instrução processual toma tempo ${ }^{279}$, sem contar o risco de lesão a direitos e garantias fundamentais e de aviltamento da dignidade do homem (v.g., admissão da tortura, da narcoanálise, do detector de mentiras ou dos estupefacientes como meios de prova $)^{280}$. Daí a advertência de Dinamarco: "o compromisso com a verdade, que é glória da boa técnica processual, será motivo de sua miséria quando levado a extremos indesejáveis"281.

Em segundo lugar, cabe ao juiz proferir a sentença com fundamento na verdade que emerge do processo (a chamada "verdade processual”), a qual é qualificada por Marques ${ }^{282}$ como "condicionada", uma vez que ela depende das provas que as partes poderiam produzir no caso concreto e que foram efetivamente produzidas e também das presunções que o ordenamento jurídico processual impõe em face do comportamento e atuação dos litigantes no curso do procedimento. Isso significa que, quando o magistrado afirma que um fato é verdadeiro, ele quer dizer que o mesmo alcançou, na sua consciência, o grau máximo de verossimilhança que, em relação aos limitados meios de cognição de que o julgador dispõe no ordenamento jurídico nacional, basta para lhe dar a certeza subjetiva de que aquele fato aconteceu ${ }^{283}$. Ao impor esses limites à indagação processual da verdade, o

\footnotetext{
${ }^{276}$ DINAMARCO, A Instrumentalidade do Processo, p. 272; BARROS, A Busca da Verdade no Processo Penal, p. 32.

${ }^{277}$ Essas noções de "verdade" e de "certeza" foram elaboradas por Malatesta (A Lógica das Provas em Matéria Ciminal, vol. I, p. 22).

${ }^{278}$ Calamandrei (Verità e Verosimiglianza nel Processo Civile, in Opere Giuridiche, vol. V, pp. 639-640) observa que, apesar da incapacidade de se alcançar a verdade absoluta, existe um dever de honestidade de empenhar-se com todas as forças para buscar aproximar-se o máximo possível dessa meta inatingível. Desse modo, o reconhecimento de que a sentença final é um juízo de verossimilhança, e não de certeza, não elide o fato de toda a estrutura do processo ser preordenada para tornar a busca da verdade o mais aprofundada e controlada possível, reduzindo ao mínimo a diferença entre esta e a verossimilhança.

279 FERNANDES DE SOUZA, Abuso de Direito Processual - uma teoria pragmática, p. 137; DINAMARCO, A Instrumentalidade do Processo, pp. 273-274; MARQUES, Manual de Direito Processual Civil, vol. 2, pp. 250-251.

280 BARROS, A Busca da Verdade no Processo Penal, pp. 45-46; GRINOVER; SCARANCE FERNANDES; GOMES FILHO, As Nulidades no Processo Penal, p. 125; CINTRA; DINAMARCO; GRINOVER, Teoria Geral do Processo, p. 358.

${ }^{281}$ A Instrumentalidade do Processo, p. 273.

${ }^{282}$ Manual de Direito Processual Civil, vol. 2, p. 250.

${ }^{283}$ CALAMANDREI, Verità e Verosimiglianza nel Processo Civile, in Opere Giuridiche, vol. V, p. 616.
} 
ordenamento jurídico prestigia o interesse social em pacificar, eliminando os conflitos da maneira mais célere possível, porém cria a possibilidade de o juiz reputar verdadeiros fatos que, na realidade, não o são (v.g., se a parte não traz aos autos provas suficientes de suas alegações, descumprindo o ônus de provar; se a lei, sem mais, prescreve ao juiz que considere como existentes determinados fatos, dispensando-o de pesquisar se são verdadeiros etc. $)^{284}$.

Por fim, não se pode esquecer que a convicção do magistrado acerca da conformidade das alegações de uma das partes com a realidade pode decorrer de erro do próprio julgador. Nesse caso, uma vez julgadas possíveis impugnações, ou decorridos todos prazos para atacar a decisão judicial descompassada com a realidade, esta transita em julgado e torna-se indiscutível, não obstante o raciocínio viciado do juiz ${ }^{285} 286$. Visando à eliminação definitiva do conflito e da insatisfação que angustia os litigantes, no interesse da paz social, o ordenamento jurídico atribui ao trânsito em julgado o efeito de criar a irrevocabilidade jurídica do comando contido na sentença, sem se preocupar se as premissas psicológicas que ensejaram tal comando são premissas de verdade ou de mera verossimilhança, ou se houve algum erro lógico por parte do magistrado ${ }^{287}$.

O que se dessume do exposto acima é que, no sistema jurídico processual brasileiro, a virtude da busca da verdade, que se liga ao escopo de atuação da vontade concreta da lei, é muitas vezes preterida em prol da virtude funcional da pacificação social, quer dizer, da eliminação célere e de modo conveniente do estado anti-social que deu causa ao processo. De acordo com Dinamarco ${ }^{288}$, isso ocorre porque o valor da primeira virtude reside na capacidade que tenha a ordem jurídica de promover a pacificação com justiça, podendo ser, então, esquecida quando a justa pacificação puder ser alcançada independentemente da prevalência da vontade concreta do direito. Assim sendo, a busca da verdade, que é a busca da fidelidade ao direito objetivo a ser declarado e atuado, situa-se

\footnotetext{
${ }^{284}$ DINAMARCO, A Instrumentalidade do Processo, pp. 277-278.

${ }^{285}$ CHIOVENDA, Instituições de Direito Processual Civil, vol. I, pp. 63-64

${ }^{286}$ A respeito da busca da verdade no processo e das balizas que a ordem jurídica lhe impõe, aceitando o risco de serem prolatadas decisões judiciais inverídicas e injustas, consultar: FERNANDES DE SOUZA, Abuso de Direito Processual - uma teoria pragmática, pp. 146-169.

287 DINAMARCO, A Instrumentalidade do Processo, pp. 272 e 278; CALAMANDREI, Verità e Verosimiglianza nel Processo Civile, in Opere Giuridiche, vol. V, pp. 617-618; CHIOVENDA, Instituições de Direito Processual Civil, vol. I, p. 65.

${ }^{288}$ A Instrumentalidade do Processo, pp. 277 e 278-279.
} 
em um patamar abaixo do escopo social de pacificar, o qual, para ser eficiente, precisa ser alcançado $\log o^{289}$.

\subsection{Conceito e conteúdo}

O dever de veracidade proíbe a parte de afirmar fato que sabe ser falso e de impugnar fato que sabe ser verdadeiro ${ }^{290}$. Também veda a descrição de fato existente, porém sem correspondência exata com a realidade ${ }^{291}$.

Afirma-se que o dever de veracidade refere-se apenas às declarações sobre circunstâncias fáticas, não às manifestações de direito ${ }^{292}$. Mas, não há como negar que algumas afirmações "de jure" também devem respeitar esse dever ${ }^{293}$. De acordo com o art. 14 do Decreto-Lei no 4.657/42 (Lei de Introdução às Normas do Direito Brasileiro) e o art. 337 do CPC, a parte que invocar Direito municipal, estadual, estrangeiro ou consuetudinário pode ter de provar o seu teor e sua vigência, caso o juiz assim determine. Se o litigante mentir a respeito do teor ou da vigência da norma de Direito municipal, estadual, estrangeiro ou consuetudinário que utilizou para sustentar sua pretensão, ele deve ser punido pela prática de litigância de má-fé, com fundamento no art. 17, II, c/c art. 18 do CPC. O mesmo deve ocorrer com a parte que cita precedente judicial inverídico com o intuito, por exemplo, de comprovar a existência de dissídio jurisprudencial a respeito da interpretação de lei federal que justifique o cabimento de recurso especial (art. 105, III, “c”, da CF c/c art. 541, parágrafo único, do CPC), ou com o escopo de demonstrar divergência jurisprudencial que fundamente o cabimento de embargos de divergência (art. 546, I e II, do CPC), ou ainda com o fim de mostrar que o recurso da parte contrária ou a decisão recorrida está em confronto com a jurisprudência dominante, legitimando a aplicação do art. 557, “caput” ou $§ 1^{\circ}$-A, respectivamente ${ }^{294}$.

\footnotetext{
${ }^{289}$ Não merece ser endossada, portanto, a opinião de Grossmann (O Dever de Veracidade no Processo Civil (exposição de direito comparado), in Revista Forense, vol. 101, pp. 287-289), no sentido de que a descoberta da verdade é o verdadeiro fim do processo.

${ }^{290}$ LENT, Diritto Processuale Civile Tedesco, $1^{\mathrm{a}}$ parte, p. 106.

291 BARBOSA MOREIRA, A Responsabilidade das Partes por Dano Processual no Direito Brasileiro, in Temas de Direito Processual, pp. 26-27.

${ }^{292}$ Nesse sentido: ROSENBERG, Tratado de Derecho Procesal Civil, tomo I, p. 381; CASTRO FILHO, Abuso do Direito no Processo Civil, p. 130.

293 Segundo Grossmann (O Dever de Veracidade das Partes Litigantes no Processo Civil (aspecto doutrinário), in Revista Forense, vol. 101, p. 482), o dever de veracidade “compreende toda declaração processual, tanto no que concerne aos fatos como no que diz respeito aos argumentos jurídicos ou à produção da prova".

${ }^{294}$ No âmbito doutrinário, esse entendimento é sustentado por Calogero (Probità, Lealtà, Veridicità nel Processo Civile, in Rivista di Diritto Processuale Civile, vol. XVI, parte I, p. 148, nt. 1), que considera
} 
O dever de veracidade diz respeito à verdade subjetiva ${ }^{295}$. Caso se exigisse a verdade objetiva, os sujeitos processuais teriam que expor no processo a realidade, ou seja, exatamente aquilo que aconteceu no plano fático. Contudo, nem sempre o ser humano tem acesso à verdade em $\mathrm{si}^{296}$. Cada um pensa, reflete, tira suas conclusões sobre o meio externo sob a influência dos seus próprios interesses e paixões, razão pela qual pode haver variação de opiniões ainda que concernentes ao mesmo evento fático ${ }^{297}$. Sendo assim, o art. 14, I, do CPC preceitua que os sujeitos do processo digam a verdade que eles conhecem, quer dizer, relatem a maneira como os fatos ocorreram do seu ponto de vista pessoal, sob o influxo de seu conhecimento cultural, sua vivência, sua inteligência, sua atenção, o seu poder de crítica e suas emoções ${ }^{298}$. Em regra, somente a mentira consciente, declarada com o propósito de desviar a vontade judicial, de prejudicar os interesses de outrem, é considera ilícita ${ }^{299}$. Quem afirma uma inverdade em juízo, mas o faz com honestidade, com convicção, não contraria o referido dispositivo do Código de Processo Civil.

desleal a conduta do advogado que, diante de um juízo de primeiro grau na província, inventa ou altera uma sedicente decisão inédita do Tribunal para fundamentar uma tese de defesa.

No âmbito jurisprudencial, essa tese foi encampada recentemente pela $2^{\mathrm{a}}$ Turma do Superior Tribunal de Justiça:

"PROCESSUAL CIVIL. AGRAVO REGIMENTAL. DEFICIÊNCIA NA FUNDAMENTAÇÃO. SÚMULA 284/STF. DECISÃO QUE INADMITIU RECURSO ESPECIAL. FUNDAMENTO INATACADO. SÚMULA 182/STJ. INVERÍDICO O ACÓRDÃO CITADO COMO REPRESENTATIVO DA DIVERGÊNCIA JURISPRUDENCIAL. LITIGÂNCIA DE MÁ-FÉ. ARTS. 17, VII, E 18 DO CPC.

1. A fundamentação deficiente do Recurso Especial impede seu conhecimento. Aplica-se, por analogia, a Súmula 284/STF.

2. Não se conhece de Agravo Regimental que deixa de impugnar os fundamentos da decisão que inadmitiu o Recurso Especial. Incide, por analogia, a Súmula 182/STJ.

3. Hipótese em que o agravante citou como representativo da controvérsia acórdão inverídico, configurando tentativa de induzir o julgador ao erro.

4. O acórdão recorrido afirmou: "a conduta da agravante é injustificável. Como é cediço, o Judiciário Paulista luta para vencer o número assustador de processos que correm, principalmente, na Segunda Instância, de modo a cumprir seu papel como Poder do Estado e satisfazer o anseio da Sociedade como um todo, que é o de solucionar prontamente as demandas, impedindo que se arrastem por anos a fio". Já o agravante sustenta não ter havido dolo na dupla interposição. Alega excesso de serviço, falta de condições de trabalho e substituição de Procuradores do Estado que oficiaram no feito.

5. Agravo Regimental não provido, com aplicação da multa prevista no artigos 17, II, e 18 do Código de Processo Civil, arbitrada em 1\% sobre o valor da causa" (destaques nossos)

(STJ, $2^{\text {a }}$ Turma, AgRg no REsp 1.239.748/PB, Rel. Min. Herman Benjamin, DJe 09/09/2011).

${ }^{295}$ BUZAID, Processo e Verdade no Direito Brasileiro, in Revista de Processo, $\mathrm{n}^{\circ}$ 47, p. 96; SOBRINHO, Dever de Veracidade das Partes no Processo Civil, pp. 118, 125, 127, 129, 133, 135, 136 e 138-139; ALVIM, Tratado de Direito Processual Civil, vol. 2, pp. 393 e 395.

${ }^{296}$ MENEZES CORDEIRO, Litigância de Má-Fé, Abuso do Direito de Ação e Culpa "in Agendo", p. 71.

${ }^{297}$ BARROS, A Busca da Verdade no Processo Penal, p. 30.

${ }^{298}$ Nesse sentido: ROSENBERG, Tratado de Derecho Procesal Civil, tomo I, pp. 381-382; LENT, Diritto Processuale Civile Tedesco, $1^{\text {a }}$ parte, p. 106.

${ }^{299}$ MENEZES CORDEIRO, Litigância de Má-Fé, Abuso do Direito de Ação e Culpa "in Agendo", p. 71; DINAMARCO, Instituições de Direito Processual Civil, vol. II, § 528-A, p. 268; FERNANDES DE SOUZA, Abuso de Direito Processual - uma teoria pragmática, p. 116. 
Mas, em alguns casos excepcionais, a inverdade embasada em imprudência ou negligência inescusável também pode contrariar o art. 14, I, do $\mathrm{CPC}^{300}$. Quando uma parte faz alegações inverídicas sem dolo, apenas por não ter ciência prévia de certas circunstâncias fáticas que vêm a ser provadas no curso do processo, deve-se verificar se ela não tinha o dever de conhecer tais fatos antes de ajuizar a demanda, hipótese em que há, sim, violação do dever de veracidade, mesmo que tenha agido em consonância com a verdade subjetiva. Como bem salienta Yarshell ${ }^{301}$, quando determinado ente é titular do poder-dever de investigar circunstâncias fáticas antes do ajuizamento da demanda - como o Ministério Público, nos limites das funções e competências que os arts. 127 e 129 da CF lhe atribuem -, o órgão judicial deve cobrar dele uma preocupação maior com a descoberta da verdade antes da opção por ingressar em juízo. Consequentemente, se um membro do Ministério Público dispensar a realização de inquérito civil (art. 129, III, da CF c/c art. $8^{\circ}$, $\S 1^{\circ}$, da Lei $\left.n^{\circ} 7.347 / 85\right)$ ou de procedimento administrativo de investigação preliminar (art. 129, VI, da CF c/c art. $8^{\circ}$ da Lei Complementar $n^{\circ}$ 75/93) e, sem qualquer justificativa aparente (v.g., urgência na propositura da ação por causa do risco de lesão grave ou de difícil reparação ao interesse transindividual), optar por ajuizar demanda embasada em fatos cuja inveracidade ele desconhece, o magistrado pode considerá-lo litigante de má-fé em razão de ter descumprido seu poder-dever de investigar as circunstâncias fáticas. Em suma, a parte que faz declaração inverídica por ter sido negligente ou imprudente na utilização do seu poder de descobrir a verdade objetiva, sem justificativa plausível, viola o art. 14, I, do CPC, ainda que tenha agido em consonância com a verdade subjetiva.

A afirmação de que a verdade exigida é, em regra, apenas a subjetiva poderia levar alguém a crer que o órgão judicial pode fiar-se tão somente no que os litigantes declaram saber para aferir se o seu modo de proceder em juízo é compatível com a norma prevista no inciso I do art. 14 do CPC. Todavia, a palavra das partes não é o único critério à disposição do magistrado. A aferição da verdade subjetiva também passa pela análise de eventuais elementos objetivos: as provas. Muitas provas não só demonstram que a versão fática alegada pela parte que as produziu é verdadeira, mas também que a parte contrária igualmente tinha conhecimento da existência dos fatos provados ou do modo de ocorrência deles, apesar de tê-los negado em juízo em defesa de sua pretensão. Dessa forma, cabe ao juiz, depois de analisar o conjunto probatório, fazer uma análise retrospectiva do que as

${ }^{300}$ CUNHA, O Dolo e o Direito Judiciário Civil, p. 20. No mesmo sentido, Yarshell (Antecipação da Prova sem o Requisito da Urgência e Direito Autônomo à Prova, p. 155) ensina que viola o dever de veracidade quem alega fatos que, de antemão, sabe ou razoavelmente deveria saber serem inverídicos.

${ }^{301}$ Antecipação da Prova sem o Requisito da Urgência e Direito Autônomo à Prova, p. 158. 
partes alegaram desde o início do processo para verificar se não existe qualquer incongruência com as provas produzidas. Caso haja, deve aplicar o disposto nos arts. 14, I, e 17, II, do CPC, mesmo se o litigante de má-fé replicar que não proferiu inverdades em juízo ou que desconhecia os fatos provados ${ }^{302}$. Aliás, alegações com esse teor reforçam a contradição com o conjunto probatório e apenas confirmam a conduta mentirosa antes praticada $^{303}$.

Exemplos verídicos talvez permitam elucidar como deve ocorrer esse exame retrospectivo da veracidade das alegações dos litigantes à luz das provas carreadas para os autos. No julgamento da Apelação no 7.717.921-2 (Relator Des. Jurandir de Sousa Oliveira), interposta em processo que tinha como objeto pedido de exibição de contrato bancário feito por cliente em face de instituição financeira, o Tribunal de Justiça de São Paulo realizou o referido exame e entendeu que esta havia alterado a verdade dos fatos,

\footnotetext{
${ }^{302}$ Menezes Cordeiro (Litigância de Má-Fé, Abuso do Direito de Ação e Culpa "in Agendo", p. 66) cita julgado em que o Supremo Tribunal de Justiça de Portugal adotou esse entendimento:

"STJ 18-Dez.-2003: sendo dado como provado um facto de conhecimento pessoal das partes, que estas expressamente negaram, não podem as mesmas eximir-se à condenação por litigância de má-fé, alegando que se exprimiram mal".

${ }^{303}$ Nesse sentido, afirmando que a prova confere conotação objetiva ao dever de veracidade: YARSHELL, Antecipação da Prova sem o Requisito da Urgência e Direito Autônomo à Prova, pp. 156-157.

No entanto, "data venia", não parece correta a proposta do referido jurista de fazer derivar do dever de veracidade (art. 14, I, do CPC) e desse contorno objetivo que o conjunto probatório lhe confere uma espécie de dever geral de informação das partes, que justificaria a produção antecipada de provas além dos casos em que hoje ela é admitida (ou seja, desatrelada das hipóteses de urgência). Para Yarshell, esse dever geral de informação faz com que a prova produzida antecipadamente deixe de ser apenas um elemento apto à convicção do órgão julgador para ser também um fator de convencimento das partes, esclarecendo-as previamente acerca de fatos relevantes relacionados à situação substancial controvertida, o que permite que elas avaliem melhor os encargos, riscos e chances de seus comportamentos em futuro e eventual processo (e.g., ajuizamento de demanda no futuro, resistência a dada pretensão, prática de atos de autocomposição etc.) e litiguem de forma mais responsável e segura (YARSHELL, Antecipação da Prova sem o Requisito da
} Urgência e Direito Autônomo à Prova, pp. 159-163, 170-171, 179-180, 199-200 e 205-206).

Essa teoria parte de duas premissas erradas:

a) não é correto afirmar que "não havendo prova pré-constituída (ou enquanto não se constitui a prova), não surge o dever ético ou jurídico de considerar elementos objetivos de instrução e, como visto, não há sentido em se cogitar de dever de veracidade" (YARSHELL, Antecipação da Prova sem o Requisito da Urgênncia e Direito Autônomo à Prova, p. 179). Na realidade, a ausência de prova nos autos apenas faz com que o órgão judicial não tenha elementos objetivos para aferir a veracidade das alegações das partes; não interfere em nada na existência do dever de dizer a verdade, que integra a esfera jurídica das partes desde o início do processo;

b) o dever geral de informação não é um corolário do dever de veracidade. Ele se relaciona com o dever de lealdade, especificamente com o dever de prontidão, cuja existência no ordenamento jurídico nacional pode ser inferida dos ônus processuais previstos nos arts. 282, III e VI; 283; 300-303; e 396 do CPC (ver o item 1.3.7.3 "infra"). Tanto é verdade que o dever geral de informação não tem uma ligação íntima com o dever de veracidade que o próprio Yarshell admite que o litigante que não produz prova antecipada e que, consequentemente, viola aquele dever geral não deve ser sancionado com espeque nos arts. 17, II, e 18 do CPC. De acordo com o jurista, nesses casos, a consequência processual consiste apenas na presunção de verdade de determinado fato, prejudicando a própria parte inerte na formação do convencimento do juiz. Em outras palavras, a "sanção" de quem não pré-constitui prova não vai além de eventual insucesso em juízo, o que está relacionado ao conceito de ônus, e não de dever (YARSHELL, Antecipação da Prova sem o Requisito da Urgência e Direito Autônomo à Prova, pp. 161, 173-174 e 193). 
impondo-lhe sanção por litigância de má-fé. No início do processo, a instituição financeira alegou que não tinha ocorrido recusa administrativa ao cliente. Porém, em seguida, ela mesma desmentiu o fato, apresentando uma gravação de conversa telefônica mantida entre as partes, na qual uma atendente do banco confirmava a solicitação e o envio dos documentos, os quais nunca foram entregues. Situação análoga ocorreu nos autos da Apelação no 1.158.237-0/05 (Relator Des. Artur Marques). Nesse processo, a parte credora requereu o início da execução para cumprimento de acordo, alegando que os valores devidos não estavam sendo depositados pelo devedor. No entanto, este demonstrou nos autos que o montante devido já se encontrava na conta corrente de titularidade do próprio credor, o que levou o Tribunal de Justiça de São Paulo a aplicar, também neste caso, as sanções previstas no art. 18 do $\mathrm{CPC}^{304} 305$.

Especificamente com relação ao réu, existe outro critério objetivo que o juiz pode utilizar para verificar se ele atua em juízo de acordo com a verdade fática subjetiva. Tratase da coerência lógica entre os fundamentos da defesa deduzidos na contestação. Os arts. 300 e 301 do CPC estabelecem que o réu tem o ônus de alegar na contestação todas as defesas que tiver para impugnar o pedido do autor, podendo cumular defesas de mérito e processuais, ainda que relativamente contraditórias entre si. O princípio da eventualidade da defesa autoriza que ele suscite defesas processuais, opondo-se ao julgamento do mérito, sem prejuízo de, em seguida, pedir que a demanda inicial seja rejeitada no mérito. Permite, outrossim, que o réu, ao alegar defesas de mérito, desenvolva uma argumentação escalonada, de modo que o acolhimento de um dos fundamentos prejudique $\mathrm{o}$ conhecimento do subsequente e assim sucessivamente. Mas, Dinamarco ${ }^{306}$ ensina que a liberdade inerente à eventualidade da defesa não é absoluta, pois grandes incoerências entre fundamentos cumulados podem significar que há mentiras ao menos em um deles, configurando litigância de má-fé (art. 17, II, do CPC). Por exemplo, em uma ação de cobrança, se o réu diz que não deve porque nunca negociou com o autor e, depois, alega

\footnotetext{
${ }^{304}$ Tais exemplos foram retirados da obra de Yarshell (Antecipação da Prova sem o Requisito da Urgência e Direito Autônomo à Prova, p. 157, nt. 32; e p. 158, nt. 33).

305 Albuquerque (Responsabilidade Processual por Litigância de Má Fé, Abuso de Direito e Responsabilidade Civil em Virtude de Actos Praticados no Processo, pp. 57 e 58) cita dois julgados do Supremo Tribunal de Justiça português em que também se constatou o desrespeito ao dever de veracidade mediante o confronto entre afirmações das partes ao longo do processo e o conjunto probatório:

"STJ - 21-4-1983: tendo-se provado factos que foram negados pelos gerentes da ré e eram do conhecimento dos mesmos, houve má fé processual";

$[\ldots]$

"STJ - 9-6-2005 (Bettencourt de Faria): a embargante negou a verdade dum facto provado, quando não podia desconhecer a sua veracidade, por ter caráter pessoal. Por isso, não merece censura a sua condenação por litigância de má fé".

${ }^{306}$ Instituições de Direito Processual Civil, vol. II, § 559, pp. 337-338.
} 
que pagou o débito, ao menos uma dessas asserções contraria o dever de veracidade. Em respeito ao princípio da cooperação (item 1.3.6 "supra”), quando o juiz constatar incompatibilidade lógica entre os fundamentos cumulados, ele deve determinar que o demandado esclareça sua defesa ${ }^{307}$. Se o litigante não se manifestar ou não esclarecer a defesa adequadamente, pode-se reputar desrespeitado o dever de veracidade previsto no inciso I do art. 14 do CPC.

\subsection{Limites do dever de veracidade}

A doutrina discute qual a exata extensão do dever geral de dizer a verdade. $\mathrm{Na}$ Itália, cujo ordenamento jurídico prevê expressamente apenas o dever de agir com probidade e com lealdade (art. 88 do CPC italiano ${ }^{308}$ ), Calogero ${ }^{309}$, Zanzucchi ${ }^{310}$, Michelli ${ }^{311}$, Satta $^{312}$, Calamandrei ${ }^{313}$, Chiovenda ${ }^{314}$, Carpi, Colesanti e Taruffo ${ }^{315}$ defendem

${ }^{307}$ Nesse sentido: MARINONI, Abuso de Defesa e Parte Incontroversa da Demanda, pp. 79 e 81-82.

308 "Art. 88 (Dever de lealdade e de probidade)

As partes e os seus defensores têm o dever de se comportar em juízo com lealdade e probidade.

Em caso de falta dos defensores a tal dever, o juiz deve comunicá-la às autoridades que exercitam o poder disciplinar sobre eles" (tradução nossa).

${ }^{309}$ Calogero (Probità, Lealtà, Veridicità nel Processo Civile, in Rivista di Diritto Processuale Civile, vol. XVI, parte I, pp. 135-136 e 147-148) afirma que, segundo o art. 29 do Projeto definitivo do Código de Processo Civil italiano ("As partes e os seus procuradores e defensores têm o dever de agir com probidade e com lealdade"), existe o dever processual de ser probo e leal, não aquele de ser verdadeiro.

${ }^{310}$ De acordo com Zanzucchi (Diritto Processuale Civile, vol. I, p. 370), o Código de Processo Civil italiano de 1865 não estabelecia expressamente um dever de agir com boa-fé no processo, o qual era deduzido pela doutrina de um complexo de dispositivos. Posteriormente, o dever de dizer a verdade foi previsto na Proposta de Chiovenda (art. 20, $\S 1^{\circ}$ ), no Projeto Carnelutti (art. 28), no Esquema Rocco (art. 25) e no Projeto preliminar Solmi (art. 26), que cominava uma pena de notável importância a quem o descumprisse. Essa previsão genérica do dever de veracidade e a sanção a quem o violasse sofreram tantas críticas que o Projeto Solmi definitivo não estatuiu a punição e mudou a fórmula do dispositivo, que passou a prever simplesmente o dever das partes e dos defensores de agir em juízo com probidade e com lealdade. Segundo Zanzucchi, a versão definitiva do artigo "tem um conteúdo bem diverso" da obrigação de dizer a verdade. Esse texto do Projeto Solmi definitivo encontra-se no atual Código de Processo Civil italiano.

311 Para Micheli (Corso di Diritto Processuale Civile, vol. I, pp. 236 e 237), as partes do processo não têm nenhum dever de dizer a verdade. Logo, não se pode impedir a discussão com ardor entre elas, que se desenvolve com frequência por meio de omissões deliberadas. Todavia, elas estão submetidas ao dever de se comportarem em juízo com lealdade ou probidade (art. 88 do CPC italiano), o que implica, por exemplo, na ilicitude da prática de indicar falsamente o próprio domicílio, com o intuito de impedir que a outra parte oponha exceção de incompetência territorial; de subtrair dos autos um documento que possa ser vantajoso à parte contrária; de modificar o estado de lugares, coisas ou pessoas que devam ser objeto de perícia ou de inspeção judicial etc.

${ }^{312}$ Satta (Diritto Processuale Civile, pp. 110-112) leciona que o dever de dizer a verdade, de cooperar com a efetiva realização da justiça, não significa impor à parte a obrigação de adotar condutas contrárias aos seus interesses, o que contrariaria o próprio conceito de parte. Segundo o jurista, a atividade da parte processual é livre, desde que não invada a esfera jurídica da parte contrária. Ele menciona os arts. 88, 89 e 96 do CPC italiano como sendo hipóteses em que, na sua opinião, a atividade processual invade ilicitamente a esfera jurídica alheia, causando dano.

${ }^{313}$ Segundo Calamandrei (Instituciones de Derecho Procesal Civil: según el nuevo código, pp. 340-341), no Direito italiano, as partes têm apenas ônus, e não dever, de dizer a verdade. Então, se elas alegam alguma 
que as partes não estão sujeitas a um dever de veracidade ${ }^{316} 317318$. No extremo oposto está a doutrina alemã (v.g., Rosenberg ${ }^{319}$ e Lent $^{320}$ ), que, embasada no $\S 138$ da ZPO da Alemanha $^{321}$, sustenta a existência do chamado "dever de completude", ou "dever de completitude", ou ainda "dever de plenitude", segundo o qual as partes têm a obrigação de

mentira em juízo, não sofrem uma sanção penal, mas correm o risco de o juiz deduzir desse comportamento negativo argumentos de prova para decidir a causa em seu desfavor (art. 116 do CPC italiano).

${ }^{314}$ Chiovenda (Principios de Derecho Procesal Civil, tomo II, pp. 211-213) sustenta que o Código de Processo Civil italiano não contém uma proibição genérica e expressa de afirmar fatos inverídicos em juízo porque: (a) normas gerais de repressão ao litigante doloso têm eficácia duvidosa; (b) se existissem tais normas, elas facilmente diminuiriam também a liberdade do litigante de boa-fé; e (c) concederiam um excessivo arbítrio ao magistrado. De acordo com o autor, é por essas razões que o legislador italiano se limitou a estabelecer apenas sanções aplicáveis a hipóteses específicas de improbidade (v.g., o art. 295 do CPC italiano, que prevê multa aplicável ao sujeito processual que nega uma escritura, sendo que, depois, fica provada a sua autoria; o art. 221 do Código Penal italiano, que criminaliza a conduta de jurar em falso como parte em demanda civil; etc.).

${ }^{315}$ Carpi, Colesanti e Taruffo (Commentario Breve al Codice di Procedura Civile, p. 267) afirmam que, diante da elasticidade e generalidade do texto do art. 88 do CPC italiano, não é possível definir de modo específico o conteúdo do dever de leadade e probidade, mas seguramente ele não abrange a obrigação de dizer a verdade, nem o dever de produzir espontaneamente documentos que possam ser úteis à parte adversária.

${ }_{316}$ Com base nessa orientação dos autores italianos, Castro Filho adota um conceito restritivo de "dever de veracidade", que, para ele, tem por conteúdo apenas a obrigação geral de não litigar de má-fé. Em suas palavras: "Obrigação, pois, de probidade, e não obrigação de verdade" (CASTRO FILHO, Abuso do Direito no Processo Civil, p. 106). Em apoio à sua tese, recorda que, na Itália, a redação do art. 26 do anterior Projeto de Código de Processo Civil, que previa o dever de veracidade (o texto era o seguinte: "As partes, os procuradores e os defensores têm a obrigação de expor ao juiz os fatos segundo a verdade e de não propor demandas, defesas, exceções ou provas que não sejam de boa-fé" - tradução nossa), foi modificada após acalorados debates, prevendo o Projeto definitivo apenas o dever de agir com probidade e com lealdade (art. 29 do Projeto definitivo, que é igual ao atual art. 88 do CPC italiano: "As partes, os seus procuradores e defensores têm o dever de agir com probidade e com lealdade"). Cita também doutrinadores italianos que fazem a distinção entre o dever de veracidade, de um lado, e o dever de lealdade e probidade, do outro, como o supracitado Zanzucchi, dentre outros (CASTRO FILHO, Abuso do Direito no Processo Civil, pp. 106-107). ${ }^{317}$ Na contramão da doutrina italiana majoritária está Grasso (La Collaborazione nel Processo Civile, in Rivista di Diritto Processuale, vol. XXI, p. 600), que enxerga no art. 88 do CPC italiano o dever da parte de dizer a verdade mesmo contra o próprio interesse.

${ }^{318}$ Não obstante o Código de Processo Civil italiano não faça menção ao dever de veracidade, existem propostas de sua inserção expressa na lei. Comoglio (Abuso del Processo e Garanzie Costituzionali, in Rivista di Diritto Processuale, Ano 63, no 2, p. 343 e nt. 113; e p. 352, nt. 147) lembra, por exemplo, o projeto de lei de reforma parcial do CPC italiano, lançado pelo Ministro Guardasigilli On. Mastella, em 2007, que propõe a criação de um $\S 3^{\circ}$ no art. 88 do CPC italiano com a seguinte redação: "As partes constituídas devem esclarecer as circunstâncias de fato de modo leal e verídico" (tradução nossa). Também no projeto de reforma do Código de processo civil elaborado pela Magistratura Democrática, em 2004-2005, pode-se encontrar proposta análoga, especificamente no art. 115, § $3^{\circ}$ : "As partes constituídas devem esclarecer as circunstâncias de fato relevantes para a causa de modo completo e verídico" (tradução nossa). O autor aduz que o dever de veracidade já se encontra previsto no art. 14 do "Codice deontologico forense", que rege a advocacia, e na legislação europeia ( $\operatorname{art} .7^{\circ}, \S 3^{\circ}$, do Reg. C.E. de 12 de Dezembro de 2006, $n^{\circ} 1896$ ).

${ }^{319}$ Tratado de Derecho Procesal Civil, tomo I, pp. 13, 28, 380-383.

${ }^{320}$ Diritto Processuale Civile Tedesco, $1^{\mathrm{a}}$ parte, pp. 106-108.

321 " $\$ 138$ (Obrigação de declarar sobre fatos)

I - As partes devem fazer suas declarações sobre circunstâncias reais de forma íntegra e de acordo com a verdade;

II - Cada parte deve pronunciar-se sobre os fatos sustentados pelo adversário;

III - Aqueles fatos que não se neguem explicitamente considerar-se-ão fatos admitidos se do resto das declarações da parte não se seguir a intenção de querer negá-los;

IV - Uma declaração de ignorância é admitida só para fatos que não tenham sido atos próprios da parte, nem objeto de sua própria percepção" (tradução nossa, baseada na versão em espanhol: ENCINAS; MÍGUEZ, Código Procesal Civil Alemán, p. 51). 
narrar os fatos que dão espeque às suas pretensões por inteiro, da forma como elas os conhecem. Ou seja, o autor e o réu devem narrar os fatos que servem de base, respectivamente, à demanda e à exceção da maneira mais completa possível, mencionando não só os elementos que lhes são favoráveis, mas também aqueles dos quais podem advir consequências que lhes são nocivas ${ }^{322}$. Parte-se do pressuposto de que tanto a falsidade quanto a reticência a respeito da causa de pedir remota podem levar o juiz a proferir uma sentença errada ${ }^{323}$.

Diante desta última tese, surge a seguinte dúvida: em respeito ao dever de veracidade, previsto no art. 14, I, do CPC, pode-se exigir que alguém alegue fatos contra si próprio, ao arrepio dos princípios "nemo tenetur edere contra se" e "nemo tenetur se detegere"?

As regras "nemo tenetur" foram amplamente aplicadas durante a Antiguidade, a Idade Média e o Direito moderno, até o século XIX. Contudo, paulatinamente caíram em desuso por causa do advento de outros institutos jurídicos incompatíveis com elas, como a obrigação de "discovery" do Direito anglo-saxônico, a "gesetzliche Exhibitionspflicht" do Direito alemão, a "Wahrheitspflicht" do Direito austríaco, o dever de lealdade e probidade do Direito italiano e o dever de veracidade dos Direitos influenciados pelo socialismo ${ }^{324}$.

Não obstante parte da doutrina defenda a remanescência do princípio de que ninguém é obrigado a articular a verdade contra si próprio, Luso Soares ${ }^{325}$ sustenta que a atual lógica do sistema processual impõe um amplo (mas não pleno) dever de veracidade. O autor português invoca a necessidade de se tentar conciliar a exigência de boa-fé nos atos processuais com uma certa elasticidade de movimento das partes. Na sua opinião, não se pode chegar ao extremo de adotar o princípio kantiano da liberdade isenta de quaisquer vínculos e limites, nem também seguir o extremo oposto, e defender que todos os atos

\footnotetext{
${ }^{322}$ É o que ensina Lent (Diritto Processuale Civile Tedesco, $1^{\mathrm{a}}$ parte, p. 107).

${ }^{323}$ Pontes de Miranda (Comentários ao Código de Processo Civil, tomo IV, p. 386), influenciado pela doutrina alemã, sustenta que o dever de veracidade abrange não só o comando de não lesar mediante mentira ou adulteração dos fatos, mas também o dever de não omitir o que sabe, tanto se a informação for desfavorável à outra parte, quanto se for favorável. Analogamente, Barbosa Moreira (A Responsabilidade das Partes por Dano Processual no Direito Brasileiro, in Temas de Direito Processual, pp. 17 e 27) afirma que o dever de completude junta-se ao dever de veracidade, de modo que a parte deve abster-se de fazer alegações cientemente falsas e também de omitir fatos relevantes de que tenha conhecimento, ainda que eles sejam suscetíveis de favorecer o adversário. Também nesse sentido, Buzaid (Processo e Verdade no Direito Brasileiro, in Revista de Processo, $\mathrm{n}^{\circ}$ 47, p. 96) ensina que o art. 14, I, do CPC estabelece que as partes devem fazer suas declarações sobre as circunstâncias fáticas com toda amplitude e conforme a verdade. Aduz que o "dever de amplitude" significa que as partes, ao mencionarem os fatos que servem de fundamento para a demanda ou a exceção, devem proceder honestamente, de modo que não apresentem apenas os fatos que lhes são favoráveis, calando-se sobre os demais.

${ }^{324}$ LUSO SOARES, A Responsabilidade Processual Civil, p. 169.

${ }^{325}$ A Responsabilidade Processual Civil, p. 169.
} 
processuais estão sob o mandato da boa-fé, devendo a parte até mesmo relatar os fatos que lhe são comprometedores ${ }^{326}$.

Esse parece ser também o entendimento de Carnelutti ${ }^{327}$, que distingue dois prismas da obrigação das partes de dizer a verdade: o lógico e o prático. Do ponto de vista prático, não há qualquer obstáculo para o reconhecimento do dever de veracidade na moderna concepção do processo civil, que dá destaque para o interesse público em se obter um provimento judicial justo. Entende-se que a parte é um instrumento do processo; em outras palavras, a parte serve ao processo, e não o processo à parte. Por causa disso, o princípio dispositivo é considerado apenas uma diretriz de conveniência, podendo ser limitado em algumas circunstâncias. Do ponto de vista lógico, porém, deve-se considerar que, apesar de o litigante ser considerado um instrumento do processo, assim como a testemunha, ele se distingue desta porque somente contribui para que o processo atinja os seus escopos se tiver iniciativa, ou seja, se for livre para agir. Dessa forma, qualquer limite imposto à parte compromete o seu rendimento em benefício do processo. Além disso, as atividades dos sujeitos parciais se desenvolvem por meio da contradição, que, por ser uma forma de luta, não pode ser totalmente privada da força e da astúcia. Portanto, quanto mais se limita a ação das partes, tanto mais se reduz o benefício advindo de sua atividade, bem como se aumenta o perigo do engano e da mentira.

Embasado nesse aspecto prático, o autor italiano conclui que o problema da existência, ou não, do dever de veracidade das partes deve ser solucionado utilizando a proporcionalidade. Cita como exemplo o ordenamento jurídico italiano, no qual a obrigação de a parte dizer a verdade existe somente nas hipóteses em que a falsificação é criminalmente proibida, em razão do seu escopo de enganar o órgão judicial (arts. 371 a 374 e 377 do CP italiano). Esse sistema tem como pressuposto a distinção entre duas espécies de condutas inverídicas: a mentira e o engano, sendo que o segundo seria uma subespécie da primeira, porém agravada pela realização de atos destinados a determinar a sua credibilidade, ou seja, a criar provas idôneas para fazer com que sua "verdade" seja $\operatorname{admitida~}^{328}$.

Seguindo a sugestão de utilizar a proporcionalidade na solução do problema, constata-se que não se pode defender que o art. 14, I, do CPC nacional abrange também um dever de completude nos moldes alemães - quer dizer, uma obrigação de a parte

\footnotetext{
${ }^{326}$ LUSO SOARES, A Responsabilidade Processual Civil, p. 157.

${ }^{327}$ Sistema de Derecho Procesal Civil, vol. II, p. 627.

${ }^{328}$ CARNELUTTI, Sistema de Derecho Procesal Civil, vol. II, pp. 627-628.
} 
mencionar não só os elementos fáticos que lhe são favoráveis, mas também aqueles que podem trazer consequências desfavoráveis à sua pretensão -, pois ele entraria em conflito patente com as normas processuais que atribuem ao autor o ônus de alegar e provar fatos que dão espeque ao seu pedido (arts. 282, III; e 333, I, do CPC) e, ao réu, o ônus de impugnar os fatos narrados na petição inicial e de alegar e provar fatos impeditivos, modificativos ou extintivos do direito do autor (arts. 300; 302; e 333, II, do CPC). Ora, não faria sentido atribuir ao réu o ônus de alegar fatos impeditivos, modificativos ou extintivos do direito do autor, se este fosse obrigado a alegar tais fatos já em sua petição inicial ${ }^{329}$.

Baptista da Silva ${ }^{330}$ também sustenta que o dever de veracidade não abrange a necessidade de o autor expor em sua petição fatos que levariam à improcedência da causa ou que serviriam para fundamentar uma reconvenção por parte do réu. Pensar de modo diferente, segundo o jurista, violaria o princípio dispositivo e também aquele segundo o qual ninguém é obrigado a produzir prova contra si ("nemo tenetur edere contra se"). Complementa que também seria contrariado o próprio art. 14 do CPC, em seu inciso IV, que proíbe as partes de produzirem provas desnecessárias à defesa de seu direito. Segundo Baptista da Silva, "nada poderia ser mais desnecessário à defesa do direito do que a produção de uma prova que o destrua" (destaques no original).

Raciocínio similar é feito por Barbi ${ }^{331}$. Para ele, impor às partes uma rigorosa disciplina moralizadora do seu comportamento contrariaria os princípios que informam o processo civil moderno, notadamente o princípio do contraditório, que atribui a cada litigante o ônus de expor e sustentar os elementos e argumentos que lhe são favoráveis. Diante desse princípio, não se pode exigir que uma parte exponha também argumentos úteis para a defesa do seu adversário. Tal dever raramente seria observado e geraria grande prejuízo para as pessoas honestas que atuam em juízo ${ }^{332}$. O seguinte comentário de Viríssimo Cunha ${ }^{333}$ parece complementar o pensamento do autor brasileiro: "Os litigantes têm de ser honestos, mas não têm de ser ingênuos. São homens, não são herois".

Originalmente, o art. 17, III, do CPC considerava ato de litigância de má-fé “omitir intencionalmente fatos essenciais ao julgamento da causa". Segundo Barbosa Moreira ${ }^{334}$,

\footnotetext{
${ }^{329}$ Contra, sustentando que o autor tem o dever de alegar a existência de litispendência e de conexão já na petição inicial: OLIVEIRA, Litigância de Má-Fé, p. 47.

${ }_{330}$ Comentários ao Código de Processo Civil, vol. 1, pp. 105-110.

${ }^{331}$ Comentários ao Código de Processo Civil, vol. I, § 154, p. 120.

${ }^{332}$ Essa advertência encontra-se na obra de Liebman (Manual de Direito Processual Civil, vol. I, § 60, p. 124).

${ }^{333}$ Simulação Processual e Anulação do Caso Julgado, p. 22.

334 A Responsabilidade das Partes por Dano Processual no Direito Brasileiro, in Temas de Direito Processual, p. 27.
} 
esse dispositivo tutelava o dever de completitude, já que punia o litigante que intencionalmente silenciasse sobre "fatos essenciais", impedindo ou tornando extremamente difícil uma decisão justa. Todavia, possivelmente em razão das críticas da doutrina nacional e estrangeira a respeito da conveniência dessa regra, ela foi suprimida do Código de Processo Civil brasileiro pela Lei no $6.771 / 80^{335}$.

Deve-se salientar que o que se defende no presente trabalho é a inexistência de um dever da parte de alegar fatos contra si própria. Não se pode inferir daí uma liberdade total dos litigantes para omitirem fatos. Grossmann ${ }^{336}$ ensina que "o silêncio constitui uma infração do dever de veracidade sempre que o conjunto essencial de circunstâncias se tornar falsificado pela omissão de um fato". Realmente, há situações em que a omissão de um determinado acontecimento implica, necessariamente, a sua negação, em ofensa ao dever de dizer a verdade. É o que ocorre, por exemplo, no caso do credor de dez parcelas vencidas que, tendo recebido o pagamento de apenas uma delas, ajuíza demanda para cobrar a dívida por inteiro. Ao omitir o pagamento da primeira parcela, a parte afirma um fato falso: não houve o pagamento de parcela alguma. Por essa razão, transgride o dever contido no inciso I do art. 14 do $\mathrm{CPC}^{337} 338$.

Mesmo dentro do âmbito de incidência do art. 14, I, do CPC, não se pode dizer que o dever de veracidade é absoluto, já que existem situações em que a mentira é tolerada. É o que sucede nos casos em que a declaração verídica põe em perigo interesses de altíssimo valor, como a vida, a saúde, a liberdade, interesses públicos (v.g., segredos militares) ou, por vezes, a fortuna. Nessas circunstâncias excepcionais, a parte se encontra em estado de necessidade, o que a exime de se comportar segundo o dever de veracidade 339340 . De

\footnotetext{
${ }^{335}$ BARBI, Comentários ao Código de Processo Civil, vol. I, § 166, p. 128.

${ }^{336}$ O Dever de Veracidade das Partes Litigantes no Processo Civil (aspecto doutrinário), in Revista Forense, vol. 101, p. 481.

${ }^{337}$ Exemplo retirado da obra de Oliveira (Litigância de Má-Fé, pp. 46-47).

${ }^{338}$ No mesmo sentido é a lição de Alvim (Tratado de Direito Processual Civil, vol. 2, p. 400):

"Ainda - e, neste particular ressalta a legitimidade da seleção de fatos - aceita-se, no direito alemão, que a parte 'não precisa proporcionar ao opositor os fundamentos para a reconvenção ou declaração de culpa mútua', desde que, acrescentamos nós, o seu relato não desfigure, em si mesmo, a veracidade dos fatos, em que se estriba. Se se requer uma separação judicial, o cônjuge-autor deve formular o seu pedido, imputando a outro o ilícito ou ilícitos que entenda tenham ocorrido, mas não tem o dever, igualmente, a se inculpar, i.e., não tem o dever de descrever tais fatos de tal forma que venha a facilitar reconvenção do seu oponente, ou, exceção da outra parte" (destaques no original).

339 GROSSMANN, O Dever de Veracidade das Partes Litigantes no Processo Civil (aspecto doutrinário), in Revista Forense, vol. 101, pp. 482-483; CASTRO FILHO, Abuso do Direito no Processo Civil, p. 108, nt. 71.

${ }^{340}$ Em sua obra, Yarshell (Antecipação da Prova sem o Requisito da Urgência e Direito Autônomo à Prova, pp. 151-154 e p. 178, nt. 83) faz menção a essa problemática interessante. O raciocínio do autor tem início com a afirmação de que, no âmbito do processo penal, há uma preponderância dos princípios do contraditório e da ampla defesa em relação aos deveres da lealdade e da colaboração, em razão da indisponibilidade dos valores com que as normas materiais de Direito penal lidam, notadamente a liberdade. Por causa disso, não se
} 
acordo com Luso Soares ${ }^{341}$, escapa do âmbito de incidência do dever de veracidade a parte que nega fatos pessoais torpes em demanda sobre o estado das pessoas, hipótese em que não se aplica a sanção por litigância de má-fé. A observação desse autor lusitano é válida também no processo civil nacional. O art. 347 do CPC brasileiro estabelece que a parte não é obrigada a depor sobre fatos criminosos ou torpes que lhe tenham sido imputados, nem sobre fatos a cujo respeito, por estado ou profissão, deva guardar segredo. Segundo Tabosa Pessoa $^{342}$, esse dispositivo não contém rol taxativo, de modo que o juiz pode reconhecer outros motivos graves que justifiquem a dispensa do dever de contribuir para a descoberta da verdade (v.g., a parte não pode ser obrigada a depor sobre fato criminoso ou torpe imputado a pessoa de sua família, nem sobre fatos que lhe tenham causado algum trauma psicológico, como acidentes ou crimes de que tenha sido vítima). Contudo, o parágrafo único do próprio art. 347 do CPC estatui que as exceções nele previstas não se aplicam às ações de filiação, de separação, de divórcio e de anulação de casamento. Tabosa Pessoa ${ }^{343}$ observa que, no que se refere aos fatos criminosos ou torpes, a parte não pode recusar-se a depor sobre eles se se tratar do fato central objeto da demanda e a sua prova não puder ser feita de outro modo. Mas, pondera que, nesses casos, se a parte for obrigada a depor e faltar com a verdade, ela não pode ser sancionada por quebra da lealdade processual porque seria o mesmo que exigir a própria confissão do delito ou do fato torpe.

Outras dúvidas pairam a respeito dos limites do dever de veracidade. A parte pode alegar em juízo fatos de cuja veracidade não esteja certa? O litigante que alega em juízo circunstâncias falsas que lhe são desfavoráveis viola o dever de dizer a verdade? Em respeito ao dever de veracidade, a parte deve alertar o órgão julgador para o fato de que, em sua decisão, ele percebeu mal a realidade fática a que o processo se refere?

Com relação à primeira questão, se a pessoa não tiver certeza quanto ao que viu ou ouviu, nada obsta que ela exponha o fato que lhe pareça ter ocorrido, porém ressalvando,

exige do réu a alegação e prova de fatos que eventualmente desprestigiem sua tese de defesa e contribuam para a sua própria condenação, afastando-se a cogitação de situações caracterizadoras de litigância de má-fé ou de descumprimento do dever de colaboração no processo penal. A partir dessa constatação, o autor questiona se, na seara processual civil, os deveres de veracidade e de colaboração também não deveriam ser mitigados dependendo da natureza dos direitos discutidos na demanda. Ele se refere especificamente aos processos que versam sobre direitos indisponíveis, como as ações de improbidade administrativa (as quais podem levar à imposição de sanções que, embora tenham natureza civil, aproximam-se bastante da penal) e as controvérsias envolvendo incapazes, reconhecimento ou negação de paternidade, ruptura da sociedade conjugal, pátrio poder e guarda dos filhos. Entretanto, não há uma preocupação do jurista em dar uma solução para o problema apontado.

${ }^{341}$ A Responsabilidade Processual Civil, pp. 169-170.

342 Comentários ao art. 347 do CPC, in MARCATO (coord.), Código de Processo Civil Interpretado, pp. 1107-1108.

${ }^{343}$ Comentários ao art. 347 do CPC, in MARCATO (coord.), Código de Processo Civil Interpretado, pp. 1108-1109 e 1111 . 
necessariamente, a dúvida ${ }^{344}$. O dever de veracidade não implica a admissibilidade em juízo tão somente de afirmações que a parte conheça como verdadeiras, nem a impossibilidade de se discutir judicialmente asserções que a parte conheça como falsas ${ }^{346}$. Esse dever visa a impedir apenas a mentira consciente.

Por causa disso, não parece totalmente correta a opinião de Grossmann ${ }^{347}$ no sentido de que a declaração ambígua da parte viola o dever de veracidade, uma vez que tende a despistar ou a enganar o juiz ou a ensejar uma interpretação errônea. Analogamente, Alvim ${ }^{348}$ estatui que o art. 14, I, do CPC abrange também o dever de não dizer coisas de modo vago. De acordo com o autor, quem, intencionalmente, afirma fatos vagos em juízo tem o propósito de confundir, o que é vedado pelo ordenamento jurídico. Ocorre que a vagueza pode ser apenas um sinal de dúvida da parte, e não de má-fé. O que, de fato, contraria o dever de veracidade é afirmar um fato ambíguo, ou vago, e não declarar a existência de dúvida a seu respeito.

Não se pode perder de vista também que a parte pode ter de descrever para o magistrado acontecimentos que lhe foram narrados por uma outra pessoa, sem poder avaliar previamente se aquilo sucedeu realmente daquela maneira (v.g., o comerciante que se torna réu em um processo que discute a validade de um negócio praticado por seu empregado). Nesse tipo de demanda, apenas por meio da atividade probatória é que se pode esclarecer o que efetivamente ocorreu ${ }^{349}$. Logo, o litigante pode, sim, alegar em juízo fatos de cuja veracidade não esteja certo.

No que concerne à segunda dúvida, deve-se, em primeiro lugar, considerar que o dever de veracidade foi concebido com o intuito não apenas de proteger o órgão jurisdicional contra o engano no momento de realizar a subsunção do fato à norma, mas também de evitar que uma parte prejudique a outra por meio de mentiras. Destarte, não contraria o referido dever a parte que declara em juízo circunstâncias que sejam favoráveis ao outro litigante, ainda que não-verdadeiras (v.g., confissão referente a fatos que, na realidade, não ocorreram; reconhecimento da procedência do pedido do autor que, de fato,

\footnotetext{
${ }^{344}$ PONTES DE MIRANDA, Comentários ao Código de Processo Civil, tomo IV, p. 386.

${ }^{345}$ Se não houver essa ressalva, ou seja, se a parte apresentar como verídicos fatos sobre cuja exatidão existem dúvidas, há violação do dever de veracidade (GROSSMANN, O Dever de Veracidade das Partes Litigantes no Processo Civil (aspecto doutrinário), in Revista Forense, vol. 101, pp. 476-477; ALVIM, Tratado de Direito Processual Civil, vol. 2, p. 397).

${ }_{346}$ ROSENBERG, Tratado de Derecho Procesal Civil, tomo I, p. 382.

${ }^{347}$ O Dever de Veracidade das Partes Litigantes no Processo Civil (aspecto doutrinário), in Revista Forense, vol. 101, p. 481.

${ }^{348}$ Tratado de Direito Processual Civil, vol. 2, pp. 393-394.

${ }^{349}$ LENT, Diritto Processuale Civile Tedesco, $1^{\mathrm{a}}$ parte, p. 106.
} 
não procede; etc. $)^{350}$, desde que digam respeito a direitos disponíveis ${ }^{351}$. Analogamente, também não viola o dever de dizer a verdade quem se abstém de impugnar ponto fático narrado pela parte contrária que sabe ser falso, mas que lhe é favorável ${ }^{352}$, desde que também se refira a direito disponível. Se o magistrado perceber que as declarações não condizem com a verdade, ele deve determinar, de ofício, o comparecimento pessoal das partes para interrogá-las sobre os fatos (art. 342 do CPC), com o fim último de verificar: (a) se a parte que está renunciando a direito disponível ou que está reconhecendo pretensão da parte contrária por meio da mentira age conscienciosamente; e (b) se esse desrespeito ao dever de veracidade realmente não está prejudicando a consecução do escopo jurídico do processo (isto é, a atuação da vontade concreta do direito substancial). A esse respeito, Couture $^{353}$ esclarece que, no processo dispositivo, a parte pode dizer a verdade e, em seguida, expressar o seu querer, hipótese em que a manifestação de vontade prevalece sobre a manifestação de conhecimento. Então, por exemplo, ao invés de o réu reconhecer a procedência do pedido do autor que, na verdade, não procede, ele pode simplesmente dizer na contestação: "Não devo o que se me reclama; mas, não quero dar seguimento a este processo e estou decidido a pôr fim nele aceitando a pretensão do autor". Nesse caso, o juiz não tem outra alternativa que não aceitar o reconhecimento da procedência do pedido e prolatar sentença de mérito favorável ao autor. Caso o juiz constate que as partes estão realizando as condutas mentirosas em conluio, com o fim de praticar ato simulado ou conseguir fim ilícito, deve condená-las pela prática de litigância de má-fé (art. 17, II, c/c art. 18 do CPC) e prolatar sentença que obste aos objetivos delas (art. 129 do CPC). Ademais, se as partes tiverem atuado com o fim de fraudar a lei, a sentença prolatada ao

\footnotetext{
${ }^{350}$ ROSENBERG, Tratado de Derecho Procesal Civil, tomo I, p. 382.

351 Adere-se, nesse aspecto, ao entendimento de Calogero (Probità, Lealtà, Veridicità nel Processo Civile, in Rivista di Diritto Processuale Civile, vol. XVI, parte I, p. 148): "Não se pode, de fato, ser desleal sem mentir; mas, se pode também mentir com boas intenções, e não se dirá desleal senão quem mente para causar dano a outrem" (tradução nossa e destaque nosso).

Esse jurista italiano também sustenta que somente o dolo processual unilateral viola o dever de lealdade e de probidade. Para ele, o dolo processual bilateral praticado em processo que não envolva interesses públicos consiste em uma manifestação legítima do princípio dispositivo. Sendo assim, na sua opinião, contraria o dever de lealdade a pessoa que mente em juízo para prejudicar a parte contrária. Por outro lado, não há qualquer deslealdade se as partes, em colusão, alteram a verdade, uma vez que a lei lhes concede o poder dispositivo, devendo o juiz julgar com base nos fatos convencionalmente criados por elas (CALOGERO, Probità, Lealtà, Veridicità nel Processo Civile, in Rivista di Diritto Processuale Civile, vol. XVI, parte I, pp. 141-145 e 148). Nesse ponto, contudo, há uma falha na teoria de Calogero, pois, como se analisará de maneira mais detalhada no item 1.3.7.1.3 "infra", o princípio dispositivo em sentido próprio estabelece apenas que as partes têm a liberdade de alegar os fatos que quiserem para sustentar suas pretensões e de silenciarem sobre fatos que não pretendam ver investigados. Ele não autoriza os litigantes a negar a existência de um fato real, nem a afirmar a ocorrência de um fato inexistente.

${ }^{352}$ LENT, Diritto Processuale Civile Tedesco, $1^{\text {a }}$ parte, p. 107.

${ }^{353}$ El Deber de las Partes de Decir la Verdad, in Estudios de Derecho Procesal Civil, t. III, pp. 246-247.
} 
final do processo e já transitada em julgado pode ser rescindida com espeque no art. 485, III, do CPC.

Quanto à última dúvida, no julgamento dos EDcl nos EDcl no AgRg no Resp no 494.021/SC, os Ministros da 2 $2^{\text {a }}$ Turma do Superior Tribunal de Justiça tiveram de decidir se litiga de má-fé, ou não, a parte que se omite em dizer que o órgão julgador teve falsa percepção da realidade fática a que o processo se refere. Tratava-se de ação ajuizada pelo Posto Marcolla Ltda. em face do Instituto Nacional do Seguro Social, visando a declarar a ilegalidade da imposição de multa moratória cobrada pela autarquia em pagamentos de contribuições efetuados diretamente em agência bancária, fora do vencimento, mas sem que houvesse qualquer notificação por parte da autarquia. $\mathrm{O}$ autor argumentava que teria os mesmos benefícios da denúncia espontânea. O juízo federal de primeiro grau julgou improcedente a demanda por entender que o recolhimento do tributo via GRP's, acrescido da respectiva multa, mesmo sem qualquer atitude do Fisco, não corresponde a pagamento antecipado, mas sim a pagamento com atraso, o que afasta o benefício da denúncia espontânea. Contra a sentença, o autor interpôs apelação, dirigida ao TRF da $4^{\mathrm{a}}$ Região. Ocorre que este órgão julgador equivocou-se ao julgar o recurso e partiu da premissa de que teria havido parcelamento. Por causa disso, aplicou os benefícios da denúncia espontânea e afastou a multa moratória. Como a decisão foi favorável ao Posto Marcolla Ltda., ele se descurou de alertar o Tribunal a respeito do equívoco do julgamento, limitando-se a opor embargos de declaração para reclamar honorários. O INSS interpôs embargos infringentes e, em seguida, recurso especial, que foi provido no STJ para reverter o julgamento, considerando a jurisprudência mais recente sobre o tema, no sentido de que parcelamento não equivale a pagamento e, por isso, não teria aplicação o art. 138 do $\mathrm{CTN}^{354}$. Contra esse acórdão, o autor interpôs agravo regimental, que foi improvido. Posteriormente, opôs embargos de declaração, que foram rejeitados. Diante dessas decisões desfavoráveis, o Posto Marcolla Ltda. opôs novos embargos declaratórios para esclarecer os fatos e informar que houve erro material por parte do TRF da $4^{a}$ Região. A $2^{a}$ Turma do STJ decidiu anular os julgamentos de todos os recursos posteriores ao da apelação e determinou que o TRF da $4^{a}$ Região corrigisse o apontado erro material. Também condenou os advogados do Posto Marcolla Ltda. ao pagamento "pro rata" de

\footnotetext{
${ }^{354}$ Esse artigo estatui o seguinte:

"Art. 138. A responsabilidade é excluída pela denúncia espontânea da infração, acompanhada, se for o caso, do pagamento do tributo devido e dos juros de mora, ou do depósito da importância arbitrada pela autoridade administrativa, quando o montante do tributo dependa de apuração.

Parágrafo único. Não se considera espontânea a denúncia apresentada após o início de qualquer procedimento administrativo ou medida de fiscalização, relacionados com a infração".
} 
multa no montante de $1 \%$ do valor atualizado da causa e de indenização no montante de $5 \%$ do valor atualizado da causa pela prática de litigância de má-fé ${ }^{355}$.

Não obstante o STJ tenha considerado que o comportamento processual ímprobo do Posto Marcolla Ltda. se subsumisse à hipótese do inciso V do art. 17 do CPC (“Art. 17. Reputa-se litigante de má-fé aquele que: [...] V-proceder de modo temerário em qualquer incidente ou ato do processo"), o que ocorreu, na verdade, foi uma violação do dever de veracidade (art. 17, II, c/c art. 14, I, do CPC).

Esse exemplo verídico parece deixar claro que a conduta do litigante que deixa de declarar ao juízo que sua decisão foi embasada em erro a respeito da realidade subjacente ao processo contraria o dever de dizer a verdade, bem como os deveres de lealdade e de cooperação.

\subsection{Conflito entre o princípio dispositivo e o dever de veracidade?}

Algumas vozes negam a existência de um dever jurídico de respeito à verdade argumentando que haveria uma incompatibilidade entre ele e o princípio dispositivo. Antes de analisar esse problema, cumpre fixar o sentido da expressão "princípio dispositivo", que se mostra extremamente equívoca, pois a doutrina nacional e a estrangeira a empregam para expressar coisas diversas.

A maior parte da doutrina afirma que o princípio dispositivo impõe ao juiz o dever de julgar a causa com base nos fatos alegados e provados pelas partes. Adota-se, literalmente, a brocardo latino "iudex iudicare debet iuxta allegata et probata partium" 356.

\footnotetext{
355 A ementa desse julgado merece ser citada "in verbis": "PROCESSO CIVIL - EMBARGOS DE EMBARGOS DECLARATÓRIOS NO AGRAVO REGIMENTAL DENÚNCIA ESPONTÂNEA - ERRO MATERIAL - INEXISTÊNCIA DE PARCELAMENTO - LITIGÂNCIA DE MÁ-FÉ - MULTA E INDENIZAÇÃO.

1. Ação que visa excluir multa cobrada em pagamento efetuado diretamente em agência bancária. Equívoco do Tribunal ao julgar apelação, que considerou tratar-se de parcelamento do débito. Ocorrência de erro material.

2. Litigância de má-fé dos advogados da empresa autora, que se omitiram em apontar a ocorrência do erro na primeira oportunidade em que se manifestaram nos autos após o julgamento, vindo a fazê-lo somente após o julgamento de diversos recursos, quando a decisão que iria prevalecer seria desfavorável à sua cliente. Imposição, aos advogados subscritores dos recursos, de multa de $1 \%$ do valor atualizado da causa, além de indenização ao recorrido de $5 \%$ do valor atualizado da causa.

3. Anulação de todos os julgamentos posteriores ao do apelo, para que o Tribunal corrija o apontado erro material.

4. Embargos de declaração acolhidos, com efeitos modificativos"

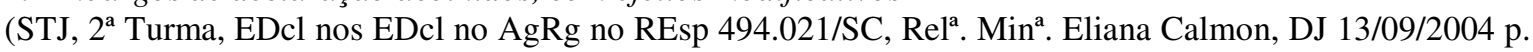
204).

${ }^{356}$ Liebman (Fondamento del Principio Dispositivo, in Problemi del Processo Civile, p. 3, nt. 1) ensina que essa máxima remonta aos Glosadores.
} 
Desse modo, o juiz não poderia levar em consideração fatos não afirmados pelas partes e também estaria proibido de colher meios de prova diversos dos eleitos e indicados pelas partes para constatar as circunstâncias fáticas alegadas no processo. Esses mesmos autores dizem que o princípio dispositivo contrapõe-se ao inquisitivo, o qual atribui ao magistrado poderes de iniciativa probatória, a fim de que se possa instruir a respeito dos fatos mencionados como fundamentos da demanda ${ }^{357}$.

Cappelletti insurge-se contra essa concepção. O autor parte da premissa de que o princípio dispositivo é um reflexo da natureza privada do objeto do processo, ou seja, do caráter disponível da relação jurídica substancial litigiosa ${ }^{358}$. Sendo o direito civil material, em regra, um direito privado, sua incidência acarreta a criação de direitos subjetivos também privados, dos quais se pode livremente dispor (mediante alienação, doação, sucessão, renúncia etc. $)^{359}$. Essa livre disponibilidade do direito subjetivo tem como consequência, em primeiro lugar, a faculdade de o seu titular escolher, também livremente, se quer pleitear, ou não, sua tutela em juízo; e, em segundo lugar, o poder de alegar os fatos que, na sua opinião, lhe dão o direito de obter o bem da vida pleiteado em juízo (causa de pedir fática da demanda) ${ }^{360}$. Daí o jurista italiano infere o princípio dispositivo em sentido material (ou em sentido próprio), que atribui exclusivamente às partes o poder de pedir a tutela jurisdicional e de fixar o objeto do processo $^{361}$.

O princípio dispositivo, consoante Cappelletti, manifesta-se por meio de uma série de regras técnicas e de subprincípios, sendo os principais ${ }^{362}$ : (a) o princípio da demanda (“nemo judex sine actore"), enunciado nos arts. $2^{\circ}$ e 262 do $\mathrm{CPC}^{363} 364$; (b) o princípio da

${ }^{357}$ Nesse sentido: BAPTISTA DA SILVA; GOMES, Teoria Geral do Processo Civil, pp. 47-48; 49-51; MARQUES, Manual de Direito Processual Civil, vol. 2, pp. 253-254; MARQUES, Instituições de Direito Processual Civil, vol. 1, pp. 101-102; LIEBMAN, Fondamento del Principio Dispositivo, in Problemi del Processo Civile, pp. 9-10; GRECO FILHO, Direito Processual Civil Brasileiro, vol. I, p. 227.

${ }^{358}$ CAPPELLETTI, El Principio Dispositivo y sus Principales Manifestaciones, in El Proceso Civil en el Derecho Comparado, p. 17; CAPPELLETTI, La Testimonianza della Parte nel Sistema dell'Oralità, vol. I, p. 319.

359 CAPPELLETTI, El Principio Dispositivo y sus Principales Manifestaciones, in El Proceso Civil en el Derecho Comparado, pp. 19 e

${ }^{360}$ CAPPELLETTI, El Principio Dispositivo y sus Principales Manifestaciones, in El Proceso Civil en el Derecho Comparado, pp. 26-27; CAPPELLETTI, La Testimonianza della Parte nel Sistema dell'Oralità, vol. I, pp. 329-331.

${ }^{361}$ CAPPELLETTI, La Testimonianza della Parte nel Sistema dell'Oralità, vol. I, pp. 357-358.

362 El Principio Dispositivo y sus Principales Manifestaciones, in El Proceso Civil en el Derecho Comparado, pp. 23-36.

${ }^{363}$ No ordenamento jurídico brasileiro, o juiz tem o poder-dever de dar início ao inventário "ex officio", caso nenhum dos legitimados arrolados nos arts. 987 e 988 do CPC o requeiram dentro do prazo de 60 dias a contar da abertura da sucessão (art. 989 do CPC), o que representa uma exceção ao princípio da demanda ou da inércia da jurisdição (MARCATO, Procedimentos Especiais, p. 221; BEDAQUE, Poderes Instrutórios do Juiz, p. 93). 
exceção, segundo o qual o juiz somente pode conhecer das exceções em sentido próprio ("exceptiones juris") que forem efetivamente alegadas pelo réu (v.g., a alegação de erro, dolo, coação, "exceptio non adimpleti contractus", compensação etc.) ${ }^{365}$; (c) o princípio da correlação entre sentença e demanda, ou da adstrição do julgamento ao pedido ("ne eat judex ultra petita partium"), previsto nos arts. 128 e 460 do $\mathrm{CPC}^{366}$; (d) o que ele chama de "princípio da impugnação privada da sentença", que abrange duas regras: (1) a que atribui apenas às partes, ao representante do Ministério Público e aos terceiros interessados o poder de interpor recursos (art. 499 do CPC), nunca ao juiz, "ex officio"367; e (2) a que estabelece que são devolvidos ao órgão jurisdicional "ad quem" exclusivamente os capítulos de sentença impugnados ("tantum devolutum quantum appellatum" - art. 515, "caput", do CPC); e (e) o princípio da disponibilidade privada do processo, que nada mais

Na opinião de Baptista da Silva e Gomes (Teoria Geral do Processo Civil, p. 51), a quebra do princípio da demanda, nesse caso, é mais aparente que real. Em primeiro lugar, o procedimento de inventário e partilha pertence ao campo da jurisdição voluntária. Além disso, na verdade, o juiz não dá início ao processo de inventário de ofício. Ele limita-se a provocar a iniciativa dos interessados. Nesse mesmo sentido, negando que o art. 989 do CPC excepcione o princípio da demanda, porém sem maiores explicações: TEIXEIRA, Código de Processo Civil Anotado, p. 551.

${ }^{364}$ Bedaque também entende que o princípio dispositivo diz respeito aos reflexos que a relação de direito material disponível pode produzir no processo. Mas, na contramão da opinião de Cappelletti, afirma que a influência do caráter disponível da relação material deduzida em juízo não abrange o monopólio da parte sobre o poder de iniciativa da demanda. Para o autor, o princípio da demanda independe da natureza do direito litigioso (BEDAQUE, Poderes Instrutórios do Juiz, pp. 91-93).

Contudo, a doutrina majoritária sustenta que o princípio da demanda é um dos corolários do princípio dispositivo em sentido próprio (MARQUES, Instituições de Direito Processual Civil, vol. 1, p. 104; DALL'AGNOL JUNIOR, O Princípio Dispositivo no Pensamento de Mauro Cappelletti, in Lex Jurisprudência dos Tribunais de Alçada Civil de São Paulo, vol. 119, p. 19; BONICIO, Introdução ao Processo Civil Moderno, p. 44).

${ }^{365}$ Cappelletti (La Testimonianza della Parte nel Sistema dell'Oralità, vol. I, pp. 339 e 343-344) observa que as objeções processuais (v.g., a incompetência absoluta, a ausência de pressupostos processuais, a incapacidade da parte $e t c$.), por se referirem a situações de ordem pública, ficam fora do âmbito do poder monopolístico das partes de alegar fatos e, consequentemente, também do vínculo do juiz de decidir "secundum allegata partium".

$\mathrm{Na}$ sua opinião, estão igualmente excluídos desse âmbito a categoria dos "meros fatos impeditivos ou extintivos”, que abrange o pagamento, a novação, a remissão, a confusão, a perda da coisa devida, a verificação da condição resolutiva etc. (exceções em sentido impróprio ou "exceptiones facti"), uma vez que a ausência de tais fatos consiste em fato constitutivo do direito alegado pelo autor, logo o juiz deve verificar a sua existência, ou não, para decidir se a demanda é fundada (CAPPELLETTI, La Testimonianza della Parte nel Sistema dell'Oralità, vol. I, pp. 345-350).

366 De acordo com Bedaque (Poderes Instrutórios do Juiz, p. 96), esse princípio não constitui dogma inafastável, tanto que o legislador permite, em casos excepcionais, que o juiz ultrapasse os limites objetivos da demanda. Cita como exemplos: (a) o art. 461, § 4 , do CPC, que permite a imposição de multa diária ao réu independementente de pedido; (b) o parágrafo único do art. 645 do CPC, que atribui ao juiz o poder de reduzir o valor de multa prevista em título executivo extrajudicial, se o considerar excessivo; e (c) o art. $7^{\circ}$ da Lei $n^{\circ} 8.560 / 92$, que admite a tutela condenatória "ex officio", versando sobre pensão alimentícia, em demanda com pedido exclusivamente declaratório de reconhecimento de paternidade.

${ }^{367}$ No Brasil, o art. 475 do CPC determina a necessária sujeição de algumas sentenças ao duplo grau de jurisdição. A melhor doutrina afirma que essa remessa oficial à instância superior não configura um verdadeiro recurso (BARBOSA MOREIRA, Comentários ao Código de Processo Civil, vol. V, p. 233). O fato é que a devolução ao órgão jurisdicional "ad quem" para reexame ocorre independentemente da vontade da parte (DALL'AGNOL JUNIOR, O Princípio Dispositivo no Pensamento de Mauro Cappelletti, in Lex Jurisprudência dos Tribunais de Alçada Civil de São Paulo, vol. 119, pp. 21-22). 
é do que a regra que atribui às partes o poder de pôr fim ao processo, sem que seja prolatada uma sentença verdadeiramente de mérito (v.g., mediante transação entre os litigantes, renúncia do autor à sua pretensão, reconhecimento da procedência do pedido pelo réu etc.).

No verso da moeda encontra-se o princípio inquisitório em sentido substancial (ou em sentido próprio), que não compele o juiz a julgar a causa segundo os fatos alegados pelas partes. Trata-se do fenômeno da abolição do vínculo do magistrado à alegação dos fatos constitutivos sob iniciativa das partes e da atribuição, a ele, de poderes de autônoma iniciativa no que concerne à instauração e à determinação do objeto do processo $^{368}$. De acordo com Cappelletti, esse princípio é um sinal da publicização do objeto do processo, ou seja, do direito material ${ }^{369}$. Ele é adotado nos sistemas jurídicos comunistas, como consequência da abolição do caráter privado dos direitos substanciais patrimoniais, tanto reais, quanto pessoais ${ }^{370}$. Explica o autor que, nesses sistemas jurídicos, a publicização dos direitos substanciais faz com que o credor seja destituído da liberdade de escolher entre exercitar, ou não, seus direitos de crédito. A inércia do titular do direito contraria as finalidades da organização socialista (v.g., planificação econômica), fazendo com que o Estado substitua a sua vontade e dê início ao processo de execução, seja mediante o ajuizamento de demanda executiva por órgãos estatais similares ao Ministério Público, seja de ofício, pelo competente órgão jurisdicional, independentemente de qualquer demanda privada ou pública ${ }^{371}$. Esse fenômeno, levado às suas últimas consequências, pode implicar a abolição do direito subjetivo, com as transformações do direito subjetivo em função ou poder ("potestà") e da relação intersubjetiva em "status" ("status potestatis") 372. Além disso, gera o grave risco de o juiz perder a sua posição de terceiro "super partes", ou seja, sua imparcialidade, e, consequentemente, de o poder jurisdicional desnaturar-se como $\operatorname{tal}^{373}$.

\footnotetext{
${ }^{368}$ CAPPELLETTI, La Testimonianza della Parte nel Sistema dell'Oralità, vol. I, pp. 357 e 358.

${ }^{369}$ CAPPELLETTI, La Testimonianza della Parte nel Sistema dell'Oralità, vol. I, p. 354.

370 CAPPELLETTI, El Principio Dispositivo y sus Principales Manifestaciones, in El Proceso Civil en el Derecho Comparado, pp. 18-20; 21-22.

${ }^{371}$ CAPPELLETTI, El Principio Dispositivo y sus Principales Manifestaciones, in El Proceso Civil en el Derecho Comparado, pp. 24-27.

${ }^{372}$ CAPPELLETTI, La Testimonianza della Parte nel Sistema dell'Oralità, vol. I, pp. 354-355.

${ }^{373}$ CAPPELLETTI, La Testimonianza della Parte nel Sistema dell'Oralità, vol. I, pp. 358-359.

Para Cappelletti, ato jurisdicional é aquele praticado no exercício de um poder ("potestà") vinculado à ação das partes. Então, quando o ordenamento jurídico atribui ao juiz poderes que o desvinculam da ação dos litigantes, seus atos perdem a natureza jurisdicional (ubi non est actio, ibi non est jurisdictio").
} 
Cappelletti ${ }^{374}$ salienta que a natureza privada do direito subjetivo substancial não exclui o caráter essencialmente público do processo, nem o interesse inderrogável do Estado na ordenada e correta administração da justiça, quer dizer, na correta aplicação das normas de direito material. É necessário distinguir as normas, poderes, deveres, faculdades e atos referentes ao pedido de tutela jurisdicional das normas, poderes, deveres, faculdades e atos correspondentes à técnica e à estrutura interna do procedimento ${ }^{375}$. Por esse motivo - diz o autor italiano -, incide em erro quem afirma que o caráter disponível da relação jurídica litigiosa implica, necessariamente, a atribuição, às partes, da plenitude dos poderes referentes ao desenvolvimento interno e à técnica do processo, notadamente o poder de iniciativa com relação às provas. Em um processo regido totalmente pelo princípio dispositivo em sentido próprio, desde que respeitados os elementos objetivos da demanda (pedido e causa de pedir), fixados monopolisticamente pelas partes, o juiz pode (e deve) exercer seu poder de iniciativa e de direção formal e material do processo para poder julgar a demanda da melhor maneira possível ${ }^{376}$. Diante disso, o jurista italiano afirma que, dos dois princípios contidos na máxima latina "iudex iudicare debet iuxta allegata et probata partium", aquele referente à necessidade de o juiz decidir a causa com base nos fatos provados exclusivamente pelas partes pode ser renegado pelo processo sem que ele deixe de ser considerado dispositivo 377378 .

\footnotetext{
${ }^{374}$ La Testimonianza della Parte nel Sistema dell'Oralità, vol. I, pp. 320-328.

375 ALVARO DE OLIVEIRA, Poderes do Juiz e Visão Cooperativa do Processo, in Revista da AJURIS, $\mathrm{n}^{\circ}$ 90 , p. 70 .

${ }^{376}$ No mesmo sentido: BEDAQUE, Poderes Instrutórios do Juiz, pp. 93-95.

${ }^{377}$ CAPPELLETTI, La Testimonianza della Parte nel Sistema dell'Oralità, vol. I, p. 333.

378 Segundo Cappelletti (La Testimonianza della Parte nel Sistema dell'Oralità, vol. I, pp. 318-319), a premissa sobre a qual ele fundamenta sua teoria (aquela segundo a qual o princípio dispositivo é um reflexo do caráter disponível do objeto do processo) também está na base da distinção, feita pela doutrina tedesca do fim do século XIX, entre:

a) o princípio dispositivo ("Dispositionsmaxime" ou "Verfügungsgrundsatz"), que confere à parte o monopólio do poder de dispor do interesse material e pedir sua tutela jurisdicional; e

b) o princípio da "trattazione" ("Verhandlungsmaxime", literalmente traduzido como "princípio do debate"), que atribui tão somente à parte o poder de determinar, passo a passo, a técnica instrumental do procedimento, ou seja, o poder de escolher os meios processuais que lhe pareçam mais adequados para perseguir o escopo visado (v.g., pedir a obtenção de uma prova, produzir um documento etc.).

Nota-se que o primeiro princípio relaciona-se com as normas, deveres, poderes e atos referentes ao momento do pedido de tutela do interesse material deduzido em juízo; enquanto o segundo concerne às normas, poderes, deveres e atos referentes à técnica e estrutura interna do processo (CAPPELLETTI, La Testimonianza della Parte nel Sistema dell'Oralità, vol. I, pp. 306-309; DALL'AGNOL JUNIOR, O Princípio Dispositivo no Pensamento de Mauro Cappelletti, in Lex - Jurisprudência dos Tribunais de Alçada Civil de São Paulo, vol. 119, p. 14; BEDAQUE, Poderes Instrutórios do Juiz, p. 88).

No entanto, Cappelletti não chancela essa doutrina tedesca. Pelo contrário, ele a critica porque a maior parte dos seus membros inclui na "Verhandlungsmaxime", além dos poderes dos litigantes relativos à iniciativa probatória, o poder monopolístico das partes de alegar fatos jurídicos, colocando em um mesmo plano dois fenômenos distintos: a seleção do material fático (referente ao momento da disposição da tutela do direito) e a escolha dos meios para provar os fatos alegados (concernente à pura e simples técnica processual). Dessa forma, diz o autor, essa corrente doutrinária incorre em perigosa contradição, pois, de um lado, reivindica ao
} 
Tendo fixado que a vinculação do juiz aos fatos provados apenas pelas partes não consiste em uma verdadeira manifestação do princípio dispositivo, pois não se trata de um reflexo necessário da natureza disponível da relação jurídica material litigiosa, Cappelletti reconhece a existência de sentidos impróprios dos princípios dispositivo e inquisitório. $\mathrm{O}$ primeiro vincula o juiz à iniciativa das partes no que concerne à técnica e ao desenvolvimento interno do processo, especificamente quanto à escolha dos instrumentos para a formação do convencimento judicial e é denominado, por Cappelletti, "princípio dispositivo em sentido processual" (ou "em sentido impróprio") ${ }^{379}$. O segundo estatui que o magistrado vincula-se à vontade das partes no que concerne aos limites da demanda, ao reconhecimento de exceções em sentido próprio e às impugnações de decisões, mas lhe atribui poderes de iniciativa probatória oficial ${ }^{380}$. Em outras palavras, consiste na abolição do monopólio das partes sobre o poder de iniciativa probatória, recebendo o nome de "princípio inquisitório em sentido processual" (ou "em sentido impróprio") 381382383.

\footnotetext{
"Dispositionsmaxime" tudo o que se refere à instauração do processo e à determinação do seu objeto; e, do outro, subtrai a esse mesmo princípio a alegação dos fatos, ou seja, o ato por meio do qual a parte determina a causa de pedir fática da demanda (CAPPELLETTI, La Testimonianza della Parte nel Sistema dell'Oralità, vol. I, pp. 317-318; 328-329; 333-334).

${ }^{379}$ CAPPELLETTI, La Testimonianza della Parte nel Sistema dell'Oralità, vol. I, p. 358.

${ }^{380}$ CAPPELLETTI, El Principio Dispositivo y sus Principales Manifestaciones, in El Proceso Civil en el Derecho Comparado, p. 39, nt. 32.

${ }^{381}$ CAPPELLETTI, La Testimonianza della Parte nel Sistema dell'Oralità, vol. I, p. 357.

${ }^{382} \mathrm{O}$ jurista italiano sustenta que este último princípio não torna o magistrado parcial, nem implica a perda da natureza jurisdicional de seus poderes, uma vez que o princípio inquisitório em sentido processual (ou em sentido impróprio) simplesmente atribui ao juiz poderes autônomos quanto ao modo de exercitar a função na qual ele é investido, a qual não deixa de ser um poder vinculado à demanda e aos limites desta, fixados pelas partes. Esclarece que o juiz deve ser imparcial com relação à ação, quer dizer, ao direito subjetivo material e ao ato por meio do qual sua tutela é pleiteada judicialmente (demanda do autor; exceção do réu); não com relação ao processo, nem à justiça da decisão (CAPPELLETTI, La Testimonianza della Parte nel Sistema dell'Oralità, vol. I, p. 359).

Liebman também entende que a imparcialidade é a nota característica da função jurisdicional, que a distingue das demais atividades públicas. Segundo o autor, o juiz julga em causa alheia, ou seja, sua posição deve ser estranha à matéria sobre a qual deve exercer a função jurisdicional. Todavia, a lição desse jurista italiano destoa da de Cappelletti quando afirma que o poder de iniciativa probatória compromete a imparcialidade psicológica da pessoa física que exerce a função jurisdicional e defende a não-ingerência do juiz na produção das provas, sob pena de a sua atividade perder a natureza jurisdicional (LIEBMAN, Fondamento del Principio Dispositivo, in Problemi del Processo Civile, pp. 11-14).

${ }^{383}$ Parte da doutrina critica a proposta de Cappelletti de distinguir sentidos próprios e impróprios dos princípios dispositivo e inquisitório, alegando que ela geraria um perigo de confusão. Nesse sentido: LIEBMAN, Fondamento del Principio Dispositivo, in Problemi del Processo Civile, p. 4, nt. 4; DALL'AGNOL JUNIOR, O Princípio Dispositivo no Pensamento de Mauro Cappelletti, in Lex Jurisprudência dos Tribunais de Alçada Civil de São Paulo, vol. 119, p. 24.

"Data venia", a crítica não parece proceder, uma vez que o intuito do autor ao proceder a essa distinção foi exatamente o contrário: ele quis superar a corrente doutrinária tradicional que confunde o princípio que atribui apenas às partes o poder de pedir a tutela jurisdicional e de fixar o objeto do processo com aquele outro que vincula o juiz à iniciativa dos litigantes no que concerne à técnica e ao desenvolvimento interno do processo, especificamente quanto à escolha dos instrumentos para a formação do convencimento judicial. Então, na verdade, a teoria de Cappelletti não causa confusão; pelo contrário, ela se propõe a terminar com uma.
} 
Percebe-se que esses conceitos ditos “impróprios” não guardam qualquer relação com a natureza disponível ou indisponível do direito substancial que se quer tutelar por meio do processo, que, segundo Cappelletti, consiste no cerne do binômio princípio dispositivo-princípio inquisitório em sentido próprio. Eles versam, na verdade, sobre o processo e a técnica processual, especificamente sobre a titularidade do poder de iniciativa probatória, poder esse que é exercido sobre os fatos jurídicos alegados pelas partes ${ }^{384}$.

A teoria de Cappelletti, que restringe o sentido próprio do princípio dispositivo somente à proibição de o juiz conhecer fatos não-articulados pelas partes, merece ser adotada, uma vez que se coaduna com a ideia de instrumentalidade do processo. Ela pressupõe a percepção de que o processo não é um fim em si mesmo, mas sim um instrumento utilizado pelo Estado para - dentre outras finalidades - compor litígios e garantir a efetividade do direito substancial ${ }^{385}$. A outra concepção do princípio dispositivo, que mantém também a estrutura interna do processo sob o domínio exclusivo das partes, especialmente o poder instrutório, tem sido muito criticada pela moderna ciência processual, pois está ligada às ultrapassadas concepções privatistas do direito processual, que elegem as partes como "donas" do processo e conferem ao juiz a posição de mero expectador $^{386}$.

O atual Código de Processo Civil brasileiro parece ter efetivamente encampado a referida teoria do autor italiano. É o que se dessume da leitura da Exposição de Motivos do Código em conjunto com alguns dos seus artigos que versam sobre os poderes do órgão jurisdicional. No item 18 da Exposição de Motivos, Alfredo Buzaid afirma que o projeto do Código de Processo Civil consagrou realmente o princípio dispositivo ${ }^{387}$. Já o art. 130

\footnotetext{
${ }^{384}$ CAPPELLETTI, La Testimonianza della Parte nel Sistema dell'Oralità, vol. I, pp. 355 e 360.

385 CAPPELLETTI, El Principio Dispositivo y sus Principales Manifestaciones, in El Proceso Civil en el Derecho Comparado, pp. 17-18.

${ }^{386}$ PORTANOVA, Princípios do Processo Civil, p. 122; BEDAQUE, Poderes Instrutórios do Juiz, p. 93.

387 É possível questionar se o Código de Processo Civil de 1973 adotou, de fato, o princípio dispositivo, suscitando como argumento o texto do art. 131 do CPC: "O juiz apreciará livremente a prova, atendendo aos fatos e circunstâncias constantes dos autos, ainda que não alegados pelas partes; [...]" (destaque nosso). Interpretado literalmente, esse artigo leva a crer que o órgão judicial pode tomar como razão de decidir quaisquer fatos comprovados nos autos, ainda que não alegados pelas partes.

No entanto, Barbi (Comentários ao Código de Processo Civil, vol. I, § 701, p. 412) explica que o art. 131 do CPC não contraria o princípio dispositivo, uma vez que ele se refere aos fatos simples, não aos fatos jurídicos. De acordo com o autor, os fatos simples não constituem, modificam, nem extinguem direitos; eles servem apenas para demonstrar a existência de fatos jurídicos (estes, sim, constitutivos, modificativos ou extintivos de direitos). Por exemplo: uma pessoa ateia fogo em seus pastos e acaba provocando um incêncio no imóvel vizinho. $\mathrm{O}$ ato de atear fogo é um fato jurídico. Já a passagem daquela pessoa, munida de um facho e de uma lata de gasolina, em direção ao local onde teve início o incêncio, são fatos simples. Estes não criam o direito do reclamante, mas servem para provar o fato jurídico.

Com efeito, a doutrina majoritária defende que, no ordenamento jurídico processual brasileiro, prevalece, o princípio dispositivo (BAPTISTA DA SILVA; GOMES, Teoria Geral do Processo Civil, p. 48; DALL'AGNOL JUNIOR, O Princípio Dispositivo no Pensamento de Mauro Cappelletti, in Lex -
} 
do CPC atribui ao juiz o poder de determinar, "ex officio", as provas necessárias à instrução do processo ${ }^{388}$. Ora, a melhor maneira de conciliar o princípio dispositivo com a previsão do poder de iniciativa probatória do juiz é adotar o entendimento que Cappelletti tem a respeito desse princípio, relegando, consequentemente, a concepção majoritária de que o juiz deve julgar a causa com base nos fatos alegados e provados pelas partes ("iudex iudicare debet iuxta allegata et probata partium") ${ }^{389}$. Pode-se afirmar, portanto, que, no ordenamento jurídico nacional, vigoram, concomitantemente: (a) o princípio dispositivo em sentido material (ou em sentido próprio), já que as partes detêm, com exclusividade, o poder de pedir a tutela jurisdicional e de fixar o objeto do processo; e (b) o princípio inquisitório em sentido processual (ou em sentido impróprio), pois, respeitados a iniciativa da demanda e os limites do objeto do processo, o magistrado possui poderes de iniciativa e de direção formal e material do processo, inclusive poderes instrutórios ${ }^{390}$.

Uma vez definido o que se entende por "princípio dispositivo", é possível discutir se ele é, ou não, incompatível com o dever das partes de dizer a verdade e, em o sendo, quais são os limites dessa incompatibilidade.

Jurisprudência dos Tribunais de Alçada Civil de São Paulo, vol. 119, p. 19). As raras situações em que é adotado o princípio inquisitório são justificadas por uma constatação de direito comparado: não obstante a maioria dos juristas faça a contraposição entre princípio dispositivo e princípio inquisitório, o fato é que os legisladores não costumam adotar exclusivamente um desses princípios. Eles coordenam e equilibram os dois, criando um tipo intermediário, em que um princípio pode predominar sobre o outro, mas nunca excluílo totalmente (CALAMANDREI, Instituciones de Derecho Procesal Civil: según el nuevo código, pp. 283284; DALL'AGNOL JUNIOR, O Princípio Dispositivo no Pensamento de Mauro Cappelletti, in Lex Jurisprudência dos Tribunais de Alçada Civil de São Paulo, vol. 119, pp. 12-13; BAPTISTA DA SILVA; GOMES, Teoria Geral do Processo Civil, p. 48; DIDIER JUNIOR, Os Três Modelos de Direito Processual: inquisitivo, dispositivo e cooperativo, in Revista de Processo, no 198, p. 216).

${ }^{388}$ Baptista da Silva e Gomes (Teoria Geral do Processo Civil, p. 49) recordam outros dispositivos do Código de Processo Civil que atribuem ao juiz o poder de iniciativa probatória, tais como: (a) o art. 342, que prevê o poder de o juiz, de ofício, em qualquer estado do processo, determinar o comparecimento pessoal das partes, a fim de interrogá-las sobre os fatos da causa; (b) o art. 335, que trata da possibilidade de o juiz, na falta de normas jurídicas particulares, aplicar as regras de experiência comum subministradas pela observação do que ordinariamente acontece e ainda as regras da experiência técnica, ressalvado, quanto a esta, o exame pericial, independentemente de qualquer iniciativa probatória das partes; (c) o art. 382, que atribui ao juiz o poder de ordenar, de ofício, à parte a exibição parcial dos livros e documentos, extraindo-se deles a suma que interessar ao litígio, bem como reproduções autenticadas; (d) o art. 440, segundo o qual o juiz pode, de ofício ou a requerimento da parte, em qualquer fase do processo, inspecionar pessoas ou coisas, a fim de se esclarecer sobre fato que interesse à decisão da causa; (e) o art. 418, que confere ao juiz o poder de ordenar, inclusive de ofício, a inquirição de testemunhas referidas nas declarações da parte ou das testemunhas, bem como a acareação de duas ou mais testemunhas ou de alguma delas com a parte.

389 No sentido de que as ideias de Cappelletti têm plena aplicação ao atual Código de Processo Civil brasileiro, consultar: BARBI, Comentários ao Código de Processo Civil, vol. I, pp. 408-409; PORTANOVA, Princípios do Processo Civil, p. 122; DALL'AGNOL JUNIOR, O Princípio Dispositivo no Pensamento de Mauro Cappelletti, in Lex - Jurisprudência dos Tribunais de Alçada Civil de São Paulo, vol. 119, pp. 20-21.

390 DALL'AGNOL JUNIOR, O Princípio Dispositivo no Pensamento de Mauro Cappelletti, in Lex Jurisprudência dos Tribunais de Alçada Civil de São Paulo, vol. 119, pp. 24-25. 
Dentre os autores que opinam no sentido da incompatibilidade entre os dois princípios, destaca-se Calamandrei ${ }^{391}$. Ao comentar a proposta de Código de Processo Civil italiano elaborada por Solmi, cujo art. 26 prevê o dever de veracidade das partes, o autor afirma que, no processo civil, as alegações dos litigantes não são, em regra, um meio de prova, mas apenas um meio de fixar o "thema probandum". Explica que, uma vez feitas as alegações fáticas, a parte tem o ônus de provar que suas afirmações são verdadeiras; se ela não consegue superar esse encargo, suas afirmações (sejam elas verdadeiras ou falsas) não têm outro valor que não o de estabelecimento de um "thema probandum". O fato de a parte dizer ou não a verdade é, do ponto de vista probatório, absolutamente indiferente, pois o juiz não só não tem o dever de acreditar no que ela afirma, mas também tem o dever de não acreditar nos fatos que ela apresenta em favor dos seus próprios interesses. Dentre outros argumentos, o autor também contesta a compatibilidade do dever de dizer a verdade com as normas que regulam a repartição, entre as partes, do ônus de alegar fatos e de provar. Por fim, ele conclui que, enquanto estiver em vigor o princípio dispositivo, a norma que consagra a obrigação de as partes dizerem a verdade não pode significar mais que um apelo, de valor sobretudo moral, ao dever genérico de boa-fé processual (dever de não litigar de má-fé, sob pena de ter que pagar os danos e as despesas extrajudiciais - a chamada "responsabilidade agravada"), sem alterar o mecanismo do sistema probatório dispositivo, baseado no jogo combinado de duas forças contrapostas, cada uma das quais tendendo a apresentar apenas aquela parte da verdade que é útil aos seus respectivos interesses.

Constata-se que, em seus argumentos, Calamandrei reiteradamente relaciona o princípio dispositivo com a produção de provas, ou seja, com o poder instrutório. Infere-se disso que ele não distingue o princípio dispositivo em sentido material (ou próprio) do princípio dispositivo em sentido processual (ou impróprio), adotando aquela teoria segundo a qual o princípio dispositivo impõe ao juiz o dever de julgar a causa com base nos fatos alegados e provados pelas partes ("iudex iudicare debet iuxta allegata et probata partium") ${ }^{392}$.

\footnotetext{
${ }^{391}$ Sul Progetto Preliminare Solmi, in Opere Giuridiche, vol. I, pp. 350-353; Instituciones de Derecho Procesal Civil: según el nuevo código, pp. 337-339.

${ }^{392}$ A correção dessa ilação pode ser confirmada em outra obra do autor, na qual ele afirma que a qualificação do processo como sendo de tipo dispositivo ou de tipo inquisitório depende da extensão dos poderes dados ao juiz para a investigação da verdade: quando a delimitação do "thema decidendum" e a busca dos meios de investigação necessários para a decisão do mérito ficam sob o poder de disposição das partes, adota-se o princípio dispositivo; por outro lado, quando a determinação do objeto do processo e a colheita do material probatório são confiadas à iniciativa do juiz, acolhe-se o princípio inquisitório (CALAMANDREI, Instituciones de Derecho Procesal Civil: según el nuevo código, pp. 283 e 328-329).
} 
De fato, o princípio dispositivo em sentido próprio não guarda qualquer ponto de contato com o dever de veracidade. Primeiramente, esse princípio não autoriza a parte a negar a existência de um fato real, nem a afirmar mentirosamente a ocorrência de um fato $^{393}$. Ele estatui que o autor e o réu têm a liberdade de alegar os fatos que quiserem para sustentar suas pretensões e de silenciar sobre fatos que não pretendam ver investigados, mas todas as suas alegações devem ser verdadeiras ${ }^{394}$. Em segundo lugar, o princípio dispositivo em sentido próprio e o dever de veracidade pertencem a planos distintos. Este deriva do caráter público do processo, do interesse estatal no atingimento dos escopos do processo, uma vez que a mentira processual do litigante obsta a concretização do escopo jurídico do processo ao impedir que o magistrado realize a subsunção da situação fática que efetivamente ocorreu à norma jurídica. O princípio dispositivo em sentido próprio, por sua vez, é um reflexo da natureza disponível da relação jurídica substancial litigiosa. Conforme se afirmou anteriormente, a natureza privada do direito subjetivo substancial não exclui o caráter público do processo, nem o interesse do Estado na correta aplicação das normas de direito material ${ }^{395}$. Portanto, o princípio dispositivo em sentido próprio e o dever de veracidade simplesmente coexistem, sem que haja qualquer incompatibilidade entre eles.

Dado que o dever das partes de dizer a verdade diz respeito à técnica processual e ao desenvolvimento interno do processo, ele se relaciona, na verdade, com o binômio princípio dispositivo-princípio inquisitivo em sentido processual (ou em sentido

\footnotetext{
Nesse mesmo trabalho, o autor constata que o então novo Código de Processo Civil italiano confere ao juiz poderes de iniciativa probatória mais amplos que a legislação processual anterior, apesar de ter mantido o princípio dispositivo. Porém, limita-se a reconhecer que a previsão legal desses poderes judiciais restringiu e atenuou bastante o princípio dispositivo e a dizer que tais poderes não são, em geral, inconciliáveis com o referido princípio porque não estão em oposição com o caráter disponível da relação jurídica de direito material litigiosa (CALAMANDREI, Instituciones de Derecho Procesal Civil: según el nuevo código, pp. 330-332). Cappelletti (La Testimonianza della Parte nel Sistema dell'Oralità, vol. I, pp. 337-338 e nota 34, nas pp. 338-339) infere desse trecho da obra de Calamandrei que o autor tem uma intuição de que a vinculação do juiz apenas àquilo que é provado pelas partes não consiste em uma manifestação do princípio dispositivo. De fato, ele realmente parece ter essa intuição, mas em nenhum momento Calamandrei esclarece - como faz Cappelletti - que o binômio princípio dispositivo-princípio inquisitório em sentido próprio não guarda qualquer relação com os poderes referentes ao desenvolvimento interno e à técnica do processo, especificamente com o poder de iniciativa probatória. Pelo contrário, ele chega a mencionar a atribuição de maiores poderes de iniciativa probatória ao órgão julgador como uma das características principais do processo inquisitório (CALAMANDREI, Instituciones de Derecho Procesal Civil: según el nuevo código, p. $335)$.

${ }^{393}$ Nesse sentido: CASTRO FILHO, Abuso do Direito no Processo Civil, p. 106, nt. 60.

${ }^{394}$ OLIVEIRA, Litigância de Má-Fé, p. 46; GROSSMANN, O Dever de Veracidade das Partes Litigantes no Processo Civil (aspecto doutrinário), in Revista Forense, vol. 101, p. 477; ALVIM, Tratado de Direito Processual Civil, vol. 2, p. 393.

${ }^{395}$ CAPPELLETTI, La Testimonianza della Parte nel Sistema dell'Oralità, vol. I, pp. 320-328.
} 
impróprio $)^{396}$. Pode-se afirmar que tanto a previsão desse dever no sistema jurídico, quanto o incremento da relevância do princípio inquisitivo em sentido processual (ou em sentido impróprio) são reflexos da publicização do processo. Esse fenômeno fez com que o processo deixasse de ser considerado um instrumento de interesse preponderantemente das partes e passasse a ser visto como um meio de o Estado alcançar certos escopos sóciopolíticos e de atuar a vontade concreta do direito material ${ }^{397}$. Para que essas finalidades institucionais do processo fossem efetivadas, foi conferido ao juiz o poder de produzir provas, mesmo contra a vontade das partes e, concomitantemente, atribuiu-se às partes e ao Estado-juiz a tarefa de buscar a verdade ${ }^{398}$.

Não obstante exista essa conexão com o princípio inquisitivo em sentido processual (ou em sentido impróprio), não se pode afirmar que o dever de veracidade seja responsável por qualquer limitação do princípio dispositivo em sentido processual (ou em sentido impróprio). Se isso fosse correto, não seria possível a coexistência dos dois em um mesmo ordenamento jurídico. No entanto, Yarshell ${ }^{399}$ observa que, nos sistemas de "Common Law", a prova fica essencialmente a cargo das partes e, mesmo assim, elas respeitam o dever de veracidade em seus depoimentos, atuando como se fossem testemunhas. O autor destaca que esses sistemas influenciados pela ideologia liberal dão mais importância ao comportamento ético e probo das partes que os sistemas de "Civil Law", que poderiam ser qualificados como intervencionistas, mas que se preocupam mais em reforçar os poderes instrutórios do juiz que em controlar a conduta dos sujeitos processuais parciais. Essa constatação põe por terra igualmente o argumento de que o dever de veracidade seja incompatível com o princípio dispositivo em sentido processual (ou em sentido impróprio).

Castro Filho ${ }^{400}$ diz que, ainda que existisse tal incompatibilidade, não haveria problema algum em fixar o dever de veracidade como uma limitação do princípio dispositivo em sentido processual, dado que este não é previsto no ordenamento jurídico brasileiro como uma garantia constitucional. Sendo esse princípio apenas uma diretriz de conveniência $^{401}$, destinada à obtenção de um rendimento melhor e mais expedito no processo, e fundada na suposição de que a verdade seria mais bem conhecida na versão das

\footnotetext{
${ }^{396}$ Nesse sentido é a doutrina de Portanova (Princípios do Processo Civil, p. 124), que inclui o dever das partes de agir com boa-fé entre os corolários do princípio dispositivo em sentido processual (que ele chama de "princípio do debate").

${ }^{397}$ A respeito dos escopos do processo, consultar o item 1.3.4 "supra".

${ }^{398}$ PORTANOVA, Princípios do Processo Civil, pp. 124 e 152.

${ }^{399}$ Antecipação da Prova sem o Requisito da Urgência e Direito Autônomo à Prova, pp. 158-159.

${ }^{400}$ Abuso do Direito no Processo Civil, p. 106.

${ }^{401}$ CARNELUTTI, Sistema de Derecho Procesal Civil, vol. II, p. 627.
} 
partes que através de uma investigação judicial ${ }^{402}$, ele não tem força suficiente para infirmar o dever de dizer a verdade ${ }^{403}$.

Em suma, há plena compatibilidade entre o dever de veracidade e o princípio dispositivo, seja este entendido em seu sentido material (ou em sentido próprio), o qual não autoriza o litigante a negar a existência de um fato que efetivamente aconteceu ou a mentir acerca da ocorrência de um fato; seja em seu sentido processual (ou em sentido impróprio), visto que, nos ordenamentos jurídicos que adotam o sistema da "Common Law", os dois coexistem, mantendo, cada um, sua integralidade.

\subsubsection{O dever de lealdade processual}

O dever de lealdade processual é uma manifestação do princípio geral de boa-fé objetiva $^{404}$ que impõe aos sujeitos processuais a moralidade e a probidade necessárias para a consecução das finalidades sócio-políticas do processo ${ }^{405}$. Está expressamente previsto no art. 14, II, do CPC: “Art. 14. São deveres das partes e de todos aqueles que de qualquer forma participam do processo: [...] II - proceder com lealdade e boa-fé,406.

Apesar de as partes atuarem em juízo sempre em busca da vitória, elas agem em cooperação com o órgão jurisdicional porque é a sua atividade dialética no processo que garante que o provimento jurisdicional seja o mais próximo possível da verdade

402 Alvaro de Oliveira (Poderes do Juiz e Visão Cooperativa do Processo, in Revista da AJURIS, nº 90, pp. 56-57) esclarece que, no século XIX, quando predominava a concepção liberal e privatista de processo, acreditava-se que o próprio interesse do litigante no direito alegado estimularia a mais rápida investigação da situação jurídica controvertida. Por essa razão, impunha-se exclusivamente às partes o poder e o ônus de trazer ao processo a matéria de fato. Contudo, a experiência acabou desmentindo a crença na eficiência desse trabalho desenvolvido exclusivamente pelas partes do processo, pois se constatou que ele relativiza além do desejável a apreciação da verdade pelo juiz, já que o força a se contentar passivamente com a versão fática trazida pelas partes.

${ }^{403}$ Deve-se ressaltar que, ao fazer essa observação, Castro Filho reporta-se ao "princípio dispositivo", de forma genérica. Ele não segue a teoria que distingue o princípio dispositivo em sentido material do princípio dispositivo em sentido processual, proposta por Cappellletti.

Porém, deduz-se que o autor brasileiro se refere ao princípio dispositivo em sentido processual (ou em sentido impróprio) porque é a ele, e não ao princípio dispositivo em sentido material, que alguns doutrinadores que não adotam a teoria distintiva de Cappelletti se referem quando afirmam que o princípio dispositivo não é absoluto, mas sim um mero "princípio de oportunidade" ou uma simples "diretriz de conveniência", visto que a vinculação do juiz à iniciativa das partes no que concerne à técnica e ao desenvolvimento interno do processo (notadamente a iniciativa com relação à produção probatória) de fato não exprime uma consequência processual necessária do caráter disponível do objeto do processo, podendo, por isso, ser relativizada em prol de um melhor exercício da função jurisdicional (CAPPELLETTI, La Testimonianza della Parte nel Sistema dell'Oralità, vol. I, p. 327, nt. 15; LIEBMAN, Fondamento del Principio Dispositivo, in Problemi del Processo Civile, p. 5).

${ }^{404}$ BAPTISTA DA SILVA, Comentários ao Código de Processo Civil, vol. 1, p. 105.

${ }^{405}$ CINTRA; DINAMARCO; GRINOVER, Teoria Geral do Processo, p. 73.

${ }^{406}$ O Projeto de Lei $\mathrm{n}^{\circ}$ 8.046/2010, que instui o novo Código de Processo Civil, contém dispositivo com esse mesmo teor: "Art. 80. São deveres das partes, de seus procuradores, e de todos aqueles que de qualquer forma participam do processo [...] II - proceder com lealdade e boa-fé". 
processual $^{407}$. Logo, os atos das partes são um fator relevante para o exercício justo da atividade jurisdicional. Se elas atuam de modo desleal, faltando com a verdade e empregando ardis fraudulentos, o processo deixa de ser um instrumento ético, destinado a pacificar os conflitos da sociedade com justiça ${ }^{408}$.

O dever de lealdade refreia a habilidade e a astúcia das partes e demais pessoas que participam do processo, estabelecendo a observância dos limites impostos pelo costume e pela moral social, bem como impondo o respeito, pelos advogados, das exigências de correção profissional $^{409}$. Segundo Barbi $^{410}$, o dever de lealdade estatui a obrigação de “obedecer às regras do jogo, no qual deve vencer aquele que realmente tem razão".

Distingue-se do dever de veracidade porque "não mentir é uma coisa; ser estratego e astuto sem cometer deslealdades, ainda que seja bastante mais subtil, constitui outra muitíssimo diferente" ${ }^{411}$.

Cintra, Dinamarco e Grinover ${ }^{412}$ denunciam a existência de alguns opositores do dever de lealdade no processo civil, os quais o considerariam um instituto violador de garantias constitucionais, pois seria inquisitivo, contrário à livre disponibilidade das partes e até um "instrumento de tortura moral". Entretanto, os três juristas, acompanhados por Barbosa Moreira ${ }^{413}$, rebatem as críticas, afirmando que essa concepção é um reflexo processual da ideologia individualista do "laissez-faire" e que, consequentemente, ignora as conotações publicistas conferidas ao processo desde a promulgação do Código de Processo Civil de $1939^{414}$. Portanto, não há qualquer incompatibilidade entre o dever de lealdade e os princípios e garantias constitucionais.

\footnotetext{
${ }^{407}$ GRINOVER, Abuso do Processo e Resistência às Ordens Judiciárias: o contempt of court, in A Marcha do Processo, p. 62.

${ }^{408}$ Nesse sentido: DONDI; GIUSSANI, Appunti sul Problema dell'Abuso del Processo Civile nella Prospettiva de Iure Condendo, in Rivista Trimestrale di Diritto e Procedura Civile, vol. 61, no 1, p. 197; PUOLI, Os Poderes do Juiz e as Reformas da Lei Processual Civil Brasileira, p. 185.

${ }^{409}$ LIEBMAN, Manual de Direito Processual Civil, vol. I, § 60, p. 124. Esse parecer é endossado por Barbi (Comentários ao Código de Processo Civil, vol. I, § 154, p. 120).

${ }^{410}$ Comentários ao Código de Processo Civil, vol. I, § 154, p. 121.

${ }^{411}$ LUSO SOARES, A Responsabilidade Processual Civil, p. 172.

${ }^{412}$ Teoria Geral do Processo, p. 74.

${ }^{413}$ A Responsabilidade das Partes por Dano Processual no Direito Brasileiro, in Temas de Direito Processual, p. 16.

${ }^{414}$ Machado Guimarães (Processo Autoritário e Regime Liberal, in Revista Forense, vol. 82, pp. 243-248) afirma que o Código de Processo Civil de 1939 adotou o chamado "processo autoritário", que é um corolário da tendência de socialização do direito, em contraposição ao "processo individualista". Segundo o doutrinador, o "processo autoritário" tinha duas características principais: (a) o reforço da autoridade do juiz no processo; e (b) a abolição e proscrição dos princípios exclusivamente dispositivos, considerados típicos do processo de caráter individualista.
} 


\subsubsection{O dever de prontidão}

O dever de prontidão constitui a face temporal do dever de lealdade, inspirado no princípio da celeridade. Consiste no dever de as partes exporem suas razões em juízo e proporem suas provas na primeira oportunidade que tiverem para falar nos autos ou o quanto antes possível, evitando que um dos litigantes surpreenda o outro com lances que este não espera ${ }^{415}{ }^{416}$. Contribui, assim, para que o processo seja realmente um jogo com cartas abertas $^{417}$.

Esse dever foi arrolado pelo "American Law Institute" e pela "Unidroit" como um dos "Principles of Transnational Civil Procedure":

11.3 $\mathrm{Na}$ fase postulatória, as partes devem apresentar, de maneira razoavelmente detalhada, os fatos relevantes, seus argumentos jurídicos e a tutela requerida e descrever de maneira suficientemente precisa os meios de prova disponíveis para serem oferecidos em suporte de suas alegações. Quando motivos sérios justificarem a incapacidade de uma parte de fornecer detalhes razoáveis sobre fatos relevantes ou especificação suficiente dos meios de prova, a corte deve levar em consideração a possibilidade de que fatos e provas necessários sejam produzidos ulteriormente no curso do procedimento (tradução nossa).

É com espeque nele que os arts. 523 e 524 do CPC português estatuem que as partes têm o ônus de juntar às suas respectivas peças iniciais os documentos destinados a

\footnotetext{
${ }^{415}$ LUSO SOARES, A Responsabilidade Processual Civil, p. 173.

${ }^{416}$ Buzaid também identifica esse dever decorrente da lealdade processual, porém não utiliza a nomenclatura "dever de prontidão":

"A lealdade, como o étimo da palavra indica a toda evidência, consiste em pautar os atos em correspondência com a lei. O Código de Processo Civil brasileiro disciplinou exaustivamente todas as manifestações das partes, estabelecendo os requisitos da petição inicial (art. 282), da contestação (arts. 300, 302 e 303) e a presunção de que são verdadeiros os fatos não impugnados, ressalvadas as exceções previstas no art. 302. Determina de modo preciso os meios legais de prova, distribuindo entre as partes o ônus de sua produção (art. 333). Para se ter uma idéia da lealdade processual, convém lembrar que o Código preceitua que 'compete à parte instruir a petição inicial (art. 282) ou a resposta (art. 297) com os documentos necessários a provar-lhe as alegações' (art. 306). Os dois momentos em que deve ser produzida a prova documental são, portanto, a petição inicial e a resposta. Não está, pois, em conformidade com a lei ocultar documento para só apresentá-lo em outra oportunidade, causando surpresa não só ao juiz como à parte contrária. Quem assim procede age com deslealdade" (Processo e Verdade no Direito Brasileiro, in Revista de Processo, $\mathrm{n}^{\mathrm{o}}$ 47, p. 96).

${ }^{417}$ Ao tratar do costume que os litigantes têm de tentar surpreender o adversário com um movimento que este não espera, ao arrepio da lealdade processual, Carnelutti (Derecho y Proceso, p. 233) compara o processo com o jogo de cartas:

"A que jogo deve assemelhar-se o processo: ao jogo de xadrez ou ao dos naipes? A diferença entre os dois está em que no primeiro o jogador não conhece os movimentos, mas conhece as armas do adversário; nas cartas, por outro lado, ignora também estas. A tentação das partes, no processo, é a de jogar cartas e não xadrez; o jogador de cartas põe sobre a mesa as cartas boas o mais tarde possível. Eu penso que o fair play processual não consente esse comportamento. O processo, em suma, deveria ser um jogo a cartas descobertas" (tradução nossa).
} 
provar os fundamentos da ação e da defesa, sancionando a apresentação feita até o encerramento da discussão em primeira instância e proibindo a junção tardia nos autos ${ }^{418}$.

$\mathrm{Na}$ Espanha, o dever de prontidão parece ter influenciado os arts. 270.2 e 286.4 da "Ley de Enjuiciamiento Civil". O primeiro artigo comina multa para o litigante que apresenta prova documental depois da fase postulatória do processo (ou seja, depois da demanda e da contestação ou, eventualmente, da "audiencia previa al juicio"), sem ser nos casos excepcionais previstos no art. 270.1 da "Ley de Enjuiciamiento Civil" (documento novo, elaborado depois da demanda, da contestação ou da "audiencia previa al juicio"; ou cuja existência a parte ignorava; ou que a parte não podia obter anteriormente por causas que não lhe podem ser imputadas), movido por intuito protelatório ou má-fé processual. De acordo com o segundo dispositivo, a parte que alega fundamentos fáticos novos depois de preclusos os atos de alegação previstos na lei deve ser condenada ao pagamento de multa, contanto que haja indícios de que o fato poderia ter sido suscitado nos momentos processuais ordinariamente previstos para esse fim e que se constate ânimo dilatório ou má-fé processual na alegação extemporânea.

No ordenamento jurídico brasileiro, o dever de prontidão pode ser inferido dos arts. 282, III e VI; 283; 300-302; e 396 do CPC, que versam sobre: (a) os ônus do autor de deduzir na petição inicial todos os fundamentos fáticos e jurídicos de seu pedido, de indicar as provas com que pretende demonstrar os fatos alegados e de já trazer para os autos os documentos indispensáveis à propositura da demanda; e (b) os ônus do réu de impugnar especificadamente, na contestação, todos e cada um dos fatos narrados na petição inicial, de alegar defesas de mérito indiretas (fatos impeditivos, modificativos e extintivos do direito do autor) e defesas processuais e de juntar aos autos documentos destinados a provar suas alegações. Há também dispositivos do Código de Processo Civil que preveem abrandamentos desses ônus, como o art. 264, que proíbe o autor de modificar a causa de pedir depois de feita a citação, exceto se houver o consentimento do réu, mantendo-se as mesmas partes, e que também veda toda e qualquer alteração da causa de pedir após o saneamento do processo; o art. 462, que estabelece que, se for verificado, depois da propositura da ação, algum fato constitutivo, modificativo ou extintivo do direito do autor, o juiz deve levá-lo em consideração na sentença; o art. 303, que permite que o réu deduza novos fundamentos defensivos depois da contestação em três hipóteses: (1) se forem relativos a direito superveniente; (2) se competir ao juiz conhecê-los de ofício; ou

${ }^{418}$ LUSO SOARES, A Responsabilidade Processual Civil, p. 173. 
(3) se a lei expressamente permitir que sejam formulados em qualquer tempo e juízo; e o art. 397, que permite a juntada de documentos novos aos autos, desde que destinados a fazer prova de fatos ocorridos depois dos articulados ou para contrapô-los aos que foram produzidos nos autos $^{419}$.

A doutrina e a jurisprudência nacionais têm, no entanto, relativizado a rigidez dessas regras que consubstanciam o dever de prontidão. Argumenta-se que a rigidez extremada diminui as faculdades das partes e o poder de direção processual do juiz, o que burocratiza o processo e o afasta do seu objetivo primordial de fazer justiça (processo justo e équo ${ }^{420}$. Configuram exemplos dessa flexibilização:

a) como se disse anteriormente, os fatos constitutivos do pedido e a matéria de defesa devem ser apresentados, respectivamente, na petição inicial e na contestação, sendo vedadas a modificação da demanda pelo autor após a citação (a não ser que haja o consentimento do réu, até o saneamento do feito) e a dedução de novas alegações pelo réu em tempo ulterior (arts. 282, III; 300; 264; e 303 do CPC). Mas, se, inadvertidamente, for introduzida no processo causa de pedir não deduzida na inicial e o contraditório abranger essa nova realidade fática, Bedaque ${ }^{421}$ adverte que o juiz deve considerá-la, em prol das ideias da instrumentalidade das formas e da celeridade processual. Segundo o doutrinador, o respeito ao princípio do contraditório faz com que esse julgamento não seja considerado "extra petita", logo, nulo. Somente se a falha comprometer definitivamente a ampla defesa e o contraditório é que se deve optar pela anulação;

b) a jurisprudência interpreta o art. 462 do CPC de maneira restritiva, exigindo que o novo fato constitutivo do direito do autor, verificado depois da propositura da ação, guarde nexo com os fatos afirmados na petição inicial, de modo que ele seria apenas um elemento omisso daqueles. Mas, com o mesmo argumento supracitado, Bedaque ${ }^{422}$ sustenta que, desde que seja respeitado o contraditório (inclusive possibilitando a produção de prova), não há prejuízo em se admitir a introdução de fatos supervenientes constitutivos do direito do autor que configurem causas de pedir novas, ou seja, fatos diversos dos afirmados na inicial;

\footnotetext{
${ }^{419}$ Caso o projeto do novo Código de Processo Civil (Projeto de Lei no 8.046/2010) seja aprovado nos termos atuais, o dever de prontidão poderá ser inferido dos arts. 293, III e IV; 294; 325, 327 e 329; 421; 304; 480; 330 e 422, que têm redação parecida com a dos mencionados dispositivos do Código atual. Contudo, não haverá qualquer norma sancionadora de comportamentos que transgridam tal dever, como há atualmente nos arts. 22; 69, I; $113, \S 1^{\circ}$; e $267, \S 3^{\circ}$, do CPC em vigor.

${ }^{420}$ DINAMARCO, Instituições de Direito Processual Civil, vol. II, § 633, p. 470.

${ }^{421}$ Efetividade do Processo e Técnica Processual, pp. 131-133.

422 Efetividade do Processo e Técnica Processual, pp. 135-137.
} 
c) o art. 303 do CPC estatui que o réu deve deduzir todos os fundamentos de defesa já na contestação, salvo as exceções previstas em seus três incisos. Segundo Dinamarco ${ }^{423}$, os tribunais têm interpretado de maneira tão ampla esses casos excepcionais previstos nos incisos do art. 303 do CPC que a preclusão dos fundamentos da defesa transformou-se em uma exceção no sistema ${ }^{424}$. Entretanto, ele adverte que, de qualquer maneira, o réu pode ficar impedido de suscitar razão de defesa tardiamente, ainda quando se trate de fundamento admitido depois da contestação, se ficar constatada sua manifesta má-fé no retardamento da alegação ou se o procedimento encontrar-se em momento avançado (v.g., se o novo fundamento defensivo envolver fatos, eventual alegação tardia não poderá ser considerada quando já estiverem superados os momentos probatórios pertinentes; se o fundamento novo for de direito, não poderá ser admitido em momentos extremamente adiantados, quando for necessário instaurar debates sobre eles; nos graus superiores da jurisdição - STJ e STF -, o réu não poderá alegar fundamento defensivo que não tenha sido alegado e apreciado na instância precedente - prequestionamento). Bedaque ${ }^{425}$ vai além da interpretação das exceções do art. 303 do CPC e afirma que o magistrado não pode desconsiderar novas alegações que o réu tenha feito após a contestação, desde que a matéria tenha sido submetida ao contraditório e que se encontre demonstrada nos autos. Segundo o autor, o juiz não pode ignorar a realidade que consta dos autos apenas para homenagear a técnica processual;

d) não obstante o art. 396 do CPC exija que o autor junte à petição inicial, bem como o réu à contestação, os documentos com o quais pretendem provar a veracidade de suas alegações, admite-se que eles juntem provas documentais depois. O que se exige logo com a petição inicial são os documentos indispensáveis à propositura da ação (art. 283 do CPC), como, por exemplo, a certidão de casamento na ação de separação judicial ${ }^{426}$;

e) o art. 300 do CPC determina que o réu especifique as provas que pretende produzir já na contestação. Todavia, os juízes admitem que ele o faça depois, juntamente com o autor (art. 324 do CPC) ${ }^{427}$.

\footnotetext{
${ }^{423}$ Instituições de Direito Processual Civil, vol. II, § 633, p. 471; e Instituições de Direito Processual Civil, vol. III, § 1.071, pp. 490-491.

${ }^{424} \mathrm{O}$ autor ensina que, salvo situações particulares, apenas os seguintes fundamentos de defesa são realmente inadmissíveis depois da contestação: (a) a compensação; (b) a incapacidade relativa do agente como vício dos negócios jurídicos; (c) o erro; (d) o dolo; (e) a coação; (f) a fraude; (g) a convenção de arbitragem; e (h) as nulidades processuais relativas.

${ }_{225}^{42}$ Efetividade do Processo e Técnica Processual, pp. 137-138.

${ }^{426}$ DINAMARCO, Instituições de Direito Processual Civil, vol. II, § 633, p. 471 e nt. 14.

${ }^{427}$ DINAMARCO, Instituições de Direito Processual Civil, vol. II, § 633, p. 471.
} 
Como se verá mais detalhadamente nos itens 2.6 e 2.7 "infra" alguns dispositivos do Código de Processo Civil sancionam quem viola o dever de prontidão: (a) o art. 22 estabelece que o réu que dilatar o julgamento da lide, em razão de não ter arguido na sua resposta fato impeditivo, modificativo ou extintivo do direito do autor, será condenado nas custas a partir do saneamento do processo e perderá, ainda que vencedor na causa, o direito a haver do vencido honorários advocatícios; (b) o art. 69, I, estatui que o réu que deixar de nomear à autoria, quando lhe competir, ficará obrigado a ressarcir perdas e danos; (c) o art. $113, \S 1^{\circ}$, comina o dever de pagar integralmente as custas ao réu que não deduzir a incompetência absoluta no prazo da contestação ou na primeira oportunidade em que lhe couber falar nos autos; e (d) o art. $267, \S 3^{\circ}$, determina que o réu que não alegar as defesas processuais previstas nos incisos IV, V e VI do mesmo dispositivo legal na primeira oportunidade que lhe caiba falar nos autos responderá pelas custas de retardamento do processo.

\subsubsection{O dever de utilidade}

O dever de utilidade veda o atraso da marcha do processo mediante o emprego de artifícios dilatórios ou outros, com o intuito de lesar a parte contrária. Mostra-se intimamente ligado aos princípios da economia processual e da lealdade ${ }^{428}$.

No Direito português, ele é previsto, em termos genéricos, nos arts. 137 e 138 do CPC, que, respectivamente, qualifica como ilícita a realização de atos processuais inúteis e regula a forma dos atos do processo, estatuindo que devem ter aquela que melhor corresponda ao fim que visam atingir. A inobservância dolosa desse princípio cabe nos domínios dos arts. 456 e 665 do CPC português, que tratam da responsabilidade no caso de litigância de má-fé e do uso anormal do processo $^{429}$.

O princípio da utilidade também se encontra positivado no art. 73 do "Codigo Procesal Civil Modelo para Iberoamerica" e no art. 63 do CPC uruguaio, que tratam dos requisitos dos atos processuais: "[...] os atos deverão ser lícitos, pertinentes e úteis" (destaque nosso).

\footnotetext{
${ }^{428}$ LUSO SOARES, A Responsabilidade Processual Civil, p. 174.

${ }^{429}$ LUSO SOARES, A Responsabilidade Processual Civil, p. 174.
} 
No ordenamento jurídico brasileiro, é possível constatar a sua presença nos arts. 14, $\mathrm{IV}^{430} ; 17$, I, IV, VI e VII c/c arts. 16 e $18^{431} ; 29^{432} ; 31^{433} ; 130 ; 400$, I e II; 407, parágrafo único; 420, parágrafo único; 426, I; 427 $7^{434} ; 416, \S 1^{\mathrm{o} 435} ; 453, \S 3^{\mathrm{o} 436} ; 538$, parágrafo único; e 557, § $2^{\circ}$, do $\mathrm{CPC}^{437}$, que impõem aos sujeitos processuais o dever de praticar apenas atos úteis e necessários à declaração ou defesa de suas pretensões e preveem consequências jurídicas negativas para quem o contraria em certas circunstâncias ${ }^{438}$.

\subsection{Objeto do abuso do processo}

\subsubsection{Direitos subjetivos processuais?}

Quando do surgimento da teoria do abuso do direito, o objeto das condutas abusivas eram os direitos reais, notadamente o direito de propriedade imobiliária. Atualmente, com o apuramento teórico do conceito, os civilistas admitem que o abuso do direito pode reportar-se ao exercício de qualquer situação jurídica, e não apenas aos direitos subjetivos ${ }^{439}$.

\footnotetext{
${ }^{430}$ Determina que as partes e todos aqueles que participam do processo têm o dever de não produzir provas, nem praticar atos inúteis ou desnecessários à declaração ou defesa do direito.

${ }^{431}$ Consideram litigância de má-fé as condutas consistentes em: (a) dedução de pretensão ou de defesa contra texto expresso de lei ou fato incontroverso; (b) oposição de resistência injustificada ao andamento do processo; (c) provocação de incidentes manifestamente infundados; e (c) interposição de recurso com intuito manifestamente protelatório; bem como cominam sanções aos litigantes que as praticam.

${ }^{432}$ Estatui que a parte, o serventuário, o órgão do Ministério Público ou o juiz que, sem justo motivo, der causa ao adiamento ou à repetição de atos processuais deverá arcar com as respectivas despesas.

${ }^{433}$ Prevê que as despesas dos atos manifestamente protelatórios, impertinentes ou supérfluos devem ser pagas pela parte que os tiver promovido ou praticado, quando impugnados pela outra.

${ }^{434}$ Atribuem ao órgão jurisdicional o poder e o dever de: (a) indeferir diligências probatórias inúteis ou meramente protelatórias; (b) indeferir a inquirição de testemunhas sobre fatos já provados por documento ou por confissão da parte, ou que só possam ser provados por meio de documento ou exame pericial; (c) dispensar as testemunhas restantes quando a parte oferecer mais de três para a prova de cada fato; (d) indeferir a perícia quando a prova do fato não depender do conhecimento especial de técnico, ou for desnecessária em vista de outras provas produzidas, ou ainda for impraticável a verificação; (e) indeferir quesitos impertinentes; (f) dispensar prova pericial quando as partes, na inicial e na contestação, apresentarem sobre as questões de fato pareceres técnicos ou documentos elucidativos que considerar suficientes.

${ }^{435}$ Proíbe as partes de fazerem perguntas ou considerações impertinentes às testemunhas.

${ }^{436}$ Impõe ao sujeito que der causa ao adiamento da audiência o dever de pagar pelas despesas acrescidas.

${ }^{437}$ Cominam sanções ao litigante que interpõe recurso manifestamente protelatório ou manifestamente inadmissível ou infundado.

${ }^{438}$ O projeto do novo Código de Processo Civil (Projeto de Lei no $8.046 / 2010$ ) tem dispositivos com redação similar à dos artigos do Código atual supracitados: arts. 80, IV; 83, I, IV, VI e VII c/c arts. 82 e 84; 95; 354, parágrafo único; 428 , I e II; $445, \S 2^{\circ} ; 449$, parágrafo único; 455 , I; 456; $347, \S 3^{\circ} ; 980$, $\S \S 4^{\circ}$, $5^{\circ}$ e $6^{\circ}$; e 975 , $\S 2^{\circ}$. Apenas o art. 31 e a parte final do parágrafo único do art. 407 do CPC atual não têm equivalentes no Projeto de Lei $n^{\circ} 8.046 / 2010$.

${ }^{439}$ MENEZES CORDEIRO, Litigância de Má-Fé, Abuso do Direito de Ação e Culpa “in Agendo”, pp. 118 e 120.
} 
No âmbito processual, a definição do objeto do abuso mostra-se mais problemática, pois há grande divergência doutrinária acerca da existência de direitos subjetivos processuais.

Para a maior parte dos autores existem direitos subjetivos processuais, dentre eles a ação ${ }^{440}$. Carnelutti, por exemplo, assevera que a ação é um direito público subjetivo ${ }^{441}$, cujo conteúdo pode ser definido como o "direito ao provimento e, em particular, à sentença, não à sentença justa ou à sentença favorável"442 (destaques no original e tradução nossa). Ele esclarece que a ação não é o direito à tutela jurídica, mas o direito ao cumprimento dos atos necessários para que se realize a tutela jurídica (ou seja, não é direito ao resultado, mas sim ao meio $)^{443}$. Para Liebman ${ }^{444}$, a ação consiste em um direito subjetivo que tem no polo passivo o Estado, mas que não se destina à obtenção de uma prestação deste. Explica que se trata de um direito de iniciativa e de impulso, por meio do qual o particular põe em movimento o exercício da função jurisdicional, visando a obter do Estado a tutela de suas pretensões. Nas palavras do autor, a ação é o "direito ao processo e ao julgamento do mérito". Mostrando-se adepto da teoria abstratista da ação, Liebman destaca que ela não garante um julgamento de mérito favorável ao autor, devendo este fazer uso dos meios previstos na lei para defender suas razões em juízo. Luso Soares ${ }^{445}$ também defende a existência de direitos no processo. Ele entende que o dever de jurisdição do magistrado, ou seja, o dever de administrar justiça às partes (art. 156, $\mathrm{n}^{\circ} 1$, do CPC português ${ }^{446}$ ), é uma contrapartida dos direitos de ação e de contradição que a lei reconhece, respectivamente, ao autor e ao réu.

Porém, alguns doutrinadores negam a categoria dos direitos subjetivos processuais, alegando que o conceito de "direito subjetivo" pressupõe conflito de interesses. É o que

\footnotetext{
440 ABDO, O Abuso do Processo, pp. 72-73; MENEZES CORDEIRO, Litigância de Má-Fé, Abuso do Direito de Ação e Culpa “in Agendo”, p. 29 e nt. 7; ALBUQUERQUE, Responsabilidade Processual por Litigância de Má Fé, Abuso de Direito e Responsabilidade Civil em Virtude de Actos Praticados no Processo, p. 105, nt. 322.

${ }^{441}$ Segundo o jurista italiano, é um "direito subjetivo" porque consiste em "um poder atribuído à vontade de uma pessoa para a prevalência de um seu interesse" (tradução nossa) e é "público" porque a ação tutela um interesse essencialmente público, que é o interesse pela justa composição da lide (CARNELUTTI, Sistema di Diritto Processuale Civile, vol. I, pp. 26, 28, 890 e 891).

${ }^{442}$ Sistema di Diritto Processuale Civile, vol. I, p. 897.

${ }^{443}$ CARNELUTTI, Sistema di Diritto Processuale Civile, vol. I, p. 898.

${ }^{444}$ Manual de Direito Processual Civil, vol. I, § 73, pp. 151-152.

${ }^{445}$ LUSO SOARES, A Responsabilidade Processual Civil, pp. 176-177.

446 "ARTIGO $156 .^{\circ}$

(Dever de administrar justiça - Conceito de sentença)

1. Os juizes têm o dever de administrar justiça, proferindo despacho ou sentença sobre as matérias pendentes e cumprindo, nos termos da lei, as decisões dos tribunais superiores".
} 
sustenta, por exemplo, Dinamarco ${ }^{447}$. O jurista parte da premissa de que "direito subjetivo" é uma situação jurídica de vantagem em relação a um bem, contrapondo-se à obrigação, que é uma situação jurídica de desvantagem em relação ao mesmo bem. Ao cumprir a obrigação, o seu titular se vê sacrificado, uma vez que realiza a entrega de um bem, ou um fazer, ou ainda um não-fazer, ao mesmo tempo em que ocorre um acréscimo no patrimônio do titular do direito subjetivo. O autor observa que, quando o Estado-juiz efetua a atividade jurisdicional, ele não tem seu patrimônio diminuído, nem sacrificado. $\mathrm{O}$ ato de julgar o mérito é a realização de uma das funções do Estado, que assumiu para si o encargo de outorgar a tutela a quem tiver razão, promovendo a pacificação social mediante o processo. Conclui, então, que o direito de ação não é um verdadeiro direito subjetivo do particular, mas, sim, o poder de criar condições para que o Estado possa decidir a demanda e, se for o caso, conceder a tutela jurisdicional ao autor.

Segundo Dinamarco, não obstante no dia-a-dia forense seja comum o uso de expressões como "direito à prova" e "direito à sentença", é mais adequado tecnicamente dizer: "poder de exigir a produção de prova" e "poder de exigir a sentença". Prossegue o autor, asseverando que também não é correto afirmar que as partes e o juiz têm obrigações no processo. O ordenamento jurídico impõe deveres aos sujeitos processuais com o objetivo imediato de criar situações processuais, e não de obter um bem da vida.

Ao tratar dessa celeuma doutrinária (representada, aqui, pelas teses de Carnelutti, de Liebman, de Luso Soares e de Dinamarco), Abdo ${ }^{448}$ lucidamente pondera que aquilo que alguns doutrinadores qualificam como sendo "direito subjetivo processual" pode ser sempre traduzido na forma de alguma situação jurídica processual. Por exemplo, é possível compreender o direito de recorrer como o ônus ou como o poder de recorrer.

Diferentemente do que ocorre com os direitos subjetivos no processo, a existência de situações ou posições jurídicas subjetivas é um tema praticamente pacífico entre os doutrinadores. Tanto os seguidores da teoria do processo como situação jurídica, quanto os da teoria do processo como relação jurídica e ainda os da teoria do processo como procedimento em contraditório explicam as condutas dos sujeitos processuais por meio das noções de situação ou de posição jurídica subjetiva ${ }^{449}$.

\footnotetext{
${ }^{447}$ Instituições de Direito Processual Civil, vol. II, § 499, pp. 215-216.

${ }^{448}$ O Abuso do Processo, p. 73.

${ }^{449}$ ABDO, O Abuso do Processo, pp. 52-59.
} 
Diante disso, chega-se à conclusão de que é mais apropriado, do ponto de vista técnico, afirmar que o objeto mínimo do abuso do processo são as situações jurídicas subjetivas processuais ${ }^{450}$.

Aliás, o fato de a prática do abuso do processo ocorrer mediante o exercício de situações jurídicas processuais é considerado a principal peculiaridade dessa espécie de abuso do direito ${ }^{451}$.

\subsubsection{Situações jurídicas processuais}

As situações que o ordenamento jurídico confere, sucessivamente, aos sujeitos processuais têm sempre por objeto uma conduta ${ }^{452}$ e podem ser divididas $\mathrm{em}^{453}$ :

a) situações processuais ativas: permitem que os seus titulares realizem atos processuais de acordo com os seus interesses ou que eles exijam de outro sujeito processual a prática de algum ato em seu beneficio. As que são atribuídas às partes fundamentam-se nas garantias constitucionais do acesso à justiça, do contraditório e da ampla defesa, visto que são exercidas por seus titulares com o intuito de buscar uma solução que lhes seja mais favorável. São elas:

1) as faculdades: consistem na liberdade de conduta da parte, que pode agir segundo sua própria vontade. Seu fundamento reside no princípio da liberdade segundo a lei, que é um dos pilares do Estado de Direito: ninguém é obrigado a fazer ou deixar de fazer alguma coisa senão em virtude de lei (art. $5^{\circ}$, III, da CF). Apenas as partes podem ser titulares de faculdades no processo, nunca o juiz. As faculdades se subdividem em: (i) faculdades processuais puras, cujo exercício só produz efeitos para seus titulares, sem atingir outrem (v.g., a faculdade de apresentar a defesa no primeiro ou no último dia do prazo; a de datilografar as alegações, ou digitá-las no computador, ou ainda manuscrevêlas etc.); e (ii) faculdades processuais não-puras, que acrescem vantagens aos sujeitos que as exercem, ou deveres para o Poder Judiciário, ou ainda desvantagens para a parte adversa. Nesses casos, além das faculdades existem ônus (quando a omissão acarretar consequências negativas para o titular da faculdade) ou poderes (quando o exercício da

\footnotetext{
${ }^{450}$ ABDO, O Abuso do Processo, pp. 72 e 74.

${ }^{451}$ ABDO, O Ato Atentatório à Dignidade da Justiça na Nova Execução Civil, pp. 3-4.

452 As situações jurídicas processuais nunca têm por objeto um bem material; é sempre uma conduta (DINAMARCO, Instituições de Direito Processual Civil, vol. II, § 492, pp. 206-207).

${ }^{453}$ DINAMARCO, Instituições de Direito Processual Civil, vol. II, §§ 492-498, pp. 206-215.
} 
faculdade criar para o seu titular o direito a uma providência do juiz ou agravar a situação da outra parte); e

2) os poderes: consistem na capacidade de produzir efeitos sobre a esfera jurídica alheia (v.g., o poder de recorrer, que cria o dever de o órgão jurisdicional superior proferir nova decisão). $\mathrm{O}$ fundamento dos poderes processuais das partes encontra-se no respeito às garantias constitucionais inerentes à participação e à defesa. Já os poderes do juiz constituem desdobramentos técnicos do poder estatal por ele exercido (poder de decidir imperativamente e de impor suas decisões aos litigantes). Cada poder do juiz corresponde a um dever de cumpri-lo, constituindo, na verdade, poderes-deveres. Assim, a posição ocupada pelo juiz é, simultaneamente, ativa e passiva;

b) situações processuais passivas: elas impelem os seus titulares à prática de um ato ou lhes impõem a aceitação de um ato alheio. Dessa forma, limitam a vontade das partes, sempre com o intuito de manter o equilíbrio entre os litigantes e também a boa ordem do processo. São elas:

1) os deveres: limitam a livre atuação de seus titulares, impondo-lhes a prática de um ato ou uma omissão em benefício do interesse da outra parte ou do Poder Judiciário (v.g., o dever de lealdade, previsto no art. 14, II, do CPC). São imperativos de conduta no interesse alheio. Os deveres decorrem da sujeição das partes ao Estado-juiz e visam à defesa do interesse público no correto e eficiente exercício da jurisdição. Desse modo, quando a parte deixa de cumprir um de seus deveres, ela compromete o interesse do Estado em exercer corretamente a jurisdição. Diferentemente dos ônus, o descumprimento de dever consiste em ato ilícito e é sempre passível de sanção para que o seu beneficiário obtenha o resultado que o cumprimento voluntário teria produzido. Daí as diversas formas de providências sancionatórias à inobservância dos deveres processuais previstas pelo ordenamento jurídico (v.g., a repressão da litigância de má-fé e dos atos atentatórios à dignidade da Justiça - arts. 16-18 e 600-601 do CPC); e

2) os ônus: os seus titulares agem na defesa de seus próprios interesses, mas sob a ameaça de se prejudicarem no caso de optarem pela omissão. De acordo com Goldschmidt $^{454}$, o ônus é um imperativo do próprio interesse, ou seja, um encargo, um peso. Há ônus quando o exercício de uma faculdade for necessário para a obtenção de uma vantagem ou para a não-ocorrência de uma desvantagem. Constata-se, assim, que os ônus só atingem seus próprios titulares, seja para beneficiá-los, seja para agravar as situações

\footnotetext{
${ }^{454}$ Teoría General del Proceso, pp. 82, 83, 84 e 85.
} 
deles. Eles não são impostos para beneficiar outro sujeito e o seu descumprimento também não causa mal algum a outras pessoas, nem frustra suas expectativas. O ordenamento jurídico outorga ônus apenas às partes. Como o juiz não tem faculdades processuais, ele também não pode ter ônus. Dinamarco ${ }^{455}$ dá destaque às diversas funções exercidas por essa situação processual passiva: enquanto alguns ônus servem de condição de eficácia para atos do próprio onerado (v.g., o ônus do preparo, que pode ensejar, se descumprido, a ineficácia da propositura da demanda ou da interposição do recurso ${ }^{456}$ ); outros funcionam como requisitos para a realização de atos por outro sujeito processual (e.g., o ônus de adiantar honorários provisórios do perito para que realize a perícia). O mesmo autor classifica os ônus em ${ }^{457}$ : (i) absolutos, cujo inadimplemento provoca, fatalmente, resultado desfavorável aos seus titulares (v.g., o ônus do preparo, que, se não for cumprido, impede o processamento do recurso); e (ii) relativos, cujos titulares, no caso de se manterem inertes, podem ser prejudicados, mas ainda assim é possível que o risco não se perfaça (v.g., o ônus de alegar incompetência absoluta, dado que o juiz pode declará-la de ofício). Os ônus se diferenciam das obrigações e dos deveres porque o inadimplemento destes dois últimos contraria a ordem jurídica e deve ser sancionado de alguma forma; já o descumprimento de um ônus não viola qualquer norma jurídica ${ }^{458}$ e apenas tem por consequência a ocorrência de uma desvantagem para o seu titular ou a não obtenção de uma vantagem.

As partes, durante todo o processo, estão em permanente estado de sujeição em relação ao Estado-juiz. A sujeição consiste na impossibilidade de se evitar os efeitos dos atos do magistrado. É um corolário do princípio da inevitabilidade da jurisdição. No polo oposto ao da sujeição está a autoridade, de titularidade do juiz. Esta é expressão do poder estatal e é ela que autoriza o magistrado: a decidir todas as situações e pretensões das partes, principalmente o mérito do processo; a realizar atos de invasão patrimonial; e também a exercer coerção sobre o obrigado para que cumpra (v.g., arts. 461, 461-A e 475-J do CPC). Dinamarco ${ }^{459}$ afirma que é no binômio autoridade-sujeição que reside a síntese das situações jurídicas passivas das partes.

\footnotetext{
${ }^{455}$ Instituições de Direito Processual Civil, vol. II, § 494, p. 210.

${ }^{456} \mathrm{O}$ ônus do preparo tem previsão expressa no art. 19 do CPC. Se o autor não fizer o depósito prévio das custas, a demanda inicial não pode ter curso, devendo o processo ser extinto (art. 257 do CPC). A parte recorrente também tem o ônus de fazer o preparo simultâneo, sob pena de ineficácia da interposição, ou seja, de deserção (art. 511 do CPC) (DINAMARCO, Instituições de Direito Processual Civil, vol. II, § 527, p. 265).

${ }^{457}$ DINAMARCO, Instituições de Direito Processual Civil, vol. II, § 494, pp. 210-211.

${ }^{458}$ Nesse sentido, afirmando que o descumprimento de um ônus não é antijurídico, mas supõe muitas vezes uma culpabilidade processual contra si mesmo: GOLDSCHMIDT, Teoría General del Proceso, pp. 95-96.

${ }^{459}$ Instituições de Direito Processual Civil, vol. II, § 492, p. 207.
} 
É importante salientar que nem sempre é possível classificar uma situação jurídica em apenas uma das categorias supracitadas. O melhor exemplo disso é a situação atribuída à parte vencida para que ela se dirija ao tribunal com pedido de novo julgamento da causa, que pode configurar um ônus (ônus de recorrer), bem como um poder (dado que, uma vez interposto o recurso, ele cria para o Poder Judiciário o dever de emitir novo julgamento sobre a demanda) ${ }^{460}$.

Alguns comportamentos regulados pelo Código de Processo Civil não podem ser considerados hipóteses de abuso do processo porque não pressupõem o exercício de qualquer situação jurídica processual. É o caso da conduta do executado prevista no art. 600, I, do CPC, consistente em fraudar a execução. A alienação ou oneração de bens nas circunstâncias previstas nos incisos do art. 593 do CPC ou no $\S 3^{\circ}$ do art. 615-A do CPC é praticada totalmente fora da relação jurídica processual ${ }^{461}$. O executado que a realiza comete, sim, um ato ilícito processual (art. 600, I, do CPC), pois viola o dever de lealdade e boa-fé (art. 14, II, do CPC) ${ }^{462}$, mas não se trata de abuso do processo ${ }^{463} 464$.

Esse mesmo raciocínio pode ser utilizado para afirmar que o $\S 4^{\circ}$ do art. 615-A do CPC também não versa sobre abuso do processo, já que o ato de averbação de certidão comprobatória do ajuizamento da execução no registro de imóveis, ou no registro de veículos, ou ainda no registro de outros bens sujeitos à penhora ou arresto não é praticado por meio do exercício de uma situação jurídica processual, apesar de gerar efeitos processuais.

Dentre as diversas situações processuais supramencionadas, Taruffo ${ }^{465}$ prega que apenas as ativas (poderes, faculdades e, para parte da doutrina, direitos) podem ser objeto

\footnotetext{
${ }^{460}$ DINAMARCO, Instituições de Direito Processual Civil, vol. II, § 526, p. 264.

${ }^{461} \mathrm{Na}$ opinião de Castro Filho (Abuso do Direito no Processo Civil, p. 161, nt. 70), a fraude à execução consiste em prática abusiva efetivada "fora do processo, ou enquanto dura a execução".

${ }^{462}$ Nesse sentido: CINTRA; DINAMARCO; GRINOVER, Teoria Geral do Processo, pp. 73-74.

${ }^{463}$ Para Abdo (O Ato Atentatório à Dignidade da Justiça na Nova Execução Civil, pp. 2, 4, 8-9 e 13), quase todas as condutas descritas no art. 600 do CPC como atos atentatórios à dignidade da Justiça configuram casos positivados de abuso do processo, exceto a contida no inciso I, referente à fraude de execução (art. 593 do CPC). A autora explica que, apesar de a fraude à execução ser um instituto de direito processual, dotado de efeitos também processuais, ela não é praticada dentro da relação jurídica processual e, por causa disso, não se amolda ao conceito de abuso do processo.

${ }^{464}$ No mesmo sentido: FERNANDES DE SOUZA, Abuso de Direito Processual - uma teoria pragmática, p. 119, nt. 73; e pp. 122-123, nt. 82.

Porém, a justificativa que ele dá para o seu entendimento parece estar errada. Segundo o doutrinador, a fraude à execução, prevista no art. 600, I, do CPC, não caracteriza hipótese de abuso porque essa conduta está prevista como crime no art. 179 do $\mathrm{CP}$, o que é incompatível com a noção de abuso do direito, já que quem pratica crime age sem direito. $\mathrm{O}$ que o autor parece desconsiderar é que toda conduta abusiva tem apenas a aparência de ser lícita, mas é, de fato, ilícita, já que contraria normas do ordenamento jurídico.

${ }_{465}$ Elementi per una Definizione di "Abuso del Processo", in AA.VV., Studi in onore di Pietro Rescigno, vol. V, pp. 1120-1121.
} 
de abuso $^{466}$. O autor argumenta que só se pode abusar de alguma coisa da qual seja possível fazer uso legítimo, respeitando algumas regras de lealdade. Em suas palavras, "pode-se abusar daquilo que se tem o direito de fazer, não daquilo que não se pode fazer" (tradução nossa). Trata-se de um corolário do requisito da aparência de legalidade, a ser estudado no item 1.6.1 "infra". Segundo o jurista italiano, o sujeito processual que faz aquilo que não pode fazer comete um comportamento ilícito, mas não recondutível ao conceito de abuso. Ele menciona os seguintes exemplos: (a) se Tício não tem o direito de realizar um certo ato processual, mas o realiza, não se pode dizer que ele cometeu um abuso; ele apenas não é legitimado a praticar aquele ato, o qual, consequentemente, é inexistente, inválido, inadmissível etc.; (b) a sentença prolatada por quem não é juiz não consiste em um abuso processual; trata-se, simplesmente, de algo que não existe no âmbito dos fenômenos juridicamente relevantes; (c) a demanda ajuizada por quem não tem legitimidade "ad causam" igualmente não representa um abuso, mas sim uma banal hipótese de carência de legitimação ativa.

No mesmo sentido é a opinião de Catalano ${ }^{467}$, no âmbito processual penal. A autora argumenta que o dever é uma situação jurídica destinada à realização do interesse de outrem, logo, considerações de ordem lógica impedem que ele seja objeto de conduta abusiva. Para ela, o comportamento que contraria um dever deve ser qualificado, pura e simplesmente, como uma violação do dever. Conclui a jurista italiana que configura uma contradição em termos considerar o "abuso de dever" como categoria dogmática autônoma em relação à violação do dever.

Todavia, nem toda a doutrina nacional compartilha desse entendimento. Abdo ${ }^{468}$ sustenta que tanto podem ser objeto de abuso as situações subjetivas ativas quanto as passivas.

Aparentemente, esse dissenso doutrinário decorre da possibilidade de a parte, ao praticar um ato, exercer múltiplas situações jurídicas ativas e passivas ao mesmo tempo. $\mathrm{O}$ exemplo do abuso do poder de recorrer é paradigmático. Quando a parte opõe embargos de declaração manifestamente protelatórios, ela está exercendo o poder e a faculdade de recorrer, que são situações ativas; simultaneamente, ela está se desincumbindo do ônus de recorrer e também está violando o dever de lealdade (art. 14, II, do CPC), que são situações

\footnotetext{
466 A leitura do seguinte trecho da obra de Menezes Cordeiro sugere que o autor também adota esse entendimento:

"Como quaisquer outras posições ativas, também o direito de ação é suscetível de abuso, com todas e as devidas consequências" (Litigância de Má-Fé, Abuso do Direito de Ação e Culpa “in Agendo”, p. 127).

${ }^{467}$ L'Abuso del Processo, p. 51.

${ }^{468}$ O Abuso do Processo, pp. 74-75.
} 
passivas. Aliás, todo ato abusivo viola o dever de lealdade. Logo, sempre que a parte abusa de uma situação jurídica ativa, ela está exercendo pelo menos uma situação passiva, que é o dever de lealdade.

É por causa desse exercício concomitante de situações jurídicas que se defende a existência de abuso tanto de situações ativas quanto de situações passivas. Ocorre que, quando Abdo afirma que há abuso de situações ativas e passivas, indistintamente, ela parece defender a possibilidade de se abusar de uma situação exclusivamente passiva. Se a autora realmente adota esse entendimento, ela se engana, uma vez que, quando a situação é exclusivamente passiva, falta um elemento essencial do ato abusivo, que é a aparência de legalidade, conforme se verá no item 1.6.1 "infra".

Um exemplo talvez esclareça melhor a questão. Quando o juízo concede antecipação de tutela mandando parar a realização de uma construção que esteja afetando um prédio histórico tombado pelo Poder Público, nasce o dever de o réu paralisar a obra, em respeito à ordem judicial (art. 14, V, do CPC). Caso ele continue a construção depois de ser intimado da decisão, estará inequivocamente afrontando o mandamento judicial e, nesse caso, não se poderá falar em abuso, já que a conduta não tem qualquer aparência de ser lícita. Esta poderá ser qualificada apenas como ato atentatório ao exercício da jurisdição (art. 14, parágrafo único, do CPC).

Em suma, existe, sim, abuso de situação jurídica passiva. Contudo, a situação passiva deve estar necessariamente acompanhada de uma situação ativa.

\subsubsection{Abuso do processo em sentido estrito e abuso de instrumentos processuais individuais}

A doutrina costuma distinguir as hipóteses de abuso de situações jurídicas processuais em duas categorias $^{469}$ :

a) abuso do processo em sentido estrito (ou abuso do recurso à tutela jurisdicional, ou abuso da tutela jurisdicional globalmente entendida): é o mau uso, por qualquer dos sujeitos processuais, do processo como um todo, ou seja, de toda a tutela jurisdicional. Em outras palavras, trata-se do abuso, pelo autor ou pelo réu, de todo o feixe de poderes e

\footnotetext{
${ }^{469}$ TARUFFO, Elementi per una Definizione di "Abuso del Processo", in AA.VV., Studi in onore di Pietro Rescigno, vol. V, pp. 1118-1119; CATALANO, L'Abuso del Processo, p. 27; PONTES DE MIRANDA, Tratado de Direito Privado, t. LIII, p. 72.
} 
faculdades que formam a ação ou a defesa ${ }^{470}$. Exemplos: (1) demandas propostas com o único escopo de causar distúrbio ou prejuízo ao adversário, ou de obter dele alguma vantagem que não se conseguiria de outro modo; (2) uso do pedido de falência como meio de cobrança, para coagir o devedor a pagar, em detrimento da via executiva, dada a grande probabilidade de esse tipo de demanda judicial acarretar ofensas drásticas ao crédito e ao bom nome da pessoa demandada ${ }^{471} 472$; (3) antes de 27 de março de $2002^{473}$, a prática de desistir da ação logo após o indeferimento do pedido de antecipação de tutela, ajuizando a mesma demanda em seguida, mas em juízo distinto ${ }^{474}$; (4) promoção de processo com o intuito de induzir a parte contrária a transigir, aceitando condições iníquas; (5) ajuizamento de ação civil pública, pelo Ministério Público, de modo temerário ou por sensacionalismo ${ }^{475}$ etc.; e

b) abuso de instrumentos processuais individuais (ou abuso de atos processuais individuais): é a utilização abusiva de instrumentos processuais específicos,

\footnotetext{
${ }^{470}$ De acordo com Dinamarco (Instituições de Direito Processual Civil, vol. II, § 539, pp. 299-301), a ação e a defesa (direito de ação e direito de defesa) são "a síntese das situações ativas das partes no processo", ou seja, são feixes de faculdades e poderes dos litigantes que permitem que eles realizem atos de seu interesse e de acordo com sua vontade, desde o início até o fim do processo. No mesmo sentido é a lição de Comoglio, Ferri e Taruffo (Lezioni sul Processo Civile, pp. 63 e 67), para quem o "poder agir em juízo" corresponde a "uma pluralidade de poderes, de iniciativas e de faculdades, que vão bem além do cumprimento do mero ato introdutivo do processo e exprimem o conjunto das atividades da parte, considerados indispensáveis para obter a tutela efetiva do direito ou do interesse lesado" (tradução nossa) e a "defesa", analogamente, "sintetiza um conjunto de atividades e de poderes, no qual se traduz o patrocínio técnico (normalmente 'necessário') do procurador legalmente exercente, sem todavia excluir a possibilidade de uma 'defesa pessoal' por quem possa diretamente 'estar em juízo' sem o ministério de um 'defensor"' (tradução nossa).

Para o jurista brasileiro supracitado, a única diferença significativa entre ação e defesa consiste no fato de que só aquela inclui o poder de dar início ao processo. Ele constata, assim, que o conceito de ação abrange os poderes de iniciativa e participação, enquanto o de defesa só inclui o de participação (DINAMARCO, Instituições de Direito Processual Civil, vol. II, § 540, pp. 294-296).

${ }^{471}$ Nesse sentido: STJ, $4^{\text {a }}$ Turma, REsp 1.712/RJ, Rel. Min. Sálvio de Figueiredo Teixeira, DJ 09/04/1990, p. 2745; STJ, $4^{\text {a }}$ Turma, REsp 157.637/SC, Rel. Min. Ruy Rosado de Aguiar, DJ 13/10/1998, p. 122.

${ }_{472}$ Acerca da propensão do processo de falência para gerar danos na parte ré, consultar: ALBUQUERQUE, Responsabilidade Processual por Litigância de Má Fé, Abuso de Direito e Responsabilidade Civil em Virtude de Actos Praticados no Processo, pp. 6-7, nt. 4.

${ }^{473}$ Data em que entrou em vigor a Lei no $10.358 / 01$, que alterou a redação do art. 253 do CPC, impedindo essa conduta.

${ }^{474}$ Trata-se de circunstância similar à que ocorreu no seguinte caso: "PROCESSUAL CIVIL. MANDADOS DE SEGURANÇA. DISTRIBUIÇÕES SUCESSIVAS. TENTATIVA DE OBTENÇÃO DE LIMINAR. PROCEDIMENTO TEMERARIO. CPC, ART. 17, V.

1. CONFIGURA-SE A LITIGANCIA DE MA-FE DE QUEM, AGINDO DE MODO TEMERARIO, DISTRIBUI NOVO MANDADO DE SEGURANÇA COM PEDIDO DE LIMINAR IDENTICO AO REQUERIDO EM OUTRA AÇÃO MANDAMENTAL PENDENTE DA APRECIAÇÃO DO JUIZ DE VARA DIVERSA.

2. RECURSO ESPECIAL CONHECIDO E PROVIDO" (destaque nosso)

(STJ, $2^{\mathrm{a}}$ Turma, REsp 74.218/RJ, Rel. Min. Peçanha Martins, DJ 11/03/1996, p. 6608).

${ }^{475}$ Os exemplos são retirados das obras de Abdo (O Abuso do Processo, pp. 90-91 e 192-196), Taruffo (Elementi per una Definizione di "Abuso del Processo", in AA.VV., Studi in onore di Pietro Rescigno, vol. V, pp. 1118-1119) e Dinamarco (Instituições de Direito Processual Civil, vol. II, § 528-A, p. 271, nt. 16).
} 
individualmente considerados, ao longo do procedimento. Exemplo: abuso do poder de recorrer (art. 538, parágrafo único; ou art. 557, § $2^{\circ}$, do CPC).

Abdo $^{476}$ prefere chamar de "abuso macroscópico" as situações de abuso processual em sentido estrito, e de "abuso microscópico" os casos de abuso de remédios processuais individuais. Acontece que, de acordo com o Dicionário Houaiss da Língua Portuguesa, "microscópico" significa visível somente por meio do microscópio; muito pequeno, minúsculo. Já "macroscópico" é aquilo que é suficientemente grande para ser observado a olho nu; que é considerado ou tomado numa dimensão da ordem do visível ou do sensível. Diante disso, é preferível não adotar essa nomenclatura, apesar de sua originalidade, uma vez que sua utilização pode sugerir que as hipóteses de abuso de instrumentos processuais individuais são de somenos importância que o abuso da tutela jurisdicional globalmente entendida.

Cumpre ressaltar que a mencionada bipartição das formas de abuso do processo denota a autonomia do instituto, uma vez que essa tipologia não é encontrada no ramo jusprivatístico da teoria do abuso do direito ${ }^{477}$.

\subsubsection{O abuso do processo em sentido estrito e as garantias fundamentais de acesso à justiça e de ampla defesa}

É difícil estabelecer, "a priori”, quando o exercício de um direito, de um poder, ou de uma faculdade se torna abusivo sem comprimir excessivamente a possibilidade de exercício da situação jurídica em questão. No caso dos direitos de ação e de defesa, o problema agrava-se ainda mais, já que são fundados em garantias de ordem constitucional.

$\mathrm{O}$ art. $5^{\circ}, \mathrm{XXXV}$, da CF prevê o chamado "princípio da inafastabilidade do controle jurisdicional”, estatuindo que "a lei não excluirá da apreciação do Poder Judiciário lesão ou ameaça a direito". Com isso, os direitos de ação e de defesa - face e verso da mesma medalha - foram elevados ao patamar constitucional. Além disso, a Constituição dá conteúdo a esses direitos ao assegurar as garantias do "devido processo legal" (art. $5^{\circ}, \mathrm{LIV}$, da CF), bem como o contraditório e a ampla defesa, com os meios e recursos inerentes a ela (art. $5^{\circ}, \mathrm{LV}$, da CF) ${ }^{478}$.

\footnotetext{
${ }^{476}$ ABDO, O Abuso do Processo, pp. 92, 189 e 199.

${ }^{477}$ Nesse sentido: CATALANO, L'Abuso del Processo, p. 27.

${ }^{478}$ Nesse sentido: GRINOVER; SCARANCE FERNANDES; GOMES FILHO, As Nulidades no Processo Penal, p. 71.
} 
Destarte, não parece infundado o temor de se limitar indevidamente a efetividade plena das garantias constitucionais de acesso à justiça e de ampla defesa (art. $5^{\circ}, \mathrm{XXXV}$ e LV, da CF) - cujas extensões ainda são incertas para a doutrina - na tentativa de estabelecer em quais casos a atuação "excessiva" dos direitos de ação e de defesa gera efeitos inaceitáveis, abusivos ${ }^{479}$.

Para resolver esse problema, é necessário ter em mente algo que os constitucionalistas nacionais e estrangeiros ensinam há bastante tempo: os direitos e garantias fundamentais, previstos na Constituição, são relativos, e não absolutos.

Partindo do pressuposto de que a garantia contida no inciso XXXV do art. $5^{\circ}$ da CF não é absoluta, fica mais fácil aceitar a constitucionalidade das regras que previnem e reprimem o abuso do direito de ação, relacionando-as entre as normas que limitam, intrinsecamente, a liberdade que as pessoas têm de agir ou estar em juízo ${ }^{480}$.

$\mathrm{O}$ mesmo raciocínio se aplica às normas preventivas e repressivas do abuso do direito de defesa: elas não contrariam o art. $5^{\circ}, \mathrm{LV}$, da $\mathrm{CF}$ porque esse dispositivo constitucional garante apenas que a defesa deve ser ampla, não que ela possa servir de fundamento para condutas ímprobas e para a atuação com desvio de finalidade, em detrimento da eficiência da administração da justiça ${ }^{481}$. Nesse sentido, Catalano ${ }^{482}$ leciona que a inviolabilidade do direito constitucional de defesa não é incompatível com a sua regulamentação normativa, a qual pode ser estabelecida de maneira direta, mediante a fixação dos requisitos dos atos singulares de defesa; ou indiretamente, por meio da definição do escopo fisiológico atribuído a cada instrumento processual. Consequentemente, as normas que previnem e reprimem as condutas defensivas abusivas,

${ }^{479}$ TARUFFO, Elementi per una Definizione di “Abuso del Processo", in AA.VV., Studi in onore di Pietro Rescigno, vol. V, pp. 1121-1222.

${ }^{480}$ Nesse sentido: MENEZES CORDEIRO, Litigância de Má-Fé, Abuso do Direito de Ação e Culpa "in Agendo", pp. 30-31; ABDO, O Abuso do Processo, p. 191; TARUFFO, General Report, in TARUFFO (ed.), Abuse of Procedural Rights: comparative standards of procedural fairness, p. 13; PUOLI, Os Poderes do Juiz $e$ as Reformas da Lei Processual Civil Brasileira, pp. 187-188; ALBUQUERQUE, Responsabilidade Processual por Litigância de Má Fé, Abuso de Direito e Responsabilidade Civil em Virtude de Actos Praticados no Processo, pp. 67-68; BEAUMONT, Report on Abuse of Procedural Rights for Australia, in TARUFFO (ed.), Abuse of Procedural Rights: comparative standards of procedural fairness, p. 103; TAELMAN, Abuse of Procedural Rights: regional report for Belgium-The Netherlands, in TARUFFO (ed.), Abuse of Procedural Rights: comparative standards of procedural fairness, pp. 132-133.

${ }^{481}$ Nesse sentido: ABDO, O Abuso do Processo, pp. 196-197; THEODORO JÚNIOR, Abuso de Direito Processual no Ordenamento Jurídico Brasileiro, in Revista Forense, v. 344, p. 52; BUZAID, Processo e Verdade no Direito Brasileiro, in Revista de Processo, no 47, p. 95; TARUFFO, Elementi per una Definizione di "Abuso del Processo", in AA.VV., Studi in onore di Pietro Rescigno, vol. V, p. 1134; DONDI; GIUSSANI, Appunti sul Problema dell'Abuso del Processo Civile nella Prospettiva de Iure Condendo, in Rivista Trimestrale di Diritto e Procedura Civile, vol. 61, $\mathrm{n}^{\circ}$ 1, p. 197; DINAMARCO, Instituições de Direito Processual Civil, vol. II, § 528-A, p. 274; FALCO, La Buona Fede e l'Abuso del Diritto: principi, fattispecie e casistica, pp. 502-503.

${ }^{482}$ L'Abuso del Processo, pp. 65-67. 
praticadas com escopo estranho à finalidade do direito de defesa, não podem ser consideradas violadoras do art. $5^{\circ}, \mathrm{LV}$, da $\mathrm{CF}$.

Picó i Junoy ${ }^{483}$ percebe, corretamente, que, no momento da efetivação das normas que previnem e sancionam a improbidade processual, ocorre uma colisão entre direitos ou bens constitucionais, a qual é resolvida pela técnica da ponderação dos interesses em conflito. De acordo com ele, as normas que previnem e sancionam as condutas processuais ímprobas regulam o exercício do direito de defesa (ou, complemente-se, o exercício do direito de ação) e, consequentemente, impõem certas restrições à eficácia desse direito fundamental. Porém, essa limitação é legítima, justificando-se pela necessidade de proteger outros valores ou bens constitucionais, quais sejam, os direitos fundamentais à tutela judicial efetiva, à ampla defesa, à igualdade processual e à duração razoável do processo.

Por conseguinte, se um instrumento processual for utilizado de modo desviado de sua finalidade, visando à obtenção de fim ilícito ou ilegítimo, há abuso processual e deve ser cominada a sanção que a lei prevê para aquela hipótese abusiva. Não importa que esse uso abstratamente encontre amparo na garantia constitucional de acesso à justiça ou na de ampla defesa, visto que têm maior relevo, nesse caso, os direitos fundamentais à tutela judicial efetiva, à ampla defesa, à igualdade processual e à duração razoável do processo. Só não se pode admitir que uma conduta processual fundada no direito de ação ou de defesa seja sancionada fora das hipóteses que o ordenamento jurídico nacional considera abusivas. Nesse caso, a inconstitucionalidade é flagrante.

\subsection{Sujeitos do abuso do processo}

Os sujeitos processuais são as pessoas que figuram como titulares de situações jurídicas ativas e passivas integrantes da relação jurídica processual (faculdades, ônus, poderes, deveres, autoridade ou sujeição) ${ }^{484}$. A doutrina os classifica em ${ }^{485}$ :

a) sujeitos parciais: atuam no processo com a intenção de satisfazer pretensão própria, ou alheia, ou de um grupo, ou ainda de toda a sociedade. Trata-se das partes (abrangendo os litisconsortes e os membros do Ministério Público) e dos advogados; e

\footnotetext{
${ }^{483}$ El Principio de la Buena Fe Procesal y su Fundamento Constitucional, in Revista de Processo, $\mathrm{n}^{\circ}$ 196, pp. 132, 145, 151-160 e 160-161.

${ }^{484}$ DINAMARCO, Instituições de Direito Processual Civil, vol. II, § 490, p. 203.

${ }^{485}$ DINAMARCO, Instituições de Direito Processual Civil, vol. II, § 490, p. 203.
} 
b) sujeitos imparciais: são os juízes e todos os auxiliares da justiça ${ }^{486}$. Também os membros do Ministério Público são considerados sujeitos imparciais quando exercem a atividade de fiscais da lei.

Visto que os sujeitos processuais são, por definição, os titulares das situações jurídicas processuais e que o objeto das condutas processuais abusivas são essas mesmas situações jurídicas, a única conclusão que se pode tirar é que apenas os sujeitos da relação jurídica processual podem praticar o abuso do processo ${ }^{487}$.

As partes são consideradas as principais responsáveis pelas práticas abusivas no processo civil ${ }^{488}$. Elas são os sujeitos interessados da relação jurídica processual, pois participam do contraditório defendendo sempre pretensão própria ou alheia e têm seus patrimônios jurídicos afetados pelos efeitos do provimento final do processo (são beneficiadas, no caso de se sagrarem vencedoras; ou prejudicadas, caso sejam vencidas) ${ }^{489}$. De acordo com Liebman, elas são "os sujeitos do contraditório instituído perante o juiz",490 (conceito puro de parte 491492 ).

É importante deixar claro que o conceito de parte processual abarca os intervenientes, que, segundo Barbosa Moreira $^{493}$, são as pessoas que ingressam voluntariamente na relação jurídica processual para postular direito seu ou da parte originária, ou que são citadas para integrá-la, em momento posterior à sua constituição,

${ }^{486}$ É importante observar que Dinamarco (Instituições de Direito Processual Civil, vol. II, § 490, p. 203) classifica o juiz e as partes como sujeitos processuais principais, sendo os auxiliares da justiça e os advogados sujeitos secundários.

${ }^{487}$ ABDO, O Abuso do Processo, p. 48.

488 THEODORO JÚNIOR, Abuso de Direito Processual no Ordenamento Jurídico Brasileiro, in Revista Forense, v. 344, pp. 47 e 63; ABDO, O Abuso do Processo, pp. 50-51.

${ }^{489}$ DINAMARCO, Instituições de Direito Processual Civil, vol. II, § 520, p. 252.

${ }^{490}$ Manual de Direito Processual Civil, vol. I, § 41, p. 89.

${ }^{491}$ Adotando-se o conceito puro de parte, consideram-se "terceiros" todos os indivíduos que não participam do processo, mesmo que tenham interesse processual. Assim, o sujeito da relação jurídica substancial controvertida (considerado parte em sentido substancial) que não seja parte em sentido processual é considerado apenas um terceiro (LIEBMAN, Manual de Direito Processual Civil, vol. I, § 41, p. 90). Também se enquadra na categoria dos terceiros o sujeito processual desinteressado, ou seja, o sujeito processual que não é parte. É o caso do magistrado, que, se fosse parte na causa, estaria impedido de atuar como juiz "ex vi" do art. 134, I, do CPC (DINAMARCO, Instituições de Direito Processual Civil, vol. II, § 520 , p. 253). Em suma, o conceito puro de terceiro é o contraposto negativo do de parte em sentido processual: consideram-se terceiros em relação a um dado processo todos aqueles que não são partes (DINAMARCO, Instituições de Direito Processual Civil, vol. II, § 587, pp. 380-381; LIEBMAN, Manual de Direito Processual Civil, vol. I, § 41, p. 90).

${ }^{492} \mathrm{O}$ conceito puro de parte é aquele estritamente processual. A ele se opõe o conceito substancial de parte, que corresponde à titularidade da relação jurídica material. Segundo Abdo (O Abuso do Processo, p. 49, nt. 7), o conceito puro de parte, proposto por Liebman, é mais consentâneo com o estudo da teoria do abuso do processo no Brasil por dois motivos: (1) é a teoria adotada pelo Código de Processo Civil de 1973; e (2) é um conceito mais amplo, sendo, por isso, coerente com o objetivo de identificar as práticas abusivas perpetradas por todos aqueles que participam do processo, seja como autor, réu, interveniente, ou magistrado.

493 A Responsabilidade das Partes por Dano Processual no Direito Brasileiro, in Temas de Direito Processual, p. 24. 
mas sem ser a título de sucessão. São exemplos de intervenientes que podem cometer abusos no processo: os terceiros intervenientes (inclusive o assistente ${ }^{494}$ ) e o arrematante ${ }^{495}$ 496

Além do demandante e do demandado, pode ser agente ou vítima de abuso processual o representante legal da parte (pais, tutor ou curador) e o órgão do Ministério Público no exercício da função de curador de incapazes ${ }^{497}$.

Em diversas situações, regras de direito material e processual determinam que os interesses de uma pessoa sejam geridos ou defendidos por outra ${ }^{498}$. Nos casos em que uma pessoa absolutamente incapaz (art. $3^{\circ}$ do CC) é parte, ela deve ser representada no processo por seus pais, ou por tutor, ou por curador. A representação importa realização dos atos processuais exclusivamente pelo representante. Se for relativamente incapaz (art. $4^{\mathrm{o}}$ do $\mathrm{CC}$ ), a pessoa deve ser apenas assistida por seu genitor, ou por tutor, ou por curador, que realiza o ato processual juntamente com ela (art. $8^{\circ}$ do CPC c/c arts. 1.634, V; 1.748, V; e 1.781 do CC). Caso o incapaz não tenha representante legal, ou se os interesses deste colidirem com os daquele, o juiz deve dar-lhe curador "ad hoc" (art. 9, I, do CPC c/c art. 1.692 do CC). O Ministério Público oficia necessariamente como assistente do incapaz (absoluto ou relativo). Sem a representação ou a assistência dos pais, do tutor ou do curador, o incapaz não tem capacidade de estar em juízo (ou capacidade processual, ou "legitimatio ad processum") 499 .

Na opinião de Castro Filho ${ }^{500}$, se houver prática de abuso do processo em benefício do incapaz, quem deve arcar com as sanções aplicadas são os seus pais, ou o tutor, ou então o curador, dependendo do caso concreto. O autor argumenta que o incapaz é parte no sentido material, uma vez que o objeto do processo diz respeito a um seu interesse; enquanto o genitor, o tutor, ou o curador é parte no sentido formal, já que é ele que participa efetivamente do processo em contraditório. Como quem realmente concorre para

\footnotetext{
${ }^{494}$ Cumpre lembrar que o legislador brasileiro, ao tratar do instituto da assistência, adotou o conceito de parte elaborado por Liebman, como se infere da análise do art. 52 (em que o assistente é tratado como "parte secundária") e do art. 55 do CPC (que prevê a projeção da eficácia preclusiva da coisa julgada sobre o terceiro que interveio como assistente) (LIEBMAN, Manual de Direito Processual Civil, vol. I, § 54, p. 115, nt. 86).

${ }^{495}$ No art. $701, \S 2^{\circ}$, do CPC, há um exemplo de conduta processual abusiva do arrematante. Ele prevê sanção para o arrematante de imóvel de incapaz que, após prestar caução idônea (art. 701, § $1^{\circ}$, do CPC), se arrepende.

${ }^{496}$ BARBOSA MOREIRA, A Responsabilidade das Partes por Dano Processual no Direito Brasileiro, in Temas de Direito Processual, pp. 24-25; CASTRO FILHO, Abuso do Direito no Processo Civil, pp. $142-$ 144; ABDO, O Abuso do Processo, p. 49, nt. 6; OLIVEIRA, Litigância de Má-Fé, pp. 69-70.

${ }^{497}$ CASTRO FILHO, Abuso do Direito no Processo Civil, pp. 117-118.

${ }^{498}$ DINAMARCO, Instituições de Direito Processual Civil, vol. II, § 439, p. 119.

${ }^{499}$ DINAMARCO, Instituições de Direito Processual Civil, vol. II, § 536, pp. 292-293.

${ }^{500}$ Abuso do Direito no Processo Civil, pp. 146-147.
} 
o ato processual abusivo é a parte em sentido formal, conclui Castro Filho que é aos pais, tutores e curadores que o Código de Processo Civil se refere quando prevê sanções aplicáveis a quem abusa do processo. $\mathrm{O}$ art. 458 do CPC português contém norma nesse sentido: "Quando a parte for um incapaz, uma pessoa colectiva ou uma sociedade, a responsabilidade das custas, da multa e da indemnização recai sobre o seu representante que esteja de má fé na causa",501.

"Data venia", essa não parece ser a solução mais consentânea com o ordenamento jurídico nacional contemporâneo e com o conceito puro de parte. Os pais, o tutor e o curador atuam no processo em nome do incapaz. Quem é parte em sentido processual, nesses casos, é o representado, e não o representante ${ }^{502}$. Por causa disso, o próprio incapaz é quem deve sofrer a sanção decorrente de abuso do processo praticado por seus pais, ou por tutor, ou por curador. O ordenamento jurídico assegura ao incapaz a possibilidade de voltar-se contra o tutor ou o curador para ser ressarcido dos danos decorrentes da conduta processual ímproba, desde que o representante tenha agido com culpa ou dolo (art. 1.752, "caput"; e art. 1.781 do CC). Se o abuso do processo houver sido praticado pelos pais, com culpa ou dolo, em detrimento do patrimônio do filho incapaz, o juiz pode, a requerimento deste ou do Ministério Público, dar-lhe curador especial, com espeque no art. 1.692 do CC.

$\mathrm{O}$ advogado também pode ser autor de comportamentos processuais abusivos. Ele deve defender em juízo os interesses da pessoa que o contratou e, para isso, pode e deve fazer uso de todas as oportunidades que o sistema lhe concede, sem, porém, deixar de observar os mesmos limites éticos cobrados das partes ${ }^{503}$. Na verdade, os deveres éticos do advogado são até maiores que os das partes, pois o art. 133 da CF e o art. 2 ${ }^{\circ}$, “caput”, da Lei no 8.906/94 consideram-no "indispensável à administração da justiça”, o que faz com que sua conduta processual deva ser sempre guiada pelo escopo de tutelar interesses públicos, que transcendem os dos seus clientes. Ele exerce um "munus publicus", um serviço de ordem pública, regulado pelo Estado no interesse da administração da justiça (art. $2^{\circ}, \S \S 1^{\circ}$ e $2^{\circ}$, da Lei n ${ }^{\circ} 8.906 / 94$ e art. $2^{\circ}$, “caput", do Código de Ética e Disciplina da

\footnotetext{
${ }^{501}$ De acordo com a doutrina lusitana, esse dispositivo não se aplica ao membro do Ministério Público, nem ao incapaz que intervém efetivamente no processo, com fundamento no art. 13 do CPC português, e comete comportamento ímprobo (REIS, Código de Processo Civil Anotado, vol. II, pp. 271-273; LUSO SOARES, A Responsabilidade Processual Civil, pp. 288-290).

${ }^{502}$ LIEBMAN, Manual de Direito Processual Civil, vol. I, § 41, p. 90; DINAMARCO, Instituições de Direito Processual Civil, vol. II, § 439, p. 119.

${ }^{503}$ PUOLI, Os Limites ao Direito de Recorrer e a Responsabilidade Civil do Advogado Perante o Cliente, in COSTA; RIBEIRO; DINAMARCO (coords.), Linhas Mestras do Processo Civil, pp. 334-335.
} 
OAB c/c art. 33 da Lei ${ }^{\circ}$ 8.906/94) $)^{504}$. Nesse sentido, o art. 34, VI, XIV e XVII, da Lei n $^{\circ}$ 8.906/94 e os arts. $2^{\circ}$, parágrafo único, II e VIII, “ $d$ ”, e $6^{\circ}$ do Código de Ética e Disciplina da $\mathrm{OAB}$ enfatizam que o advogado deve exercer sua função de maneira proba, respeitando os deveres de lealdade, de veracidade e de boa-fé e recusando-se a auxiliar seu cliente a praticar fraude ou qualquer ato contrário à lei ${ }^{505}$. Então, quando o causídico, conscientemente, pratica atos processuais destinados a satisfazer o interesse do seu cliente em conseguir um objetivo ilegal por meio do processo, ou em protelar o feito, ou em alterar a verdade dos fatos relevantes para o julgamento da demanda, ele também comete abuso do processo, em coautoria com a parte por ele representada. $\mathrm{O}$ art. 32, parágrafo único, da Lei $\mathrm{n}^{\circ}$ 8.906/94 trata expressamente disso, estatuindo que, em caso de lide temerária, o advogado é solidariamente responsável com seu cliente, desde que coligado com este para lesar a parte contrária, o que deve ser apurado em ação própria.

Há situações em que a prática do abuso do processo é imputável exclusivamente ao advogado do autor ou do réu ${ }^{506}$. A título exemplificativo, podem ser mencionados os comportamentos consistentes em: (a) interpor recurso com fundamento em argumentos que não se concatenam e que nem mesmo se relacionam com o caso concreto (art. 17, V, do $\mathrm{CPC})^{507}$; (b) acordar com o defensor da parte contrária a obtenção de longos e repetidos

\footnotetext{
${ }^{504}$ Deve-se destacar, contudo, que o fato de os causídicos exercerem funções públicas não faz deles órgãos do Estado (GUIMARÃES DE SOUZA, O Advogado, p. 141).

${ }^{505}$ Esses dispositivos legais merecem ser citados textualmente:

"Art. 34. Constitui infração disciplinar:

$[\ldots]$

VI - advogar contra literal disposição de lei, presumindo-se a boa-fé quando fundamentado na inconstitucionalidade, na injustiça da lei ou em pronunciamento judicial anterior;

$[\ldots]$

XIV - deturpar o teor de dispositivo de lei, de citação doutrinária ou de julgado, bem como de depoimentos, documentos e alegações da parte contrária, para confundir o adversário ou iludir o juiz da causa; $[\ldots]$

XVII - prestar concurso a clientes ou a terceiros para realização de ato contrário à lei ou destinado a fraudá-la";

“Art. $2^{o}$, parágrafo único. São deveres do advogado:

$[\ldots]$

II - atuar com destemor, independência, honestidade, decoro, veracidade, lealdade, dignidade e boa-fé;

$[\ldots]$

VIII - abster-se de:

$[\ldots]$

d) emprestar concurso aos que atentem contra a ética, a moral, a honestidade e a dignidade da pessoa humana";

"Art. $6^{\circ}$ É defeso ao advogado expor os fatos em Juízo falseando deliberadamente a verdade ou estribandose na má-fé".

${ }^{506}$ CASTRO FILHO, Abuso do Direito no Processo Civil, pp. 117-118.

${ }^{507}$ Nesse sentido, porém fundamentando a condenação nos incisos II e IV do art. 17 do CPC: TJSP, $4^{\circ}$ Grupo de Direito Privado, Embargos de Declaração nº 0262311-63.2011.8.26.0000/50000, Rel. Des. Miguel Brandi, DJ/SP 15/02/2012, p. 687.
} 
adiamentos, transformando o processo em uma "lis immortalis" no art. 34, VIII e, eventualmente, XIX, da Lei $n^{\circ}$ 8.906/94; (c) ajuizar demanda ou provocar incidente em expressa contrariedade à lei (art. 17, I ou VI, do CPC), sem invocar a Constituição Federal, o valor "justiça”" ou algum precedente judicial favorável, e sem ter informado o seu cliente, com antecedência e de forma clara e inequívoca, a respeito dos eventuais riscos da sua pretensão e das consequências que poderiam advir da demanda, ao arrepio do art. $2^{\circ}$, parágrafo único, VII, do Código de Ética e Disciplina da OAB c/c art. 33 da Lei $\mathrm{n}^{\circ}$ 8.906/94 e do art. 34, VI, da Lei nº 8.906/94; etc.

Cumpre frisar a gravidade dos atos de improbidade processual do advogado. $\mathrm{O}$ legislador constituinte e o infraconstitucional estabeleceram a necessidade de as pessoas atuarem em juízo por meio de advogados (art. 133 da CF; art. 36 do CPC; e art. 3º, “caput", da Lei $\mathrm{n}^{\mathrm{o}} 8.906 / 94$ ) com o intuito de ${ }^{509}$ : (a) evitar o excesso de conflitualidade que existiria se fosse promovido um debate direto entre o autor e o réu nos autos do processo e nas audiências, dada a existência de interesses contrapostos e, algumas vezes, de um histórico de choques e contraditas entre as partes; (b) evitar o ajuizamento de demandas inviáveis e a dedução de argumentos juridicamente irrelevantes, uma vez que o advogado fica incumbido de realizar uma triagem, recusando as causas inviáveis e atendendo apenas aos argumentos juridicamente relevantes; (c) facilitar o processo e julgamento das demandas, uma vez que os advogados deduzem os pedidos e as defesas de seus clientes em conformidade com as normas processuais e substantivas; (d) assegurar a paridade de armas entre as partes do processo e, com isso, garantir a concreta atuação do contraditório e, consequentemente, a imparcialidade do órgão julgador. $\mathrm{O}$ abuso de situações jurídicas processuais pelo causídico infirma essas vantagens advindas da sua presença no processo. Sempre que um advogado aceita defender em juízo um cliente cuja pretensão seja ilegal, contrária à verdade, ou manifestamente improcedente, a segunda das vantagens supracitadas esvai-se. A terceira também é perdida quando o advogado utiliza instrumentos processuais para protelar o andamento normal do processo. Por fim, o último benefício mencionado é igualmente prejudicado nos casos em que o advogado de uma das partes se une à parte contrária em conluio, lesando seu próprio cliente por meio de um processo simulado.

\footnotetext{
${ }^{508}$ Exemplo mencionado por Taruffo (Elementi per una Definizione di "Abuso del Processo", in AA.VV., Studi in Onore di Pietro Rescigno, vol. V, p. 1133).

${ }_{509}$ MENEZES CORDEIRO, Litigância de Má-Fé, Abuso do Direito de Ação e Culpa "in Agendo", p. 26; GRINOVER; SCARANCE FERNANDES; GOMES FILHO, As Nulidades no Processo Penal, p. 73.
} 
Apesar de a grande maioria dos atos processuais ímprobos ser de autoria das partes e seus advogados, o magistrado também comete abusos ${ }^{510}$. Dentre os comportamentos abusivos que o juiz pode praticar no processo, destacam-se a atuação dolosa ou fraudulenta e a recusa, a omissão, ou o retardamento, sem justo motivo, em determinar providência que deva ordenar de ofício ou após requerimento da parte (art. 133 do CPC).

Não se pode esquecer dos terceiros que colaboram com o Estado-juiz na justa composição da lide, atuando no processo sem o intuito de satisfazer uma pretensão própria (v.g., as testemunhas ${ }^{511}$ e os auxiliares da justiça). Excepcionalmente, esses sujeitos também podem cometer condutas processuais ímprobas. Castro Filho ${ }^{512}$ cita como exemplo a testemunha ou o perito que exagera na pretensão à indenização dos prejuízos advindos do cumprimento de seu múnus, ou que simula a existência de tais danos.

\subsection{Requisitos para classificar um ato processual como abusivo}

\footnotetext{
${ }^{510}$ A doutrina majoritária entende ser possível a prática de abuso do processo por magistrado: TARUFFO, General Report, in TARUFFO (ed.), Abuse of Procedural Rights: comparative standards of procedural fairness, p. 19; COMOGLIO, Abuso del Processo e Garanzie Costituzionali, in Rivista di Diritto Processuale, Ano 63, no 2, p. 320; DONDI; GIUSSANI, Appunti sul Problema dell'Abuso del Processo Civile nella Prospettiva de Iure Condendo, in Rivista Trimestrale di Diritto e Procedura Civile, vol. 61, $\mathrm{n}^{\circ} 1$, p. 194; ABDO, O Abuso do Processo, pp. 50 e 183-188; THEODORO JÚNIOR, Abuso de Direito Processual no Ordenamento Jurídico Brasileiro, in Revista Forense, v. 344, pp. $46-47$ e 63; PEYRANO, Abuso de los Derechos Procesales, in BARBOSA MOREIRA (coord.), Abuso dos Direitos Processuais, pp. 70, 74-75 e 76; LUCAS SOSA, Abuso de Derechos Procesales, in BARBOSA MOREIRA (coord.), Abuso dos Direitos Processuais, pp. 64-65; HAZARD JR., Abuse of Procedural Rights: regional report for the United States, in TARUFFO (ed.), Abuse of Procedural Rights: comparative standards of procedural fairness, p. 51; FENTIMAN, Abuse of Procedural Rights: the position of English Law, in TARUFFO (ed.), Abuse of Procedural Rights: comparative standards of procedural fairness, pp. 53, 55 e 56; BEAUMONT, Report on Abuse of Procedural Rights for Australia, in TARUFFO (ed.), Abuse of Procedural Rights: comparative standards of procedural fairness, p. 106; TAELMAN, Abuse of Procedural Rights: regional report for Belgium-The Netherlands, in TARUFFO (ed.), Abuse of Procedural Rights: comparative standards of procedural fairness, p. 144; HESS, Abuse of Procedure in Germany and Austria, in TARUFFO (ed.), Abuse of Procedural Rights: comparative standards of procedural fairness, pp. 167-168 e 177; NORMAND, Final Report: the two approaches to the abuse of procedural rights, in TARUFFO (ed.), Abuse of Procedural Rights: comparative standards of procedural fairness, pp. 241-242.

A exceção é Castro Filho (Abuso do Direito no Processo Civil, p. 117), que sustenta que o juiz, por ser órgão do Estado, é sempre o sujeito passivo das condutas ímprobas.

${ }^{511}$ Costuma-se afirmar que a testemunha é apenas uma fonte de prova, não tendo a condição de sujeito do processo.

Dinamarco (Instituições de Direito Processual Civil, vol. II, § 490, p. 204; Instituições de Direito Processual Civil, vol. III, $\S \S 1.180-1.181$, pp. 634-637), com razão, opõe-se a esse entendimento. De acordo com ele, a testemunha é uma fonte de prova e também um "sujeito processual limitado", uma vez que ela é titular de algumas situações jurídicas processuais ativas (v.g., direito ao reembolso das despesas e eventuais prejuízos suportados em virtude do seu comparecimento, faculdade de requerer a dispensa de depor, direito de ser dispensada quando a escusa for procedente, direito de ser tratada com urbanidade e respeito pelo juiz e pelos advogados etc.) e passivas (deveres de comparecimento, de depoimento e de veracidade).

${ }^{512}$ Abuso do Direito no Processo Civil, p. 145.
} 
Poucos autores se dispuseram a definir os contornos do conceito de abuso do processo, identificando os requisitos essenciais dos comportamentos processuais abusivos. No Brasil, quem realizou essa tarefa de maneira mais detalhada foi Abdo.

A autora identifica quatro requisitos cumulativos para qualificar um ato processual como abusivo:

a) a aparência de legalidade;

b) o exercício da situação subjetiva com desvio de finalidade;

c) o elemento subjetivo (dolo e culpa); e

d) o dano.

Cumpre analisar pormenorizadamente cada um deles.

\subsubsection{Aparência de legalidade}

No âmbito do Direito privado, um dos atributos característicos do abuso do direito é a aparência de licitude (ou de legalidade). É o que ensina Venosa, ao afirmar que o ato abusivo é "ato jurídico aparentemente lícito, mas que, levado a efeito sem a devida regularidade, ocasiona um resultado tido como ilícito"513.

Como os processualistas "importaram" a teoria do abuso do direito do Direito privado, o mesmo deve valer na seara processual.

A pergunta que vem imediatamente à mente quando se afirma que o abuso do processo exige aparência de licitude é: o ato processual deve aparentar licitude para quem? Ele deve parecer lícito, necessariamente, para os terceiros estranhos ao processo e, eventualmente, para algum ou alguns dos sujeitos processuais não envolvidos em sua prática. Por exemplo, se o réu afirma fatos inverídicos em sua contestação, o autor com certeza sabe que aquela conduta processual é ilícita e se subsume ao inciso II do art. 17 do CPC. Mas, para o juiz da causa e para os terceiros estranhos ao processo, ela aparenta ser lícita, pois eles não conseguem imediatamente notar que há contrariedade ao art. 14, I, do CPC. Já na hipótese, de rara ocorrência, de todos os sujeitos processuais (autor, réu e juiz) se unirem em conluio para utilizar o processo para conseguir fim proibido por lei (art. 485, III, do CPC), apenas os terceiros que não integram a lide têm a impressão de que a conduta é lícita.

513 Abuso de Direito, in Revista da Faculdade de Direito das Faculdades Metropolitanas Unidas de São Paulo, v. 2, no 2, p. 254. 
Segundo $\mathrm{Abdo}^{514}$, a aparência de licitude do ato processual abusivo decorre de dois fatores:

a) a atribuição, pelo ordenamento jurídico, de situações jurídicas aos sujeitos processuais, o que ocorre ao longo de todo o procedimento e até mesmo antes de ser constituída a relação jurídica processual ${ }^{515}$; e

b) a possibilidade de os sujeitos processuais utilizarem livremente (ou seja, de modo não-vinculado) as diversas situações processuais subjetivas de que são titulares, em atenção às garantias constitucionais da liberdade e da legalidade.

Por outro lado, deve-se considerar elidida a aparência de legalidade sempre que a conduta do sujeito do processo violar algum dever processual de maneira patente ou implicar o descumprimento de provimento judicial, de natureza antecipatória ou final.

\subsubsection{Comportamentos processuais que não podem ser considerados abuso do processo por falta de aparência de legalidade}

Relacionar a aparência de licitude dentre os elementos caracterizantes do abuso do processo faz com que diversos comportamentos processuais previstos no Código de Processo Civil não possam ser considerados abusivos. São exemplos:

a) o descumprimento e o cumprimento inexato de provimentos mandamentais, bem como a criação de embaraços à efetivação de provimentos judiciais de natureza antecipatória ou final, em contrariedade ao que dispõe o art. 14, V, do CPC (ato atentatório ao exercício da jurisdição - art. 14, parágrafo único, do CPC) ${ }^{516} 517$;

\footnotetext{
${ }^{514}$ O Abuso do Processo, pp. 78-79 e 100-101.

${ }^{515}$ Comoglio (Abuso del Processo e Garanzie Costituzionali, in Rivista di Diritto Processuale, Ano 63, $\mathrm{n}^{\circ} 2$, p. 327) ensina que, caso uma pessoa desprovida de qualquer situação jurídica processual pratique um ato no processo e viole os deveres de lealdade e boa-fé, essa conduta não deve ser considerada abusiva. Trata-se de hipótese de usurpação, que gera consequências jurídicas processuais próprias, como a inexistência ou a nulidade do ato, ou então a inadmissibilidade do remédio ilegitimamente apresentado.

516 De acordo com Tabosa Pessoa (Comentários ao art. 340 do CPC, in MARCATO (coord.), Código de Processo Civil Interpretado, p. 1086; Comentários ao art. 342 do CPC, in MARCATO (coord.), Código de Processo Civil Interpretado, pp. 1091-1092), a violação de qualquer dos deveres enumerados no art. 340 do CPC ("Art. 340. Além dos deveres enumerados no art. 14, compete à parte: I-comparecer em juízo, respondendo ao que lhe for interrogado; II - submeter-se à inspeção judicial, que for julgada necessária; III - praticar o ato que lhe for determinado"), bem como o desrespeito à ordem prevista no art. 342 do CPC (“Art. 342. O juiz pode, de ofício, em qualquer estado do processo, determinar o comparecimento pessoal das partes, a fim de interrogá-las sobre os fatos da causa”), devem ser considerados hipóteses de descumprimento de provimento mandamental, ensejando a incidência do art. 14, parágrafo único, do CPC.

${ }^{517}$ Há algum tempo, os juristas brasileiros demonstram interesse pelo "contempt of court", oriundo do Direito anglo-americano. A relevância do estudo desse instituto aumentou porque alguns dispositivos do Código de Processo Civil nacional, especificamente os arts. 14, V e parágrafo único, e 600-601, cominam sanções para quem realiza condutas similares ao "contempt of court" (DINAMARCO, Instituições de Direito Processual Civil, vol. II, § 528, p. 266; e § 529, p. 275; DINAMARCO, Instituições de Direito Processual Civil, vol. IV,
} 
$\S 1.348$, p. 80; ASSIS, O Contempt of Court no Direito Brasileiro, pp. 1, 10, 11 e 12-13; ABDO, O Abuso do Processo, pp. 244-245; AMORIM SILVA, O Contempt of Court no Direito Processual Civil Brasileiro, in Revista de Processo, $\mathrm{n}^{\circ}$ 191, pp. 103-110; OLIVEIRA BARBOSA; LIMA NETO, Anotações Acerca do Contempt of Court no Direito Norte-Americano, in Revista de Processo, $\mathrm{n}^{\circ}$ 192, p. 162). Diante disso, é oportuno analisar se o ato de "contempt of court" deve, ou não, ser considerado abuso do processo.

$\mathrm{O}$ "contempt of court" consiste na prática de um ato de desprezo ao órgão judicial ou à pessoa que desempenha a função jurisdicional ou na desobediência a uma ordem judicial, que impede a adequada administração da justiça e diminui a dignidade ou a autoridade do Judiciário (BUENO, Contribuição ao Estudo do Contempt of Court e seus Reflexos no Processo Civil Brasileiro, pp. $70-71$ e 123-124; GRINOVER, Abuso do Processo e Resistência às Ordens Judiciárias: o contempt of court, in A Marcha do Processo, p. 65; OLIVEIRA BARBOSA; LIMA NETO, Anotações Acerca do Contempt of Court no Direito Norte-Americano, in Revista de Processo, $\mathrm{n}^{\circ}$ 192, pp. 137-138; ASSIS, O Contempt of Court no Direito Brasileiro, p. 3; AMORIM SILVA, O Contempt of Court no Direito Processual Civil Brasileiro, in Revista de Processo, no 191, pp. 85-86). Consoante o título 18, seção 401, do "United Sates Code", o órgão judicial tem poder para punir mediante multa, prisão ou ambos, a seu critério, os seguintes atos de desprezo à sua autoridade, e nenhum outro: (a) o mau comportamento de qualquer pessoa na sua presença ou tão próximo que obstrua a administração da justiça; (b) o mau comportamento de qualquer um dos seus funcionários no exercício de sua função; (c) a desobediência ou a resistência a uma decisão mandamental legítima, um processo, uma ordem, uma regra, um decreto, ou um comando.

Qualquer pessoa que realize comportamento considerado desafiador à dignidade ou autoridade da Corte pode ser condenada pela prática de "contempt of court", seja ela uma das partes, advogado, xerife (policial), testemunha, jurado, magistrado, ou terceiro estranho ao processo (OLIVEIRA BARBOSA; LIMA NETO, Anotações Acerca do Contempt of Court no Direito Norte-Americano, in Revista de Processo, no 192, p. 139).

A doutrina adota diversas classificações do "contempt of court". Quanto ao local de sua prática, pode ser: (a) "contempt" direto (ou "contempt in the face of court"), que ocorre no fórum, na presença do magistrado; ou (b) "contempt" indireto (ou "contempt ex facie", ou "constructive contempt"), que ocorre fora das audiências ou sessões. Com relação ao escopo da sanção, classifica-se em: (a) "contempt" criminal, se o objetivo for reforçar a autoridade do órgão judicial por meio da punição do autor do ato de desrespeito (função punitiva); e (b) "contempt" civil, se visar a compelir o cumprimento de uma ordem imposta pelo juízo (função coercitiva) ou a reparar os danos sofridos pela parte contrária em decorrência do ato de desacato, caso a ordem judicial violada não possa mais ser cumprida (função compensatória). O comportamento que configura "contempt" criminal precisa ser intencional, enquanto o civil não tem como elemento essencial a intenção de desacatar o juízo (OLIVEIRA BARBOSA; LIMA NETO, Anotações Acerca do Contempt of Court no Direito Norte-Americano, in Revista de Processo, $\mathrm{n}^{\circ}$ 192, pp. 138-139, 147-155 e 157-160; ASSIS, O Contempt of Court no Direito Brasileiro, pp. 3-5; AMORIM SILVA, O Contempt of Court no Direito Processual Civil Brasileiro, in Revista de Processo, $\mathrm{n}^{\circ}$ 191, pp. 87-91; GRINOVER, Abuso do Processo e Resistência às Ordens Judiciárias: o contempt of court, in A Marcha do Processo, pp. 65-66).

$\mathrm{O}$ poder que os órgãos jurisdicionais têm para reprimir tais condutas denomina-se "contempt power". As sanções mais aplicadas são: a prisão civil, a multa e o sequestro de bens. Os órgãos jurisdicionais possuem ampla liberdade, dentro da esfera do razoável, para escolher o mecanismo mais efetivo para estimular o cumprimento da ordem judicial ou punir o autor do "contempt of court" (OLIVEIRA BARBOSA; LIMA NETO, Anotações Acerca do Contempt of Court no Direito Norte-Americano, in Revista de Processo, $\mathrm{n}^{\circ}$ 192, pp. 131 e 138; e 155-157; ASSIS, O Contempt of Court no Direito Brasileiro, p. 5; AMORIM SILVA, O Contempt of Court no Direito Processual Civil Brasileiro, in Revista de Processo, $\mathrm{n}^{\mathrm{o}}$ 191, pp. 91-93; GRINOVER, Abuso do Processo e Resistência às Ordens Judiciárias: o contempt of court, in A Marcha do Processo, p. 65).

Levando em consideração que os elementos essenciais do ato processual abusivo são: (a) a aparência de legalidade; (b) o exercício da situação jurídica processual com desvio de finalidade, para a obtenção de um fim ilícito ou ilegítimo; (c) eventualmente, o elemento subjetivo (dolo ou culpa); e (d) o dano (item 1.6 "supra"), nem todo "contempt of court" deve ser considerado abuso do processo. Para confirmar isso, basta analisar alguns dos exemplos de "contempt of court" mencionados por Bueno (Contribuição ao Estudo do Contempt of Court e seus Reflexos no Processo Civil Brasileiro, pp. 124-127). Comete, concomitantemente, ato de "contempt of court" e abuso do processo o advogado que faz afirmações inverídicas no processo em nome de seu cliente (art. 17, II, do CPC); ou que, apesar das recomendações contrárias do órgão judicial, continua a trazer aos autos milhares de documentos já considerados desnecessários para o deslinde do feito, com o intuito de comprometer a organização dos autos pelo cartório e atrasar a prolação da tutela jurisdicional (art. 17, IV, do CPC). Por outro lado, não consistem em abuso processual os comportamentos consistentes em: 
b) o emprego de expressões injuriosas pelas partes e seus advogados, nos escritos apresentados no processo, ou em audiência, violando os deveres previstos nos arts. 15 e 446, III, do CPC;

c) o lançamento de cotas marginais ou interlineares nos autos, ao arrepio do art. 161 do CPC;

d) o descumprimento, por advogados (privados ou públicos) e membros do Ministério público, do prazo legal para o exercício do direito à vista dos autos fora do cartório (arts. 195, 196 e 197 do CPC);

e) a recusa, pelo terceiro, sem justo motivo, a cumprir a ordem judicial de exibição de documento ou coisa que se ache em seu poder, contrariando o inciso II do art. 341, do CPC e levando o juiz a aplicar o art. 362 do CPC;

f) o inadimplemento ou o adimplemento extemporâneo, pela parte vencida, do dever de cumprir o disposto no título executivo, ensejando a incidência dos arts. $461, \S \S 4^{\circ}$ a 6 ; 461-A; 475-J; e 645 do CPC;

g) a resistência injustificada às ordens judiciais, materializada em verdadeira recusa do executado, mediante atos formais ${ }^{518}$; e a abstinência do executado em indicar ao juiz onde se encontram os bens integrantes do seu patrimônio suscetíveis de constrição judicial e seus respectivos valores, ofendendo os deveres previstos no art. 600, III e IV, do CPC;

h) a conduta do exequente que, na alienação em hasta pública, arremata bens com valor que exceda o seu crédito, mas não deposita a diferença dentro de três dias, como manda o art. 690-A, parágrafo único, do CPC;

a) recusar o cumprimento de ordem judicial de fazer ou deixar de fazer algo;

b) insultar o juiz, a outra parte e o advogado desta na sala de audiência;

c) publicar anúncio condenando a reputação do juiz que atuou no processo, sugerindo que a decisão desfavorável por ele proferida foi fruto de acordo com a parte contrária;

d) retirar a roupa e deitar-se no chão da sala de audiência como forma de protesto contra a decisão proferida pelo magistrado;

e) tornar público fato indecoroso da vida íntima do juiz, com o objetivo de intimidá-lo ou de retirar-lhe a autoridade para a condução dos trabalhos na sala de audiências;

f) publicar, às vésperas do julgamento, reportagens condenando abertamente o acusado e ameaçando os jurados na hipótese de absolvição;

g) jogar gás hilariante na sala de audiência ou fazer barulho fora das dependências do fórum, utilizando música alta ou fogos de artifício, com o intuito de atrapalhar o andamento dos trabalhos jurisdicionais.

As duas primeiras condutas não podem ser consideradas atos processuais abusivos porque lhes falta a aparência de legalidade. Os demais exemplos de "contempt of court" mencionados nem mesmo pressupõem o exercício de situação jurídica processual, logo, também não configuram abuso do processo.

Nesse mesmo sentido é a opinião de Abdo (O Abuso do Processo, p. 248), para quem "abuso do processo e contempt of court não se confundem, muito embora haja, entre ambos, coincidência quanto a algumas hipóteses de ocorrência, bem como parcial identidade de efeitos sancionatórios".

${ }^{518}$ Abdo (O Ato Atentatório à Dignidade da Justiça na Nova Execução Civil, p. 10) cita o seguinte exemplo: o executado, depois de intimado, não coloca à disposição do juízo o bem móvel penhorado para fins de avaliação. 
i) o arrematante e o seu fiador que, na alienação em hasta pública, não pagam o preço no prazo estabelecido, acarretando a aplicação do art. 695 do CPC;

j) o atentado (arts. 879 a 881 do CPC), que é a "criação de situação nova, ou a mudança de status quo, pendente a lide, lesiva à parte e sem razão de direito" ${ }^{„ 519}$. Uma vez feita a citação no processo, tudo que interessa à instrução e à futura decisão da demanda deve permanecer como está. É a violação desse dever processual que consiste no atentado $^{520}$. Não é necessária a infração de uma ordem judicial para que ele ocorra. Quem desrespeita mandado judicial faz mais que atentar e se expõe a sanções específicas ${ }^{521}$. De acordo com o art. 879 do CPC, “comete atentado a parte que no curso do processo: I viola penhora, arresto, sequestro ou imissão na posse; II-prossegue em obra embargada; III - pratica outra qualquer inovação ilegal no estado de fato". Quem pratica um desses comportamentos comete atentado, independentemente de vir a vencer ou a perder a ação ${ }^{522}$. O atentado é considerado um ato-fato jurídico processual ilícito, já que a sua ocorrência independe de dolo ou de culpa da parte ${ }^{523}$; etc.

Em todas essas condutas, ou há a violação de um dever de maneira patente (v.g., arts. 15 c/c 446, III; 161; 195, 196 e 197; 690-A, parágrafo único; 695; 879 a 881 do CPC), ou há o descumprimento de um provimento judicial, de natureza antecipatória ou final (e.g., arts. 14, V e parágrafo único; 341, II c/c 362; 461, §§ $4^{\circ}$ a 6 $6^{\circ}$; 461-A; 475-J; 600, III e IV; 645 do CPC), o que elimina a aparência de legalidade e impossibilita sua classificação como hipóteses de abuso do processo ${ }^{524}$.

\subsubsection{Exercício da situação jurídica processual com desvio de finalidade, para atingir escopo ilícito ou ilegítimo}

A ordem jurídica de um determinado Estado, manifestada por meio do seu Direito positivo, é elaborada com o intuito de organizar a vida da sociedade instalada em seu território, retirando dos indivíduos o poder de fazer justiça com as próprias mãos.

\footnotetext{
${ }^{519}$ PONTES DE MIRANDA, Comentários ao Código de Processo Civil, tomo XII, p. 381.

${ }^{520}$ PONTES DE MIRANDA, Comentários ao Código de Processo Civil, tomo XII, pp. 388, 389 e 390.

${ }^{521}$ PONTES DE MIRANDA, Comentários ao Código de Processo Civil, tomo XII, p. 391.

${ }^{522}$ PONTES DE MIRANDA, Comentários ao Código de Processo Civil, tomo XII, p. 383.

${ }^{523}$ PONTES DE MIRANDA, Comentários ao Código de Processo Civil, tomo XII, pp. 382 e 392.

${ }^{524}$ Por esse motivo, não parecem corretas, "data venia", as seguintes opiniões de Abdo (O Ato Atentatório à Dignidade da Justiça na Nova Execução Civil, pp. 2, 4, 8-9, 11 e 13):

a) todas as condutas descritas no art. 600 do CPC configuram casos positivados de abuso do processo, exceto a descrita no inciso I desse dispositivo; e

b) o art. 475-J, “caput”, do CPC contém norma preventiva do abuso processual.
} 
Constata-se, assim, uma finalidade social do ordenamento jurídico, qual seja, a de assegurar a existência do homem em sociedade com seus semelhantes ${ }^{525}$.

Ao lado dessa chamada "finalidade social" - que diz respeito a todo o Direito objetivo -, é possível identificar diversos outros fins sociais, econômicos, políticos, éticos, que impregnam a concepção de normas individuais e de sistemas de normas jurídicas. Especificamente no tocante às normas jurídicas processuais, elas são concebidas tendo como escopo os fins sociais, políticos e jurídico mencionados no item 1.3.4 "supra".

E da mesma forma como o processo possui seus objetivos próprios, cada remédio processual também se destina a uma certa finalidade. Daí o ensinamento de que os atos jurídicos processuais são uma espécie de ato jurídico em sentido estrito, uma vez que a vontade do agente é um elemento essencial à sua existência, porém é irrelevante para a determinação das suas consequências, as quais já são previamente estabelecidas pela lei ${ }^{526}$.

Partindo do pressuposto de que o processo como um todo e os instrumentos processuais individuais possuem finalidades específicas e pré-definidas, pode-se afirmar que, quando uma pessoa emprega um determinado remédio processual, ela escolhe, de maneira implícita, conscientemente ou não, o escopo ao qual o mesmo é funcionalmente orientado (e.g., quando se propõe uma demanda, objetiva-se a obtenção de um provimento jurisdicional acerca dela; quando se dá início a um processo de execução, o que se quer é a satisfação coativa de um direito etc.). Em outras palavras, a escolha de utilizar um certo remédio processual, por si só, individualiza ou, pelo menos, condiciona também a escolha do objetivo que se quer alcançar com aquele instrumento. A outra face da mesma moeda consiste no fato de que a satisfação do desejo de alcançar uma determinada finalidade mediante o processo é condicionada pela existência de algum instrumento processual concebido para obtê-la. Assim, não se pode perseguir no processo um escopo diverso daqueles para o alcance dos quais o ordenamento jurídico prevê remédios processuais. Existe, portanto, uma correspondência biunívoca entre meios e fins, entre remédios processuais e escopos que se tem em vista ${ }^{527} 528$.

\footnotetext{
${ }^{525}$ CASTRO FILHO, Abuso do Direito no Processo Civil, pp. 19-20.

${ }^{526}$ BEDAQUE, Efetividade do Processo e Técnica Processual, pp. 406-410.

${ }^{527}$ TARUFFO, Elementi per una Definizione di "Abuso del Processo", in AA.VV., Studi in Onore di Pietro Rescigno, vol. V, pp. 1125-1126.

528 Essa correspondência não é singular e monodimensional. Isso porque, não raramente, um mesmo instrumento processual pode ser utilizado para alcançar diversos fins (v.g., os vários efeitos processuais e substanciais da litispendência), bem como um mesmo fim pode ser perseguido mediante instrumentos diversos (por exemplo, a prova de um fato pode ser obtida mediante diversos meios de prova) (TARUFFO, Elementi per una Definizione di "Abuso del Processo", in AA.VV., Studi in Onore di Pietro Rescigno, vol. V, pp. 1126-1127).
} 
O abuso do processo consiste exatamente na deturpação dessa correspondência. De acordo com Taruffo ${ }^{529}$, o abuso pode ser definido como "o emprego de um remédio processual para o conseguimento de um fim que não é próprio daquele remédio, uma vez. que não faz parte do âmbito dos escopos para cujo atingimento ele é preordenado" (tradução nossa). Então, a chave para identificar o abuso de uma situação jurídica processual está no fim visado por seu titular: se ele coincidir com os escopos para os quais aquele específico instrumento processual foi concebido, o uso é legítimo; se houver uma distorsão da finalidade própria do instrumento processual, há abuso ${ }^{530}$.

Logicamente, a possibilidade de se abusar de uma situação jurídica processual depende da existência de um mínimo de discricionariedade do sujeito legitimado a exercitá-la. Desse modo, comportamentos rigorosamente vinculados a normas jurídicas não podem ser tidos como abusivos, uma vez que o sujeito processual pode escolher apenas entre obedecer e não obedecer à norma ${ }^{531}{ }^{532}$. O abuso somente ocorre quando o titular de um poder discricionário, que tem à sua disposição diversas possibilidades de conduta (e não só a escolha entre obedecer e não obedecer a norma), opta por agir de uma maneira censurável do ponto de vista de alguns "standards" valorativos ${ }^{533}$.

Essa questão da discricionariedade do sujeito processual merece ser mais bem explicada, dada a sua importância para a compreensão do abuso do processo.

No ordenamento jurídico processual brasileiro, vige a regra da legalidade das formas, que estabelece que as formas do procedimento são regidas pela $1 \mathrm{ei}^{534}$. Sendo assim, o titular de situações jurídicas processuais deve respeitar limites de forma e de conteúdo para a prática de atos processuais ${ }^{535}$ :

a) limites formais: referem-se ao lugar, ao tempo e ao modo de praticar os atos processuais. O desrespeito aos limites formais não configura, por si só, abuso do processo;

\footnotetext{
${ }^{529}$ Elementi per una Definizione di "Abuso del Processo", in AA.VV., Studi in Onore di Pietro Rescigno, vol. V, p. 1127.

530 Nesse sentido: COMOGLIO, Abuso del Processo e Garanzie Costituzionali, in Rivista di Diritto Processuale, Ano 63, n 2, pp. 319-320; FALCO, La Buona Fede e l'Abuso del Diritto: principi, fattispecie e casistica, pp. 25 e 503-504; OLIVEIRA, Litigância de Má-Fé, p. 34; DINAMARCO, Instituições de Direito Processual Civil, vol. II, § 528-A, p. 273.

531 A conduta processual contrária a uma norma que impõe um comportamento específico pode ser considerada ilegítima, ensejando uma série de consequências jurídicas negativas (v.g., sanções pecuniárias, nulidade ou inadmissibilidade de atos processuais, decadência, preclusão, efeitos probatórios negativos, susumbência na causa etc.), mas não é, por si só, um abuso do processo.

${ }^{532}$ Nesse sentido: CATALANO, L'Abuso del Processo, pp. 53-54.

533 TARUFFO, Elementi per una Definizione di "Abuso del Processo", in AA.VV., Studi in Onore di Pietro Rescigno, vol. V, pp. 1122-1125.

${ }^{534}$ CINTRA; DINAMARCO; GRINOVER, Teoria Geral do Processo, pp. 329-330.

535 CINTRA; DINAMARCO; GRINOVER, Teoria Geral do Processo, pp. 330-339; ABDO, O Abuso do Processo, pp. 75-77; BARBOSA MOREIRA, A Responsabilidade das Partes por Dano Processual no Direito Brasileiro, in Temas de Direito Processual, p. 17.
} 
b) limites de conteúdo, dentre eles, o dever de lealdade processual.

Observados esses limites de forma e de conteúdo, as partes têm liberdade para exercer suas situações jurídicas subjetivas como melhor lhes aprouver, segundo suas estratégias de atuação processual. Esse "espaço de manobra" resulta do respeito às garantias constitucionais da legalidade, do devido processo legal e da liberdade (art. $5^{\circ}$, "caput" e incisos II e LIV, da CF) ${ }^{536}$.

Todavia, essa liberdade de atuação é relativa, e não absoluta ${ }^{537}$, uma vez que, sob a ótica da teoria da instrumentalidade do processo, cada um dos instrumentos processuais de que as partes podem fazer uso deve-se destinar à realização dos escopos sociais, políticos e jurídico do processo ${ }^{538}$. Em outras palavras, o limite dessa liberdade é a proibição do desvio de finalidade. Se o instrumento processual for utilizado de modo desviado de seu escopo, há abuso processual.

Há, então, uma relação de implicação entre a possibilidade de se configurar o abuso e a atribuição de uma certa margem de discricionariedade ao titular da situação jurídica subjetiva $^{539}$.

Mas, Taruffo ${ }^{540}$ adverte que, para que haja abuso do processo, não basta o emprego do instrumento processual para a obtenção de um fim distinto dos seus escopos típicos. É necessário que o intuito do litigante ímprobo seja, além de impróprio para o instrumento processual em questão, também ilícito ou ilegítimo ${ }^{541}$. Assim, o fulcro do critério para

\footnotetext{
${ }^{536}$ ABDO, O Abuso do Processo, p. 77.

${ }^{537}$ ABDO, O Abuso do Processo, pp. 78 e 101.

${ }^{538}$ ABDO, O Abuso do Processo, pp. 85 e 89-90.
}

539 No entanto, quando a discricionariedade for ilimitada, ou seja, quando todas as opções de conduta do sujeito processual forem permitidas pelo ordenamento jurídico, sendo indiferente qual a sua escolha comportamental, não se pode falar em abuso (e.g., a possibilidade de escolher entre: não tutelar o direito violado; tentar uma conciliação; instituir um painel arbitral para solucionar o litígio; ou ajuizar uma demanda). Segundo Taruffo (Elementi per una Definizione di "Abuso del Processo", in AA.VV., Studi in Onore di Pietro Rescigno, vol. V, pp. 1123-1124), é necessário que haja uma ordem de preferência ou de prioridade entre as alternativas de comportamentos possíveis ou que sejam previstas conexões necessárias entre os instrumentos e os escopos que o sujeito processual possa escolher discricionariamente.

${ }^{540}$ Elementi per una Definizione di "Abuso del Processo", in AA.VV., Studi in Onore di Pietro Rescigno, vol. V, p. 1128.

${ }^{541}$ Abdo (O Abuso do Processo, pp. 92-94) aponta quatro motivos para não se adotar o desvio de finalidade como único elemento caracterizador do abuso:

a) isso reduziria muito a aplicação da teoria do abuso do processo;

b) a aplicação do critério do desvio de finalidade é de alta complexidade, notadamente nos casos em que a lei não prevê expressamente os fins a que se destinam algumas situações jurídicas atribuídas aos sujeitos processuais;

c) seria um critério demasiadamente rigoroso, uma vez que consideraria abusiva qualquer conduta que buscasse alcançar uma finalidade qualquer distinta daquela definida como típica do instrumento processual em análise;

d) seria incompatível com os princípios da atipicidade da garantia da ação e da fungibilidade recursal, os quais são acolhidos pelo ordenamento jurídico brasileiro. Logo, faria com que situações que atualmente são consideradas legítimas fossem consideradas abusivas. Por exemplo: a parte que interpõe um recurso tido 
identificar o abuso de uma situação jurídica processual não é apenas a impropriedade do escopo do seu titular com relação à função típica do instrumento processual empregado, mas, sobretudo, a qualificação negativa desse escopo ${ }^{542} 543$.

No Brasil, a investigação dos escopos do processo e dos instrumentos processuais fica a cargo da doutrina e da jurisprudência. No entanto, a lei brasileira estatui - aí sim de maneira expressa - quais finalidades são consideradas ilícitas ou ilegítimas, não podendo ser perseguidas pelos sujeitos processuais. Por exemplo, infere-se dos arts. 14; 17; 125, II e III; 129; 538, parágrafo único; 557, § $2^{\circ}$; e 600 , II, do CPC que as pessoas não podem utilizar o processo para violar os deveres de veracidade, de lealdade ou de boa-fé; para deduzir pretensão ou defesa destituída de fundamentação séria; para praticar ato inútil ou desnecessário à declaração ou defesa de direito; para conseguir objetivo ilegal; para praticar ato simulado; nem para protelar a entrega da tutela jurisdicional ou se opor injustificadamente a ela ${ }^{544}$.

como "impróprio", porém dentro do prazo do recurso próprio, havendo dúvida objetiva acerca de qual deles é cabível no caso concreto; a parte que propõe medida cautelar atípica quando há previsão legal de medida cautelar típica para o caso em apreço.

${ }^{542}$ Não pode ser considerado abusivo, portanto, o emprego desvirtuado de um instrumento processual, porém perseguindo um escopo legítimo (v.g., ajuiza-se uma demanda, não com o intuito de iniciar um processo de conhecimento, mas apenas para interromper a prescrição) (TARUFFO, Elementi per una Definizione di "Abuso del Processo", in AA.VV., Studi in Onore di Pietro Rescigno, vol. V, p. 1128).

${ }^{543}$ Abdo (O Abuso do Processo, pp. 94-98 e 102) aponta outros critérios, além da mencionada ilicitude ou ilegitimidade do escopo visado pelo agente, como idôneos a caracterizar, ao lado do desvio de finalidade, o abuso do processo:

a) a falta de seriedade do sujeito processual, que é um critério muito utilizado nos países da "Common Law" para identificar os atos processuais abusivos. Trata-se da denominada "frivolousness", que pode ser traduzida como "frivolidade" ou "leviandade" no exercício da situação jurídica. O Código de Processo Civil de 1939 considerava a falta de seriedade como um dos elementos caracterizadores do abuso do processo, pois estabelecia que a parte que ajuizasse demanda por mero capricho devia responder por perdas e danos (art. $3^{\circ}$, "caput", do CPC39);

b) a lesividade causada à administração da justiça;

c) a presença de dolo ou culpa.

A autora afirma que, no caso concreto, para identificar se foi praticado algum abuso, é necessário que se demonstre a presença do desvio de finalidade combinado com pelo menos um dos critérios supracitados ou com algum outro, dado que na sua opinião esse rol é exemplificativo.

"Data venia", não concordamos com essa proposta de elencar outros critérios para caracterizar o abuso do processo. A presença de dolo ou culpa, como se verá no item 1.6.3.4 "infra", não é imprescindível, logo, não pode ser considerada um elemento característico do abuso do processo. Já a lesividade causada à administração da justiça é uma consequência do abuso (item 1.6.4 “infra”), e não um critério. Por fim, a falta de seriedade do sujeito processual está inserida no critério da ilegitimidade do escopo do agente. Portanto, os únicos verdadeiros elementos de identificação de condutas processuais abusivas são os apontados por Taruffo: (a) a impropriedade do escopo do sujeito em relação à função típica do instrumento processual empregado; e (b) a qualificação negativa desse escopo (ilegítimo ou ilícito).

544 Segundo Comoglio (Abuso del Processo e Garanzie Costituzionali, in Rivista di Diritto Processuale, Ano $63, n^{\circ} 2$, p. 320), para que se possa distinguir com precisão o uso regular do processo do seu uso abusivo, é preciso que haja uma previsão normativa adequada, que estabeleça, "fattispecie" por "fattispecie", quais condições ou limites devem ser alcançados para que o uso correto de uma determinada situação jurídica subjetiva converta-se em um uso desleal, impróprio, ou seja, abusivo.

Percebe-se que a lei brasileira não segue essa orientação à risca, já que apenas prevê, de maneira genérica, quais finalidades dos sujeitos processuais são consideradas ilícitas ou ilegítimas. 
Por fim, cumpre observar que, na prática, a identificação desse elemento caracterizante do abuso do processo mostra-se bastante complexa. Primeiro, é necessário que o magistrado avalie o contexto em que foi empregado o instrumento processual (sujeitos, momento processual, circunstâncias externas ao processo), para verificar se ele é idôneo a produzir outros efeitos (processuais ou extraprocessuais) além daqueles que lhe são próprios. Constatada a existência de efeitos atípicos, deve-se verificar se são ilegítimos ou ilícitos. Em seguida, se a resposta for positiva, o juiz precisa analisar se esses efeitos representam o escopo real que o sujeito processual quis perseguir ${ }^{545}$. Somente se o resultado for novamente afirmativo é que se pode afirmar que realmente se trata de um abuso de situação jurídica processual.

\subsubsection{Comportamentos processuais que não podem ser considerados abuso do processo por falta de desvio de finalidade}

Parte da doutrina nacional considera que os arts. 475-O, I e II; e 811 do $\mathrm{CPC}^{546}$ tratam, respectivamente, de hipóteses de abuso do poder de promover a execução provisória e de abuso do poder de ajuizar demanda cautelar, uma vez que os comportamentos neles previstos teriam aparência de legalidade e consistiriam no exercício de situações jurídicas processuais com desvio de finalidade e com produção de danos.

Castro Filho ${ }^{547}$ afirma que, tanto na efetivação de medida cautelar ou antecipatória da tutela, quanto na execução provisória de sentença, a parte exerce o poder de dispor de meios executivos para efetivar um título judicial cuja existência é instável. Para ele, esse poder é abusado em decorrência: (a) da insuficiente ponderação que o seu titular faz das

\footnotetext{
${ }^{545}$ TARUFFO, Elementi per una Definizione di "Abuso del Processo", in AA.VV., Studi in Onore di Pietro Rescigno, vol. V, p. 1129.

${ }^{546}$ Esses dispositivos legais estatuem, respectivamente, o seguinte:

“Art. 475-O. A execução provisória da sentença far-se-á, no que couber, do mesmo modo que a definitiva, observadas as seguintes normas:

I - corre por iniciativa, conta e responsabilidade do exequente, que se obriga, se a sentença for reformada, a reparar os danos que o executado haja sofrido;

II - fica sem efeito, sobrevindo acórdão que modifique ou anule a sentença objeto da execução, restituindose as partes ao estado anterior e liquidados eventuais prejuízos nos mesmos autos, por arbitramento";

"Art. 811. Sem prejuízo do disposto no art. 16, o requerente do procedimento cautelar responde ao requerido pelo prejuízo que lhe causar a execução da medida:

I - se a sentença no processo principal lhe for desfavorável;

II - se, obtida liminarmente a medida no caso do art. 804 deste Código, não promover a citação do requerido dentro em 5 (cinco) dias;

III - se ocorrer a cessação da eficácia da medida, em qualquer dos casos previstos no art. 808, deste Código; IV - se o juiz acolher, no procedimento cautelar, a alegação de decadência ou de prescrição do direito do autor (art. 810)".

${ }^{547}$ Abuso do Direito no Processo Civil, pp. 109-111; 164-166;172-183.
} 
próprias razões; ou (b) do mero emprego do processo por quem não tem razão, gerando dano a outrem, merecedor de reparação. De acordo com o jurista, o poder de disposição dos meios executivos apenas é concedido a quem tem razão. Logo, há má utilização desse poder e, consequentemente, abuso se ele for exercido e, ao final do processo, for verificada a falta de razão.

Outro autor que trata desse assunto é Martins ${ }^{548}$. Na opinião desse jurista, a execução provisória da sentença é o terreno apropriado para a doutrina do abuso do processo. Ele ensina que, se o litigante que promove a execução provisória sucumbe ao final, em razão do provimento do recurso e da consequente reforma ou anulação da decisão exequenda, ele deve devolver os proventos da execução e restaurar o estado patrimonial anterior porque aquele que executa uma decisão ainda não definitiva é considerado sempre imprudente.

Algumas vozes simplesmente anunciam que os arts. 475-O, I e II; e 811 do CPC versam sobre abuso do processo, sem maiores explicações. É o caso de Theodoro Júnior ${ }^{549}$, que arrola o art. 475-O, I e II, do CPC como uma hipótese de abuso dos mecanismos processuais específicos na execução; e de Iocohama ${ }^{550}$, que cita o art. 811 do CPC como um caso de infração à lealdade processual cometida pela parte.

Acontece que, se os arts. 475-O, I e II; e 811 do CPC realmente tratassem de comportamentos abusivos, nos quais houvesse o exercício de situações jurídicas processuais com desvio de finalidade, para atingir escopos ilícitos ou ilegítimos, os atos neles previstos deveriam ser considerados ilícitos (item 1.8 "infra"). Mas, não é esse o entendimento da doutrina, que identifica a execução provisória que tenha lesado o executado, com superveniente reforma ou anulação do título, e a medida cautelar que tenha causado danos ao requerido e que tenha sido revogada posteriormente como exemplos de atos-fatos jurídicos processuais lícitos indenizativos ${ }^{551}$.

$\mathrm{Na}$ verdade, as normas supracitadas integram um sistema de balanceamento de certezas, probabilidades e riscos, inerente a toda a ordem processual, identificado por Dinamarco $^{552}$. De acordo com esse jurista, a ordem jurídica quer que, tanto quanto

\footnotetext{
${ }^{548}$ O Abuso do Direito e o Ato Ilícito, pp. 78-79.

${ }_{554}$ Abuso de Direito Processual no Ordenamento Jurídico Brasileiro, in Revista Forense, v. 344, p. 61.

${ }^{550}$ Litigância de Má-Fé e Lealdade Processual, p. 199.

${ }^{551}$ Nesse sentido: DIDIER JÚNIOR; NOGUEIRA, Teoria dos Fatos Jurídicos Processuais, pp. 44 e 46 ; BRAGA, Primeiras Reflexões sobre uma Teoria do Fato Jurídico Processual - plano de existência, in DIDIER JÚNIOR; EHRHARDT JÚNIOR (coords.), Revisitando a Teoria do Fato Jurídico: homenagem a Marcos Bernardes de Mello, p. 465.

${ }^{552}$ Instituições de Direito Processual Civil, vol. I, § 55, pp. 146-149; Instituições de Direito Processual Civil, vol. IV, § 1.828, pp. 906-907; A Instrumentalidade do Processo, pp. 279-287; 305; 306-312.
} 
possível, as decisões estatais sejam tomadas mediante critérios de certeza, diminuindo ao máximo os riscos de incerteza e de erro. Mas, levando em consideração que o risco de errar é inerente a qualquer processo (projeção da própria falibilidade humana), que a obsessão pela verdade é utópica e que é necessário um equilíbrio entre as exigências de celeridade e de ponderação, o legislador deliberadamente admite que o juiz tome certas decisões após uma mera avaliação da "probabilidade suficiente". A probabilidade consiste na preponderância dos elementos convergentes à aceitação de uma proposição sobre os elementos divergentes. Ela é mais que a credibilidade e a verossimilhança, mas é menos que a certeza. Sujeita-se ao critério da probalibilidade, por exemplo, a execução provisória, que é feita sempre sob o risco de que, inexistente o crédito, seja desconstituído o título executivo por decisão do órgão jurisdicional superior. O mesmo ocorre com as medidas de urgência (cautelares e antecipatórias de tutela), que o juiz concede ou nega embasado nas incertezas representadas pelo "fumus boni juris", e não na demonstração cabal da ocorrência dos fatos relevantes. O risco de erro nesses casos, com infidelidade ao ordenamento substancial, é manifesto. Mas, o legislador entende que a probabilidade de acerto é boa, permitindo que o escopo social de pacificação seja alcançado com menos delongas, o que compensa os riscos na maioria dos casos. O doutrinador explica que, em contrapartida, para garantir a segurança do sistema, o legislador estabelece mecanismos capazes de reduzir os riscos a níveis aceitáveis e de corrigir possíveis erros. Entre esses mecanismos estão: (a) o art. 475-O, II, do CPC, que prevê o desfazimento da execução provisória, reconduzindo-se as partes e seu patrimônio ao "status quo ante", caso a sentença exequenda seja reformada pelo tribunal que julgar o recurso interposto contra ela; e (b) a possibilidade de se revogar as medidas cautelares e as concessivas de antecipação de tutela, com restituição das partes e coisas ao "status quo ante" e responsabilização civil do beneficiário pelos danos eventualmente causados (art. 807, “caput", $2^{\mathrm{a}}$ parte; e art. 811 do CPC).

Taruffo $^{553}$ esclarece que a mera produção de consequências negativas, danosas, não é suficiente para a identificação do abuso do processo, uma vez que elas podem decorrer também do uso legítimo, não-abusivo, de um instrumento processual. De acordo com ele, para que haja abuso processual, é necessário não só a produção de efeitos danosos, mas também a constatação de que tais consequências não são próprias do remédio processual utilizado. Sendo assim, não resta dúvida de que os arts. 475-O, I e II; e 811 do CPC não

${ }^{553}$ Elementi per una Definizione di "Abuso del Processo", in AA.VV., Studi in Onore di Pietro Rescigno, vol. V, pp. 1129-1130. 
visam a reprimir o abuso processual, visto que a produção de danos na esfera jurídica da parte contrária decorre naturamente do exercício legítimo do poder de promover a execução provisória e do poder de ajuizar a demanda cautelar, inexistindo utilização do remédio processual com desvio de finalidade ${ }^{554}$.

Logo, quando os litigantes utilizam, de forma abusiva, os poderes de promover a execução provisória e de ajuizar a demanda cautelar, devem incidir tanto os dispositivos supracitados, que integram o sistema de balanceamento de certezas, probabilidades e riscos, quanto as normas repressoras do abuso do processo ${ }^{555}$. Por exemplo, se o autor da cautelar mente para demonstrar o "periculum in mora", obtém a medida cautelar e promove a sua efetivação, gerando danos para a parte contrária, mas advém sentença que lhe é desfavorável no processo principal, ele deve não só ser condenado a ressarcir os prejuízos, com fundamento no art. 811, I, do CPC, mas também sofrer as sanções previstas no art. 18 do CPC, por ter praticado litigância de má-fé (art. 17, II, do CPC) ${ }^{556}$.

\subsubsection{Elemento subjetivo (dolo e culpa)}

Desde o período de formação do instituto do abuso do direito, os juristas discutem de modo acalorado a relevância conferida ao elemento subjetivo (dolo ou culpa) na configuração do ato abusivo.

\footnotetext{
${ }^{554}$ No mesmo sentido é o magistério de Milman, para quem "o dever do autor da ação cautelar de indenizar os eventuais prejuízos causados pela execução da medida, nos casos do art. 811 do Código de Processo Civil, por si só nada tem a ver com o exercício ímprobo na demanda judicial" (Improbidade Processual: comportamento das partes e de seus procuradores no processo civil, p. 296).

555 Nesse sentido, a respeito do abuso da cautelar: MILMAN, Improbidade Processual: comportamento das partes e de seus procuradores no processo civil, pp. 208-209 e 296-297.

${ }^{556}$ Recentemente, o Superior Tribunal de Justiça apreciou caso de utilização temerária de ação cautelar:

"RECURSO ESPECIAL. RESPONSABILIDADE CIVIL. MICROSOFT. SUSPEITA DE PIRATARIA DE SOFTWARE. CAUTELAR DE VISTORIA, BUSCA E APREENSÃO. ABUSO DE DIREITO CONFIGURADO. DANOS MORAIS. QUANTUM. REEXAME DE PROVAS. SÚMULA O7/STJ.

1. Ação de indenização movida por empresa demandada pela Microsoft, mediante ação de busca $e$ apreensão, para vistoria de seus computadores e verificação da ocorrência de pirataria de "software".

2. Vistoria realizada, mediante ordem judicial concedida "inaudita altera pars", que não localizou nenhum "software" da empresa requerente da medida.

3. Apesar da importância de se assegurar ao autor de obra intelectual o direito de fiscalização de sua correta utilização, reconhecimento, no caso, da ocorrência de abuso de direito.

4. Interpretação do disposto no art. 14, § 5, da Lei 9.609/98, à luz da norma do art. 187 do CC/2002.

5. Elisão das conclusões do aresto recorrido que demandaria o revolvimento dos meios de convicção dos autos, providência vedada nesta sede nos termos da súmula 07/STJ.

6. Manutenção do valor arbitrado com razoabilidade pelas instâncias de origem a título de indenização pelos danos morais (cem mil reais) para o caso concreto.

(STJ, $3^{\text {a }}$ Turma, REsp 1.114.889/DF, Rel. Min. Paulo de Tarso Sanseverino, DJe 30/10/2012).
} 
É possível distinguir três correntes doutrinárias acerca dessa problemática: teorias subjetivistas (ou psicológicas), teorias objetivistas (ou finalistas) e teorias mistas (ou ecléticas).

\subsubsection{Teorias subjetivistas (ou psicológicas)}

Os seguidores dessa corrente doutrinária consideram o elemento subjetivo (ou seja, o dolo ou a culpa) imprescindível para caracterizar o ato abusivo. Subdividem-se em três teses $^{557}$ :

a) considera-se abusivo o ato praticado com a exclusiva intenção de prejudicar outrem. Vários autores franceses do século XIX e do início do século XX adotaram esse entendimento, dentre eles: Bonnecase, Demogue e Lalou;

b) os elementos essenciais para configurar a abusividade do ato são: o elemento subjetivo e a ausência de proveito com a sua prática ou de utilidade para o agente. Assim, se o indivíduo pratica um ato que sabe ser lesivo a outrem, porém o faz pretendendo obter para si um proveito ou utilidade, não comete abuso do direito. É o que defende Ripert;

c) há identidade de pressupostos entre o ato abusivo e o ato ilícito. Ou seja, para que reste caracterizado o abuso é necessário provar a prática de uma ação ou omissão culposa ou dolosa, a produção de um dano efetivo e o vínculo de causalidade entre este e aquela. Léon e Henri Mazeaud são adeptos desta corrente.

No âmbito legislativo, encamparam teorias subjetivistas: o Código alemão de 1900, § 226; o Código Civil suíço de 1907, art. 2º o Código Civil turco de 1926, art. $2^{\text {o }}$; e o Código Civil chinês de $1929^{558}$.

A crítica que se faz a essas teorias é que elas reduzem muito o âmbito de aplicação da doutrina do abuso do direito, dada a dificuldade de se provar o intento maléfico do agente nos casos concretos 559 .

\subsubsection{Teorias objetivistas (ou finalistas)}

\footnotetext{
${ }^{557}$ ABDO, O Abuso do Processo, pp. 38 e 116.

${ }^{558}$ CASTRO FILHO, Abuso do Direito no Processo Civil, p. 26.

${ }^{559}$ ABDO, O Abuso do Processo, p. 39.
} 
Sustentam que o elemento subjetivo não tem importância na caracterização do abuso. São utilizados os seguintes critérios para constatar o abuso do direito, dentre outros $^{560}$ :

a) desatendimento aos fins econômicos ou sociais do direito;

b) ausência de motivos sérios ou legítimos para a prática do ato;

c) falta de utilidade para o agente ou de interesse em praticar o ato;

d) exercício anormal ou irregular do direito.

Todos eles têm em comum a proibição do desvio de finalidade no exercício do direito subjetivo.

O maior expoente dessa corrente doutrinária foi Saleilles, para quem a configuração do ato abusivo depende da conjunção de dois elementos: (1) ausência de interesse legítimo ou de utilidade para o titular do direito; e (2) uso anormal do direito, que consiste na contrariedade à sua destinação econômico-social ${ }^{561}$.

No direito positivo, consagraram a teoria objetiva: o Código Civil soviético de 1923, art. 1º e o Código Civil brasileiro de 1916, art. 160, I ${ }^{562} 563$. Quanto ao atual Código Civil brasileiro, a maioria da doutrina entende que o seu art. 187 é uma hipótese de ato ilícito objetivo 564565 .

\subsubsection{Teorias mistas (ou ecléticas)}

Alguns doutrinadores combinam critérios objetivos e subjetivos para aferir a abusividade do ato. Adotam, assim, teorias mistas, que mesclam elementos das teorias subjetivistas e objetivistas. Dentre essas teorias, destaca-se a de Josserand, que merece uma exposição mais aprofundada.

\footnotetext{
${ }^{560}$ ABDO, O Abuso do Processo, pp. 39 e 116.

561 ABDO, O Abuso do Processo, pp. 39-40.

562 Bevilaqua (Código Civil dos Estados Unidos do Brasil Comentado, vol. 1, p. 348) expressamente afirma que o art. 160, I, do CC16 adotou a orientação finalista de Saleilles.

${ }^{563}$ CASTRO FILHO, Abuso do Direito no Processo Civil, p. 27.

${ }^{564}$ MIRAGEM, Abuso do Direito: ilicitude objetiva no direito privado brasileiro, in Revista dos Tribunais, vol. 842, pp. 13, 15, 21-22, 26 e 36; ASCENSÃO, A Desconstrução do Abuso do Direito, in Revista de Direito do Tribunal de Justiça do Estado do Rio de Janeiro, ${ }^{\circ}$ 66, pp. 72-73; BARBOSA MOREIRA, Abuso do Direito, in Revista Trimestral de Direito Civil, vol. 13, p. 105; BRAGA NETTO, Teoria dos Ilícitos Civis, p. 121.

É o que também estabelece o enunciado no 37 das Jornadas de Direito Civil do CEJ:

"Art. 187: A responsabilidade civil decorrente do abuso do direito independe de culpa e fundamenta-se somente no critério objetivo-finalístico".

565 Theodoro Júnior (Comentários ao Novo Código Civil, vol. III, t. II, pp. 129-133), porém, discorda, elegendo o dolo ou a culpa como pressuposto do abuso do direito.
} 
Josserand $^{566}$ faz uma análise da jurisprudência francesa de sua época e reconhece a existência de quatro critérios constitutivos do abuso do direito:

a) critério intencional: há abuso quando o titular do direito o exerce com a intenção de prejudicar outrem, bem como quando age com dolo ou culpa;

b) critério técnico: a "faute" (ou "falta" ${ }^{567}$ na execução do direito é o elemento que caracteriza o abuso;

c) critério econômico: o exercício do direito de maneira totalmente desinteressada, sem qualquer interesse legítimo, configura abuso do direito; e

d) critério social (ou finalista): o abuso consiste no exercício do direito de maneira desviada de sua função social.

Após estudar os três primeiros critérios, o autor conclui que, apesar de servirem para identificar vários casos de abuso do direito, eles só explicam parcialmente o fenômeno ${ }^{568}$. Para ele, o verdadeiro critério do abuso é o desvio da função social do direito, que engloba todos os demais (a intenção de prejudicar, a "faute" e a falta de interesse no exercício) $^{569}$.

O critério finalista parte do pressuposto de que todo direito é um "direito-função", uma vez que, quando a sociedade cria uma situação jurídica ativa e a atribui a um sujeito, ela o faz tendo em vista uma finalidade. Josserand denomina essa finalidade social de "espírito do direito". Toda vez que a conduta do titular do direito for contrária a esse “espírito", há abuso ${ }^{570}$.

O próprio Josserand admite que o critério finalista, proveniente do espírito do direito, é muito abstrato e fugidio, o que torna difícil a sua aplicação. Diante disso, ele propõe que os juízes façam uso da noção de "motivo legítimo" para a aferição da ocorrência, ou não, de desvio da função social. Segundo o autor, cabe ao magistrado verificar se o motivo (ou seja, o móvel anímico) que levou o titular do direito a praticar o

\footnotetext{
${ }^{566}$ De l'Esprit des Droits et de leur Relativité - théorie dite de l'abus des droits, p. 341.

${ }^{567}$ A "faute" (falta) estava prevista no art. 1.382 do Código Civil francês de 1804, que tinha o seguinte teor: "Toda e qualquer conduta comum do homem que causa a outrem um dano obriga-o, pela falta na qual ele incorreu, a repará-lo" (tradução nossa).

Segundo Menezes Cordeiro (Litigância de Má-Fé, Abuso do Direito de Ação e Culpa "in Agendo”, pp. 7980, nt. 203; 146-147; 167), o sistema de responsabilidade civil do "Code Napoléon" era simplesmente baseado na "faute". A "faute" era o pressuposto único da imputação delitual e, mais tarde, obrigacional, consistindo em um misto de culpa e de ilicitude. Por causa de sua imprecisão, o conceito de "faute" permite desenvolvimentos bastante amplos no campo da responsabilidade civil.

${ }^{568}$ JOSSERAND, De l'Esprit des Droits et de leur Relativité - théorie dite de l'abus des droits, pp. 368-369.

569 JOSSERAND, De l'Esprit des Droits et de leur Relativité - théorie dite de l'abus des droits, pp. 368 e 370.

${ }^{570}$ JOSSERAND, De l'Esprit des Droits et de leur Relativité - théorie dite de l'abus des droits, p. 370.
} 
ato era compatível, ou não, com a função social do direito. Se a resposta for positiva, a conduta é legítima; se for negativa, há abuso do direito ${ }^{571}$.

Deve-se salientar que, ao longo dos anos, independentemente de alterações legislativas, um mesmo direito pode ter seu "espírito" alterado por causa da evolução das ideias e dos costumes. Desse modo, um certo motivo que era justificável pode tornar-se revelador de um abuso. Em razão dessa flexibilidade, as noções de "motivo legítimo" e de "abuso" constituem instrumentos importantes de adaptação do direito ao meio social no qual, e pelo qual, ele se realiza ${ }^{572}$.

Josserand $^{573}$ pondera que é muito difícil de a pessoa lesada pela conduta abusiva provar em juízo que o titular do direito agiu sem um motivo legítimo, pois essa é uma prova negativa. Diante dessa dificuldade, ele sugere que a pessoa prejudicada procure demonstrar, não que o titular do direito agiu sem motivo legítimo, mas sim que ele praticou o ato impelido por um motivo ilegítimo. De acordo com o autor, as principais categorias de propósitos ilegítimos são as seguintes ${ }^{574}$ : (a) colusão (ou concerto fraudulento); (b) fraude à lei; (c) dolo; (d) intenção de prejudicar; (e) má-fé; e (f) motivos simplesmente faltosos ("fautifs"). Nos quatro primeiros (colusão, fraude à lei, dolo e intenção de prejudicar), o titular do direito age com consciência do dano e também com vontade de causá-lo. Já quando atua de má-fé, ele tem consciência do dano, mas não tem vontade de causá-lo. Por fim, nos motivos simplesmente faltosos ("fautifs"), o titular do direito nem mesmo tem consciência do dano. Josserand esclarece que esse rol é simplesmente enunciativo, contendo apenas as principais categorias de propósitos ilegítimos.

Foge dos objetivos do presente trabalho analisar profundamente cada um desses motivos ilegítimos. O que se pretende com esta breve exposição da teoria elaborada por Josserand é aclarar o seu caráter misto. Ela é objetiva, pois pressupõe que o juiz identifique qual é, em abstrato, a função social do direito que se reputa violado. Porém, ela também se mostra subjetiva porque, uma vez identificada a função social do direito, cabe ao juiz

\footnotetext{
${ }^{571}$ Nas palavras do autor:

"[...] nós somos obrigados a pôr nossas faculdades jurídicas a serviço de um motivo adequado ao seu espírito e à sua missão, se não, nós não as exercemos de verdade, mas nós abusamos delas" (tradução nossa) (JOSSERAND, De l'Esprit des Droits et de leur Relativité - théorie dite de l'abus des droits, p. 375).

572 JOSSERAND, De l'Esprit des Droits et de leur Relativité - théorie dite de l'abus des droits, pp. 379-380 e 396.

${ }^{573}$ De l'Esprit des Droits et de leur Relativité - théorie dite de l'abus des droits, p. 380.

${ }^{574}$ JOSSERAND, De l'Esprit des Droits et de leur Relativité - théorie dite de l'abus des droits, pp. 381-383.
} 
investigar qual motivo levou o seu titular a agir e, em seguida, analisar se ele estava, ou não, em sintonia com o "espírito do direito" "575.

\subsubsection{Da prescindibilidade do dolo e da culpa no abuso do processo}

A teoria do abuso do processo, como um ramo da teoria do abuso do direito, também apresenta discussões acerca da prescindibilidade, ou não, do elemento subjetivo na configuração da conduta abusiva. É possível identificar as seguintes opiniões:

a) para Dinamarco ${ }^{576}$, as multas a que aludem os arts. 18 e 601 do CPC não têm caráter indenizatório, mas sim repressivo e sua imposição depende sempre da demonstração de dolo processual, que é definido pelo autor como "conduta maliciosa, conscientemente endereçada a obter vantagem ilícita mediante prejuízo de outrem". De acordo com ele, os atos processuais sem esse teor subjetivo antiético, praticados com mera culpa, são insuscetíveis de reprimendas;

b) Stoco $^{577}$ sustenta que só ocorre abuso no processo se a parte agir com dolo (intenção deliberada de prejudicar, de causar dano, de obter vantagem ilícita ou de retardar $\mathrm{o}$ andamento do processo), ainda que eventual (o agente assume o risco de produzir o dano), ou com culpa grave (o autor não quer o resultado lesivo, mas comporta-se como se o tivesse querido). $\mathrm{O}$ abuso cometido por quem age com culpa leve (em que o paradigma é a diligência que o homem médio observa em sua conduta) ou levíssima (tem como parâmetro um grau de diligência que supera a do homem médio) é considerado irrelevante. Aduz o autor que, nas hipóteses previstas no art. 17, IV a VII, do CPC, a culpa é presumida, embora não seja dispensada ${ }^{578}$;

c) diante da dificuldade em perquirir a intenção do agente ao praticar os atos processuais, Barbi ${ }^{579}$ entende que, se fosse exigida a intenção de prejudicar (dolo) em todas as condutas do art. 17 do CPC, seria impossível uma repressão mais enérgica da má conduta das partes ${ }^{580}$. Por causa disso, sustenta que apenas em algumas hipóteses previstas

\footnotetext{
575 JOSSERAND, De l'Esprit des Droits et de leur Relativité - théorie dite de l'abus des droits, pp. 341 e 385-387.

${ }_{576}$ Instituições de Direito Processual Civil, vol. II, § 528-A, pp. 272 e 273; § 529, p. 277.

${ }^{577}$ Abuso do Direito e Má-Fé Processual - aspectos doutrinários, pp. 71, 73, 90, 94, 96-97, 150 e 151.

${ }^{578}$ STOCO, Abuso do Direito e Má-Fé Processual - aspectos doutrinários, p. 107.

${ }^{579}$ Comentários ao Código de Processo Civil, vol. I, § 159, pp. 124-125.

${ }^{580}$ Essa dificuldade na aplicação das normas repressoras do abuso do processo, causada pela exigência de atuação dolosa da parte, não foi constatada pelos processualistas apenas recentemente. Bonumá (Direito Processual Civil. vol. I. São Paulo: Saraiva e Cia., 1946, pp. 511-512) relata o mesmo problema quando o Código de Processo Civil de 1939 era vigente.
} 
nesse dispositivo o legislador expressamente exige o dolo, enquanto em outras está implícita a exigência somente de culpa grave. Dá como exemplo das primeiras o inciso III e, das últimas, os incisos I e VI. Quanto ao art. 22 do CPC, o autor defende que a sua aplicação não depende da intenção do réu, requerendo apenas a demonstração de culpa ${ }^{581}$;

d) Theodoro Júnior ${ }^{582}$ também afirma que a parte somente comete ato de litigância de má-fé se agir com dolo, salvo nas hipóteses dos incisos I, V e VI do art. 17 do CPC, em que se exige culpa grave;

e) para Barbosa Moreira ${ }^{583}$, o elemento subjetivo só é relevante para caracterizar a litigância de má-fé quando o legislador expressamente exige da parte uma atitude psicológica. Em seu texto, datado de 1977, o autor afirmou que essa exigência era encontrada nos incisos I ("não possa razoavelmente desconhecer"), II ("intencionalmente"), III ("intencionalmente") e IV ("com o intuito de conseguir objetivo ilegal") do art. 17 do CPC. Porém, os textos desses incisos foram profundamente alterados pela Lei $\mathrm{n}^{\circ}$ 6.771/80 e houve a inserção do inciso VII pela Lei $\mathrm{n}^{\circ}$ 9.668/98. Levando em consideração a redação atual do art. 17 do CPC, pode-se afirmar que somente nos incisos III ("para conseguir objetivo ilegal") e VII ("com intuito manifestamente protelatório") o legislador exige uma conduta dolosa de maneira expressa. Segundo o doutrinador, nas demais hipóteses desse dispositivo, em que o legislador silenciou a respeito do "animus" do agente, a parte pode ser punida pela simples prática da conduta descrita na lei, ou seja, pela simples verificação objetiva do tipo legal;

f) Vincenzi ${ }^{584}$ distingue dois tipos de responsabilidade processual: (1) a subjetiva, dos arts. 16 a 18 e 22 do CPC, que exigem dolo ou culpa para incidirem; e (2) a objetiva, dos arts. 20, 273 e 811 do CPC, que prescindem de elemento subjetivo, de modo que a responsabilidade decorre da simples movimentação da máquina judiciária;

Também não se trata de um fenômeno típico do Direito brasileiro. Versando sobre o Direito português, Menezes Cordeiro (Litigância de Má-Fé, Abuso do Direito de Ação e Culpa "in Agendo", pp. 50-51) faz comentário semelhante aos dos mencionados autores nacionais:

"No âmbito do Direito penal, estamos perante condutas muito enérgicas (as que integrem os tipos legais de crimes). Aí, o juízo de dolo, verificados os factos, é relativamente fácil. Fora dele e, designadamente, no Direito civil ou no Direito processual civil, onde não há tipos de ilícitos mas, antes, fórmulas gerais, qualquer conduta, por disparatada que se apresente, pode ser sempre defendida como (meramente) negligente. Exigir o dolo para pôr em ação a responsabilidade civil equivale, de facto, a bloqueá-la: a prova do dolo é muito difícil".

${ }_{581}$ BARBI, Comentários ao Código de Processo Civil, vol. I, § 203, p. 153.

${ }_{582}$ Abuso de Direito Processual no Ordenamento Jurídico Brasileiro, in Revista Forense, v. 344, pp. 56 e 62.

583 A Responsabilidade das Partes por Dano Processual no Direito Brasileiro, in Temas de Direito Processual, p. 26.

${ }^{584}$ A Boa-Fé no Processo Civil, pp. 98-104. 
g) para $\mathrm{Abdo}^{585}$, o ordenamento jurídico brasileiro optou pelo critério objetivofinalístico, mas isso não significa que a conduta processual abusiva deva ser totalmente desprovida de dolo ou culpa. Os arts. 273, II, e 17, IV, do CPC, por exemplo, exigem o dolo ou a culpa grave para incidirem, dada a presença dos vocábulos "manifesto", "propósito" e "oposição", que - segundo a autora - indicam a conduta dolosa do sujeito. Por outro lado, o art. 17, I, do CPC reclama apenas a culpa leve (falta de cautela, mediante negligência, imprudência ou imperícia);

h) Lucon $^{586}$ diz que os incisos I, VI e VII do art. 17 do CPC exigem dolo ou culpa grave para incidirem. Quanto às demais hipóteses de litigância de má-fé, elas só se configuram se houver dolo por parte do agente;

i) Oliveira ${ }^{587}$ também defende que a presença do dolo ou da culpa grave é imprescindível para a caracterização da litigância de má-fé. A autora esclarece que, em algumas das hipóteses elencadas no art. 17 do CPC, prescinde-se da intenção do agente, uma vez que o seu querer é considerado implícito na conduta (v.g., no inciso I);

j) na opinião de Taruffo ${ }^{588}$, não se pode falar de abuso do processo prescindindo do requisito subjetivo. $\mathrm{O}$ autor insere no rol de elementos essenciais do abuso do processo a vontade do agente de produzir consequências negativas distintas das que tipicamente derivam do exercício da situação jurídica processual de que é titular. Ele apenas não deixa claro se é necessário que haja sempre dolo, ou se condutas praticadas com culpa (grave ou leve) também podem ser consideradas abusivas.

O Brasil não é o único país em que a doutrina discute se o abuso do processo tem, ou não, como elemento essencial o dolo ou a culpa. Essa discussão é comum a todos os ordenamentos jurídicos que não exijam expressamente algum elemento subjetivo nas hipóteses legalmente previstas de improbidade processual ${ }^{589}$. Peyrano ${ }^{590}$ e Lucas Sosa ${ }^{591}$

\footnotetext{
585 O Abuso do Processo, pp. 120-121.

${ }^{586}$ Abuso do Exercício do Direito de Recorrer, in NERY JÚNIOR; ALVIM WAMBIER (coords.), Aspectos Polêmicos e Atuais dos Recursos Cíveis e de Outras Formas de Impugnação às Decisões Judiciais, pp. 884885.

${ }^{587}$ Litigância de Má-Fé, pp. 34, 36.

${ }^{588}$ Elementi per una Definizione di "Abuso del Processo", in AA.VV., Studi in Onore di Pietro Rescigno, vol. V, pp. 1130 e 1131.

${ }^{589}$ Em Portugal, por exemplo, o legislador se preocupou em explicitar, no $\S 2^{\circ}$ do art. 456 do CPC, a necessidade de dolo ou culpa grave na litigância de má-fé:

"Diz-se litigante de má fé quem, com dolo ou negligência grave:

a) Tiver deduzido pretensão ou oposição cuja falta de fundamento não devia ignorar;

b) Tiver alterado a verdade dos factos ou omitido factos relevantes para a decisão da causa;

c) Tiver praticado omissão grave do dever de cooperação;

d) Tiver feito do processo ou dos meios processuais um uso manifestamente reprovável, com o fim de conseguir um objectivo ilegal, impedir a descoberta da verdade, entorpecer a acção da justiça ou protelar, sem fundamento sério, o trânsito em julgado da decisão" (destaque nosso).
} 
comunicam que, na Argentina, também se debate muito essa questão. Eles, particularmente, preferem a teoria objetiva, entendendo ser desnecessário o elemento subjetivo na configuração das condutas abusivas. No Uruguai, a doutrina e a jurisprudência majoritárias são no sentido de que o abuso processual somente ocorre se o sujeito agir com dolo ou culpa grave. Porém, alguns juristas uruguaios se opõem a esse entendimento, sustentando que o comportamento meramente culposo também pode ser considerado abusivo e acarretar sanções para o sujeito processual que o praticou ${ }^{592}$. Após analisar relatórios elaborados por autores de diversos países, Taruffo ${ }^{593}$ chegou à seguinte conclusão acerca desse tema: "Na maior parte dos sistemas, o estado mental subjetivo do autor de um comportamento abusivo tem alguma importância; contudo, a relevância atual desse estado mental varia muito" (tradução nossa).

Levando em consideração apenas o ordenamento jurídico pátrio, parece ser mais correta a tese segundo a qual nem sempre é necessária a presença de algum elemento subjetivo (dolo ou culpa) para caracterizar o abuso do processo. Afirma-se isso porque o legislador realmente deixa claro, em diversas ocasiões, que a existência de dolo ou culpa grave é relevante para que determinado ato processual seja qualificado como abusivo. São exemplos disso o art. 17, VII (que exige "intuito manifestamente protelatório" da parte para incidir); e o art. 233 do CPC (faz menção expressa ao dolo do sujeito processual). Por outro lado, em outros dispositivos, ele não faz qualquer alusão à atitude psicológica dos litigantes (v.g., art. 17, I; art. 22; art. 69, I; e art. 267, § 3º do CPC). Essas divergências nos textos legais denotam a correção da teoria da prescindibilidade do dolo e da culpa no abuso do processo ${ }^{594}$.

Isso, contudo, não eliminou totalmente as discussões acerca do elemento subjetivo do abuso do processo em solo lusitano. A doutrina e a jurisprudência debatem, por exemplo, em quais condutas típicas de litigância de má-fé é necessário o dolo e em quais basta a negligência grave para que haja responsabilidade (MENEZES CORDEIRO, Litigância de Má-Fé, Abuso do Direito de Ação e Culpa "in Agendo", p. 56).

${ }^{590}$ Abuso de los Derechos Procesales, in BARBOSA MOREIRA (coord.), Abuso dos Direitos Processuais, pp. 71 e $72-73$.

${ }^{591}$ Abuso de Derechos Procesales, in BARBOSA MOREIRA (coord.), Abuso dos Direitos Processuais, pp. 51-54.

${ }^{592}$ Landoni Sosa (El Abuso de los Derechos Procesales, in BARBOSA MOREIRA (coord.), Abuso dos Direitos Processuais, pp. 140-146 e 151) é um representante da tese majoritária, enquanto Greif (El Abuso del Derecho y la Responsabilidad Civil Emergente en el Derecho Uruguayo, in BARBOSA MOREIRA (coord.), Abuso dos Direitos Processuais, pp. 158-160; 163-165; e 168-170) faz parte da corrente minoritária no Uruguai.

${ }_{593}$ General Report, in TARUFFO (ed.), Abuse of Procedural Rights: comparative standards of procedural fairness, p. 22.

${ }^{594}$ No Brasil, essa teoria é adotada não só por Barbosa Moreira (cuja opinião foi mencionada "supra" e serviu de base para o entendimento ora esposado), mas também por Castro Filho (Abuso do Direito no Processo Civil, p. 29) e, aparentemente, por Fernandes de Souza (Abuso de Direito Processual - uma teoria pragmática, pp. 113-114, 117 e 131, nt. 97). 
Esse entendimento coaduna-se até mesmo com a teoria do abuso do direito de Josserand. Como já se afirmou anteriormente (item 1.6.3.3 "supra"), o jurista francês sustenta que o verdadeiro critério constitutivo do abuso é o desvio da função social do direito (ou, segundo ele, o desvio do "espírito do direito") 595 . Para facilitar a aplicação do critério finalista, que é muito abstrato, o autor propõe o uso da noção de "motivo legítimo", a qual é a exteriorização daquele critério ${ }^{596}$. Para ele, portanto, a análise da presença do motivo ilegítimo serve apenas para revelar a ocorrência, ou não, de desvio da função social em cada caso concreto. Ocorre que, no âmbito processual, o legislador brasileiro já estatui, de antemão, quais condutas processuais são praticadas com desvio de finalidade, para atingir escopo ilícito ou ilegítimo (v.g., art. 17; art. 233; art. 538, parágrafo único; 557, § $2^{\circ}$; art. 600, II, do CPC etc.), tornando desnecessário perquirir se o móvel anímico que levou o sujeito processual a praticar o ato concreto era compatível, ou não, com a função social da situação jurídica processual por ele exercida, exceto se a lei assim o exigir.

Além disso, Josserand apresenta um rol exemplificativo de propósitos ilegítimos, os quais revelariam a ocorrência de desvio da função social, contendo seis categorias ${ }^{597}:$ (1) colusão (ou concerto fraudulento); (2) fraude à lei; (3) dolo; (4) intenção de prejudicar; (5) má-fé; e (6) motivos simplesmente faltosos ("fautifs"). O doutrinador explica que, na colusão, na fraude à lei, no dolo e na intenção de prejudicar, o titular do direito age com consciência do dano e também com vontade de causá-lo. Já no caso de atuação de má-fé, ele tem consciência do dano, mas não tem vontade de causá-lo. Por fim, nos motivos simplesmente faltosos ("fautifs"), o titular do direito não tem consciência do dano. Constata-se que o referido jurista também não exige, sempre, a presença de um elemento subjetivo para caracterizar o abuso do direito, o que demonstra que não é um absurdo sustentar a possibilidade de algumas hipóteses de abuso processual concretizarem-se independentemente de dolo ou de culpa do agente ${ }^{598}$.

\footnotetext{
595 JOSSERAND, De l'Esprit des Droits et de leur Relativité - théorie dite de l'abus des droits, pp. 368 e 370 .

${ }^{596}$ JOSSERAND, De l'Esprit des Droits et de leur Relativité - théorie dite de l'abus des droits, p. 375.

${ }^{597}$ JOSSERAND, De l'Esprit des Droits et de leur Relativité - théorie dite de l'abus des droits, pp. 381-383.

598 Oteiza (Abuso de los Derechos Procesales en América Latina, in BARBOSA MOREIRA (coord.), Abuso dos Direitos Processuais, pp. 21-22) também menciona a teoria de Josserand ao sustentar que o dolo ou a culpa não é um elemento essencial do abuso do processo:

"Participo da tese que não restringe a responsabilidade pelo uso abusivo das vias processuais àqueles casos em que quem cause um dano tenha atuado de forma dolosa ou com culpa grave. Quando um dos sujeitos atua sem motivo legítimo (nas palavras de Josserand) quebra o princípio da boa-fé e tal situação se produz não somente no agir doloso, podendo estar presente naqueles casos em que a diligência empregada para examinar sua própria conduta rompe o parâmetro médio de razoabilidade na apreciação das consequências dos atos. A relação processual impõe aos partícipes do processo a obrigação de se conduzir de acordo com a finalidade própria de um debate dirigido a resolver o conflito com justiça. A seriedade dessa obrigação
} 
Por fim, cumpre mencionar um argumento de ordem histórica contrário à imprescindibilidade do requisito subjetivo para a configuração do abuso do processo: segundo Menezes Cordeiro ${ }^{599}$, a introdução do requisito do dolo para a caracterização da litigância de má-fé no Direito lusitano foi parte de um movimento doutrinário no sentido de proteger os advogados e procuradores contra a incidência de leis que versavam sobre a sua responsabilidade processual, especificamente os $\S \S 7^{\circ}$ e $10^{\circ}$ do Título XLVIII do Livro I das Ordenações Filipinas. Ou seja, diante dos rigores da lei, a doutrina fixou um requisito subjetivo de difícil comprovação, com o escopo de dificultar a punição dos sujeitos processuais nos casos concretos. Posteriormente, essa orientação foi incorporada em diplomas legislativos portugueses, a começar pela Lei da Boa Razão, chegando ao atual Código de Processo Civil português, cujo art. 456, $\S 2^{\circ}$, elenca a presença do dolo ou da negligência grave como essencial para a caracterização da litigância de má-fé.

Pode-se afirmar, portanto, que não merece ser acolhida a tese que elege a demonstração do dolo ou da culpa como um elemento essencial dos atos processuais abusivos, não só porque ela parece contrariar a vontade do legislador brasileiro (que em diversos trechos da lei não exige a presença de qualquer elemento subjetivo para que incidam as sanções por abuso do processo) e a teoria de Josserand, mas também porque permitiria a impunidade de muitos casos de improbidade processual, notadamente aqueles em que é difícil perquirir se a parte agiu impelida por algum desses elementos anímicos, o que neutralizaria, na prática, o funcionamento das normas sancionatórias.

\subsubsection{Dano}

O sujeito que comete abuso do processo serve-se da atividade dos órgãos judiciais injustificadamente, em razão de erro grosseiro ou de temeridade, ou então maliciosamente, com o intuito de prejudicar outrem ou de obter resultados ilícitos que não conseguiria atingir sem o concurso estatal. Como a manutenção da estrutura do Poder Judiciário demanda elevados custos, ele desperdiça o dinheiro público e, consequentemente, lesa o Estado $^{600}$.

permite valorar com amplitude e determinar a existência de responsabilidade quando é possivel inferir a disfuncionalidade do comportamento" (tradução nossa).

${ }_{599}$ Litigância de Má-Fé, Abuso do Direito de Ação e Culpa “in Agendo", pp. 41-42 e 52.

${ }^{600}$ CASTRO FILHO, Abuso do Direito no Processo Civil, pp. 32-33 e 190. 
Somem-se a isso os danos causados à eficiência da administração da justiça ${ }^{601}$, que nem sempre têm expressão econômica ${ }^{602}$. O abuso de situações jurídicas processuais impede o processo de atuar a vontade concreta do direito material (escopo jurídico), de pacificar os litigantes com justiça, de educar as pessoas para que respeitem os direitos alheios (escopos sociais) e de contribuir para a estabilidade das instituições (escopo político). Em suma, as condutas abusivas dos sujeitos processuais são fatores que embaraçam o correto exercício da função jurisdicional pelo Estado ${ }^{603}$.

$\mathrm{O}$ fato de o comportamento processual abusivo afetar, invariavelmente, o interesse público é importante porque faz com que o "improbus litigator" mereça sempre ser sancionado, independentemente de ter, ou não, lesado a parte contrária ou um terceiro estranho ao processo ${ }^{604}$.

Além do prejuízo causado ao Estado, a conduta abusiva de uma das partes potencializa o dano marginal do processo ${ }^{605}$, o que acaba atingindo os direitos da parte contrária. Também pode lesar o âmbito extrapatrimonial da esfera jurídica do litigante

${ }^{601}$ DONDI; GIUSSANI, Appunti sul Problema dell'Abuso del Processo Civile nella Prospettiva de Iure Condendo, in Rivista Trimestrale di Diritto e Procedura Civile, vol. 61, no 1, pp. 193-194; LUCON, Abuso do Exercício do Direito de Recorrer, in NERY JÚNIOR; ALVIM WAMBIER (coords.), Aspectos Polêmicos e Atuais dos Recursos Cíveis e de Outras Formas de Impugnação às Decisões Judiciais, pp. 882, 885 e 893; BARBOSA MOREIRA, A Responsabilidade das Partes por Dano Processual no Direito Brasileiro, in Temas de Direito Processual, p. 16; TARUFFO, General Report, in TARUFFO (ed.), Abuse of Procedural Rights: comparative standards of procedural fairness, pp. 5 e 15; THEODORO JÚNIOR, Abuso de Direito Processual no Ordenamento Jurídico Brasileiro, in Revista Forense, v. 344, pp. 52-53; OLIVEIRA, Litigância de Má-Fé, pp. 66-67, 73-75 e 81; VIRÍSSIMO CUNHA, Simulação Processual e Anulação do Caso Julgado, pp. 42-44; PUOLI, Os Poderes do Juiz e as Reformas da Lei Processual Civil Brasileira, p. 196; ALBUQUERQUE, Responsabilidade Processual por Litigância de Má Fé, Abuso de Direito e Responsabilidade Civil em Virtude de Actos Praticados no Processo, pp. 55-56; BEAUMONT, Report on Abuse of Procedural Rights for Australia, in TARUFFO (ed.), Abuse of Procedural Rights: comparative standards of procedural fairness, p. 102; FALCO, La Buona Fede e l'Abuso del Diritto: principi, fattispecie e casistica, p. 506.

${ }^{602}$ PEYRANO, Abuso de los Derechos Procesales, in BARBOSA MOREIRA (coord.), Abuso dos Direitos Processuais, p. 76.

${ }^{603}$ Quando Menezes Cordeiro (Litigância de Má-Fé, Abuso do Direito de Ação e Culpa “in Agendo”, p. 56) afirma que a lei processual pune a litigância de má-fé independentemente do resultado e que, por causa disso, ela segue o caminho da ilicitude como desvalor da conduta, e não como desvalor do resultado, ele parece ignorar que o abuso do processo tenha sempre essa eficácia lesiva ao Estado.

${ }^{604}$ CASTRO FILHO, Abuso do Direito no Processo Civil, pp. 33 e 190-191; TAELMAN, Abuse of Procedural Rights: regional report for Belgium-The Netherlands, in TARUFFO (ed.), Abuse of Procedural Rights: comparative standards of procedural fairness, pp. 127-128.

${ }^{605} \mathrm{O}$ dano marginal é aquele gerado pelo tempo que se demora para praticar todos os atos do procedimento tendentes a outorgar a prestação jurisdicional definitiva a quem tem razão. É uma perda de tempo natural, fisiológica, que pode ter várias origens, dentre elas: o grande número de recursos e remédios que o ordenamento jurídico prevê para impugnar os atos decisórios; a demora excessiva no julgamento desses recursos e remédios; o efeito suspensivo dos recursos; a desvalorização das decisões de primeiro grau; a excessiva duração da instrução probatória etc. (LUCON, Abuso do Exercício do Direito de Recorrer, in NERY JÚNIOR; ALVIM WAMBIER (coords.), Aspectos Polêmicos e Atuais dos Recursos Cíveis e de Outras Formas de Impugnação às Decisões Judiciais, p. 878). 
adversário, já que causa também danos morais em alguns casos ${ }^{606} 607$. Daí a doutrina considerar o abuso do processo um "ilícito pluriofensivo" 608 .

Portanto, é impossível o abuso processual não gerar, na prática, algum resultado danoso. Sendo assim, o dano deve ser considerado mais uma consequência natural do abuso do processo que um requisito para sua ocorrência ${ }^{609}$.

Aliás, em alguns casos, abusividade do ato processual é revelada somente com a produção das consequências negativas. Por exemplo, quando uma das partes requer a expedição de carta precatória para a realização de um determinado ato fora da comarca em que tramita o processo (arts. 200-201 do CPC), normalmente o juiz só consegue aferir se aquela conduta era, ou não, inútil e protelatória com a resposta do juízo deprecado ${ }^{610}$.

\subsection{Circunstâncias que não configuram requisitos do ato processual abusivo}

Depois de tratar dos requisitos necessários para classificar um ato processual como abusivo, cumpre destacar algumas circunstâncias processuais que não integram a essência do abuso do processo.

A primeira delas é a sucumbência do litigante que perpetrou a conduta abusiva. $\mathrm{Na}$ maioria dos casos, a parte que é considerada "improbus litigator" também tem a sua demanda julgada improcedente. Porém, é perfeitamente possível que uma pessoa que tenha razão no âmbito do direito substancial cometa uma conduta processual ímproba. Nesses casos, ainda que o magistrado, no final do processo, entenda que a pretensão do litigante ímprobo é justa, ele deve aplicar-lhe as sanções prescritas pela lei. Assim, a sentença judicial fica com pelo menos dois capítulos: um julgando procedente o pedido da parte e outro a condenando pela prática processual abusiva.

\footnotetext{
${ }^{606}$ ABDO, O Abuso do Processo, pp. 123-126; OLIVEIRA, Litigância de Má-Fé, pp. 66-67 e 81.

607 Mesmo antes da Constituição Federal de 1988, que pioneiramente positivou a possibilidade de se indenizar os danos morais (art. $5^{\circ}, \mathrm{X}, \mathrm{da} \mathrm{CF}$ ), a doutrina já defendia a tese de que o abuso do processo gera dano moral. Nesse sentido: CASTRO FILHO, Abuso do Direito no Processo Civil, pp. 203-206.

${ }^{608}$ Nesse sentido: TARUFFO, Elementi per una Definizione di "Abuso del Processo", in AA.VV., Studi in Onore di Pietro Rescigno, vol. V, p. 1132; DONDI; GIUSSANI, Appunti sul Problema dell'Abuso del Processo Civile nella Prospettiva de Iure Condendo, in Rivista Trimestrale di Diritto e Procedura Civile, vol. 61, no 1, p. 194.

${ }^{609}$ Taruffo (Elementi per una Definizione di "Abuso del Processo", in AA.VV., Studi in Onore di Pietro Rescigno, vol. V, p. 1131) e Abdo (O Abuso do Processo, p. 123), por exemplo, sustentam que a efetiva produção de consequências danosas é essencial para a caracterização do abuso do processo.

${ }^{610}$ Exemplo fornecido por Abdo (O Abuso do Processo, p. 123).
} 
Logo, não se pode considerar a sucumbência como um indício de litigância de máfé $^{611}$, nem a procedência da demanda como uma imunidade às sanções decorrentes do abuso do processo, já que "mesmo quem tem o direito a seu favor deve agir corretamente em juízo para a sua defesa" ${ }^{\text {612 }} 613$.

Contudo, há casos em que a improcedência muito provavelmente acarreta também o reconhecimento do abuso do processo perpetrado pelo litigante vencido. Por exemplo, quando se demanda em juízo a execução de obrigação contraída sob fraude, erro, dolo, violência ou coação; ou quando se pleiteia o adimplemento de dívida que sabidamente já foi paga ${ }^{614}$. Nesses casos, a cobrança da dívida em juízo pressupõe uma distorção da verdade subjetiva, ou seja, uma violação do dever de veracidade (arts. 14, I; e 17, II, do CPC), já que ninguém pleitearia em juízo a cobrança de uma dívida afirmando, na petição inicial, que ela foi constituída, por exemplo, mediante coação. Então, quando o juiz constata a existência da fraude, do erro, do dolo, da violência, da coação, ou do pagamento, e se convence de que o litigante mentiu dolosamente em juízo, ele deve julgar a demanda improcedente e, imediatamente, condenar o demandante pela prática de litigância de má-fé.

Em tese, é igualmente irrelevante para a constatação do abuso do processo a verificação da perfeição dos atos processuais.

Em respeito ao princípio do devido processo legal, todo o processo é regido por regras preestabelecidas. Algumas delas prescrevem requisitos para a perfeição do ato jurídico processual. Dinamarco ${ }^{615}$ classifica esses requisitos em:

a) formais, que são extrínsecos ao ato processual, dizendo respeito ao modo, ao tempo e ao lugar de sua prática;

b) não-formais, os quais exigem que: (1) o autor do ato seja pessoa a quem o Direito atribuiu qualidade para realizá-lo; (2) o autor tenha manifestado a vontade de produzir os resultados do ato; (3) o efeito visado seja materialmente possível; (4) os

\footnotetext{
${ }^{611}$ Nesse sentido: CASTRO FILHO, Abuso do Direito no Processo Civil, pp. 133 e 164; VINCENZI, A BoaFé no Processo Civil, p. 100; DINAMARCO, Instituições de Direito Processual Civil, vol. II, § 528-A, p. 271; OLIVEIRA, Litigância de Má-Fé, pp. 38 e 69; LUSO SOARES, A Responsabilidade Processual Civil, pp. 192-193.

${ }^{612}$ BARBI, Comentários ao Código de Processo Civil, vol. I, § 168, p. 130.

${ }^{613}$ Os tribunais franceses parecem não compartilhar desse entendimento, pois há julgados no sentido de que a pessoa que triunfa, ainda que parcialmente, em sua demanda ou em seu recurso não pode ser condenada pela prática de abuso processual (Nouveau Code de Procédure Civile, p. 56, nt. 3 ao art. 32.1; e p. 363, nt. 9 ao art. 559).

${ }^{614}$ Nesse sentido: CASTRO FILHO, Abuso do Direito no Processo Civil, pp. 132-133.

No entanto, o autor parece ser muito severo ao sustentar que o acolhimento da exceção de pagamento do débito sempre enseja a condenação do demandante por abuso do processo. Quando o autor da demanda desconhecer o pagamento do débito pelo réu, não há litigância de má-fé.

${ }^{615}$ DINAMARCO, Instituições de Direito Processual Civil, vol. II, § 703, p. 597.
} 
resultados sejam também admitidos pelo Direito; e (5) o ato seja juridicamente adequado à produção dos resultados pretendidos.

Tais requisitos não devem ser desprezados porque constituem um fator de segurança para o processo, contribuindo para a justiça da decisão. Sua observância garante: (a) a igualdade das partes; (b) a efetividade do contraditório; (c) o atingimento da finalidade do ato; e (d) que o procedimento não seja conduzido de modo arbitrário pelo órgão jurisdicional ${ }^{616}$.

Versando sobre o abuso do direito no Código de Processo Civil de 1939, Castro Filho ${ }^{617}$ defende que a falta de condição da ação, ou de pressuposto processual, ou de requisito especial para certos atos judiciais ou procedimentos (e.g., os atuais arts. 283; 950; 967, "caput", do $\mathrm{CPC}^{618}$ etc.), ou ainda a presença de algum fato impeditivo ou extintivo do processo (v.g., litispendência, coisa julgada, fatos que ensejam a extinção do processo sem o julgamento do mérito etc.) ou de certas defesas prévias (por exemplo, o benefício de inventário, previsto no art. 1.792 do CC, em virtude do qual o herdeiro não responde por encargos superiores às forças da herança) indica o uso indevido do processo por parte do autor da demanda. Mas, diante da presunção relativa de que as pessoas atuam em juízo de boa-fé, o jurista observa que a caracterização do abuso do processo nesses casos exige a demonstração da ocorrência de dolo, fraude, simulação, erro grosseiro, emulação, capricho, temeridade, violência, intuito protelatório, desrespeito ao dever de veracidade, ou o exercício do poder de dispor de meios executivos para efetivar um título judicial provisório.

Analogamente, ao tratar do abuso do processo por parte do réu, o mesmo doutrinador $^{619}$ explica que a parte deve preencher exigências processuais para utilizar os meios de defesa, sendo necessária a satisfação de certas condições da ação (legitimidade “ad causam"), de certos pressupostos processuais (como a capacidade processual) e de requisitos especiais, bem como a inexistência de determinados fatos impeditivos e extintivos do processo (como a litispendência e a coisa julgada relativamente à defesa

\footnotetext{
${ }^{616}$ Nesse sentido: BEDAQUE, Efetividade do Processo e Técnica Processual, pp. 411 e 418.

${ }^{617}$ Abuso do Direito no Processo Civil, pp. 118-124, 130-131, 133-135, 159, 161, 163-164, 167.

${ }^{618}$ Esses artigos determinam, respectivamente, o seguinte:

"Art. 283. A petição inicial será instruída com os documentos indispensáveis à propositura da ação";

"Art. 950. Na petição inicial, instruída com os títulos da propriedade, designar-se-á o imóvel pela situação e denominação, descrever-se-ão os limites por constituir, aviventar ou renovar e nomear-se-ão todos os confinantes da linha demarcanda";

"Art. 967. A petição inicial, elaborada com observância dos requisitos do art. 282 e instruída com os títulos de domínio do promovente [...]".

${ }^{619}$ CASTRO FILHO, Abuso do Direito no Processo Civil, pp. 137, 140-141, 161, 163-164, 167.
} 
arguida). A insatisfação de qualquer uma dessas exigências processuais, segundo o jurista, é indício de uso indevido do processo. Porém, para que se considere que o réu cometeu abuso no exercício do seu direito de defesa, Castro Filho afirma que é preciso demonstrar que ele procedeu com dolo, fraude, simulação, erro grosseiro, emulação, capricho, temeridade, violência ou falta ao dever de veracidade.

O que se infere da teoria de Castro Filho é que a constatação do desrespeito a algum requisito para a perfeição do ato processual é nada mais que um indício de improbidade. Apenas se pode afirmar que alguém cometeu conduta abusiva quando um ato processual de sua autoria materializar todos os elementos que constituem o suporte fático hipotético de alguma das normas que previnem ou sancionam expressamente o abuso do processo, acarretando a incidência desta. Caso contrário, a imperfeição (formal ou nãoformal) do ato jurídico processual configura apenas um vício, que pode ensejar diversos efeitos, dependendo da natureza e da gravidade do defeito e também da natureza do próprio ato (desde a mera irregularidade até a inexistência do ato jurídico, passando pela nulidade, pela ineficácia e pela impossibilidade ou retardo do julgamento do mérito da causa) $)^{620621}$.

Nada impede, porém, o legislador de descrever no suporte fático hipotético de norma jurídica que previne ou sanciona o abuso do processo a prática de um ato processual imperfeito, que não preencha requisitos formais ou não-formais. Nesse caso, toda vez que um sujeito praticar aquele ato processual da maneira viciada descrita na norma, esta incide inexoravelmente e ele passa a ser considerado um litigante ímprobo. Por exemplo, no inciso I do art. 17 do CPC, o legislador considera litigante de má-fé quem deduz pretensão contra texto expresso de lei. Sendo assim, deve-se considerar "improbus litigator" quem ajuíza uma demanda juridicamente impossível, que é aquela que "de algum modo colide com regras superiores do direito nacional e, por isso, sequer comporta apreciação mediante exame de seus elementos concretos" ${ }^{\text {622 }}$. Outro exemplo: o inciso VI do art. 17 do CPC diz ser litigante de má-fé a pessoa que provoca incidentes manifestamente infundados. Subsume-se a esse dispositivo o comportamento da parte que interpõe recurso considerado inadmissível em razão de ela ter praticado anteriormente ato impeditivo do

${ }^{620}$ DINAMARCO, Instituições de Direito Processual Civil, vol. II, § 705, p. 599.

${ }^{621}$ É o que também se infere da obra de Fernandes de Souza (Abuso de Direito Processual - uma teoria pragmática, p. 121):

"[...] o só fato de o processo ter sido extinto sem julgamento do mérito não implica reconhecer abuso do direito de demanda, porquanto a ação, no dizer de Degenkolb, é um direito público subjetivo, reconhecido a quem creia, de boa-fé, ter razão. Importa saber se houve dolo, culpa ou, em outras palavras, intenção de prejudicar, descaso, temeridade no momento de considerar a propositura da ação".

${ }_{622}$ DINAMARCO, Instituições de Direito Processual Civil, vol. II, § 543, p. 307. 
poder de recorrer (v.g., desistência do pedido ou do processo por parte do autor; reconhecimento do pedido por parte do réu).

Por conseguinte, Taruffo ${ }^{623}$ está correto ao distinguir as "simple' violations of procedural rules" das " "abusive' violations of procedural rules". Segundo o jurista italiano, o ato abusivo pode ser cometido mediante a violação de uma regra processual, mas há também situações em que o abuso se refere ao exercício formalmente legítimo de situações subjetivas.

Em resumo, pode-se afirmar que não configuram requisitos do abuso do processo: o julgamento de improcedência da demanda do "improbus litigator" e a imperfeição (formal ou não-formal) do ato processual, muito embora algum comportamento ímprobo concreto possa, eventualmente, ter uma dessas características ou ambas.

\subsection{Ato processual abusivo como espécie do gênero "fatos jurídicos processuais lato sensu ilícitos"}

Com o escopo de ordenar a conduta humana, as normas jurídicas valoram os fatos da vida e erigem à categoria de "fatos jurídicos" aqueles que têm relevância para o relacionamento inter-humano, atribuindo-lhes consequências específicas (efeitos jurídicos) em relação aos homens. Somente o fato que esteja regulado por uma norma jurídica pode ser considerado um "fato jurídico", ou seja, um fato gerador de direitos, deveres, pretensões, obrigações ou qualquer outro efeito jurídico ${ }^{624}$. Segundo a melhor doutrina, fato jurídico é "o fato ou complexo de fatos sobre o qual incidiu a regra jurídica; portanto, o fato de que dimana, agora, ou mais tarde, talvez condicionalmente, ou talvez não dimane eficácia jurídica" ${ }^{, 625}$.

Diversos doutrinadores se dispuseram a elaborar uma taxonomia dos fatos jurídicos. Dentre as várias classificações, destaca-se a proposta por Pontes de Miranda, a qual foi aprofundada por Marcos Bernardes de Mello ${ }^{626}$. O autor alagoano adota como

\footnotetext{
${ }^{623}$ General Report, in TARUFFO (ed.), Abuse of Procedural Rights: comparative standards of procedural fairness, pp. 8-9.

${ }^{624}$ MELLO, Teoria do Fato Jurídico: plano da existência, pp. 7-9.

${ }^{625}$ PONTES DE MIRANDA, Tratado de Direito Privado, t. I, p. 77.

${ }^{626}$ Existem outras classificações dos fatos jurídicos, como, por exemplo, a de Gomes (Introdução ao Direito Civil, pp. 188-189), que os agrupa em duas grandes categorias:

a) a dos acontecimentos naturais, que podem ser (1) ordinários (v.g., nascimento, morte, decurso de tempo, frutificação de plantas) ou (2) extraordinários (e.g., caso fortuito, força maior, "factum principis"); e

b) a das ações humanas, que podem ser (1) de efeitos jurídicos voluntários (atos jurídicos "lato sensu”); ou

(2) de efeitos jurídicos involuntários (atos ilícitos).
} 
critério de classificação os dados essenciais que integram o suporte fático hipotético de cada fato jurídico, descritos nas normas jurídicas ${ }^{627}$.

Os suportes fáticos das normas jurídicas são compostos por vários elementos, dentre os quais está o cerne do fato jurídico, que o define e caracteriza como espécie ${ }^{628}$. Os seguintes elementos são identificados como nucleares (cerne) dos fatos jurídicos, capazes de diferenciá-los: (a) a conformidade ou não-conformidade com o direito; e (b) a presença, ou não, de ato humano volitivo no suporte fático tal como descrito hipoteticamente na norma jurídica ${ }^{629}$.

O mesmo autor aduz que os fatos jurídicos também podem ser divididos em: instantâneos ou permanentes, e positivos ou negativos.

Teixeira de Freitas (Código Civil: esboço, pp. 143-150), nos arts. 431 a 444 do seu "Esboço de Código Civil", divide os "fatos em geral" em dois grupos:

a) os fatos exteriores (definidos, por exclusão, como aqueles "que não são ações ou omissões voluntárias $e$ involuntárias"), que podem ser: (1) necessários, se infalivelmente tiverem de existir (v.g., morte); ou (2) fortuitos, se puderem ou não existir (e.g., nascimento)

b) os fatos humanos, que podem ser: (1) involuntários, nas espécies (i) necessários (ações e omissões involuntárias, próprias ou de outrem, que infalivelmente têm de existir, como, por exemplo, a legítima defesa e o estado de necessidade) ou (ii) fortuitos (ações e omissões involuntárias, próprias ou de outrem, que podem ou não existir) e ( $\alpha$ ) lícitos ou ( $\beta$ ) ilícitos; ou (2) voluntários, nas espécies (i) ilícitos ou (ii) lícitos, sendo que estes últimos ainda se subdividem em $(\alpha)$ atos jurídicos (são os atos lícitos que têm por fim imediato alguma aquisição, modificação ou extinção de direitos), que podem ser atos entre vivos (aqueles cuja eficácia não depende do falecimento das pessoas de cuja vontade emanaram, como, por exemplo, os contratos) ou disposições de última vontade (que só produzem efeito depois do falecimento daqueles de cuja vontade emanaram, como os testamentos); e, por exclusão, $(\beta)$ atos lícitos que não são atos jurídicos (são os atos lícitos que não têm por fim imediato alguma aquisição, modificação ou extinção de direitos, os quais somente produzem efeitos nos casos expressamente declarados no Código Civil, nos Códigos de Comércio e no Código de Processo).

Prefere-se a classificação de Pontes de Miranda a essas duas por ser ela mais precisa, por ser capaz de abranger todas as espécies de fatos jurídicos possíveis e por adotar uma terminologia mais adequada e expressiva (MELLO, Teoria do Fato Jurídico: plano da existência, pp. 109 e 110).

${ }^{627}$ É válido lembrar que a norma jurídica é uma proposição prescritiva cuja estrutura é composta por duas partes: (a) a previsão de uma hipótese fática condicionante da existência do fato jurídico (suporte fático hipotético ou abstrato); e (b) a prescrição dos efeitos atribuídos ao fato jurídico respectivo (preceito abstrato) (MELLO, Teoria do Fato Jurídico: plano da existência, pp. 20, 38-39 e 66-68).

${ }^{628}$ Geralmente, o suporte fático é complexo, sendo composto por vários fatos. Estes podem ser classificados como (MELLO, Teoria do Fato Jurídico: plano da existência, pp. 49-62):

a) elementos nucleares: fatos considerados pela norma jurídica essenciais à sua incidência e consequente criação do fato jurídico. Eles se subdividem em duas espécies: (1) elementos cerne, que são os fatos que determinam a configuração final do suporte fático e fixam, no tempo, a sua concreção; e (2) elementos completantes do núcleo, que são outros fatos que completam o núcleo do suporte fático. A falta de algum elemento nuclear implica a inexistência do fato jurídico;

b) elementos complementares: são fatos que complementam o núcleo do suporte fático dos atos jurídicos lícitos "lato sensu" (atos jurídicos "stricto sensu" e negócios jurídicos) e se referem, exclusivamente, à perfeição de seus elementos. Podem ser relativos ao sujeito, ao objeto ou à forma de manifestação da vontade. Constituem pressupostos de validade ou de eficácia do ato jurídico, sem qualquer influência no plano da existência; e

c) elementos integrativos: são atos jurídicos praticados por terceiros (geralmente, autoridade pública) que integram o negócio jurídico no plano da eficácia, permitindo que se irradie certo efeito que se adiciona à eficácia normal do negócio jurídico. Na verdade, eles não compõem o suporte fático do negócio jurídico, logo não interferem na sua existência, validade ou eficácia própria. Atuam apenas no plano da eficácia, irradiando certos efeitos próprios do negócio jurídico que dependem expressamente dele.

${ }^{629}$ MELLO, Teoria do Fato Jurídico: plano da existência, pp. 111-112. 
Com base na análise do elemento cerne do suporte fático, chegou-se à seguinte classificação dos fatos jurídicos "lato sensu"

a) fato jurídico "stricto sensu": fato jurídico cujo suporte fático é composto apenas por fatos da natureza, não havendo qualquer ato humano como elemento essencial à sua existência (v.g., nascimento, morte, produção de frutos, aluvião, avulsão etc.);

b) ato-fato jurídico: fato jurídico cujo suporte fático prevê uma situação de fato que somente pode materializar-se como resultante de uma conduta humana. Não obstante a conduta humana seja essencial à sua existência, a norma jurídica considera irrelevante a circunstância de ter, ou não, havido vontade em praticá-la, dando mais realce ao resultado fático que decorre dela que a ela própria (e.g., caça, pesca, especificação, desforço pessoal imediato praticado dentro dos limites previstos no art. 1210, § $1^{\circ}$, do CC, decadência, prescrição etc.);

c) ato jurídico "lato sensu": fato jurídico cujo suporte fático tem como cerne uma exteriorização consciente de vontade dirigida à obtenção de um resultado juridicamente protegido ou não-proibido e possível. Divide-se em duas subespécies: (1) o ato jurídico "stricto sensu", que tem como elemento cerne do suporte fático a manifestação ou declaração consciente de vontade sem poder de autoregramento, visto que inexiste escolha de categoria jurídica e os efeitos resultantes do fato já são predispostos pelas normas jurídicas e não podem ser alterados pela vontade dos interessados (v.g., a constituição de domicílio por meio do estabelecimento de residência com ânimo definitivo, o reconhecimento da filiação não resultante de casamento, o perdão, a quitação, a interpelação para constituir o devedor em mora etc.); e (2) o negócio jurídico, que tem como elemento cerne do suporte fático a manifestação ou declaração consciente de vontade com poder de autoregramento, ou seja, com poder de escolha da categoria jurídica e, dentro de limites prescritos pelo ordenamento jurídico, de estruturação do conteúdo eficacial da relação jurídica correspondente, podendo regular a amplitude, o surgimento, a permanência e a intensidade dos efeitos (e.g., testamento, instituição de fundação, derrelicção, oferta, aceitação, contrato de compra-e-venda, acordo de acionistas, contrato de constituição de sociedade etc.).

Todas essas espécies de fatos jurídicos "lato sensu" podem-se configurar como ilícitos, caso tenham como elementos cerne do suporte fático: (a) a contrariedade a direito, ou seja, a violação de normas jurídicas e, consequentemente, da ordem jurídica como um

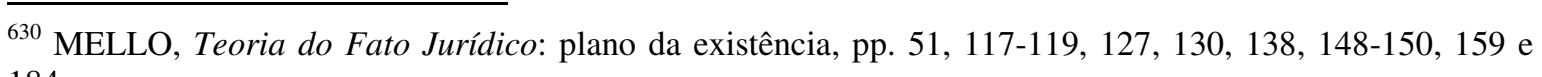
184. 
todo; e (b) a imputabilidade, que é a capacidade para praticar ato ilícito. Existem, então, fatos jurídicos "stricto sensu" ilícitos (por exemplo, as hipóteses de responsabilidade por prejuízos decorrentes de caso fortuito ou força maior previstas nos arts. 399; 667, $\S 1^{\text {o }}$; e 868 do $\mathrm{CC}$ ), atos-fatos jurídicos ilícitos (e.g., o ato infracional praticado por criança ou adolescente - art. 103 da Lei $n^{\circ}$ 8.069/90) e atos ilícitos “lato sensu”, que se subdividem em três espécies: ato ilícito "stricto sensu" (ou ato ilícito absoluto, previsto no art. 186 do CC), ato ilícito relativo (que ocorre sempre que o devedor impossibilita a prestação culposamente, incide em mora ou cumpre insatisfatoriamente sua obrigação) e ato ilícito criminal (crimes e contravenções penais) ${ }^{631}$.

Não obstante Pontes de Miranda tenha elaborado essa teoria do fato jurídico tendo em vista o Direito privado, sua aplicação não é adstrita a esse setor do Direito. Como o conceito de "fato jurídico" faz parte da Teoria Geral do Direito, a referida teoria mostra-se útil para todas as áreas do conhecimento jurídico. Diversos juristas contemporâneos pregam a sua aplicação inclusive na seara processual, classificando os fatos jurídicos processuais "lato sensu" em ${ }^{632}$ :

a) fatos jurídicos processuais "stricto sensu", como a morte de uma das partes ou do advogado de uma delas (art. 265, I e $\$ \S 1^{\circ}$ e $2^{\circ}$; e art. 43 do CPC); os acontecimentos que caracterizam a força maior (art. 265, V, do CPC); o parentesco (art. 134, IV, do CPC); os acontecimentos que caracterizam a calamidade pública (art. 182, parágrafo único, do CPC); o avançar da idade (art. 1211-A do CPC e art. 71 da Lei ${ }^{\circ} 10.741 / 03$ ) etc. ${ }^{633}$;

b) atos-fatos jurídicos processuais, tais como: o adiantamento das custas processuais; o preparo (art. 511 do CPC); a revelia (art. 319 do CPC); a execução provisória de decisão posteriormente reformada ou anulada (arts. 475-O; e 273, § $3^{\circ}$, do

\footnotetext{
${ }^{631}$ MELLO, Teoria do Fato Jurídico: plano da existência, pp. 51, 113, 219, 230 e 235-246.

${ }^{632}$ Nesse sentido: DIDIER JÚNIOR; NOGUEIRA, Teoria dos Fatos Jurídicos Processuais, pp. 38-66; BRAGA, Primeiras Reflexões sobre uma Teoria do Fato Jurídico Processual - plano de existência, in DIDIER JÚNIOR; EHRHARDT JÚNIOR (coords.), Revisitando a Teoria do Fato Jurídico: homenagem a Marcos Bernardes de Mello, pp. 461-473.

${ }^{633}$ Alguns autores negam a existência de fatos jurídicos processuais "stricto sensu", como, por exemplo, Liebman (Manual de Direito Processual Civil, vol. I, § 98, pp. 221-222). Porém, a maioria dos processualistas aceita essa espécie de fatos jurídicos processuais "lato sensu" (v.g., CINTRA; DINAMARCO; GRINOVER, Teoria Geral do Processo, pp. 341-342; DINAMARCO, Instituições de Direito Processual Civil, vol. II, pp. 485-488; GRECO FILHO, Direito Processual Civil Brasileiro, vol. II, p. 6; REDENTI; VELLANI, Diritto Processuale Civile, vol. 1, p. 228; COUTURE, Fundamentos do Direito Processual Civil, p. 110.

Para uma abordagem mais aprofundada desse assunto, com análise dos argumentos das correntes doutrinárias a favor e contra a categoria dos fatos jurídicos processuais "stricto sensu", consultar: DIDIER JÚNIOR; NOGUEIRA, Teoria dos Fatos Jurídicos Processuais, pp. 40-43.
} 
CPC); a medida cautelar que tenha causado prejuízo ao requerido e que tenha sido revogada posteriormente (art. 811 do CPC); a preclusão temporal ${ }^{634}$ etc.;

c) atos jurídicos processuais "stricto sensu", cujos principais exemplos são a petição inicial, a citação, a intimação, a contestação, a confissão, a interposição de recurso, a penhora, dentre outros; e

d) negócios jurídicos processuais, como a convenção para reduzir ou prorrogar prazo dilatório (art. 181 do CPC); a convenção de suspensão do processo (arts. 265, II; e 792 do CPC); a convenção de adiamento da audiência (art. 453, I, do CPC); a convenção sobre distribuição do ônus da prova (art. 333, parágrafo único, do CPC); a renúncia ao prazo (art. 186 do CPC); a desistência do recurso; a desistência do processo (arts. 267, VIII; e 158, parágrafo único, do CPC); a renúncia ao poder de recorrer etc ${ }^{635}$.

São identificados também fatos jurídicos processuais "lato sensu” ilícitos, que são os atos processuais praticados em desconformidade com o Direito, como, por exemplo, os atos atentatórios ao exercício da jurisdição (art. 14, parágrafo único, do CPC), os atos de litigância de má-fé (art. 17 do CPC), os atos atentatórios à dignidade da Justiça (art. 600 do CPC), a conduta do executado que impede a entrada do oficial de justiça, tentando obstar a penhora (arts. 660-662 do CPC), o atentado (arts. 879-881 do CPC) etc.

No que concerne às condutas abusivas - praticadas tanto no âmbito do Direito privado, quanto no processo -, alguns doutrinadores negam que elas façam parte do grupo dos fatos jurídicos "lato sensu" ilícitos.

Abdo $^{636}$, por exemplo, afirma que ato abusivo e ato ilícito distinguem-se fundamentalmente. Argumenta que o ato ilícito é "aquele que viola frontalmente a lei e não pressup̃oe a existência de qualquer direito do agente", enquanto que o ato abusivo "pressupõe a existência de um direito subjetivo ou de uma situação jurídica subjetiva de

\footnotetext{
${ }^{634}$ Contra, considerando as omissões das partes como fatos jurídicos processuais "stricto sensu": CINTRA; DINAMARCO; GRINOVER, Teoria Geral do Processo, pp. 341-342; DINAMARCO, Instituições de Direito Processual Civil, vol. II, pp. 485 e 486-488.

${ }^{635}$ A existência de verdadeiros negócios jurídicos no processo é bastante controvertida na doutrina. Liebman (Manual de Direito Processual Civil, vol. I, § 102, pp. 226-227), Denti (Negozio Processuale, in Enciclopedia del Diritto, vol. XXVIII, pp. 138-145), Dinamarco (Instituições de Direito Processual Civil, vol. II, p. 484), Cintra e Grinover (Teoria Geral do Processo, p. 342), por exemplo, recusam a figura do negócio jurídico processual; já Greco Filho (Direito Processual Civil Brasileiro, vol. II, p. 7), Dondina (Atti Processuali (civili e penali), in Novissimo Digesto Italiano, vol. I, t. II, pp. 1519-1520), Barbosa Moreira (Convenções das Partes sobre Matéria Processual, in Temas de Direito Processual - terceira série, pp. 87-98) e Fazzalari (Instituições de Direito Processual, p. 416) admitem-na. O tratamento exaustivo desse tema problemático demandaria o estudo dos argumentos pró e contra o reconhecimento dos negócios jurídicos processuais, o que foge do escopo do presente trabalho. Remete-se o leitor para a doutrina supramencionada e para a obra de Didier Júnior e Nogueira (Teoria dos Fatos Jurídicos Processuais, pp. 54-64).

${ }^{636}$ O Ato Atentatório à Dignidade da Justiça na Nova Execução Civil, p. 3. Nesse sentido, da mesma autora: O Abuso do Processo, pp. 18-19, 104-105.
} 
titularidade do agente, exercidos de maneira anormal, com desvio de finalidade" (destaques no original).

Analogamente, Cunha de Sá $^{637}$ sustenta que o ato abusivo não é um ato lícito, nem um ato ilícito: "entre a conformidade ao direito ou licitude e aquela específica desconformidade ou contraditoriedade a que se usa dar o nome de ilicitude, tem lugar uma outra espécie de contraditoriedade que é tecnicamente qualificada como abuso de direito".

Nessa mesma toada, Limongi França ${ }^{638}$ entende que o ato abusivo é "uma categoria de conteúdo próprio [...], que se situa na zona intermediária entre o ato lícito e o ato ilícito".

$\mathrm{O}$ intuito desses autores que distinguem o ato abusivo do ato ilícito é fazer frente à corrente doutrinária (encabeçada por Planiol ${ }^{639}$ ) que nega autonomia dogmática ao abuso do direito, inserindo-o na categoria jurídica dos atos ilícitos, ou seja, dos atos praticados sem direito ou com excesso de direito, com base no argumento de que o direito cessa no momento em que começa o abuso, já que uma coisa não pode ser conforme ao direito e contrária a ele ao mesmo tempo ${ }^{640}$.

Esse entendimento de que o ato abusivo seria um "tertium genus", ao lado do ato ilícito e do ato lícito, não merece ser adotado, uma vez que contraria a supramencionada teoria ponteana dos fatos jurídicos. Consoante essa teoria, ou o fato jurídico (entendido aqui em seu sentido amplo) tem no cerne de seu suporte fático os elementos "contrariedade a direito" e "imputabilidade" e, nesse caso, deve ser considerado um fato jurídico ilícito, ou esses elementos não fazem parte de seu suporte fático e ele deve ser classificado como um fato jurídico lícito. "Tertium non datur". E não há duvida de que o comportamento abusivo seja "contra jus", uma vez que, no âmbito do Direito privado, ele viola princípios gerais de boa-fé que vinculam integrativamente as partes, tanto na preparação e na celebração, quanto na execução do ato negocial que deu origem ao direito objeto do abuso $^{641}$. O mesmo vale para a seara processual, em que o ato abusivo vai de encontro a diversas garantias individuais, princípios processuais e deveres gerais dos sujeitos do

\footnotetext{
${ }^{637}$ Abuso do Direito, pp. 331-332.

${ }^{638}$ Responsabilidade Civil e Abuso de Direito, in Revista do Advogado, no 19, p. 42.

${ }^{639}$ Traité Élémentaire de Droit Civil, $2^{\circ}$ tomo, p. 284.

${ }^{640}$ É o que se infere das obras de Abdo (O Abuso do Processo, pp. 103-104) e de Cunha de Sá (Abuso do Direito, pp. 321-333).

${ }^{641}$ COMOGLIO, Abuso del Processo e Garanzie Costituzionali, in Rivista di Diritto Processuale, Ano 63, $\mathrm{n}^{\circ}$ 2, pp. 320 e 321-322.
} 
processo previstos expressamente na Constituição Federal e no Código de Processo Civil, além de desrespeitar as finalidades institucionais do processo (item 1.3.4 "supra") ${ }^{642}$.

Ademais, os doutrinadores que defendem esse entendimento parecem limitar a ilicitude aos atos ilícitos "stricto sensu", previstos no art. 186 do CC, ou seja, às condutas humanas voluntárias que, intencionalmente ou em razão de negligência, de imprudência, ou de imperícia, transgridem direta e imediatamente uma norma legal e, por isso, violam um dever genérico de conduta, causando danos a terceiros, dos quais decorre o dever de reparação (art. 927 do CC). Ocorre que a norma do art. 186 do CC não trata da ilicitude como gênero, mas sim de uma espécie de ato ilícito, o ato ilícito "stricto sensu" ou ato ilícito absoluto. As outras espécies de ilícitos estão definidas em outras normas jurídicas específicas. Logo, o simples fato de uma certa conduta contrária a direito e imputável a alguém não se caracterizar como ato ilícito "stricto sensu" (art. 186 do CC) não quer dizer que ela não seja ilícita ${ }^{643}$. De acordo com Mello ${ }^{644}$, a ilicitude se configura nas situações em que: (a) há a produção de dano na esfera jurídica alheia, sem o consentimento de seu titular ou autorização do ordenamento jurídico; (b) o devedor, nas relações jurídicas de crédito, descumpre sua obrigação ou a cumpre mal e incide em mora, ou ainda impossibilita a prestação culposamente; (c) o ato é praticado ao arrepio de direito absoluto de natureza pessoal (como os direitos da personalidade) ou real (como o direito de propriedade); (d) há infração de interesse juridicamente protegido que não constitui direito subjetivo (v.g., violação de interesses transindividuais); (e) existe abuso ou exercício irregular de direito; ou (f) alguém pratica ato jurídico contrariando norma jurídica cogente (por exemplo, se alguém celebrar contrato sobre objeto ilícito).

Desde a entrada em vigor do Código Civil de 2002, a discussão a respeito do caráter ilícito dos comportamentos abusivos perdeu força, sendo praticamente encerrada, uma vez que esse diploma legislativo considera, expressamente, o ato abusivo como ilícito $^{645}$. Com efeito, o art. 187 desse diploma legislativo, a respeito do abuso do direito, está localizado no Título III do Livro III da Parte Geral do Código Civil, destinado à regulação "Dos atos ilícitos". Além disso, ele é dotado da seguinte redação: "Também comete ato ilícito o titular de um direito que, ao exercê-lo, excede manifestamente os limites impostos pelo seu fim econômico ou social, pela boa-fé ou pelos bons costumes"

\footnotetext{
${ }^{642}$ Nesse sentido: CUNHA, O Dolo e o Direito Judiciário Civil, pp. 14-15; VIRÍSSIMO CUNHA, Simulação Processual e Anulação do Caso Julgado, pp. 45-46.

${ }^{643}$ MELLO, Teoria do Fato Jurídico: plano da existência, pp. 231-233; BRAGA NETTO, Teoria dos Ilícitos Civis, pp. 122-123.

${ }^{644}$ Teoria do Fato Jurídico: plano da existência, pp. 217-218.

${ }^{645}$ LAUTENSCHLÄGER, Abuso do Direito, p. 55.
} 
(destaque nosso). Isso, contudo, não quer dizer que o legislador considere idênticas as realidades descritas nos arts. 186 e 187 do CC. Enquanto o primeiro dispositivo legal versa sobre o ato ilícito praticado sem que haja qualquer direito ou prerrogativa em favor do seu autor, o segundo trata de uma forma de ilicitude cuja configuração depende da titularidade de uma prerrogativa assegurada pelo ordenamento jurídico (um direito, uma faculdade, um poder etc.), bem como do exercício da mesma em descompasso com limites axiológicomateriais. Ademais, a realização da ilicitude prevista no art. 186 do CC exige a comprovação da culpa "lato sensu", elemento esse prescindível para a configuração da ilicitude descrita no art. 187 do CC. Por esses motivos, as condutas reguladas pelos arts. 186 e 187 do CC devem ser consideradas formas distintas pelas quais a ilicitude pode-se manifestar no campo do Direito privado ${ }^{646}$.

Conclui-se que, na classificação dos fatos jurídicos, o lugar certo do ato abusivo é no grupo dos fatos jurídicos "lato sensu" ilícitos, seja porque o núcleo do seu suporte fático contém os elementos da contrariedade a direito e da imputabilidade, seja em razão da localização e do teor do art. 187 do CC.

${ }^{646}$ Nesse sentido: BOULOS, Abuso do Direito no Novo Código Civil, pp. 45-48. 


\section{HIPÓTESES DE ABUSO DO PROCESSO PREVISTAS NO CÓDIGO DE PROCESSO CIVIL BRASILEIRO}

\subsection{Considerações preliminares}

Levando em consideração os elementos caracterizadores do abuso do processo descritos no item 1.6 "supra", é possível identificar diversos comportamentos abusivos no Código de Processo Civil. O presente capítulo destina-se ao exame dessas hipóteses legais de abuso processual.

No entanto, essa não é uma empreitada fácil. Uma breve análise das obras já publicadas acerca do tema leva o estudioso a perceber que inexiste consenso entre os autores com relação às condutas ímprobas previstas expressamente no Código de Processo Civil brasileiro, nem quanto à maneira de abordá-las. Alguns doutrinadores preferem estudar as hipóteses de abuso de acordo com o momento processual em que podem ser praticadas $^{647}$. Outros organizam os comportamentos ímprobos em duas grandes categorias: abuso macroscópico e abuso microscópico ${ }^{648}$. Também é possível analisar os diversos tipos de atos processuais abusivos de acordo com o sujeito processual que os pratica ${ }^{649}$. Há ainda quem examine as condutas abusivas respeitando a sequência em que elas aparecem no Código de Processo Civil ${ }^{650}$.

Neste trabalho, as hipóteses legais de improbidade processual são divididas de acordo com as situações jurídicas processuais que constituem o objeto do abuso, ou seja, de acordo com os poderes, faculdades, ônus, deveres e poderes-deveres que os sujeitos do processo utilizam para praticar o abuso. Os seguintes comportamentos abusivos serão estudados nos itens subsequentes:

a) abuso do processo ou de poder processual mediante a dedução de pretensão ou de defesa contra texto expresso de lei ou fato incontroverso (art. 17, I, do CPC);

b) utilização do processo para conseguir objetivo ilegal (art. 17, III, do CPC);

c) utilização do processo como instrumento para simulação (art. 129 do CPC);

d) violação do dever de veracidade (arts. 17, II; e 233 do CPC);

\footnotetext{
${ }^{647}$ Nesse sentido: THEODORO JUNIOR, Abuso de Direito Processual no Ordenamento Jurídico Brasileiro, in Revista Forense, v. 344, pp. 58-62.

${ }^{648}$ Nesse sentido: ABDO, O Abuso do Processo, pp. 189-226.

${ }^{649}$ Nesse sentido: IOCOHAMA, Litigância de Má-Fé e Lealdade Processual, pp. 133-206.

${ }^{650}$ Nesse sentido: MILMAN, Improbidade Processual: comportamento das partes e de seus procuradores no processo civil, pp. 131-211.
} 
e) violação do dever de prontidão (arts. $22 ; 113, \S 1^{\text {o }}$; e 267 , $\S 2^{\circ}$, do CPC);

f) abuso do poder de nomear à autoria (art. 69 do CPC);

g) utilização de poderes e faculdades processuais para opor resistência injustificada ao andamento do processo (art. 17, IV, do CPC);

h) utilização de poderes e faculdades processuais de modo temerário (art. 17, V, do CPC);

i) abuso do poder de provocar incidentes no processo (art. 17, VI, do CPC);

j) abuso do poder de recorrer (arts. 17, VII; 538, parágrafo único; e 557, § $2^{\circ}$, do $\mathrm{CPC})$;

k) abuso do processo da rescisória (art. 488, II, do CPC);

1) utilização de poderes e faculdades processuais para opor-se maliciosamente à execução (art. 600, II, do CPC);

m) abuso do poder de opor embargos do devedor (art. 740, parágrafo único, do CPC);

n) abuso do poder de se arrepender da arrematação de bem imóvel de incapaz (art. $701, \S 2^{\circ}$, do CPC);

o) abuso do poder de opor embargos à execução de segunda fase (art. 746, § $3^{\circ}$, do CPC);

p) abuso de poder-dever por magistrado; e

q) abuso de poder-dever por auxiliar da justiça.

Percebe-se que essa disposição das "fattispecies" abusivas não respeita a ordem em que elas aparecem no Código de Processo Civil. Isso porque, na medida do possível, tentou-se organizá-las na mesma sequência em que as situações jurídicas processuais são sucessivamente atribuídas aos sujeitos processuais ao longo do procedimento.

\subsection{Abuso do processo ou de poder processual mediante a dedução de pretensão ou de defesa contra texto expresso de lei ou fato incontroverso (art. 17, I, do CPC)}

O inciso I do art. 17 do CPC considera como litigância de má-fé duas condutas: (a) deduzir pretensão ou defesa contra texto expresso de lei; e (b) deduzir pretensão ou defesa contra fato incontroverso ${ }^{651} 652$.

${ }^{651}$ Trata-se de comportamentos abusivos similares ao "frivolous claim" e à "frivolous objection" do Direito norte-americano. Consoante a "Rule" 11 das "Federal Rules of Civil Procedure" e a "Rule" 3.1 das "Model Rules of Professional Conduct" editadas pela "American Bar Association", considera-se "frivolous" a 
A primeira conduta pode ser praticada pelo autor e pelo réu ${ }^{653}$, em qualquer ato ao longo do processo (na propositura da demanda, na resposta a ela, em recurso, em contrarrazões etc. $)^{654}$.

O dispositivo legal em análise liga-se ao dever contido no inciso III do art. 14 do CPC: "Art. 14. São deveres das partes e de todos aqueles que de qualquer forma participam do processo: [...] III - não formular pretensões, nem alegar defesa, cientes de que são destituídas de fundamento" ${ }^{955}$. Buzaid ${ }^{656}$ explica que a pessoa só deve defender o seu direito, como autora, ré ou interveniente, se ela estiver convencida do seu fundamento legal. Caso contrário, a pretensão ou defesa deduzida em juízo configura a "aemulatio", que consiste na intenção de praticar ato para tutelar direito sem utilidade própria ou com mínima utilidade própria, ou com o objetivo de prejudicar outrem.

Todavia, não se pode querer inferir do art. 17, I, $1^{\mathrm{a}}$ parte, do CPC um dever de não ajuizar demandas, ou de não as perder, ou ainda de não resistir em juízo para a tutela das suas próprias situações jurídicas materiais. A Constituição Federal garante a todo cidadão o direito de recorrer ao Judiciário para reagir contra lesão ou ameaça a direito (art. $5^{\circ}$, XXXV, da CF). Quem tem razão, ou julga sem culpa tê-la, não pode ter essa garantia constitucional limitada. $\mathrm{O}$ que se veda são os comportamentos processuais destinados a assegurar a defesa de direitos, poderes ou faculdades inexistentes ou que jamais foram perturbados $^{657}$.

dedução de um pedido ou de uma defesa sem embasamento legal ou fundamento fático (HAZARD JR., Abuse of Procedural Rights: regional report for the United States, in TARUFFO (ed.), Abuse of Procedural Rights: comparative standards of procedural fairness, p. 50). Dondi (Cultura dell'Abuso e Riforma del Processo Civile Negli Stati Uniti, in Rivista di Diritto Processuale, Ano 50, no 3, pp. 797 e 798) ensina que, para não ser considerada frívola, é necessário que a pretensão ou a defesa da parte: (a) não seja destinada à obtenção de um escopo impróprio (intenção de provocar distúrbio, de retardar o provimento da tutela jurisdicional ou de aumentar o custo do processo); e (b) seja firmemente fundamentada com indicação precisa de circunstâncias fáticas e embasada em dispositivos legais expressos ou em uma análise da lei destinada a superar dispositivos legais expressos com base em um "argumento de boa-fé" ("good faith argument").

Analogamente, na Inglaterra, as "Civil Procedure Rules" consideram abuso do processo a dedução de pedido obviamente mal fundamentado ("Rule" 3.4, (2), "b", c/c "Practice Direction" 3A, 1.5), ainda que o litigante honestamente acredite que tem razão (ANDREWS, Abuse of Process in English Civil Litigation, in TARUFFO (ed.), Abuse of Procedural Rights: comparative standards of procedural fairness, p. 69).

${ }^{652}$ No Código de Processo Civil projetado (Projeto de Lei $\mathrm{n}^{\circ}$ 8.046/2010), a mesma norma consta do art. 83, I.

${ }^{653}$ BARBI, Comentários ao Código de Processo Civil, vol. I, § 160, p. 125; OLIVEIRA, Litigância de Má$F e ́$, p. 38.

${ }^{654}$ DINAMARCO, Instituições de Direito Processual Civil, vol. II, § 528-A, p. 267; ABDO, O Abuso do Processo, p. 190, nt. 2.

${ }^{655}$ OLIVEIRA, Litigância de Má-Fé, p. 37.

${ }^{656}$ Processo e Verdade no Direito Brasileiro, in Revista de Processo, no 47, p. 97.

657 ALBUQUERQUE, Responsabilidade Processual por Litigância de Má Fé, Abuso de Direito e Responsabilidade Civil em Virtude de Actos Praticados no Processo, pp. 132-133; REIS, Código de Processo Civil Anotado, vol. II, p. 261. 
Convém sublinhar que isso não configura um alinhamento do Código de Processo Civil brasileiro à teoria concreta da ação, segundo a qual o direito de ação depende da existência do direito material pleiteado em juízo. Não se estabelece, como condição para o exercício do direito de ação ou de defesa, que o autor ou o réu seja realmente titular do direito substancial que se arroga ${ }^{658}$. Apenas se destaca a circunstância de o apelo aos meios judiciais ter limites, sendo ilícito o uso materialmente distorcido e indevido do processo ${ }^{659}$.

A fórmula "texto expresso de lei", contida no art. 17, I, do CPC, deve ser interpretada com as devidas margens de tolerância, uma vez que nem sempre os textos legais são tão claros ou precisos a ponto de poderem ser interpretados de uma única maneira ${ }^{660}$. Para que haja litigância de má-fé é preciso que o comando contrariado pelo autor ou pelo réu seja inequívoco ${ }^{661}$. Se a interpretação de uma lei é discutida pelos tribunais ou pela doutrina, a parte que defende uma das correntes interpretativas em juízo não pode ser considerada litigante de má-fé, ainda que haja jurisprudência em sentido contrário $^{662}$. Ademais, como a jurisprudência não é imutável, não se pode negar à parte o direito de pleitear uma leitura do texto legal que lhe pareça mais correta e favorável à sua pretensão ${ }^{663}$. Há vários exemplos de alterações de posicionamentos pacíficos dos tribunais em decorrência do esforço argumentativo de advogados, ensejando inclusive o cancelamento de súmulas ${ }^{664}$.

O intuito do legislador não é restringir o contraditório e o direito de defesa, impondo às partes e seus procuradores a resignação à jurisprudência estabelecida e obstando à evolução desta ${ }^{665}$. O que o art. $17, \mathrm{I}, 1^{\mathrm{a}}$ parte, do CPC visa a reprimir é a conduta do advogado despreparado, que invoca dispositivos legais que não incidem na situação fática por ele narrada, ou que sustenta um posicionamento doutrinário minoritário, porém sem demonstrar que conhece o posicionamento adotado pelos tribunais, nem

\footnotetext{
${ }^{658}$ REIS, Código de Processo Civil Anotado, vol. II, p. 258.

659 ALBUQUERQUE, Responsabilidade Processual por Litigância de Má Fé, Abuso de Direito e Responsabilidade Civil em Virtude de Actos Praticados no Processo, pp. 119-120, nt. 363.

${ }^{660}$ DINAMARCO, Instituições de Direito Processual Civil, vol. II, § 528-A, p. 268.

${ }^{661}$ OLIVEIRA, Litigância de Má-Fé, p. 38.

${ }^{662}$ Nesse sentido: "Não se caracteriza a litigância de má-fé se a parte argui teses de direito que, embora não prevalentes na jurisprudência, encontram respaldo em doutrina ou em votos minoritários (RF 328/208)" (NEGRÃO; GOUVÊA; BONDIOLI; FONSECA, Código de Processo Civil e Legislação Processual em Vigor, p. 132, art. 16, nt. 4).

${ }^{663}$ BARBI, Comentários ao Código de Processo Civil, vol. I, § 160, p. 125; OLIVEIRA, Litigância de MáFé, p. 39.

${ }^{664}$ Bernardo Pimentel Souza, atualizador da obra de Barbi, informa que o Plenário do Supremo Tribunal Federal cancelou os enunciados $\mathrm{n}^{\text {os }} 506$ e 599, respectivamente em 2004 e 2007, atendendo aos corretos argumentos de advogados (BARBI, Comentários ao Código de Processo Civil, vol. I, § 160, p. 125, nt. 11).

${ }^{665}$ DINAMARCO, Instituições de Direito Processual Civil, vol. II, § 528-A, p. 268.
} 
apontar o seu desacerto ${ }^{666}$. Trata-se de norma louvável, considerando que uma das razões de ser da necessidade de as pessoas atuarem em juízo por meio de advogados é exatamente impedir a dedução de pedidos e causas de pedir inviáveis juridicamente.

Escapa, igualmente, do âmbito de incidência do art. 17, I, $1^{\mathrm{a}}$ parte, do CPC a conduta da pessoa que ajuíza demanda requerendo a não-aplicação de determinado ato normativo em um caso concreto, arguindo a sua inconstitucionalidade ou injustiça. Nesse caso, não há litigância de má-fé, uma vez que o legislador presume a boa-fé do litigante que advoga contra literal disposição de lei fundamentado na inconstitucionalidade ou na injustiça desta (art. 34, VI, da Lei no $8.906 / 94)^{667}$.

Os seguintes comportamentos processuais são exemplos de dedução de pretensão ou defesa contra texto expresso de lei: (a) interpor recurso contra sentença proferida em liquidação, com o intuito de rediscutir a sentença proferida na ação de conhecimento, contrariando o art. 475-G do $\mathrm{CPC}^{668}$; (b) ajuizar demanda que já foi apreciada em sentença transitada em julgado formal e materialmente, ao arrepio do que dispõem os arts. 467 (“Denomina-se coisa julgada material a eficácia, que torna imutável e indiscutível a sentença, não mais sujeita a recurso ordinário ou extraordinário" - destaque nosso) e 267, V, do CPC ("Extingue-se o processo, sem resolução de mérito: [...] V - quando o juiz acolher a alegação [...] de coisa julgada" - destaque nosso); (c) ajuizar demanda que já foi proposta anteriormente por três vezes, sendo que os processos precedentes foram extintos com fundamento no art. 267, III, do CPC, comportamento esse que contraria o art. 268, parágrafo único, do CPC; (d) uma vez cessada a eficácia de medida cautelar, repetir pedido de tutela cautelar sem invocar novo fundamento, em violação ao art. 808, parágrafo único, do CPC; (e) sendo demandada uma sociedade sem personalidade jurídica, apresentar defesa alegando a irregularidade de sua constituição, o que é vedado pelo art. $12, \S 2^{\circ}$, do CPC; (f) ajuizar demanda juridicamente impossível, ou seja, que "de algum modo colide com regras superiores do direito nacional e, por isso, sequer comporta apreciação mediante exame de seus elementos concretos" $" 669$.

A incidência do art. 17, I, $1^{\text {a }}$ parte, do CPC não exige qualquer atitude psicológica do litigante. A mera dedução de pretensão ou de defesa contra texto expresso de lei implica que a parte seja considerada litigante de má-fé e sofra as sanções previstas nos arts. 16 e 18

\footnotetext{
${ }^{666}$ BARBI, Comentários ao Código de Processo Civil, vol. I, § 160, p. 126.

${ }^{667}$ OLIVEIRA, Litigância de Má-Fé, pp. 37 e 71.

${ }^{668}$ Exemplo mencionado por Oliveira (Litigância de Má-Fé, p. 39), embasado em um caso concreto julgado pelo Tribunal de Justiça do Mato Grosso.

${ }^{669}$ DINAMARCO, Instituições de Direito Processual Civil, vol. II, § 543, p. 307.
} 
do CPC. Caso o texto legal estatuísse que se considera litigante de má-fé quem houver deduzido pretensão ou defesa cuja falta de fundamento "não podia razoavelmente desconhecer", ou "não ignorava", ou ainda "não devia ignorar", poder-se-ia, realmente, cogitar a existência de algum elemento subjetivo no suporte fático dessa espécie de abuso do processo $^{670}$. Contudo, o legislador brasileiro optou por uma hipótese de incidência objetiva, de modo que, nem o dolo, nem a culpa grave, é relevante para caracterizar essa conduta ímproba ${ }^{671}$.

Com relação à segunda parte do art. 17, I, do CPC, Barbi ${ }^{672}$ afirma que se aplica apenas ao réu, uma vez que só ele pode tornar controverso ou incontroverso um fato, por meio da contestação. Já Dinamarco ${ }^{673}$ sustenta a aplicação do dispositivo para ambas as partes, com fundamento em uma interpretação mais abrangente da expressão "fato incontroverso". Segundo o jurista, são "fatos incontroversos" não só os que a parte já tenha reconhecido ou afirmado no processo, mas também os reconhecidos ou afirmados extraprocessualmente, os notórios e os que resultem de conquistas científicas idôneas.

Não obstante as duas interpretações sejam plausíveis, é preferível a primeira, já que quem deduz pretensão ou defesa em contradição com fatos já reconhecidos extraprocessualmente (prova pré-constituída), ou notórios, ou que resultem de conquistas científicas idôneas, altera a verdade, logo, sua conduta é mais bem situada no inciso II do art. 17 do CPC.

Depois de ter tornado incontroverso um fato afirmado pelo autor - seja por meio da confirmação desse fato na contestação, seja mediante a sua não-negação (descumprimento do ônus da impugnação especificada - art. 302 do CPC) -, o réu não pode apresentar

\footnotetext{
${ }^{670}$ Até 1980, a conduta prevista no art. 17, I, do CPC era a seguinte: “deduzir pretensão ou defesa, cuja falta de fundamento não possa razoavelmente desconhecer". Segundo os autores que estudaram o dispositivo legal com essa redação antiga, era necessária a presença do elemento subjetivo (não poder "razoavelmente desconhecer" a falta de fundamento) para que a norma fosse aplicada no caso concreto. Nesse sentido: BARBOSA MOREIRA, A Responsabilidade das Partes por Dano Processual no Direito Brasileiro, in Temas de Direito Processual, p. 26; OLIVEIRA, Litigância de Má-Fé, p. 36; FERNANDES DE SOUZA, Abuso de Direito Processual - uma teoria pragmática, p. 110; PONTES DE MIRANDA, Comentários ao Código de Processo Civil, tomo I, p. 402. Foi a Lei $n^{\circ}$ 6.771/80 que modificou a redação do referido inciso do art. 17 do $\mathrm{CPC}$, retirando o elemento subjetivo.

${ }^{671}$ Nesse ponto, o ordenamento jurídico brasileiro distingue-se bastante do lusitano. O legislador português já adotou as três fórmulas subjetivas mencionadas, exigindo sempre o dolo ou a culpa grave, ao lado da falta de fundamento, para considerar o sujeito processual litigante de má-fé. Fê-lo, respectivamente, no art. 465 do Código Alberto dos Reis, de 1939 (“falta de fundamento não podia razoavelmente desconhecer"), no $\S 2^{\circ}$ do art. 456 do Código de Processo Civil de 1961 ("falta de fundamento não ignorava") e na alínea " $a$ " do $§ 2^{\circ}$ desse mesmo art. 456, após a reforma de 1995/1996 ("falta de fundamento não devia ignorar"). Acerca desse tema na doutrina portuguesa, consultar: MENEZES CORDEIRO, Litigância de Má-Fé, Abuso do Direito de Ação e Culpa "in Agendo", pp. 47-52 e 56-57.

${ }^{672}$ Comentários ao Código de Processo Civil, vol. I, § 160, p. 126.

${ }^{673}$ Instituições de Direito Processual Civil, vol. II, § 528-A, pp. 267-268.
} 
defesa impugnando-o. Isso não se confunde, porém, com a defesa de mérito indireta, por meio da qual o réu admite o fato como verdadeiro, mas apresenta outros fatos impeditivos, modificativos ou extintivos dos efeitos normais daquele ${ }^{674}$.

Da mesma forma como a incidência da $1^{\mathrm{a}}$ parte do inciso I do art. 17 do CPC não exige qualquer atitude psicológica do litigante, a incidência da $2^{\mathrm{a}}$ parte também independe de dolo ou culpa.

\subsection{Utilização do processo para conseguir objetivo ilegal (art. 17, III, do CPC)}

Nos termos do art. 17, III, do CPC, a parte que "usar do processo para conseguir objetivo ilegal" é considerada litigante de má-fé ${ }^{675}$. O legislador utilizou uma expressão bastante ampla, que abrange todos os casos em que o ajuizamento da demanda é, em si mesmo, um expediente para obter o que a lei veda, às vezes a dano de terceiros ${ }^{676}$. Trata-se de hipótese de abuso do processo em sentido estrito (item 1.4.3 "supra") ${ }^{677}$.

Nota-se que essa conduta processual abusiva não se confunde com a descrita no art. 17, I, $1^{\text {a }}$ parte, do CPC, qual seja, a dedução de pretensão ou defesa contra texto expresso de lei. Barbosa Moreira ${ }^{678}$ explica que o "objetivo ilegal" mencionado no inciso III do art. 17 do CPC não é diretamente ligado ao pedido, como ocorre no inciso I desse mesmo dispositivo legal. Trata-se, por exemplo, da conduta de ajuizar demanda com o escopo de expor a parte contrária à desonra pública, ou de abalar-lhe o crédito, ou ainda de pressionála psicológica ou economicamente para obter favores ou vantagens indevidas etc.

Pontes de Miranda ${ }^{679}$ cita os seguintes exemplos de utilização do processo com o intuito de conseguir objetivo ilegal: (a) a ação condenatória proposta pelo credor com o escopo de diminuir o prestígio econômico do devedor, uma vez que este está viajando e, se fosse comunicado, teria saldado de imediato seu débito; (b) a reconvenção em que o demandado quer tornar público que terceira pessoa, que auxiliou no negócio jurídico em segredo, conhecia o que se passou; (c) o interveniente que visa a mostrar ao público o que se passou e ainda se passa entre ele e o autor, ou o réu.

\footnotetext{
${ }^{674}$ BARBI, Comentários ao Código de Processo Civil, vol. I, § 160, p. 126.

${ }^{675} \mathrm{Se}$ o Projeto de Lei $\mathrm{n}^{\circ}$ 8.046/2010 for aprovado, sancionado e publicado com sua redação atual, essa norma estará prevista no art. 83, III, do novo Código de Processo Civil.

${ }^{676}$ DINAMARCO, Instituições de Direito Processual Civil, vol. II, § 528-A, p. 268.

677 ABDO, O Abuso do Processo, p. 189.

678 A Responsabilidade das Partes por Dano Processual no Direito Brasileiro, in Temas de Direito Processual, p. 27.

${ }^{679}$ Comentários ao Código de Processo Civil, tomo I, pp. 403-404.
} 
Outro comportamento abusivo que se subsume ao inciso III do art. 17 do CPC é a "sham litigation", identificada pela jurisprudência norte-americana. Trata-se da utilização do direito de petição à Administração (art. 5, XXXIV, "a", da CF) ou do direito de acesso ao Poder Judiciário (art. $5^{\circ}, \mathrm{XXXV}$, da CF) com intuito anticoncorrencial, ou seja, com o escopo de limitar, falsear ou de qualquer forma prejudicar a livre concorrência ou a livre iniciativa, ou de dominar mercado relevante de bens ou serviços, ou de aumentar arbitrariamente os lucros, ou ainda de exercer de forma abusiva posição dominante (art. 36, I, II, III e IV, da Lei $n^{\circ} 12.529 / 11$ ), ainda que tais objetivos ilícitos não sejam efetivamente alcançados. No julgamento do caso "Professional Real Estate Investors, Inc. et al. v. Columbia Pictures Industries, Inc. et al. (508 U.S. 49, 113 S.Ct. 1920, 123 L.Ed.2d 611)", a Suprema Corte dos Estados Unidos da América identificou dois elementos cumulativos que caracterizam a "sham litigation": (a) a demanda é objetivamente infundada, de modo que nenhum litigante sensato poderia, realisticamente, contar com uma decisão de mérito favorável; e (b) a motivação do litigante é interferir diretamente nas relações negociais do seu concorrente, utilizando o processo como uma arma anticoncorrencial ${ }^{680}$.

A prática de ato processual que contrarie um negócio jurídico previamente celebrado pelas partes também configura a hipótese de litigância de má-fé prevista no inciso III do art. 17 do CPC, uma vez que a violação de deveres contratuais é considerada ato ilícito (especificamente, ato ilícito relativo ${ }^{681}$ ). Por exemplo: autor e réu celebram acordo extrajudicial em que o primeiro se compromete a desistir da ação em curso, desde que o segundo doe bem imóvel a uma terceira pessoa. Uma vez efetivada a doação, se o autor não cumprir sua obrigação de desistir da ação, estará utilizando o processo para conseguir objetivo ilegal $^{682} 683$.

\footnotetext{
${ }^{680}$ Para uma análise da origem do instituto da "sham litigation", do seu conceito, dos critérios para sua identificação e da questão da competência do Sistema Brasileiro de Defesa da Concorrência - SBDC para tratar da matéria, consultar: FIDELIS, Sham Litigation e o Sistema Brasileiro de Defesa da Concorrência, "passim".

${ }^{681}$ MELLO, Teoria do Fato Jurídico: plano da existência, p. 234.

${ }^{682}$ No julgamento do REsp 656.103/DF (STJ, Rel. Min. Jorge Scartezzini, DJ 26/02/2007, p. 595), os Ministros da $4^{\text {a }}$ Turma do Superior Tribunal de Justiça consideraram que esse comportamento configura violação dos deveres de lealdade processual e de boa-fé (art. 14, II, do CPC), mas não o subsumiram ao art. 17, III, do CPC. Decidiram que, se essa conduta dificultar sobremaneira o desempenho do direito à ampla defesa e ao contraditório pelo réu e acarretar a prolação de sentença de procedência dos pedidos integrantes da petição inicial, fica caracterizado o dolo da parte vencedora em detrimento da parte vencida, o que torna o "decisum" passível de desconstituição por meio de ação rescisória (art. 485, III, do CPC).

${ }^{683}$ Acerca da possibilidade de as partes celebrarem convenções processuais fora das hipóteses previstas "expressis verbis" na lei (v.g., art. 111; art. 265, II; art. 333, parágrafo único; art. 792 do CPC etc.), consultar: BARBOSA MOREIRA, Convenções das Partes sobre Matéria Processual, in Temas de Direito Processual terceira série, "passim", notadamente pp. 91-92.
} 
Alguns doutrinadores sustentam que a situação prevista no art. 17, III, não se confunde com a que consta do art. 129 do CPC. Barbi ${ }^{684}$, por exemplo, defende que a primeira consiste na conduta da parte que tem objetivo ilícito, em detrimento da parte contrária; diferentemente do art. 129 do CPC, que trata do acordo entre as partes no sentido de praticar ato simulado ou de obter fim proibido pelo ordenamento jurídico. No mesmo sentido, Barbosa Moreira ${ }^{685}$ afirma que o art. 17, III, do CPC somente é aplicável na hipótese de colusão entre as partes (art. 129 do CPC) se existir um outro litigante de boa-fé (interveniente ou litisconsorte de alguma das partes conluiadas), a quem a colusão cause prejuízo $^{686}$.

Outros autores, contudo, entendem que o conluio entre autor e réu no sentido de utilizar o processo para a prática de ato simulado ou para o conseguimento de fim proibido pelo ordenamento jurídico configura a hipótese do art. 17, III, do CPC. É o caso de Yarshell $^{687}$, para quem a conduta de utilizar o processo como instrumento da simulação se subsume ao inciso III do art 17 do CPC. Mas, o jurista ressalva que a simulação processual destinada a fraudar a execução deve ser considerada ato atentatório à dignidade da Justiça (art. 600, I, do CPC), e não uma hipótese de litigância de má-fé (art. 17 do CPC). Dinamarco $^{688}$ menciona como exemplos de aplicação do art. 17, III, do CPC dois casos de uso do processo para a efetivação de simulação: (a) demanda de separação judicial destinada a frustrar credores, mediante a subtração dos bens de um dos cônjuges à responsabilidade patrimonial (art. 591 do CPC), ou ajuizada com o escopo de afastar inelegibilidades; (b) dois sujeitos simulam a existência de litígio referente a terras em relação às quais nenhum deles tem título legítimo, com o intuito de obter para um deles um título aparentemente legítimo e, com isso, lesar possuidores.

A razão parece estar com esta segunda corrente doutrinária, eis que a norma contida no art. 129 do CPC visa apenas a evitar a concretização do escopo das partes de usar o

\footnotetext{
${ }^{684}$ Comentários ao Código de Processo Civil, vol. I, § 162, pp. 126-127.

${ }^{685}$ A Responsabilidade das Partes por Dano Processual no Direito Brasileiro, in Temas de Direito Processual, pp. 27-28.

${ }^{686}$ Esse parece ser também o entendimento de Tornaghi (Comentários ao Código de Processo Civil, vol. I, p. 155), que afirma o seguinte ao comentar essa hipótese de litigância de má-fé:

"Pode acontecer que haja colusão entre autor e réu, para lesar terceiro. Pense-se, por exemplo, na execução por dívida inexistente, com o intuito de retirar ao réu o patrimônio que garantiria os verdadeiros credores. Neste caso, o juiz, proferirá sentença que obste aos objetivos das partes (v. comentários ao art. 129); o terceiro que, eventualmente, haja sofrido algum prejuízo, só em ação própria poderia obter o ressarcimento. Não assim se for interveniente no processo, pois então o juiz poderá condenar os ímprobos litigantes na mesma sentença em que trancar o processo".

${ }^{687}$ Simulação e Processo de Execução, in ALVIM WAMBIER (coord.), Processo de Execução e Assuntos Afins, p. 233.

${ }^{688}$ Instituições de Direito Processual Civil, vol. II, § 528-A, p. 268.
} 
processo para praticar simulação entre elas ou para obter fim antijurídico. Quando essa norma preventiva se mostra ineficaz, as partes que se valeram (ou tentaram, sem sucesso, se valer) do processo para realizar ato simulado ou obter fim ilícito merecem ser sancionadas (arts. 16 e 18 do CPC) e a punição que recebem tem como fundamento o art. 17, III, do CPC 689 .

\subsection{Utilização do processo como instrumento para simulação}

\subsubsection{Conceito e classificação}

No direito material, a simulação caracteriza-se pela divergência intencional entre a vontade real e a declarada, de modo que as partes se portam deliberadamente em desconformidade com a sua intenção com o fim de enganar outrem. Não obstante as partes envolvidas na simulação não queiram propriamente os efeitos do ato simulado (já que, em tese, ele foi praticado contra a sua verdadeira vontade), elas almejam a sua aparência, a sua forma, a qual serve como um instrumento para atingirem os resultados que realmente desejam.

De acordo com Yarshell ${ }^{690}$, essa noção de simulação aplica-se totalmente à seara processual. O processo é utilizado por muitos indivíduos como um instrumento de consumação e êxito da simulação, pois o provimento judicial respalda o ato simulado entre as partes, emprestando-lhe uma aparência de legalidade que o distancia de eventuais ataques. No processo, também é possível que uma das partes pratique atos contrários à sua real intenção com o intuito de dificultar a constatação da simulação pelo magistrado (v.g., o demandado contesta o pedido, oferece impugnação ao cumprimento de sentença etc., quando, na verdade, quer fazer prevalecer a pretensão do demandante).

Levando isso em consideração, pode-se conceituar a "simulação processual" como sendo "a divergência intencional, por entendimento oculto das partes no processo, entre a vontade real delas e as suas atividades processuais formalmente contraditórias, divergência [essa] dirigida a enganar o juiz ou terceiros" $" 691$.

\footnotetext{
${ }^{689}$ Nesse sentido: VINCENZI, A Boa-Fé no Processo Civil, pp. 113-114.

${ }^{690}$ Simulação e Processo de Execução, in ALVIM WAMBIER (coord.), Processo de Execução e Assuntos Afins, pp. 229-230.

${ }^{691}$ VIRISSIMO CUNHA, Simulação Processual e Anulação do Caso Julgado, p. 173.
} 
As finalidades anormais que os litigantes podem perseguir por meio do processo simulado são ${ }^{692}$ :

a) a obtenção de resultado prático equivalente a um negócio que as partes não conseguiriam celebrar validamente; ou

b) a anulação de uma relação jurídica que, de acordo com o ordenamento jurídico, é indissolúvel; ou ainda

c) fazer crer existente um estado jurídico que as partes entre si reconhecem inexistente.

A doutrina distingue dois tipos de simulação: a inocente e a fraudulenta. Segundo Carnelutti $^{693}$, para que se possa falar em processo simulado é necessário (e suficiente) que o processo e o seu resultado (a sentença) tenham de existir e operar somente em confronto com terceiros, não entre as partes. Já a fraude bilateral no processo ocorre se as partes, em conluio, tiverem o intuito de desviar o processo do seu fim natural, que é a justa composição da lide. O jurista argumenta que nem todas as hipóteses de fraude bilateral no processo são também hipóteses de simulação. Em sua obra, publicada em 1.928, cita como exemplo o caso dos cônjuges que ajuízam demanda um contra o outro com o objetivo de obterem o resultado prático de uma doação entre si, o que seria vedado pelo Direito material italiano da época. Para o jurista, nesse caso, não há processo simulado porque o resultado visado não seria obtido se a sentença não devesse valer também entre as partes, ou seja, não existe discrepância entre a declaração juridicamente relevante dos litigantes e as suas vontades internas. Aduz o doutrinador que, por outro lado, pode ocorrer verdadeira e própria simulação sem que haja fraude. Cita o seguinte exemplo: dois juristas têm opiniões contrastantes a respeito de uma questão e, com o fim de obter do Poder Judiciário a solução para sua rusga acadêmica, fingem a existência de uma lide envolvendo o tema discutido e ajuízam demanda pleiteando sua solução. No âmbito doutrinário nacional, Barbosa Moreira ${ }^{694}$ diferencia o processo simulado do processo fraudulento, afastando-se um pouco da teoria carneluttiana. Ele observa que, no processo simulado, as partes não têm o intuito de aproveitar-se do resultado do pleito, nem dos efeitos jurídicos do provimento jurisdicional, a não ser como simulacro para prejudicar terceiros. Já no processo fraudulento, as partes querem, desde o início, o resultado da demanda e elas se valem do processo porque ele se lhes apresenta como o único instrumento para atingir um fim ilícito.

\footnotetext{
${ }^{692}$ CHIOVENDA, Instituições de Direito Processual Civil, vol. I, p. 70.

${ }^{693}$ Contro il Processo Fraudolento, in Studi di Diritto Processuale, vol. II, pp. 26 e 28-29.

${ }^{694}$ Comentários ao Código de Processo Civil, vol. V, pp. 127-128.
} 
Segundo o jurista, um exemplo clássico de processo fraudulento é o ajuizamento de ação de nulidade ou de anulação de matrimônio, realizado por um dos cônjuges em prévio concerto com o outro, com o escopo de dissolver o vínculo conjugal fora das hipóteses legais. Tanto o autor, quanto o réu, unidos em conluio, contribuem para alcançar o fim fraudulento: o primeiro invoca fatos inverídicos e produz provas falsas, enquanto o segundo deixa de oferecer contestação.

Yarshell $^{695}$ concorda com essa distinção, porém, explica que é principalmente a simulação fraudulenta que interessa ao processo, pois é difícil conceber que alguém ajuíze uma demanda com o objetivo de simular, mas sem o escopo de lesar terceiro ou violar o ordenamento jurídico. Afirma que a simulação acaba frequentemente figurando como instrumento para a fraude.

Já Viríssimo Cunha ${ }^{696}$ desintegra o conceito de "simulação processual" em três modalidades ou tipos distintos, ordenados segundo a intensidade crescente com que o fenômeno simulatório se apresenta neles: (a) litígio simulado, que é o simples entendimento oculto das partes sobre o mérito da causa, com a intenção comum de o resultado processual (lícito ou ilícito, mas geralmente ilícito) ser válido não só para com terceiros, mas também para com as próprias partes, sendo o juiz estranho a esse entendimento (é a hipótese mínima); (b) resultado processual simulado, que é o entendimento oculto das partes sobre o mérito da causa, acrescido da intenção comum de o resultado processual só existir para com terceiros, sendo o juiz estranho a esse entendimento (é a hipótese média); e (c) sentença simulada, que é o entendimento oculto entre as partes e o próprio juiz, ou seja, juiz e partes, de comum acordo, fingem um processo que, na sua recíproca intenção, se destina a valer só em relação a terceiros (é a hipótese máxima). Segundo o doutrinador lusitano, as duas últimas espécies não são mais que formas complexas da primeira.

Quando as partes do processo se unem em conluio para, imediatamente, induzir em erro o juiz e, mediatamente, atingir qualquer fim diverso dos escopos normais do processo, diz-se que há "dolo ${ }^{697}$ processual bilateral” (ou "colusão", ou “dolo colusivo", ou "dolo convencional”, ou ainda "dolo fiduciário"). Este se opõe ao dolo processual unilateral, que

\footnotetext{
695 Simulação e Processo de Execução, in ALVIM WAMBIER (coord.), Processo de Execução e Assuntos Afins, pp. 230-231 e 232, nt. 19.

${ }^{696}$ Simulação Processual e Anulação do Caso Julgado, pp. 144-164.

${ }^{697}$ A palavra "dolo" é utilizada, nessa expressão, no sentido de "conduta enganosa" (VIRÍSSIMO CUNHA, Simulação Processual e Anulação do Caso Julgado, p. 41).
} 
ocorre sempre que uma parte procede com o fim de prejudicar a outra ${ }^{698}$. O dolo processual bilateral também pode configurar-se por conivência do representante de uma das partes (o representante do autor conluia-se com o réu, ou o representante do réu conluia-se com o autor, algumas vezes sem a intenção de prejudicar a pessoa representada, outras com o escopo de fraudar o representado em benefício do próprio representante e do adversário $)^{699}$. Existe, outrossim, o chamado “dolo total ou universal”, que é a conjugação de dolo das partes e do juiz. Nessa hipótese, autor, réu e juiz estão todos de acordo em desviar o processo da sua função normal, fingindo um litígio que todos sabem que não existe de fato, de modo que a sentença é um mero simulacro destinado a valer só para terceiros (o magistrado afirma que condena, mas não quer condenar ninguém; ou então absolve, mas não quer proferir absolvição alguma) $)^{700}$.

Considerando que a relação jurídica processual é composta por três polos (autor, réu e Estado-juiz), parte da doutrina afirma que é impróprio empregar a expressão "processo simulado" para designar o comportamento do autor e do réu que se conluiam para praticar ato simulado ou conseguir fim proibido por lei (art. 129 do CPC). Para esses autores, só se pode falar realmente em processo simulado se as duas partes e também o magistrado estiverem envolvidos na conduta abusiva ${ }^{701}$. Com o devido respeito que essa corrente doutrinária merece, as expressões "processo simulado" e "simulação processual" são empregadas no presente trabalho para fazer referência tanto a hipóteses de dolo total, quanto de dolo processual bilateral.

\footnotetext{
${ }^{698}$ Deve-se ressaltar a distinção entre dolo processual bilateral e dolo unilateral bissingular (ou cruzado, ou recíproco, ou ainda simultâneo). Enquanto no primeiro os litigantes entram em acordo para induzir em erro o juiz, no segundo há desacordo entre as partes, pois uma quer prejudicar a outra; é má-fé contra má-fé.

${ }^{699}$ Esse é um dos comportamentos que configuram o que Luso Soares denomina "dolo da parte unilateral plural misto" (A Responsabilidade Processual Civil, p. 274).

${ }^{700}$ Acerca das modalidades ou categorias de dolo processual e da distinção entre dolo processual unilateral e dolo processual bilateral, consultar: CALOGERO, Probità, Lealtà, Veridicità nel Processo Civile, in Rivista di Diritto Processuale Civile, vol. XVI, parte I, pp. 139-140; VIRÍSSIMO CUNHA, Simulação Processual e Anulação do Caso Julgado, pp. 47-59; 145-146; LUSO SOARES, A Responsabilidade Processual Civil, pp. 256-290.

701 Nesse sentido: YARSHELL, Simulação e Processo de Execução, in ALVIM WAMBIER (coord.), Processo de Execução e Assuntos Afins, p. 228, nt. 5.

Esse parece ser também o entendimento de Viríssimo Cunha (Simulação Processual e Anulação do Caso Julgado, p. 169):

"Em sentido técnico, a expressão processo simulado significaria que a simulação incide directamente no próprio processo, em bloco, e isso só acontece na modalidade sentença simulada [que, segundo o autor, coincide com a hipótese de dolo total ou universal]. Não nas modalidades restantes [refere-se ao litígio simulado e ao resultado processual simulado]. Dada a circunstância de nestas o juiz ser alheio ao pacto, nunca a simulação incide na sentença, nunca a sentença é pròpriamente simulada. A simulação processual condiciona-a, vicia-a, objectiva-se nela: mas isto e mais nada, Mais longe não podemos ir" (destaques no original).
} 


\subsubsection{Hipóteses de ocorrência}

A utilização do provimento judicial como um instrumento de consumação da simulação pode ocorrer tanto no processo de conhecimento, quanto no de execução. Neste, a simulação se mostra mais preocupante em razão dos efeitos práticos que a tutela jurisdicional executiva pode gerar (expropriação, desapossamento e transformação), os quais favorecem bastante quem pretenda utilizar o processo para lesar interesses de terceiros $^{702}$. O processo de execução utilizado para a prática de simulação pode estar fundado em título executivo extrajudicial ou judicial (apesar de ser preferível o primeiro fundamento, já que a passagem pela fase de conhecimento para a formação do título executivo judicial incrementa as chances de o órgão jurisdicional detectar a presença do conluio fraudulento $)^{703}$.

Podem ser mencionados diversos exemplos de utilização de processos cognitivos e executivos para o cometimento de simulação.

Nas obras de Couture ${ }^{704}$ e de Carnelutti ${ }^{705}$ são encontrados dois casos clássicos, que merecem ser citados. O primeiro é o do fazendeiro abastado que induziu a genitora do seu filho, com quem não era casado, a constituir um certo indivíduo como procurador da criança para poder promover processo simulado de investigação de paternidade. Nesse processo, uma vez citado, o fazendeiro negou todos os fatos narrados na petição inicial e o advogado da parte autora, que agia em conluio com ele, não produziu prova alguma, o que ensejou a improcedência total da demanda. O segundo é o famoso caso PecorainoD’Angelo, apreciado pela "Corte di Cassazione" italiana em 1.925. Nele, uma mulher foi induzida a ajuizar demanda de nulidade do seu casamento por violência, fundamentando sua pretensão com afirmações e provas falsas. Como o seu marido não a contradisse no processo, o juízo de primeiro grau julgou a ação procedente e declarou a nulidade. Em seguida, a mulher se arrependeu, confessou o que fez e interpôs recurso, mas a "Corte di Cassazione" rejeitou-o por não ter sido apresentado pela parte sucumbente.

Há ainda quem ajuíze ação possessória, em conluio com o réu, com o escopo de fazer prova pré-constituída para futura ação de usucapião (simulação da existência do ato

\footnotetext{
${ }^{702}$ YARSHELL, Simulação e Processo de Execução, in ALVIM WAMBIER (coord.), Processo de Execução e Assuntos Afins, pp. 228 e 233.

${ }^{703}$ YARSHELL, Simulação e Processo de Execução, in ALVIM WAMBIER (coord.), Processo de Execução e Assuntos Afins, p. 235.

${ }^{704}$ Revocación de los Actos Procesales Fraudulentos, in Estudios de Derecho Procesal Civil, t. III, pp. 388389.

${ }^{705}$ Contro il Processo Fraudolento, in Studi di Diritto Processuale, vol. II, p. 25.
} 
jurídico de ofensa à posse do autor); ou então ação de despejo, com o intuito apenas de demonstrar a posse indireta do bem ao qual a demanda se refere, visando a pré-constituir prova para futura ação possessória ou de usucapião (simulação da existência do negócio jurídico de locação) $)^{706}$.

É possível também que o devedor, com o intuito de dilapidar seu patrimônio penhorável, ajuste-se com uma pessoa de sua confiança ou com um dos seus credores para que seja ajuizada contra ele ação de execução por quantia certa, ou para entrega de coisa certa, fazendo com que a alienação de seus bens ocorra por comando estatal, e não de maneira voluntária ( $v . g$., mediante compra e venda, dação em pagamento, doação etc.). Nesses casos, a pessoa que adquire os bens do devedor também se beneficia, eis que fica resguardada contra eventual declaração de ineficácia do ato em razão de reconhecimento de fraude à execução ou de fraude contra credores, já que se trata de aquisição qualificável como originária ${ }^{707}$. Quando se pratica esse tipo de fraude processual, comumente o arrematante dos bens nem mesmo os retira, de fato, da esfera de disponibilidade do executado-simulador ${ }^{708}$. A transferência simulada de patrimônio também pode ser feita por meio de ação de execução de obrigação de emitir declaração de vontade (arts. 466-A a 466-C do CPC) $)^{709}$.

Atualmente, a simulação processual praticada no âmbito da Justiça do Trabalho é considerada um problema bastante sério. O exemplo mais comum é aquele em que o empregador demite o empregado e o orienta a procurar certos advogados, que ajuízam ação em nome desse trabalhador com o escopo de firmar acordo na Justiça do Trabalho relativo ao pagamento de verbas rescisórias, com quitação do extinto contrato de trabalho. Nesses casos, os valores a serem pagos pelo empregador ao empregado são combinados antes da audiência e costumam ser inferiores aos efetivamente devidos segundo a lei trabalhista. Além de impedir que o trabalhador receba todas as verbas rescisórias a que tem direito, esse comportamento processual ímprobo viola o art. 477, $\S 1^{\circ}$, da CLT, segundo o qual a extinção do contrato do trabalhador com mais de um ano de serviço deve ser homologada pelo sindicato ou perante a autoridade do Ministério do Trabalho e Emprego. Contraria,

\footnotetext{
${ }^{706}$ NERY JÚNIOR; ANDRADE NERY, Código de Processo Civil Comentado e Legislação Extravagante, p. 388.

${ }^{707}$ YARSHELL, Simulação e Processo de Execução, in ALVIM WAMBIER (coord.), Processo de Execução e Assuntos Afins, p. 234.

${ }^{708}$ É o que alerta Yarshell (Simulação e Processo de Execução, in ALVIM WAMBIER (coord.), Processo de Execução e Assuntos Afins, p. 236).

${ }^{709}$ YARSHELL, Simulação e Processo de Execução, in ALVIM WAMBIER (coord.), Processo de Execução e Assuntos Afins, p. 235, nt. 26.
} 
outrossim, o direito do empregado com menos de um ano de serviço de receber o pagamento das verbas rescisórias diretamente, mediante recibo ${ }^{710}$.

\subsubsection{Identificação nos casos concretos}

A constatação da ocorrência dessa espécie de abuso do processo em sentido estrito pode ser feita:

a) pelo terceiro potencialmente prejudicado pela simulação (ou por quem esteja incumbido de falar em seu nome ou em defesa de seus interesses). Para que isso ocorra, é necessário que a pessoa tenha conhecimento do processo que está sendo utilizado como meio para a simulação, o que é difícil de suceder na praxe. Segundo Yarshell ${ }^{711}$, é mais factível que isso ocorra na hipótese de insolvência civil, uma vez que se possibilita a intervenção de todos os credores (art. 768 do CPC). O terceiro pode denunciar a simulação por meio de uma simples petição dirigida ao juízo competente, ou de um recurso, ou mediante o ajuizamento de uma demanda autônoma, ou ainda por meio de uma ação rescisória. Optando pelo primeiro instrumento de denúncia, o terceiro não pode pretender deduzir qualquer outra alegação que não os argumentos a respeito da suposta simulação. Trata-se de uma intervenção atípica, que não se amolda a qualquer uma das modalidades de intervenção de terceiro previstas no Código de Processo Civil $^{712}$. O terceiro potencialmente lesado pela simulação tem legitimidade para interpor recurso porque ele se ajusta à figura do "terceiro prejudicado" do art. 499 do $\mathrm{CPC}^{713}$. De acordo com o $\S 1^{\circ}$ do art. 499 do CPC, ele precisa demonstrar seu interesse jurídico em intervir na relação jurídica processual, que decorre do nexo de interdependência entre uma relação jurídica de que seja titular e a relação jurídica deduzida no processo $^{714}$. Se houver o ajuizamento de ação autônoma, é conveniente a distribuição por dependência e a determinação da

\footnotetext{
${ }^{710}$ A gravidade desse comportamento processual ímprobo levou a Procuradoria Regional do Trabalho da $2^{\mathrm{a}}$ Região a fazer uma campanha de combate à lide simulada (Trabalhador - você conhece seus direitos?. Disponível em: <http://www.prt2.mpt.gov.br/img/slides/slide_03_g.jpg>. Acesso em: 08/07/2012) e a Procuradoria Regional do Trabalho da $5^{\text {a }}$ Região a lançar um encarte sobre esse tema (Combate à Lide Simulada: como agir legalmente no momento da extinção do contrato de trabalho. Disponível em: $<$ http://www.prt5.mpt.gov.br/cartilhas/lidesimulada.pdf >. Acesso em: 08/07/2012).

711 Simulação e Processo de Execução, in ALVIM WAMBIER (coord.), Processo de Execução e Assuntos Afins, p. 227, nt. 3.

712 Por essa razão, Yarshell (Simulação e Processo de Execução, in ALVIM WAMBIER (coord.), Processo de Execução e Assuntos Afins, p. 243, nt. 52) afirma que ela não pode ser obstada com fundamento no art. 280, I, do CPC ou no art. 10 da Lei n $^{\circ}$ 9.099/95.

713 Nesse sentido: YARSHELL, Simulação e Processo de Execução, in ALVIM WAMBIER (coord.), Processo de Execução e Assuntos Afins, p. 243, nt. 51.

${ }^{714}$ BARBOSA MOREIRA, Comentários ao Código de Processo Civil, vol. V, pp. 294-296.
} 
suspensão do processo supostamente abusivo até o desfecho da ação que discute a ocorrência de simulação, desde que as alegações trazidas pelo terceiro sejam plausíveis e sérias e que haja risco de irreversibilidade ${ }^{715}$. Por fim, no caso de o processo simulado já se ter extinguido com sentença de mérito transitada em julgado formal e materialmente, o art. 487, II, do CPC arrola o "terceiro juridicamente interessado" em denunciar a improbidade entre os legitimados à ação rescisória (art. 485, III, $2^{\mathrm{a}}$ parte, do CPC);

b) pelo próprio magistrado, de ofício, no curso do processo simulado ${ }^{716}$. Também é algo raro, pois o juiz não conta com a colaboração de qualquer das partes na identificação da conduta processual abusiva ${ }^{717}$;

c) pelo órgão do Ministério Público, seja na posição de parte, seja na de "custos legis", sem jamais ter atuado no feito como parte. Como fiscal da lei, o membro do Ministério Público pode interpor recurso, com espeque no $\S 2^{\circ}$ do art. 499 do CPC, pleiteando o reconhecimento da simulação e a aplicação das sanções cabíveis aos litigantes ímprobos ${ }^{718}$. Pode, outrossim, ajuizar ação rescisória fundada na "colusão entre as partes, a fim de fraudar a lei” (art. 485, III, $2^{\mathrm{a}}$ parte; e art. 487, III, “ $b$ ”, do CPC);

d) por algum sujeito parcial do processo que não se tenha envolvido no conluio formado entre os demais litigantes (v.g., pelo denunciado, em caso de conluio entre o denunciante e a outra parte; pelo assistente, em caso de conluio entre as partes principais etc $\left.{ }^{719}\right)$

e) por algum (ou alguns) dos litigantes ímprobos que se tenha arrependido de praticar a simulação processual. Trata-se de hipótese rara, mas factível. É oportuno lembrar que, no caso Pecoraino-D'Angelo, em que se pediu a nulidade de um casamento com fundamento em alegações falsas, considerado um dos exemplos mais famosos de processo

\footnotetext{
${ }^{715}$ YARSHELL, Simulação e Processo de Execução, in ALVIM WAMBIER (coord.), Processo de Execução e Assuntos Afins, pp. 243-244.

${ }^{716}$ Caso o magistrado constate indícios de cometimento de ilícito criminal, pode determinar a suspensão do processo e a remessa de peças ao Ministério Público, aguardando até que outros elementos que demonstrem a utilização do processo para consumar a simulação sejam coligidos, seja no âmbito do inquérito policial, seja no âmbito de ação penal (YARSHELL, Simulação e Processo de Execução, in ALVIM WAMBIER (coord.), Processo de Execução e Assuntos Afins, p. 241).

${ }^{717}$ YARSHELL, Simulação e Processo de Execução, in ALVIM WAMBIER (coord.), Processo de Execução e Assuntos Afins, p. 227.

${ }^{718}$ Nesse sentido, estatuindo que, em Portugal, o Ministério Público, sendo parte acessória, tem legitimidade para recorrer de acórdão que tenha afastado a aplicação do art. 665 do CPC português (que contém norma similar à do art. 129 do CPC nacional): REIS, Código de Processo Civil Anotado, vol. V, pp. 108-109.

${ }^{719}$ Exemplos mencionados por Barbosa Moreira (Comentários ao Código de Processo Civil, vol. V, p. 174) ao sustentar que, no caso de pluralidade de partes, aquela que não tenha participado do conluio pode pleitear a rescisão da sentença.
} 
simulado, a autora se arrependeu do seu comportamento ímprobo e confessou a simulação ao Estado-juiz ${ }^{720}$.

A dificuldade não se localiza somente na percepção de que um determinado processo está sendo utilizado como meio para a prática de simulação. Mesmo quando se identifica a conduta abusiva, é bastante difícil provar sua ocorrência ${ }^{721}$.

Como não se pode esperar que alguém que quer praticar simulação declare em juízo sua verdadeira intenção, Yarshell ${ }^{722}$ observa que a conduta das partes é um importante fator para a detecção do abuso do processo. Nesses casos, ganha importância a prova indiciária da simulação. Consideram-se indícios dela, dentre outros ${ }^{723}$ :

a) a desnecessidade de celebrar o negócio cujo adimplemento forçado é pleiteado judicialmente. Caso se constate que o devedor assumiu, em curto espaço de tempo, obrigações comprometedoras da totalidade ou de parte expressiva de seu patromônio, sem que haja explicação razoável para isso, há indício de simulação. A perquirição da causa que levou as partes ao negócio pode ser feita mediante um exame mais amplo de sua situação patrimonial, o que se dá por meio da verificação das suas declaraçãoes de bens e rendimentos, das movimentações bancárias, da sua escrituração (se a parte for pessoa jurídica) etc. Obviamente, essa investigação deve ser feita pelo magistrado por meio de decisões muito bem fundamentadas e com respeito ao contraditório;

b) a relação de parentesco, amizade, dependência ou qualquer outro vínculo entre as partes, já que a simulação pressupõe confiança entre os envolvidos. A constatação dessa circunstância resulta da coincidência de nomes ou de outros dados que denunciem o vínculo de confiança (v.g., coincidência de endereços, de números de telefone etc.). É possível também que um terceiro que se sinta prejudicado leve ao órgão jurisdicional a notícia do intuito simulatório das partes. Excepcionalmente, com espeque no art. 130 do CPC, o magistrado também pode decretar, fundamentadamente, a quebra do sigilo dos dados telefônicos das partes, com o fim de rastrear ligações telefônicas feitas entre os simuladores, ou ligações feitas por outras pessoas relacionadas ao negócio sobre o qual paira suspeita;

\footnotetext{
${ }^{720}$ CARNELUTTI, Contro il Processo Fraudolento, in Studi di Diritto Processuale, vol. II, p. 25.

${ }^{721}$ YARSHELL, Simulação e Processo de Execução, in ALVIM WAMBIER (coord.), Processo de Execução e Assuntos Afins, pp. 227 e 228.

${ }^{722}$ YARSHELL, Simulação e Processo de Execução, in ALVIM WAMBIER (coord.), Processo de Execução e Assuntos Afins, p. 228 e nt. 4; e p. 235.

${ }^{723}$ YARSHELL, Simulação e Processo de Execução, in ALVIM WAMBIER (coord.), Processo de Execução e Assuntos Afins, pp. 236-240.
} 
c) a conduta indiciária dos envolvidos, dentro e fora do processo. Deve-se verificar, por exemplo, a conduta social das partes; analisar seu caráter, sua personalidade, se já cometeram anteriormente atos atentatórios ao direito de outrem, mediante simulação ou não etc. O comportamento do suposto devedor em outros processos ajuizados por autênticos credores também ajuda na identificação da simulação. Por exemplo: configura indício de simulação a constatação de que, nos demais processos, o credor usa todos os meios de defesa admitidos no ordenamento jurídico, enquanto que, na execução movida pelo falso credor, não esboça resistência alguma à pretensão executiva ou, se resiste, o faz de forma desproporcional se comparada com a apresentada nos outros processos. Nesse caso, tudo indica que o devedor quer fazer com que o processo em que ocorre a simulação atinja mais rapidamente a fase de expropriação e satisfação do exequente, em detrimento dos demais credores. Algumas condutas praticadas dentro do próprio processo também denotam a ocorrência da simulação. Nesse sentido, Reis ${ }^{724}$ afirma que é possível inferir da argumentação da petição inicial e da contestação que não existe verdadeiro conflito, que por trás da controvérsia formal há, na verdade, um conluio entre autor e réu. O jurista lusitano ensina também que, quando o objetivo dos litigantes é provocar uma sentença de improcedência, eles não produzem qualquer prova que demonstre os fatos constitutivos do direito do autor. Na fase ou no processo de execução, há outros atos e omissões que podem evidenciar a ocorrência de simulação processual, os quais foram identificados por Yarshell ${ }^{725}$ : o executado que se apressa em ingressar na relação jurídica processual, dandose por citado; o executado que não se insurge para fazer valer a ordem legal do art. 655 do CPC; o executado que deixa de oferecer impugnação ao cumprimento de sentença ou de opor embargos à execução; o exequente que concorda com o valor atribuído pelo executado ao bem penhorado, o qual se mostra visivelmente incompatível com a verdadeira expressão patrimonial da coisa; o exequente que, depois de arrematar ou adjudicar o bem, não requer a respectiva imissão na posse, ou deixa de registrar a carta de sentença ou de adjudicação, ou ainda não toma outras providências que deveriam complementar a alienação do domínio feita judicialmente etc.

É importante lembrar que a presença de apenas um desses indícios não implica, necessariamente, o reconhecimento de que as partes usam o processo como um meio de praticar simulação. Para chegar a essa conclusão, é preciso que o indício se coadune com o

\footnotetext{
${ }^{724}$ Código de Processo Civil Anotado, vol. V, p. 104.

725 Simulação e Processo de Execução, in ALVIM WAMBIER (coord.), Processo de Execução e Assuntos Afins, pp. 239-240.
} 
conjunto das demais circunstâncias de fato que gravitam em torno do fato principal $^{726}$. Em caso de dúvida, deve-se considerar o comportamento lícito ${ }^{727}$.

Se o magistrado conseguir identificar terceiras pessoas que possam, eventualmente, ser prejudicadas pela simulação, ele pode determinar que elas sejam cientificadas e autorizar que tragam aos autos elementos que confirmem, ou não, a prática processual abusiva das partes. Essa atuação dos possíveis prejudicados configura uma intervenção atípica, que não integra qualquer das modalidades de intervenção de terceiro previstas no Código de Processo Civil ${ }^{728}$. Ela não implica o alargamento do objeto do processo, pois o terceiro não pode pretender deduzir pretensão própria nos autos. Ele apenas ajuda o magistrado a identificar a utilização do processo como instrumento de simulação ${ }^{729}$.

A decisão acerca da utilização, ou não, do processo para a prática de simulação ou para a obtenção de objetivo antijurídico precisa ser adequadamente motivada, devendo o juiz indicar quais elementos objetivos o levaram àquela conclusão ${ }^{730}$.

O reconhecimento judicial da utilização do processo como instrumento para praticar simulação acarreta as seguintes consequências jurídicas:

a) prolação de sentença que obste ao objetivo das partes (art. 129 do CPC);

b) reparação de perdas e danos (arts. 16 e 18 do CPC); e

c) multa (art. 18 do CPC).

Se as partes tiverem utilizado processo de conhecimento para a consumação da simulação, e o terceiro só tomar conhecimento disso quando a decisão final de mérito já estiver transitada em julgado materialmente, ele pode ajuizar ação rescisória com espeque no inciso III do art. 485 do CPC.

Em regra, na hipótese de utilização do processo de execução para a prática de simulação, não é cabível a ação rescisória, pois somente em casos excepcionais o juízo da execução profere alguma sentença que se possa reputar "de mérito", como exige o "caput"

\footnotetext{
726 Nesse sentido: YARSHELL, Simulação e Processo de Execução, in ALVIM WAMBIER (coord.), Processo de Execução e Assuntos Afins, p. 237.

${ }^{727}$ COUTURE, Revocación de los Actos Procesales Fraudulentos, in Estudios de Derecho Procesal Civil, t. III, pp. 401-402.

${ }^{728} \mathrm{O}$ art. 54 do Código de Processo Civil uruguaio estabelece que, se houver suspeita de fraude ou colusão no processo, o órgão judicial pode, de ofício ou após requerimento do Ministério Público ou de alguma das partes, ordenar a citação de pessoas que possam ser prejudicadas pelo comportamento ímprobo para que façam valer seus direitos. Pode-se suspender o processo por até 40 dias para que essa providência seja tomada.

${ }^{729}$ YARSHELL, Simulação e Processo de Execução, in ALVIM WAMBIER (coord.), Processo de Execução e Assuntos Afins, pp. 242 e 243.

${ }^{730}$ YARSHELL, Simulação e Processo de Execução, in ALVIM WAMBIER (coord.), Processo de Execução e Assuntos Afins, p. 242.
} 
do art. 485 do $\mathrm{CPC}^{731}$. Segundo Yarshell ${ }^{732}$, se o terceiro lesado constatar o escopo fraudulento das partes apenas depois de encerrado o processo executivo, tendo já se operado a expropriação, o desapossamento ou a transformação, ele pode ajuizar demanda anulatória com o objetivo de desconstituir os atos processuais, principalmente o ato que consubstanciou a expropriação, o desapossamento ou a transformação, retornando, assim, ao "status quo ante". Na opinião do autor, o terceiro lesado pode fazer isso até mesmo quando o executado-simulador houver oposto embargos à execução. Saliente-se que a anulação do ato que consubstanciou a expropriação, o desapossamento ou a transformação não pode prejudicar terceiros de boa-fé, nem anular atos e contratos celebrados com o dono aparente dos bens ${ }^{733}$.

\subsection{Violação do dever de veracidade (arts. 17, II; e 233 do CPC)}

O ordenamento jurídico brasileiro estatui que, na narração dos fatos que fundamentam sua pretensão, o litigante deve ser fiel à verdade subjetiva, ou seja, ao que ele realmente entende que ocorreu (art. 14, I, do CPC) ${ }^{734}$.

Viola esse dever quem "pretender convocar alguém a juízo para discutir o que não existe (fato não proposto) ou que existe de modo diverso (fato-produto de alteração da verdade), ${ }^{, 735}$.

\footnotetext{
${ }^{731}$ Dinamarco (Instituições de Direito Processual Civil, vol. IV, § 1.849, p. 931) ensina que, no processo ou fase executiva, o mérito (ou seja, a pretensão do exequente) jamais é julgado. Segundo Barbosa Moreira (Comentários ao Código de Processo Civil, vol. V, p. 112), somente em casos muito especiais o juízo da execução profere uma sentença que pode ser considera "de mérito", citando com exemplo a decisão que indefere a inicial por verificar, desde logo, a ocorrência de prescrição (art. 295, IV, c/c art. 598 do CPC). É possível encontrar julgados do Superior Tribunal de Justiça admitindo ação rescisória de sentença que extingue a execução com fundamento no inciso I do art. 794 do CPC, pois, na opinião dos ministros, a decisão que extingue a execução em razão do pagamento integral do débito tem conteúdo material e, consequentemente, gera coisa julgada material (nesse sentido: STJ, 6a Turma, REsp 238.059/RN, Rel. Min. Fernando Gonçalves, DJ 10/04/2000, p. 144; STJ, 6ª Turma, REsp 147.735/SP, Rel. Min. Vicente Leal, DJ 12/06/2000, p. 139).

${ }^{732}$ Simulação e Processo de Execução, in ALVIM WAMBIER (coord.), Processo de Execução e Assuntos Afins, p. 244.

${ }^{733}$ É o que Couture (Revocación de los Actos Procesales Fraudulentos, in Estudios de Derecho Procesal Civil, t. III, pp. 396-397) estatui no art. 577 do seu projeto de Código de Processo Civil:

"Poderá pedir-se, ainda depois de terminado o processo, a anulação dos atos realizados mediante dolo, fraude ou colusão.

Essa anulação poderá ser requerida somente por aqueles a quem o dolo, a fraude ou a colusão tenha causado prejuízo e de acordo com os princípios mencionados nos artigos anteriores. Os terceiros também podem solicitar essa anulação.

Se os atos forem anulados, restabelecer-se-ão as coisas ao estado anterior aos mesmos. Mas, em nenhum caso, a anulação poderá prejudicar terceiros de boa-fé, nem anular os atos e contratos celebrados com o dono aparente dos bens" (tradução e destaque nossos).

${ }^{734}$ Acerca do dever de veracidade, consultar o item 1.3.7.1 "supra".

${ }^{735}$ CASTRO FILHO, Abuso do Direito no Processo Civil, p. 131.
} 
Os seguintes dispositivos do Código de Processo Civil preveem condutas contrárias ao dever de veracidade: o art. 17, II, e o art. 233. O comportamento descrito no inciso II do art. 69 do CPC também consiste em uma violação do dever de veracidade, mas ele será estudado no item 2.7 "infra", uma vez que se trata de uma espécie de abuso do poder de nomear à autoria.

$\mathrm{O}$ art. 17, II, do CPC reputa litigante de má-fé a parte que altera a verdade dos fatos, ou seja, que alega a inexistência de fatos que, na realidade, existem, ou que afirma a existência de fatos que não existem ${ }^{736}$, ou ainda que descreve fato existente, porém sem correspondência exata com a realidade ${ }^{737} 738$.

Uma demanda fundada em fatos consabidamente falsos pode ser extremamente danosa. Isso porque a parte de boa-fé no processo pode demorar anos para demonstrar a mentira e, durante esse período, despenderá seu tempo e dinheiro (custas processuais, honorários advocatícios, deslocamentos até o fórum para a realização de audiências etc.), além de sofrer incômodos e, eventualmente, danos morais graves decorrentes do processo. Ainda que a sentença final seja justa, porque embasada na verdade, ela não será capaz de suprimir o sofrimento gerado pela falsidade, o qual foi infligido ao longo de todo o "iter" processual $^{739}$.

A alteração consciente da verdade fática, realizada com o intuito de obter decisão de mérito favorável, é identificada pela doutrina lusitana como uma das modalidades de “dolo substancial” (ou “dolo material”, ou "dolo essencial”, ou ainda "má-fé substancial”), uma vez que se refere à relação jurídica material ou de direito substantivo, contrapondo-se ao "dolo instrumental" (ou "má-fé instrumental), que diz respeito ao uso manifestamente reprovável do processo ou das situações jurídicas processuais, tendente a impedir a defesa do opositor, a deturpar a convicção dele e a prejudicar a justiça da sentença ${ }^{740}$.

Cumpre, todavia, destacar que essa nomenclatura não se mostra tecnicamente correta, pois as situações de "dolo substancial" apontadas pelos autores lusitanos não

\footnotetext{
736 BARBI, Comentários ao Código de Processo Civil, vol. I, § 161, p. 126; BUZAID, Processo e Verdade no Direito Brasileiro, in Revista de Processo, n 47, p. 97.

737 BARBOSA MOREIRA, A Responsabilidade das Partes por Dano Processual no Direito Brasileiro, in Temas de Direito Processual, pp. 26-27.

${ }^{738}$ O Projeto de Lei $n^{\circ} 8.046 / 2010$, em trâmite no Congresso Nacional, que versa sobre o novo Código de Processo Civil, prevê a mesma regra em seu art. 83, II.

${ }^{739}$ MENEZES CORDEIRO, Litigância de Má-Fé, Abuso do Direito de Ação e Culpa “in Agendo”, p. 30.

${ }^{740}$ MENEZES CORDEIRO, Litigância de Má-Fé, Abuso do Direito de Ação e Culpa "in Agendo", p. 50; ALBUQUERQUE, Responsabilidade Processual por Litigância de Má Fé, Abuso de Direito e Responsabilidade Civil em Virtude de Actos Praticados no Processo, pp. 48-49; REIS, Código de Processo Civil Anotado, vol. II, pp. 263-264; LUSO SOARES, A Responsabilidade Processual Civil, pp. 269-270; VIRÍSSIMO CUNHA, Simulação Processual e Anulação do Caso Julgado, pp. 48-49.
} 
pressupõem a ofensa a qualquer posição jurídica substancial, mas sim a posições jurídicas processuais. Ou seja, trata-se de ilícitos processuais, e não materiais. Faz-se referência à relação jurídica substancial apenas para explicar que tais condutas visam a transmitir ao juiz uma ideia distorcida acerca dos contornos e características dessa mesma relação ${ }^{741}$. Diante dessa imprecisão terminológica, é preferível não empregar tais expressões no Direito brasileiro. De fato, os doutrinadores nacionais optam por designar essa espécie de abuso processual como "comportamento incorreto (ou abusivo) das partes com referência ao conteúdo das alegações por elas feitas em juízo", em oposição ao "comportamento incorreto (ou abusivo) que diz respeito à forma por que as partes atuam no processo" ${ }^{, 742}$.

Em sua redação original, o art. 17, II, do CPC exigia expressamente que a alteração da verdade fosse intencional: “Art. 17. Reputa-se litigante de má-fé aquele que: [...] II alterar intencionalmente a verdade dos fatos". Foi a Lei $n^{\circ} 6.771 / 80$ que suprimiu do texto legal esse elemento subjetivo ${ }^{743}$. Não obstante essa alteração legislativa, uma interpretação literal do atual inciso II do art. 17 do CPC legitima a afirmação de que persiste a exigência do elemento subjetivo como requisito necessário para que a parte seja considerada litigante de má-fé. Isso porque o verbo "alterar" pressupõe, por si mesmo, o conhecimento da verdade que se modifica. A pessoa que, após ter uma falsa percepção da realidade, narra em juízo um fato inverídico não altera a verdade; apenas age embasada em erro, que não configura má-fé 744 .

Uma hipótese de alteração da verdade dos fatos (art. 17, II, do CPC) encontra-se positivada no art. 940 do $\mathrm{CC}^{745}$ :

Aquele que demandar por dívida já paga, no todo ou em parte, sem ressalvar as quantias recebidas ou pedir mais do que for devido, ficará obrigado a pagar ao devedor, no primeiro caso, o dobro do que houver cobrado e, no segundo, o equivalente do que dele exigir, salvo se houver prescrição.

De acordo com a jurisprudência pacífica do Supremo Tribunal Federal e do Superior Tribunal de Justiça, para que fique caracterizada a conduta descrita nesse dispositivo do Código Civil é necessário que a cobrança excessiva tenha ocorrido de má-

\footnotetext{
741 ALBUQUERQUE, Responsabilidade Processual por Litigância de Má Fé, Abuso de Direito e Responsabilidade Civil em Virtude de Actos Praticados no Processo, p. 43, nt. 118, e pp. 52-53.

${ }^{742}$ Nesse sentido: BARBOSA MOREIRA, A Responsabilidade das Partes por Dano Processual no Direito Brasileiro, in Temas de Direito Processual, p. 17; e FERNANDES DE SOUZA, Abuso de Direito Processual - uma teoria pragmática, p. 114.

${ }^{743}$ OLIVEIRA, Litigância de Má-Fé, p. 42; BUZAID, Processo e Verdade no Direito Brasileiro, in Revista de Processo, $\mathrm{n}^{\circ}$ 47, p. 97; FERNANDES DE SOUZA, Abuso de Direito Processual - uma teoria pragmática, pp. 110 e 116.

${ }_{744}^{74}$ Nesse sentido: BARBI, Comentários ao Código de Processo Civil, vol. I, § 161, p. 126.

${ }^{745}$ OLIVEIRA, Litigância de Má-Fé, p. 48.
} 
$\mathrm{fe}^{746}$. Isso corrobora o entendimento, exposto anteriormente, de que somente pode ser considerada litigante de má-fé, com espeque no art, 17, II, do CPC, a parte que altera a verdade fática intencionalmente.

Conforme ficou consignado no item 1.3.7.1.1 "supra", declarações sobre certas circunstâncias jurídicas também precisam observar o dever de veracidade. Sendo assim, pratica o comportamento abusivo previsto no inciso II do art. 17 do CPC o litigante que: (a) mente a respeito do teor ou da vigência da norma de Direito municipal, estadual, estrangeiro ou consuetudinário que utilizou para sustentar sua pretensão (art. 14 do Decreto-Lei $n^{\circ}$ 4.657/42; e art. 337 do CPC); (b) menciona precedente judicial inverídico com o intuito de comprovar a existência de dissídio jurisprudencial a respeito da interpretação de lei federal que justifique o cabimento de recurso especial (art. 105, III, “c”, da CF c/c art. 541, parágrafo único, do CPC), ou com o escopo de demonstrar divergência jurisprudencial que fundamente o cabimento de embargos de divergência (art. 546, I e II, do CPC), ou ainda com o fim de mostrar que o recurso da parte contrária ou a decisão recorrida está em confronto com a jurisprudência dominante, legitimando a aplicação do art. 557, “caput” ou $\S 1^{\circ}$-A, respectivamente ${ }^{747}$.

Outra conduta contrária ao dever de dizer a verdade consta do "caput" do art. 233 do CPC, que estatui: "A parte que requerer a citação por edital, alegando dolosamente os requisitos do art. 231, I e II, incorrerá em multa de 5 (cinco) vezes o salário mínimo vigente na sede do juízo" ${ }^{\text {"748. }}$.

A citação por edital pode ocorrer apenas em três hipóteses: (a) quando desconhecido ou incerto o réu; (b) quando ignorado, incerto ou inacessível o lugar em que se encontrar; e (b) nos casos expressos em lei (art. 231 do CPC). Se a citação editalícia não for prevista expressamente na lei, o juiz somente a defere se houver uma declaração do demandante, ou uma certidão do oficial de justiça, de que o demandado é desconhecido ou incerto ou de que ele se encontra em lugar ignorado, incerto ou inacessível (art. 232, I, c/c

\footnotetext{
${ }^{746}$ É o que estatui o enunciado da súmula no 159 do STF: “Cobrança excessiva, mas de boa-fé, não dá lugar às sanções do art. 1.531 do Código Civil”. Percebe-se que a súmula faz referência ao art. 1.531 do CC16, que é equivalente ao atual art. 940 do CC.

Atualmente, o Superior Tribunal de Justiça encampa esse entendimento. Nesse sentido: STJ, $1^{\text {a }}$ Turma, REsp 446.724/DF, Rela ${ }^{\text {. Mina }}$. Denise Arruda, DJ 25/06/2007, p. 219.

${ }^{747}$ Nesse sentido, no âmbito doutrinário: CALOGERO, Probità, Lealtà, Veridicità nel Processo Civile, in Rivista di Diritto Processuale Civile, vol. XVI, parte I, p. 148, nt. 1.

Nesse sentido, no âmbito jurisprudencial: STJ, $2^{\mathrm{a}}$ Turma, AgRg no REsp 1.239.748/PB, Rel. Min. Herman Benjamin, DJe 09/09/2011.

${ }^{748}$ Caso o projeto do novo Código de Processo Civil (Projeto de Lei no 8.046/2010) seja aprovado nos termos atuais, essa hipótese abusiva constará do art. 227.
} 
art. 231, I e II, do CPC). Ao fazer essa declaração, o autor deve respeitar o dever de veracidade, caso contrário comete abuso do processo ${ }^{749}$.

Analogamente ao que ocorre com o art. 17, II, do CPC, o art. 233 do CPC somente incide se o demandante alterar a verdade fática intencionalmente, ou seja, se ele: (a) conhecer quem é o demandado, mas declarar que se trata de pessoa desconhecida ou incerta; ou (b) conhecer o lugar em que o demandado se encontra, mas declarar que se trata de lugar desconhecido ou incerto; ou ainda (c) souber que o lugar em que o demandado se encontra é acessível, mas declarar que não o é. Segundo Barbosa Moreira ${ }^{750}$, o dolo deve ficar comprovado por elementos constantes dos autos, podendo o órgão judicial inferi-lo de indícios.

Caso o demandante tenha uma falsa percepção da realidade e, por causa disso, afirme que o demandado é desconhecido ou incerto ou que ele se encontra em lugar ignorado, incerto ou inacessível, a norma em comento não pode incidir, uma vez que a atuação da parte é condizente com a verdade subjetiva. A única consequência da citação por edital fundada em erro é a nulidade do ato de comunicação processual (art. 247 do CPC), se ficar demonstrado que o réu sofreu prejuízo ${ }^{751}$.

O requerimento de citação por edital fundado em alegação mentirosa acarreta as seguintes consequências jurídicas: (a) nulidade do ato de comunicação processual (art. 247 do CPC); (b) multa (art. 233 do CPC); (c) ressarcimento de danos (arts. 16 e 18 do CPC); e (d) obrigação de arcar com o custo do processo (art. 18 do CPC), já que essa conduta não difere da prevista no art. 17 , II, do $\mathrm{CPC}^{752}$.

\subsection{Violação do dever de prontidão}

O dever de prontidão determina que as partes exponham suas razões em juízo e indiquem suas provas tão prontamente quanto haja possibilidade de fazê-lo, evitando que

\footnotetext{
749 Grossmann (O Dever de Veracidade das Partes Litigantes no Processo Civil (aspecto doutrinário), in Revista Forense, vol. 101, p. 482) estatui que a "falsa indicação dos domicílios, deve ser considerada como contravenção ao dever de veracidade".

${ }^{750}$ O Novo Processo Civil Brasileiro, p. 31.

${ }^{751}$ Nesse sentido: SILVA DINAMARCO, Comentários ao art. 233 do CPC, in MARCATO (coord.), Código de Processo Civil Interpretado, p. 666.

${ }^{752}$ Em sentido contrário, entendendo que não se pode cumular a sanção prevista no art. 233 do CPC com as previstas no art. 18 do CPC: SILVA DINAMARCO, Comentários ao art. 233 do CPC, in MARCATO (coord.), Código de Processo Civil Interpretado, p. 667.

Mas, como se verá no item 3.11.3 "infra", a doutrina majoritária entende que é possível aplicar mais de uma sanção em razão da prática de um mesmo ato processual abusivo, desde que elas não tenham a mesma natureza (v.g., não se pode cumular a multa no valor de 5 vezes o salário mínimo, prevista no art. 233 do CPC, com a multa no montante de até $1 \%$ do valor da causa, contida no art. 18 do CPC).
} 
um litigante surpreenda o outro com lances que este não espera ${ }^{753}$. É deduzido dos arts. 282, III e VI; 283; 300-302; e 396 do CPC $^{754}$.

Algumas normas do ordenamento jurídico processual brasileiro tratam de comportamentos que afrontam o dever de prontidão e cominam sanções à parte que os pratica. Elas estão previstas nos arts. 22;113, § $1^{\text {o }}$; e 267, § $3^{\circ}$, do CPC. Como as suas hipóteses de incidência são muito diferentes entre si e exigem a abordagem de diversos conceitos doutrinários, devem ser analisadas em separado, de maneira mais minuciosa. $\mathrm{O}$ art. 69, I, do CPC também prevê uma conduta processual contrária ao dever de prontidão, mas, como se trata de uma hipótese bastante singular, que diz respeito à nomeação à autoria, ela será analisada no item 2.7 "infra", referente ao abuso do poder de nomear à autoria.

\subsubsection{Art. 22 do CPC}

Antes do Código de Processo Civil de 1973, o ordenamento jurídico brasileiro não continha um dispositivo com conteúdo similar ao do atual art. 22. O art. 277 do CPC39 aproximava-se deste ao estatuir que a parte devia arguir as nulidades sempre que tivesse de falar nos autos e, caso não o fizesse desde logo, respondia pelas custas acrescidas com a repetição de atos ou com o suprimento de sua falta ${ }^{755}$.

Consoante a redação atual do art. 22 do CPC, o réu que dilatar o julgamento da lide em razão de não ter arguido na sua resposta fato impeditivo, modificativo ou extintivo do direito do autor será condenado a pagar custas a partir do saneamento do processo e perderá, ainda que vencedor na causa, o direito de haver do vencido honorários advocatícios $^{756}$.

O fim principal dessa regra é evitar que o réu adote comportamento desleal consistente em silenciar, no início do processo, a respeito de fato impeditivo, modificativo ou extintivo do direito do autor, fazendo com que este opte por uma determinada conduta processual e, em seguida, surpreendê-lo com novos argumentos defensivos ${ }^{757}$. Além disso,

\footnotetext{
${ }^{753}$ LUSO SOARES, A Responsabilidade Processual Civil, p. 173.

${ }^{754}$ Para uma análise mais detalhada desse assunto, ver o item 1.3.7.3 "supra".

${ }^{755}$ BARBI, Comentários ao Código de Processo Civil, vol. I, § 194, p. 150.

756 O Projeto de Lei $\mathrm{n}^{\circ}$ 8.046/2010 (que institui o novo Código de Processo Civil) não trata desse comportamento ímprobo.

${ }^{757}$ Nesse sentido: CARNELUTTI, Derecho y Proceso, p. 234. O jurista ensina que o dano advindo do descumprimento do dever de prontidão não está na prática de atos processuais que seriam desnecessários se o litigante tivesse agido com lealdade desde o início do processo, mas sim em não ter podido uma das partes ajustar sua conduta processual como teria feito se a parte contrária tivesse dito no início do processo o que
} 
Barbi $^{758}$ afirma que ela obsta o dispêndio inútil de tempo e de recursos financeiros e humanos do Judiciário, uma vez que, quanto mais a parte atrasa para alegar os fatos que constituem sua defesa, mais o processo é inutilmente postergado. De acordo com Dinamarco $^{759}$, o art. 22 do CPC visa a favorecer a celeridade processual e, consequentemente, a tempestividade da tutela jurisdicional, reprimindo deslealdades.

Passando à análise dos elementos do suporte fático da norma em questão, a palavra "resposta" utilizada pelo legislador refere-se tanto à contestação (arts. 300 a 314 do CPC), quanto às exceções (arts. 304 a 314 do CPC). A terceira modalidade de resposta do réu, que é a reconvenção (arts. 315 a 318), não é considerada abrangida ${ }^{760}$, uma vez que, nela, há uma inversão na posição das partes, atuando o réu como autor-reconvindo.

A utilização, pelo legislador, da expressão "a partir do saneamento do processo" poderia levar o intérprete a entender que o dispositivo em questão não pode ser aplicado no procedimento sumário, nem na execução, dado que não há previsão de uma fase saneadora em tais procedimentos. Todavia, tem razão Barbi $^{761}$ ao afirmar que tal distinção não é razoável e, por isso, não deve ser feita. O jurista argumenta que, quanto aos embargos do executado e à impugnação, o art. 598 do CPC autoriza expressamente a aplicação subsidiária à execução das normas referentes à fase cognitiva, abrangendo o art. 22 do CPC. O mesmo autor aduz que esse dispositivo pode incidir com frequência nas execuções fundadas em título executivo extrajudicial, em que o executado pode alegar tardiamente o pagamento ou prová-lo nos autos. Theodoro Júnior ${ }^{762}$, Wambier, Alvim Wambier e Medina $^{763}$ corroboram essa tese, admitindo, expressamente, a aplicação do art. 22 do CPC à fase executiva.

Barbi ${ }^{764}$ ensina que o "fato impeditivo, modificativo ou extintivo do direito do autor" pode ser relativo ao direito substancial em discussão ou à relação jurídica processual. No plano do direito substancial, fatos impeditivos (ou obstativos) são aqueles que impedem o nascimento do direito subjetivo (por exemplo, a ilicitude da causa da

preferiu declarar mais tarde, no último momento. Por causa disso, ele afirma que tem pouca eficácia a punição de condenar a parte desleal a pagar os gastos despendidos pelo outro litigante em razão da atividade processual desnecessária. De acordo com o autor, o mais correto seria prever sanções disciplinares ao advogado que atuar deslealmente e criar normas que impeçam a parte de retardar a exposição de suas razões e a proposição de suas provas além dos limites do necessário.

${ }^{758}$ Comentários ao Código de Processo Civil, vol. I, § 195, p. 150.

${ }^{759}$ Instituições de Direito Processual Civil, vol. II, p. 675.

${ }^{760}$ BARBI, Comentários ao Código de Processo Civil, vol. I, § 196, p. 150.

761 Comentários ao Código de Processo Civil, vol. I, § 404, pp. 153-154.

762 Os Embargos do Devedor Após as Reformas do CPC Efetuadas pelas Leis $\mathrm{n}^{\mathrm{os}} 11.232$ e 11.382 , in Revista Forense, vol. 391, p. 115.

${ }^{763}$ Breves Comentários à Nova Sistemática Processual Civil 2, p. 152.

${ }^{764}$ Comentários ao Código de Processo Civil, vol. I, § 198, p. 151; § 200, p. 152. 
obrigação). Os fatos extintivos são aqueles que extinguem o direito, como o pagamento, a novação, a prescrição e a transação. Finalmente, os fatos modificativos têm por eficácia a alteração, qualitativa ou quantitativa, do direito subjetivo. Por exemplo, a perda da coisa demandada, após o início do processo, ensejando a sua substituição por outra, consiste em uma alteração qualitativa; já o pagamento parcial do débito exigido causa uma modificação quantitativa. $\mathrm{Na}$ seara processual, os fatos impeditivos são aqueles que impedem o surgimento ou o desenvolvimento da relação jurídica processual, como a incapacidade das partes, a incompetência absoluta do juízo e a litispendência. Consideram-se fatos extintivos da relação jurídica processual: a coisa julgada, a renúncia à ação após o início da causa, a decadência e a prescrição (esta deixou de ser uma exceção em sentido estrito com o advento da Lei $\mathrm{n}^{\mathrm{o}} 11.280 / 06$, que alterou o art. 219, $\S 5^{\circ}$, do CPC e revogou o art. 194 do CC). Dentre os fatos que modificam a relação jurídica processual, podem ser citados: a mudança na demanda, alterando seu objeto, bem como a mudança de um dos sujeitos da relação jurídica processual por motivo de morte.

Uma leitura sistemática do Código de Processo Civil permite a conclusão de que o seu art. 22 refere-se apenas às objeções, não às exceções em sentido estrito. Se o réu não deduzir em sua resposta todas as exceções em sentido estrito de natureza substancial (v.g., erro, dolo, fraude, coação, compensação), ele não as poderá alegar mais tarde, pois o art. 303 do CPC veda isso expressamente. Quanto às exceções em sentido estrito de natureza processual (v.g., incompetência relativa, nulidades relativas, abandono da causa pelo autor por mais de 30 dias, mudança da parte pela alienação do objeto da demanda), o art. 245 do CPC estatui que o poder de as alegar preclui se a parte não o utilizar na primeira oportunidade que tiver para falar nos autos ${ }^{765}$. Em suma, se o réu não alegar em sua resposta os fatos que constituem exceções em sentido estrito, ele não poderá argui-los mais tarde, nem poderá o juiz conhecer deles de ofício.

Segundo Barbi ${ }^{766}$, a aplicação do art. 22 do CPC não depende de intenção do réu. Porém, como a norma pune a negligência ou falha da parte, pressupõe a exigência de culpa. Se ficar demonstrado que a parte agiu sem culpa (e.g., se o réu ignorava o fato ou se só tomou conhecimento dele posteriormente), a pena deve ser relevada. Caso o réu prove

\footnotetext{
${ }^{765}$ BARBI, Comentários ao Código de Processo Civil, vol. I, § 199, pp. 151-152; e § 201, pp. 152-153.

${ }^{766}$ Comentários ao Código de Processo Civil, vol. I, § 203, p. 153.
} 
que deixou de alegar o fato por motivo de força maior, o art. 517 do CPC permite que ele o argua até mesmo na apelação ${ }^{767}$.

A jurisprudência do Superior Tribunal de Justiça posiciona-se no sentido de sujeitar ao art. 22 do CPC o executado que, com comprovada a má-fé, argui a tese da impenhorabilidade do bem constrito pela primeira vez tardiamente, depois de apresentada a defesa de mérito (v.g., em sede de apelação contra sentença proferida em embargos à execução; ou em embargos à arrematação) $)^{768}$.

Caso o juiz constate que a parte ré deixou de alegar em sua resposta todos os fatos impeditivos, modificativos e extintivos do direito do autor, de natureza material ou processual, que configurem objeções, ele deve condená-la ao pagamento das custas a partir do saneamento do processo e declarar a perda do direito de haver do vencido honorários advocatícios, apesar de ela ser vencedora na causa. Assim, o autor vencido deve pagar as custas somente até o saneamento do processo ${ }^{769}$.

\subsubsection{Art. 113, $\S 1^{\circ}$, do CPC}

Tradicionalmente, a competência é descrita como uma parcela da função jurisdicional que é atribuída para cada juízo, dentro da qual (mas não além dela) ele pode exercer sua função ${ }^{770}$.

No entanto, nota-se que, de fato, o que se reparte não é a jurisdição como poder, nem como função, mas sim as atividades jurisdicionais ${ }^{771}$. A jurisdição é una, uma vez que

\footnotetext{
${ }^{767}$ Nesse sentido: "A arguição da prescrição, feita tardiamente, quando poderia ter sido apresentada com a resposta, provocando dilatamento no se julgar a lide, importa para o arguente perda do direito a honorários advocatícios. $O$ art. 22 do CPC só não incide se a parte desconhecia, quando da resposta, a circunstância extintiva do direito ou se ocorrera motivo de força maior a impedir a arguição (RJTJERGS 150/452)" (NEGRÃO; GOUVÊA; BONDIOLI; FONSECA, Código de Processo Civil e Legislação Processual em Vigor, p. 157, art. 22, nt. 4)

${ }^{768}$ Nesse sentido: STJ, $4^{a}$ Turma, REsp 981.532/RJ, Rel. Min. Luis Felipe Salomão, DJe 29/08/2012; STJ, $4^{\text {a }}$ Turma, REsp 467.246/RS, Rel. Min. Aldir Passarinho Júnior, DJ 12/08/2003, p. 236; STJ, 4ª Turma, REsp 262.654/RS, Rel. Min. Sálvio de Figueiredo Teixeira, DJ 20/11/2000, p. 302.

${ }^{769}$ BARBI, Comentários ao Código de Processo Civil, vol. I, § 202, p. 153.

${ }^{770}$ Nesse sentido é a lição de Liebman (Manual de Direito Processual Civil, vol. I, § 24, p. 55):

"O exercício da função jurisdicional acha-se distribuído entre os numerosos órgãos da autoridade judiciária ordinária, aos quais ela é atribuída segundo as regras e com as limitações que foram expostas acima $\left(n^{\circ} 4 e\right.$ segs.); tal distribuição é feita de modo a que cada um fique com uma fração, uma parte da função jurisdicional, que constitui a sua competência, em cujo âmbito, e não além dele, pode exercer as suas funções. Diz-se, por isso, que a competência é a quantidade de jurisdição cujo exercício é atribuído a cada órgão, ou seja, a 'medida da jurisdição'. Em outras palavras, ela determina em que casos e com relação a que controvérsias tem cada órgão em particular o poder de emitir provimentos, ao mesmo tempo em que delimita, em abstrato, o grupo de controvérsias que lhe são atribuídas".

Pontes de Miranda parece compartilhar desse entendimento, pois define competência como o "poder de julgar 'repartido"' (Comentários ao Código de Processo Civil, tomo II, p. 172).
} 
é uma expressão do poder estatal, o qual se caracteriza também pela unidade. O Estado possui apenas uma única capacidade de decidir e impor decisões imperativamente, eliminando litígios; não existem várias dessas capacidades, cada uma exercida por um juiz nacional. Destarte, cada juiz, de qualquer grau, exerce a mesma jurisdição ${ }^{772}$. É por causa disso que Marcato ${ }^{773}$, com mais precisão, prefere definir competência como "os limites legais impostos ao exercício válido e regular do poder jurisdicional". Para o autor, "a competência legitima o exercício do poder, pelo órgão jurisdicional, em um processo concretamente considerado" (destaques no original) ${ }^{774}$.

Tendo como base esta última definição, a incompetência deve ser entendida como a falta de legitimidade do juízo para exercitar o poder jurisdicional. A intensidade da incompetência depende da natureza da norma jurídica que o autor infringiu quando realizou o ajuizamento da demanda ${ }^{775}$ :

a) se a norma reguladora da competência tiver por fim a tutela de interesse público, a sua violação enseja a incompetência absoluta do órgão jurisdicional perante o qual a demanda foi ajuizada;

b) se a norma reguladora da competência for protetiva do interesse de qualquer das partes, sua inobservância acarreta a incompetência relativa do órgão jurisdicional.

Diferentemente da incompetência relativa, a absoluta não pode ser afastada pelas partes, seja por acordo expresso (mediante eleição de foro), seja por acordo tácito (inércia do réu ao constatar a incompetência do juízo em que foi indevidamente ajuizada a ação) ${ }^{776}$. Coerente com a ideia de que é impossível modificar a competência absoluta, o legislador estabeleceu no art. 113 do CPC o poder-dever do juiz de reconhecê-la de ofício. Assim, uma vez convencido de sua incompetência absoluta, o juiz não pode deixar de declará-la, ainda que o réu não alegue nada a respeito ou que todos os litigantes se oponham a isso ${ }^{777}$.

\footnotetext{
${ }^{771}$ DINAMARCO, Instituições de Direito Processual Civil, vol. I, § 109, pp. 303-304.

${ }_{772}$ DINAMARCO, Instituições de Direito Processual Civil, vol. I, § 128, p. 333.

${ }^{773}$ Breves Considerações sobre Jurisdição e Competência, in Revista de Processo, no 66, p. 27.

${ }^{774}$ Acerca desse assunto, mostra-se bastante esclarecedora a doutrina de Dinamarco (Instituições de Direito Processual Civil, vol. I, § 128, p. 333):

"A distribuição do exercício da jurisdição entre Justiças (Federal, Estaduais, do Trabalho etc.) ou entre juízes pertencentes à mesma Justiça apresenta a temática da competência, tradicionalmente conceituada como medida da jurisdição. A jurisdição nacional (única) é exercida por todos os juízes do país, mas a cada um deles ou a cada grupo de juízes (Justiças) a Constituição e a lei atribuem a missão de exercê-la com relação a determinadas pessoas, sobre tais ou quais espécies jurídico-materiais de litígios (de direito do trabalho, de direito penal, de direito civil em geral, de direito de família), em determinado lugar e nos variados graus de jurisdição (a competência dos tribunais)" (destaques no original).

${ }^{775}$ MARCATO, Breves Considerações sobre Jurisdição e Competência, in Revista de Processo, nº 66, p. 36.

${ }^{776}$ BARBI, Comentários ao Código de Processo Civil, vol. I, § 636, p. 372

${ }^{777}$ BARBI, Comentários ao Código de Processo Civil, vol. I, § 637, pp. 372-373.
} 
O juízo deve declarar-se incompetente o quanto antes possível, de preferência no momento do despacho da inicial ou quando o processo chegar ao seu conhecimento. Caso não perceba inicialmente a incompetência absoluta, ele pode fazer a declaração em qualquer outro momento do procedimento até a prolação da sentença (art. 463 do CPC), de ofício ou após alegação da parte, independentemente de exceção ritual (art. 113, "caput", c/c art. 301, II e $\S 4^{\circ}$, do CPC) ${ }^{778}$.

Essa ausência de preclusão temporal decorre da gravidade do vício que macula os atos processuais decisórios praticados por juízo absolutamente incompetente ${ }^{779}$. O art. 113, $\S 2^{\circ}$, do CPC estabelece que tais atos são nulos e a doutrina classifica essa nulidade como insanável $^{780}$, o que justifica a possibilidade de ajuizamento da ação rescisória (art. 485, II, do CPC) caso o ato viciado seja uma sentença de mérito já transitada em julgado.

Com o intuito de evitar o prosseguimento de processo eivado de tal vício, o art. $113, \S 1^{\circ}$, do CPC estatui limites temporais para o demandado alegar a incompetência absoluta: no prazo da contestação ou na primeira oportunidade em que lhe couber falar nos autos. Se o réu não se desincumbir do ônus de respeitar esses limites ${ }^{781}$, ele não fica impedido de alegar a incompetência mais tarde, pois o próprio "caput" do art. 113 do CPC garante que o poder de arguir a incompetência absoluta não preclui, podendo ser exercitado em qualquer tempo e grau de jurisdição, enquanto não houver o trânsito em julgado da decisão que aprecia o mérito da demanda (sentença ou acórdão) ${ }^{782}$. Contudo, nesse caso, a lei lhe impõe uma sanção pela alegação intempestiva, consistente na responsabilidade integral pelas custas (art. $113, \S 1^{\circ}$, do CPC) $)^{783}$.

O objetivo dessa norma é punir o réu que, ciente da incompetência absoluta do juízo desde o início do processo, não a alega na primeira oportunidade que tem para falar nos autos, esperando para surpreender os outros sujeitos processuais quando o processo estiver mais adiantado, dando ensejo à declaração de invalidade dos atos decisórios

\footnotetext{
${ }^{778}$ A arguição de incompetência absoluta pode ser feita em preliminar de contestação (art. 301, II, do CPC) ou, depois desse momento processual, mediante simples petição. Não é necessário utilizar a exceção de incompetência prevista nos arts. 304-314 do CPC (BARBI, Comentários ao Código de Processo Civil, vol. I, $\S 640$, p. 374).

${ }_{779}$ BARBI, Comentários ao Código de Processo Civil, vol. I, § 637, p. 373.

${ }^{780}$ Nesse sentido: MARCATO, Breves Considerações sobre Jurisdição e Competência, in Revista de Processo, no 66, p. 36.

${ }^{781} \mathrm{Na}$ opinião de Barbi (Comentários ao Código de Processo Civil, vol. I, § 638, p. 373), o réu tem verdadeiro dever de respeitar esses limites temporais.

782 Afasta-se, assim, a possibilidade de ocorrer o fenômeno da prorrogação (MARCATO, Breves Considerações sobre Jurisdição e Competência, in Revista de Processo, ${ }^{\circ}$ 66, p. 37).

${ }^{783} \mathrm{O}$ projeto do novo Código de Processo Civil (Projeto de Lei no ${ }^{\circ}$ 8.046/2010) não prevê norma análoga à do art. $113, \S 1^{\circ}$, do CPC em vigor.
} 
eventualmente já prolatados (art. 113, $\S 2^{\circ}$, do $\left.\mathrm{CPC}\right)^{784}$. Em suma, reprime-se a conduta avessa ao dever de prontidão.

Logicamente, se o réu for revel, não comparecendo no processo em momento algum, e o juiz, mais tarde, reconhecer de ofício a incompetência absoluta, não incide o art. $113, \S 1^{\mathrm{o}}$, do CPC. Conforme o ensinamento de Barbi ${ }^{785}$, nesse caso, não se pode atribuir ao demandado qualquer conduta maliciosa, nem mesmo erro grosseiro. Aliás, se é que existe erro nessa situação, ele partiu do autor, que não ajuizou a demanda no juízo correto.

O art. $113, \S 1^{\circ}$, do CPC também não incide se a parte demonstrar que não alegou a incompetência absoluta na primeira oportunidade que teve para falar nos autos por motivo de força maior.

\subsubsection{Art. 267, $\$ 3^{\circ}$, do CPC}

A partir do momento em que o réu é regularmente citado, tem início o prazo para apresentar sua resposta, que no procedimento comum ordinário é de 15 dias (art. 297 c/c art. 241 do CPC). Dentro desse prazo, ele pode ${ }^{786}$ :

a) reconhecer expressamente a procedência do pedido ou permitir que se opere o efeito da revelia (arts. 269, II; e 319 do CPC). Nesses casos, em regra, é prolatada sentença de mérito favorável ao autor (arts. 329 e 330, II, do CPC);

b) contestar a pretensão deduzida pelo autor. $O$ réu pode fazer isso apresentando em juízo: (1) defesa substancial (ou de mérito) direta, por meio da qual ele nega a existência ou o modo de ocorrência dos fatos constitutivos do direito do autor; ou (2) defesa substancial (ou de mérito) indireta, que consiste na alegação de fatos impeditivos, modificativos ou extintivos do direito do autor; ou ainda (3) defesa processual indireta (art. 301 do CPC);

c) opor exceção de incompetência, de suspeição ou de impedimento (art. 304 do CPC);

d) contra-atacar, deduzindo sua própria pretensão mediante reconvenção (art. 315 do CPC) ou pedido contraposto (art. 278, $\S 1^{\circ}$, do CPC; arts. 17, parágrafo único; e 31 da Lei no 9.099/95).

\footnotetext{
${ }^{784}$ Nesse sentido é a lição de Barbi, que entende que o art. $113, \S 1^{\circ}$, do CPC destina-se a "punir a malícia na omissão em arguir, logo que possível, a incompetência" (Comentários ao Código de Processo Civil, vol. I, § 639, pp. 373-374).

${ }_{785}^{7}$ Comentários ao Código de Processo Civil, vol. I, § 639, pp. 373-374.

${ }^{786}$ MARCATO, Procedimentos Especiais, pp. 24-25.
} 
De acordo com a parte final do art. 267, § $3^{\circ}$, do CPC, o réu que não alegar determinadas defesas processuais que configuram objeções ${ }^{787}$ na primeira oportunidade em que lhe couber falar nos autos fica obrigado a pagar as custas pelo retardamento do processo $^{788}$. Tais matérias defensivas são:

a) a ausência de pressupostos de constituição e de desenvolvimento válido e regular do processo (art. 267, IV, do CPC). Dinamarco ${ }^{789}$ leciona que se trata dos "requisitos sem os quais não se forma um processo viável", entendendo por "viável" a relação processual que existe e que reúne forças suficientes para alcançar o objetivo final de conceder tutela jurisdicional a quem tiver direito. Esses requisitos dividem-se em dois grupos:

1) requisitos prévios de existência da relação jurídica processual, que são: (i) a propositura de uma demanda inicial; e (ii) a investidura do órgão jurisdicional ao qual a demanda é dirigida, quer dizer, o órgão deve figurar entre os componentes do Poder Judiciário (art. 92 da CF);

2) requisitos prévios de viabilidade da relação jurídica processual, quais sejam: (i) a regularidade da demanda proposta (ou seja, a demanda não pode ser corporificada em petição inicial inepta - art. 295, I e parágrafo único, do CPC); (ii) a plena capacidade do sujeito que propõe a demanda (capacidade de ser parte, capacidade de estar em juízo e capacidade postulatória); e (iii) a personalidade jurídica da pessoa que figura no polo passivo (ou seja, basta a capacidade de ser parte);

b) a ocorrência de perempção ("extinção do direito de ação por força da inércia no curso do processo" ${ }^{, 790}$, prevista no art. 268, parágrafo único, c/c art. 267, III e V, do CPC), de litispendência ou de coisa julgada (ambas visam a impedir a repropositura da mesma demanda em juízo ${ }^{791}$ - art. $301, \S \S 1^{\circ}$ e $2^{\circ}$, do CPC -, com a diferença de que, quando se alega litispendência, o primeiro processo ainda se encontra pendente, ou seja, ainda não houve julgamento com ou sem resolução do mérito; enquanto que a defesa fundada no óbice representado pela coisa julgada pressupõe que o primeiro processo já se encontre

\footnotetext{
${ }^{787}$ Há hipóteses em que o juiz deve examinar defesa a favor do réu até mesmo de ofício. Trata-se das chamadas "objeções" (e.g., as questões enumeradas nos incisos do art. 301 do CPC, exceto o compromisso arbitral; a decadência; a prescrição). Já as defesas que o réu tem, necessariamente, que alegar para que o magistrado reconheça a sua ocorrência são denominadas "exceções em sentido estrito" (v.g., arguição de incompetência relativa) (MARCATO, Procedimentos Especiais, p. 25).

${ }^{788}$ O Código de Processo Civil projetado (Projeto de Lei $n^{\circ} 8.046 / 2010$ ) silenciou a respeito dessa conduta abusiva.

${ }^{789}$ Instituições de Direito Processual Civil, vol. III, § 833, pp. 130-131; Instituições de Direito Processual Civil, vol. II, § 503, pp. 221-224.

${ }^{790}$ DINAMARCO, Instituições de Direito Processual Civil, vol. III, § 840, p. 137.

791 MARCATO, Comentários ao art. 301 do CPC, in MARCATO (coord.), Código de Processo Civil Interpretado, pp. 991-992.
} 
extinto, tendo ocorrido julgamento definitivo do mérito com trânsito em julgado material $^{792}$ );

c) o não-preenchimento de alguma das condições da ação, que são a possibilidade jurídica da demanda, o legítimo interesse de agir e a legitimidade "ad causam" (ativa e passiva), tendo o art. 267, VI, do CPC adotado a proposta doutrinária original de Liebman $^{793}$.

Costuma-se classificar as defesas processuais (ou defesas técnicas, ou ainda defesas preliminares ao mérito) em: (a) peremptórias, que obstam a apreciação do pedido, já que levam o juízo a extinguir o processo sem julgamento do mérito; ou (b) dilatórias, que prolongam o curso do processo ${ }^{794}$. As matérias do art. $267, \S 3^{\circ}$, do CPC situam-se no primeiro grupo $^{795}$.

É exatamente o fato de tais defesas ensejarem a extinção do processo sem julgamento do mérito que faz com que a inércia em alegá-las, ao arrepio do dever de prontidão, seja danosa. Quando o réu tem ciência da ocorrência de qualquer uma delas, mas se recusa a alegá-la imediatamente, com o intuito de surpreender a parte contrária, causa prejuízo para esta, que continua atuando no processo com a esperança de ter o mérito de sua demanda julgado procedente, despendendo inutilmente seu dinheiro com honorários advocatícios, eventualmente também com honorários periciais, com obtenção de documentos; desperdiçando seu tempo reunindo-se com seu representante judicial, deslocando-se para as audiências etc. Além de incrementar a frustração da expectativa do autor de ter o seu pedido julgado, esse tipo de atitude desleal lesa o Estado, pois faz com que a estrutura administrativa do Poder Judiciário e também o trabalho de seus magistrados e funcionários sejam empregados por mais tempo que o necessário em um processo fadado ao insucesso, onerando os cofres públicos ao bel-prazer do réu.

Analogamente ao que ocorre com o art. 22 do CPC, a norma prevista na parte final do art. 267, $\S 3^{\circ}$, do CPC não incide se a parte desconhecia as defesas processuais na primeira oportunidade em que se manifestou nos autos, pois agiu sem culpa. $\mathrm{O}$ dispositivo

\footnotetext{
792 DINAMARCO, Instituições de Direito Processual Civil, vol. III, §§ 841-843, pp. 137-139.

${ }^{793}$ DINAMARCO, Instituições de Direito Processual Civil, vol. III, § 832, pp. 129-130.

794 MARCATO, Comentários ao art. 301 do CPC, in MARCATO (coord.), Código de Processo Civil Interpretado, p. 990; MARCATO, Procedimentos Especiais, p. 26.

795 De acordo com a doutrina, as referidas matérias configuram pressupostos de admissibilidade do julgamento do mérito, sem os quais o magistrado não pode decidir qual das partes tem razão e qual não a tem na fase cognitiva do processo. Sob o prisma do polo passivo da demanda, são defesas processuais; já do ponto de vista do órgão jurisdicional, situam-se no patamar das preliminares ao julgamento do mérito (DINAMARCO, Instituições de Direito Processual Civil, vol. III, §§ 830 e 831, pp. 127-129).
} 
também não se aplica se o demandado demonstrar que deixou de alegar o fato por motivo de força maior.

Caso o juiz constate que a parte ré deixou de alegar, na primeira oportunidade em que lhe cabia falar nos autos, as matérias defensivas constantes dos incisos IV, V e VI do art. 267 do CPC, ele deve condená-la ao pagamento das custas pelo retardamento do processo.

\subsection{Abuso do poder de nomear à autoria (art. 69 do CPC)}

A nomeação à autoria é o "pedido feito pelo réu, de ser excluído da relação processual por ilegitimidade ad causam, sendo sucedido por um terceiro", ${ }^{\text {,796 }}$. Dentro do prazo de 15 dias para a resposta (art. 64, $1^{\text {a }}$ parte, do CPC), contado a partir da citação (arts. 241 e 297 do CPC), o réu nomeia o terceiro à autoria, ou seja, indica-o como verdadeiro responsável e requer que ele seja citado. Assim, mediante um incidente razoavelmente simples, antecipam-se soluções para a questão da legitimidade passiva, dando a oportunidade de o autor retificar a mira da demanda já ajuizada ${ }^{797}$.

A doutrina classifica a nomeação à autoria como uma intervenção de terceiro provocada (ou coata), pois ela é feita no interesse da parte que a provoca, ou seja, ela tem origem na vontade da parte e não na do terceiro. No entanto, Dinamarco ${ }^{798}$ reconhece que a inserção dessa espécie de intervenção de terceiro no grupo das intervenções coatas é discutível, pois o nomeado não se torna parte no processo independentemente de sua própria vontade. Pelo contrário, só com o concurso de sua vontade ele permanecerá na relação jurídica processual, já que o nomeado possui a faculdade de recusar a nomeação, hipótese em que o processo continua em face do nomeante (art. 66, parte final, do CPC).

Há duas hipóteses gerais de admissibilidade da nomeação à autoria no Código de Processo Civil ${ }^{799}$ :

a) consoante o art. 62 do CPC, "aquele que detiver a coisa em nome alheio [ou seja, o detentor $\left.{ }^{800}\right]$, sendo-lhe demandada em nome próprio, deverá nomear à autoria o proprietário ou o possuidor". Abrange causas versando sobre direitos reais e também pessoais (v.g., ações reivindicatórias, possessórias, comodato, locação);

\footnotetext{
${ }^{796}$ DINAMARCO, Instituições de Direito Processual Civil, vol. II, § 599, p. 404.

${ }^{797}$ DINAMARCO, Instituições de Direito Processual Civil, vol. II, § 599, p. 407.

${ }^{798}$ Instituições de Direito Processual Civil, vol. II, § 588, p. 382.

${ }^{799}$ DINAMARCO, Instituições de Direito Processual Civil, vol. II, § 599, pp. 404-405.

${ }^{800}$ Considera-se detentor "aquele que, achando-se em relação de dependência para com outro, conserva a posse em nome deste e em cumprimento de ordens ou instruções suas" (art. 1.198 do CC).
} 
b) também é possível realizar essa modalidade de intervenção de terceiro na "ação de indenização, intentada pelo proprietário ou pelo titular de um direito sobre a coisa, toda vez que o responsável pelos prejuízos alegar que praticou o ato por ordem, ou em cumprimento de instruções de terceiro" (art. 63 do CPC), ordens ou instruções essas que o réu não poderia deixar de atender. Desse modo, só tem direito à nomeação aquele que é mero causador direto dos danos. Se o réu participou do ato danoso com poder de decisão, ele é responsável perante a lei civil, logo deve ser considerado parte legítima e não pode realizar nomeação à autoria.

No Código de Processo Civil de 1939, a nomeação à autoria era uma faculdade do réu (art. 100 do CPC39). Porém, com o advento do Código de 1973, passou-se a discutir qual a situação jurídica exercida pelo nomeante. De um lado, com foco no texto do art. 62 do CPC ("deverá nomear à autoria"), Barbi ${ }^{801}$ e Rocha ${ }^{802}$ entendem que se trata de um dever do réu, cuja infração acarreta a responsabilidade pelo ressarcimento das perdas e danos causados (art. 69 do CPC). Do outro, e com mais razão, Dinamarco ${ }^{803}$ e Bedaque ${ }^{804}$ sustentam que o Código de Processo Civil instituiu para o réu um ônus, cujo descumprimento dá ensejo à obrigação de ressarcir as perdas e os danos.

O art. 69 do CPC prevê duas hipóteses de abuso do poder e do ônus de nomear à autoria: (a) a não-desincumbência do ônus de nomear à autoria, contrariando o dever de prontidão; e (b) a nomeação à autoria de pessoa diversa daquela em cujo nome o litigante detém a coisa demandada, desrespeitando o dever de veracidade ${ }^{805}$.

Consoante o inciso I do art. 69 do $\mathrm{CPC}$, o réu que deixa de nomear à autoria, quando lhe competir, tem a obrigação de ressarcir perdas e danos.

A incidência dessa norma não depende de dolo do réu, mas pressupõe a exigência de culpa, visto que pune a negligência do litigante. Em tese, se a parte demonstrar que agiu sem culpa, a pena deve ser relevada. Mas, na prática, isso é difícil de ocorrer, uma vez que, por definição, o detentor tem conhecimento de que detém a coisa em nome de outrem e o causador direto do dano também sabe que cometeu o ato lesivo por ordem, ou em cumprimento de instrução, de outra pessoa.

\footnotetext{
${ }^{801}$ Comentários ao Código de Processo Civil, vol. I, § 394, p. 251.

${ }^{802}$ Nomeação à Autoria, p. 77.

${ }^{803}$ Instituições de Direito Processual Civil, vol. II, § 599, p. 405.

${ }^{804}$ Comentários ao art. 69 do CPC, in MARCATO (coord.), Código de Processo Civil Interpretado, p. 146.

${ }^{805}$ Se o Projeto de Lei $n^{\circ} 8.046 / 2010$ for aprovado, sancionado e publicado com sua redação atual, essas hipóteses de abuso processual deixarão de existir, já que o capítulo do novo Código de Processo Civil que trata da intervenção de terceiros (arts. 308 a 322) nem mesmo prevê o poder de nomear à autoria.
} 
Quem sofre os danos decorrentes da omissão do réu em nomear à autoria é o autor $^{806}$, que inicialmente acredita ter ajuizado uma demanda regular, preenchendo todas as condições da ação, mas, depois, é surpreendido pela ilegitimidade do réu porque este deixou de indicar o verdadeiro responsável logo no começo do processo, ao arrepio do dever de prontidão ${ }^{807}$. Barbi ${ }^{808}$ observa que a pessoa que deveria ter sido nomeada também é lesada, mencionando o seguinte exemplo: imagine-se que o réu seja vencido e condenado a entregar a coisa que detinha em nome alheio (art. 62 do CPC). Uma vez executada a sentença, a pessoa que não foi nomeada pode ajuizar uma ação em face do autor da primeira demanda para reaver a coisa. Contudo, ainda que ela vença a causa, terá prejuízos decorrentes do tempo que ficou sem a posse da coisa, da contratação de advogados, da produção de provas etc. Como todos esses danos decorrem da omissão do réu, este tem o dever de indenizá-los (art. 69, I, do CPC).

É oportuno lembrar que a "legitimatio ad causam" é uma típica matéria de ordem pública e que a omissão da nomeação à autoria não enseja qualquer preclusão referente ao seu controle pelo magistrado. O juiz pode reconhecer a ilegitimidade "ad causam" de ofício a qualquer momento (art. 267, $\S 3^{\circ}$, do CPC), pronunciando a carência de ação do autor $^{809}$.

Caso o réu se encontre em alguma das situações previstas nos arts. 62 e 63 do CPC, não faça a nomeação à autoria no prazo para a resposta (art. $64,1^{\mathrm{a}}$ parte, $\mathrm{CPC}$ ) e, depois, alegue ilegitimidade passiva, cabe ao magistrado reconhecer a falta de condição da ação, extinguir o processo sem julgamento do mérito (art. 267, VI, do CPC), e sancionar o réu, não apenas condenando-o ao ressarcimento das perdas e danos, com fulcro no art. 69, I, do CPC, mas também o responsabilizando pelas custas de retardamento, com espeque no art. 267, $\S 3^{\circ}$, parte final, do CPC.

O inciso II do art. 69 do CPC prevê a responsabilidade por perdas e danos do réu que nomeia à autoria pessoa diversa daquela em cujo nome detém a coisa demandada. Esse dispositivo refere-se especificamente à hipótese de nomeação à autoria prevista no art. 62 do CPC.

\footnotetext{
${ }^{806}$ DINAMARCO, Instituições de Direito Processual Civil, vol. II, § 599, p. 406.

${ }^{807}$ Barbi (Comentários ao Código de Processo Civil, vol. I, § 395, p. 252) não vislumbra qualquer prejuízo que o autor da ação possa ter com a omissão do réu em realizar a nomeação à autoria, uma vez que a realização do seu direito independe desse comportamento da parte contrária. Contudo, o doutrinador ressalva que, se em um caso concreto eventualmente ocorrer prejuízo ao autor, o réu deve indenizá-lo, pois a norma do art. 69, I, do CPC tem caráter geral e amplo.

${ }^{808}$ Comentários ao Código de Processo Civil, vol. I, § 395, pp. 251-252.

${ }^{809}$ DINAMARCO, Instituições de Direito Processual Civil, vol. II, § 599, p. 406.
} 
A alteração da verdade fática precisa ser intencional, ou seja, o réu precisa saber quem é o indivíduo em nome de quem ele detém a coisa demandada e nomear à autoria outra pessoa, contrariando o dever de dizer a verdade subjetiva. Se o demandado tiver uma falsa percepção da realidade e, em razão disso, nomear à autoria pessoa diversa daquela em cujo nome detém a coisa, o art. 69, II, do CPC não pode incidir, uma vez que a atuação da parte é condizente com a verdade subjetiva ${ }^{810}$.

Segundo Barbi ${ }^{811}$, quando o réu nomeia à autoria pessoa diversa daquela em cujo nome detém a coisa demandada, tanto o autor quanto a pessoa que deveria ser nomeada podem sofrer prejuízos. O autor é lesado porque tem que arcar com despesas inúteis e ainda corre o risco de se consumar o fato da prescrição a favor do verdadeiro possuidor. Quanto à pessoa que devia ser nomeada, o jurista afirma que o réu lhe causa prejuízo porque “assim o fazendo, está, na verdade, omitindo a nomeação à pessoa a quem ela corretamente deverá ser feita".

As asserções feitas por Barbi são parcialmente corretas. Realmente, o demandante sofre dano quando o réu nomeia à autoria pessoa diversa daquela em cujo nome detém a coisa demandada. Mas, com o devido respeito, o jurista se engana ao afirmar que o indivíduo em cujo nome o réu realmente detém a coisa sofre prejuízo quando essa conduta ímproba acontece. Quem é lesada de verdade nesse caso é a pessoa nomeada à autoria, que precisa, por exemplo, contratar um advogado para poder defender-se no processo, sendo que lhe falta legitimidade de parte ${ }^{812}$.

Rocha $^{813}$ nega que o nomeado à autoria em desrespeito ao dever de veracidade tenha direito ao ressarcimento de perdas e danos. O doutrinador parte do pressuposto de que a pessoa só pode sofrer algum dano se integrar a relação jurídica processual. Alega que o ingresso do indivíduo erroneamente nomeado à autoria no processo depende do reconhecimento da qualidade que lhe foi imputada (art. 66 do CPC), o que, na sua opinião, isenta o réu de qualquer responsabilidade pelos prejuízos que eventualmente sofra. A falha na argumentação desse doutrinador consiste no fato de ele não admitir que o nomeado à autoria sofre prejuízo mesmo antes de substituir o réu. Na realidade, a pessoa nomeada à autoria em desrespeito ao dever de veracidade tem despesas ainda que ela queira apenas

\footnotetext{
${ }^{810}$ Nesse sentido, entendendo que a nomeação à autoria de pessoa diversa daquela em cujo nome detém a coisa demandada fundada em erro de fato não enseja responsabilidade: ROCHA, Nomeação à Autoria, p. 79. ${ }^{811}$ Comentários ao Código de Processo Civil, vol. I, § 396, p. 252.

${ }^{812}$ Nesse sentido: DINAMARCO, Instituições de Direito Processual Civil, vol. II, § 599, p. 406.

${ }^{813}$ Nomeação à Autoria, pp. 79-80.
} 
negar a qualidade que lhe foi imputada, já que ela não pode fazer isso sem antes constituir um advogado para representá-la em juízo.

\subsection{Utilização de poderes e faculdades processuais para opor resistência injustificada ao andamento do processo (arts. 17, IV, do CPC)}

O inciso IV do art. 17 do CPC prevê a conduta abusiva consistente em "opor resistência injustificada ao andamento do processo", ou seja, em dificultar, embaraçar, procrastinar a marcha normal do processo ${ }^{814} 815$.

Relaciona-se diretamente com o dever previsto no art. 14, IV, do CPC: “Art. 14. São deveres das partes e de todos aqueles que de qualquer forma participam do processo: [...] IV - não produzir provas, nem praticar atos inúteis ou desnecessários à declaração ou defesa do direito" $" 816$. Trata-se de dispositivo que visa a resguardar a celeridade processual.

Nem toda a resistência ao andamento do processo pode ser considerada uma conduta abusiva; para tal, é necessário que ela seja "injustificada". Logo, sempre que o sujeito for movido por algum motivo legítimo, seu comportamento procrastinatório não pode ser considerado abusivo, o que o juiz deve aferir à vista das circunstâncias de cada caso concreto $^{817}$. Por exemplo: não pratica litigância de má-fé a parte que se opõe ao andamento de processo manifestamente ilegal, arbitrário ou viciado pelo excesso ou abuso de poder, já que nesse caso há uma justificativa ${ }^{818}$.

De acordo com Dinamarco ${ }^{819}$, incorre na hipótese de litigância de má-fé prevista no inciso IV do art. 17 do CPC a parte que retarda maliciosamente o processo com o objetivo de: (a) criar condições para melhor negociar à custa da necessidade da parte contrária; (b) evitar o desembolso do que deve; (c) fazer com que a tutela jurisdicional não chegue a tempo de ser útil etc.

Uma das condutas que reconhecidamente configura resistência injustificada ao andamento do processo é a produção de provas desnecessárias. O magistrado tem poderes para indeferir diligências inúteis ou meramente protelatórias, velando pela rápida solução

\footnotetext{
${ }^{814}$ BARBOSA MOREIRA, A Responsabilidade das Partes por Dano Processual no Direito Brasileiro, in Temas de Direito Processual, p. 28.

${ }^{815}$ No Projeto de Lei $n^{\circ} 8.046 / 2010$, em trâmite no Congresso Nacional, que versa sobre o novo Código de Processo Civil, esse comportamento também é considerado litigância de má-fé (art. 83, IV).

${ }^{816}$ OLIVEIRA, Litigância de Má-Fé, pp. 52-53.

817 BARBOSA MOREIRA, A Responsabilidade das Partes por Dano Processual no Direito Brasileiro, in Temas de Direito Processual, p. 28; OLIVEIRA, Litigância de Má-Fé, pp. 53-54.

${ }^{818}$ TORNAGHI, Comentários ao Código de Processo Civil, vol. I, p. 155.

${ }^{819}$ Instituições de Direito Processual Civil, vol. II, § 528-A, pp. 268-269.
} 
do litígio (arts. 125, II; e 130 do CPC). Mas, se a inutilidade da prova para o julgamento da demanda for constatada somente após a sua produção, cabe ao juiz sancionar a parte desleal com base nos arts. 17, IV; e 18 do CPC 820821.

A resistência injustificada ao andamento do processo pode ser oposta mediante qualquer instrumento processual, ou seja, mediante o exercício de qualquer situação jurídica ativa (poder ou faculdade). São exemplos: (a) o advogado de dois ou mais réus que, depois de escoado "in albis" o prazo de quinze dias para apresentar a resposta, substabelece parcialmente a procuração em outro advogado, visando a obter o benefício do prazo em dobro (art. 191 do CPC) e, assim, afastar os efeitos da revelia; (b) a parte que arrola testemunha residente em outro país, mas que nada sabe sobre os fatos da causa, com o intuito de retardar a instrução ${ }^{822}$; (c) o chamamento ao processo da União Federal, nos termos do art. 77, III, do CPC, em ação visando ao fornecimento de medicamentos movida

\footnotetext{
${ }^{820}$ OLIVEIRA, Litigância de Má-Fé, pp. 52-53.

${ }^{821}$ Nos Estados Unidos, a produção de provas desnecessárias ou inúteis também é considerada um problema de abuso processual.
}

No processo civil norte-americano, existe a fase da "discovery", que ocorre logo no início do procedimento e que consiste em um mecanismo de investigação de fatos e de coleta de provas necessárias à resolução do litígio. A "discovery" permite que cada litigante sonde as provas que a parte contrária possui em seu desfavor e obtenha provas que lhe sejam benéficas. A colheita do material probatório é realizada por iniciativa dos advogados das partes, mediante a troca recíproca de "requests of discovery", com a supervisão do juiz, mas sem a necessidade de autorização prévia deste. Os principais instrumentos de condução da "discovery" são: (a) a "deposition", que é a inquirição de uma pessoa (parte ou testemunha) sob juramento e registro literal do seu depoimento; (b) a inspeção de documentos e outras coisas que estejam na posse da parte contrária ou de terceiros; (c) o exame da condição física ou mental de pessoa relevante para o processo, o qual é realizado por um especialista, geralmente um médico; e (d) "demands for admission", que consiste na apresentação de declarações fáticas à parte contrária e requerimento de que esta as admita como verdadeiras. Os resultados produzidos na "discovery" podem ser utilizados no julgamento (ZACLIS, Direito Processual Civil Estadunidense, in CRUZ E TUCCI (coord.), Direito Processual Civil Americano Contemporâneo, pp. 190191; DONDI, Cultura dell'Abuso e Riforma del Processo Civile Negli Stati Uniti, in Rivista di Diritto Processuale, Ano 50, $\mathrm{n}^{\circ}$ 3, p. 792; HAZARD JR.; TARUFFO, American Civil Procedure: an introduction, pp. 114-117).

Dentre as hipóteses de exercício abusivo da "discovery" estão: (a) a "overuse of discovery" ou "overdiscovery", que é o requerimento superabundante de exibição de meios de prova, notadamente documentos, com a intenção de agravar o custo do processo para a parte contrária e, eventualmente, forçá-la a celebrar um acordo; (b) a "bulk discovery", que é o fornecimento de um elevado volume de documentos, com o intuito de ocultar aqueles efetivamente relevantes para o caso concreto ou de dificultar sua individuação e uso no processo; e (c) o "fishing trip", que é o requerimento genérico e vago de informações, com o escopo de se preparar para o ajuizamento de outra demanda ou de desenvolver defesa (DONDI, Cultura dell'Abuso e Riforma del Processo Civile Negli Stati Uniti, in Rivista di Diritto Processuale, Ano 50, no 3, pp. 793-794; YARSHELL, Antecipação da Prova sem o Requisito da Urgência e Direito Autônomo à Prova, pp. 196-197; ZACLIS, Direito Processual Civil Estadunidense, in CRUZ E TUCCI (coord.), Direito Processual Civil Americano Contemporâneo, p. 191; HAZARD JR.; TARUFFO, American Civil Procedure: an introduction, p. 118; KANE, Civil Procedure in a Nutshell, pp. 150-151; TARUFFO, General Report, in TARUFFO (ed.), Abuse of Procedural Rights: comparative standards of procedural fairness, pp. 17-18; HAZARD JR., Abuse of Procedural Rights: regional report for the United States, in TARUFFO (ed.), Abuse of Procedural Rights: comparative standards of procedural fairness, p. 49; DONDI, Effettività dei Provvedimenti Istruttori del Giudice Civile, p. 182).

${ }^{822}$ Esses dois primeiros exemplos são da obra de Dinamarco (Instituições de Direito Processual Civil, vol. II, $\S 528-A$, p. 269). 
apenas em face do Estado ${ }^{823}$; (d) a parte que se ausenta do domicílio para evitar intimação ${ }^{824}$; (e) a apresentação de sucessivos pedidos de reconsideração em face de acórdão $^{825}$; (f) o litigante que invoca exceção de compromisso arbitral (art. 301, IX e $\S 4^{\circ}$, do CPC) quando não tem meios próprios para instalar a arbitragem, impossibilitando o autor de obter um título executivo ${ }^{826}$; etc.

Não só comportamentos comissivos, mas também omissivos podem ser utilizados pelo sujeito processual para opor resistência injustificada à marcha do feito. É o caso, v.g., da parte que não comparece à audiência para dar causa a adiamento ${ }^{827}$.

Barbosa Moreira ${ }^{828}$ sustenta que a parte que deixa de se submeter à inspeção judicial, sem alegar um motivo justo, perfaz o comportamento previsto no art. 17, IV, do CPC. Porém, "data venia", esse entendimento não parece acertado. O mencionado dispositivo do Código de Processo Civil versa sobre uma conduta abusiva e um dos elementos essenciais do abuso processual é a aparência de legalidade (item 1.6.1 "supra"). Sendo assim, como a conduta da parte que se recusa, sem justo motivo, a se submeter à inspeção viola patentemente o inciso II do art. 340 do CPC, ela não pode ser considerada um abuso do processo, visto que lhe falta a aparência de licitude. Além disso, essa conduta não embaraça efetivamente a marcha normal do processo, pois, como o próprio Barbosa

${ }^{823}$ No julgamento do AgR no RE 607.381/SC (STF, $1^{\text {a }}$ Turma, DJe-116 DIVULG 16-06-2011 PUBLIC $17-$ 06-2011), o Relator Ministro Luiz Fux esclareceu que o escopo do chamamento ao processo é garantir ao devedor solidário o direito de regresso, caso seja vencido na demanda. Ocorre que, nas ações visando ao fornecimento de medicamentos movidas em face do Estado, não há que se falar em direito de regresso, pois, mesmo que a União integre o polo passivo do feito, em caso de procedência da demanda, é o Estado que arcará sozinho com o ônus do fornecimento do medicamento requerido, pois essa foi a escolha do demandante. Diante disso, o Ministro Relator decidiu que, naquele caso concreto, o chamamento ao processo da União pelo Estado de Santa Catarina consistia em medida meramente protelatória, que não trazia qualquer utilidade ao processo e que atrasava a resolução do feito, revelando-se meio inconstitucional para evitar o acesso aos remédios necessários para o restabelecimento da saúde da parte recorrida (art. 196 da CF). Não obstante a adoção desse entendimento, os Ministros do Supremo Tribunal Federal não aplicaram o art. 18 do CPC, com fundamento no inciso IV do art. 17 do CPC.

No mesmo sentido é a jurisprudência do Superior Tribunal de Justiça: STJ, $2^{\mathrm{a}}$ Turma, REsp 1.009.947/SC, Rel. Min. Castro Meira, DJe 19/04/2012; STJ, $2^{\text {a }}$ Turma, AgRg no AREsp 28.136/SC, Rel. Min. Herman Benjamin, DJe 17/10/2011; STJ, $1^{\text {a }}$ Turma, AgRg no AREsp 28.718/SC, Rel. Min. Benedito Gonçalves, DJe 30/09/2011; STJ, 2a Turma, AgRg no REsp 1.249.125/SC, Rel. Min. Humberto Martins, DJe 21/06/2011; STJ, $1^{\text {a }}$ Turma, AgRg no Ag 1.331.775/SC, Rel. Min. Luiz Fux, DJe 22/02/2011.

${ }^{824}$ BARBOSA MOREIRA, A Responsabilidade das Partes por Dano Processual no Direito Brasileiro, in Temas de Direito Processual, p. 28.

${ }^{825}$ Nesse sentido: STJ, $6^{\mathrm{a}}$ Turma, RCDESP no Ag 1.269.673/PR, Rel ${ }^{\mathrm{a}}$. Min ${ }^{\mathrm{a}}$. Maria Thereza de Assis Moura, DJe 11/10/2010.

${ }^{826}$ Consoante Menezes Cordeiro (Litigância de má-fé, abuso do direito de ação e culpa "in agendo”, p. 130), a jurisprudência alemã considera essa conduta uma manifestação de "tu quoque" na seara processual.

Acerca do "tu quoque", consultar o item 1.1 "supra".

827 OLIVEIRA, Litigância de Má-Fé, p. 50; BARBOSA MOREIRA, A Responsabilidade das Partes por Dano Processual no Direito Brasileiro, in Temas de Direito Processual, p. 28; TORNAGHI, Comentários ao Código de Processo Civil, vol. I, p. 155.

${ }^{828}$ O Novo Processo Civil Brasileiro, p. 74. 
Moreira $^{829}$ defende, o juiz pode tomar a recusa injustificada como elemento de convicção (indício) acerca do fato sobre o qual pretendia esclarecer-se, de modo que a formação do seu convencimento e a prolação da decisão não são postergados. Apesar de esse comportamento não configurar um abuso e de não se subsumir ao art. 17 do CPC, ele é um ilícito processual e deve ser sancionado nos termos do art. 14, V e parágrafo único, do $\mathrm{CPC}^{830}$.

Aparentemente, apenas o réu teria interesse em resistir injustificadamente ao andamento do processo, retardando a decisão final da causa ou a execução da sentença condenatória. Contudo, na prática, é possível que também o demandante cometa essa conduta processual ímproba ${ }^{831}$. A doutrina aventa os seguintes exemplos: se o devedor ajuíza uma demanda para declarar a invalidade ou a inexistência de uma obrigação, a demora na decisão é de seu interesse (notadamente em período de inflação) porque retardará o pagamento do crédito $^{832}$; em ação que versa sobre o sistema financeiro da habitação, uma vez obtida a liminar ou a antecipação de tutela que suspende a execução extrajudicial, é possível que o autor passe a resistir ao andamento do processo, com o escopo de permanecer o máximo de tempo possível no imóvel pagando o mínimo ou até sem $\operatorname{pagar}^{833}$.

\subsection{Utilização de poderes e faculdades processuais de modo temerário (art. 17, V, do CPC)}

A parte que procede de modo temerário em qualquer incidente ou ato do processo comete o comportamento abusivo descrito no art. 17, V, do $\mathrm{CPC}^{834}$.

A conduta processual temerária pode resultar de dolo ou de culpa grave ${ }^{835}$. No primeiro caso, a pessoa ajuíza demanda consciente de que é infundada, porém tem a

\footnotetext{
${ }^{829}$ O Novo Processo Civil Brasileiro, p. 74.

${ }^{830}$ Nesse sentido: TABOSA PESSOA, Comentários ao art. 340 do CPC, in MARCATO (coord.), Código de Processo Civil Interpretado, p. 1086.

${ }^{831} \mathrm{O}$ legislador parece admitir isso no art. $8^{\circ}$ da Lei ${ }^{\circ} 12.016 / 09:$

“Art. $8^{o}$ Será decretada a perempção ou caducidade da medida liminar ex officio ou a requerimento do Ministério Público quando, concedida a medida, o impetrante criar obstáculo ao normal andamento do processo ou deixar de promover, por mais de 3 (três) dias úteis, os atos e as diligências que lhe cumprirem" (destaque nosso).

${ }^{832}$ BARBI, Comentários ao Código de Processo Civil, vol. I, § 163, p. 127; e § 223, p. 165.

${ }^{833}$ OLIVEIRA, Litigância de Má-Fé, p. 50.

${ }^{834}$ Caso o projeto do novo Código de Processo Civil (Projeto de Lei no 8.046/2010) seja aprovado nos termos atuais, essa hipótese de litigância de má-fé constará do inciso V do art. 83.

835 Nesse sentido: CASTRO FILHO, Abuso do Direito no Processo Civil, pp. 91-92; DINAMARCO, Instituições de Direito Processual Civil, vol. II, § 528-A, p. 269; OLIVEIRA, Litigância de Má-Fé, p. 60.
} 
esperança de se tornar vitoriosa ao fim do processo apenas em razão de algum erro judicial. A temeridade por culpa grave consiste na conduta de ingressar em juízo com imprudência, sem ponderar suficientemente as razões que apoiam a pretensão, ou com incoerência de posições que repugne ao senso comum. Na opinião de Reis ${ }^{836}$, atua temerariamente a parte que ingressa em juízo sem levar em consideração as razões relevantes que comprometam sua pretensão.

Agem de maneira temerária, por exemplo: (a) a parte que, depois de suscitar exceção de incompetência relativa, passa a sustentar a competência do foro originário da causa, sem justificativa razoável para essa mudança de atitude; (b) o advogado que substabelece os poderes "ad judicia" em um outro profissional, que é cônjuge ou parente do magistrado, em linha reta ou na linha colateral até o segundo grau, com o fim de gerar a causa de impedimento do juiz (art. 134, IV, do CPC), ofendendo o parágrafo único do art. 134 do $\mathrm{CPC}^{837}$; (c) o executado que oferece o bem imóvel de sua residência à penhora e, em seguida, apresenta embargos ou impugnação ou até mesmo "exceção de préexecutividade", alegando tratar-se de um imóvel impenhorável por força da Lei $\mathrm{n}^{\circ}$ $8.009 / 90^{838}$; (d) a parte que suscita conflito de competência depois de já ter oferecido exceção de incompetência no mesmo processo (art. 117, “caput”, do CPC); (e) o sujeito que nega a competência do tribunal arbitral e, uma vez ajuizada demanda no Poder Judiciário, referente ao mesmo litígio, deduz a exceção da cláusula arbitral $^{839}$; (f) a parte que arrola o juiz da causa como testemunha e, depois de este se declarar impedido, desiste de seu depoimento (art. 409, I, do CPC); (g) a parte que atua no processo sem respeitar a forma prevista na lei e, em seguida, requer a decretação da nulidade do próprio ato (art. 243 do $\mathrm{CPC})^{840}$; (h) a parte que, ciente da existência de um vício, silencia a seu respeito e,

\footnotetext{
${ }^{836}$ Código de Processo Civil Anotado, vol. II, p. 262.

${ }^{837}$ Os dois primeiros exemplos são oriundos da obra de Dinamarco (Instituições de Direito Processual Civil, vol. II, § 528-A, p. 269).

${ }^{838}$ Acerca da discussão a respeito do oferecimento do bem de família à penhora pelo próprio devedor, consultar: TARTUCE, A Polêmica do Bem de Família Ofertado, "passim".

${ }^{839}$ Menezes Cordeiro (Litigância de má-fé, abuso do direito de ação e culpa "in agendo”, p. 128, nt. 354, e p. 129) e Albuquerque (Responsabilidade Processual por Litigância de Má Fé, Abuso de Direito e Responsabilidade Civil em Virtude de Actos Praticados no Processo, p. 76, nt. 198), com espeque na jurisprudência alemã, citam esse comportamento como exemplo de "venire contra factum proprium" processual.

Acerca do "venire contra factum proprium", consultar o item 1.1 "supra".

${ }^{840}$ Segundo Martins-Costa (A Boa-Fé no Direito Privado: sistema e tópica no processo obrigacional, p. 464, nt. 202), a regra do "tu quoque" expressa-se, em matéria processual, no art. 243 do CPC, que veda a alegação, em proveito próprio, de nulidade provocada pela parte.

Acerca do "tu quoque", consultar o item 1.1 "supra".
} 
em seguida, surpreende os demais sujeitos da relação jurídica processual com alegação de nulidade relativa (em contrariedade expressa ao art. 245 do CPC) ou até absoluta ${ }^{841}$.

Como o texto do o art. 17, V, do CPC trata apenas da conduta temerária em ato ou incidente do processo, a norma nele prevista não abrange o ajuizamento temerário da demanda, hipótese que se subsume ao inciso I do mesmo dispositivo legal ${ }^{842843}$.

Tanto o autor quanto o réu podem ser sancionados por terem procedido de modo temerário em incidente ou ato do processo. A condenação independe do resultado final da demanda, eis que mesmo a parte vencedora pode ser sancionada por ter agido de modo temerário em algum ato ou incidente ${ }^{844}$.

\subsection{Abuso do poder de provocar incidentes no processo (arts. 17, VI, do CPC)}

Uma das figuras de litigância de má-fé é a da parte que ocasiona incidentes manifestamente infundados (art. 17, VI, do CPC), ou seja, que provoca "providências ou decisões judiciárias interlocutórias em situação de visível falta de direito"

Ela possui estreita relação com o dever das partes de não formular pedidos cientes de que são destituídos de fundamento (art. 14, III, do CPC) ${ }^{847}$.

Harmoniza-se também com a hipótese de litigância de má-fé descrita no inciso IV do art. 17 do CPC, já que toda parte que dá ensejo a incidentes manifestamente infundados também obsta, injustificadamente, a marcha normal do processo ${ }^{848}$. No entanto, a recíproca não é verdadeira, uma vez que é possível opor resistência injustificada ao andamento do processo por outros meios que não a provocação de um incidente manifestamente infundado.

O legislador empregou o termo "incidente" nesse artigo do Código de Processo Civil em sentido amplo, abrangendo tanto os incidentes processuais (e.g., a impugnação ao

\footnotetext{
${ }^{841}$ De acordo com Menezes Cordeiro (Litigância de má-fé, abuso do direito de ação e culpa “in agendo”, p. 130), a jurisprudência alemã considera que há exercício abusivo de posições processuais (especificamente na modalidade "inalegabilidade") quando o indivíduo, subitamente, invoca irregularidades formais em um processo de recuperação que foi considerado como eficaz pelas partes durante bastante tempo.

Acerca da "inalegabilidade", consultar o item 1.1 "supra".

${ }_{842}$ BARBI, Comentários ao Código de Processo Civil, vol. I, § 164, p. 127.

${ }^{843}$ Oliveira (Litigância de Má-Fé, p. 60) discorda, aventando dois exemplos: (a) ajuizamento de nova demanda, enquanto pende outra idêntica; e (b) ajuizamento de diversas demandas com a mesma causa de pedir e o mesmo pedido, utilizando o autor mecanismos para evitar a distribuição por dependência.

${ }^{844}$ BARBI, Comentários ao Código de Processo Civil, vol. I, § 164, p. 127.

${ }^{845}$ DINAMARCO, Instituições de Direito Processual Civil, vol. II, § 528-A, p. 270.

${ }^{846}$ Norma análoga à do art. 17, VI, do CPC atual está prevista no art. 83, VI, do Projeto de Lei no 8.046/2010, que institui o novo Código de Processo Civil.

${ }^{847}$ OLIVEIRA, Litigância de Má-Fé, p. 62.

${ }^{848}$ Nesse sentido: OLIVEIRA, Litigância de Má-Fé, pp. 52 e 61.
} 
valor da causa, as exceções, o conflito de competência), quanto as ações incidentes (v.g., a ação declaratória incidental, o incidente de falsidade, a reconvenção, a denunciação da lide, os embargos do devedor, os embargos de terceiro) ${ }^{849}$.

Ainda a respeito da abrangência dessa palavra, é pertinente lembrar que, até 1998, quem abusava do poder de recorrer era sancionado com espeque no art. 17, VI, do CPC, com a justificativa de que o procedimento recursal consiste em um incidente processual. Quando a Lei $n^{\circ}$ 9.668/98 inseriu o inciso VII no art. 17, versando sobre a interposição de recursos manifestamente protelatórios, alguns doutrinadores e tribunais passaram a entender que seria mais adequado enquadrar os casos de abuso recursal sempre nesse novo dispositivo legal, relegando a incidência do inciso VI apenas para condutas abusivas praticadas em outros incidentes processuais. Ocorre que nem todo recurso abusivo é interposto com intuito manifestamente protelatório (art. 17, VII, do CPC). É possível (e bastante comum), por exemplo, que a parte interponha recurso manifestamente inadmissível (v.g., recurso patentemente intempestivo; recurso interposto depois de a parte sucumbente ter renunciado ao poder de recorrer - art. 502 do CPC - ou ter aceitado a decisão - art. 503 do CPC; recurso interposto pelo autor depois de ter desistido do pedido ou do processo; recurso interposto pelo réu depois de ter reconhecido a procedência do pedido do autor ${ }^{850}$ ) ou manifestamente infundado (e.g., recurso sem fundamento ou com fundamentação insuficiente; recurso fundado em argumento contrário à jurisprudência consolidada), logo abusivo, mas sem ter o fim de atrasar o processo. Nesse caso, há, evidentemente, litigância de má-fé; não com fundamento no inciso VII, mas sim no inciso VI do art. 17 do $\mathrm{CPC}^{851}$.

Mas, se, no mesmo processo, a parte interpuser outro recurso com fundamentação idêntica à daquele que foi anteriormente qualificado como "manifestamente infundado" (art. 17, VI, do CPC), sua conduta processual já pode ser considerada como movida por um “intuito manifestamente protelatório”, autorizando a aplicação do art. 17, VII, do CPC.

\footnotetext{
${ }^{849}$ OLIVEIRA, Litigância de Má-Fé, p. 61.

${ }^{850} \mathrm{O}$ ato da parte que diretamente enseja decisão que lhe é desfavorável (v.g., desistência do pedido ou do processo por parte do autor; reconhecimento do pedido por parte do réu) é considerado impeditivo do poder de recorrer, ensejando a inadmissibilidade de recurso eventualmente interposto por ela. Segundo Barbosa Moreira (O Juízo de Admissibilidade no Sistema dos Recursos Civis, pp. 93-97; Comentários ao Código de Processo Civil, vol. V, p. 341), trata-se de hipótese de preclusão lógica, bem como de uma manifestação do princípio que proíbe o "venire contra factum proprium".

${ }^{851}$ Não obstante Oliveira (Litigância de Má-Fé, pp. 39-40, 61 e 62) entenda que, a partir da edição da Lei $n^{\circ}$ 9.668/98, a interposição de recurso com fundamentação contrária à jurisprudência se inclui no âmbito de incidência do inciso VII do art. 17 do CPC, ela admite como uma das hipóteses de provocação de incidente manifestamente infundado (art. 17, VI, do CPC) o comportamento da parte que recorre apresentando fundamentação totalmente divorciada da decisão recorrida.
} 
A doutrina concebeu um expediente para auxiliar os magistrados na identificação dos comportamentos processuais concretos que se incluem no âmbito de aplicação do art. 17, VI, do CPC e dos que se furtam a ele: como a falta de fundamento deve ser aferível de plano, "ictu oculi", a elaboração de um arrazoado extenso para rejeitar o incidente ou decidir contrariamente ao que foi pedido, cuja redação demande bastante esforço intelectual do magistrado, configura um indício de que a parte não provocou um incidente manifestamente infundado. Em contrapartida, se sobressair, logo à primeira vista, a inexistência de qualquer argumento sério, digno de meditação, sendo suficiente uma argumentação singela, pouco elaborada, para repelir o incidente, ele é manifestamente infundado ${ }^{852}$.

Com razão, Barbi ${ }^{853}$ entende que a incidência do art. 17, VI, do CPC não exige elemento subjetivo doloso. Basta a constatação da falta de fundamentação do incidente para que o juiz considere a parte que o provocou um litigante de má-fé.

Não obstante a conduta prevista no dispositivo em comento seja praticada com mais frequência pelo réu, o autor também pode levá-la a efeito ${ }^{854}$, da mesma forma como foi visto "supra" nos comentários ao art. 17, IV, do CPC.

Um exemplo de provocação de incidente manifestamente infundado consiste na arguição de exceção de incompetência manifestamente descabida. Em sua obra, Oliveira ${ }^{855}$ menciona um caso concreto em que o Instituto Nacional do Seguro Social - INSS apresentou exceção de incompetência para que a ação fosse remetida ao foro de sua sede, ao arrepio do $\S 3^{\circ}$ do art. 109 da CF ("Serão processadas e julgadas na justiça estadual, no foro do domicílio dos segurados ou beneficiários, as causas em que forem parte instituição de previdência social e segurado, sempre que a comarca não seja sede de vara do juízo federal, e, se verificada essa condição, a lei poderá permitir que outras causas sejam também processadas e julgadas pela justiça estadual") ${ }^{856}$. O intuito do "improbus litigator", ao realizar essa conduta abusiva, costuma ser de protelar a solução da causa, uma vez que, no Direito brasileiro, o recebimento da exceção de incompetência tem o

\footnotetext{
${ }^{852}$ OLIVEIRA, Litigância de Má-Fé, p. 62; BARBOSA MOREIRA, A Responsabilidade das Partes por Dano Processual no Direito Brasileiro, in Temas de Direito Processual, p. 29; CARRILHO LOPES, Tutela Antecipada Sancionatória (art. 273, inc. II, do Código de Processo Civil), p. 118.

${ }^{853}$ Comentários ao Código de Processo Civil, vol. I, § 165, p. 128.

${ }^{854}$ BARBI, Comentários ao Código de Processo Civil, vol. I, § 165, pp. 127-128.

${ }^{855}$ Litigância de Má-Fé, p. 39.

${ }^{856}$ A autora cita esse caso como exemplo de concretização do inciso I do art. 17 do CPC. No entanto, como a exceção de incompetência consiste em um incidente processual, parece ser mais acertado enquadrá-lo no inciso VI desse artigo do Código de Processo Civil.
} 
efeito de suspender o processo até o julgamento definitivo do incidente (art. 306 do (PC) $)^{857}$.

Outro exemplo é oferecido pelo próprio legislador, no texto do "caput" do art. 668 do CPC: "O executado pode, no prazo de 10 (dez) dias após intimado da penhora, requerer a substituição do bem penhorado, desde que comprove cabalmente que a substituição não trará prejuizo algum ao exequente e será menos onerosa para ele devedor (art. 17, incisos IV e VI, e art. 620)". Se o incidente de substituição da penhora for suscitado por quem não dispõe de oferta razoavelmente positiva de troca (como no exemplo ideal da troca por dinheiro) ou de motivos sérios a embasar a solicitação, fica caracterizada a litigância de má-fée ${ }^{858}$.

Por fim, percebe-se que a falta de fundamentação também caracteriza o comportamento de litigância de má-fé consistente em "proceder de modo temerário em qualquer incidente ou ato do processo" ${ }^{\# 59}$. O que diferencia as condutas abusivas descritas nos incisos V e VI do art. 17 é o "animus" do agente: na primeira, o litigante age em juízo consciente de que não tem razão (dolo) ou sem ponderar suficientemente os fundamentos de sua pretensão (culpa grave); na segunda, ele provoca algum incidente processual que é visivelmente infundado, sendo irrelevante a sua intenção. Em suma: o inciso V do art. 17 do CPC exige a presença de elemento subjetivo para que seja aplicado no caso concreto, enquanto o inciso VI do mesmo dispositivo é puramente objetivo, bastando a patente falta de fundamentação do incidente para ele incidir.

\subsection{Abuso do poder de recorrer}

\subsubsection{Características gerais do abuso recursal e hipóteses previstas no CPC}

O abuso recursal consiste em uma espécie de abuso de instrumento processual individual em que o objeto da conduta abusiva é o poder e o ônus de recorrer. Para referirse a ele, a doutrina costuma utilizar as expressões "abuso do poder de recorrer", ou "abuso do ônus de recorrer" ${ }^{860}$, ou ainda "abuso do direito de recorrer" $" 861862$.

\footnotetext{
${ }^{857}$ ABDO, O Abuso do Processo, pp. 215 e 217.

858 PUOLI, Comentários ao art. 668 do CPC, in MARCATO (coord.), Código de Processo Civil Interpretado, p. 2142.

${ }^{859}$ OLIVEIRA, Litigância de Má-Fé, p. 62.

${ }^{860}$ ABDO, O Abuso do Processo, p. 204.
} 
De acordo com Lucon ${ }^{863}$, duas particularidades do ordenamento jurídico brasileiro levam os sujeitos processuais a utilizar os recursos de forma abusiva, como meio de atrasar o andamento do processo:

a) a previsão legal de efeito suspensivo para a maioria dos recursos ${ }^{864}$; e

b) a desvalorização das decisões proferidas em primeiro grau de jurisdição (que nada mais é do que um corolário da primeira particularidade).

A doutrina também identifica uma espécie de tradição cultural brasileira de a parte não se conformar com a sentença prolatada pelo juiz de primeiro grau e interpor todos os recursos que o sistema processual the oferece. Isso faz com que o segundo grau de jurisdição seja, na prática, uma fase obrigatória do procedimento e que o acesso aos tribunais de superposição (STJ e STF) seja algo ordinário, como se houvesse um princípio do triplo ou do quádruplo grau de jurisdição ${ }^{865}$. Esse fator cultural com certeza também contribui para o abuso do poder recursal ${ }^{866}$.

${ }^{861}$ LUCON, Abuso do Exercício do Direito de Recorrer, in NERY JÚNIOR; ALVIM WAMBIER (coords.), Aspectos Polêmicos e Atuais dos Recursos Cíveis e de Outras Formas de Impugnação às Decisões Judiciais, p. 883.

${ }^{862}$ Quanto a esta última expressão, cumpre fazer a observação de que ela é menos preferível do ponto de vista técnico por causa da discussão doutrinária acerca da existência, ou não, de direitos subjetivos no processo (ABDO, O Abuso do Processo, p. 204). Remete-se o leitor ao item 1.4.1 "supra", onde esse tema foi tratado.

${ }^{863}$ Abuso do Exercício do Direito de Recorrer, in NERY JÚNIOR; ALVIM WAMBIER (coords.), Aspectos Polêmicos e Atuais dos Recursos Cíveis e de Outras Formas de Impugnação às Decisões Judiciais, pp. 875 e 900.

${ }^{864}$ Menezes Cordeiro (Litigância de Má-Fé, Abuso do Direito de Ação e Culpa “in Agendo", p. 24) observa que, no Direito português, os recursos não contribuem muito para o atraso na prestação da tutela jurisdicional porque eles são, em regra, dotados de efeito meramente devolutivo, salvo algumas exceções como a do arrendamento.

${ }^{865}$ VINCENZI, A Boa-Fé no Processo Civil, pp. 104 e 107-108; PUOLI, Os Limites ao Direito de Recorrer e a Responsabilidade Civil do Advogado Perante o Cliente, in COSTA; RIBEIRO; DINAMARCO (coords.), Linhas Mestras do Processo Civil, p. 337.

${ }^{866}$ Essa tradição cultural de inconformismo com as decisões judiciais e de abuso na interposição de recursos parece remontar ao Direito romano-canônico e ao Direito lusitano.

O processo romano-canônico caracterizava-se pela divisão em fases (ou "termini", ou "stadia") sucessivas e independentes entre si. Por causa disso, havia a prolação de várias sentenças interlocutórias, que versavam principalmente sobre questões processuais. Tanto essas sentenças interlocutórias, quanto as definitivas, eram apeláveis e, caso nenhuma das partes recorresse, tornavam-se imutáveis.

Essa amplitude do poder de recorrer gerou abusos, acarretando uma reação por parte da Igreja nos Concílios de Latrão, da Basileia e de Trento. Neste último, realizado entre os anos de 1545 e 1563, o jurisconsulto e teólogo Giovanni Groppero demonstrou que a apelação contra as interlocutórias causava prejuízos para a pronta decisão da causa, o que também gerava danos para a justiça e as partes. Essa tese restou vitoriosa e o Concílio votou princípio no sentido de proibir a apelação das interlocutórias, exceto quando produzissem dano irreparável ou tivessem força de definitiva. Por meio da Bula "Benedictus Deus", de 26 de janeiro de 1564, o Papa Pio IV aprovou as resoluções do Concílio (BUZAID, Do Agravo de Petição no Sistema do Código de Processo Civil, pp. 23-24 e nt. 32; LOBO DA COSTA, O Agravo no Direito Lusitano, in AZEVEDO; LOBO DA COSTA, Estudos de História do Processo: recursos, pp. 137-141; AZEVEDO; TUCCI, Lições de História do Processo Civil Lusitano, p. 245).

No processo lusitano, durante os reinados de D. Afonso III (1248 a 1279) e de D. Diniz (1279 a 1325), o recurso de apelação era cabível tanto contra as sentenças definitivas (que julgavam todo o litígio), quanto 
O sujeito ativo dessa espécie abusiva é a pessoa que tem legitimidade recursal, ou seja: a parte sucumbente, o terceiro prejudicado e também o representante do Ministério Público (art. 499 do CPC). Se a parte não tem legitimidade recursal, ela não é titular do poder de recorrer, logo, não pode dele abusar ${ }^{867}$.

Fazendo uso dos já mencionados requisitos para caracterizar o abuso do processo em geral $^{868}$, pode-se afirmar que, para que haja abuso do poder de recorrer, é necessário:

a) aparência de legalidade do recurso interposto, a qual decorre de dois fatores: (1) da liberdade que o sujeito tem de utilizar ou não o recurso; e (2) da legalidade do recurso, ou seja, da sua previsão no ordenamento jurídico nacional ${ }^{869}$;

b) exercício do poder de recorrer com desvio de finalidade, para atingir escopo ilícito ou ilegítimo; e

c) em alguns casos, dolo ou culpa.

O Código de Processo Civil de 1939 não previa especificamente o abuso do poder de recorrer. Aplicavam-se aos recursos abusivos as normas gerais acerca do abuso processual, notadamente o artigo 63 do CPC39, que se referia genericamente à parte vencida que se houvesse "conduzido de modo temerário no curso da lide" (“caput"), à parte vencedora que tivesse "se conduzido de modo temerário em qualquer incidente ou ato do processo" $\left(\S 1^{\circ}\right)$ e também à parte vencedora ou vencida que tivesse "procedido com dolo, fraude, violência ou simulação" $\left(\S 2^{\circ}\right)^{870}$.

contra as interlocutórias (que resolviam incidente do procedimento) (Ordenações Afonsinas, Livro III, Título LXXII, $\left.\S 1^{\circ}\right)$.

Ocorre que essa ampla recorribilidade produziu consequências deletérias: entravou a marcha dos processos, incentivou a chicana e enfraqueceu a ideia de prestação jurisdicional célere.

Diante dessa situação, D. Afonso IV (1325-1357) vetou a apelação de sentenças interlocutórias, exceto em três hipóteses (Ordenações Afonsinas, Livro III, Título LXXII, $\S \S 4^{\circ}, 5^{\circ}, 6^{\circ}$ e 12 ): (a) se o dano decorrente da sentença interlocutória não pudesse ser corrigido na sentença definitiva; (b) se não pudesse ser proferida a sentença definitiva depois da decisão interlocutória ou, caso fosse possível a prolação, não se pudesse jamais recobrar o dano produzido pela execução da interlocutória; ou (c) se a decisão determinasse a citação do réu para responder demanda aforada em lugar perigoso, seja em razão da peste, seja pela existência de inimigos. Desse modo, eventual agravo causado por uma sentença interlocutória simples era reparado apenas na ocasião do julgamento da apelação interposta contra a sentença definitiva, caso o juiz não a tivesse revogado antes, de ofício ou a pedido da parte lesada. Essa regra introduziu no Direito lusitano a distinção entre sentença interlocutória simples e sentença interlocutória com força de definitiva e, a partir dessa dicotomia, originaram-se os estormentos de agravo, as cartas testemunháveis e, posteriormente, as várias espécies de recurso de agravo (BUZAID, Do Agravo de Petição no Sistema do Código de Processo Civil, pp. 30-31 e 3334; LOBO DA COSTA, O Agravo no Direito Lusitano, in AZEVEDO; LOBO DA COSTA, Estudos de História do Processo: recursos, pp. 145-149; AZEVEDO; TUCCI, Lições de História do Processo Civil Lusitano, pp. 246-249 e 251-255).

${ }^{867}$ ABDO, O Abuso do Processo, pp. 203-204.

${ }^{868}$ Requisitos esses tratados no tem 1.6 "supra".

${ }^{869}$ ABDO, O Abuso do Processo, p. 204.

${ }^{870}$ CASTRO FILHO, Abuso do Direito no Processo Civil, pp. 156-157. 
Já o atual Código de Processo Civil brasileiro faz menção expressa ao abuso do poder de recorrer em três situações. São elas:

a) no art. 17, VII, do CPC, que qualifica a interposição de recurso com intuito manifestamente protelatório como ato de litigância de má-fé;

b) no art. 538, parágrafo único, do CPC, que comina sanções à parte que opõe embargos de declaração manifestamente protelatórios; e

c) no art. 557, $\S 2^{\circ}$, do CPC, que prevê punições aplicáveis na hipótese de o agravo previsto no art. 557, $\S 1^{\circ}$, ou no art. 545 do CPC ser considerado manifestamente inadmissível ou infundado.

As peculiaridades de cada um desses dispositivos merecem ser abordadas em separado.

Deve-se salientar que algumas hipóteses de abuso do poder recursal não são abrangidas pelas normas supracitadas, mas mesmo assim são consideradas atos de litigância de má-fé porque se subsumem ao inciso VI do art. 17 do $\mathrm{CPC}^{871}$.

\subsubsection{Art. 17, VII, do CPC}

O art. 17 do CPC prevê um rol taxativo ${ }^{872}$ de situações que o legislador reputou como atos de litigância de má-fé. Dentre elas, no inciso VII, está a interposição de "recurso com intuito manifestamente protelatório" 873.

O dispositivo em comento correlaciona-se com o dever contido no art. 14, IV, do CPC: "não produzir provas, nem praticar atos inúteis ou desnecessários à declaração ou defesa do direito" ${ }^{, 74}$.

Originalmente, a interposição de recurso procrastinatório, distinto dos embargos de declaração ${ }^{875}$, era sancionada com fundamento no inciso IV ("resistência injustificada ao andamento do processo") 876 ou no inciso VI ("provocar incidentes manifestamente

\footnotetext{
${ }^{871}$ Acerca da possibilidade de aplicar o art. 17, VI, do CPC a casos de abuso recursal, consultar o item 2.10 "supra" e o item 2.11.2 "infra".

872 NERY JÚNIOR; ANDRADE NERY, Código de Processo Civil Comentado e Legislação Extravagante, pp. 213-214.

${ }^{873}$ O projeto do novo Código de Processo Civil (Projeto de Lei $n^{\circ}$ 8.046/2010) prevê essa mesma figura abusiva no art. 83, VII.

${ }_{874}$ OLIVEIRA, Litigância de Má-Fé, p. 62.

875 Desde a publicação do Código de Processo Civil, em 1.973, o parágrafo único do art. 538 traz norma acerca dos embargos de declaração manifestamente protelatórios.

${ }^{876}$ LUCON, Abuso do Exercício do Direito de Recorrer, in NERY JÚNIOR; ALVIM WAMBIER (coords.), Aspectos Polêmicos e Atuais dos Recursos Cíveis e de Outras Formas de Impugnação às Decisões Judiciais, p. 884; ABDO, O Abuso do Processo, p. 202.
} 
infundados" $)^{877}$ do art. 17 do CPC $^{878}$. Foi a Lei $n^{\circ} 9.668$ que, em 1998, inseriu o inciso VII no mencionado dispositivo legal, versando expressamente sobre a interposição de recurso com intuito manifestamente protelatório.

Para que o recurso seja considerado abusivo com base no art. 17, VII, do CPC, é necessário que a parte atue "com intuito manifestamente protelatório", ou seja, com dolo, de modo consciente e voluntário, ou, pelo menos, com culpa grave ${ }^{879}$ (item 1.6.3.4 "supra").

De acordo com a doutrina e os tribunais, as seguintes situações denotam a interposição de recurso com escopo manifestamente procrastinatório:

a) a interposição de recurso contra decisão já transitada em julgado;

b) a menção, nas razões recursais, a matéria já preclusa ${ }^{880}$. Dentre as espécies de preclusão, a que mais facilmente pode ser utilizada na prática de uma conduta abusiva é a lógica $^{881}$. Ela ocorre, por exemplo, quando a parte renuncia ao direito sobre que se funda a ação (art. 269, V, do CPC), ou reconhece a procedência do pedido (art. 269, II, do CPC), ou ainda celebra transação judicial (art. 269, III, do CPC) e, em seguida, interpõe recurso contra a sentença ${ }^{882}$. Trata-se de exemplo de "venire contra factum proprium" cometido no processo, contrariando a boa-fé processual (art. 14, II, do CPC). Quanto à preclusão temporal, a doutrina pondera que, na maioria dos casos em que há interposição de recurso intempestivo, a parte recorrente sequer tem consciência disso. Ademais, há situações excepcionais em que o recurso interposto fora do prazo legal é admissível, como, por exemplo, quando os servidores do Judiciário estão em greve durante o período recursal; ou quando há irregularidade na intimação etc ${ }^{883}$. Diante disso, apenas o recurso

${ }^{877}$ NERY JÚNIOR; ANDRADE NERY, Código de Processo Civil Comentado e Legislação Extravagante, p. 215; OLIVEIRA, Litigância de Má-Fé, p. 61.

${ }^{878}$ PUOLI, Os Limites ao Direito de Recorrer e a Responsabilidade Civil do Advogado Perante o Cliente, in COSTA; RIBEIRO; DINAMARCO (coords.), Linhas Mestras do Processo Civil, pp. 342-343.

${ }^{879}$ LUCON, Abuso do Exercício do Direito de Recorrer, in NERY JÚNIOR; ALVIM WAMBIER (coords.), Aspectos Polêmicos e Atuais dos Recursos Cíveis e de Outras Formas de Impugnação às Decisões Judiciais, pp. 884-885.

${ }^{880}$ Nesse sentido: "A discussão de matéria preclusa configura manifesta protelação (JTJ 162/79)" (NEGRÃO; GOUVÊA; BONDIOLI; FONSECA, Código de Processo Civil e Legislação Processual em Vigor, p. 136, art. 17, nt. 28).

${ }^{881}$ LUCON, Abuso do Exercício do Direito de Recorrer, in NERY JÚNIOR; ALVIM WAMBIER (coords.), Aspectos Polêmicos e Atuais dos Recursos Cíveis e de Outras Formas de Impugnação às Decisões Judiciais, p. 887.

${ }_{882}$ Abdo ( $O$ Abuso do Processo, p. 207) adverte que a parte que interpõe recurso contra sentença que homologa transação judicial nem sempre comete abuso do processo. Cita como exemplo de caso em que não há improbidade processual a interposição de recurso pleiteando a anulação da própria transação, com fundamento na existência de vício de manifestação da vontade.

${ }^{883}$ LUCON, Abuso do Exercício do Direito de Recorrer, in NERY JÚNIOR; ALVIM WAMBIER (coords.), Aspectos Polêmicos e Atuais dos Recursos Cíveis e de Outras Formas de Impugnação às Decisões Judiciais, p. 887; ABDO, O Abuso do Processo, p. 206. 
manifestamente intempestivo pode ser considerado abusivo. Por fim, com relação à preclusão consumativa, o desvio de finalidade não é tão evidente, logo, é mais difícil de configurar o abuso processual. Segundo $\mathrm{Abdo}^{884}$, há abuso, por exemplo, quando a parte interpõe dois recursos diferentes, dentro do mesmo prazo recursal, contra a mesma decisão, movida pelo intuito de tumultuar o processo $^{885}$;

c) razões recursais contrárias a entendimento jurisprudencial já pacificado há muito tempo. Com razão, Abdo $^{886}$ esclarece que, para que o recurso contrário a entendimento consolidado na jurisprudência seja tachado de abusivo, é essencial que o desvio de finalidade seja evidente, o que pode ser verificado por meio da análise da viabilidade das razões apresentadas pelo recorrente diante do que sustentam a doutrina e os tribunais, independentemente do fato de o posicionamento adotado ser majoritário ou não. Se as razões recursais apresentadas encontram algum fundamento doutrinário ou jurisprudencial, ainda que minoritário, não se pode considerar abusivo o recurso ${ }^{887}$. Nessa mesma linha de pensamento, Lucon ${ }^{888}$ observa que o simples fato de as razões do recurso questionarem uma tese já consolidada em um tribunal não significa que o recorrente esteja litigando de má-fé. As orientações jurisprudenciais não são absolutas e, para que sejam um dia alteradas, é necessário contestá-las pela via recursal ${ }^{889} 890$. Porém, o doutrinador aponta duas situações em que, na sua opinião, se deve reconhecer a litigância de má-fé: (1) se o recorrente contrariar entendimento já sumulado pelos Tribunais Superiores ${ }^{891}$; (2) se as

\footnotetext{
${ }^{884}$ O Abuso do Processo, p. 207.

${ }^{885}$ Trata-se de situação análoga à decidida pelo Superior Tribunal de Justiça no seguinte caso: STJ, $3^{\mathrm{a}}$ Turma, REsp 92.312/RJ, Rel. Min. Carlos Alberto Menezes Direito, DJ 01/12/1997, p. 62737.

${ }^{886}$ O Abuso do Processo, pp. 208-209.

${ }^{887}$ Demonstrando simpatia por essa tese, Dinamarco (Instituições de Direito Processual Civil, vol. II, § 528-
} A, p. 270) afirma que, para o recurso ser considerado manifestamente protelatório, é preciso que ele desafie a jurisprudência do tribunal destinatário, do STJ ou do STF "sem fundamentos mais sérios".

${ }_{888}$ Abuso do Exercício do Direito de Recorrer, in NERY JÚNIOR; ALVIM WAMBIER (coords.), Aspectos Polêmicos e Atuais dos Recursos Cíveis e de Outras Formas de Impugnação às Decisões Judiciais, pp. 888889.

${ }^{889}$ É o que ensina Reis (Código de Processo Civil Anotado, vol. II, p. 266), referindo-se ao Direito português: "O art. $769^{\circ}$ prevê e admite a alteração dos assentos; e o meio que os interessados têm de provocar a alteração é levarem recurso até ao Supremo e procurarem aí convencer os julgadores de que a jurisprudência do assento deve ser modificada. Não pode, por isso, qualificar-se de litigante de má fé aquele que sustenta e pretende fazer vingar doutrina contrária à de um assento, se o faz no propósito declarado de conseguir que o assento seja alterado. Em tal hipótese o recorrente não faz uso reprovável do recurso, com o fim de entorpecer a acção da justiça; exerce poder legal e propõe-se um objectivo perfeitamente lícito".

${ }^{890}$ Sabiamente, Barbosa Moreira (Comentários ao Código de Processo Civil, vol. V, pp. 676-677) pondera que, apesar de serem contrárias à jurisprudência predominante no tribunal, o relator deve examinar com cuidado as razões do recurso porque elas podem trazer argumentos novos, até então não considerados pelos desembargadores e ministros, levando a uma alteração de seu posicionamento.

${ }^{891}$ Nesse sentido: STJ, $1^{\text {a }}$ Turma, EDcl no AgRg no REsp 491.725/PR, Rel. Min. José Delgado, DJ 06/10/2003, p. 214; STJ, $1^{\text {a }}$ Turma, EDcl no AgRg no Ag 418.205/SP, Rel. Min. José Delgado, DJ 01/07/2002, p. 257; STJ, $1^{\text {a }}$ Turma, AgRg no REsp 637.927/BA, Rel. Min. José Delgado, DJ 04/04/2005, p. 197. 
razões do recurso que busca a reforma da orientação consolidada do tribunal forem genéricas, ou seja, padronizadas ${ }^{892}$;

d) ausência ou insuficiência de fundamentação recursal, com o intuito deliberado de prejudicar a parte contrária. Lucon ${ }^{893}$ relata como exemplo o caso da parte que interpõe recurso especial ou extraordinário sem mencionar nas razões do recurso qualquer fundamento em norma federal ou constitucional, respectivamente. Outras hipóteses são citadas por Dinamarco ${ }^{894}$ : recurso em que nenhum fundamento relevante é desenvolvido; invocação, nas razões recursais, de legislação impertinente ou de jurisprudência sem relação com o caso.

Não há dúvida de que esses comportamentos são abusivos. É necessário, contudo, esclarecer que a parte que impugna decisão já transitada em julgado, ou que recorre com fundamento em matéria já preclusa ou em argumento contrário à jurisprudência consolidada, ou ainda que interpõe recurso sem fundamento ou com fundamentação insuficiente não comete, necessariamente, um ato protelatório, mas sim um ato inadmissível ou infundado. Logo, se o litigante interpuser o agravo previsto no art. 557, § $1^{\circ}$, ou no art. 545 do CPC nessas circunstâncias, o seu comportamento se subsume ao art. 557, $\S 2^{\circ}$, do CPC, que será mais bem estudado no item 2.11.4 "infra"; se for interposto qualquer outro recurso com essas características, incide o art. 17, VI, do CPC ${ }^{895}$. Para que fique caracterizado o intuito manifestamente protelatório, ensejando a aplicação do inciso VII do art. 17 do CPC, é preciso que a esses elementos seja adicionada: (a) a eficácia suspensiva do recurso utilizado de forma ímproba (pois, sem suspender a eficácia imediata da decisão recorrida, o recurso manifestamente inadmissível ou infundado não protela

\footnotetext{
${ }^{892}$ Nesse sentido: STJ, $1^{\text {a }}$ Turma, AgRg no REsp 164.363/SC, Rel. Min. José Delgado, DJ 15/06/1998, p. 66; STJ, $1^{a}$ Turma, AgRg no Ag 181.335/MG, Rel. Min. José Delgado, DJ 03/08/1998, p. 165.

${ }^{893}$ Abuso do Exercício do Direito de Recorrer, in NERY JÚNIOR; ALVIM WAMBIER (coords.), Aspectos Polêmicos e Atuais dos Recursos Cíveis e de Outras Formas de Impugnação às Decisões Judiciais, p. 890. ${ }^{894}$ Instituições de Direito Processual Civil, vol. II, § 528-A, p. 270.

${ }^{895}$ A favor dessa tese podem-se mencionar os seguintes julgados do Superior Tribunal de Justiça:

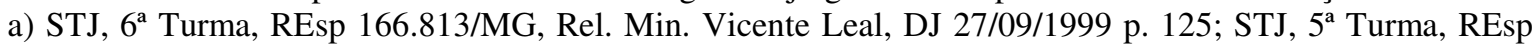
193.505/RS, Rel. Min. Felix Fischer, DJ 05/04/1999, p. 146, que confirmam acórdãos dos Tribunais de origem que aplicaram o art. 17, VI, do CPC para sancionar a parte que interpôs recurso versando sobre matéria já preclusa;

b) STJ, $1^{\text {a }}$ Turma, EDcl no AgRg no REsp 491.725/PR, Rel. Min. José Delgado, DJ 06/10/2003, p. 214; e STJ, $1^{\text {a }}$ Turma, AgRg no REsp 637.927/BA, Rel. Min. José Delgado, DJ 04/04/2005, p. 197, que consideraram os recorrentes litigantes de má-fé, com fundamento no art. 17, IV e VII, do CPC, por terem impugnado decisões que estavam em consonância com entendimento sumulado do Superior Tribunal de Justiça. O mais correto seria subsumir a interposição de recurso fundado em argumento contrário à jurisprudência sumulada ao inciso VI do art. 17 do CPC, que considera litigante de má-fé quem provoca incidentes manifestamente infundados. Mas, considerando que o litigante que dá ensejo a incidente manifestamente infundado também obsta, injustificadamente, a marcha normal do processo (item 2.10 "supra"), não é incorreto aplicar a essa conduta o inciso IV do art. 17 do CPC.
} 
suficientemente a tutela jurisdicional a ponto de ficar evidenciado o intuito procrastinatório do recorrente); ou (b) o fato de a parte estar reiterando recurso manifestamente inadmissível ou infundado ${ }^{896}$; ou ainda (c) o fato de ela já ter praticado, anteriormente, no mesmo processo, algum ato manifestamente protelatório (v.g., art. 17, VII; ou art. 538, parágrafo único, do $\mathrm{CPC}$ ), ou manifestamente infundado (art. 17, VI, do CPC), ou temerário (art. 17, V, do CPC), ou de resistência injustificada ao andamento do processo (art. 17, IV, do CPC).

A má-fé na utilização do princípio da fungibilidade recursal também configura a hipótese abusiva prevista no art. 17, VII, do CPC. Os requisitos para que se aplique o princípio da fungibilidade recursal são: (1) a existência de dúvida objetiva acerca de qual o recurso cabível no caso em tela; (2) a inexistência de erro grosseiro; e (3) a interposição do recurso dentro do prazo que a lei estabelece para o recurso que o órgão jurisdicional entende que é cabível no caso concreto ${ }^{897}$. Há abuso se o recorrente, imbuído de má-fé, interpõe um recurso dotado de prazo maior no lugar de outro, com o fim de ganhar tempo e prejudicar a parte contrária ${ }^{898}$.

No que concerne ao âmbito de incidência, o art. 17, VII, do CPC é uma norma genérica, aplicável a qualquer tipo de recurso que seja interposto com intuito meramente protelatório (v.g., apelação, agravo, recurso especial, recurso extraordinário etc.). A única exceção são os embargos de declaração, que, quando são opostos com intuito

${ }^{896}$ É o que estatui o seguinte julgado do Superior Tribunal de Justiça:

"DIREITO ADMINISTRATIVO. PROCESSUAL CIVIL. AGRAVO REGIMENTAL NO AGRAVO REGIMENTAL NO AGRAVO REGIMENTAL NO AGRAVO DE INSTRUMENTO. AGRAVO INTERPOSTO CONTRA DECISÃO COLEGIADA. NÃO-CABIMENTO. CONVERSÃO EM EMBARGOS DE DECLARAÇÃO. PRINCÍPIO DA FUNGIBILIDADE. INAPLICABILIDADE. PRECEDENTE DO STJ. LITIGÂNCIA DE MÁ-FÉ CONFIGURADA. MULTA DE $1 \%$ SOBRE O VALOR DA CAUSA. IMPOSIÇÃO. ARTS. 17, VI E VII, C/C 18, CAPUT, DO CPC. AGRAVO NÃO-CONHECIDO.

1. É firme a jurisprudência do Superior Tribunal de Justiça no sentido de não ser cabível agravo regimental contra decisão colegiada, conforme dispõem os arts. 258, 259 e 263 do RISTJ, hipótese em que não é aplicável o princípio da fungibilidade para o acolher como embargos de declaração, porquanto constitui erro grosseiro.

2. A reiterada utilização de recursos incabíveis revela-se verdadeira litigância de má-fé pela procrastinação injustificada do processo, o que autoriza a imposição da multa de $1 \%$ sobre o valor da causa, nos termos dos arts. 17, VI e VII, c/c 18, caput, do CPC.

3. Agravo regimental não-conhecido" (destaque nosso)

(STJ, 5 Turma, AgRg no AgRg no AgRg no Ag 985603 / RJ, Rel. Min. Arnaldo Esteves Lima, DJe 09/03/2009).

${ }^{897}$ Nesse sentido é a jurisprudência do Superior Tribunal de Justiça: STJ, $1^{\text {a }}$ Turma, AgRg na MC 747/PR, Rel. Min. Humberto Gomes de Barros, DJ 03/04/2000, p. 111; STJ, $1^{\text {a }}$ Turma, RCDESP na RCDESP no Ag 750.223/MG, Rel. Min. Luiz Fux, DJ 18/12/2006, p. 319; STJ, 5 a Turma, AgRg nos EDcl no RMS 21.694/ES, Rel ${ }^{a}$. Minna Laurita Vaz, DJ 06/08/2007, p. 543; STJ, 2a Seção, AgRg na Rcl 963/RJ, Rel ${ }^{a}$. Mina .

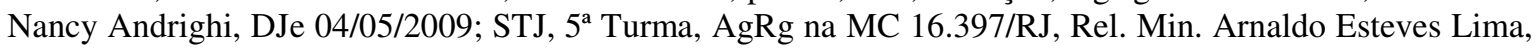
DJe 24/05/2010.

${ }^{898}$ LUCON, Abuso do Exercício do Direito de Recorrer, in NERY JÚNIOR; ALVIM WAMBIER (coords.), Aspectos Polêmicos e Atuais dos Recursos Cíveis e de Outras Formas de Impugnação às Decisões Judiciais, pp. 889-890. 
manifestamente procrastinatório, implicam a incidência do art. 538, parágrafo único, do CPC, e não do art.17 do $\mathrm{CPC}^{899}$.

\subsubsection{Art. 538, parágrafo único, do CPC}

Estatui a primeira parte do parágrafo único do art. 538 do $\mathrm{CPC}$ que, quando os embargos forem manifestamente protelatórios, o juiz ou o tribunal deve declarar que o são e condenar o embargante a pagar ao embargado multa não excedente de $1 \%$ (um por cento) do valor da causa ${ }^{900}$.

Costuma-se abusar do poder de opor embargos de declaração por causa da desnecessidade de preparo (art. 536, parte final, do CPC) e do seu efeito de interromper o prazo para interposição de qualquer outro meio de impugnação da decisão judicial (art. 538, “caput”, do CPC), o que permite atrasar a formação da coisa julgada ${ }^{901}$.

Os embargos de declaração são utilizados licitamente quando visam a:

a) eliminar obscuridades e contradições intrínsecas à decisão ou sanar omissões dela (art. 535 do CPC);

b) prequestionar matéria que conste de norma federal ou constitucional. De acordo com a súmula $\mathrm{n}^{\mathrm{o}} 98$ do $\mathrm{STJ}^{902}$, os embargos declaratórios opostos com o escopo de prequestionar matéria de norma federal ou constitucional não podem ser considerados "manifestamente protelatórios" porque a parte que os opõe não tem o objetivo de retardar a prestação da tutela jurisdicional, mas, sim, viabilizar o acesso ao Superior Tribunal de Justiça ou ao Supremo Tribunal Federal, via recurso especial ou recurso extraordinário, respectivamente ${ }^{903}$. Mas, é importante ter em mente que a finalidade de prequestionar não exclui, "de per se", a incidência da multa. Se a parte fizer uso dos embargos de declaração prequestionadores com desvio de finalidade, movida também pelo intento de procrastinar o processo, incide a sanção prevista no art. 538, parágrafo único, do $\mathrm{CPC}^{904}$ 905; e

\footnotetext{
${ }^{899}$ OLIVEIRA, Litigância de Má-Fé, pp. 63-64.

900 O Código de Processo Civil projetado (Projeto de Lei n ${ }^{\circ} 8.046 / 2010$ ) trata da oposição de embargos de declaração manifestamente protelatórios nos parágrafos $4^{\circ}, 5^{\circ}$ e $6^{\circ}$ do art. 980.

${ }^{901}$ MILMAN, Improbidade Processual: comportamento das partes e de seus procuradores no processo civil, pp. 160-161; ABDO, O Abuso do Processo, p. 210; THEODORO JÚNIOR, Abuso de Direito Processual no Ordenamento Jurídico Brasileiro, in Revista Forense, v. 344, p. 59.

902 Súmula $\mathrm{n}^{\mathrm{o}} 98$ do STJ: "Embargos de declaração manifestados com notório propósito de prequestionamento não têm caráter protelatório".

${ }^{903}$ LUCON, Abuso do Exercício do Direito de Recorrer, in NERY JÚNIOR; ALVIM WAMBIER (coords.), Aspectos Polêmicos e Atuais dos Recursos Cíveis e de Outras Formas de Impugnação às Decisões Judiciais, p. 896.

${ }_{904}$ LUCHI DEMO, Embargos de Declaração: aspectos processuais e procedimentais, p. 138.
} 
c) corrigir certos erros graves e perceptíveis a um exame objetivo. Trata-se dos embargos com caráter infringente, os quais são utilizados, por exemplo, para corrigir decisão que julga intempestivo recurso interposto dentro do prazo.

Se os embargos forem opostos com objetivo diverso desses três, eles devem ser considerados abusivos ${ }^{906}$ e sancionados com base no parágrafo único do art. 538 do CPC, já que são manifestamente inadmissíveis ou infundados, sendo patente o desvio da finalidade inerente a esse remédio recursal. O intuito procrastinatório do recorrente resta evidenciado pela manifesta falta de fundamento do ato por ele praticado, somada ao efeito interruptivo do prazo para a oferta de outros recursos, que caracteriza essa espécie recursal. Isso porque, considerando a eficácia interruptiva própria dos embargos de declaração, nada justifica a utilização desse recurso em situação totalmente fora das suas hipóteses de cabimento senão o intuito do embargante de protelar a prestação efetiva da tutela jurisdicional.

Luchi Demo ${ }^{907}$ anuncia quatro situações em que há abusividade na oposição dos embargos de declaração:

a) se o recurso for manifestamente infundado;

b) se o recurso for oposto contra decisão prolatada por juízo de primeira instância e versar sobre prequestionamento. $\mathrm{O}$ autor observa que somente em dois casos se admite a oposição de embargos de declaração com fins de prequestionamento contra decisão prolatada em primeira instância: (1) decisão das turmas recursais dos Juizados Especiais (art. 41 da Lei n ${ }^{o}$ 9.099/95); e (2) decisão prolatada em processo de execução fiscal cujo valor da causa seja igual ou inferior a 50 OTN's (art. 34 da Lei $n^{\circ} 6.830 / 80$ ), dado que, nesses dois casos, a sentença é impugnável via recurso extraordinário;

c) se o embargante mencionar, nas razões do recurso, situação fática inexistente ou mentirosa, ou negar fato existente (e.g., se pedir para que o órgão judicial se manifeste

\footnotetext{
${ }^{905}$ Há jurisprudência do Superior Tribunal de Justiça nesse sentido: "PROCESSUAL - EMBARGOS DECLARATÓRIOS - RECURSO PROTELATÓRIO PREQUESTIONAMENTO DE TEMA JÁ SUPERADO PELO SUPREMO TRIBUNAL FEDERAL MULTA.

- Nada justifica a pretensão de questionar matéria já superada pelo Supremo Tribunal Federal, fazendo com que aquela altíssima Corte se afogue na repetição de julgamentos. Semelhante recalcitrância explicase apenas, com a constatação de que a recorrente inspira-se no intuito de protelar a efetiva entrega da prestação jurisdicional.

- Incide na multa cominada pelo Art. 538, Parágrafo Único, do CPC, a parte que opõe embargos declaratórios, no escopo de suscitar questão já superada na jurisprudência" (destaque nosso).

(STJ, $1^{\text {a }}$ Turma, REsp 131.781/SP, Rel. Min. Humberto Gomes de Barros, DJ 19/10/1998, p. 24).

906 ABDO, O Abuso do Processo, pp. 210-211.

${ }^{907}$ Embargos de Declaração: aspectos processuais e procedimentais, pp. 138-140.
} 
expressamente sobre determinada questão, supostamente omitida, mas que, na verdade, estava decidida em sentido contrário aos interesses do recorrente ${ }^{908}$ );

d) se a parte opuser os embargos tão somente visando a rediscutir questões já apreciadas e decididas.

No julgamento dos EDcl nos EDcl no REsp 859.977/DF (2 $2^{\text {a Turma, DJe }}$ 2409/2009), a relatora Ministra Eliana Calmon didaticamente elaborou um rol de condutas que a jurisprudência do Superior Tribunal de Justiça considera protelatórias e, consequentemente, passíveis de sanção:

a) renovar embargos de declaração sem causa jurídica ou fundamentação adequada;

b) não apontar qualquer omissão ou vício no julgamento anterior;

c) visar a modificar os fundamentos da decisão embargada;

d) reiterar anteriores embargos de declaração, nos quais a matéria foi expressa e fundamentadamente aclarada;

e) retardar indevidamente o desfecho do processo;

f) utilizar os embargos de declaração quando há outro recurso cabível para a finalidade colimada.

\subsubsection{Reincidência em abuso do poder de opor embargos de declaração}

Nos casos em que a parte reincide na prática de opor embargos manifestamente protelatórios, o órgão judicial pode elevar o montante da multa, que era de até $1 \%$ do valor da causa, a até $10 \%$ desse valor. É o que determina a $2^{a}$ parte do parágrafo único do art. 538 do CPC $^{909}$.

Barbosa Moreira ${ }^{910}$ esclarece dois trechos que se mostram um tanto obscuros no texto desse dispositivo legal:

a) o uso da expressão "reiteração de embargos protelatórios" não quer dizer que se exija a reprodução idêntica de embargos de declaração já qualificados como protelatórios em um momento anterior. Para que a multa seja elevada a até $10 \%$ do valor da causa basta

\footnotetext{
908 Nesse sentido: STJ, 4 a Turma, EDcl no REsp 56.554/RS, Rel. Min. Aldir Passarinho Junior, DJ 04/03/2002, p. 257.

${ }^{909}$ Se o Projeto de Lei no 8.046/2010 for aprovado, sancionado e publicado com sua redação atual, não será mais possível cometer esse comportamento processual abusivo, pois o $\S 5^{\circ}$ do art. 980 do novo Código de Processo Civil considerará inadmissíveis novos embargos declaratórios se os anteriores houverem sido declarados protelatórios.

${ }^{910}$ Comentários ao Código de Processo Civil, vol. V, pp. 573-574.
} 
que sejam opostos novos embargos também considerados protelatórios, ainda que por um motivo diferente do adotado para considerar o recurso anterior como tal;

b) quando o legislador estatui que "a multa é elevada a até 10\%", ele não quer dizer que a multa de $10 \%$ deva ser somada à sanção anterior de $1 \%$, referente aos primeiros embargos protelatórios. Incide apenas uma única multa, a qual é exasperada a até $10 \%$ do valor da causa no caso de reiteração de embargos de declaração protelatórios.

O que a doutrina nacional discute, ultimamente, é o modo como o juízo deve proceder em caso de segunda reiteração de embargos procrastinatórios, ou seja, quando a parte já reiterou os embargos de declaração protelatórios, foi condenada a pagar multa de até $10 \%$ do valor da causa, e mesmo assim opõe novos embargos de declaração considerados manifestamente protelatórios (oposição de embargos de declaração procrastinatórios por três vezes sucessivas).

Segundo Barbosa Moreira ${ }^{911}$ e Luchi Demo ${ }^{912}$, não incidem duas multas em caso de sucessão de embargos de declaração procrastinatórios. Há apenas uma única multa, a qual é exasperada a até $10 \%$ do valor da causa. Ou seja, o valor da sanção pecuniária fica restrito ao teto de $10 \%$, ainda que a parte oponha mais que dois embargos de declaração protelatórios.

Com o devido respeito, quando o legislador diz que "na reiteração de embargos protelatórios, a multa é elevada a até 10\%”, não parece que ele queira sancionar múltiplas reiterações de embargos de declaração procrastinatórios com apenas uma única multa de até $10 \%$ do valor da causa. É mais provável que o seu intuito seja de sancionar cada reiteração com uma multa de até um décimo do valor da causa. Desse modo, quando acontece a primeira reiteração, a multa, que era de até $1 \%$, é elevada a até $10 \%$ do valor da causa. Se a parte quiser opor pela terceira vez os embargos declaratórios com o fim de procrastinar o feito, ela deve depositar a multa de até $10 \%$ do valor da causa e ficará sujeita a uma outra multa, no montante também de até $10 \%$ do valor da causa.

Não procede o argumento de que a multa cominada na segunda reiteração seria a mesma aplicada na primeira reiteração, porém exasperada e limitada a 10\% do valor da causa. Isso porque, consoante o próprio art. 538, parágrafo único, do $\mathrm{CPC}$, a multa referente à primeira reiteração deverá, necessariamente, ser depositada para que o juiz conheça da segunda reiteração: "Na reiteração de embargos protelatórios, a multa é elevada a até $10 \%$ (dez por cento), ficando condicionada a interposição de qualquer

911 Comentários ao Código de Processo Civil, vol. V, pp. 573-574.

${ }^{912}$ Embargos de Declaração: aspectos processuais e procedimentais, pp. 142 e 146. 
outro recurso ao depósito do valor respectivo" (destaque nosso). Uma multa que já foi paga não pode ter o seu valor agravado.

$\mathrm{Na}$ opinião de Luchi Demo ${ }^{913}$, a partir do terceiro recurso de embargos de declaração protelatórios, o juiz deve não só aplicar a sanção pecuniária no montante de até $10 \%$ do valor da causa, mas também considerar inadmissível o último recurso e negar o seu efeito interruptivo de outros prazos recursais. No mesmo sentido, Didier Junior ${ }^{914}$ defende que o Direito brasileiro nem mesmo admite que a parte oponha embargos de declaração protelatórios por três vezes sucessivas. Para ele, a segunda oposição abusiva gera a perda do direito de embargar pela terceira vez (preclusão por ato ilícito). Ocorre que essa punição consistente na rejeição da eficácia interruptiva do prazo para a interposição de outros recursos, própria dos embargos de declaração, não está expressamente prevista no ordenamento jurídico nacional, logo, a sua aplicação violaria o princípio da legalidade, como se verá de maneira mais detalhada no item 3.11.4 "infra".

\subsubsection{Art. 557, $\S 2^{\circ}$, do CPC}

Desde $1998^{915}$, o "caput" do art. 557 do CPC atribui ao relator a faculdade de negar $^{916}$ seguimento a recurso manifestamente inadmissível, improcedente, prejudicado ou em confronto ("rectius", em contraste ${ }^{917}$ ) com súmula ou com jurisprudência dominante do respectivo tribunal, do Supremo Tribunal Federal, ou de Tribunal Superior. Analogamente, se a decisão recorrida estiver em manifesto confronto ("rectius", contraste) com súmula ou com jurisprudência dominante do Supremo Tribunal Federal, ou de Tribunal Superior (mas não com jurisprudência dominante do tribunal competente para julgar o recurso ${ }^{918}$ ), $\mathrm{o}$ relator pode dar provimento ao recurso.

Essas decisões monocráticas do relator são impugnáveis por meio do agravo previsto no parágrafo primeiro do mesmo dispositivo, o qual deve ser interposto no prazo de cinco dias e dirigido ao órgão competente para o julgamento do recurso. Após a

\footnotetext{
${ }^{913}$ Embargos de Declaração: aspectos processuais e procedimentais, pp. 146-151.

${ }^{914}$ Editorial 22, p. 1; Editorial 122, p. 1.

915 Ano em que a Lei no 9.756 atribuiu a redação atual ao art. 557 do CPC.

${ }^{916}$ Não obstante o legislador utilize a palavra "negará", que poderia dar a impressão de que se trata de um dispositivo de incidência imperativa, a doutrina afirma que não se pode entender como obrigatório o exercício do poder atribuído pelo art. 557 do CPC ao relator. Nesse sentido: BARBOSA MOREIRA, Comentários ao Código de Processo Civil, vol. V, p. 674.

${ }^{917}$ Barbosa Moreira (Comentários ao Código de Processo Civil, vol. V, p. 675) observa que, na verdade, é a tese jurídica sustentada pelo recorrente, e não o recurso em si, que pode contrariar súmula ou jurisprudência dominante, colocando-se em contraste (e não em confronto) com o seu conteúdo.

${ }^{918}$ BARBOSA MOREIRA, Comentários ao Código de Processo Civil, vol. V, p. 677.
} 
interposição, o relator pode retratar-se. Não havendo retratação, deve apresentar o processo em mesa, proferindo voto. Caso o agravo seja provido, o recurso tem seguimento.

$\mathrm{O} \S 2^{\circ}$ do art. 557 do CPC sanciona a conduta de interpor esse agravo do art. 557, $\S$ $1^{\circ}$, do CPC em situações nas quais ele seja manifestamente inadmissível ou infundado:

Quando manifestamente inadmissível ou infundado o agravo, o tribunal condenará o agravante a pagar ao agravado multa entre um e dez por cento do valor corrigido da causa, ficando a interposição de qualquer outro recurso condicionada ao depósito do respectivo valor ${ }^{919}$.

Há ainda uma segunda hipótese de incidência da norma prevista no art. 557, § $2^{\circ}$, do CPC. Quando o recurso extraordinário ou o recurso especial não é admitido, cabe agravo nos próprios autos, no prazo de 10 dias, tendo a parte o ônus de interpor um agravo para cada recurso não admitido (art. 544, "caput" e $\S 1^{\circ}$ do CPC). Da decisão do relator que não conhecer desse agravo nos próprios autos, negar-lhe provimento ou decidir, desde logo, o recurso não admitido na origem, caberá agravo, no prazo de 5 dias, ao órgão competente. De acordo com o art. 545 do CPC, se esse segundo recurso de agravo, interposto no prazo de 5 dias, for manifestamente inadmissível ou infundado, aplica-se o $\S$ $2^{\circ}$ do art. 557 do CPC, quer dizer, o tribunal deve condenar o agravante a pagar ao agravado multa entre $1 \%$ e $10 \%$ do valor corrigido da causa, ficando a interposição de qualquer outro recurso condicionada ao depósito do respectivo valor.

Sustenta Lucon ${ }^{920}$ que o art. 557, § $2^{\circ}$, do CPC não admite interpretação extensiva, de modo que a sanção nele prevista não pode incidir nos recursos de apelação e embargos infringentes, nem em sede de ação rescisória, uma vez que o texto legal somente faz referência ao recurso de agravo.

Consoante a jurisprudência do Superior Tribunal de Justiça, o art. 557, § $2^{\circ}$, do CPC incide quando as razões recursais contrariam:

a) tese já sumulada ${ }^{921}$;

b) tese fixada em incidente de uniformização jurisprudencial ${ }^{922}$;

\footnotetext{
${ }^{919}$ Norma similar consta do art. $975, \S 2^{\circ}$, do Projeto de Lei no $8.046 / 2010$, que versa sobre o novo Código de Processo Civil:

"Quando manifestamente inadmissível o agravo interno, assim declarado em votação unânime, o tribunal condenará o agravante a pagar ao agravado multa fixada entre um e dez por cento do valor corrigido da causa, ficando a interposição de qualquer outro recurso condicionada ao depósito prévio do respectivo valor, ressalvados os beneficiários da gratuidade de justiça que, conforme a lei, farão o pagamento ao final".

${ }_{920}$ Abuso do Exercício do Direito de Recorrer, in NERY JÚNIOR; ALVIM WAMBIER (coords.), Aspectos Polêmicos e Atuais dos Recursos Cíveis e de Outras Formas de Impugnação às Decisões Judiciais, p. 891.

921 Nesse sentido: STJ, 4a Turma, AgRg no Ag 1.153.411/RS, Rel. Min. Luis Felipe Salomão, DJe 27/04/2010; STJ, 4 ${ }^{a}$ Turma, AgRg no REsp 1.115.995/SC, Rel. Min. Luis Felipe Salomão, DJe 27/04/2010; STJ, 4 a Turma, AgRg no REsp 1.149.408/MG, Rel. Min. Luis Felipe Salomão, DJe 27/04/2010.
} 
c) tese já consolidada em julgamento submetido à sistemática do art. 543-C do $\mathrm{CPC}^{923}$;

d) jurisprudência pacífica ${ }^{924}$;

e) tese já aplicada em outros julgados (ou seja, quando há precedentes no mesmo sentido $)^{925}$.

De acordo com coletânea de julgados apresentada por Barbosa Moreira ${ }^{926}$, o Supremo Tribunal Federal vem aplicando esse dispositivo nos seguintes casos:

a) quando o agravante teima em pleitear o julgamento de recurso extraordinário interposto com base em normas infraconstitucionais ${ }^{927}$;

b) quando o agravante insiste em recurso extraordinário que pretende a revisão dos fatos assentados pelo tribunal a quo ${ }^{928}$;

c) quando são oferecidos embargos de divergência em relação a tema que já foi examinado pelo Plenário, com resultado oposto ao das razões do recorrente ${ }^{929}$.

\subsection{Abuso do processo da rescisória (art. 488, II, do CPC)}

A rescisória é conceituada pela melhor doutrina como a "ação por meio da qual se pede a desconstituição de sentença trânsita em julgado, com eventual rejulgamento, a seguir, da matéria nela julgada"930. Trata-se de uma ação autônoma de impugnação de decisões judiciais cujos possíveis fundamentos constam de rol taxativo previsto no art. 485 do $\mathrm{CPC}^{931}$.

O Código de Processo Civil de 1973 ampliou os casos de rescindibilidade de sentenças passadas em julgado, em confronto com o que dispunha o art. 798 do Código de Processo Civil de $1939^{932}$. Diante dessa facilitação da rescisão de sentenças, o legislador

${ }^{922}$ Nesse sentido: STJ, $4^{\text {a }}$ Turma, AgRg no REsp 989.625/RS, Rel. Min. Luis Felipe Salomão, DJe 03/05/2010.

${ }^{923}$ Nesse sentido: STJ, $2^{\mathrm{a}}$ Turma, AgRg no Ag 1.193.199/PR, Rel ${ }^{\mathrm{a}}$. Min ${ }^{\mathrm{a}}$. Eliana Calmon, DJe 03/05/2010; STJ, $1^{a}$ Seção, AgRg no REsp 1.134.665/SP, Rel. Min. Luiz Fux, DJe 26/04/2010.

${ }_{924}$ Nesse sentido: STJ, $4^{\mathrm{a}}$ Turma, AgRg no Ag 1.233.055/RS, Rel. Min. Luis Felipe Salomão, DJe 27/04/2010; STJ, $4^{a}$ Turma, AgRg no Ag 1.232.097/MG, Rel. Min. Luis Felipe Salomão, DJe 27/04/2010.

${ }_{925}$ Nesse sentido: STJ, $4^{a}$ Turma, AgRg no Ag 793.669/BA, Rel. Min. Luis Felipe Salomão, DJe 03/05/2010.

${ }^{926}$ Comentários ao Código de Processo Civil, vol. V, p. 679, nt. 52.

${ }^{927}$ Nesse sentido: STF, $2^{\mathrm{a}}$ Turma, AI 273.246 AgR/SP, Rel. Min. Marco Aurélio, DJ 20/04/2001, p. 00111.

${ }^{928}$ Nesse sentido: STF, $2^{\mathrm{a}}$ Turma, AI 272.846 AgR/RS, Rel. Min. Marco Aurélio, DJ 25/05/2001, p. 00012.

${ }^{929}$ Nesse sentido: STF, Tribunal Pleno, RE 222.516 embargos-AgR/DF, Rel. Min. Marco Aurélio, DJ 18/05/2001, p. 00443.

930 BARBOSA MOREIRA, Comentários ao Código de Processo Civil, vol. V, p. 100.

${ }_{931}^{93}$ BARBOSA MOREIRA, Comentários ao Código de Processo Civil, vol. V, p. 155.

${ }^{932}$ Uma análise detalhada das diferenças entre os dispositivos do Código de Processo Civil de 1939 que regulavam a rescindibilidade de sentenças, de um lado, e os do Código de 1973, do outro, pode ser 
ficou receoso de que houvesse uma utilização desmedida de ações rescisórias e, por causa disso, atribuiu ao autor o ônus de depositar a importância de 5\% do valor da causa no momento do ajuizamento da petição inicial, a título de multa caso a ação venha a ser declarada inadmissível ou improcedente por unanimidade de votos (art. 488, II, do CPC) ${ }^{933}$ 934. A realização do depósito é requisito necessário para que o relator profira despacho liminar de conteúdo positivo, deferindo a petição inicial ${ }^{935}$. Faltando o depósito, a petição inicial deve ser indeferida liminarmente (art. 490, II, do CPC $)^{936}$.

Essas normas visam a garantir o ajuizamento comedido e fundado de ações rescisórias, cujo uso é considerado excepcional no ordenamento jurídico brasileiro, dada a sua eficácia desconstitutiva da coisa julgada e, consequentemente, supressiva da segurança jurídica. É lícito afirmar, então, que o objetivo do depósito no montante de 5\% do valor da causa (art. 488, II, do CPC) é sancionar o exercício abusivo do poder de ajuizar ações rescisórias ${ }^{937}$, abuso esse evidenciado pela unanimidade no acórdão de inadmissibilidade da ação ou no acórdão de improcedência do pedido de rescisão da sentença impugnada ("iudicium rescindens") ${ }^{938}$.

A hipótese de abuso do processo em sentido estrito contida no art. 488, II, do CPC relaciona-se com o dever das partes de "não formular pretensões, nem alegar defesa, cientes de que são destituídas de fundamento" (art. 14, III, do CPC) ${ }^{939}$. Trata-se, na verdade, de uma subespécie do comportamento ímprobo previsto na $1^{\mathrm{a}}$ parte do inciso I do art. 17 do CPC, consistente na dedução em juízo de pretensão contra texto expresso de lei, porém agravada pela excepcionalidade desse meio de ataque à coisa julgada que é a ação rescisória.

O parágrafo único do art. 488 do CPC isenta do depósito a União, os Estados, os Municípios e o Ministério Público. Até o fim da década de 80 e início da de 90 do século

encontrada em: BARBOSA MOREIRA, Comentários ao Código de Processo Civil, vol. V, pp. 104-105 e 118 .

933 BARBOSA MOREIRA, Comentários ao Código de Processo Civil, vol. V, p. 182.

${ }^{934}$ Essa exigência de depósito encontra precedentes no Direito comparado: nos arts. 1703 e 1799 da antiga "Ley de Enjuiciamiento Civil" espanhola; no art. 418 do "Codice di Procedura Civile" do Estado do Vaticano; e nos arts. 364 e 398, alínea 3, do "Codice di Procedura Civile" italiano, cujos textos foram posteriormente modificados pela Lei $\mathrm{n}^{\mathbf{0}}$ 793, de 18/10/1977, a qual extinguiu o instituto (BARBOSA MOREIRA, Comentários ao Código de Processo Civil, vol. V, p. 182 e nt. 180).

${ }^{935}$ BARBOSA MOREIRA, Comentários ao Código de Processo Civil, vol. V, pp. 183 e 189.

${ }^{936}$ Normas iguais às contidas nos arts. 488, II; e 490, II, do CPC atual estão inseridas no art. 921 , II e $\S 2^{\circ}$, do Projeto de Lei $\mathrm{n}^{\circ} 8.046 / 2010$, que trata do novo Código de Processo Civil.

937 Comentários ao Código de Processo Civil, vol. V, pp. 182 e 213.

938 De acordo com a doutrina, o resultado do "iudicium rescissorium" não influi na determinação do destino do depósito previsto no art. 488, II, do CPC (BARBOSA MOREIRA, Comentários ao Código de Processo Civil, vol. V, p. 212).

${ }_{939}$ MILMAN, Improbidade Processual: comportamento das partes e de seus procuradores no processo civil, p. 191. 
passado, a jurisprudência do Supremo Tribunal Federal e do Superior Tribunal de Justiça era no sentido de que os órgãos da Administração indireta da União, dos Estados e dos Municípios, inclusive suas autarquias, estariam excluídos da isenção prevista no dispositivo legal em exame ${ }^{940}$. Contudo, a Lei $n^{\circ} 8.620 / 90$ estendeu ao Instituto Nacional do Seguro Social (INSS) os mesmos privilégios assegurados à Fazenda Pública. Desde então, o Superior Tribunal de Justiça passou a entender que as ações rescisórias propostas por essa autarquia federal não precisam recolher o depósito previsto no art. 488, II, do CPC, o que ficou cristalizado no enunciado $\mathrm{n}^{\circ} 175$ de sua súmula de jurisprudência (DJ 31/10/1996, p. 42124) ${ }^{941}$. Mais tarde, o art. 24-A da Lei $n^{\circ}$ 9.028/95 (acrescentado pela Medida Provisória $n^{\circ} 1.984$ e, mais recentemente, pela de $n^{\circ} 2.180-35 / 01$ ) expressamente isentou do imposto prévio a União e também suas autarquias e fundações.

A doutrina discute se a isenção atinge também os beneficiários da justiça gratuita. Para Barbosa Moreira ${ }^{942}$, não obstante o depósito do art. 488, II, do CPC não se encontre no rol do art. $3^{\circ}$ da Lei $n^{\circ} 1.060 / 50$, ele não pode ser exigido sob pena de tolher a possibilidade de as pessoas carentes de recursos financeiros ajuizarem ações rescisórias, o que violaria o art. $5^{\circ}, \mathrm{XXXV}$, da $\mathrm{CF}^{943}$.

\subsection{Utilização de poderes e faculdades processuais para opor-se maliciosamente à execução (art. 600, II, do CPC)}

$\mathrm{O}$ art. 600 do CPC versa sobre "ato atentatório à dignidade da Justiça", ou seja, enumera os atos que o legislador considera transgressores da dignidade do Poder Judiciário $^{944}$.

\footnotetext{
${ }^{940}$ Nesse sentido: STF, Tribunal Pleno, AR 1.120 AgR/RJ, Rel. Min. Rafael Mayer, DJ 11/12/1981, p. 12836; STF, $1^{\text {a }}$ Turma, RE 111.669, Rel. Min. Sydney Sanches, DJ 21/04/1989, p. 5857; STJ, $1^{\text {a }}$ Seção, AR 126/RJ, Rel. Min. Geraldo Sobral, DJ 18/09/1989, p. 14656.

${ }^{941}$ Esse verbete sumular continua sendo aplicado atualmente, como se infere da análise dos seguintes julgados: STJ, $3^{\text {a }}$ Seção, AR 459/SP, Rel. Min. Maria Thereza de Assis Moura, DJe 12/11/2008; STJ, $5^{\text {a }}$ Turma, REsp 749.714/DF, Rel. p/ acórdão Min. Gilson Dipp, DJ 14/11/2005, p. 400.

${ }^{942}$ Comentários ao Código de Processo Civil, vol. V, pp. 182-183.

${ }^{943}$ Caso o projeto do novo Código de Processo Civil (Projeto de Lei no 8.046/2010) seja aprovado nos termos atuais, haverá uma norma expressamente nesse sentido na parte final do $\S 1^{\circ}$ do art. 921 :

"§ $1^{\circ}$ Não se aplica o disposto no inciso II [referente ao depósito da importância de 5\% sobre o valor da causa, a título de multa] à União, ao Estado, ao Distrito Federal, ao Município, respectivas autarquias e fundações de direito público, ao Ministério Público, e aos que tenham obtido o benefício da gratuidade de justiça" (destaques nossos).

944 Dinamarco (Instituições de Direito Processual Civil, vol. I, § 154, p. 369) ensina que o vocábulo "Justiça", grafado com letra inicial maiúscula, se refere ao conjunto das instituições judiciárias nacionais, não se confundindo com "justiça”, grafado com inicial minúscula, que é o predicado daquilo que é justo.

Por outro lado, Abdo (O Ato Atentatório à Dignidade da Justiça na Nova Execução Civil, p. 1) defende que a palavra "justiça" contida no art. 600 do CPC deveria estar grafada com letra inicial minúscula, em razão do
} 
Alguns doutrinadores afirmam que esse dispositivo foi inspirado no instituto do “contempt of court" do Direito anglo-americano ${ }^{945}$. Esse entendimento, porém, não é pacífico. Assis ${ }^{946}$, por exemplo, critica a qualificação da multa prevista no art. 601 do CPC como sendo referente à prática de "contempt of court" porque - segundo o autor - a pena característica do verdadeiro desacato ao tribunal é a prisão do infrator, a qual não é prevista no ordenamento jurídico brasileiro.

Tanto o art. 600, quanto o art. 601 do CPC, configuram desdobramento lógico das regras dos arts. 14 a 18 do $\mathrm{CPC}$, instituindo um dever de lealdade na fase executiva ${ }^{947}$. A existência de normas tratando especificamente da improbidade processual do executado é justificada por causa da maior necessidade de repressão às condutas tendentes a frustrar a eficácia da atividade jurisdicional executiva, dado que o título executivo é, em si mesmo, um atestado da existência do direito do exequente, que apenas excepcionalmente pode ser posta em questão (mediante impugnação ou embargos à execução - arts. 475-L, VI; e 745, $\mathrm{V}$, do $\mathrm{CPC})^{948}$. Em outras palavras, como a efetividade da tutela jurisdicional na execução é mais veemente, os atos desleais do executado se mostram tão graves que não merecem ser rechaçados de modo genérico, como os demais atos processuais ímprobos ${ }^{949}$.

É oportuno salientar que os arts. 600 e 601 do CPC referem-se apenas à conduta ímproba praticada pelo devedor-executado. Caso o credor-exequente realize ato abusivo, que configure uma das condutas descritas no art. 17 do CPC, ele é sancionado com base nos arts. 16 e 18 do CPC, não no art. 601 do $\mathrm{CPC}^{950}$.

$\mathrm{O}$ rol de atos que caracterizam atentado contra a dignidade da Justiça é taxativo. No entanto, Assis ${ }^{951}$ anota que os comportamentos previstos no art. 600 do CPC são tão amplos que, na prática, a enumeração é exemplificativa. Aparentemente, nenhum ato de má-fé do executado escapa da incidência desse dispositivo ${ }^{952}$.

fato de o dispositivo em análise versar sobre os atos atentatórios à dignidade do Poder Judiciário, e não do valor filosófico "Justiça".

${ }^{945}$ Nesse sentido: DINAMARCO, Instituições de Direito Processual Civil, vol. II, § 529, p. 275; PUOLI, Os Poderes do Juiz e as Reformas da Lei Processual Civil Brasileira, pp. 196-197.

${ }^{946}$ Manual da Execução, § 72, p. 370.

${ }_{947}$ ASSIS, Manual da Execução, $\$ 71$, p. 366.

948 CARMONA, Comentários ao art. 600 do CPC, in MARCATO (coord.), Código de Processo Civil Interpretado, p. 1961; DINAMARCO, Instituições de Direito Processual Civil, vol. II, § 529, p. 275.

949 OLIVEIRA, Litigância de Má-Fé, p. 51.

${ }^{950}$ ASSIS, Manual da Execução, § 71, pp. 366-367; DINAMARCO, Instituições de Direito Processual Civil, vol. II, § 529, p. 275.

${ }^{951}$ Manual da Execução, $\S 72$, p. 368.

952 Por exemplo, no julgamento do AgRg no Ag 342.203/RJ (Rel. Min. Carlos Alberto Menezes Direito, DJ 07/05/2001, p. 141), a $3^{\text {a }}$ Turma do Superior Tribunal de Justiça entendeu que configura ato atentatório à dignidade da Justiça a conduta de tentar suspender a praça de imóvel, porém sem que os termos contidos na ação de exoneração gerem os efeitos alegados para defender a tese de suspensão da praça. 
Interessa, no presente momento, analisar a conduta prevista no art. 600, II, do CPC, que consiste na oposição maliciosa à execução, mediante o emprego de ardis e meios $\operatorname{artificiosos}^{953}$.

Entende-se por "ardil" a artimanha utilizada pelo executado para evitar que o processo ou a fase de execução tenha curso normal. Os "meios artificiosos" são as tramas e os truques de que esse mesmo indivíduo faz uso para opor-se aos atos executivos ${ }^{954}$.

Para que reste caracterizada essa hipótese de ato atentatório à dignidade da Justiça é necessário que a conduta seja qualificada como maliciosa, com o uso de ardis e meios artificiosos, e que haja desvio de finalidade ${ }^{955}$. Por exemplo: o executado que se recusa a figurar como depositário do bem penhorado de sua propriedade, com o intuito de criar incidente processual e procrastinar a execução; o executado que ocupa imóvel onde não residia apenas para evitar a penhora, com fundamento na Lei $n^{\circ} 8.009 / 90^{956}$. Mas não é só isso.

Segundo Assis ${ }^{957}$, o elemento subjetivo (dolo ou culpa grave) é imprescindível para

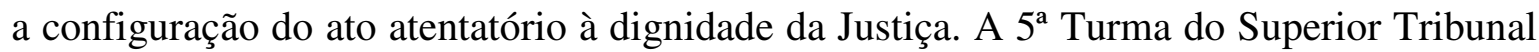
de Justiça parece defender o mesmo, ao sustentar que não há ato atentatório sem "atitude maliciosa da parte" ${ }^{, 958}$.

A redação original do art. 601 do CPC exigia que o juiz, antes de aplicar qualquer sanção, advertisse o executado que o seu comportamento configurava ato atentatório à dignidade da Justiça. A redação que a Lei $\mathrm{n}^{\circ}$ 8.953/94 conferiu a esse dispositivo legal suprimiu esse requisito. Todavia, os doutrinadores defendem que o juiz continua não podendo aplicar as sanções previstas no art. 601 do CPC sem antes advertir o executado, como estatui o art. 599, II, do $\mathrm{CPC}^{959}$.

\footnotetext{
${ }^{953}$ O Projeto de Lei no 8.046/2010 (que institui o novo Código de Processo Civil) traz norma análoga no art. 733, II:

"Art. 733. Considera-se atentatória à dignidade da justiça a conduta comissiva ou omissiva do executado que:$$
[\ldots]
$$$$
\text { II - se opõe maliciosamente à execução, empregando ardis e meios artificiosos". }
$$

954 CARMONA, Comentários ao art. 600 do CPC, in MARCATO (coord.), Código de Processo Civil Interpretado, p. 1962.

${ }_{955}$ ABDO, O Ato Atentatório à Dignidade da Justiça na Nova Execução Civil, pp. 10 e 15.

956 CARMONA, Comentários ao art. 600 do CPC, in MARCATO (coord.), Código de Processo Civil Interpretado, p. 1962.

${ }^{957}$ Manual da Execução, § 72, p 368.

${ }^{958}$ STJ, $5^{\mathrm{a}}$ Turma, REsp 117.611/SP, Rel. Min. Felix Fischer, DJ 15/12/1997, p. 66483.

${ }^{959}$ Acerca desse requisito, consultar o item 3.2.1 "infra".
} 


\subsection{Abuso do poder de opor embargos do devedor (art. 740, parágrafo único, do CPC)}

Os embargos do devedor consistem em uma ação incidental ao processo executivo na qual o executado apresenta a sua defesa a fim de afastar uma execução injusta ou ilegal, deduzindo razões e formulando pedidos ${ }^{960}$. Visam a resguardar o interesse legítimo do executado de não se submeter à atividade executiva quando tenha deixado de haver razão para que ela se desenvolva, bem como quando o seu desenvolvimento extravase os limites estritos em que se deve conter ${ }^{961}$.

A doutrina dominante afirma que eles possuem natureza jurídica de ação de conhecimento $^{962}$, na qual o executado-embargante é o autor e o exequente-embargado é o réu, podendo ser declaratória, constitutiva e até mesmo condenatória ${ }^{963}$.

No ordenamento jurídico atual, posterior à entrada em vigor das Leis ${ }^{\text {os }} 11.232 / 05$ e 11.382/06, o gênero "embargos do devedor" é constituído pelas seguintes espécies ${ }^{964}$ :

a) embargos à execução, oponíveis na fase inicial da execução e regulados no art. 745 do CPC;

b) embargos à adjudicação, alienação ou arrematação, disciplinados no art. 746 do $\mathrm{CPC}$; e

960 LUCON, Comentários ao art. 736 do CPC, in MARCATO (coord.), Código de Processo Civil Interpretado, p. 2312; ASSIS, Manual da Execução, § 483, p. 1166.

${ }_{961}$ BARBOSA MOREIRA, O Novo Processo Civil Brasileiro, p. 295.

${ }^{962}$ Nesse sentido: ASSIS, Manual da Execução, § 482, pp. 1164-1166; BARBOSA MOREIRA, O Novo Processo Civil Brasileiro, p. 296; THEODORO JÚNIOR, Os Embargos do Devedor Após as Reformas do CPC Efetuadas pelas Leis ${ }^{\text {os }} 11.232$ e 11.382, in Revista Forense, vol. 391, pp. 116-117; THEODORO JÚNIOR, Curso de Direito Processual Civil, vol. II, p. 429; MIRANDA; PIZZOL, Novos Rumos da Execução por Quantia Certa Contra Devedor Insolvente: o cumprimento de sentença, in ALVIM WAMBIER (coord.), Aspectos Polêmicos da Nova Execução - 3: de títulos judiciais - Lei 11.232/2005, pp. 209-210; LUCON, Comentários ao art. 736 do CPC, in MARCATO (coord.), Código de Processo Civil Interpretado, p. 2312.

Em sentido contrário, quase isolado, sustentando tratar-se de defesa do executado, similar à contestação existente no processo de conhecimento: PABST, Natureza Jurídica dos Embargos do Devedor, pp. 65-75.

963 De acordo com Miranda e Pizzol (Novos Rumos da Execução por Quantia Certa Contra Devedor Insolvente: o cumprimento de sentença, in ALVIM WAMBIER (coord.), Aspectos Polêmicos da Nova Execução - 3: de títulos judiciais - Lei 11.232/2005, p. 210 e nts. 63, 64 e 65), os embargos equivalem a uma ação declaratória de inexistência no caso de o juízo reconhecer a falta de citação no processo de conhecimento (art. 741, I, do CPC); têm natureza desconstitutiva se o magistrado reconhecer o excesso de execução e reduzir o valor da obrigação (art. $741, \mathrm{~V}$, c/c art. 743, I, do CPC); e consistem em ação condenatória na hipótese de o exequente cobrar quantia já paga, desde que se admita que o embargante peça a condenação do embargado (exequente) ao pagamento do dobro do valor que já havia sido pago, conforme o art. 940 do CPC.

Já para Greco Filho (Direito Processual Civil Brasileiro, vol. III, p. 123), os embargos do devedor somente podem ter natureza de ação constitutiva negativa (quando visam a desconstituir o título executivo) ou declaratória negativa (quando visam a declarar a inexistência da relação jurídica que o título aparenta documentar).

${ }_{964}$ BARBOSA MOREIRA, O Novo Processo Civil Brasileiro, p. 299. 
c) embargos à execução contra a Fazenda Pública, regidos pelos arts. 741 a 743 do $\mathrm{CPC}^{965966}$.

Theodoro Júnior ${ }^{967}$ classifica os embargos do devedor em:

a) embargos ao direito de execução (ou embargos de mérito), em que o devedor impugna o direito do credor de propor a ação executiva (v.g., os embargos em que se alega pagamento, ou novação, ou ainda remissão da dívida); e

b) embargos aos atos de execução (ou embargos de rito, ou de forma), em que o devedor contesta a regularidade formal do título, da citação ou de algum ato sucessivo do processo ou a sua oportunidade. Podem ser de dois tipos: (1) embargos de ordem, que visam à anulação do processo (e.g., os embargos que tratam da impropriedade de forma, da falta do direito de postular em juízo, da ausência de título executivo etc.); ou (2) embargos elisivos, supressivos ou modificativos dos efeitos da execução (v.g., os embargos que tratam da impenhorabilidade, do benefício de ordem, do excesso de penhora, da litispendência, do direito de retenção etc.).

Essa classificação mostra-se útil para a melhor compreensão de dois temas: competência para processar e julgar os embargos e coisa julgada. Enquanto os embargos ao direito de execução são sempre processados e julgados pelo juízo da execução, os embargos aos atos de execução podem, em certos casos, ser julgados pelo juízo deprecado, como se infere do art. 747 do CPC: "Na execução por carta, os embargos serão oferecidos no juízo deprecante ou no juízo deprecado, mas a competência para julgá-los é do juízo deprecante, salvo se versarem unicamente vícios ou defeitos da penhora, avaliação ou alienação dos bens" ${ }^{968}$. Quanto à coisa julgada, a sentença dos embargos de mérito, que

965 Faz-se abstração dos chamados "embargos na execução por carta” (art. 747 do CPC), cuja única peculiaridade diz respeito à competência.

966 Com mais precisão, Greco Filho (Direito Processual Civil Brasileiro, vol. III, p. 125) ensina que os embargos podem ser classificados segundo diversos critérios:

a) quanto ao título, podem ser embargos em execução fundada em título judicial (sentença ou equiparado) ou embargos em execução fundada em título extrajudicial;

b) quanto ao momento, podem ser embargos após a citação (denominados embargos à execução - art. 745 do CPC) ou embargos à arrematação ou à adjudicação (art. 746 do CPC);

c) quanto à matéria alegável, ela é restrita nos embargos contra título judicial (na execução contra a Fazenda Pública, na execução de sentença arbitral, sentença estrangeira e sentença penal condenatória), incluídos os embargos de retenção por benfeitorias; e irrestrita nos embargos contra título extrajudicial na execução por quantia, para entrega de coisa ou na de obrigação de fazer ou não-fazer e nos embargos especiais na insolvência (art. 755 do CPC).

${ }^{967}$ Os Embargos do Devedor Após as Reformas do CPC Efetuadas pelas Leis $\mathrm{n}^{\mathrm{os}} 11.232$ e 11.382 , in Revista Forense, vol. 391, p. 117; Curso de Direito Processual Civil, vol. II, p. 430.

${ }_{968}$ Theodoro Júnior (Os Embargos do Devedor Após as Reformas do CPC Efetuadas pelas Leis $\mathrm{n}^{\mathrm{os}} 11.232 \mathrm{e}$ 11.382, in Revista Forense, vol. 391, p. 120) salienta que o juízo deprecado é competente tão somente no caso de os embargos tratarem "unicamente" de vícios ou defeitos da penhora, avaliação ou alienação dos bens. Se o embargante alegar outras matérias além dessas, a competência que deve prevalecer é a do juízo 
versa sobre o direito substancial do exequente, transita em julgado formal e materialmente. Já a dos embargos de rito ou de forma transita em julgado apenas formalmente ${ }^{969}$.

Quem tem legitimidade para propor embargos é o sujeito que figura no polo passivo do processo de execução, ou seja, em regra, o devedor designado no título executivo $^{970}$. São igualmente legitimados os terceiros com responsabilidade executiva (e.g., fiador, sócio, sucessor, sub-rogado etc.), desde que possam ser atingidos pela execução, e o cônjuge do executado, para defender sua meação, se a penhora recair sobre bem imóvel, por exemplo. Consoante a súmula nº 196 do STJ, o curador especial também tem legitimidade para apresentar embargos, tutelando os interesses do executado citado por edital ou por hora certa que permanecer revel ("Súmula 196: Ao executado que, citado por edital ou por hora certa, permanecer revel, será nomeado curador especial, com legitimidade para apresentação de embargos" $)^{971}$. Lucon ${ }^{972}$ ensina que o Ministério Público tem legitimidade para opor embargos, objetivando sempre a tutela do interesse público (v.g., no caso de execução de título judicial oriundo de ação popular, quando esta se desvia de seus fins). Os terceiros que não sejam responsáveis patrimonialmente, nem partes no processo de execução, não são legitimados a opor embargos do devedor. Caso sejam atingidos por atos executivos, podem apenas propor embargos de terceiro (arts. 1.046 e ss. do CPC) para defenderem seus interesses ${ }^{973}$.

O oferecimento dos embargos independe de prévia segurança do juízo, propiciada por penhora, depósito ou caução (art. 736, “caput”, do CPC), e deve ser feito dentro do

deprecante. O jurista recomenda que, nesses casos, os embargos sejam formulados em peças separadas, uma vez que o processamento do feito que trata do mérito independe do aperfeiçoamento da penhora.

969 THEODORO JÚNIOR, Os Embargos do Devedor Após as Reformas do CPC Efetuadas pelas Leis $n^{\text {os }}$ 11.232 e 11.382, in Revista Forense, vol. 391, pp. 117 e 119-120.

${ }^{970}$ Com razão, Lucon (Comentários ao art. 736 do CPC, in MARCATO (coord.), Código de Processo Civil Interpretado, p. 2318) observa que o legitimado ativo no processo de embargos pode não ser, necessariamente, o sujeito passivo da relação jurídica de direito material. Por exemplo, no caso de execução movida contra parte ilegítima (art. 741, III; ou art. 745, V, do CPC), o executado tem legitimidade para oferecer embargos, apesar de não ser o devedor.

${ }^{971}$ Lucon (Comentários ao art. 736 do CPC, in MARCATO (coord.), Código de Processo Civil Interpretado, pp. 2320-2321) é contrário à possibilidade de o curador especial opor embargos, uma vez que: (a) no processo de execução não há contestação, nem o efeito material da revelia; (b) o curador especial é mero substituto processual, não podendo propor demandas, como é o caso dos embargos à execução; e (c) sua atuação pode vir a penalizar injustamente o executado, pois, se for prolatada sentença de improcedência nos embargos e ela transitar em julgado formal e materialmente, este fica impedido de questionar futuramente o mérito da execução por meio de demanda cognitiva autônoma, visando à declaração de inexistência do crédito por alguma causa impeditiva, modificativa ou extintiva da obrigação (v.g., o pagamento, ou a compensação), por força da exceção de coisa julgada (art. 267, V, do CPC).

972 Comentários ao art. 736 do CPC, in MARCATO (coord.), Código de Processo Civil Interpretado, p. 2321.

${ }^{973}$ THEODORO JÚNIOR, Os Embargos do Devedor Após as Reformas do CPC Efetuadas pelas Leis $\mathrm{n}^{\text {os }}$ 11.232 e 11.382, in Revista Forense, vol. 391, pp. 117-118; BARBOSA MOREIRA, O Novo Processo Civil Brasileiro, pp. 296-297; LUCON, Comentários ao art. 736 do CPC, in MARCATO (coord.), Código de Processo Civil Interpretado, pp. 2317-2320. 
prazo de 15 dias, tendo como termo inicial a data da juntada aos autos do mandado de citação ou, no caso dos embargos na execução por carta precatória, a data da juntada da comunicação, feita pelo juízo deprecado ao deprecante, de que a citação foi realizada (art. 738, “caput" e $\S 2^{\circ}$, do CPC $)^{974} 975$. Aplica-se a regra geral de que o “dies a quo" não se computa (art. 184 do CPC) ${ }^{976}$. Devem ser distribuídos por dependência ao juízo da causa principal (a ação de execução), autuados em apartado e instruídos com cópias das peças processuais relevantes (e.g., título executivo, documentos externos ao título que atestem a exigibilidade da obrigação, procurações, citação, auto de penhora ${ }^{977}$ ), as quais podem ser declaradas autênticas pelo advogado, sob sua responsabilidade pessoal (art. 736, parágrafo único, do CPC).

Em regra, os embargos do executado são destituídos de eficácia suspensiva. Excepcionalmente, o magistrado pode atribuir-lhe efeito suspensivo, de ofício ou após requerimento do embargante ${ }^{978}$, desde que: (a) os seus fundamentos sejam relevantes; (b) o prosseguimento da execução manifestamente possa causar ao executado grave dano de difícil ou incerta reparação; e (c) a execução já esteja garantida por penhora, depósito ou caução suficientes. Se qualquer uma dessas circunstâncias desaparecer, a decisão relativa aos efeitos dos embargos pode ser modificada ou revogada, de ofício ou depois de provocação da parte interessada ${ }^{979}$, por decisão judicial fundamentada (art. 739-A, "caput" e $\S \S 1^{\circ}$ e $2^{\circ}$, do CPC). O recurso cabível contra a decisão interlocutória que versa sobre a

\footnotetext{
974 Segundo Theodoro Júnior (Os Embargos do Devedor Após as Reformas do CPC Efetuadas pelas Leis $n^{\text {os }}$ 11.232 e 11.382, in Revista Forense, vol. 391, p. 123), se, porventura, o juízo deprecado restar inerte, não informando o juízo deprecante a respeito da realização da citação, o prazo para a oposição dos embargos começa a correr da juntada da precatória cumprida aos autos da execução.

${ }^{975}$ Essa regra não se aplica aos embargos à adjudicação, alienação ou arrematação, que devem ser opostos no prazo de 5 dias, contados da adjudicação, da alienação ou da arrematação (art. 746, "caput", do CPC).

976 THEODORO JÚNIOR, Os Embargos do Devedor Após as Reformas do CPC Efetuadas pelas Leis $n^{\text {os }}$ 11.232 e 11.382, in Revista Forense, vol. 391, p. 122.

977 THEODORO JÚNIOR, Os Embargos do Devedor Após as Reformas do CPC Efetuadas pelas Leis $\mathrm{n}^{\text {os }}$ 11.232 e 11.382, in Revista Forense, vol. 391, p. 121; LUCON, Comentários ao art. 736 do CPC, in MARCATO (coord.), Código de Processo Civil Interpretado, pp. 2314 e 2315.

${ }^{978} \mathrm{O}$ texto do art. 739-A do CPC dá a entender que o requerimento do embargante é um elemento essencial para a atribuição de efeito suspensivo aos embargos. Porém, Lucon (Comentários ao art. 739-A do CPC, in MARCATO (coord.), Código de Processo Civil Interpretado, p. 2334) estatui que o juiz pode conceder o efeito suspensivo de ofício, não obstante a inexistência de pedido do embargante nesse sentido, desde que estejam presentes os três requisitos enunciados pelo $\S 1^{\circ}$ do art. 739-A do CPC.

979 Lucon (Comentários ao art. 739-A do CPC, in MARCATO (coord.), Código de Processo Civil Interpretado, p. 2334) tem opinião aparentemente distinta do texto legal, que, à primeira vista, exige a existência de requerimento da parte interessada para que a decisão relativa aos efeitos dos embargos possa ser modificada ou revogada. De acordo com o doutrinador, basta que sejam apresentados novos fundamentos, não apreciados pelo julgador e que tenham o condão de suspender a execução ou de determinar o seu prosseguimento, para que a decisão acerca dos efeitos dos embargos possa ser modificada "ex officio".
} 
atribuição de efeito suspensivo aos embargos é o agravo de instrumento, já que o ato impugnado pode causar dano de difícil reparação à parte ${ }^{980}$.

Deve-se salientar que a suspensão da execução eventualmente produzida pelos embargos nem sempre é total. Quando o embargante alega apenas excesso de execução, apresentando o valor que entende correto, com a memória de cálculo atualizada, a suspensão é objetivamente parcial, pois se limita à parcela controvertida, prosseguindo a execução definitivamente quanto à parte incontroversa (art. 739-A, §§ $3^{\circ}$ e $5^{\circ}$, do CPC). Já na hipótese de os embargos versarem sobre matéria que beneficie apenas o embargante (v.g., ilegitimidade "ad causam"), a suspensão é subjetivamente parcial, prosseguindo a execução definitivamente em relação aos demais executados (art. 739-A, § $4^{\circ}$, do CPC) ${ }^{981}$. De qualquer maneira, a concessão de efeito suspensivo aos embargos não impede a efetivação de atos de penhora e avaliação dos bens (art. 739-A, § 6 ${ }^{\circ}$, do CPC), já que não provocam transferência patrimonial ${ }^{982}$.

O parágrafo único do art. 740 do CPC, com redação dada pela Lei n ${ }^{\circ}$ 11.382/06, prevê hipótese de abuso do poder de opor embargos do devedor: "No caso de embargos manifestamente protelatórios, o juiz imporá, em favor do exequente, multa ao embargante em valor não superior a $20 \%$ (vinte por cento) do valor em execução" 983 .

Esse dispositivo se aplica a todos os embargos do devedor, exceto aos embargos à adjudicação, alienação ou arrematação, cujo exercício abusivo é sancionado pelo parágrafo único do art. 746 do CPC (item 2.16 "infra”).

Preliminarmente, cumpre observar que o art. 740, parágrafo único, do CPC contém norma especial em relação à prevista no art. 600, II, c/c art. 601 do CPC, já que a oposição de embargos manifestamente protelatórios nada mais é do que um ato de resistência maliciosa à execução, atentatório à dignidade da Justiça ${ }^{984}$. Sendo assim, os embargos manifestamente protelatórios opostos antes da vigência da Lei ${ }^{\circ} 11.382 / 06$, que conferiu ao art. 740, parágrafo único, do CPC sua atual redação, devem ser punidos com uma multa

\footnotetext{
${ }^{980}$ BARBOSA MOREIRA, O Novo Processo Civil Brasileiro, p. 304; LUCON, Comentários ao art. 739-A do CPC, in MARCATO (coord.), Código de Processo Civil Interpretado, pp. 2333-2334.

981 LUCON, Comentários ao art. 739 do CPC, in MARCATO (coord.), Código de Processo Civil Interpretado, p. 2330; LUCON, Comentários ao art. 739-A do CPC, in MARCATO (coord.), Código de Processo Civil Interpretado, pp. 2334-2335.

982 LUCON, Comentários ao art. 739 do CPC, in MARCATO (coord.), Código de Processo Civil Interpretado, p. 2335.

${ }_{983} \mathrm{O}$ art. 876, parágrafo único, do projeto do novo Código de Processo Civil (Projeto de Lei no 8.046/2010) considera a oposição de embargos manifestamente protelatórios conduta atentatória à dignidade da justiça (art. 733 do projeto do novo CPC).

${ }^{984}$ Nesse sentido: THEODORO JÚNIOR, Os Embargos do Devedor Após as Reformas do CPC Efetuadas pelas Leis nos 11.232 e 11.382, in Revista Forense, vol. 391, p. 126; THEODORO JÚNIOR, Curso de Direito Processual Civil, vol. II, p. 441.
} 
em valor não superior a $20 \%$ do valor do débito em execução, não com fundamento no dispositivo em comento, mas sim no art. 601 do CPC $^{985}$.

Para que o art. 740, parágrafo único, do CPC incida, é necessário que os embargos do devedor sejam "manifestamente protelatórios" (destaque nosso), ou seja, exige-se a presença do dolo, do intuito manifesto de protelar, ou de culpa grave a ele equiparável ${ }^{986}$. Sancionar o embargante sem que esse requisito seja preenchido contraria o princípio da legalidade e viola as garantias do contraditório e da ampla defesa (art. $5^{\circ}, \mathrm{LV}$, da CF). Não se pode aplicar a multa, por exemplo, apenas porque os embargos foram rejeitados ou porque se constatou algum erro de direito ou de fato ${ }^{987}$. Também não parece correto sustentar que o caráter evidentemente procrastinatório dos embargos se manifeste na formulação de defesa contra direito evidente; ou na argumentação contra fatos incontroversos no processo ${ }^{988}$; ou na dedução de argumentos manifestamente infundados ${ }^{989}$; ou na invocação de fundamento não incluído entre os admitidos pelos arts. 741 e 745 do $\mathrm{CPC}^{990}$; ou ainda na inexistência de qualquer possibilidade de êxito, constatada a partir da mera leitura da petição inicial ${ }^{991}$. Nesses casos, os embargos são manifestamente incabíveis ou improcedentes, mas não são necessariamente protelatórios. Para que o intuito manifestamente protelatório fique evidente, é necessário, além da manifesta falta de fundamentação jurídica ou fática, que o embargante: (a) pleiteie a atribuição de efeito suspensivo aos embargos (pois, sem suspender o curso da execução, os embargos manifestamente incabíveis ou improcedentes não protelam suficientemente a prolação da tutela jurisdicional no processo principal a ponto de ficar evidenciado o intuito

\footnotetext{
${ }^{985}$ Theodoro Júnior (Os Embargos do Devedor Após as Reformas do CPC Efetuadas pelas Leis $n^{\text {os }} 11.232$ e 11.382, in Revista Forense, vol. 391, p. 127) parece defender entendimento diferente:

"Há um problema de direito intertemporal a ser enfrentado na aplicação da pena criada pela Lei $n^{o}$ 11.382/2006 para os embargos manifestamente protelatórios. É que em se tratando de sanção ou pena, por princípio (CF, art. $5^{\circ}$, XXXIX), não pode ser aplicada a embargos ajuizados antes da lei que a instituiu, ainda que se possa reconhecê-los como manifestamente protelatórios. Não há pena sem lei que a comine (nulla poena sine lege) e se o fato incriminado foi praticado quando inexistia previsão legal da pena, não pode a lei superveniente atingi-lo, como bem observa Flávio Luiz Yarshell" (destaques no original).

${ }_{986}$ Contra, defendendo que a incidência do art. 740, parágrafo único, do CPC independe de culpa ou intenção do embargante: LUCON, Comentários ao art. 740 do CPC, in MARCATO (coord.), Código de Processo Civil Interpretado, p. 2345.

${ }_{987}$ THEODORO JÚNIOR, Os Embargos do Devedor Após as Reformas do CPC Efetuadas pelas Leis $\mathrm{n}^{\text {os }}$ 11.232 e 11.382, in Revista Forense, vol. 391, p. 127.

${ }^{988}$ Nesse sentido: THEODORO JÚNIOR, Os Embargos do Devedor Após as Reformas do CPC Efetuadas pelas Leis $\mathrm{n}^{\text {os }} 11.232$ e 11.382, in Revista Forense, vol. 391, p. 126; THEODORO JÚNIOR, Curso de Direito Processual Civil, vol. II, p. 440.

${ }_{989}$ Nesse sentido: LUCON, Comentários ao art. 739 do CPC, in MARCATO (coord.), Código de Processo Civil Interpretado, , p. 2328.

${ }_{990}^{99}$ Nesse sentido: BARBOSA MOREIRA, O Novo Processo Civil Brasileiro, p. 303.

${ }^{991}$ Nesse sentido: SCARPINELlA BUENO, A Nova Etapa da Reforma do Código de Processo Civil, vol. 3 , pp. 266 e 289.
} 
procrastinatório do seu autor); ou (b) já tenha praticado, anteriormente, no mesmo processo ou na causa principal, algum ato manifestamente protelatório (v.g., art. 17, VII; ou art. 538, parágrafo único, do $\mathrm{CPC}$ ), ou manifestamente infundado (art. 17, VI, do CPC), ou temerário (art. 17, V, do CPC), ou de resistência injustificada ao andamento do processo (art. 17, IV, do CPC). Assis ${ }^{992}$ vislumbra outra hipótese de embargos manifestamente protelatórios: trata-se do comportamento do embargante que, depois de alegar excesso de execução, sem indicar na petição inicial o valor que entende correto (art. 739-A, § 5º do CPC), e de receber prazo para corrigir a inicial (dilatando, assim, a duração do processo), permanece inerte.

Cumpre esclarecer que a oposição de embargos manifestamente incabíveis ou improcedentes também consiste em abuso processual. Apenas não acarreta a incidência do art. 740, parágrafo único, do CPC, uma vez que lhe falta a característica manifestamente protelatória. A repressão a esse comportamento deve ser feita com fundamento nos arts. 600, II; e 601 do CPC porque se trata de um ato de resistência maliciosa à execução.

O embargante que agiu com propósito de protelar a execução deve ser sancionado não somente com a multa de até $20 \%$ do valor da execução, prevista no art. 740 , parágrafo único, do CPC, mas também com o dever de ressarcir os prejuízos sofridos pela parte contrária e com a obrigação de arcar com o custo financeiro do processo, previstos no art. 18 do $\mathrm{CPC}^{993}$. Caso o magistrado constate o abuso processual do embargante "in limine litis", deve aplicar essas sanções e também rejeitar os embargos com espeque no inciso III do art. 739 do $\mathrm{CPC}^{994}$.

\subsection{Abuso do poder de se arrepender da arrematação de bem imóvel de incapaz (art.} 701, $\$ 2{ }^{\circ}$, do CPC)

No procedimento da execução por quantia certa, existe a "hasta pública", que é uma sucessão de atos processuais realizada com o objetivo de obter a arrematação do bem

\footnotetext{
${ }_{992}$ Manual da Execução, § 513.1.3, p. 1242; e $§ 528.3$, p. 1264.

${ }^{993}$ Lucon (Comentários ao art. 740 do CPC, in MARCATO (coord.), Código de Processo Civil Interpretado, p. 2345) reconhece, expressamente, a possibilidade de se cumular a multa do art. 740, parágrafo único, com a sanção de caráter reparatório do art. 18 do CPC, porém silencia a respeito da obrigação de arcar com o custo do processo.

994 Admitem a aplicação simultânea do art. 739, III, e do art. 740, parágrafo único, do CPC: DINAMARCO, Instituições de Direito Processual Civil, vol. IV, § 1.783, p. 828; THEODORO JÚNIOR, Os Embargos do Devedor Após as Reformas do CPC Efetuadas pelas Leis n ${ }^{\text {os }} 11.232$ e 11.382, in Revista Forense, vol. 391, pp. 126 e 127; THEODORO JÚNIOR, Curso de Direito Processual Civil, vol. II, pp. 440 e 441-442; BARBOSA MOREIRA, O Novo Processo Civil Brasileiro, p. 303; ASSIS, Manual da Execução, § 513.1.3, p. 1242; SCARPINELLA BUENO, A Nova Etapa da Reforma do Código de Processo Civil, vol. 3, p. 289.
} 
penhorado $^{995}$, ou seja, a alienação do bem penhorado contra a entrega do valor oferecido $^{996}$. Pode-se dizer, de forma simplificada, que se trata de um meio de converter em dinheiro os bens penhorados, para, com o produto, satisfazer o exequente, independentemente de qualquer colaboração por parte do executado ${ }^{997}$.

Consoante o "caput" do art. 686 do CPC, a alienação em hasta pública só ocorre se o exequente não requerer a adjudicação dos bens penhorados (art. 685-A do CPC), nem a alienação por iniciativa particular (art. 685-C do CPC).

O procedimento da alienação em hasta pública é composto de três etapas principais ${ }^{998}$ :

a) publicação de edital para convocação de licitantes, garantindo a prévia divulgação da notícia de que os bens serão alienados. Quanto maior o número de pessoas cientes de que haverá a oferta pública de bem penhorado, maior a probabilidade de comparecerem pretendentes a arrematar, o que incentiva a competitividade e, consequentemente, aumenta a probabilidade de obtenção de lances mais elevados ${ }^{999}$. Devem constar do edital as seguintes informações: características do bem penhorado; seu estado de conservação; eventuais ônus incidentes sobre ele; o valor mínimo a ser ofertado; o dia, a hora e o local em que a hasta pública se realizará; a comunicação de que, "se o bem não alcançar lanço superior à importância da avaliação, seguir-se-á, em dia e hora que forem desde logo designados entre os dez e os vinte dias seguintes, a sua alienação pelo maior lanço (art. 692)"; e indicação do dia, hora e lugar para a eventual segunda praça ou segundo leilão, sob pena de a realização de uma ou de outro depender de nova publicação $^{1000}$. Quando o valor dos bens penhorados não exceder 60 vezes o valor do salário mínimo vigente na data da avaliação, a publicação do edital é dispensada. Nesse caso, o preço da arrematação não pode ser inferior ao da avaliação (art. $686, \S 3^{\circ}$, do CPC). Além da publicação do edital, certas pessoas devem ser especificamente cientificadas

\footnotetext{
995 DINAMARCO, Instituições de Direito Processual Civil, vol. IV, § 1.706, p. 649.

996 De acordo com Dinamarco (Instituições de Direito Processual Civil, vol. IV, § 1.706-A, p. 650), "arrematação é o ato de arrematar, ou seja, a aquisição do bem em hasta pública contra a entrega do valor oferecido". A maior parte dos doutrinadores nacionais contemporâneos defende que a arrematação é um ato estatal imperativo, ou seja, uma forma coativa de alienação judicial de bens do executado para a satisfação do exequente, e não um negócio jurídico de compra-e-venda, que pressupõe consenso entre as partes (BARBOSA MOREIRA, O Novo Processo Civil Brasileiro, p. 258; DINAMARCO, Instituições de Direito Processual Civil, vol. IV, § 1.706-A, p. 650; SCARPINELLA BUENO, Comentários ao art. 686 do CPC, in MARCATO (coord.), Código de Processo Civil Interpretado, pp. 2181-2182). Na opinião de Assis (Manual da Exесис̧ão, $\S 274$, pp. 766-770), trata-se de um negócio jurídico de direito público e processual, celebrado entre o Estado, que detém o poder de dispor, e o adquirente.

${ }^{997}$ BARBOSA MOREIRA, O Novo Processo Civil Brasileiro, p. 258.

${ }^{998}$ BARBOSA MOREIRA, O Novo Processo Civil Brasileiro, pp. 258-263.

${ }^{999}$ DINAMARCO, Instituições de Direito Processual Civil, vol. IV, § 1.708, p. 658.

${ }^{1000}$ DINAMARCO, Instituições de Direito Processual Civil, vol. IV, § 1.708, p. 659.
} 
acerca da designação da hasta pública: (1) o executado (art. 687, § 5º do CPC), sob pena de nulidade da arrematação (art. 694, § 1º, I, do CPC); (2) o eventual senhorio direto, se o bem for enfitêutico; ou o credor pignoratício, hipotecário, ou anticrético, ou ainda o usufrutuário, se pesar sobre o bem qualquer desses ônus, caso contrário a arrematação é considerada ineficaz em relação à pessoa não-intimada (art. 619 do CPC) e pode ser tornada sem efeito (art. 694, § 1º, VI; c/c art. 698 do CPC); e (3) a União, o Estado e o Município em que estiver o bem, caso tenha sido objeto de tombamento por seu valor histórico ou artístico (art. 22, § $4^{\circ}$, do Decreto-lei $n^{\circ} 25 / 37$ ), também sob pena de nulidade da arrematação (art. 694, § $1^{\circ}$, I, do CPC);

b) licitação pública, em que comparecem pretendentes ao bem penhorado e cada um faz sua oferta em dinheiro. A modalidade de procedimento licitatório a ser adotada em cada caso varia de acordo com a natureza do bem: se o bem penhorado for imóvel, a licitação é feita em praça; se for móvel, em leilão, exceto nos casos em que a atribuição de alienar é privativa dos corretores da Bolsa de Valores (arts. 686, IV; e 704 do CPC) ${ }^{1001}$. Considera-se vitorioso o indivíduo que apresentar o "melhor lanço ou proposta mais conveniente" (art. 690, $\S 3^{\circ}$, do CPC), entendendo-se por "melhor lanço" o maior dos valores ofertados e por "proposta mais convincente" a que expressar melhores condições de pagamento, garantias etc ${ }^{1002}$. Na primeira sessão, só se aceitam lances com valor superior ao da avaliação; já na segunda, o bem é alienado pelo maior lance (art. 686, VI, do (PC), ainda que não atinja o valor da avaliação, mas desde que não se trate de "preço vil" (art. 692, “caput”, do CPC). Caso a segunda praça ou o segundo leilão também seja negativo, a doutrina vislumbra duas soluções: (1) ou se procede à substituição da penhora,

\footnotetext{
${ }^{1001}$ A natureza do bem não é o único elemento distintivo entre essas duas modalidades de hasta pública. Elas também diferem com relação (BARBOSA MOREIRA, O Novo Processo Civil Brasileiro, pp. 260-261; DINAMARCO, Instituições de Direito Processual Civil, vol. IV, § 1.707, pp. 651-655; SCARPINELLA BUENO, Comentários ao art. 686 do CPC, in MARCATO (coord.), Código de Processo Civil Interpretado, p. 2181):

a) ao local de sua realização: a praça deve ser realizada no átrio do edifício do fórum, enquanto o leilão deve ocorrer onde estiverem os bens ou no lugar designado pelo magistrado (art. $686, \S 2^{\circ}$; e art. 705, II, do CPC); b) à pessoa responsável pela respectiva realização: na praça, o pregão deve ser feito pelo oficial de justiça (na verdade, a lei atribui essa função ao "porteiro dos auditórios", mas essa figura não existe mais na organização judiciária brasileira) ou, na Justiça Federal, pelo depositário-avaliador-leiloeiro (arts. 36, VI; e 41, XIV, da Lei no 5.010/66); já no leilão, quem o faz é o leiloeiro público da escolha do exequente (arts. 688, parágrafo único; 705 e 706 do CPC) ou, nas comarcas em que inexista leiloeiro oficial habilitado, o oficial de justiça, na qualidade de oficial-porteiro;

c) à pessoa que deve arcar com os custos: na praça, as despesas são carregadas ao devedor; já no leilão, é o arrematante quem deve pagar a comissão estabelecida em lei ou arbitrada pelo juiz para o leiloeiro (art. 705, IV, do CPC); e

d) à maior ou menor rigidez no tocante ao valor das ofertas admissíveis, já que o art. 701 do CPC impede a alienação de bem imóvel pertencente a incapaz por valor abaixo de $80 \%$ do da avaliação.

${ }^{1002}$ DINAMARCO, Instituições de Direito Processual Civil, vol. IV, § 1.706-A, p. 651; e § 1.710, p. 664.
} 
quer dizer, penhoram-se outros bens do executado (art. 656, VI, do CPC); (2) ou se realiza uma terceira hasta pública, que deve ser precedida de novo edital, atendendo às exigências do art. 686 do $\mathrm{CPC}^{1003}$. O exequente pode requerer que a alienação seja realizada por meio da rede mundial de computadores, com uso de páginas virtuais criadas pelos Tribunais ou por entidades públicas ou privadas em convênio firmado com eles, ao invés de seguir o procedimento previsto nos arts. 686 a 689 do CPC (art. 689-A, “caput”, do CPC). O arrematante deve pagar o valor do seu lance vitorioso imediatamente ou, se prestar caução idônea (real ou fidejussória ${ }^{1004}$ ), no prazo de até 15 dias. Tratando-se de bem imóvel, o preço, nunca inferior à avaliação, pode ser dividido em parcelas, desde que se pague pelo menos $30 \%$ dele à vista e se garanta o restante por hipoteca instituída sobre o próprio imóvel arrematado. No caso de arrematação a prazo, os pagamentos feitos pelo arrematante pertencerão ao exequente até o limite de seu crédito e os subsequentes, ao executado (art. 690, "caput" e $\S \S 1^{\circ}$ e $4^{\circ}$, do CPC). Se o próprio exequente arrematar os bens, ele não é obrigado a depositar o dinheiro oferecido, mas, se o valor deles exceder o seu crédito, deve depositar a diferença dentro do prazo de 3 dias, sob pena de ser tornada sem efeito a arrematação (art. 690-A, parágrafo único, do CPC); e

c) assinatura do auto de arrematação. Este é lavrado logo depois do encerramento da licitação e dele devem constar as condições pelas quais o bem foi alienado (art. 693, “caput”, do CPC). Uma vez assinado o auto pelo juiz, pelo arrematante e pelo serventuário da justiça ou leiloeiro, a arrematação é considerada perfeita, acabada e irretratável, ainda que venham a ser julgados procedentes eventuais embargos do executado (art. 694, “caput", do CPC). Deve-se ressaltar que não é a lavratura e assinatura do auto que transfere ao arrematante a propriedade da coisa. Isso só ocorre com a tradição, se for bem móvel, ou com o registro da carta de arrematação (título formal da aquisição ${ }^{1005}$ ), se imóvel (arts. 1.267 e 1.245 do CC, respectivamente) ou móvel sujeito a registro (v.g., veículo

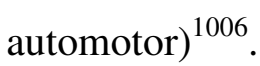

O art. 701 do CPC trata especificamente da hipótese de alienação coativa de imóvel pertencente a executado incapaz. Estatui que, se não forem formulados lances de pelo menos $80 \%$ do valor da avaliação na segunda praça, o juiz deve confiar o imóvel do incapaz à guarda e administração de depositário idôneo (muito provavelmente, o

\footnotetext{
${ }^{1003}$ Nesse sentido: SCARPINELLA BUENO, Comentários ao art. 686 do CPC, in MARCATO (coord.), Código de Processo Civil Interpretado, pp. 2186-2187.

${ }^{1004}$ DINAMARCO, Instituições de Direito Processual Civil, vol. IV, § 1.711, p. 665.

1005 ASSIS, Manual da Execução, § 313, p. 841.

${ }^{1006}$ DINAMARCO, Instituições de Direito Processual Civil, vol. IV, § 1.712, p. 667; § 1.713, p. 668; e § 1.716 , p. 672.
} 
representante do incapaz ${ }^{1007}$ ) e adiar a alienação pelo prazo de até 1 ano, podendo autorizar a sua locação durante esse período (art. 701, “caput" e $\S 3^{\circ}$, do CPC) ${ }^{1008}$. Caso algum pretendente demonstre interesse pela aquisição do imóvel durante o adiamento, e preste caução idônea, assegurando o preço da avaliação, o juiz deve ordenar a alienação do bem em praça (art. 701, § $1^{\circ}$, do CPC). A caução pode ser real ou fidejussória e o seu valor não deve ser inferior a $20 \%$ da proposta, para poder satisfazer eventual multa aplicada ao arrependido (art. 701, $\S 2^{\circ}$, do CPC) e também o acréscimo de despesas ${ }^{1009}$. A praça designada pelo juiz, com espeque no $\S 1^{\circ}$ do art. 701 do CPC, limita-se a apenas uma sessão, na qual não se podem oferecer lances inferiores ao do valor da avaliação ${ }^{1010}$. Como ocorre em toda licitação, é necessário publicar edital para que a data da nova praça seja amplamente conhecida ${ }^{1011}$.

Esgotado o prazo de até 1 ano sem que alguém tenha ofertado o preço da avaliação, e tendo sido infrutífera eventual praça realizada durante esse período, o imóvel deve ser levado novamente a praça, quando poderá ser alienado pelo maior lance (art. $701, \S 4^{\circ}$, do CPC), desde que não configure "preço vil" ${ }^{1012}$. De acordo com Assis ${ }^{1013}$, se o juiz verificar que as condições de mercado recomendam o negócio, ele pode autorizar o retorno do imóvel à hasta até mesmo antes do término do prazo de adiamento.

O escopo da regra prevista no art. 701 do CPC é impedir a alienação inoportuna do imóvel, protegendo os interesses do executado incapaz e atendendo ao disposto no art. 620 do $\mathrm{CPC}^{1014}$.

No $\S 2^{\circ}$ do referido dispositivo legal, encontra-se norma que sanciona o comportamento ímprobo do pretendente à arrematação: se ele não arrematar concretamente o bem, nem outra pessoa o fizer, o juiz deve condená-lo a pagar multa no montante de $20 \%$ do valor da avaliação, em benefício do incapaz, valendo a decisão como título

1007 Nesse sentido: SCARPINELLA BUENO, Comentários ao art. 701 do CPC, in MARCATO (coord.), Código de Processo Civil Interpretado, p. 2226.

1008 Havendo locação do imóvel, o inquilino deve pagar os alugueres diretamente ao credor do incapaz, abatendo-se do crédito as importâncias recebidas, conforme as regras da imputação em pagamento (arts. 675 e 723 do CPC), e observando-se eventuais interesses ou necessidades do executado devidamente justificados e comprovados (SCARPINELLA BUENO, Comentários ao art. 701 do CPC, in MARCATO (coord.), Código de Processo Civil Interpretado, p. 2226).

É importante esclarecer que a locação do imóvel não obsta a alienação coativa do bem ao fim do prazo de adiamento (art. 701, § 4º do CPC) (ASSIS, Manual da Exесис̧ão, § 314.2, p. 844).

1009 ASSIS, Manual da Execução, § 314.3, p. 845.

${ }^{1010}$ ASSIS, Manual da Execução, § 314.3, p. 845.

1011 OLIVEIRA, Multa no Código de Processo Civil, p. 118.

1012 SCARPINELLA BUENO, Comentários ao art. 701 do CPC, in MARCATO (coord.), Código de Processo Civil Interpretado, p. 2226; ASSIS, Manual da Execução, § 314.4, p. 845; OLIVEIRA, Multa no Código de Processo Civil, p. 120.

${ }^{1013}$ Manual da Execução, $\S \S 314$ e 314.3, p. 844.

${ }^{1014}$ ASSIS, Manual da Execução, § 314, pp. 843-844. 
executivo $^{1015}$. Com isso, o legislador deixa claro que o pretendente à arrematação é proibido de "venire contra factum proprium". Ele não pode dar a entender, em um primeiro momento, que tem interesse pela aquisição do imóvel do incapaz e, em um segundo momento, desistir de arrematá-lo. Além disso, essa norma visa a punir a conduta do sujeito que realiza atos desnecessários e infrutíferos, prejudicando a efetivação do direito do exequente ${ }^{1016}$.

Com razão, Oliveira ${ }^{1017}$ ensina que a multa prevista no $\S 2^{\circ}$ do art. 701 do CPC não deve incidir quando o pretendente à arrematação houver formulado pedido de desistência antes de o juiz deferir o anterior pedido de realização da nova praça. Já no caso de o pedido de desistência da arrematação ser formulado após o deferimento do pedido de realização da nova praça, mas antes da publicação do respectivo edital, o doutrinador sustenta que a sanção não pode ser relevada, pois, segundo ele, houve efetiva prestação jurisdicional durante a apreciação do requerimento. Ocorrendo isso, o edital da nova praça não deve ser publicado e o juiz deve aguardar o esgotamento do prazo do adiamento para tomar a providência prevista no $\S 4^{\circ}$ do art. 701 do CPC. Por fim, o jurista trata da hipótese em que o pedido de desistência da arrematação é formulado somente depois da publicação do edital. Nesse caso, ele entende que a nova praça já designada deve ser realizada e que, se nela o bem for alienado para terceira pessoa pelo valor da avaliação, o juiz não deve punir o antigo pretendente à arrematação, uma vez que não houve qualquer prejuízo à atividade jurisdicional e a aplicação da multa nessa situação ensejaria o enriquecimento indevido do incapaz ${ }^{1018}$. Apenas se a nova praça for infrutífera é que o juiz deve condenar o pretendente à arrematação arrependido a pagar multa em favor do incapaz.

Em princípio, segundo o "caput” do art. 690-A do CPC, qualquer pessoa, física ou jurídica, que esteja na livre administração de seus bens é legitimada a formular lances e, consequentemente, a cometer o comportamento abusivo previsto no art. 701, § $2^{\circ}$, do CPC, inclusive o exequente. Dinamarco ${ }^{1019}$ informa que, de acordo com essa regra geral, não podem participar da licitação os incapazes, as pessoas falidas e as instituições financeiras

1015 A mesma norma consta do art. 846, $\S 2^{\mathbf{o}}$, do Código de Processo Civil projetado (Projeto de Lei $\mathrm{n}^{\mathrm{o}}$ 8.046/2010).

${ }^{1016}$ OLIVEIRA, Multa no Código de Processo Civil, p. 119.

1017 OLIVEIRA, Multa no Código de Processo Civil, pp. 118-119.

${ }^{1018}$ Esse parece ser também o entendimento de Assis (Manual da Execução, § 314.3, p. 845):

"Nada obstante a designação de nova praça, é possível que ninguém pretenda o imóvel - a alienação a terceiro põe termo, tout court, ao assunto -, nem o postulante da providência honre a proposta. Em tal contingência, o juiz imporá ao arrependido multa equivalente a vinte por cento do preço da avaliação, 'valendo a decisão como título executivo' (art. 701, $\S 2^{\circ}$ )" (destaque nosso).

${ }^{1019}$ Instituições de Direito Processual Civil, vol. IV, § 1.707-A, p. 655. 
postas em regime de liquidação extrajudicial, já que não têm legitimidade para gerir seus próprios negócios. Os incisos do art. 690-A do CPC também proíbem a formulação de lances por: (a) tutores, curadores ${ }^{1020}$, testamenteiros, administradores, síndicos (abrangendo tanto a figura do síndico dos condomínios horizontais, quanto a do administrador judicial, que oficia na recuperação judicial e na falência ${ }^{1021}$ ) e liquidantes, quanto aos bens confiados a sua guarda e responsabilidade; (b) mandatários, quanto aos bens de cuja administração ou alienação estejam encarregados; (c) juizes, membros do Ministério Público e da Defensoria Pública, escrivães e demais servidores e auxiliares da Justiça ${ }^{1022}$. O objetivo da lei é evitar os conflitos de interesses que poderiam surgir se essas pessoas licitassem, visto que todas elas têm alguma responsabilidade em relação ao bem penhorado ou à própria pessoa do executado ${ }^{1023}$. Segundo o art. 695 do CPC, o arrematante e o seu fiador que não pagarem, no prazo estabelecido pelo juiz, o valor da oferta feita pelo primeiro e garantida pelo segundo não podem participar da nova praça ou leilão.

Finalmente, deve-se salientar que a hipótese abusiva do art. 701, $\S 2^{\circ}$, do CPC é praticada por uma parte, não por terceiro. De acordo com Dinamarco ${ }^{1024}$, o indivíduo que oferece lance na praça ou leilão e é admitido a participar intervém no processo como parte, pedindo ao juiz que aceite sua proposta e, consequentemente, lhe defira a transferência da titularidade do bem levado a pregão. Esses sujeitos são titulares de algumas situações jurídicas processuais, como a faculdade e o poder de impugnar a participação de outro licitante ou o lance que ofereceu, a faculdade e o poder de discutir a suficiência de seu próprio lance quando for tachado de "oferta vil", a faculdade e o poder de recorrer em caso de ser contrariado etc. O juiz defere somente a demanda de um dos licitantes, rejeitando todas as outras.

\footnotetext{
${ }^{1020} \mathrm{Na}$ opinião de Dinamarco (Instituições de Direito Processual Civil, vol. IV, § 1.707-A, p. 656), os genitores estão na mesma situação dos tutores e curadores, logo também não devem ser admitidos a oferecer lance.

${ }^{1021}$ DINAMARCO, Instituições de Direito Processual Civil, vol. IV, § 1.707-A, p. 656.

${ }^{1022}$ A doutrina esclarece que o juiz e o promotor de justiça são impedidos de licitar apenas em hasta pública referente a processos do foro onde exercem suas funções. Analogamente, os defensores públicos são impedidos em relação aos processos afetos à defensoria em que servem. Com relação aos auxiliares da justiça, eles não podem participar de licitações referentes a processos nos quais oficiem ou tenham oficiado ou que estejam em curso no ofício judiciário onde atuam (DINAMARCO, Instituições de Direito Processual Civil, vol. IV, § 1.707-A, p. 657).

${ }^{1023}$ DINAMARCO, Instituições de Direito Processual Civil, vol. IV, § 1.707-A, pp. 655-656.

${ }^{1024}$ Instituições de Direito Processual Civil, vol. IV, § 1.419, pp. 179-180; § 1.706-A, p. 651.
} 


\subsection{Abuso do poder de opor embargos à execução de segunda fase (art. $746, \S^{\circ}$, do CPC)}

O ordenamento jurídico atribui ao executado, depois da adjudicação, da alienação ou da arrematação, o poder de opor os chamados "embargos à execução de segunda fase", com o fim de obstar o ato de expropriação aplicado no caso concreto ${ }^{1025}$.

Consoante o "caput" do art. 746 do CPC, apenas duas matérias de defesa podem ser alegadas pelo executado-embargante:

a) a nulidade da execução (v.g., falta de intimação de cônjuge, impenhorabilidade do bem, preço vil ${ }^{1026}$ etc.); e

b) causa extintiva da obrigação (e.g., pagamento, novação, transação, prescrição).

Nas duas hipóteses, é necessário que o fato suscitado seja superveniente à penhora $^{1027}$, excetuadas as matérias de ordem pública (v.g., ausência de alguma condição da ação, ou de pressuposto de constituição e desenvolvimento do processo etc.), que podem e devem ser conhecidas pelo magistrado a qualquer tempo ${ }^{1028}$.

No julgamento do Agravo Regimental no Agravo de Instrumento no 463.584/GO, a $3^{\text {a }}$ Turma do Superior Tribunal de Justiça decidiu que não é possível discutir sobre o valor do débito exequendo nos embargos à arrematação, uma vez que esse instrumento processual pode ser utilizado apenas nas hipóteses previstas no art. 746 do CPC (Rel. Min. Humberto Gomes de Barros, DJ 18/12/2006, p. 360).

No âmbito doutrinário, Lucon ${ }^{1029}$ defende uma visão ampliativa das hipóteses de cabimento dos embargos à execução de segunda fase. Para ele, o rol de matérias contido no

\footnotetext{
${ }^{1025}$ Como o art. 746 do CPC menciona apenas estes três meios de expropriação: adjudicação, alienação e arrematação, os demais não podem ser obstados mediante os embargos de segunda fase (v.g., o desconto em folha e o usufruto) (LUCON, Comentários ao art. 746 do CPC, in MARCATO (coord.), Código de Processo Civil Interpretado, p. 2371).

1026 Lucon (Comentários ao art. 746 do CPC, in MARCATO (coord.), Código de Processo Civil Interpretado, p. 2373) afirma que na expressão "nulidade da execução", contida no "caput" do art. 746 do CPC, está compreendida a hipótese de alegação de nulidade do ato de transferência do bem em razão do preço vil. Segundo o jurista, o valor abaixo do qual o preço é considerado vil deve ser estabelecido caso a caso. Porém, a jurisprudência vem fixando-o em sessenta por cento do valor fixado na avaliação (percentual esse que era o estabelecido nas execuções fiscais pelo art. 37 do Decreto-Lei no 960/1938, que já se encontra revogado). Quando o bem for de incapaz, essa porcentagem sobe para oitenta por cento do valor da avaliação (art. 701 do CPC).

${ }^{1027}$ Nesse sentido é a jurisprudência do Superior Tribunal de Justiça: STJ, $4^{\text {a }}$ Turma, AgRg no Ag 388.053/RJ, Rel. Min. Aldir Passarinho Júnior, DJ 12/08/2002, p. 219; STJ, $3^{a}$ Turma, REsp 37.433/SP, Rel. Min. Eduardo Ribeiro, D.J.U. 22/11/1993, p. 24952.

${ }^{1028}$ LUCON, Comentários ao art. 746 do CPC, in MARCATO (coord.), Código de Processo Civil Interpretado, pp. 2371 e 2372.

${ }^{1029}$ Comentários ao art. 746 do CPC, in MARCATO (coord.), Código de Processo Civil Interpretado, p. 2371.
} 
"caput" do art. 746 do CPC é meramente exemplificativo, de modo que o executado pode alegar também qualquer causa impeditiva ou modificativa da obrigação, desde que superveniente à penhora.

O prazo para a oposição desses embargos é de cinco dias, contados da adjudicação, da alienação por iniciativa particular ou da arrematação, ou seja, o "dies a quo" é a data da assinatura do auto de adjudicação ou do auto de arrematação, já que é nesse momento que o ato se perfaz (arts. 685-B e 694, "caput", do CPC), ou então é a data do termo nos autos, que formaliza a alienação (art. 685-C, $\S 2^{\circ}$, do CPC) ${ }^{1030}{ }^{1031}$. Cumpre notar que a adjudicação, a alienação ou a arrematação configura pressuposto específico de admissibilidade dos embargos de segunda fase ${ }^{1032} 1033$. A existência de pedido de remição feito antes da assinatura do auto de arrematação obsta o perfazimento desse ato complexo e, consequentemente, também suspende o prazo para a oposição dos embargos ${ }^{1034}$. Todavia, se o requerimento de remição for realizado depois de efetivada a praça, ele perde a eficácia suspensiva ${ }^{10351036}$.

Considerado isoladamente, o ato de transferência patrimonial (praça ou leilão) é irrelevante para a contagem do prazo para a oposição de embargos à arrematação. Porém, se o executado não foi regularmente intimado de tal ato, o termo inicial do prazo de cinco dias para opor os embargos é o momento do cumprimento do mandado de imissão na posse, no caso de bens imóveis, ou do mandado de busca e apreensão, no caso de bens móveis. Caso o bem móvel já tenha sido apreendido, a transferência patrimonial realiza-se por meio de tradição, da qual o executado deve ser intimado ${ }^{1037}$.

\footnotetext{
${ }^{1030}$ BARBOSA MOREIRA, O Novo Processo Civil Brasileiro, p. 297.

${ }^{1031}$ A $1^{\text {a }}$ Turma do Superior Tribunal de Justiça decidiu que, como os embargos à arrematação têm natureza de ação cognitiva, semelhante à da ação anulatória autônoma, a oposição após o decurso desse prazo não acarreta necessariamente sua extinção, podendo ser recebidos e processados como ação autônoma, porém sem a eficácia de suspender a execução. O fundamento da decisão do Superior Tribunal de Justiça foram os princípios da instrumentalidade das formas e da economia processual (REsp 539.153/RS, Rel. Min. Teori Albino Zavascki, DJ 03/04/2006, p. 228).

${ }^{1032}$ Nesse sentido é o entendimento da doutrina: LUCON, Comentários ao art. 746 do CPC, in MARCATO (coord.), Código de Processo Civil Interpretado, p. 2372.

${ }^{1033}$ No entanto, com fundamento na instrumentalidade processual, a $1^{\text {a }}$ Turma do Superior Tribunal de Justiça afirmou que a falta de assinatura no auto de arrematação não impede a utilização dos embargos de segunda fase para pleitear o desfazimento de arrematação efetuada a preço vil, já que essa causa de nulidade pode ser declarada pelo juízo de ofício ou a requerimento da parte interessada, por simples petição, sendo desnecessária a oposição dos embargos (Resp 848.834/RS, Rel. Min. José Delgado, DJ 26/10/2006, p. 253).

${ }^{1034}$ Nesse sentido: STJ, 3 a Turma, REsp 20.172/PR, Rel. Min. Dias Trindade, DJ 27/05/1992, p. 7397.

${ }_{1035}$ Nesse sentido: STJ, $3^{\text {a }}$ Turma, REsp 11.420/DF, Rel. Min. Dias Trindade, DJU 28/10/1991, p. 15255.

1036 LUCON, Comentários ao art. 746 do CPC, in MARCATO (coord.), Código de Processo Civil Interpretado, pp. 2372 e 2373-2374.

1037 LUCON, Comentários ao art. 746 do CPC, in MARCATO (coord.), Código de Processo Civil Interpretado, p. 2374.
} 
Entende-se que os embargos à execução de segunda fase possuem natureza jurídica de ação, que dá origem a um processo de conhecimento ${ }^{1038}$. Como o mérito desses embargos afeta não só os interesses do exequente, mas também os do adquirente, pois diz respeito à desconstituição do ato de transferência patrimonial, ambos devem figurar no polo passivo da demanda, em litisconsórcio necessário ${ }^{1039}$. A ausência do arrematante na qualidade de litisconsorte passivo necessário acarreta a nulidade absoluta do processo de embargos de segunda fase ${ }^{1040}$.

A oposição e o recebimento dos embargos pode ensejar a suspensão da expedição ou entrega da carta de adjudicação, de alienação ou de arrematação, se assim o juiz determinar. É possível também a suspensão do curso da execução forçada, caso o juiz se convença do preenchimento dos requisitos do art. 739-A do $\mathrm{CPC}^{1041}$.

Depois de oferecidos os embargos de segunda fase, o adquirente passa a ter o poder de desistir da aquisição ocorrida por meio da adjudicação, da alienação ou da arrematação, em razão dos inconvenientes que essa ação gera para ele. $\mathrm{O}$ ato de desistência é unilateral, não podendo o exequente e o juiz se opor a ele ${ }^{1042}$. Por causa disso, caso se requeira a desistência, o juiz deve deferi-la de plano, liberando imediatamente o depósito feito pelo adquirente (art. 746, $\S \S 1^{\circ}$ e $2^{\circ}$, c/c art. 694, $\S 1^{\circ}$, IV, do CPC).

$\mathrm{O} \S 3^{\circ}$ do art. 746 do CPC atribui ao juiz o poder-dever de impor multa ao executado-embargante, caso constate que os embargos à execução de segunda fase são manifestamente protelatórios ${ }^{1043}$.

Na opinião de Lucon ${ }^{1044}$, devem ser considerados manifestamente protelatórios os embargos de segunda fase opostos com espeque em argumentos manifestamente

1038 LUCON, Comentários ao art. 746 do CPC, in MARCATO (coord.), Código de Processo Civil Interpretado, p. 2374.

1039 LUCON, Comentários ao art. 746 do CPC, in MARCATO (coord.), Código de Processo Civil Interpretado, p. 2373.

${ }^{1040}$ Nesse sentido é a jurisprudência do Superior Tribunal de Justiça: STJ, $2^{\text {a }}$ Turma, Resp 18.550/SP, Rel. Min. Antonio de Pádua Ribeiro, DJ 22/11/1993, p. 24931; STJ, $4^{\text {a }}$ Turma, Resp 45.514/MG, Rel. Min. Barros Monteiro, DJ 06/06/1994, p. 14281.

${ }^{1041}$ LUCON, Comentários ao art. 746 do CPC, in MARCATO (coord.), Código de Processo Civil Interpretado, p. 2372.

1042 LUCON, Comentários ao art. 746 do CPC, in MARCATO (coord.), Código de Processo Civil Interpretado, p. 2374.

${ }^{1043}$ Se o Projeto de Lei $n^{\text {o }} 8.046 / 2010$ for aprovado, sancionado e publicado com sua redação atual essa hipótese de abuso processual deixará de existir, uma vez que no novo Código de Processo Civil não haverá mais a possibilidade de a parte opor embargos à execução de segunda fase. Consoante os $\S \S 3^{\circ}$ e $4^{\circ}$ do art. 857 do Projeto de Lei no 8.046/2010, expedida, após dez dias, a carta de arrematação ou a ordem de entrega, eventual vício deverá ser arguido em ação autônoma, na qual o arrematante figurará como litisconsorte necessário. Uma vez julgado procedente o pedido da ação autônoma, as partes serão restituídas ao estado anterior, ressalvada a possibilidade de reparação de perdas e danos. De acordo com Marinoni e Mitidiero $(O$ Projeto do CPC: crítica e propostas, p. 161), essa "ação autônoma" a que o projeto se refere é a ação anulatória, prevista no art. 929 do Código projetado. 
infundados, denotando abuso do direito (art. 187 do CC), independentemente de dolo ou culpa ou da ocorrência concreta de dano.

Com o devido respeito, não é esse o entendimento que se dessume do texto legal. De acordo com o art. 746, $\S 3^{\circ}$, do CPC, o magistrado só pode impor multa ao embargante se se convencer de que os embargos à execução de segunda fase foram opostos com intuito manifestamente protelatório. Exige-se, assim, a presença do dolo, do intuito manifesto de procrastinar, ou da culpa grave a ele equiparável. Sancionar o embargante sem que esse requisito seja preenchido contraria o princípio da legalidade e viola as garantias do contraditório e da ampla defesa (art. $5^{\circ}, \mathrm{LV}$, da CF).

Para que fique caracterizado o intuito manifestamente protelatório, é necessário, além da manifesta falta de fundamentação jurídica ou fática, que o embargante: (a) pleiteie a atribuição de efeito suspensivo aos embargos (pois, sem suspender o curso da execução, os embargos manifestamente incabíveis ou improcedentes não protelam suficientemente a prolação da tutela jurisdicional no processo principal a ponto de ficar evidenciado o intuito procrastinatório do seu autor); ou (b) já tenha praticado, anteriormente, no mesmo processo ou na causa principal, algum ato manifestamente protelatório (e.g., art. 17, VII; ou art. 538, parágrafo único, do $\mathrm{CPC}$ ), ou manifestamente infundado (art. 17, VI, do CPC), ou temerário (art. 17, V, do CPC), ou de resistência injustificada ao andamento do processo (art. 17, IV, do CPC). A decisão que reconhece os embargos à execução de segunda fase como manifestamente protelatórios deve ser fundamentada.

Deve-se salientar que a oposição de embargos de segunda fase manifestamente infundados também consiste em abuso processual. Apenas não acarreta a incidência do art. $746, \S 3^{\circ}$, do CPC, uma vez que lhe falta a característica manifestamente protelatória. A repressão a esse comportamento deve ser feita com fundamento nos arts. 600, II; e 601 do CPC porque se trata de um ato de resistência maliciosa à execução.

O montante da multa aplicável ao embargante com espeque no $\S 3^{\circ}$ do art. 746 do CPC não pode ser superior a $20 \%$ do valor da execução e deve destinar-se a quem desistiu da aquisição.

\subsection{Abuso de poder-dever por magistrado}

1044 Comentários ao art. 746 do CPC, in MARCATO (coord.), Código de Processo Civil Interpretado, p. 2374. 
No item 1.6 "supra", ficou consignado que os elementos essenciais para classificar um ato processual como abusivo são: (a) a aparência de legalidade; (b) o exercício da situação jurídica processual com desvio de finalidade, para atingir escopo ilícito ou ilegítimo; (c) eventualmente, o elemento subjetivo (dolo ou culpa); e (d) o dano, que é uma consequência natural do abuso processual. Se a conduta do magistrado preencher todos esses requisitos, não há dúvida de que ele comete abuso do processo ${ }^{1045} 1046$.

A única peculiaridade do abuso processual cometido por juiz é o seu objeto, ou seja, a situação jurídica que é exercida de maneira ímproba. O abuso do processo ocorre sempre no exercício de uma situação jurídica ativa (faculdade ou poder) ou então no exercício de uma situação jurídica passiva (ônus ou dever) necessariamente acompanhada de uma situação ativa (item 1.4.2 "supra"). Ocorre que o juiz não é titular das mesmas situações jurídicas que as partes. Ele não tem faculdades, uma vez que estas pressupõem a disponibilidade de bens ou de situações jurídicas e o juiz está no processo para regular os interesses das partes, sobre os quais ele não tem qualquer disponibilidade. O órgão jurisdicional também não é dotado de ônus processuais. Como o ônus vincula o recebimento de um benefício ou o sofrimento de uma perda ao exercício de uma faculdade, ele não pode ser atribuído ao Estado-juiz, já que este não tem faculdades, pois tutela apenas interesses alheios, pertencentes à partes. $\mathrm{O}$ ordenamento jurídico outorga ao juiz poderes processuais, porém eles são diferentes dos das partes, pois vêm sempre atados ao dever de exercê-los, constituindo, na verdade, poderes-deveres. Trata-se de um corolário do "due process of law", que impõe limites ao exercício do poder judicial e exige que ele seja exercido no sentido do bem-comum e da justiça social ${ }^{1047}$. Conclui-se que o abuso do magistrado se caracteriza por ocorrer sempre no exercício de poderes-deveres.

\footnotetext{
${ }^{1045}$ A quase unanimidade dos doutrinadores reconhece a possibilidade de o juiz praticar abuso do processo. Sobre esse assunto, consultar o item 1.5 "supra".

${ }^{1046}$ Iocohama (Litigância de Má-Fé e Lealdade Processual, pp. 193-195) inclui entre os exemplos de atos abusivos praticados por magistrados as seguintes condutas: (a) exceder os limites da lide, conhecendo de questões que não são cognoscíveis de ofício e que não foram suscitadas pelas partes (art. 128 do CPC); (b) proferir sentença de natureza diversa da pedida pelo autor ou condenar o réu em quantidade superior ou em objeto diverso do que lhe foi demandado (art. 460 do CPC); (c) inovar no processo depois de extinta sua função jurisdicional (arts. 463, 521 e 475-G do CPC); (d) não tratar com urbanidade as partes, os advogados, os membros do Ministério Público, as testemunhas, os auxiliares da justiça (art. 35, IV, da LC 35/79); (e) receber, a qualquer título ou pretexto, custas ou participação em processo (art. 95, parágrafo único, II, da $\mathrm{CF}$ ); (f) manifestar, por qualquer meio de comunicação, opinião sobre processo pendente de julgamento ou juízo depreciativo sobre despachos, votos ou sentenças de órgãos judiciais (art. 36, III, da LC 35/79).

Porém, tais comportamentos não podem ser considerados hipóteses de abuso processual, uma vez que lhes falta o requisito da aparência de licitude. Além disso, com relação à última conduta, ela nem mesmo consiste no exercício de uma situação jurídica processual.

${ }^{1047}$ Acerca das situações jurídicas processuais atribuídas ao juiz, consultar: DINAMARCO, Instituições de Direito Processual Civil, vol. II, § 492, pp. 206-207; §§ 496-497, pp. 211-214.
} 
Alguns doutrinadores afirmam que essa característica, aliada ao fato de o juiz ser uma autoridade no processo, permitem que o ato judicial abusivo seja equiparado à figura do abuso de poder, oriunda do Direito administrativo ${ }^{1048}$. Para que os agentes públicos exerçam as funções que lhes são legalmente atribuídas, o ordenamento jurídico lhes confere certos poderes administrativos, que são prerrogativas especiais de direito público peculiares à sua qualificação de prepostos do Estado. Esses poderes devem ser exercidos por seus titulares para a consecução dos fins públicos, dentro dos limites que a lei estabelece. Sendo assim, eles são irrenunciáveis e devem ser obrigatoriamente exercidos por seus titulares, sendo vedada a inércia. Por causa desse aspecto dúplice, são considerados poderes-deveres de agir. Sempre que o agente público exerce um poder administrativo fora dos objetivos traçados pelo ordenamento jurídico, ele comete abuso de poder. A doutrina reconhece duas formas de abuso de poder: (a) o excesso de poder, que consiste na atuação do agente público fora dos limites de sua competência administrativa (ou o agente invade atribuições cometidas a outro agente, ou exerce atividades que a lei não lhe confere); e (b) o desvio de poder (ou desvio de finalidade), que é o exercício do poder visando a alcançar fim diverso daquele permitido pela lei, em descompasso com o interesse público ${ }^{1049}$.

Entretanto, com o devido respeito a essa corrente doutrinária, não é correto equiparar o abuso do processo cometido pelo magistrado com a figura do abuso de poder. Diferentemente da seara administrativa, em que a atuação do agente público fora dos limites de sua competência (excesso de poder) é abrangida pelo conceito de abuso de poder, no âmbito processual, a atuação do juiz fora dos limites da competência do órgão jurisdicional no qual exerce sua função não consiste, por si só, em uma conduta abusiva, uma vez que não se evidencia qualquer desvio de finalidade. $O$ único ponto em comum que se pode vislumbrar entre o comportamento abusivo do magistrado e o abuso de poder do agente público é o fato de ambos terem como objeto poderes-deveres. Mas, até nesse aspecto a compatibilidade entre as duas figuras não é total. De acordo com Carvalho Filho $^{1050}$, o desvio de poder é uma conduta mais visível nos atos discricionários, ou seja, naqueles atos cuja prática é submetida a juízo de conveniência e oportunidade do agente público competente. Acontece que, no processo, o juiz não possui poderes discricionários

\footnotetext{
1048 Nesse sentido: ABDO, O Abuso do Processo, pp. 50 e 184-185; NORMAND, Final Report: the two approaches to the abuse of procedural rights, in TARUFFO (ed.), Abuse of Procedural Rights: comparative standards of procedural fairness, p. 247; LUCAS SOSA, Abuso de Derechos Procesales, in BARBOSA MOREIRA (coord.), Abuso dos Direitos Processuais, p. 64.

${ }^{1049}$ CARVALHO FILHO, Manual de Direito Administrativo, pp. 41-42 e 44.

1050 Manual de Direito Administrativo, p. 44.
} 
dessa espécie. Sendo a discricionariedade o poder de escolha entre duas ou mais condutas igualmente legítimas, o juiz não pode agir discricionariamente porque, em regra, só uma decisão é legítima, sendo as demais incompatíveis com os direitos e garantias dos litigantes $^{1051}$. Logo, não existem atos processuais discricionários abusivos. Portanto, o abuso processual do juiz e o abuso de poder não podem ser equiparados porque possuem âmbitos distintos de aplicação e, além disso, dizem respeito ao exercício de situações jurídicas de natureza distinta ${ }^{1052}$.

O abuso cometido por magistrado pode manifestar-se tanto por comportamentos comissivos, quanto por comportamentos omissivos ${ }^{1053}$. São hipóteses de comportamentos comissivos abusivos: o adiamento e a repetição de atos processuais sem justo motivo (arts. 29 e 453, § $3^{\circ}$, do CPC); a prática de atos processuais inúteis (v.g., deferir a produção de provas inúteis ou meramente protelatórias, ao arrepio do art. 130 do CPC e, eventualmente, do art. 400, I ou II, ou do art. 407, parágrafo único, $2^{\text {a }}$ parte, do CPC; designar audiência de conciliação depois de ambas as partes terem-se manifestado no sentido da impossibilidade de celebrarem qualquer acordo, contrariando o texto do $\S 3^{\circ}$ do art. 331 do CPC; designar audiências de conciliação e de instrução e julgamento, apesar de o réu ter alegado em sua contestação a existência de cláusula arbitral celebrada entre as partes; designar audiência de instrução quando o caso é, legalmente, de julgamento antecipado da demanda etc.); a atuação com dolo; a atuação fraudulenta (art. 133, I, do CPC); a prolação de sentença mal motivada (art. 93, IX, da CF); a pressão exercida sobre uma das partes para que aceite proposta de transação desfavorável na audiência de conciliação; o indeferimento do pedido

${ }^{1051}$ DINAMARCO, Instituições de Direito Processual Civil, vol. II, § 497, p. 213.

1052 No exercício da função jurisdicional, o magistrado pode cometer abusos processuais, e não abuso de poder. No entanto, o Código de Processo Civil também atribui ao juiz diversos poderes de natureza administrativa, integrantes do poder de policia, tais como: (a) o poder manter a ordem e o decoro na audiência; (b) o poder de ordenar que se retirem da sala da audiência os indivíduos que se comportarem de maneira inconveniente; (c) o poder de requisitar a força policial quando for necessário; (d) o poder de exortar os advogados das partes e o órgão do Ministério Público a discutirem a causa com elevação e urbanidade; (e) o poder de prender em flagrante o sujeito que praticar algum ato ilícito penal na sala da audiência etc. Tratase da chamada "polícia das audiências", que nada mais é do que o poder de restringir a liberdade das pessoas, segundo critérios razoáveis de proporcionalidade, visando à manutenção da ordem, do decoro e do clima de recíproco respeito entre os sujeitos processuais, que são condições necessárias para o exercício da função jurisdicional (DINAMARCO, Instituições de Direito Processual Civil, vol. II, § 513, pp. 245-246). No exercício dessa atividade administrativa, o juiz pode cometer abuso de poder.

Um exemplo de abuso de poder judicial é o comportamento do magistrado que, tendo-se exasperado com uma das partes ou com um dos advogados, determina sua retirada da sala de audiências, inclusive com o uso da força policial. Abdo ( $O$ Abuso do Processo, p. 184) menciona essa conduta como hipótese de abuso processual, visto que o poder de polícia foi exercido com desvio de finalidade. Porém, esse entendimento não parece correto porque os poderes de "polícia das audiências" são exercidos pelo juiz enquanto autoridade pública, independentemente da posição de sujeito da relação processual (BARBI, Comentários ao Código de Processo Civil, vol. I, $\S 675$, p. 394). Em outras palavras, essa não é uma hipótese de abuso processual porque não há, nela, o exercício de uma situação jurídica processual.

${ }_{1053}$ ABDO, O Abuso do Processo, pp. 184 e 185-186. 
de aplicação do art. 620 do CPC, sendo que, no caso concreto, existe outro meio de promover a execução que é menos gravoso para o executado e igualmente idôneo a satisfazer a pretensão do exequente ${ }^{1054}$ etc. Como exemplos de comportamentos ímprobos omissivos do magistrado, podem-se mencionar: a não-designação de audiência de conciliação; o desrespeito negligente a prazos estabelecidos na lei (e.g., os prazos para proferimento de despachos, decisões e sentenças previstos nos arts. 189 e 456 do CPC), violando a garantia da duração razoável do processo (art. 5 $5^{\circ}$ LXXVIII, da CF); a falta de prevenção ou de repressão a atos inúteis, manifestamente protelatórios ou contrários à dignidade da Justiça (art. 125, II e III, do CPC c/c art. 5 , LXXVIII, da CF); a recusa, a omissão e o retardamento, sem justo motivo, em determinar providência que deva ordenar de ofício ou após requerimento da parte (art. 133, II, do CPC) (v.g., o não-cumprimento desidioso de carta precatória); o desatendimento ao dever de cooperação (e.g., o juiz tem dúvida acerca de alegação, pedido ou posição da parte em juízo, mas não se esclarece junto dela, o que acarreta a prolação de decisão fundada em percepções equivocadas; o magistrado deixa de apontar as deficiências da postulação da parte e de lhe oferecer oportunidade para supri-las e, ao fim do processo, não conhece do pedido em razão de defeito processual sanável; o órgão jurisdicional decide questão de ofício, surpreendendo as partes, que não foram previamente consultadas) etc $^{1055}$. Segundo Theodoro Júnior ${ }^{1056}$, as condutas judiciais abusivas mais frequentes são a omissão e o retardamento de decidir.

O comportamento ímprobo do magistrado não recai apenas sobre instrumentos processuais específicos. Da mesma forma como as partes podem abusar do processo como um todo (o chamado "abuso do processo em sentido estrito"), o magistrado também pode abusar da tutela jurisdicional globalmente entendida. Essa espécie de improbidade processual ocorre, por exemplo, quando o juiz tem conhecimento dos fatos pela petição inicial e pela contestação, forma sua convicção precipitadamente e, então, desvirtua toda a ulterior atividade de instrução probatória ou a aplicação do direito apenas para refletir nos

\footnotetext{
${ }^{1054}$ Segundo Pontes de Miranda (Comentários ao Código de Processo Civil, tomo X, p. 43), "na aplicação do art. 620, o juiz não tem arbítrio, mas sim dever de escolher o modo menos gravoso para o devedor" ${ }^{1055}$ Exemplos auferidos das obras de Abdo (O Abuso do Processo, pp 185-186), Iocohama (Litigância de Má-Fé e Lealdade Processual, pp. 193-195), Baptista da Silva (Comentários ao Código de Processo Civil, vol. 1, p. 104), Mitidiero (Colaboração no Processo Civil como Prêt-à-Porter? Um Convite ao Diálogo para Lenio Streck, in Revista de Processo, $\mathrm{n}^{\circ}$ 194, pp. 64-65), Theodoro Júnior (Direito Fundamental à Duração Razoável do Processo, pp. 13 e 18) e Peyrano (Abuso de los Derechos Procesales, in BARBOSA MOREIRA (coord.), Abuso dos Direitos Processuais, pp. 74-75 e 76).

${ }^{1056}$ Abuso de Direito Processual no Ordenamento Jurídico Brasileiro, in Revista Forense, v. 344, p. 63.
} 
autos o resultado que preconcebeu ${ }^{1057}$. Outro exemplo é a simulação processual praticada com "dolo total ou universal", em que há entendimento oculto entre as partes e o juiz no sentido de desviar o processo da sua função normal ${ }^{1058}$.

Facilmente se constata que o legislador não dedica a mesma atenção ao comportamento processual ímprobo das partes e dos órgãos jurisdicionais. Enquanto dezenas de dispositivos do Código de Processo Civil tratam das hipóteses de abuso praticadas pelas partes e das respectivas consequências jurídicas, apenas quatro artigos regulam o abuso processual praticado por magistrados: 29, 133, 198 e $199^{1059}$. O primeiro diz que as despesas dos atos que forem adiados ou tiverem de repetir-se ficarão a cargo do juiz que, sem justo motivo, houver dado causa ao adiamento ou à repetição. De acordo com o segundo, o juiz que, no exercício de suas funções, proceder com dolo ou fraude ou que recusar, omitir ou retardar, sem justo motivo, providência que deva ordenar de ofício ou a requerimento da parte deve responder por perdas e danos. O terceiro estatui que as partes, bem como o órgão do Ministério Público, podem representar ao presidente do Tribunal de Justiça contra o juiz que excede prazos previstos em lei. Uma vez distribuída a representação ao órgão competente, instaura-se procedimento para apuração da responsabilidade administrativa do magistrado. O art. 199 do CPC apenas estende essa mesma regra aos ministros dos Tribunais Superiores que excederem prazos previstos em lei, na forma que dispuser o respectivo regimento interno ${ }^{1060}$.

\subsection{Abuso de poder-dever por auxiliar da justiça}

Os auxiliares de justiça podem ser conceituados como as pessoas que, em caráter permanente ou de maneira eventual, colaboram nos processos, prestando serviços complementares à jurisdição, sob as ordens do juiz e em regime de subordinação funcional a ele ${ }^{1061}$.

\footnotetext{
${ }^{1057}$ Exemplo de Laspro (A Responsabilidade Civil do Juiz, p. 236), também mencionado na obra de Abdo ( $O$ Abuso do Processo, p. 186). Consoante o primeiro jurista, trata-se de ação dolosa, devendo o juiz ser responsabilizado pelo erro judiciário.

${ }^{1058}$ Acerca dessa hipótese de abuso processual, consultar o item 2.4.1 "supra".

${ }^{1059}$ Nesse sentido: ABDO, O Abuso do Processo, p. 186, que apenas não faz menção ao art. 29 do CPC.

${ }^{1060}$ No Projeto de Lei no 8.046/2010, em trâmite no Congresso Nacional, que versa sobre o novo Código de Processo Civil, essas normas constam, respectivamente, dos arts. 95; 123; e 204. Não ha previsão de regra análoga à do atual art. 199 no Código projetado.

${ }^{1061}$ BARBI, Comentários ao Código de Processo Civil, vol. I, § 761, p. 448; DINAMARCO, Instituições de Direito Processual Civil, vol. I, § 339, p. 662; e § 341, p. 665; DINAMARCO, Instituições de Direito Processual Civil, vol. II, § 514, p. 247.
} 
$\mathrm{O}$ art. 139 do CPC enumera alguns deles, a título exemplificativo: o escrivão, o oficial de justiça, o perito, o depositário, o administrador e o intérprete. Além desses, o Código de Processo Civil menciona também o contador, o partidor (arts. 141, IV, "c"; 475$\mathrm{B}, \S \S 3^{\mathrm{o}}$ e $4^{\mathrm{o}} ; 769 ; 770 ; 1.003$, parágrafo único; $1.013, \S 1^{\circ}$; e 1.023 do CPC) e o inventariante (arts. 12, V e $\S 1^{\text {o }}$; 753, III; 990-998; 1.000, II e parágrafo único; 1.001; $1.011 ; 1.018$, parágrafo único; $1.021 ; 1.036 ; 1.043, \S 1^{\circ}$, do CPC)

A doutrina classifica os auxiliares da justiça levando em consideração dois critérios $^{1062}$ :

a) a subordinação permanente ou eventual ao Poder Judiciário. De acordo com esse critério, consideram-se auxiliares permanentes aqueles que ocupam cargos públicos criados por lei e regidos por normas estatutárias contidas em leis, regimentos internos etc. (e.g., escrivão, oficial de justiça, escrevente, distribuidor, contador, partidor etc.). Já os auxiliares eventuais não pertencem aos quadros do funcionalismo da Justiça e são chamados a colaborar com esta caso a caso (v.g., peritos, avaliadores, arbitradores, intérpretes, inventariantes, liquidantes etc.);

b) o regime de remuneração. Por esse aspecto, podem ser: (1) servidores da Justiça, que são os auxiliares da Justiça que ocupam cargos nos quadros do funcionalismo e percebem somente vencimentos dos cofres públicos (e.g., o escrivão); ou (2) serventuários, que trabalham em regime misto, sendo remunerados pelo Estado e também pelas partes ("pro labore facto"), por meio do recebimento de custas e emolumentos (v.g., o oficial de justiça, que percebe vencimentos fixos e mais os emolumentos devidos pelas partes em razão das diligências realizadas, nos termos do que dispuser a lei de organização judiciária $\left.^{1063}\right)^{1064}$.

Como o ordenamento jurídico lhes atribui legitimidade para a prática de atos processuais, os auxiliares da justiça são considerados sujeitos processuais, especificamente sujeitos secundários do processo ${ }^{1065}$.

$\mathrm{O}$ auxiliar da justiça pode cometer abuso do processo desde que pratique conduta que: (a) tenha aparência de legalidade; (b) consista no exercício de situação jurídica

\footnotetext{
1062 DINAMARCO, Instituições de Direito Processual Civil, vol. I, § 346, pp. 672-674.

${ }^{1063}$ DINAMARCO, Instituições de Direito Processual Civil, vol. I, § 349, p. 677.

1064 Dinamarco (Instituições de Direito Processual Civil, vol. I, § 346, p. 674) menciona ainda outros auxiliares da justiça, que são arredios ao enquadramento nessas categorias tradicionais. São eles: o conciliador, o juiz leigo e o árbitro que atuam nos Juizados Especiais. Esses auxiliares, que foram instituídos pela Lei $\mathrm{n}^{\circ}$ 9.099/95, têm como diferencial o fato de o ordenamento jurídico lhes atribuir, parcialmente, algumas funções que ordinariamente seriam do juiz, porém sem terem o poder de "imperium". Por esse motivo, são reunidos na categoria dos "auxiliares parajurisdicionais".

${ }^{1065}$ DINAMARCO, Instituições de Direito Processual Civil, vol. I, § 341, p. 665.
} 
processual com desvio de finalidade, para atingir escopo ilícito ou ilegítimo; (c) eventualmente, seja dolosa ou culposa; e (d) cause dano a algum sujeito do processo (item 1.6 "supra") $)^{1066}$.

O abuso do processo perpetrado por auxiliar da justiça assemelha-se ao praticado por magistrado, uma vez que ambos ocorrem no exercício de poderes-deveres processuais. $\mathrm{Na}$ relação jurídica processual, os auxiliares da justiça são titulares de poderes e deveres processuais necessários para o exercício das respectivas funções. Assim como o juiz, eles não têm faculdades, nem se sujeitam a ônus. As partes não se sujeitam aos auxiliares da justiça e estes, logicamente, não exercem qualquer autoridade sobre elas ${ }^{1067}$.

As condutas ímprobas dos auxiliares da justiça podem ser comissivas ou omissivas. Os seguintes comportamentos exemplificam a primeira espécie: o adiamento e a repetição de atos processuais sem justo motivo ${ }^{1068}$ (arts. $29^{1069}$ e $453, \S 3^{\circ}$, do CPC); a prática, por escrivão ou oficial de justiça, de ato nulo com dolo ou culpa (art. 144, II, do CPC); a prestação de informações inverídicas, com dolo ou culpa, por perito ou intérprete (arts. 147 e 153 do CPC); a produção de prejuízo a uma das partes em decorrência de conduta dolosa ou culposa do depositário ou do administrador (art. 150 do CPC); a transferência de praça ou leilão causada por conduta culposa de escrivão, oficial de justiça ${ }^{1070}$ ou leiloeiro (art. 688, parágrafo único, do CPC); a atuação do avaliador com dolo (art. 683, I, do CPC) etc. Constitui exemplo de comportamento abusivo omissivo a recusa, por parte do escrivão ou

\footnotetext{
${ }^{1066}$ Na opinião de Iocohama (Litigância de Má-Fé e Lealdade Processual, pp. 205-206), o depositário infiel, que não cumpre a ordem judicial de entrega da coisa ou do equivalente em dinheiro em 24 horas (art. 904 do CPC), o auxiliar de justiça que recebe custas indevidas ou excessivas (art. 30 do CPC) e o que dá causa ao desaparecimento de autos (art. 1.069 do CPC) cometem abuso processual. No entanto, essas condutas não têm aparência de serem lícitas, logo não podem ser consideradas hipóteses de abuso.

${ }^{1067}$ DINAMARCO, Instituições de Direito Processual Civil, vol. II, § 514, pp. 247-248.

${ }^{1068}$ De acordo com Barbi (Comentários ao Código de Processo Civil, vol. I, § 218, p. 162), se a repetição do ato acontecer em razão de algum defeito decorrente do despreparo do auxiliar da justiça, não se deve considerar o motivo como justo.

${ }^{1069}$ Barbi (Comentários ao Código de Processo Civil, vol. I, § 219, pp. 162-163) salienta que a palavra "serventuário", contida no art. 29 do CPC, deve receber interpretação ampliativa, considerando-se que estão nela incluídos todos os funcionários do Poder Judiciário que atuarem no feito, como o escrivão, o distribuidor, o contador, o oficial de justiça, o intérprete etc. Segundo o autor, duas razões justificam essa exegese:

a) o legislador, ao elaborar os arts. 139 a 152 do CPC, não foi muito preciso a respeito da utilização do termo "serventuário";

b) considerar como "serventuário" apenas o escrivão, como sugere a rubrica da Seção I do Capítulo V do Título IV do Livro I do CPC ("Do Serventuário e do Oficial de Justiça"), contraria a vontade do legislador, que preferiu ampliar a abrangência da regra, incluindo não só o representante do Ministério Público, mas também o magistrado.

${ }^{1070}$ O Código de Processo Civil faz menção ao "porteiro" (art. 688, parágrafo único, do CPC), que, em leis mais antigas, era o auxiliar da justiça incumbido de apregoar partes e testemunhas e de prestar assistência ao juiz nas audiências. No entanto, hoje, não existe mais essa figura, sendo a sua função exercida pelo oficial de justiça (art. 143, IV, do CPC) (DINAMARCO, Instituições de Direito Processual Civil, vol. I, § 350, pp. 678-679).
} 
do oficial de justiça, sem justo motivo, em praticar, dentro do prazo, o ato imposto pela lei ou determinado pelo magistrado (art. 144, I, do CPC).

Outra semelhança entre os atos abusivos dos auxiliares da justiça e os dos juízes é a pouca atenção que lhes dá o legislador, em comparação com o amplo tratamento legislativo dos comportamentos ímprobos das partes. Apenas oito artigos do Código de Processo Civil tratam desse assunto: (a) o art. 29 estatui que as despesas dos atos adiados ou repetidos ficarão a cargo do serventuário que, sem justo motivo, houver dado causa ao adiamento ou à repetição; (b) o art. 144 estabelece que o escrivão e o oficial de justiça são civilmente responsáveis quando, sem justo motivo, se recusarem a cumprir, dentro do prazo, os atos que lhes impõe a lei ou que são fixados pelo juiz ${ }^{1071}$; bem como quando praticarem ato nulo com dolo ou culpa; (c) segundo o art. 147, o perito que, por dolo ou culpa, prestar informações inverídicas deve ressarcir os prejuízos causados à parte, além de fícar inabilitado a funcionar em outras perícias por 2 anos e de incorrer na sanção que a lei penal estabelecer; (d) o art. 153 apenas estende ao intérprete, oficial ou não, a norma contida no art. 147; (e) de acordo com o art. 150, o depositário e o administrador que, por dolo ou culpa, lesarem as partes, devem responder pelos prejuízos causados, além de perderem a remuneração que lhes foi arbitrada, ressalvado o direito a haver o que legitimamente despenderam no exercício do encargo; (f) consoante o inciso I do art. 683 do CPC, é admitida nova avaliação quando qualquer das partes arguir, fundamentadamente, a ocorrência de dolo do avaliador (g) o art. 688, parágrafo único, determina que o escrivão, o porteiro ("rectius", oficial de justiça) ou o leiloeiro que culposamente causar a transferência de praça ou leilão deve responder pelas despesas da nova publicação, podendo o juiz aplicar-lhe a pena de suspensão por 5 a 30 dias; e (h) o art. 995, II e VI, afirma que o inventariante deve ser removido se não der ao inventário andamento regular, suscitando dúvidas infundadas ou praticando atos meramente protelatórios, ou se sonegar, ocultar ou desviar bens do espólio ${ }^{1072}$. Indiretamente, o inciso VII do art. 1.218 do CPC também versa sobre um comportamento abusivo praticado por auxiliar da justiça. Ele

\footnotetext{
1071 De acordo com o "caput" do art. 190 do CPC, incumbe ao serventuário remeter os autos conclusos no prazo de 24 horas e executar os atos processuais no prazo de 48 horas, contados (a) da data em que houver concluído o ato processual anterior, se lhe foi imposto pela lei; ou (b) da data em que tiver ciência da ordem, quando determinada pelo juiz.

Compete ao juiz verificar se o serventuário excedeu, sem motivo legítimo, os prazos que o Código de Processo Civil estabelece. Uma vez apurada a falta, o magistrado deve mandar instaurar procedimento administrativo, na forma da Lei de Organização Judiciária (arts. 193 e 194 do CPC).

1072 Caso o projeto do novo Código de Processo Civil (Projeto de Lei no 8.046/2010) seja aprovado nos termos atuais, os mencionados os atos abusivos dos auxiliares da justiça estarão previstos, respectivamente, nos arts. 95; 134; 137; 143; 140; 878, I; 838, § 9º 608 , II e VI.
} 
estatui que continuam em vigor, até serem incorporados nas leis especiais, os dispositivos do Código de Processo Civil de 1939 concernentes à dissolução e liquidação das sociedades, dentre os quais está o art. 661, que prevê a destituição, ex-officio ou a requerimento de qualquer interessado, dos liquidantes que faltarem ao cumprimento do dever, ou retardarem injustificadamente o andamento do processo, ou procederem com dolo ou má-fé, ou tiverem interesse contrário ao da liquidação. 


\section{CONSEQUÊNCIAS JURÍDICAS DO ABUSO DO PROCESSO}

Já se constatou, anteriormente, que o abuso de situações jurídicas processuais viola as garantias da inafastabilidade do controle jurisdicional (art. $5^{\circ}, \mathrm{XXXV}$, da CF), da razoável duração do processo (art. 5, LXXVIII, da CF), da igualdade e da ampla defesa (art. 5', "caput" e LV, da CF), além de impedir que o processo alcance suas finalidades institucionais (escopos sociais, políticos e jurídico) e de contrariar o princípio da boa-fé (art. 14, II, do CPC), o princípio da cooperação e os deveres gerais dos sujeitos processuais (item 1.3 "supra").

Diante de todo esse potencial lesivo, é pertinente que se faça a seguinte pergunta: se as condutas processuais ímprobas são nocivas para todos os jurisdicionados, contribuindo para o bloqueio da justiça, por que elas são tão comuns no dia-a-dia forense? Menezes Cordeiro ${ }^{1073}$ afirma que a razão disso está no fato de, para cada prejudicado por tais práticas, existir sempre um beneficiado. Consoante o autor lusitano, se o abuso processual não gerasse vantagem alguma para as pessoas, a própria dinâmica social encontraria soluções para esse problema.

Pensando em despersuadir o "improbus litigator" mediante a cessação ou, ao menos, redução das vantagens que ele possa querer obter com o uso desvirtuado do processo, o legislador brasileiro estabeleceu, no Código de Processo Civil, diversas consequências jurídicas negativas para a prática do abuso de situações jurídicas processuais:

a) reparação de perdas e danos (arts. 16 e 18; 69; 133; 144, II; 147; 150; e 153 do $\mathrm{CPC}$ );

b) multa (arts. 18; 233; 488, II; 538, parágrafo único; 557, § 2º 601; 701, § 2; 740, parágrafo único; e 746, $\S 3^{\circ}$, do CPC);

c) pagamento da multa como pressuposto objetivo de admissibilidade de recursos posteriores (arts. 538, parágrafo único; e 557, § 2 $2^{\circ}$, do CPC);

d) obrigação de arcar com o custo do processo (arts. 18;22;29;31;113, § $1^{\text {o }}$; e $267, \S 3^{\circ}$, do CPC);

e) antecipação de tutela (art. 273, II, do CPC);

f) prolação de sentença que obste ao objetivo das partes de praticar ato simulado ou de conseguir fim ilícito por meio do processo (art. 129 do CPC);

${ }^{1073}$ Litigância de Má-Fé, Abuso do Direito de Ação e Culpa “in Agendo”, pp. 17-18 e 28. 
g) cabimento de ação rescisória (art. 485 do CPC);

h) relativização da coisa julgada;

i) nulidade do ato processual; e

j) remoção do inventariante (art. 995, II e VI, do CPC) ${ }^{1074}$.

Originalmente, o art. 601 do CPC previa ainda uma "pena de silêncio": uma vez advertido o executado, se ele continuasse praticando atos atentatórios à dignidade da Justiça, o magistrado podia proibi-lo de se manifestar nos autos. Ele ficava, a partir da preclusão da decisão, impedido de requerer, reclamar, recorrer ou praticar qualquer ato no processo até que a pena lhe fosse relevada.

Tratava-se de sanção excessiva e de manifesta inconstitucionalidade porque violava as garantias do contraditório, da ampla defesa e do devido processo legal ${ }^{1075}$. Ademais, ela se mostrava ineficaz, pois, como não havia uma constrição patrimonial, o executado não tinha qualquer interesse concreto em falar nos autos ${ }^{1076}$. Afirma-se também que essa punição era muito rigorosa à parte e desconsiderava que o ato atentatório à dignidade da Justiça pode ser obra exclusiva do advogado, sem a conivência de seu cliente ${ }^{1077}$.

Com o advento da Lei $n^{\circ} 8.593 / 94$, essa sanção foi trocada pela multa. A atual medida sancionatória mostra-se consentânea com as garantias do acesso à justiça (art. $5^{\circ}$, $\mathrm{XXXV}$, da CF) e do contraditório (art. $5^{\circ}, \mathrm{LV}, \mathrm{CF}$ ), as quais asseguram ao executado o direito de controlar todos os atos processuais executivos, acompanhando a legalidade da sua realização e verificando se a execução está sendo efetivada do modo que lhe seja menos gravoso ${ }^{1078}$.

\subsection{Reparação de perdas e danos}

A produção de danos materiais e morais é considerada algo inerente ao abuso de situações jurídicas processuais. Assim, para que a teoria do abuso do processo não seja

\footnotetext{
${ }^{1074}$ Há também consequências criminais da improbidade processual, porém a sua análise foge do objeto do presente trabalho, que se limita a estudar as normas sobre abuso do processo contidas no Código de Processo Civil. A respeito dos efeitos penais do abuso processual, consultar: ABDO, O Abuso do Processo, pp. 242243; e CASTRO FILHO, Abuso do Direito no Processo Civil, pp. 201-202.

${ }^{1075}$ ABDO, O Ato Atentatório à Dignidade da Justiça na Nova Execução Civil, p. 12; AMORIM SILVA, O Contempt of Court no Direito Processual Civil Brasileiro, in Revista de Processo, $\mathrm{n}^{\circ}$ 191, p. 103.

1076 ASSIS, Manual da Execução, § 71, p. 366.

${ }^{1077}$ DINAMARCO, Instituições de Direito Processual Civil, vol. II, § 529, p. 277.

1078 CARMONA, Comentários ao art. 601 do CPC, in MARCATO (coord.), Código de Processo Civil Interpretado, p. 1964; ASSIS, Manual da Execução, § 71, p. 367.
} 
inócua, cumpre impor ao autor do ato ímprobo a obrigação de restabelecer ao "status quo ante" a esfera jurídica da parte prejudicada ${ }^{1079}$.

No princípio do século XX, no afã de defender a autonomia do processo com relação ao Direito substancial, alguns juristas alemães sustentaram a irrelevância da ilicitude processual. Afirmava-se que o próprio processo, por meio de sua regulamentação legal, seria um meio suficiente para proteger as partes contra eventuais danos decorrentes de condutas processuais, sem necessidade ou possibilidade de indenização. Não obstante essa orientação tenha sido acolhida, por algum tempo, pelo Judiciário da Alemanha, ela foi largamente combatida e encontra-se superada atualmente, tendo mero valor didático ${ }^{1080}$.

Hoje, não há dúvida de que uma parte pode ser responsabilizada se a sua conduta processual atingir situações jurídicas substantivas de outro sujeito do processo, bem como de que inexiste qualquer incompatibilidade entre essa responsabilidade e a já consolidada autonomia do Direito processual.

O Estado moderno detém o poder de dirimir conflitos e pacificar pessoas, declarando qual o direito no caso concreto e promovendo a sua realização prática (jurisdição). Em contrapartida à proibição de que os cidadãos façam justiça com as próprias mãos ${ }^{1081}$, o Estado põe à sua disposição meios judiciais para a resolução de conflitos interindividuais ${ }^{1082}$. Mas, quando um indivíduo exercita o seu direito de acesso ao Poder Judiciário, que possui perante o Estado, ele não está autorizado a lesar direito ou qualquer outra situação jurídica material de outra pessoa. Assim, o art. $5^{\circ}, \mathrm{XXXV}$, da CF não restringe, de modo algum, o princípio do "neminem laedere". Defender o contrário contrariaria o escopo jurídico do processo, que consiste na atuação da vontade concreta do Direito material e que integra o próprio conceito de processo ${ }^{1083} 1084$.

\footnotetext{
1079 ABDO, O Abuso do Processo, p. 229.

1080 ALBUQUERQUE, Responsabilidade Processual por Litigância de Má Fé, Abuso de Direito e Responsabilidade Civil em Virtude de Actos Praticados no Processo, pp. 96-102.

${ }^{1081}$ A norma que proíbe a autotutela no ordenamento jurídico brasileiro consta dos arts. 345 e 350 do CP. Porém, ela é relativizada, por exemplo, pelo direito de retenção (arts. 578; 644; 1.219; 1.433, II; 1.434 do CC etc.), pela permissão de desforço imediato (art. 1.210, $\S 1^{\circ}$, do $\mathrm{CC}$ ), pelo direito de cortar raízes e ramos de árvores limítrofes que ultrapassem a estrema do prédio (art. 1.283 do CC), pela autoexecutoriedade das decisões administrativas, pelo poder de efetuar prisões em flagrante (art. 301 do CPP) e pela permissão de praticar atos em legítima defesa e em estado de necessidade (arts. 24-25 do CP; arts. 188 e 929-930 do CC) (CINTRA; DINAMARCO; GRINOVER, Teoria Geral do Processo, pp. 27 e 31).

${ }^{1082}$ Acerca da evolução da autotutela para a jurisdição, consultar: CINTRA; DINAMARCO; GRINOVER, Teoria Geral do Processo, pp. 22-26.

1083 Cintra, Dinamarco e Grinover (Teoria Geral do Processo, p. 25) conceituam "processo" como o "instrumento por meio do qual os órgãos jurisdicionais atuam para pacificar as pessoas conflitantes, eliminando os conflitos e fazendo cumprir o preceito jurídico pertinente a cada caso que lhes é apresentado em busca de solução" (destaque nosso).

1084 ALBUQUERQUE, Responsabilidade Processual por Litigância de Má Fé, Abuso de Direito e Responsabilidade Civil em Virtude de Actos Praticados no Processo, pp. 114-119.
} 
Em diversos momentos, o Código de Processo Civil nacional trata expressamente do dever de o sujeito processual ímprobo ressarcir as perdas e danos decorrentes da sua conduta abusiva. Isso ocorre nos seguintes dispositivos:

a) arts. 16 e 18 do CPC, que versam sobre a responsabilidade das partes (autor, réu e interveniente) por perdas e danos decorrentes de litigância de má-fé ${ }^{1085}$;

b) art. 69 do CPC, que prevê a responsabilidade do réu por perdas e danos decorrentes do abuso do poder de nomear à autoria;

c) art. 133 do CPC, que regula a responsabilidade do juiz por perdas e danos decorrentes da prática de abuso processual; e

d) arts. 144, II; 147; 150; e 153 do CPC, que tratam da responsabilidade dos auxiliares da justiça por perdas e danos oriundos de suas condutas abusivas.

Passa-se, a partir de agora, a analisar cada um desses artigos de lei de maneira mais detalhada.

\subsubsection{Responsabilidade das partes pelo ressarcimento de perdas e danos decorrentes de litigância de má-fé}

Os arts. 16 e 18 do CPC estatuem o seguinte:

Art. 16. Responde por perdas e danos aquele que pleitear de má-fé como autor, réu ou interveniente.

Art. 18. O juiz ou tribunal, de ofício ou a requerimento, condenará o litigante de má-fé a pagar multa não excedente a um por cento sobre o valor da causa e a indenizar a parte contrária dos prejuízos que esta sofreu, mais os honorários advocatícios e todas as despesas que efetuou.

$\S 1^{\mathrm{o}}$ Quando forem dois ou mais os litigantes de má-fé, o juiz condenará cada um na proporção do seu respectivo interesse na causa, ou solidariamente aqueles que se coligaram para lesar a parte contrária.

$\S 2^{\circ} \mathrm{O}$ valor da indenização será desde logo fixado pelo juiz, em quantia não superior a $20 \%$ sobre o valor da causa, ou liquidado por arbitramento ${ }^{1086} 1087$.

${ }^{1085}$ Barbi (Comentários ao Código de Processo Civil, vol. I, § 157, p. 123) observa que a Seção I e a Seção II do Capítulo II do Livro I do Código de Processo Civil regem as condutas de pessoas diversas. Enquanto a primeira, que abrange os arts. 14 e 15 do CPC, especifica os deveres das partes e de seus procuradores; a segunda, que contém os arts. 16 a 18 do CPC, trata apenas da responsabilidade das partes por dano processual, ou seja, por danos que a parte cause a outro litigante no exercício de situações jurídicas processuais.

${ }^{1086}$ Em diversos ordenamentos jurídicos é possível encontrar normas a respeito da responsabilidade das partes por perdas e danos decorrentes do abuso do processo.

$\mathrm{O}$ art. 71, $1^{\mathrm{a}}$ parte, do "Código Procesal Civil Modelo para Iberoamérica" e o art. 61 do CPC uruguaio preceituam que, quando a má-fé ou a temeridade estiver plenamente assentada, a parte pode ser condenada a ressarcir danos e prejuízos, em outro processo ou no mesmo, se houver pedido expresso nesse sentido.

Analogamente, o $\S 1^{\circ}$ do art. 456 do CPC português estabelece que a parte litigante de má-fé deve ser condenada ao pagamento de indenização à parte contrária, se esta a pedir. 
De acordo com o $\S 1^{\circ}$ do art. 96 do CPC italiano, a parte sucumbente que houver agido ou resistido em juízo com má-fé ou culpa grave deve ser condenada ao ressarcimento dos danos. Essa "responsabilità aggravata" do litigante temerário pressupõe: (a) que ele tenha sucumbido totalmente; (b) que a sua conduta tenha produzido como efeito direto e imediato um prejuízo à parte contrária; e (c) que esteja presente um elemento subjetivo (dolo processual ou culpa grave). É necessário que a parte interessada requeira o ressarcimento dos danos, pois o juízo não pode pronunciar-se sobre a "responsabilità aggravata" de ofício. O pedido deve ser feito no mesmo processo em que o comportamento abusivo foi praticado (CARPI; COLESANTI; TARUFFO, Commentario Breve al Codice di Procedura Civile, pp. 286 e 288; LIEBMAN, Manual de Direito Processual Civil, vol I, § 64, p. 132). O órgão julgador deve liquidar os danos na sentença. O $\S 3^{\circ}$ do art. 96 do CPC italiano, inserido pelo art. 45, § 12, da Lei no 69/2009, estatui o seguinte: "Em todo caso, quando pronuncia sobre as despesas em conformidade com o artigo 91, o juiz, também de ofício, pode ainda condenar a parte sucumbente ao pagamento, a favor da parte contrária, de uma soma equitativamente determinada" (tradução nossa). De acordo com Falco (La Buona Fede e l'Abuso del Diritto: principi, fattispecie e casistica, pp. 519-523), esse dispositivo autoriza o juiz a condenar o sucumbente que tenha agido ou resistido em juízo com má-fé ou culpa grave ao pagamento de uma quantia equitativamente determinada, em favor da parte contrária, de ofício ou após requerimento desta, independentemente de prova do prejuízo. O jurista italiano observa que o referido dispositivo generalizou a norma contida no art. 385 , $\S 4^{\circ}$, do CPC italiano ("Quando pronuncia sobre as despesas, também nas hipóteses do artigo 375, a Corte, também de oficio, condena, ainda, a parte sucumbente ao pagamento, a favor da parte contrária, de uma soma equitativamente determinada, não superior ao dobro dos máximos tarifários, se considera que esta propôs o recurso ou resistiu a ele também só com culpa grave"), tanto que a Lei ${ }^{\circ}$ 69/2009, que introduziu o primeiro, ab-rogou o segundo (Art. 46, § 20, da Lei nº 69/2009: "No artigo 385 do Código de Processo Civil, o quarto parágrafo é abrrogado" - tradução nossa).

No ordenamento jurídico inglês, duas espécies de comportamento abusivo acarretam o dever de ressarcir perdas e danos (ANDREWS, Abuse of Process in English Civil Litigation, in TARUFFO (ed.), Abuse of Procedural Rights: comparative standards of procedural fairness, pp. 75-79):

a) o ajuizamento de demanda sem fundamento razoável e provável e com intuito malicioso. Trata-se do chamado "tort of malicious prosecution", que, segundo Fentiman (Abuse of Procedural Rights: the position of English Law, in TARUFFO (ed.), Abuse of Procedural Rights: comparative standards of procedural fairness, p. 60), raramente ocorre na prática; e

b) o ajuizamento de demanda com intuito ilegítimo (v.g., com o escopo de lesar economicamente o réu; ou com o fim de obter documentos da parte contrária etc.), e não para tutelar algum direito substancial. Denomina-se "tort of abuse of legal process".

Na Austrália, existe o "tort of collateral abuse of legal process", que consiste na utilização do processo com o propósito preponderante de obter um fim impróprio. A parte lesada por esse comportamento ímprobo tem direito à indenização das perdas e danos (BEAUMONT, Report on Abuse of Procedural Rights for Australia, in TARUFFO (ed.), Abuse of Procedural Rights: comparative standards of procedural fairness, pp. 101-102 e 104).

O art. 32.1 do "Code de Procédure Civile" francês estatui que a pessoa que age em juízo de maneira dilatória ou abusiva pode ser condenada ao ressarcimento de perdas e danos. O dever de indenizar é imposto, igualmente, para quem: (a) com intuito dilatório, se abstém de formular o "appel incident" (similar à apelação adesiva do Direito brasileiro) ou o "appel provoqué" de maneira suficientemente rápida (art. 550 do "Code de Procédure Civile"); (b) interpõe "appel" dilatória ou abusiva (art. 559 do "Code de Procédure Civile"); (c) interpõe recurso extraordinário ("tierce opposition", "recours en révision" ou "pourvoi en cassation") dilatório ou abusivo (art. 581 do "Code de Procédure Civile"); ou (d) faz uso do "pourvoi en cassation" de maneira abusiva e tem o recurso improvido ou não-conhecido (art. 628 do "Code de Procédure Civile”). Na França, entende-se que há abuso quando o ato processual não é embasado em algum elemento preciso e determinado e é particularmente infundado, temerário e malévolo (Nouveau Code de Procédure Civile, p. 362, nt. 4 "bis" ao art. 559). A jurisprudência majoritária exige que o litigante tenha agido com máfé ou culpa grave para que seja cominado o dever de ressarcir perdas e danos em um caso concreto, porém também há decisões condenatórias fundadas apenas na "imprudência censurável" ("légèreté blâmable") e na "falta" ("faute"), ainda que não grosseira ou dolosa (Nouveau Code de Procédure Civile, p. 56, nt. 1 ao art. 32.1 ; e p. 362 , nt. 4 ao art. 559).

No ordenamento jurídico belga, existe norma similar à contida no art. 32.1 do "Code de Procédure Civile" francês. Consoante o art. 780bis do "Code Judiciaire" da Bélgica, a parte que utiliza o processo para fins manifestamente dilatórios ou abusivos pode ser condenada ao ressarcimento de perdas e danos.

De acordo com Hess (Abuse of Procedure in Germany and Austria, in TARUFFO (ed.), Abuse of Procedural Rights: comparative standards of procedural fairness, p. 153) e Normand (Final Report: the two approaches to the abuse of procedural rights, in TARUFFO (ed.), Abuse of Procedural Rights: comparative standards of 
Para que a análise desses dois dispositivos fique mais clara, cumpre cindi-la em seis itens: (a) natureza jurídica da responsabilidade; (b) amplitude do dever de indenizar; (c) montante da indenização; (d) sujeitos passivo e ativo da obrigação de indenizar; (e) cominação do dever de indenizar; e (f) possibilidade de pleitear a indenização por meio de demanda autônoma.

\subsubsection{Natureza jurídica da responsabilidade}

A doutrina discute qual é a natureza jurídica dessa responsabilidade civil decorrente do ato de litigância de má-fé.

Para Stoco ${ }^{1088}$, somente se pode imputar ao litigante de má-fé o dever de indenizar pelas perdas e danos se ele agiu com dolo ou culpa grave, respeitando o princípio da responsabilidade subjetiva previsto no art. 186 do CC.

Em posição diametralmente oposta encontra-se Dinamarco ${ }^{1089}$, sustentando que a responsabilidade civil estabelecida no art. 16 do CPC é objetiva em relação ao dano, de modo que é irrelevante questionar se o litigante de má-fé teve a intenção de causá-lo ou mesmo a consciência de sua dimensão. De acordo com o autor, é suficiente que haja a intenção de prejudicar o processo e seu andamento por meio de conduta tipificada no art. 17 do CPC.

Este segundo entendimento parece ser o mais consentâneo com o texto do art. 16 do CPC, que não faz qualquer menção a conduta culposa ou dolosa (como faz o art. 186 do $\mathrm{CC})$.

procedural fairness, p. 245), a seção 408 da ZPO austríaca prevê o dever de ressarcir perdas e danos decorrentes de demanda manifestamente vexatória.

${ }^{1087}$ Normas análogas constam dos arts. 82 e 84 do Projeto de Lei no 8.046/2010 (que institui o novo Código de Processo Civil):

"Art. 82. Responde por perdas e danos aquele que pleitear de má-fé como autor, réu ou interveniente";

"Art. 84. O juiz ou tribunal, de ofício ou a requerimento, condenará o litigante de má-fé a pagar multa que não deverá ser inferior a dois por cento, nem superior a dez por cento, do valor corrigido da causa e a indenizar a parte contrária dos prejuízos que esta sofreu, além de honorários advocatícios e de todas as despesas que efetuou.

$\S 1^{\circ}$ Quando forem dois ou mais os litigantes de má-fé, o juiz condenará cada um na proporção do seu respectivo interesse na causa ou solidariamente aqueles que se coligaram para lesar a parte contrária.

$\S 2^{\circ} O$ valor da indenização será desde logo fixado pelo juiz, em quantia sobre o valor da causa, ou, caso não seja possível mensurá-la desde logo, liquidada por arbitramento ou pelo procedimento comum.

$\S 3^{\circ}$ Quando o valor da causa for irrisório ou inestimável, a multa referida no caput poderá ser fixada em até dez vezes o valor do salário mínimo".

${ }^{1088}$ Abuso do Direito e Má-Fé Processual - aspectos doutrinários, pp. 95-96.

1089 Instituições de Direito Processual Civil, vol. II, § 528-A, p. 272. 


\subsubsection{Amplitude do dever de indenizar}

Infere-se do disposto no art. 16 do CPC que o dever de indenizar os prejuízos decorrentes da prática de litigância de má-fé mostra-se bastante amplo. Abrange o que a parte perdeu, bem como o que ela deixou de ganhar, ou seja: os danos emergentes (e.g., despesas extraordinárias que a parte teve em decorrência de atos procrastinatórios da outra parte; em caso de abuso do processo em sentido estrito, como, por exemplo, ajuizamento de demanda contra texto expresso de lei - art. 17, I, do CPC -, as despesas com honorários advocatícios contratuais ${ }^{1090}{ }^{1091}$ ) e também os lucros cessantes (exemplo destes: se uma empresa propõe uma demanda infundada em face de sua concorrente com o fim de macular a sua reputação comercial, incluem-se nos lucros cessantes os valores dos negócios que a empresa-ré deixou de celebrar em razão da existência do processo) ${ }^{1092}$, tanto de natureza patrimonial, quanto moral ${ }^{1093} 1094$.

${ }^{1090}$ Pode-se aplicar, por analogia, o seguinte entendimento jurisprudencial do Superior Tribunal de Justiça: "CIVIL E PROCESSUAL CIVIL. VALORES DESPENDIDOS A TÍTULO DE HONORÁRIOS ADVOCATÍCIOS CONTRATUAIS. PERDAS E DANOS. PRINCÍPIO DA RESTITUIÇÃO INTEGRAL.

1. Aquele que deu causa ao processo deve restituir os valores despendidos pela outra parte com os honorários contratuais, que integram o valor devido a título de perdas e danos, nos termos dos arts. 389 , 395 e 404 do CC/02.

2. Recurso especial a que se nega provimento" (destaque nosso)

(STJ, $3^{\text {a } T u r m a, ~ R E s p ~ 1.134 .725 / M G, ~ R e l . ~ M i n . ~ N a n c y ~ A n d r i g h i, ~ D J e ~ 24 / 06 / 2011) . ~}$

${ }^{1091}$ Segundo Reis (Código de Processo Civil Anotado, vol. II, p. 275), em Portugal, a indenização decorrente da prática de litigância de má-fé pode consistir "no reembolso das despesas a que a má fé obrigou a parte contrária, incluindo os honorários dos mandatários ou técnicos" (destaque nosso).

1092 ABDO, O Abuso do Processo, p. 229; BEDAQUE, Comentários ao art. 18 do CPC, in MARCATO (coord.), Código de Processo Civil Interpretado, p. 64.

1093 Stoco (Abuso do Direito e Má-Fé Processual - aspectos doutrinários, pp. 98-100) sustenta que a expressão "perdas e danos", contida no art. 16 do CPC, diz respeito tão somente aos lucros cessantes e aos danos materiais emergentes. Para ele, se houver dano moral, a sua reparação deve ser pleiteada por meio de ação autônoma.

Por outro lado, tratando do tema quando o Código de Processo Civil de 1939 ainda era vigente, Castro Filho (Abuso do Direito no Processo Civil, pp. 204-205) defende que é possível, sim, a condenação da parte a reparar o dano moral decorrente do abuso do processo. Fundamenta seu pensamento no teor genérico do texto do art. $3^{\circ}$ do CPC39, que apenas mencionava a responsabilidade da parte pelas "perdas e danos", sem limitá-la aos prejuízos de ordem patrimonial. Como o legislador não distinguiu as perdas e danos de ordem patrimonial das de ordem moral quando tratou da repressão do abuso do processo - argumenta o autor -, não pode o intérprete fazer essa distinção. Além disso, o jurista lembra que seria contrário aos fins do Estado permitir que o direito de demandar, concebido como um instrumento para realizar o direito, fosse convertido em um instrumento para causar danos de qualquer natureza aos cidadãos.

Essa argumentação de Castro Filho mostra-se coerente também com o ordenamento jurídico brasileiro atual. Dado que, nos arts. 16 e 18 do CPC, não há qualquer distinção entre danos materiais e morais, ou entre danos emergentes e lucros cessantes, não cabe ao intérprete distinguir.

Nesse sentindo, afirmando que o dever de indenizar previsto nos arts. 16 e 18 do CPC abrange os danos de ordem moral e também material: OLIVEIRA, Litigância de Má-Fé, pp. 66-67.

${ }^{1094} \mathrm{O}$ art. 457, § $1^{\circ}$, do CPC português estabelece que:

"A indemnização pode consistir:

a) No reembolso das despesas a que a má fé do litigante tenha obrigado a parte contrária, incluindo os honorários dos mandatários ou técnicos;

b) No reembolso dessas despesas e na satisfação dos restantes prejuízos sofridos pela parte contrária como 
A doutrina discute se, nos casos em que o autor da demanda, agindo de má-fé, pleiteia o adimplemento de dívida já paga, no todo ou em parte, sem ressalvar quantias já recebidas, ou pede mais que o "quantum" realmente devido (art. 17, II, do CPC) ${ }^{1095}$, as penalidades previstas no art. 940 do CC (pagamento, ao devedor, do dobro do valor cobrado, no primeiro caso; e pagamento do montante exigido, no segundo) estão incluídas no dever de ressarcir os prejuízos sofridos pela parte contrária previsto nos arts. 16 e 18 do CPC.

Na opinião de Oliveira ${ }^{1096}$, quando se constata que o autor ajuizou a demanda sabendo que a dívida já estava paga, deve-se aplicar apenas o art. 940 do CC. Argumenta

consequência directa ou indirecta da má fé.

o juiz optará pela indemnização que julgue mais adequada à conduta do litigante de má-fé, fixando-a sempre em quantia certa".

A leitura desse dispositivo dá a entender que, no Direito lusitano atual, o litigante de má-fé também deva indenizar todos os prejuízos que sua conduta tenha causado à parte contrária, como ocorre no Brasil.

Porém, os órgãos judiciais portugueses adotam interpretação bastante restritiva ao aplicá-lo nos casos concretos, deixando diversos danos por ressarcir. De acordo com Menezes Cordeiro (Litigância de Má-Fé, Abuso do Direito de Ação e Culpa "in Agendo", pp. 57-58 e 59), três fatores contribuem para isso:

a) são ressarcidos apenas os danos causados por condutas dolosas ou grosseiramente negligentes;

b) o $\S 2^{\circ}$ do art. 457 do CPC português estabelece que, se o juiz não tiver elementos para fixar logo na sentença o montante da indenização, ele deve ouvir as partes e fixar depois, "com prudente arbítrio", o que lhe "parecer razoável", podendo reduzir aos justos limites as verbas de despesas e os honorários advocatícios apresentados pela parte. Consoante o autor lusitano, essa "prudência" judicial mencionada na lei é, na verdade, uma mensagem subliminar para que se minimize a indenização, deixando prejuízos por indenizar; c) os dispositivos do Código de Processo Civil português que versam sobre a litigância de má-fé foram, historicamente, concebidos apenas para policiar as atitudes aberrantes das partes, e não para tutelar as pessoas lesadas, indenizando os prejuízos que sofreram em razão dos atos processuais ilícitos e culposos.

Albuquerque (Responsabilidade Processual por Litigância de Má Fé, Abuso de Direito e Responsabilidade Civil em Virtude de Actos Praticados no Processo, pp. 44-45, 47, 53-59) explica que, no Direito lusitano, os fins do instituto da litigância de má-fé não são ressarcitórios ou indenizatórios, mas sim: (a) sancionatórios de condutas que transgridam o interesse público de respeito pelo processo, pelo tribunal e pela justiça; e (b) compensatórios. Por causa disso, a responsabilidade decorrente da litigância de má-fé (arts. 456 e ss. do CPC português) abrange apenas os danos oriundos de ofensa a situações jurídicas processuais, nunca os decorrentes de descumprimento de situações jurídicas substanciais. Assim, o que determina o montante da indenização a pagar não é a medida do dano sofrido pela parte lesada, mas tão somente a gravidade da conduta processual do litigante ímprobo.

A doutrina portuguesa afirma que as seguintes condutas processuais lesivas não se incluem no âmbito do dever de ressarcir decorrente da litigância de má-fé (MENEZES CORDEIRO, Litigância de Má-Fé, Abuso do Direito de Ação e Culpa "in Agendo", pp. 185-186):

a) os atos danosos ilícitos meramente negligentes;

b) as condutas ilícitas cuja lesividade se prolongue no tempo, não se limitando ao mero incidente de má-fé;

c) os atos ilícitos que sejam complexos quanto à sua origem e quanto às consequências que produzem;

d) as atuações ilícitas que envolvam a conjugação com terceiras pessoas;

e) as condutas cuja ilicitude provenha não do processo em si, mas da conjugação de diversos processos;

f) os atos que impliquem descumprimento de negócios jurídicos (v.g., pacto de "non petendo", convenção arbitral) e, eventualmente, a incidência de cláusulas penais.

Nesses casos, é necessário o ajuizamento de uma demanda própria, pleiteando a indenização dos danos não abarcados pelo instituto da litigância de má-fé, com fundamento em institutos próprios do Direito material, como o abuso do direito e a responsabilidade civil.

${ }^{1095}$ Acerca dessa hipótese abusiva, consultar o item 2.5 "supra".

${ }^{1096}$ Litigância de Má-Fé, p. 48. 
que esse dispositivo legal não pode ser aplicado juntamente com o art. 18 do CPC porque haveria dupla punição ("bis in idem”).

Em artigo científico publicado quando o Código Civil de 1916 ainda estava em vigor, Alencar Rodrigues ${ }^{1097}$ sustenta que, nesses casos, o correto é aplicar apenas as sanções previstas no art. 18 do CPC. Ele justifica que o referido dispositivo do Código de Processo Civil regulou inteiramente a matéria versada no art. 1.531 do CC16 (cujo conteúdo é similar ao do atual art. 940 do CC), revogando-o implicitamente ("lex posterior derogat priori’), como estatui o art. $2^{\circ}, \S 1^{\circ}$, do Decreto-Lei n ${ }^{\circ} 4.657 / 42$ (Lei de Introdução às Normas do Direito Brasileiro).

Seguindo esse mesmo raciocínio, atualmente, dever-se-ia aplicar apenas o art. 940 do CC, já que, com o advento do novo Código de Civil, em 2.002, essa norma de Direito material teria revogado implicitamente o art. 18 do CPC.

"Data venia", parece que a melhor solução é a aventada por Iocohama ${ }^{1098}$, que possibilita a incidência concomitante das duas normas (art. 940 do CC e art. 16 c/c art. 18 do CPC). Para ele, o demandante que pleiteia valores já recebidos ou superiores aos merecidos deve ser condenado a pagar ao demandado o dobro do montante já recebido ou o valor exigido a mais, nos termos do art. 940 do CC. Se ficar comprovado que tais valores não são suficientes para reparar os danos materiais e morais efetivamente causados à parte contrária, o juiz deve condenar o litigante ímprobo a inteirar o montante necessário para indenizar integralmente a vítima do abuso processual, com fundamento nos arts. 16 e 18 do CPC. Segundo o autor, o que é vedado, por ser "bis in idem", é condenar com base tanto no art. 940 do CC, quanto nos arts. 16 e 18 do CPC, sendo que a incidência do primeiro dispositivo já seria capaz de reparar os prejuízos efetivamente existentes e comprovados.

A responsabilidade civil decorrente do abuso do processo pode ser não só aquiliana (ou seja, extracontratual), mas também contratual. Esta última ocorre nos casos em que a atuação processual ímproba contraria: (a) um dever acordado pelas partes por meio de negócio jurídico (v.g., obrigação de desistir de uma determinada demanda judicial; obrigação de não recorrer de uma determinada decisão; convenção de arbitragem; obrigação de as partes de um contrato não recorrerem aos tribunais antes de decorrido determinado período de tempo, que é o denominado "pactum de non petendo"; obrigação de, em caso de litígio oriundo de determinado contrato, fazer, durante um período fixado,

${ }^{1097}$ A Litigância de Má-Fé e o Direito do Trabalho. Disponível em: <http://www.buscalegis.ufsc.br/revistas/ files/anexos/22767-22769-1-PB.htm>. Acesso em: 15/11/2012.

${ }^{1098}$ Litigância de Má-Fé e Lealdade Processual, pp. 282-283. 
todos os melhores esforços para obter uma conciliação antes de apelar para o Judiciário etc.); ou (b) um dever acessório decorrente do princípio da boa-fé ${ }^{1099}$.

Essa grande amplitude do dever de indenizar possui espeque constitucional. $\mathrm{O}$ art. $5^{\circ}, \mathrm{XXXV}$, da CF garante a todos que não se excluirá da apreciação do Poder Judiciário qualquer lesão ou ameaça a direito. Logo, uma eventual negativa da possibilidade de a parte pleitear em juízo a integral reparação dos danos que o processo lhe tenha causado equivaleria a uma denegação da garantia constitucional da inafastabilidade do controle jurisdicional. Não se pode perder de vista também que desamparar a dimensão da responsabilidade civil equivale a desamparar o próprio direito ou bem jurídico lesado. Destarte, se ficassem por ressarcir danos decorrentes do abuso do processo, seriam contrariados diversos direitos constitucionalmente garantidos, notadamente: (a) os princípios da propriedade privada e da livre iniciativa econômica, quanto aos danos patrimoniais (arts. 5', XXII; e 170, “caput” e II, da CF); e (b) os direitos fundamentais previstos nos incisos $\mathrm{V}$ e $\mathrm{X}$ do art. $5^{\circ}$ da $\mathrm{CF}$, quanto aos danos morais ${ }^{1100}$.

Como em todo caso de responsabilidade civil, é indispensável que a parte prejudicada pela conduta abusiva prove que realmente sofreu os danos alegados para que se caracterize o dever de indenizar, ainda que não se determine desde logo o seu valor ${ }^{1101}$. Não são indenizados danos meramente imagináveis ${ }^{1102}$.

Isso só não é válido para uma espécie de consequência danosa produzida pela grande maioria dos comportamentos processuais abusivos: o agravamento do dano marginal do processo, cuja existência e montante é difícil de provar plenamente. Se o juízo exigisse a comprovação das perdas e danos decorrentes da demora que a conduta ímproba causou na entrega da prestação jurisdicional, seria bastante rara a incidência do art. 18 do CPC. Nesses casos, dispensa-se a parte de produzir prova dos danos e o órgão jurisdicional deve liquidá-los equitativamente, com base em elementos do caso concreto (v.g., a

\footnotetext{
1099 ALBUQUERQUE, Responsabilidade Processual por Litigância de Má Fé, Abuso de Direito e Responsabilidade Civil em Virtude de Actos Praticados no Processo, pp. 139-143.

1100 ALBUQUERQUE, Responsabilidade Processual por Litigância de Má Fé, Abuso de Direito e Responsabilidade Civil em Virtude de Actos Praticados no Processo, pp. 104-108; e 121, nt. 366; MENEZES CORDEIRO, Litigância de Má-Fé, Abuso do Direito de Ação e Culpa "in Agendo", p. 186.

${ }_{1101}$ ABDO, O Abuso do Processo, p. 232; BARBOSA MOREIRA, A Responsabilidade das Partes por Dano Processual no Direito Brasileiro, in Temas de Direito Processual, p. 33; TARUFFO, General Report, in TARUFFO (ed.), Abuse of Procedural Rights: comparative standards of procedural fairness, p. 23; OLIVEIRA, Litigância de Má-Fé, p. 81; FERNANDES DE SOUZA, Abuso de Direito Processual - uma teoria pragmática, p. 124, nt. 83.

${ }_{1102}$ BARBI, Comentários ao Código de Processo Civil, vol. I, § 167, p. 129.
} 
natureza da conduta protelatória, a intensidade do dolo, os efeitos práticos na esfera jurídica da parte contrária etc. $)^{1103}$.

É igualmente necessária a demonstração da relação de causalidade entre a conduta processual ímproba e o dano ${ }^{1104}$. Ocorre que, muitas vezes, a atuação abusiva de uma das partes somente causa dano à outra por meio da prática de um ato judicial (por exemplo, o sujeito ajuíza demanda com fundamento em fatos inverídicos e pleiteia a concessão de antecipação de tutela com base em provas falsas; não obstante o demandante tenha praticado o ato abusivo, quem lesa imediatamente o demandado é o juiz, ao deferir a tutela antecipada). Mas, nesses casos, a intermediação de um ato do juiz não interrompe o nexo de causalidade.

Seguindo a teoria da causalidade adequada, Albuquerque ${ }^{1105}$ explica que, para que haja a responsabilização do autor de um ato ilícito, não é necessário que o seu comportamento tenha produzido, sozinho, o dano. $\mathrm{O}$ dever de indenizar existe independentemente de o comportamento do autor do fato ilícito danoso ter gerado os prejuízos mediatamente, após a verificação de outras circunstâncias, como a intromissão de um ato de terceiro. O essencial é que o fato ilícito seja condição do dano, ou seja, que haja um nexo de causalidade, mas nada impede que coexistam mais de uma causa, ou que haja a intervenção de terceiros. O requisito para que o autor do fato ilícito inicial seja responsabilizado é que o seu comportamento crie para os bens jurídicos atingidos uma especial situação de perigo, que seja capaz de tornar provável a intromissão do terceiro ou, pelo menos, de favorecer essa intromissão mediante a criação de um risco acima do normal. Se o ato do terceiro, que causou imediatamente o dano, for considerado um efeito adequado do ato ilícito praticado anteriormente, ele deve ser imputado ao autor deste primeiro fato. Apenas se concorrer, decisivamente, para a verificação do prejuízo uma circunstância extraordinária ou um ato de terceiro que seja totalmente indiferente ao fato ilícito primitivo é que a responsabilidade do autor deste estará excluída, dada a interrupção do processo causal por ele desencadeado. Nesse caso, o fato ilícito inicial é considerado irrelevante, na ordem natural das coisas, para a verificação do dano ocorrido.

${ }^{1103}$ Nesse sentido: FALCO, La Buona Fede e l'Abuso del Diritto: principi, fattispecie e casistica, pp. 517518; BEDAQUE, Comentários ao art. 18 do CPC, in MARCATO (coord.), Código de Processo Civil Interpretado, p. 64.

${ }^{1104}$ DINAMARCO, Instituições de Direito Processual Civil, vol. II, § 528-A, pp. 272 e 273; PONTES DE MIRANDA, Comentários ao Código de Processo Civil, tomo I, p. 386.

${ }^{1105}$ Responsabilidade Processual por Litigância de Má Fé, Abuso de Direito e Responsabilidade Civil em Virtude de Actos Praticados no Processo, pp. 143-150. 
Nas situações em que a conduta ímproba de uma parte lesa a outra somente após uma atuação do órgão jurisdicional, a existência do nexo de causalidade é patente. É o comportamento abusivo inicial do litigante que cria o risco de dano à esfera jurídica alheia. A intervenção do órgão judicial é necessária e inevitável em todo o processo e ela só prejudica imediatamente uma das partes porque foi precedida pela conduta abusiva da outra. A verdadeira condição do dano, então, é o ato processual ímprobo; se fosse excluído este, a atividade do juiz, por si própria, não causaria prejuízo algum. Só se poderia cogitar de interrupção do nexo causal nesses casos se houvesse o cometimento de abuso de poderdever pelo próprio magistrado (art. 133 do CPC).

\subsubsection{Montante da indenização}

No que concerne ao valor da indenização, o art. $18, \S 2^{\circ}$, do CPC determina que ele seja desde logo fixado pelo juiz em quantia não superior a $20 \%$ sobre o valor da causa ou seja liquidado por arbitramento. Barbi ${ }^{1106}$ defende a correção do estabelecimento desse limite, que, segundo ele, é útil para facilitar e orientar a atividade do juiz.

Ocorre que essa regra parece estar em confronto com o "caput" do mesmo dispositivo, que não faz qualquer restrição quantitativa, estatuindo que o litigante de má-fé deve ser condenado a "indenizar a parte contrária dos prejuízos que esta sofreu, mais os honorários advocatícios e todas as despesas que efetuou" (destaques nossos).

A interpretação sistemática do "caput" e do $\S 2^{\circ}$ do art. 18 do CPC leva à conclusão de que, até o limite de $20 \%$ do valor da causa, o juiz pode fixar o montante da indenização de forma matemática nos próprios autos. Se vislumbrar que esse limite não indeniza por completo a parte lesada pelo ato abusivo, ele deve apenas condenar por litigância de má-fé e remeter a apuração do "quantum” da indenização à liquidação 110711081109 .

\footnotetext{
${ }^{1106}$ Comentários ao Código de Processo Civil, vol. I, § 170, p. 131.

${ }^{1107}$ Nesse sentido: OLIVEIRA, Litigância de Má-Fé, p. 80; STOCO, Abuso do Direito e Má-Fé Processualaspectos doutrinários, pp. 105-106; DINAMARCO, Instituições de Direito Processual Civil, vol. II, § 528-A, p. 272 .

${ }_{1108}$ Esse tema, contudo, não é pacífico.

Abdo (O Abuso do Processo, pp. 232-233), por exemplo, afirma que, quando o valor da indenização exceder a $20 \%$ do valor da causa, a condenação do litigante de má-fé ao pagamento da quantia ressarcitória superior ao teto depende de pedido expresso do interessado e deve ser apurada em demanda autônoma.

Já os desembargadores do antigo Segundo Tribunal de Alçada Civil do Estado de São Paulo firmaram o seguinte entendimento acerca dessa questão, contido no Enunciado no 32 do Centro de Estudos e Pesquisas (CEDES), aprovado por unanimidade na sessão de 25 de abril de 1995: "A penalidade por litigância de má-fé pode ser imposta pelo juiz, de ofício, respeitado o limite de $20 \%$ do valor atualizado da causa, mas a indenização dos prejuízos, excedente desse limite, depende de pedido expresso da parte, submete-se ao princípio do contraditório e é liquidável por arbitramento".
} 
Mostra-se pertinente a crítica feita por Dinamarco ${ }^{1110}$ ao fato de a lei eleger o valor da causa como base para o cálculo do teto de $20 \%$ a título de indenização, já que um dos comportamentos ímprobos que o autor da demanda pode praticar consiste em dissimular a expressão econômica do litígio, atribuindo à causa um valor menor que o real.

Não obstante o art. 18, § $2^{\circ}$, do CPC fale em liquidação do valor da condenação por arbitramento, a doutrina reconhece que a sentença também pode ser submetida às outras modalidades de liquidação. Por exemplo, se a conduta abusiva continuou gerando danos após a sua prática, exacerbando o montante dos lucros cessantes, deve-se proceder à liquidação por artigos ${ }^{111}$. Uma interpretação restritiva do texto legal, admitindo apenas a liquidação por arbitramento, contrariaria o direito constitucional de acesso ao Poder Judiciário (art. 5, $\mathrm{XXXV}$, da $\mathrm{CF}$ ), pois, em alguns casos, impediria a vítima de obter a reparação integral dos danos oriundos do abuso do processo ${ }^{1112}$.

\subsubsection{Sujeitos passivo e ativo da obrigação de indenizar}

Estatui o art. 16 do CPC que a parte que pratica atos de má-fé responde pelas perdas e danos causados à parte contrária.

Estão sujeitos a essa responsabilidade: o autor, o réu e o terceiro interveniente (sujeito que ingressa no processo mediante intervenção de terceiro, voluntária ou provocada - v.g., o assistente, o litisdenunciado, o chamado ao processo etc. ${ }^{1113}$ ). $\mathrm{O}$ litisconsorte e o opoente estão incluídos nos conceitos de autor e de réu ${ }^{1114}$.

O beneficiário da justiça gratuita não é isento da obrigação de indenizar, uma vez que a hipossuficiência econômica não configura uma imunidade ${ }^{1115}$.

Podem ser sujeitos passivos da obrigação de indenizar tanto pessoas físicas, quanto pessoas jurídicas ${ }^{1116}$. Em caso de abuso do processo perpetrado por procurador municipal,

\footnotetext{
${ }^{1109}$ O Projeto de Lei no 8.046/2010, que institui o novo Código de Processo Civil, abandonou o limite de 20\% sobre o valor da causa: "O valor da indenização será desde logo fixado pelo juiz, em quantia sobre o valor da causa, ou, caso não seja possível mensurá-la desde logo, liquidada por arbitramento ou pelo procedimento comum" (art. $84, \S 2^{\circ}$ ).

${ }_{1110}$ Instituições de Direito Processual Civil, vol. II, § 528-A, p. 272, nt. 18.

1111 ABDO, O Abuso do Processo, p. 234; OLIVEIRA, Litigância de Má-Fé, p. 81.

1112 OLIVEIRA, Litigância de Má-Fé, p. 81.

1113 OLIVEIRA, Litigância de Má-Fé, pp. 69-70; DINAMARCO, Instituições de Direito Processual Civil, vol. II, § 528-A, p. 270.

${ }_{1114}$ BARBI, Comentários ao Código de Processo Civil, vol. I, § 158, p. 124.

1115 Nesse sentido: BARBI, Comentários ao Código de Processo Civil, vol. I, § 167, p. 129; OLIVEIRA, Litigância de Má-Fé, p. 72.

É o que se infere também do enunciado cível no 27 do TJSP, dirigido aos Juizados Especiais: “A gratuidade da justiça não abrange o valor devido em condenação por litigância de má-fé”.
} 
ou estadual, ou federal, ou por advogado da União, ou ainda por membro do Ministério Público $^{1117}$, a responsabilidade pelo pagamento da indenização é da Fazenda Pública municipal, estadual ou federal, com fundamento no art. $37, \S 6^{\circ}$, da CF. O ente público tem, logicamente, direito regressivo contra o seu representante nos casos de dolo ou culpa na atuação processual abusiva ${ }^{1118}$. De acordo com a doutrina, o representante do Ministério Público só pode ser pessoalmente responsabilizado por eventuais danos causados a uma das partes do processo se houver atuado com dolo ou fraude (art. 85 do CPC), não bastando o comportamento culposo ${ }^{1119}$.

Como o juiz e seus auxiliares não são partes, eles não são suscetíveis de responsabilidade por litigância de má-fé, comportando os seus abusos e infrações repressão de outra ordem (itens 3.1.4 e 3.1.5 "infra") ${ }^{1120}$.

É possível que, em um mesmo processo, mais de um sujeito processual pratique atos abusivos. Nesse caso, é necessário distinguir duas situações em que o dever de reparar as perdas e danos tem tratamento distinto ${ }^{1121}$ :

a) se os sujeitos processuais realizaram condutas abusivas independentes entre si, devem ocorrer condenações autônomas, de modo que cada sujeito responda pelos danos que a sua própria infração produziu. Exemplo: o réu deduziu defesa que sabia ser

${ }^{1116}$ Em Portugal, a doutrina diverge a respeito da interpretação do art. 458 do CPC português, que possui o seguinte teor: "Quando a parte for um incapaz, uma pessoa colectiva ou uma sociedade, a responsabilidade das custas, da multa e da indemnização recai sobre o seu representante que esteja de má fé na causa".

Segundo Menezes Cordeiro (Litigância de Má-Fé, Abuso do Direito de Ação e Culpa "in Agendo", pp. 58 e 60), esse dispositivo legal estabelece que uma pessoa jurídica não pode ser condenada como litigante de máfé, devendo a sanção recair sobre a pessoa física que a representa em juízo. O jurista menciona diversos julgados nesse sentido, inclusive do Supremo Tribunal de Justiça de Portugal.

Já Albuquerque (Responsabilidade Processual por Litigância de Má Fé, Abuso de Direito e Responsabilidade Civil em Virtude de Actos Praticados no Processo, pp. 59-64) adota uma interpretação diferente. Na sua opinião, o art. 458 do CPC português estatui que o representante da pessoa jurídica só responde pela litigância de má-fé se ele próprio atuar com má-fé. Ou seja, o representante pode ser responsabilizado apenas se tiver atuado com culpa pessoal e na medida dessa culpa. Caso não se prove sua má-fé, quem responde é a pessoa jurídica representada. De acordo com o autor, essa tese foi adotada pelo Tribunal Constitucional português.

${ }^{1117}$ De acordo com Dinamarco (Instituições de Direito Processual Civil, vol. II, § 528-A, p. 271, nt. 16; e p. 274), a Fazenda Pública litiga de má-fé quando insiste em cobrar judicialmente contribuições tributárias que reiteradamente os tribunais venham declarando indevidas, bem como quando interpõe recursos excessivos, insistindo repetidamente em teses já superadas pela jurisprudência. Quanto ao Ministério Público, ele pode litigar de má-fé ajuizando ações civis públicas de modo temerário, ou por vaidade, ou ainda por sensacionalismo.

${ }_{1118}$ Nesse sentido: CASTRO FILHO, Abuso do Direito no Processo Civil, p. 146; OLIVEIRA, Litigância de Má-Fé, pp. 42 e 70; ABDO, O Abuso do Processo, p. 231.

${ }^{1119}$ NERY JÚNIOR; ANDRADE NERY, Código de Processo Civil Comentado e Legislação Extravagante, p. 320; BEDAQUE, Comentários ao art. 85 do CPC, in MARCATO (coord.), Código de Processo Civil Interpretado, p. 188.

${ }^{1120}$ DINAMARCO, Instituições de Direito Processual Civil, vol. II, § 528-A, p. 273; OLIVEIRA, Litigância de Má-Fé, p. 70.

${ }_{1121}$ BARBOSA MOREIRA, A Responsabilidade das Partes por Dano Processual no Direito Brasileiro, in Temas de Direito Processual, pp. 31-32. 
infundada e o autor procedeu de modo temerário em um incidente processual. Cada uma das partes responde em face da outra pelos danos que a sua respectiva conduta abusiva causou, podendo haver compensação entre os valores das indenizações recíprocas ${ }^{1122}$;

b) se os sujeitos processuais praticaram, ambos, a mesma infração, eles devem sofrer uma só sanção. Trata-se da hipótese regulada pelo art. 18, § $1^{\circ}$, do CPC, que determina a distribuição da responsabilidade por perdas e danos do seguinte modo $^{1123}$ : (1) se houve conluio entre os sujeitos para lesar a parte contrária, eles devem ser condenados solidariamente, podendo-se exigir de qualquer um deles o pagamento do valor por inteiro; (2) se não ficar caracterizado tal conluio, cada litigante deve ser condenado proporcionalmente ao seu respectivo interesse na causa ("verbi gratia", se dois corréus, que possuem interesses equivalentes, opõem resistência injustificada ao andamento do processo de maneira autônoma, cada um deles deve responder pela metade do valor devido a título de indenização) ${ }^{11241125}$.

O credor da indenização é a parte que sofreu comprovado prejuízo em razão do ato abusivo. Em geral, é a parte contrária, mas também pode ser um litisconsorte da parte que praticou o ato abusivo ou um seu assistente (e.g., quando autor e réu utilizam o processo para conseguir objetivo ilegal, causando prejuízo ao assistente de um deles) ${ }^{1126}$.

Se houver pluralidade de prejudicados, cada um deve ter o seu respectivo prejuízo ressarcido de maneira integral ${ }^{1127}$. Saliente-se que eles não são credores solidários do valor devido pelo "improbus litigator". Se o juiz, no caso concreto, não tiver condições de estabelecer o montante do prejuízo de cada um, ele deve dividir a quantia integral devida a

\footnotetext{
${ }^{1122}$ No mesmo sentido: OLIVEIRA, Litigância de Má-Fé, p. 72.

${ }^{1123}$ BARBI, Comentários ao Código de Processo Civil, vol. I, § 169, p. 130.

${ }^{1124} \mathrm{O}$ art. 97 do CPC italiano prevê norma similar à contida no art. 18, § $1^{\circ}$, do CPC nacional, estatuindo que, se mais de um litigante agir ou resistir em juízo com má-fé ou culpa grave e sucumbir, o juiz deve condenálos na proporção do respectivo interesse na causa (entendido como interesse por um determinado provimento judicial e pelas vantagens patrimoniais e morais dele decorrentes). No caso de os litigantes ímprobos terem interesse comum, o juiz pode pronunciar condenação solidária entre eles. O "interesse comum" pode consistir em um idêntico interesse pessoal no provimento judicial, bem como pode resultar da identidade de questões levantadas e discutidas ou da convergência das condutas defensivas. A avaliação da sua presença no caso concreto está inserida no âmbito do poder discricionário do magistrado italiano. A condenação solidária pode ser pronunciada mesmo se não houver pedido explícito nesse sentido. Se a sentença silenciar a respeito da repartição do dever de ressarcir entre os litigantes ímprobos, o $\S 2^{\circ}$ desse mesmo dispositivo legal estatui que ela deve ser feita em quotas iguais (CARPI; COLESANTI; TARUFFO, Commentario Breve al Codice di Procedura Civile, p. 289).

${ }^{1125}$ A mesma norma que consta, atualmente, do $\S 1^{\circ}$ do art. 18 do CPC está prevista no $\S 1^{\circ}$ do art. 84 do Código de Processo Civil projetado (Projeto de Lei no 8.046/2010).

${ }^{1126}$ Por causa disso, a doutrina afirma que onde se lê "parte contrária", no "caput" e no $\S 1^{\circ}$ do art. 18 do CPC, deve-se ler "parte prejudicada". Nesse sentido: BARBOSA MOREIRA, A Responsabilidade das Partes por Dano Processual no Direito Brasileiro, in Temas de Direito Processual, pp. 32-33; TORNAGHI, Comentários ao Código de Processo Civil, vol. I, p. 157; ABDO, O Abuso do Processo, pp. 231-232; OLIVEIRA, Litigância de Má-Fé, pp. 72-73.

${ }^{1127}$ ABDO, O Abuso do Processo, p. 232.
} 
título de indenização em partes iguais entre os vários prejudicados, como manda o art. 257 do $\mathrm{CC}^{11281129}$.

É importante lembrar que a aplicação das sanções previstas para o litigante de máfé independe do teor do julgamento da demanda. Para que uma parte seja sancionada por abuso de situação jurídica processual não é necessário que ela tenha sucumbido no processo (item 1.7 "supra”). Desse modo, a parte que cometeu ato de litigância de má-fé pode ser condenada a ressarcir os danos causados à outra parte e a pagar os honorários advocatícios e a multa prevista no art. 18 do CPC ainda que ela tenha obtido sentença de mérito totalmente favorável ao seu pedido inicial ${ }^{1130}$.

\subsubsection{Cominação do dever de indenizar e cobrança da quantia devida}

Preliminarmente, deve-se salientar que o "caput" do art. 18 do CPC, com redação dada pela Lei $\mathrm{n}^{\circ} 8.952 / 94$, autoriza o magistrado a fixar de ofício a obrigação de indenizar as perdas e danos decorrentes da litigância de má-fé, independentemente de qualquer pedido da parte lesada ${ }^{1131} 11321133$.

1128 “Art. 257. Havendo mais de um devedor ou mais de um credor em obrigação divisível, esta presume-se dividida em tantas obrigações, iguais e distintas, quantos os credores ou devedores".

${ }^{1129}$ BARBOSA MOREIRA, A Responsabilidade das Partes por Dano Processual no Direito Brasileiro, in Temas de Direito Processual, p. 33.

${ }^{1130}$ ABDO, O Abuso do Processo, pp. 230-231; BARBOSA MOREIRA, A Responsabilidade das Partes por Dano Processual no Direito Brasileiro, in Temas de Direito Processual, p. 25; THEODORO JÚNIOR, Abuso de Direito Processual no Ordenamento Jurídico Brasileiro, in Revista Forense, v. 344, p. 48; LUCON, Abuso do Exercício do Direito de Recorrer, in NERY JÚNIOR; ALVIM WAMBIER (coords.), Aspectos Polêmicos e Atuais dos Recursos Cíveis e de Outras Formas de Impugnação às Decisões Judiciais, p. 892; VINCENZI, A Boa-Fé no Processo Civil, p. 100; BARBI, Comentários ao Código de Processo Civil, vol. I, § 168, p. 130; REIS, Código de Processo Civil Anotado, vol. II, pp. 255, 258 e 270.

${ }^{1131}$ ABDO, O Abuso do Processo, pp. 233-234; LUCON, Abuso do Exercício do Direito de Recorrer, in NERY JÚNIOR; ALVIM WAMBIER (coords.), Aspectos Polêmicos e Atuais dos Recursos Cíveis e de Outras Formas de Impugnação às Decisões Judiciais, p. 893; BEDAQUE, Comentários ao art. 18 do CPC, in MARCATO (coord.), Código de Processo Civil Interpretado, p. 64.

${ }^{1132}$ Os juristas que lidaram com a problemática do abuso do processo no Código de Processo Civil de 1939 discordavam acerca da possibilidade de o juiz cominar de ofício a multa e o dever de ressarcimento das perdas e danos. Havia três correntes a respeito dessa questão:

a) uma delas sustentava que o juiz somente podia condenar ao pagamento das perdas e danos e ao pagamento do décuplo das custas se houvesse pedido da parte lesada pela conduta abusiva, feito por meio de reconvenção;

b) outra defendia que o juiz podia aplicar essas sanções "ex officio", no mesmo processo;

c) por fim, alguns autores pregavam uma solução mista para o problema. Castro Filho (Abuso do Direito no Processo Civil, pp. 208-209), por exemplo, defende que o juiz podia proceder "ex officio" com relação às sanções consistentes em multa e custas agravadas que revertessem ao Estado, dado o caráter penal dessas punições e o interesse público em jogo, enquanto as sanções consistentes em multa que revertesse em favor da parte (arts. 817 e 978 do CPC39), reembolso de despesas (art. 63, "caput" e $\S 1^{\circ}$, do CPC39) e perdas e danos (art. $3^{\circ}$ do CPC39) somente podiam ser aplicadas se a parte lesada requeresse ao juiz, em qualquer fase do processo no qual a conduta abusiva tivesse sido cometida. $O$ jurista alerta que a exigência de que as sanções processuais fossem discutidas em sede de reconvenção gerava o risco de as condutas abusivas 
Em regra, a cominação da obrigação de indenizar os prejuízos oriundos do abuso processual deve constar de um capítulo próprio no dispositivo da sentença ou do acórdão, em atenção ao princípio da concentração da decisão ${ }^{1134}$. Nesse capítulo, o órgão jurisdicional deve explicitar qual hipótese típica de abuso foi praticada pela parte no caso

ficarem impunes, caso o momento procedimental para apresentar a reconvenção já tivesse passado, ou caso o procedimento não admitisse a demanda reconvencional (art. 192 do CPC39), ou ainda caso se entendesse que aquela não era hipótese de cabimento de reconvenção (art. 190 do CPC39).

Quando entrou em vigor o Código de Processo Civil de 1973, essa dissensão continuou, uma vez que o texto do artigo 18 estatuía apenas que: "o litigante de má-fé indenizará à parte contrária os prejuízos que esta sofreu, mais os honorários advocatícios e todas as despesas que efetuou".

Uma parte da doutrina defendia a necessidade do pedido, embasada tanto na ideia de que o direito à indenização das perdas e danos tem natureza patrimonial, disponível, não podendo o magistrado impor a sanção dos arts. 16 e 18 do CPC sem o pedido explícito da parte interessada (BUZAID, Processo e Verdade no Direito Brasileiro, in Revista de Processo, no 47, p. 97), quanto no argumento de que o princípio geral que proíbe o juiz de julgar "ex officio" só fica afastado diante de regra inequívoca (como a dos arts. 20, "caput" e $\S 1^{\circ}$; e 538, parágrafo único, do $\mathrm{CPC}$ ), de modo que a redação do art. 18 do CPC se compadece com ele (BARBOSA MOREIRA, A Responsabilidade das Partes por Dano Processual no Direito Brasileiro, in Temas de Direito Processual, p. 30).

Já a outra parcela dos doutrinadores sustentava a dispensabilidade do pedido expresso de ressarcimento dos danos. Em obra publicada em 1974, Tornaghi (Comentários ao Código de Processo Civil, vol. I, pp. 150 e 157) afirma que, se as disposições dos arts. 16 e 18 do CPC apenas estabelecessem a responsabilidade civil por dano, elas seriam normas de Direito material e estariam deslocadas num Código de Processo Civil. Na verdade - ensina o autor -, essas normas funcionam como preceitos cujo destinatário é o juiz, estatuindo que ele condenará o litigante de má-fé a ressarcir o prejuízo causado por seu procedimento ímprobo, sem necessidade de ação própria ou de pedido da parte prejudicada.

As opiniões dos ministros do Superior Tribunal de Justiça a respeito desse tema eram igualmente divididas (consultar, por exemplo, contra a condenação de ofício, os seguintes julgados: STJ, $1^{\mathrm{a}}$ Turma, REsp 48988/SP, Rel Min. Cesar Asfor Rocha, DJ 15/08/1994, p. 20307; STJ, $1^{\text {a }}$ Turma, REsp 51896/RS, Rel. Min. Cesar Asfor Rocha, DJ 21/11/1994, p. 31723; STJ, $3^{\text {a }}$ Turma, REsp 3098/RS, Rel. Min. Cláudio Santos, DJ 17/09/1990; STJ, $3^{\text {a }}$ Turma, REsp 11530/SP, Rel. Min. Eduardo Ribeiro, DJ 09/09/1991, p. 12201; STJ, $3^{\text {a }}$

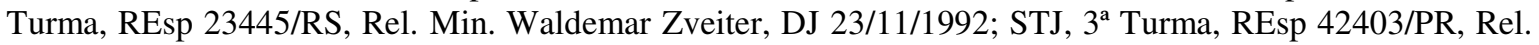
Min. Waldemar Zveiter, DJ 27/06/1994, p. 16975; STJ, 5a Turma, REsp 27873/SP, Rel. Min. Assis Toledo, DJ 09/11/1992. Em sentido contrário: STJ, $1^{\text {a }}$ Turma, REsp 55187/SP, Rel. Min. Humberto Gomes de Barros, DJ 28/11/1994, p. 32586; STJ, $2^{\text {a }}$ Turma, REsp 13722/SP, Rel. Min. Antônio de Pádua Ribeiro, DJ 13/06/1994, p. 15094; STJ, $4^{\text {a }}$ Turma, Resp 17608/SP, Rel. Min. Athos Carneiro, DJ 03/08/1992; STJ, $4^{\mathrm{a}}$ Turma, REsp 23384/RJ, Rel. Min. Fontes de Alencar, DJ 30/08/1993, p. 17297; STJ, 2a Seção, EREsp 36718/RS, Rel. para Acórdão Min. Sálvio de Figueiredo Teixeira, DJ 13/02/1995, p. 2195).

A alteração que as Leis $n^{\text {os }}$ 8.952/94 e 9.668/98 fizeram no art. 18 do CPC, inserindo a expressão "de ofício ou a requerimento", serviu para encerrar essa discussão acerca da possibilidade de condenação do litigante de má-fé de ofício pelo magistrado (BARBI, Comentários ao Código de Processo Civil, vol. I, § 167, p. 129; PUOLI, Os Poderes do Juiz e as Reformas da Lei Processual Civil Brasileira, p. 196; OLIVEIRA, Litigância de Má-Fé, p. 76; FERNANDES DE SOUZA, Abuso de Direito Processual - uma teoria pragmática, p. 124, nt. 83).

O legislador brasileiro parece ter optado pela melhor solução, uma vez que a litigância de má-fé viola o dever de boa-fé e lealdade processual e prejudica o interesse público de compor os litígios por meio da correta aplicação da lei, ofendendo a própria administração da Justiça, pela qual o juiz tem a obrigação de velar (art. 125, III, do CPC).

${ }^{1133}$ Já em Portugal, o art. 456, § $1^{\circ}$, do CPC atribui à parte lesada pela litigância de má-fé o ônus de pleitear a indenização (MENEZES CORDEIRO, Litigância de Má-Fé, Abuso do Direito de Ação e Culpa "in Agendo”, p. 57; ALBUQUERQUE, Responsabilidade Processual por Litigância de Má Fé, Abuso de Direito e Responsabilidade Civil em Virtude de Actos Praticados no Processo, p. 48; REIS, Código de Processo Civil Anotado, vol. II, pp. 267 e 279).

${ }^{1134}$ Esse princípio está previsto no art. 459 c/c art. 458, II e III, do CPC. Estabelece que é na sentença que o magistrado deve concentrar o exame e o pronunciamento acerca de todas as questões de mérito, além da decisão pela procedência ou improcedência do pedido (DINAMARCO, Ação Rescisória contra Decisão Interlocutória, in Nova Era do Processo Civil, pp. 285-286). 
concreto. Em seguida, deve fixar o montante da indenização até o limite de $20 \%$ do valor da causa (art. 18, $\S 2^{\circ}$, do $\mathrm{CPC}$ ). Se o órgão julgador constatar que esse limite não indeniza por completo a parte lesada pelo ato abusivo, deve apenas condenar por litigância de má-fé e remeter a apuração do "quantum" da indenização à liquidação (item 3.1.1.3 "supra").

Embora a condenação decorrente da prática de litigância de má-fé deva constar sempre da sentença, se o magistrado constatar que um dos sujeitos processuais praticou uma conduta ímproba no curso do processo, é aconselhável que ele profira, imediatamente, uma decisão interlocutória declarando a abusividade do ato e subsumindo-o a um, ou alguns, dos dispositivos legais que preveem hipóteses típicas de abuso processual (arts. 17; 69; 600 do CPC etc.). Para Iucker ${ }^{135}$, essa reação imediata do juiz é salutar porque dá ao sujeito processual ímprobo a oportunidade de deixar de agir como antes e adotar uma posição mais cautelosa dali em diante. Uma vez precluso o poder de impugnar a decisão interlocutória que detecta o abuso do processo - preclusão essa que pode ser temporal (em razão do decurso "in albis" do prazo para a interposição do recurso cabível), lógica (decorrente da aquiescência à decisão ou da renúncia ao poder de interpor o recurso cabível) ou consumativa (efeito do efetivo julgamento do último recurso cabível) -, ela transita em julgado. Ao sentenciar, o juiz deve reservar um capítulo específico no dispositivo para reiterar a condenação por litigância de má-fé e também fixar o montante da indenização até o limite de $20 \%$ do valor da causa, ou então apenas remeter a apuração do "quantum" da indenização à liquidação se constatar que o limite de $20 \%$ do valor da causa não indeniza por completo a parte prejudicada pelo ato (art. $18, \S 2^{\circ}$, do CPC).

Se a prática do abuso processual for reconhecida na sentença do juízo de primeiro grau e for mantida pelo Tribunal, os ministros do Superior Tribunal de Justiça entendem que eventual recurso especial contra o capítulo do acórdão versando sobre a obrigação de indenizar prevista nos arts. 16 e 18 do CPC não pode ser conhecido porque sua apreciação implicaria o reexame do contexto fático-probatório, o que seria inviável ante o óbice da súmula $\mathrm{n}^{\mathrm{o}} 7$ do $\mathrm{STJ}^{1136}$. Apenas em casos excepcionais, quando a decisão do Tribunal " $a$ quo" a respeito da sanção por abuso do processo for manifestamente desarrazoada, é que se admite o cabimento do recurso especial (e.g., é admissível recurso especial contra acórdão

\footnotetext{
${ }^{1135}$ Litigância de Má-Fé, pp. 65-66 e 81.

1136 Nesse sentido: STJ, 4 ${ }^{\mathrm{a}}$ Turma, AgRg no AREsp 28.639/RS, Rel ${ }^{\mathrm{a}}$. Min ${ }^{\mathrm{a}}$. Maria Isabel Gallotti, DJe 27/09/2012; STJ, $2^{\text {a }}$ Turma, AgRg nos EDcl no AREsp 51.988/RS, Rel. Min. Cesar Asfor Rocha, DJe 10/08/2012; STJ, $1^{\text {a }}$ Turma, AgRg no AREsp 7.598/RS, Rel. Min. Arnaldo Esteves Lima, DJe 12/12/2011; STJ, $4^{a}$ Turma, AgRg no Ag 1.306.184/SC, Rel. Min. Luis Felipe Salomão, DJe 04/11/2011; STJ, $3^{\text {a }}$ Turma, AgRg nos EDcl no Ag 1.195.138/DF, Rel. Min. Sidnei Beneti, DJe 29/06/2010; STJ, $2^{\text {a }}$ Turma, AgRg no Ag 1.259.714/SP, Rela ${ }^{\mathrm{a}}$ Min ${ }^{\mathrm{a}}$. Eliana Calmon, DJe 16/04/2010; STJ, 5 ${ }^{\mathrm{a}}$ Turma, REsp 193.504/RS, Rel. Min. Gilson Dipp, DJ 08/11/1999 p. 87.
} 
que aplica as sanções previstas nos arts. 18 e 538, parágrafo único, do CPC à parte que opôs embargos de declaração com notório propósito de prequestionamento, ao arrepio da súmula $\mathrm{n}^{\mathrm{o}} 98$ do $\left.\mathrm{STJ}^{1137}\right)^{1138}$.

É possível promover a execução provisória (art. 475-O do CPC) do capítulo do acórdão que contém a obrigação líquida de indenizar os prejuízos oriundos do abuso processual $^{1139}$. Logicamente, uma vez transitado em julgado o capítulo da sentença ou o do acórdão que comina a obrigação líquida de reparar perdas e danos decorrentes da litigância de má-fé, ele pode ser executado definitivamente pela parte interessada ${ }^{1140}$. A execução desse título executivo é regida pelas normas relativas ao cumprimento de sentença que reconhece obrigação de pagar quantia certa (art. 475-J e ss. do CPC) ${ }^{1141}$. Caso a obrigação não seja líquida, o interessado precisa promover a atividade cognitiva tendente à quantificação do valor da condenação (incidente processual de liquidação de sentença item 3.1.1.3 "supra").

Se houver processo de execução ou fase executiva em curso, a cobrança da obrigação de reparar perdas e danos decorrentes da litigância de má-fé deve ser promovida no próprio processo, como determina o art. 739-B do CPC ${ }^{1142}$. Nesse caso, a execução do capítulo da sentença ou do acórdão que aplica o art. 18 do CPC tem autonomia completa em relação à execução em curso, pois ocorre em autos apensos ${ }^{1143}$. Incumbe à parte prejudicada pela litigância de má-fé a extração das peças processuais necessárias para

${ }^{1137}$ Nesse sentido: STJ, $1^{\text {a }}$ Turma, REsp 1.037.915/SP, Rel. Min. José Delgado, DJe 24/04/2008; STJ, $2^{\mathrm{a}}$ Turma, REsp 976.186/PR, Rel ${ }^{\mathrm{a}}$. Min ${ }^{\mathrm{a}}$. Eliana Calmon, DJe 07/04/2008; STJ, $1^{\mathrm{a}}$ Turma, REsp 1.032.488/PB, Rel. Min. José Delgado, DJe 27/03/2008; STJ, $2^{\text {a }}$ Turma, REsp 613.184/RS, Rel. Min. João Otávio de Noronha, DJ 15/08/2007, p. 257; STJ, $1^{\text {a }}$ Turma, EDcl nos EDcl no AgRg no Ag 677.304/SP, Rel. Min. Luiz Fux, DJ 14/12/2006, p. 254; STJ, $2^{\text {a }}$ Turma, REsp 760.182/RJ, Rel. Min. João Otávio de Noronha, DJ 16/10/2006, p. 349; STJ, 2 ${ }^{\mathrm{a}}$ Turma, REsp 698.762/RS, Rel ${ }^{\mathrm{a}}$. Minª ${ }^{\mathrm{a}}$ Eliana Calmon, DJ 03/10/2005, p. 209; STJ, 6a Turma, REsp 389.625/MG, Rel. Min. Fernando Gonçalves, DJ 07/04/2003, p. 347.

${ }^{1138}$ A doutrina de Reis (Código de Processo Civil Anotado, vol. II, pp. 282-283) é nesse sentido. Ele sustenta que o Supremo Tribunal de Justiça português pode alterar a decisão do tribunal de instância a respeito da litigância de má-fé, não obstante se trate de questão essencialmente fática. Mas, pondera que essa ingerência só é permitida em casos excepcionais, quando o julgamento do tribunal de instância for manifestamente injustificado.

${ }^{1139} \mathrm{O}$ capítulo da sentença que condena ao ressarcimento de perdas e danos decorrentes da litigância de máfé não pode ser executado provisoriamente porque a apelação cabível nesse caso tem efeito devolutivo e suspensivo (art. 520 do CPC).

${ }^{1140}$ IOCOHAMA, Litigância de Má-Fé e Lealdade Processual, p. 285.

${ }^{1141}$ THEODORO JÚNIOR, Curso de Direito Processual Civil, vol. II, p. 442; LUCON, Comentários ao art. 739-B do CPC, in MARCATO (coord.), Código de Processo Civil Interpretado, p. 2337; LUCON, Execução de Título Extrajudicial, p. 31; IOCOHAMA, Litigância de Má-Fé e Lealdade Processual, pp. 286-288.

${ }^{1142}$ O projeto do novo Código de Processo Civil (Projeto de Lei n ${ }^{\circ}$ 8.046/2010) estatui o mesmo no art. 736:

"Art. 736. A cobrança de multa ou de indenizações decorrentes de litigância de má-fé ou de prática de ato atentatório a dignidade da justiça será promovida no próprio processo de execução, em autos apensos, operando-se o pagamento por compensação ou por execução".

1143 LUCON, Comentários ao art. 739-B do CPC, in MARCATO (coord.), Código de Processo Civil Interpretado, p. 2337; LUCON, Execução de Título Extrajudicial, p. 31. 
justificar a medida, as quais serão autuadas em apenso ao processo executivo em curso. Dentre essas peças, deve figurar a decisão que cominou o dever de reparar as perdas e danos e fixou seu valor ${ }^{1144}$.

Não obstante o referido artigo exija, expressamente, que a execução da obrigação de ressarcir perdas e danos seja realizada em autos apensos, Oliveira ${ }^{1145}$ tem razão ao admitir que ela seja efetivada conjuntamente com a execução principal, nos mesmos autos, desde que o sujeito beneficiado pela indenização figure como exequente na execução em curso e que esta seja do tipo "execução por quantia certa". Se o beneficiário da obrigação de ressarcir perdas e danos decorrentes da litigância de má-fé for o executado, ou então se a execução principal for do tipo "execução para a entrega de coisa" ou "execução de obrigação de fazer" ou "de não fazer", a cobrança do valor da indenização deve ser promovida em autos apensos mesmo, como estatui o art. 739-B do CPC.

Caso a vítima do ato de litigância de má-fé figure como executado no processo de execução ou na fase executiva em curso, ela pode requerer, nos autos apensos, a compensação entre o montante que deve para o exequente e o valor da indenização, desde que este seja líquido ${ }^{1146}$.

\subsubsection{Possibilidade de pleitear a indenização por meio de demanda autônoma}

Durante a vigência do Código de Processo Civil de 1939, a maioria da doutrina afirmava que a indenização por perdas e danos prevista no art. $3^{\circ}$ tinha que ser pleiteada em outro processo. Apenas nos casos do art. 63 do CPC39, que cominava uma sanção menor, é que a condenação do litigante de má-fé se dava no mesmo processo.

Constatou-se, porém, que essa sistemática acabava desestimulando o prejudicado pela conduta abusiva a buscar reparação, notadamente quando o valor do seu prejuízo era pequeno $^{1147}$.

Visando a resolver esse problema, o Código de Processo Civil de 1973 estatui, em seu art. $18, \S 2^{\circ}$, que o "valor da indenização será desde logo fixado pelo juiz, em quantia não superior a $20 \%$ sobre o valor da causa".

${ }^{1144}$ LUCON, Comentários ao art. 739-B do CPC, in MARCATO (coord.), Código de Processo Civil Interpretado, p. 2337; LUCON, Execução de Título Extrajudicial, p. 30.

${ }_{1145}$ Multa no Código de Processo Civil, pp. 26-27.

1146 LUCON, Comentários ao art. 739-B do CPC, in MARCATO (coord.), Código de Processo Civil Interpretado, p. 2337; LUCON, Execução de Título Extrajudicial, p. 30; OLIVEIRA, Multa no Código de Processo Civil, p. 27; THEODORO JÚNIOR, Curso de Direito Processual Civil, vol. II, p. 442.

${ }^{1147}$ BARBI, Comentários ao Código de Processo Civil, vol. I, § 170, p. 130. 
No entanto, essa norma não pode ser encarada como um óbice legal para que o interessado busque, mediante o ajuizamento de demanda autônoma, o ressarcimento integral de danos sofridos em razão de litigância de má-fé. O intuito do legislador de 1973, ao prevê-la, foi evitar que a parte lesada pela litigância de má-fé tivesse de discutir a questão em outro processo, no qual poderia novamente ser vítima de abuso processual. Em momento algum se quis restringir as chances de obtenção do ressarcimento integral do prejuízo causado pelo abuso processual; pelo contrário, o escopo do legislador sempre foi facilitar o máximo possível a indenização. Logo, defender que a apreciação da litigância de má-fé deve ficar circunscrita ao processo onde o comportamento ímprobo ocorreu contraria a "mens legis", pois significaria uma penalização da vítima e um favorecimento do litigante ímprobo, dada a limitação dos meios de reação daquela contra o comportamento processual abusivo deste $e^{1148} 11491150$.

A correção desse entendimento é contestada por Stoco ${ }^{1151}$, para quem o magistrado que preside o processo é o único legitimado para reconhecer a litigância de má-fé nos autos. Embasado nessa premissa, ele assegura que não é possível alegar a prática de litigância de má-fé em um outro processo para fundamentar indenização autônoma quando o juiz da causa não a tenha reconhecido, sob pena de violação da coisa julgada. O que o ordenamento permite, segundo o autor, é apenas a complementação da indenização antes reconhecida, realizada por meio de outra ação e em juízo diverso.

Com o devido respeito, não parece estar totalmente correta a tese desse doutrinador. Para ser mais bem analisada, essa situação deve ser decomposta em duas: (1) na primeira, o magistrado aprecia a suspeita de litigância de má-fé, conclui por sua inexistência e, após

1148 ALBUQUERQUE, Responsabilidade Processual por Litigância de Má Fé, Abuso de Direito e Responsabilidade Civil em Virtude de Actos Praticados no Processo, pp. 65-66.

${ }^{1149}$ Consoante Baptista da Silva (Comentários ao Código de Processo Civil, vol. 1, p. 115) e Nery Júnior e Andrade Nery (Código de Processo Civil Comentado e Legislação Extravagante, p. 218), existem julgados do Tribunal de Justiça de Santa Catarina, do Tribunal de Justiça de São Paulo e do Supremo Tribunal Federal no sentido de que é possível ajuizar ação autônoma visando à indenização de dano processual, ainda que a litigância de má-fé não tenha sido decidida e sequer suscitada na ação.

${ }^{1150}$ Luso Soares (A Responsabilidade Processual Civil, pp. 182-183) ensina que, no Direito português, há hipóteses em que a indenização por ato de litigância de má-fé não só pode como deve ser fixada por outro órgão jurisdicional, mediante um outro processo. Por exemplo, se o magistrado constatar que uma das partes utilizou como prova documento falso que produziu ou fez produzir, ele deve condená-la ao pagamento da multa prevista no art. 456, $\mathrm{n}^{\mathrm{o}} 1$, do CPC português. Porém, a parte contrária somente pode pleitear a indenização do prejuízo que eventualmente sofreu (ressarcimento esse previsto no mesmo art. 456, n 1 , do CPC português) em um processo movido no juízo criminal, o qual deve utilizar o art. 457 do CPC português para determinar o conteúdo da indenização. O autor fundamenta esse seu entendimento no art. 29 do antigo Código de Processo Penal português, que possuía redação similar à do atual art. 71 do CPP português (" $O$ pedido de indemnização civil fundado na prática de um crime é deduzido no processo penal respectivo, só o podendo ser em separado, perante o tribunal civil, nos casos previstos na lei").

${ }^{1151}$ Abuso do Direito e Má-Fé Processual - aspectos doutrinários, pp. 128-131. 
o trânsito em julgado da sentença, um segundo processo é iniciado com o fim de obter novamente a indenização; (2) na segunda, o juiz nem mesmo suscita a prática de litigância de má-fé em sua sentença e, em seguida ao trânsito em julgado desta, a parte que se considera prejudicada ajuíza ação indenizatória.

Na primeira hipótese, há, sim, ofensa à coisa julgada material ${ }^{1152}$. Já no segundo caso, é lícito à parte supostamente lesada pleitear em demanda autônoma o ressarcimento dos danos que alega ter sofrido ${ }^{1153}$.

Oliveira $^{1154}$ sustenta que a demanda autônoma destinada a reclamar prejuízos decorrentes de abuso processual deve ter como causa de pedir jurídica os arts. 186 e 927 do CC (equivalentes ao art. 159 do CC16), e não os arts. 16 e 18 do CPC, que, na sua opinião, fundamentam a indenização apenas no mesmo processo em que foi constatada a conduta ímproba.

Ao que tudo indica, a jurista adota esse fundamento para a demanda autônoma porque ela pressupõe que somente comete litigância de má-fé a parte que atua com dolo ou culpa. Logo, para ela, os pressupostos de incidência do art. $16 \mathrm{c} / \mathrm{c}$ art. 18 do CPC e do art. 186 c/c art. 927 do CC são os mesmos: conduta dolosa ou culposa, dano e nexo de causalidade.

Contudo, conforme ficou consignado no item 3.1.1.1 "supra", a responsabilidade civil prevista no art. 16 do CPC é objetiva em relação ao dano, de modo que é irrelevante questionar se o litigante de má-fé teve a intenção de causá-lo ou mesmo a consciência de sua dimensão. Basta a intenção de prejudicar o processo e seu andamento por meio de alguma das condutas tipificadas no art. 17 do $\mathrm{CPC}^{1155}$.

Além disso, o entendimento de Oliveira não pode ser acolhido pelos partidários da tese de que existem hipóteses objetivas de litigância de má-fé, cujas concretizações independem de dolo ou de culpa do agente. Caso contrário, a incoerência entre as hipóteses de incidência dos arts. 16 e 18 do CPC, de um lado, e dos arts. 186 e 927 do CC, do outro, especificamente com relação ao "animus" do agente, obstaria o ressarcimento integral dos

\footnotetext{
${ }^{1152}$ Segundo Albuquerque (Responsabilidade Processual por Litigância de Má Fé, Abuso de Direito e Responsabilidade Civil em Virtude de Actos Praticados no Processo, p. 66, nt. 174), o Supremo Tribunal de Justiça português já decidiu que o pedido de condenação por litigância de má-fé não pode ser aferido em demanda autônoma se já tiver sido decidido na própria ação, a não ser que o novo processo destine-se a apreciar fatos novos ou aspectos do comportamento da parte que não tenham sido objeto do julgamento anterior.

${ }^{1153}$ É esse o entendimento de Barbosa Moreira (A Responsabilidade das Partes por Dano Processual no Direito Brasileiro, in Temas de Direito Processual, p. 30).

${ }^{1154}$ Litigância de Má-Fé, pp. 81-82.

${ }^{1155}$ DINAMARCO, Instituições de Direito Processual Civil, vol. II, § 528-A, p. 272.
} 
danos em muitos casos de improbidade processual, gerando situações de impunidade. Seria possível, por exemplo, que a demanda autônoma fosse julgada procedente com relação ao pedido de declaração da ocorrência do ato de litigância de má-fé previsto no art. 17, VI, do CPC (provocação de incidente manifestamente infundado) em processo anterior; mas improcedente quanto ao pedido de condenação ao ressarcimento de perdas e danos, por não se ter demonstrado que o sujeito processual agiu de maneira voluntária, ou com negligência ou imprudência (art. 186 do CC).

Então, para manter a coerência com a opção de seguir a teoria segundo a qual nem sempre é necessária a presença de algum elemento subjetivo (dolo ou culpa) para caracterizar o abuso processual (item 1.6.3.4 "supra"), defende-se, no presente trabalho, que a parte lesada pela litigância de má-fé deve fundamentar a demanda autônoma de ressarcimento dos danos nos arts. 16 e 18 do CPC, e não nos arts. 186 e 927 do CC.

No processo indenizatório, o autor tem o ônus de provar a ocorrência da conduta processual abusiva e também o montante do seu prejuízo material e moral ${ }^{1156}$.

Por fim, deve-se destacar que a demanda autônoma de ressarcimento dos danos sofridos em razão da litigância de má-fé precisa ser ajuizada antes do esgotamento do prazo prescricional de 3 anos previsto no art. 206, § $3^{\circ}$, V, do CC (“Art. 206. Prescreve: [...] $\S 3^{o}$ Em três anos: [...] V - a pretensão de reparação civil").

\subsubsection{Responsabilidade do réu pelo ressarcimento das perdas e danos decorrentes de abuso do poder de nomear à autoria}

$\mathrm{O}$ réu que abusa do poder de nomear à autoria, seja omitindo-se de realizar a nomeação à autoria, seja nomeando à autoria pessoa diversa daquela em nome de quem detém a coisa demandada, deve ressarcir os prejuízos causados pela sua conduta ímproba $\left(\right.$ art. 69 do CPC) ${ }^{1157}$.

Trata-se de responsabilidade civil extracontratual objetiva em relação ao dano, sendo irrelevante questionar se o demandado teve a intenção de causá-lo ou mesmo a consciência de sua dimensão. Basta à parte lesada alegar que sua demanda foi rejeitada por ser outro o titular da situação de direito material posta na inicial e demonstrar que o réu

\footnotetext{
1156 ABDO, O Abuso do Processo, p. 234.

${ }^{1157}$ O projeto do novo Código de Processo Civil (Projeto de Lei $n^{\circ} 8.046 / 2010$ ) não prevê o poder de nomear à autoria no capítulo que trata da intervenção de terceiros (arts. 308 a 322), logo, não há, nele, um dispositivo similar ao art. 69 do CPC atual.
} 
praticou alguma das condutas previstas nos incisos do art. 69 do CPC, causando-lhe prejuízo $^{1158}$.

Quanto à amplitude do dever de indenizar fundado no art. 69 do CPC, ela é similar à do dever de ressarcimento da parte litigante de má-fé (arts. 16 e 18 do CPC). Abrange tanto os danos emergentes, quanto os lucros cessantes ${ }^{1159}$, de natureza patrimonial e moral.

Na hipótese prevista no inciso I do art. 69 do CPC, são credores da indenização o autor da demanda e a pessoa que deveria ter sido nomeada à autoria. Já na hipótese do inciso II, os credores são o autor da demanda e a pessoa erroneamente nomeada à autoria (ver item 2.7 "supra").

Bedaque $^{1160}$ e Rocha ${ }^{1161}$ sustentam que o pedido indenizatório fundado no art. 69 do CPC deve ser formulado mediante demanda autônoma. Já Barbi ${ }^{1162}$ entende que, quando a conduta prevista no art. 69, II, do CPC causa prejuízo ao autor, a obrigação de ressarcir os danos pode ser imposta ao réu no mesmo processo, aplicando-se o art. 18 do CPC por analogia, uma vez que a situação se subsume nas hipóteses dos incisos II e VI do art. 17 do CPC.

Com o devido respeito, os três doutrinadores parecem se enganar. A pretensão indenizatória embasada no art. 69 do CPC pode, sim, ser deduzida no mesmo processo em que o poder de nomear à autoria foi utilizado de modo ímprobo, já que nenhum artigo do Código de Processo Civil dispõe em sentido contrário. Acontece que, quando o réu nomeia à autoria pessoa diversa daquela em cujo nome detém a coisa demandada (art. 69, II, do CPC), e esta reconhece a qualidade que lhe é atribuída (faltando com o dever de veracidade), ele não pode ser condenado, no mesmo processo, a ressarcir as perdas e danos porque não integra mais a relação jurídica processual. A partir do momento em que o nomeado é citado e reconhece a qualidade que lhe é atribuída, ele sucede o nomeante e passa a ser o réu (art. 66 do CPC).

Portanto, a pretensão indenizatória fundada no art. 69 do CPC deve ser, em regra, deduzida no mesmo processo em que o comportamento ímprobo foi praticado. A única exceção é a hipótese em que o réu nomeia à autoria pessoa diversa daquela em cujo nome detém a coisa demandada (art. 69, II, do CPC) e ela reconhece a qualidade que lhe é atribuída, ao arrepio do dever de veracidade.

1158 BEDAQUE, Comentários ao art. 69 do CPC, in MARCATO (coord.), Código de Processo Civil Interpretado, p. 146; DINAMARCO, Instituições de Direito Processual Civil, vol. II, § 599, p. 405.

${ }^{1159}$ ROCHA, Nomeação à Autoria, p. 79.

${ }^{1160}$ Comentários ao art. 69 do CPC, in MARCATO (coord.), Código de Processo Civil Interpretado, p. 146.

${ }^{1161}$ Nomeação à Autoria, p. 80.

${ }^{1162}$ Comentários ao Código de Processo Civil, vol. I, § 396, p. 252. 


\subsubsection{Responsabilidade do juiz pelo ressarcimento das perdas e danos decorrentes da prática de abuso processual}

O magistrado, no exercício da função jurisdicional, pode causar prejuízos a um dos litigantes ou a ambas as partes de um processo. Consoante o art. 133 do CPC, o juiz responde pessoalmente por perdas e danos que sejam decorrentes de: (a) conduta dolosa ou fraudulenta; ou (b) recusa, omissão ou retardamento, sem justo motivo, em determinar providência que devia ordenar de ofício ou após requerimento da parte 116311641165 .

A restrição da responsabilização do juiz apenas aos casos de dolo ou fraude e retardamento ou omissão devidamente constatados é justificada com base na garantia da atividade do órgão jurisdicional. Segundo Greco Filho ${ }^{1166}$, se houvesse responsabilidade por meros erros judiciários, ainda que culposos, a justiça ficaria comprometida porque o magistrado restaria temeroso em decidir.

O dolo previsto no inciso I do art. 133 do CPC consiste na vontade deliberada do juiz de prejudicar uma das partes, mostrando-se irrelevante o intuito por trás dessa vontade (v.g., beneficiar a parte contrária, beneficiar a si mesmo ou terceira pessoa, desejo de causar mal, desejo de vingança, mero capricho etc. $)^{1167}$. Laspro ${ }^{1168}$ observa, entretanto, que a caracterização do dolo não exige, necessariamente, o propósito de causar o mal, bastando que o agente proceda com consciência de que o seu comportamento pode ser lesivo. $\mathrm{O}$ mesmo doutrinador acrescenta que a responsabilidade do juiz pode-se fundar também em dolo eventual. Cita o exemplo do juiz que, para atender ao pedido de um amigo, concede medida liminar sem examinar o processo e causa danos ao requerido. Nesse caso, o juiz não tinha, efetivamente, a intenção de lesar a parte; mas, ao conceder a liminar naquela

\footnotetext{
${ }^{1163} \mathrm{O}$ art. 133 do CPC reproduz, em linhas gerais, a regra contida no art. 121 do CPC39. Este dispositivo, por sua vez, foi inspirado no art. 55 do Projeto definitivo do Código de Processo Civil italiano, que é o atual art. 55 do CPC da Itália (BARBI, Comentários ao Código de Processo Civil, vol. I, § 705, p. 416).

${ }^{1164} \mathrm{O}$ art. 35 do "Código Procesal Civil Modelo para Iberoamérica" e o art. 26, $1^{\mathrm{a}}$ parte, do CPC uruguaio preveem normas similares à do art. 133 do CPC: "Responsabilidade do Tribunal - Os magistrados serão responsáveis por: (1) demoras injustificadas em decidir; (2) proceder com dolo ou fraude; (3) sentenciar cometendo erro inescusável" (tradução nossa).

Nos Estados Unidos da América, em regra, os magistrados não são responsáveis por perdas e danos decorrentes de atos praticados no exercício da atividade jurisdicional. Contudo, eles podem ser responsabilizados se ficar comprovada a prática deliberada de comportamento abusivo, sem ter uma justificativa sustentável. De acordo com Hazard Jr. (Abuse of Procedural Rights: regional report for the United States, in TARUFFO (ed.), Abuse of Procedural Rights: comparative standards of procedural fairness, p. 47), a prova dessa circunstância é rara.

${ }^{1165}$ No Código de Processo Civil projetado (Projeto de Lei n ${ }^{\circ}$ 8.046/2010), essa norma consta do art. 123.

${ }^{1166}$ Direito Processual Civil Brasileiro, vol. I, p. 231.

${ }^{1167}$ BARBI, Comentários ao Código de Processo Civil, vol. I, § 706, p. 417.

${ }^{1168}$ A Responsabilidade Civil do Juiz, p. 234.
} 
circunstância, assumiu, intencionalmente, posição que poderia levar ao dano, logo deve ressarcir os prejuízos ${ }^{1169}$.

Procede com fraude o magistrado que utiliza o processo para iludir, enganar ${ }^{1170}$, causando prejuízo a uma das partes ou a terceiros ${ }^{1171}$. Cumpre mencionar a existência de crítica doutrinária à redação do art. 133, I, do CPC, no sentido de que a palavra "fraude" é supérflua. Alguns autores consideram que o dolo é suficiente para criar a responsabilidade pessoal do magistrado, independentemente da existência também de fraude. Afirma-se que a presença desta não agrava em nada a responsabilidade judicial decorrente do comportamento judicial doloso ${ }^{1172}$.

O inciso II do art. 133 do CPC prevê três condutas judiciais. Todas elas dispensam o dolo para ensejar a responsabilidade civil do magistrado que as pratica ${ }^{1173}$. De acordo com Barbi ${ }^{1174}$, elas caracterizam culpa do juiz, que não cumpre o seu dever legal de determinar providências ou de fazê-lo nos prazos da lei.

A primeira delas é a recusa do juiz, que consiste na negativa deste em praticar determinado ato requerido pela parte ${ }^{1175}$. Não fica caracterizada essa hipótese de conduta judicial culposa quando o juiz profere despacho recusando-se a tomar uma medida pleiteada por entendê-la sem base legal. Desde que aja um ato judicial indeferindo o pedido fundamentadamente, a função do juiz foi desempenhada, ainda que sua interpretação do texto da lei não esteja correta. Barbi ${ }^{1176}$ afirma que existe uma única possibilidade de recusa culposa: se o juiz proferir despacho dizendo apenas que não quer se manifestar sobre o pedido de providência feito pela parte. O mesmo doutrinador admite que, a rigor, esse caso se enquadra na hipótese de omissão.

A omissão é a conduta do magistrado que se mantém inerte, ou seja, que não toma a providência que deveria determinar de ofício, segundo a lei, ou que lhe foi anteriormente requerida por uma das partes ${ }^{1177}$.

O terceiro comportamento judicial é o retardamento, que nada mais é do que a realização de providência extemporânea, fora do prazo que a lei fixa para a sua prática ${ }^{1178}$.

\footnotetext{
${ }^{1169}$ LASPRO, A Responsabilidade Civil do Juiz, pp. 235-236.

1170 BEDAQUE, Comentários ao art. 133 do CPC, in MARCATO (coord.), Código de Processo Civil Interpretado, p. 392.

${ }^{1171}$ LASPRO, A Responsabilidade Civil do Juiz, p. 237.

1172 Nesse sentido: BARBI, Comentários ao Código de Processo Civil, vol. I, § 706, p. 417.

1173 BEDAQUE, Comentários ao art. 133 do CPC, in MARCATO (coord.), Código de Processo Civil Interpretado, p. 392.

${ }^{1174}$ Comentários ao Código de Processo Civil, vol. I, § 708, p. 418.

1175 BARBI, Comentários ao Código de Processo Civil, vol. I, § 707, p. 418.

${ }^{1176}$ Comentários ao Código de Processo Civil, vol. I, § 708, p. 418.

${ }^{1177}$ BARBI, Comentários ao Código de Processo Civil, vol. I, § 707, p. 418.
} 
Na aplicação da regra contida no art. 133, II, do CPC, não se pode fechar os olhos para a realidade. É consabido que, na prática forense, são frequentes os pequenos atrasos no despacho dos feitos, seja porque o magistrado está com excesso de serviço, seja em razão da necessidade de maior estudo para decidir questões mais complexas. Constata-se, por causa disso, uma tácita aceitação dos atrasos judiciais, de modo que o dever de indenizar perdas e danos não surge sempre que o juiz recusa, omite ou retarda, sem justo motivo, providência que devia ordenar de ofício ou a requerimento da parte. Consoante o parágrafo único do art. 133 do CPC, se ocorrer uma dessas situações, a responsabilidade civil só ocorre se: (a) a parte fizer um requerimento, por intermédio do escrivão, para que o juiz determine a providência; e (b) a inércia judicial em despachar se mantiver por mais dez dias. Caso a providência judicial seja realizada dentro do decêndio, o juiz não responde por eventuais perdas e danos causados à parte. Trata-se de uma verdadeira purgação de $\operatorname{mora}^{1179}$.

Caso o magistrado pratique as condutas previstas no inciso II do art. 133 do CPC movido por motivo justo (v.g., excesso de serviço), não há culpa e, consequentemente, também não há a responsabilidade civil ${ }^{1180}$. Theodoro Júnior ${ }^{1181}$ critica o fato de o legislador ter exigido a ausência de motivo justo como condição para que o juiz seja pessoalmente responsabilizado pelos danos decorrentes de recusa, omissão ou retardamento. Segundo o doutrinador, o juiz pode sempre encontrar um "motivo" para “justificar" seu comportamento, como por exemplo o público e notório excesso de serviço que sobrecarrega todo o Poder Judiciário brasileiro, aliado à crônica insuficiência numérica de servidores e magistrados.

O pedido de indenização das perdas e danos causados por conduta do magistrado deve ser feito mediante demanda autônoma, em processo distinto daquele no qual se deram os atos judiciais ilícitos. Na demanda indenizatória, a parte prejudicada figura como autor e o juiz, como réu ${ }^{1182}$.

Para que o juiz seja condenado com fundamento no dispositivo legal em estudo, é necessário que a parte interessada demonstre a ocorrência do dano (material ou moral), bem como da relação de causalidade entre a conduta judicial e a lesão à sua esfera

\footnotetext{
${ }^{1178}$ BARBI, Comentários ao Código de Processo Civil, vol. I, § 707, p. 418.

${ }^{1179}$ BARBI, Comentários ao Código de Processo Civil, vol. I, § 710, p. 419.

1180 BEDAQUE, Comentários ao art. 133 do CPC, in MARCATO (coord.), Código de Processo Civil Interpretado, p. 392; BARBI, Comentários ao Código de Processo Civil, vol. I, § 709, p. 418.

1181 Abuso de Direito Processual no Ordenamento Jurídico Brasileiro, in Revista Forense, v. 344, pp. 46-47.

1182 BEDAQUE, Comentários ao art. 133 do CPC, in MARCATO (coord.), Código de Processo Civil Interpretado, p. 392; BARBI, Comentários ao Código de Processo Civil, vol. I, § 712, p. 419.
} 
jurídica $^{183}$. Caso contrário, não há responsabilidade civil, o que não exclui eventual responsabilidade nas searas administrativa e penal ${ }^{1184}$.

Na prática, é bastante difícil de se encontrar uma demanda que tenha sido ajuizada com fundamento no art. 133 do CPC e julgada procedente. A doutrina afirma que isso decorre do medo que as partes têm de sofrer represálias em razão de terem acusado o juiz ${ }^{1185}$ e também da má redação do inciso II do art. 133 do CPC, que exige a ausência de "justo motivo" para a responsabilização pelas perdas e danos ${ }^{1186}$. Dessa constatação não se pode inferir, contudo, a desnecessidade de tal regra, uma vez que ela serve de advertência aos juízes brasileiros e também deixa claro à população que os magistrados não têm a prerrogativa de agir mal impunemente ${ }^{1187}$.

Por fim, é importante observar que a responsabilidade pessoal do magistrado, embasada no art. 133 do CPC, não afasta a responsabilidade civil do Estado fundada no art. $37, \S 6^{\circ}$, da CF, a qual é objetiva, independentemente de dolo ou culpa ${ }^{1188}$. Sendo assim, a pessoa lesada pelo comportamento judicial pode pleitear a indenização diretamente em face do Estado. Nesse caso, se os danos decorrerem de conduta culposa ou dolosa do juiz (art. 133 do CPC e art. 49 da LOMAN), o Estado, depois de condenado, tem direito de regresso contra ele $\left(37, \S 6^{\circ}, 2^{a} \text { parte, da } \mathrm{CF}\right)^{1189}$.

\subsubsection{Responsabilidade dos auxiliares da justiça pelo ressarcimento das perdas e danos decorrentes da prática de abuso processual}

1183 BEDAQUE, Comentários ao art. 133 do CPC, in MARCATO (coord.), Código de Processo Civil Interpretado, p. 392.

1184 BARBI, Comentários ao Código de Processo Civil, vol. I, § 711, p. 419.

1185 Esse não é um fenômeno exclusivamente brasileiro, sendo encontrado também em outros países (TAELMAN, Abuse of Procedural Rights: regional report for Belgium-The Netherlands, in TARUFFO (ed.), Abuse of Procedural Rights: comparative standards of procedural fairness, p. 144; NORMAND, Final Report: the two approaches to the abuse of procedural rights, in TARUFFO (ed.), Abuse of Procedural Rights: comparative standards of procedural fairness, p. 247).

1186 THEODORO JÚNIOR, Abuso de Direito Processual no Ordenamento Jurídico Brasileiro, in Revista Forense, v. 344, pp. 46-47 e 63.

${ }^{1187}$ Nesse sentido: BARBI, Comentários ao Código de Processo Civil, vol. I, § 705, p. 417.

1188 BEDAQUE, José Roberto dos Santos. Comentários ao art. 133 do CPC. In MARCATO, Antonio Carlos (coord.). Código de Processo Civil Interpretado. $3^{\text {a }}$ ed. São Paulo: Atlas, 2008, p. 392, p. 392.

${ }^{1189}$ Porém, nem toda a doutrina concorda com isso. Greco Filho (Direito Processual Civil Brasileiro, vol. I, p. 232) cita dois motivos para negar a incidência do art. $37, \S 6^{\circ}$, da CF nos casos previstos nos incisos do art. 133 do CPC. Em primeiro lugar, afirma que o magistrado não é funcionário público em sentido estrito, logo sua atividade não está regulada no capítulo da Constituição Federal onde se encontra o referido artigo 37, que trata dos funcionários públicos. Aduz que a responsabilidade do juiz e do próprio Estado pela atividade jurisdicional nem mesmo se encontra dentro do âmbito de incidência do art. $37, \S 6^{\circ}$, da $\mathrm{CF}$, pois esse dispositivo admite o direito de regresso no caso culpa e o juiz não poderia responder por eventuais erros judiciais culposos, sob pena de comprometimento de todo o sistema de aplicação do direito. 
Quando um auxiliar da justiça, no exercício de sua função, pratica um ato abusivo e lesa uma das partes, o Estado responde objetivamente pela conduta danosa, com fundamento no art. $36, \S 6^{\circ}$, da CF. Dinamarco ${ }^{1190}$ esclarece que a responsabilidade do Estado ocorre inclusive se o dano for causado por auxiliar eventual (v.g., perito, intérprete, arbitrador, conciliador), uma vez que ele exerce função estatal, apesar de ser profissional autônomo. Se o comportamento causador do dano for doloso ou culposo, esse mesmo dispositivo constitucional garante ao Estado o direito de regresso contra o auxiliar da justiça.

Além dessa responsabilidade objetiva do Estado perante o jurisdicionado, o ordenamento jurídico brasileiro prevê a responsabilidade civil subjetiva dos auxiliares da justiça perante a parte lesada pelo abuso processual. Versam sobre esse tema os arts. 144, 147 e 150 do CPC.

$\mathrm{O}$ art. 144 do CPC prevê a responsabilidade civil do escrivão e do oficial de justiça pelos comportamentos ímprobos omissivos e comissivos descritos em seus dois incisos ${ }^{1191}$.

O escrivão (ou secretário, ou diretor de secretaria, ou chefe de secretaria ${ }^{1192}$ ) é considerado o mais importante dos elementos que compõem o juízo, depois, é claro, do juiz $^{1193}$. Ele é o diretor de uma unidade funcional judiciária, ou repartição pública, que é o cartório ou secretaria do juízo ${ }^{1194}$. Sua principal atividade é a de documentação, sendo ele incumbido de redigir inúmeras peças do processo, termos, autos etc., e de reuni-las, juntamente com outras elaboradas pelas partes, pelo juiz e por outros auxiliares da justiça, formando os autos.

Depois do escrivão, o oficial de justiça (também chamado de "meirinho") é tido como o mais necessário dos auxiliares da justiça. Ele é titular de diversos poderes-deveres que o impelem a realizar diligências processuais necessárias para o julgamento da demanda, as quais devem ser praticadas fora do local onde trabalham o juiz e o escrivão $^{1195}$. O oficial de justiça efetua essas diligências sempre no cumprimento de ordens

\footnotetext{
${ }^{1190}$ Instituições de Direito Processual Civil, vol. I, § 342, p. 667.

${ }^{1191}$ Se o Projeto de Lei $n^{\circ} 8.046 / 2010$ for aprovado, sancionado e publicado com sua redação atual, essa regra constará do art. 134 do novo Código de Processo Civil.

1192 Essa denominação consta dos arts. 159, § $1^{\circ} ; 166$ e ss. (rubrica da seção); 223 e 438 do CPC (DINAMARCO, Instituições de Direito Processual Civil, vol. I, § 348, p. 676, nt. 6).

${ }^{1193}$ BARBI, Comentários ao Código de Processo Civil, vol. I, § 765, p. 451.

${ }^{1194}$ DINAMARCO, Instituições de Direito Processual Civil, vol. II, § 516, p. 249.

1195 Nas palavras de Barbi (Comentários ao Código de Processo Civil, vol. I, § 773, p. 456), o oficial de justiça é "o braço com que o juiz toma as medidas de ordem material que a causa exigir".
} 
do juiz, expressas em mandados redigidos pelo cartório e assinados pelo escrivão (arts. 225 e 577 do CPC $)^{1196}$.

Consoante o inciso I do art. 144 do CPC, o escrivão e o oficial de justiça são civilmente responsáveis quando, sem justo motivo, se recusam a cumprir dentro do prazo: (a) os atos que lhes impõe a lei ${ }^{1197}$; ou (b) os atos que o juiz a que estão subordinados lhes comete (art. 141, II; e art. 143, II, do CPC). A aplicação dessa norma prescinde de recusa expressa do auxiliar da justiça em praticar o ato. Basta o decurso do prazo "in albis"1198.

O próprio art. 144, I, do CPC, lido "a contrario sensu", estatui que a ocorrência de justo motivo exclui a obrigação indenizatória. Barbi ${ }^{1199}$ ensina que se deve considerar "justo" qualquer motivo que leve ao atraso sem culpa do escrivão ou do oficial de justiça, como, por exemplo, o excesso de serviço. Porém, o mesmo jurista adverte que não se pode considerar como justificada a recusa fundada no entendimento pessoal de que a ordem do juiz é incorreta. Isso porque o auxiliar que cumpre uma ordem judicial não tem responsabilidade perante a parte, visto que se limita a executar determinação de autoridade que lhe é superior hierarquicamente.

${ }^{1196}$ DINAMARCO, Instituições de Direito Processual Civil, vol. I, § 349, pp. 677-678; DINAMARCO, Instituições de Direito Processual Civil, vol. II, § 517, p. 249.

${ }^{1197} \mathrm{O}$ art. 141 do CPC fixa os seguintes poderes-deveres do escrivão: (a) redigir, em forma legal, os ofícios, mandados, cartas precatórias e demais atos que pertencem ao seu ofício ( $v . g$., alvarás, autos, termos, assentadas de testemunhas, depoimentos das testemunhas e das partes etc.); (b) executar as ordens judiciais, promovendo citações (quando tiverem de ser praticadas pelo correio ou por edital, nos termos dos arts. $223 \mathrm{e}$ 232, II, do CPC) e intimações (art. 237 do CPC), bem como praticando todos os demais atos que lhe forem atribuídos pelas normas de organização judiciária; (c) comparecer às audiências para documentar o trabalho nelas realizado (v.g., lavratura do termo de audiência, previsto no art. 457 do CPC; lavratura do termo de inquirição de testemunhas etc.) ou, não podendo fazê-lo, designar para substituí-lo escrevente juramentado, de preferência datilógrafo ou taquígrafo; (d) ter os autos sob sua guarda e responsabilidade; e (e) fornecer, independentemente de despacho, certidão de qualquer ato ou termo do processo. Compete-lhe também a realização dos atos administrativos e de impulso processual "sem caráter decisório" que o juiz lhe delegar (art. 93, XIV, da CF) (DINAMARCO, Instituições de Direito Processual Civil, vol. I, § 348, p. 676; DINAMARCO, Instituições de Direito Processual Civil, vol. II, § 516, p. 249).

Por força do art. 143 do CPC, o oficial de justiça é titular destes poderes-deveres: (a) realizar pessoalmente atos de comunicação processual (citações e intimações) e de constrição judicial sobre pessoas ou coisas (v.g., prisão civil, penhora, arrecadação em processo falimentar, arresto, sequestro, busca-e-apreensão etc.) e mais diligências próprias do seu ofício ( $v$.g., constatações, como a determinada para o fim de verificar o abandono do imóvel na pendência da ação de despejo - art. 66 da Lei $n^{\circ}$ 8.245/91), certificando no mandado os fatos ocorridos nas diligências realizadas (v.g., não localização do citando, recusa do citando em receber a citação, ocultação do citando, falta de condições da pessoa para receber a citação ou a intimação etc.), com menção de lugar, dia e hora; (b) executar as ordens do juiz a que estiver subordinado (e.g., transportar autos, quando o lugar de trabalho do juiz não for junto ao cartório; entregar autos ao Tribunal, em decorrência da interposição de recurso); (c) entregar, em cartório, o mandado, logo depois de cumprido; (d) estar presente às audiências e coadjuvar o juiz na manutenção da ordem (v.g., apregoar partes e testemunhas; se alguma pessoa perturbar a audiência e o juiz determinar a sua retirada, cabe ao oficial de justiça executar essa ordem); e (e) escolher o bem a penhorar e avaliar o bem penhorado, exceto se o magistrado tiver estabelecido alguma determinação específica ou a parte tiver feito regular indicação (DINAMARCO, Instituições de Direito Processual Civil, vol. I, § 349, p. 677; DINAMARCO, Instituições de Direito Processual Civil, vol. II, § 517, pp. 249-250; BARBI, Comentários ao Código de Processo Civil, vol. I, §§ 776 e 778, p. 457).

${ }^{1198}$ BARBI, Comentários ao Código de Processo Civil, vol. I, § 780, p. 458.

${ }^{1199}$ Comentários ao Código de Processo Civil, vol. I, § 780, p. 458. 
No item II do art. 144 do CPC está prevista a responsabilidade civil do escrivão e do oficial de justiça pela prática de ato nulo com dolo ou culpa.

A simples realização de um ato nulo não implica necessariamente o dever de reparar eventual dano dele decorrente. É essencial que o escrivão ou o oficial de justiça tenha agido com dolo (intenção de praticar o ato viciado) ou culpa (negligência, imprudência ou imperícia) ${ }^{1200}$. De acordo com Barbi ${ }^{1201}$, considera-se culposo o ato praticado em desacordo com o texto expresso da lei, pois demonstra imperícia (v.g., penhora realizada com arrombamento de casa e de móveis sem ordem do juiz, por apenas um oficial de justiça e sem a presença de testemunhas, afrontando os arts. 660 e 661 do CPC).

Para que haja responsabilidade civil do escrivão ou do oficial de justiça é necessário que o seu comportamento tenha causado algum dano a uma das partes do processo. Caso não se demonstre a ocorrência de qualquer prejuízo, o art. 144 do CPC não incide $^{1202}$.

A pretensão indenizatória deve ser objeto de processo autônomo, distinto daquele no qual ocorreu o ato ilícito. Os debates acerca da prática do ato lesivo, da existência de dano, bem como da extensão deste tumultuariam todo o processo, apesar de serem do interesse apenas da parte lesada e do auxiliar da justiça. Daí o acerto da necessidade de se pleitear a responsabilidade civil em demanda autônoma ${ }^{1203}$.

No art. 147 do CPC, está prevista a obrigação de o perito ressarcir os danos que sua conduta abusiva, dolosa ou culposa, causar à parte ${ }^{1204}$.

O perito é indispensável para o exame de coisas ou pessoas quando o magistrado não tem conhecimentos técnicos ou científicos especializados para isso (v.g., conhecimentos de engenharia, economia, medicina, odontologia, contabilidade etc.) (arts. 145 e 335 do CPC) ${ }^{1205}{ }^{1206}$. Trata-se de um auxiliar eventual da justiça, uma vez que ele

\footnotetext{
${ }^{1200}$ BARBI, Comentários ao Código de Processo Civil, vol. I, § 781, pp. 458-459.

${ }^{1201}$ Comentários ao Código de Processo Civil, vol. I, \$ 781, p. 459.

1202 BARBI, Comentários ao Código de Processo Civil, vol. I, § 779, p. 458.

${ }^{1203}$ BARBI, Comentários ao Código de Processo Civil, vol. I, § 782, p. 459.

1204 O Projeto de Lei $n^{\circ} 8.046 / 2010$, em trâmite no Congresso Nacional, que versa sobre o novo Código de Processo Civil, prevê norma similar em seu art. 137.

1205 DINAMARCO, Instituições de Direito Processual Civil, vol. I, § 356, pp. 682 e 683; BARBI, Comentários ao Código de Processo Civil, vol. I, § 783, p. 460.

${ }^{1206} \mathrm{O}$ "caput" do art. 145 do CPC estatui o seguinte: "Quando a prova do fato depender de conhecimento técnico ou científico, o juiz será assistido por perito [...]” (destaque nosso). Não obstante o texto legal dê a entender que o magistrado deve, obrigatoriamente, ser assistido pelo perito sempre que a prova do fato depender de conhecimentos técnicos ou científicos, a doutrina entende que apenas quando o juiz não tem esses conhecimentos é que realmente se mostra necessária a atuação do referido auxiliar da justiça no processo. De fato, quando o juiz possui os conhecimentos necessários para decidir a demanda, a assessoria do
} 
colabora no processo por escolha e nomeação do juiz, em cada caso concreto (art. 421 do CPC) $)^{1207}$.

O conceito amplo de "perito" abrange também o avaliador e o arbitrador ${ }^{1208}$. A avaliação tem por objeto coisas móveis ou imóveis e é realizada na execução forçada (arts. 680 e ss; art. 722 do CPC), no inventário ou arrolamento de bens (arts. 1.033; 1.035, parágrafo único; e 1.036, $\S 1^{\circ}$, do CPC), nos processos de alienação judicial (art. 1.114 do CPC), na execução fiscal (arts. $7^{\circ}, \mathrm{V}$; e 13 da Lei $n^{\circ}$ 6.830/80), nas desapropriações imobiliárias (arts. 23 e ss. do Decreto-lei n 3.365/41) etc. Já o arbitramento diz respeito ao valor de serviços, de atividades ou de bens imateriais em geral, estando previsto na liquidação por arbitramento (art. 475-D do CPC); na apuração do valor das obrigações de fazer não-cumpridas, para os fins do art. 634 do CPC; e nas ações demarcatórias (art. 956 do CPC). Nem o avaliador, nem o arbitrador, precisa ter conhecimentos científicos profundos ou formação universitária. Ambos se sujeitam à disciplina geral do perito, inclusive com relação à remuneração, aos deveres e às responsabilidades ${ }^{1209}$.

Há, ainda, uma função análoga à do perito, que é a do intérprete. Barbi ${ }^{1210}$ ensina que ele é um verdadeiro perito ao qual o legislador preferiu dar tratamento separado, em razão das peculiaridades de sua função. O art. 151 do CPC incumbe o intérprete de: (a) analisar documento de entendimento duvidoso, redigido originalmente em língua estrangeira $^{1211}$; (b) verter em português as declarações verbais das partes e das testemunhas que não conhecerem o idioma nacional, bem como traduzir para a língua que a parte ou a testemunha saiba falar as perguntas feitas pelo magistrado e pela parte contrária na audiência; (c) traduzir a linguagem mímica dos surdos-mudos, desde que estes não possam

perito se mostra desnecessária, pois: caso as conclusões do perito estiverem em desacordo com o entendimento do magistrado, este pode não as acolher (art. 436 do CPC); por outro lado, se o laudo pericial se harmonizar com o entendimento do magistrado, ele se mostra inútil, uma vez que o juiz pode limitar-se a expor seus próprios motivos na sentença, sem se referir ao trabalho do perito (BARBI, Comentários ao Código de Processo Civil, vol. I, § 784, p. 461).

${ }^{1207}$ DINAMARCO, Instituições de Direito Processual Civil, vol. I, § 356, pp. 682 e 684.

${ }^{1208}$ Isso justifica o fato de o legislador, algumas vezes, se referir ao avaliador e ao arbitrador como "perito" (v.g., arts. 475-D; 722; e 1.114 do CPC). De acordo com Dinamarco (Instituições de Direito Processual Civil, vol. I, § 357, p. 684), o avaliador e o arbitrador são "peritos menores".

${ }_{1209}$ DINAMARCO, Instituições de Direito Processual Civil, vol. I, § 357, pp. 684-685.

${ }^{1210}$ Comentários ao Código de Processo Civil, vol. I, § 806, p. 472.

1211 Os doutrinadores salientam que essa atividade do intérprete não se confunde com a desenvolvida pelo tradutor público. Este elabora versões em português de documentos redigidos em língua estrangeira, possibilitando que estes sejam juntados aos autos (art. 157 do CPC). Somente se, no processo, for suscitada dúvida sobre a tradução, em alguma parte do texto, e o juiz não tiver conhecimento para solucioná-la, é que se nomeia um intérprete. Em suma: a função do intérprete no processo não é a de traduzir documentos escritos em língua que não a portuguesa, mas sim a de esclarecer eventuais dúvidas surgidas na tradução anteriormente apresentada (BARBI, Comentários ao Código de Processo Civil, vol. I, \$§ 802 e 803, pp. 470471). 
transmitir sua vontade por escrito, e também traduzir para essa linguagem as perguntas que o magistrado e a parte contrária fizerem ao depoente surdo-mudo ao longo da audiência. Caso o magistrado consiga, pessoalmente, realizar essas atividades, não é preciso o auxílio do intérprete ${ }^{1212}$. Todo intérprete, oficial ou não ${ }^{1213}$, uma vez nomeado pelo juiz, é obrigado a exercer a sua função (arts. 153 e 339 do CPC), salvo escusa por motivo legítimo $^{1214}$.

Se o perito (em sentido amplo) ou o intérprete, dolosa ou culposamente, prestar informações inverídicas no desempenho de sua função, ele fica sujeito a diversas consequências jurídicas sancionatórias, dentre elas a responsabilidade civil pelos prejuízos que eventualmente causar à parte (art. $147 \mathrm{c} / \mathrm{c}$ art. 153 do $\left.\mathrm{CPC}^{1215}\right)$.

Constata-se que a incidência do art. 147 do CPC depende do preenchimento de dois requisitos: (a) a prestação de informações inverídicas, ao arrepio do art. 422 do CPC (que estatui que o perito "cumprirá escrupulosamente o encargo que lhe foi cometido, independentemente de termo de compromisso"1216); e (b) a existência de dolo ou culpa.

Há dolo toda vez que o perito ou o intérprete exerce sua função com o intuito de prestar informações inverídicas. Para a configuração da culpa, basta a atuação negligente, imprudente ou imperita (v.g., perito que presta informações erradas em razão de ter sido desidioso no exame do objeto da perícia, ou de desconhecer informações técnicas ou científicas necessárias para o exercício da função) ${ }^{1217}$.

Logicamente, para que se reconheça o dever de indenizar, é necessário também demonstrar a existência de prejuízo a alguma das partes, apesar de esse não ser um requisito essencial para a aplicação das demais consequências jurídicas previstas no art. 147 do $\mathrm{CPC}^{1218}$.

O pedido indenizatório fundado no dispositivo em exame deve ser feito em ação própria, quer dizer, em processo distinto daquele no qual o perito ou o intérprete prestou a

\footnotetext{
1212 BARBI, Comentários ao Código de Processo Civil, vol. I, § 801, p. 470.

1213 Considera-se "oficial" o intérprete que ocupa cargo ou ofício público específico de tradutor ou de intérprete. Mas, nada impede que a escolha do juiz recaia em pessoa que não tenha esse cargo ou ofício público.

${ }_{1214}^{12}$ BARBI, Comentários ao Código de Processo Civil, vol. I, § 812, p. 474.

$1215 \mathrm{O}$ art. 143 do Projeto de Lei $\mathrm{n}^{\circ}$ 8.046/2010, que institui o novo Código de Processo Civil, tem a mesma redação do art. 153 do CPC atual.

${ }^{1216}$ Segundo Dinamarco (Instituições de Direito Processual Civil, vol. I, § 356, p. 683), o art. 422 do CPC contém deveres quanto ao desempenho correto do encargo do perito e quanto à probidade e imparcialidade nesse desempenho.

${ }^{1217}$ BARBI, Comentários ao Código de Processo Civil, vol. I, § 788, p. 464.

${ }^{1218}$ BARBI, Comentários ao Código de Processo Civil, vol. I, § 788, p. 463; e $\$ \$ 789$ e 790, p. 464.
} 
informação inverídica. Nesse novo processo, figura como autor a parte lesada e, como réu, o perito ou o intérprete ${ }^{1219}$.

Finalmente, o art. 150 do CPC trata do dever de o depositário e o administrador repararem os danos decorrentes de suas condutas ímprobas ${ }^{1220}$.

O depositário é o auxiliar da justiça que possui a função de guardar e conservar bens sujeitos a constrição judicial (bens arrecadados, postos sob arresto, penhora, sequestro ou busca-e-apreensão) (art. 148 do CPC), evitando que se deteriorem ou sejam extraviados, até que lhes seja dada uma destinação definitiva ${ }^{1221}$. Ele recebe a coisa em decorrência de decisão judicial e tem sua situação regulada por normas de direito público do Código de Processo Civil ${ }^{1222}$.

Denomina-se "administrador" o auxiliar da justiça incumbido de guardar e conservar bens sujeitos a "usufruto de imóvel ou de empresa" "1223, que pode ocorrer na execução por quantia certa (arts. 716-729 do CPC). Diferentemente do depositário, ele não só guarda e conserva o bem apreendido, mas também o mantém em atividade e produção, propiciando ao exequente a percepção dos frutos até que o crédito seja satisfeito (art. 722 do CPC) $)^{12241225}$.

Apesar da distinção teórica entre depositário e administrador, o legislador trata os dois auxiliares da mesma forma, diferenciando-os apenas nominalmente, como se infere

${ }^{1219}$ BARBI, Comentários ao Código de Processo Civil, vol. I, § 790, p. 464.

${ }^{1220}$ Caso o projeto do novo Código de Processo Civil (Projeto de Lei $\mathrm{n}^{\circ}$ 8.046/2010) seja aprovado nos termos atuais, essa mesma norma constará do art. 140.

${ }^{1221}$ DINAMARCO, Instituições de Direito Processual Civil, vol. I, § 354, pp. 680-681.

1222 Não se confunde, portanto, com o depositário que recebe a coisa em consequência de contrato de depósito, cuja atividade é regida pelo próprio negócio jurídico e pelos arts. 627 a 646 do CC (BARBI, Comentários ao Código de Processo Civil, vol. I, § 793, p. 466).

Apesar da distinção, constata-se que o Código de Processo Civil, ao disciplinar a figura do depositário (arts. 148 e ss. do CPC), reproduz aproximadamente as normas do Código Civil referentes ao depósito em direito privado (arts. 627-652 do CC) (DINAMARCO, Instituições de Direito Processual Civil, vol. I, § 354, p. 681).

${ }^{1223}$ Dinamarco (Instituições de Direito Processual Civil, vol. I, § 355, p. 682, nt. 12) critica o fato de o legislador empregar o termo "usufruto" nos arts. 716-729 do CPC, uma vez que, no Direito privado, a percepção de frutos para a satisfação do crédito denomina-se "anticrese", e não "usufruto" (arts. 1506-1510 do CC). Aduz o doutrinador que a anticrese e o usufruto têm origem contratual, não sendo correto - em sua opinião - denominar um instituto que visa à satisfação coercitiva do direito pela terminologia do Direito privado.

1224 BARBI, Comentários ao Código de Processo Civil, vol. I, § 792, pp. 465-466; DINAMARCO, Instituições de Direito Processual Civil, vol. I, § 355, pp. 681-682.

${ }^{1225}$ De acordo com Dinamarco (Instituições de Direito Processual Civil, vol. I, § 355, p. 682), é muito rara a utilização do instituto do "usufruto de imóvel ou de empresa", de modo que as organizações judiciárias não têm instituído a figura do administrador judicial como auxiliar permanente da Justiça. O que ocorre é a nomeação de um administrador privado, com espeque no art. 719 do CPC. Ele é tratado como auxiliar eventual da Justiça, mas tem todos os direitos, deveres e responsabilidades que a lei atribui ao administrador público. O autor relata também que, às vezes, na prática judiciária, nomeiam-se administradores judiciais para sociedades sobre as quais litigam as partes, como medida urgente inominada. Nesses casos, os administradores também são considerados auxiliares eventuais da justiça. 
dos textos dos arts. 148 ("A guarda e conservação de bens penhorados, arrestados, sequestrados ou arrecadados serão confiadas a depositário ou a administrador, não dispondo a lei de outro modo") e 677 do CPC ("Quando a penhora recair em estabelecimento comercial, industrial ou agrícola, bem como em semoventes, plantações ou edifício em construção, o juiz nomeará um depositário, determinando-lhe que apresente em 10 (dez) dias a forma de administração [...]”). De acordo com Barbi ${ }^{1226}$, no fundo, ambos são depositários, segundo a linguagem tradicional.

Quando o depositário ou o administrador não pode cuidar de todos os bens depositados em um processo, seja em razão do seu grande número, seja por causa de sua localização diversificada, o parágrafo único do art. 149 do CPC permite que o juiz nomeie um ou mais prepostos dele. Apesar de nomeadas pelo magistrado, essas pessoas são subordinadas ao depositário ou ao administrador, que as indica e remunera. Elas não são consideradas auxiliares da justiça ${ }^{1227}$.

Segundo o art. 150 do CPC, o depositário ou o administrador que causar prejuízos às partes, em decorrência de conduta dolosa ou culposa, deve responder civilmente por eles e também perder o direito à remuneração ${ }^{1228}$. Caso já tenha recebido o valor da remuneração, deve restituí-lo ${ }^{1229}$.

Barbi ${ }^{1230}$ ensina que, se o magistrado constatar indícios fortes da presença de dolo ou culpa na conduta do depositário ou do administrador, ele deve, por cautela, determinar a suspensão do pagamento da remuneração do auxiliar da justiça até a extinção do processo destinado a apurar a existência de pretensão indenizatória fundada no art. 150 do CPC.

Além da remuneração pelo seu trabalho, esses auxiliares da justiça têm direito ao reembolso das despesas que tiverem que fazer com a guarda e conservação dos bens (v.g., gastos com aluguel de pastos para a colocação de animais depositados, despesas com a

${ }^{1226}$ Comentários ao Código de Processo Civil, vol. I, § 792, pp. 465-466.

${ }^{1227}$ BARBI, Comentários ao Código de Processo Civil, vol. I, § 798, p. 468.

${ }^{1228}$ Tanto o depositário, quanto o administrador, devem receber uma remuneração pelo serviço prestado. $\mathrm{O}$ art. 149 do CPC enumera critérios para a sua fixação: a situação dos bens, o tempo do serviço e as dificuldades de sua execução. Para Barbi (Comentários ao Código de Processo Civil, vol. I, § 797, p. 468), deve também influir no montante da remuneração o valor da coisa, apesar de o legislador não mencionar expressamente esse critério.

Em alguns Estados, a função de depositário é exercida por funcionários públicos (cargo de depositário público), cuja remuneração é fixada pela legislação estadual, seja na forma de custas, seja na de vencimento fixo pago pelo ente da Federação (BARBI, Comentários ao Código de Processo Civil, vol. I, § 796, p. 467). Porém, a tendência nos sistemas atuais de organização judiciária é no sentido de não instituir a figura do depositário público, o que leva os juízes a valer-se de particulares, que passam a figurar como auxiliares eventuais da Justiça. Uma vez aceito o encargo, o particular passa a ser titular de todos os deveres e responsabilidades de um depositário (DINAMARCO, Instituições de Direito Processual Civil, vol. I, § 354, p. 681).

${ }^{1229}$ BARBI, Comentários ao Código de Processo Civil, vol. I, § 799, p. 469.

${ }^{1230}$ Comentários ao Código de Processo Civil, vol. I, § 800, p. 469. 
contratação de pessoa que cuide deles e com o fornecimento de remédios e assistência veterinária; gastos decorrentes de aluguel de garagem para guarda de veículo etc.). A indenização de tais despesas deve ser feita antes da entrega da coisa, aplicando-se ao caso a regra do art. 644 do $\mathrm{CC}^{1231}{ }^{1232}$. Esse direito ao reembolso das despesas permanece no patrimônio jurídico do depositário ou do administrador que tenha exercido sua função com dolo ou culpa, nos termos do art. 150 do CPC. Caso contrário, haveria enriquecimento indevido da parte com as quantias gastas em benefício da coisa depositada ${ }^{1233}$.

A parte lesada pelo comportamento doloso ou culposo do depositário ou do administrador precisa pleitear a indenização por meio de demanda autônoma, dando origem a um outro processo, no qual ela figura como autora e o auxiliar da justiça causador do dano, como réu.

Constata-se, a partir da análise dos arts. 144, 147, 150 e 153 do CPC, que o legislador se refere apenas ao escrivão, ao oficial de justiça, ao perito, ao depositário, ao administrador e ao intérprete, ignorando os outros auxiliares de justiça, como o distribuidor, o contador, o partidor etc $^{1234}$. Dessa omissão não se pode inferir que esses auxiliares da justiça estejam imunes à responsabilidade civil subjetiva pelos danos que seus comportamentos abusivos causarem às partes. A responsabilidade civil extracontratual é uma categoria do Direito civil e a norma prevista nos arts. 186 e 927 do CC aplica-se a todas essas pessoas ${ }^{1235}$.

\subsection{Multa}

\subsubsection{Aspectos gerais}

\footnotetext{
1231 “Art. 644. O depositário poderá reter o depósito até que se lhe pague a retribuição devida, o líquido valor das despesas, ou dos prejuízos a que se refere o artigo anterior, provando imediatamente esses prejuízos ou essas despesas.

Parágrafo único. Se essas dívidas, despesas ou prejuízos não forem provados suficientemente, ou forem ilíquidos, o depositário poderá exigir caução idônea do depositante ou, na falta desta, a remoção da coisa para o Depósito Público, até que se liquidem".

${ }_{1232}$ BARBI, Comentários ao Código de Processo Civil, vol. I, § 797, p. 468.

1233 BARBI, Comentários ao Código de Processo Civil, vol. I, § 799, p. 469.

${ }^{1234}$ BARBI, Comentários ao Código de Processo Civil, vol. I, § 761, p. 448.

${ }^{1235}$ Nesse sentido: DINAMARCO, Instituições de Direito Processual Civil, vol. I, § 342, p. 667.
} 
A doutrina considera a imposição de punições ao litigante ímprobo uma consequência natural do ato abusivo ${ }^{1236} \mathrm{e}$, dentre as diversas sanções possíveis, a multa é reputada a mais eficiente ${ }^{1237}$.

Entende-se que a multa por abuso do processo tem natureza parapenal. Ela é regida pelos princípios da responsabilidade civil, o que implica a inexistência de uma relação típica entre fato e pena e a atribuição de relevância ao ressarcimento do dano patrimonial sofrido pela vítima. Afasta-se, assim, do Direito penal, em que a responsabilidade criminal é prevista e estatuída mediante normas típicas e a indenização patrimonial tem relevância secundária $^{1238}$.

Em regra, quando o legislador opta por sancionar um comportamento processual abusivo por meio de multa, ele adota a seguinte técnica:

a) elege uma alíquota, que pode ter valor fixo (v.g., 5\%, 20\% etc.) ou variável (e.g., até $1 \%$, até $10 \%$ etc.); e

b) escolhe uma base de cálculo, que pode ser o valor atualizado da causa ${ }^{1239}$, ou o valor atualizado do débito em execução, ou ainda o valor da avaliação do bem.

O valor da multa no caso concreto resulta da conjugação desses dois fatores, quais sejam, a alíquota prevista na lei e a base de cálculo.

Essa estrutura é encontrada na quase totalidade dos artigos do Código de Processo Civil que preveem a aplicação da multa como sanção pelo abuso do processo: o art. 18 comina multa não excedente a $1 \%$ do valor da causa; o art. 488 , II, comina multa no valor

1236 ABDO, O Abuso do Processo, p. 227; TARUFFO, General Report, in TARUFFO (ed.), Abuse of Procedural Rights: comparative standards of procedural fairness, p. 22.

${ }^{1237}$ TARUFFO, General Report, in TARUFFO (ed.), Abuse of Procedural Rights: comparative standards of procedural fairness, p. 24.

${ }_{1238}$ LUSO SOARES, A Responsabilidade Processual Civil, pp. 41-42.

1239 Apesar de o legislador se referir apenas ao "valor da causa", a verdadeira base de cálculo do montante da multa é o "valor atualizado da causa":

"PROCESSUAL CIVIL. INEXISTÊNCIA DE IRREGULARIDADES NO ACÓRDÃO. MULTA DE LITIGÂNCIA DE MÁ-FÉ. INCIDÊNCIA SOBRE O VALOR DA CAUSA, DEVIDAMENTE CORRIGIDO. ESCLARECIMENTOS.

1. Pedido para que a aplicação da multa de litigância de má-fé tenha como base de cálculo o valor da condenação, e não o da causa, a fim de garantir efetividade ao instituto da penalização pela litigância de má-fé, previsto no art. 16 e seguintes, do CPC.

2. $O$ art. 18, do CPC, é expresso no sentido de que "o juiz ou tribunal, de ofício ou a requerimento, condenará o litigante de má-fé a pagar multa não excedente a um por cento sobre o valor da causa e a indenizar a parte contrária dos prejuízos que esta sofreu, mais os honorários advocatícios e todas as despesas que efetuou".

3. O teor do artigo citado é claro: a multa incidirá sobre o valor da causa, não da condenação. No entanto, a mesma há de ser devidamente atualizada monetariamente até o seu efetivo pagamento, devendo as partes aguardar a fase de execução para que se proceda aos cálculos do que for devido.

4. Embargos parcialmente acolhidos"

(STJ, $1^{\text {a }}$ Turma, EDcl nos EDcl no AgRg no Ag 455.825/MG, Rel. Min. José Delgado, DJ 31/03/2003, p. 159) 
de 5\% do valor da causa; os arts. 538, parágrafo único, e 557, § $2^{\circ}$, impõem multas cujos valores não podem ser superiores a $1 \%$ ou a $10 \%$ do valor da causa; os arts. $601 ; 740$, parágrafo único; e $746, \S 3^{\circ}$, prescrevem multas em montante não superior a $20 \%$ do valor atualizado do débito em execução ${ }^{1240}$; e o $\S 2^{\circ}$ do art. 701 impõe multa de $20 \%$ do valor da avaliação do bem. A única exceção à regra é o art. 233 do CPC, que prevê multa no valor fixo de cinco vezes o salário mínimo vigente na sede do juízo ${ }^{1241}$.

Taruffo $^{1242}$ chama a atenção para a possibilidade de os magistrados abusarem de um poder amplo de fixar multas e de determinar os seus valores. Diante disso, ele sugere que os órgãos jurisdicionais tenham apenas os poderes necessários para imporem multas proporcionais à relevância de cada conduta abusiva, evitando, assim, eventuais excessos dos juízes.

No Brasil, essa recomendação já é adotada, visto que quase todos os dispositivos do Código de Processo Civil que prescrevem a aplicação da multa como sanção pelo abuso do processo limitam o poder do órgão jurisdicional de fixar o seu valor, mediante a previsão de alíquotas fixas ou variáveis. No caso específico da multa prevista no art. 233 do CPC, o magistrado não tem margem alguma de liberdade para fixar o seu valor, que só pode ser de cinco salários mínimos ${ }^{1243} 1244$.

${ }^{1240}$ De acordo com Assis (Manual da Execução, § 71, p. 367), quando o legislador prevê, no art. 601 do CPC, que a multa deve ser de " $20 \%$ do valor atualizado do débito em execução", ele se refere apenas à execução por quantia certa, olvidando-se das demais espécies executivas. Nestas, o magistrado deve mensurar o valor da multa com base no valor da causa.

${ }^{1241}$ No projeto do novo Código de Processo Civil (Projeto de Lei $n^{\circ}$ 8.046/2010), as normas que sancionam o abuso do processo com multa têm a mesma estrutura, alterando apenas os valores das alíquotas: o art. 84 comina multa cujo valor não pode ser inferior a $2 \%$, nem superior a $10 \%$ do valor corrigido da causa, exceto nos casos em que o valor da causa for irrisório ou inestimável, hipótese em que o montante da multa pode ser fixado em até 10 vezes o valor do salário mínimo; o art. 921, II, prevê multa no valor de 5\% do valor da causa; o art. $980, \S 4^{\circ}$, impõe multa com valor não superior a $5 \%$ do valor da causa; o art. 975 , $\S 2^{\circ}$, fixa o valor da multa entre $1 \%$ e $10 \%$ do valor corrigido da causa; o art. 733, parágrafo único, prescreve multa em montante não superior a $20 \%$ do valor atualizado do débito em execução; e o $\S 2^{\circ}$ do art. 846 estabelece multa de $20 \%$ do valor da avaliação do bem. O único dispositivo do Código projetado que prevê multa em valor fixo, de cinco vezes o salário mínimo, é o art. 227, que é análogo ao art. 233 do CPC atual.

1242 General Report, in TARUFFO (ed.), Abuse of Procedural Rights: comparative standards of procedural fairness, p. 24.

${ }^{1243}$ SILVA DINAMARCO, Comentários ao art. 233 do CPC, in MARCATO (coord.), Código de Processo Civil Interpretado, p. 666.

${ }^{1244} \mathrm{O}$ legislador francês e o belga também acolhem a orientação de Taruffo. Os arts. 32.1, 559, 581 e 628 do "Code de Procédure Civile" da França cominam multa ("amende civile") no valor de até 3.000 euros para o litigante que, respectivamente, agir em juízo de maneira dilatória ou abusiva, interpuser recurso ordinário (especificamente, o "appel") dilatório ou abusivo, interpuser recurso extraordinário ("tierce opposition", "recours en révision" ou "pourvoi en cassation") dilatório ou abusivo, ou fizer uso do "pourvoi en cassation" de maneira abusiva e tiver o recurso improvido ou não-conhecido. O art. 780bis do "Code Judiciaire" da Bélgica estabelece que a parte que utiliza o processo para fins manifestamente dilatórios ou abusivos pode ser condenada a uma multa de 15 a 2.500 euros.

O mesmo se verifica na Argentina. Diversos dispositivos do Código de Processo Civil argentino estabelecem limites para o poder do magistrado de fixar o valor da multa aplicável em casos de abuso processual. Por exemplo: (a) de acordo com o art. 29, a parte que opõe exceção de impedimento ou de suspeição 
No entanto, a técnica escolhida pelo legislador brasileiro está longe de ser considerada impecável pela integralidade da doutrina. Critica-se, por exemplo, o fato de a maioria das multas ter como base de cálculo o valor da causa, uma vez que este não interfere em nada na gravidade do comportamento processual abusivo ${ }^{1245}$. A doutrina também mostra descontentamento com relação à alíquota de $1 \%$ do valor da causa, prevista no "caput" do art. 18 do CPC, pois, nas demandas de pequeno valor, a sanção é tão diminuta que se mostra inócua ${ }^{1246} 1247$. Afirma-se também que essas sanções pecuniárias afetam desigualmente sujeitos processuais com diferentes condições financeiras ${ }^{1248}$. Na mesma toada, coloca-se em dúvida a eficácia da cominação de multa nos casos de abuso do

("recusación") maliciosa pode ser condenada ao pagamento de multa de até 900.000 pesos por cada exceção; (b) o art. 45 estatui que, quando o juiz se convencer de que a parte vencida, total ou parcialmente, teve conduta maliciosa ou temerária, ele pode impor multa cujo valor varia entre 5 e $30 \%$ do valor da causa, ou entre 300.000 e 13.000 .000 de pesos; (c) consoante o art. 145, o demandante que afirma falsamente que ignora o domicílio do demandado, ou que desconhece o domicílio do demandado por não ter empregado a devida diligência, implicando a notificação da parte contrária por edital, deve ser condenado ao pagamento de multa no valor de 150.000 a 15.000 .000 pesos; (d) de acordo com o art. 167, o magistrado que excede o prazo para prolatar a sentença definitiva fica sujeito a multa no valor de até $15 \%$ da sua remuneração básica; (e) o art. 436 comina multa de 100.000 a 1.500 .000 pesos para a testemunha que alega falsamente estar impossibilitada de comparecer ao fórum, com o fim de prestar o depoimento em sua residência; (f) o art. 525, 2, fixa multa no valor de até $30 \%$ do montante da dívida para o demandado que, na preparação da via executiva, afirma falsamente que não é inquilino, ensejando a cobrança do débito pelo procedimento sumário; (g) segundo o art. 551, o executado que litiga sem razão válida, ou que obstrui o curso normal do processo com articulações manifestamente improcedentes, ou que de qualquer maneira atrasa injustificadamente o trâmite processual, pode ser sancionado com uma multa cujo montante varia entre $5 \%$ e $30 \%$ do valor da dívida, segundo o impacto de sua conduta imprópria na demora do procedimento; etc.

Similarmente, na Espanha, os artigos da "Ley de Enjuiciamiento Civil" que sancionam comportamentos processuais ímprobos com multa limitam o poder do magistrado de fixar o valor da punição, prevendo montantes mínimos e máximos. Para exemplificar, merecem ser citados os seguintes dispositivos: (a) art. 112.1, que prevê multa de 30.000 a 1.000 .000 de pesetas (de 180 a 6.000 euros) em caso de oposição de exceção de impedimento ou de suspeição ("recusación de jueces y magistrados") com má-fé; (b) art. 228.2, que pune a pessoa que promove, de forma temerária, incidente de nulidade de atuações com multa de 90 a 600 euros; (c) art. 247.3, que estatui que o órgão jurisdicional pode impor multa de 180 a 6.000 euros à parte que violou as regras da boa-fé processual, contanto que o montante da punição não seja superior à terça parte do valor da causa; (d) art. 270.2, que comina multa de 30.000 a 200.000 pesetas (de 180 a 1.200 euros) para o litigante que apresenta prova documental depois da demanda e da contestação ou, eventualmente, da "audiencia previa al juicio", sem ser nos casos excepcionais previstos no art. 270.1 do mesmo diploma legal (documento novo, elaborado depois da demanda, da contestação ou da "audiencia previa al juicio"; ou cuja existência a parte ignorava; ou que a parte não pôde obter anteriormente por causas que não lhe podem ser imputadas), movido por intuito protelatório ou má-fé processual; (e) art. 286.4, segundo o qual a parte que alega fundamentos fáticos novos depois de preclusos os atos de alegação previstos na lei pode ser condenada ao pagamento de multa de 20.000 a 100.000 pesetas (de 120 a 600 euros), contanto que haja indícios de que o fato poderia ter sido suscitado nos momentos processuais ordinariamente previstos para esse fim e que se constate ânimo dilatório ou má-fé processual na alegação extemporânea; (f) art. 320.3, que estabelece que a impugnação temerária do valor probatório de um documento público pode acarretar a obrigação de pagar multa de 20.000 a 100.000 pesetas (de 120 a 600 euros); etc.

${ }^{1245}$ BARBOSA MOREIRA, Comentários ao Código de Processo Civil, vol. V, p. 572.

${ }^{1246}$ OLIVEIRA, Litigância de Má-Fé, p. 69.

${ }^{1247}$ Se o Projeto de Lei $n^{\circ} 8.046 / 2010$ for aprovado, sancionado e publicado com sua redação atual, essa crítica não será válida para o novo Código de Processo Civil, pois ele estabelece que o montante mínimo da multa para quem comete litigância de má-fé é de $2 \%$ do valor corrigido da causa (art. 84, "caput"). Além disso, o $\$ 3^{\circ}$ do art. 84 do Código projetado determina o seguinte: "Quando o valor da causa for irrisório ou inestimável, a multa referida no caput poderá ser fixada em até dez vezes o valor do salário mínimo".

${ }^{1248}$ BARBOSA MOREIRA, Comentários ao Código de Processo Civil, vol. V, p. 572. 
processo praticados por beneficiários da justiça gratuita, dada a (alegada) falta de bens destes últimos ${ }^{1249}$.

Consoante o "caput" do art. 18 do CPC, a multa decorrente da litigância de má-fé pode ser imposta pelo juízo de ofício ou após requerimento da parte interessada. O mesmo ocorre com as demais multas previstas no Código de Processo Civil como sanção pelo abuso do processo (v.g., as multas do art. $233^{1250}$; do art. 538, parágrafo único; do art. 557, $\S 2^{\mathrm{o}^{1251}}$; do art. 601 do $\left.\mathrm{CPC}^{1252}\right)$.

A multa regida pelo art. 601 do CPC tem, contudo, uma peculiaridade: antes de sancionar o executado com ela, o magistrado deve adverti-lo de que a sua conduta pode ser considerada um ato atentatório à dignidade da Justiça (art. 599, II, do CPC), dando-lhe oportunidade para que cesse a prática abusiva ${ }^{1253}$. A única exceção é a hipótese contida no art. 600, I, do CPC, que configura desde logo ato atentatório à dignidade da Justiça, eis que a advertência se mostra totalmente irrelevante depois que o ato de fraude à execução já foi praticado $^{1254}{ }^{1255}$. Caso a advertência não seja efetuada, Assis ${ }^{1256}$ sustenta que a sanção eventualmente aplicada é nula.

Se o órgão jurisdicional se omitir, ou se negar a aplicar a multa sancionatória de abuso de situação jurídica processual, a parte lesada pode opor embargos de declaração para suprir essa omissão ou desfazer a contradição ${ }^{1257}$.

\footnotetext{
${ }^{1249}$ MENEZES CORDEIRO, Litigância de Má-Fé, Abuso do Direito de Ação e Culpa “in Agendo”, p. 27.

${ }^{1250}$ BARBOSA MOREIRA, O Novo Processo Civil Brasileiro, p. 31; SILVA DINAMARCO, Comentários ao art. 233 do CPC, in MARCATO (coord.), Código de Processo Civil Interpretado, p. 666.

${ }^{1251}$ LUCON, Abuso do Exercício do Direito de Recorrer, in NERY JÚNIOR; ALVIM WAMBIER (coords.), Aspectos Polêmicos e Atuais dos Recursos Cíveis e de Outras Formas de Impugnação às Decisões Judiciais, p. 893; BARBOSA MOREIRA, Comentários ao Código de Processo Civil, vol. V, p. 572.

${ }^{1252}$ ABDO, O Ato Atentatório à Dignidade da Justiça na Nova Execução Civil, p. 12.

${ }^{1253}$ Assis (Manual da Execução, § 71, p. 367; e § 72, p. 368) explica que o texto original do art. 601 do CPC exigia que o juiz, antes de aplicar qualquer sanção, advertisse o executado de que o seu comportamento configurava ato atentatório à dignidade da Justiça. A redação que a Lei $\mathrm{n}^{\circ}$ 8.953/94 conferiu a esse dispositivo legal suprimiu esse requisito. Todavia, o juiz continua não podendo aplicar as sanções nele previstas sem antes advertir o executado, como estatui o art. 599, II, do CPC. Segundo o jurista, o procedimento para punir o ato atentatório à dignidade da Justiça caracteriza-se, assim, pela gradatividade: primeiro, o juiz adverte o devedor de que o seu ato é reprovável; depois, em caso de reiteração ou insistência no ato, respeitada a garantia da ampla defesa, há a punição mediante decisão interlocutória motivada.

${ }^{1254}$ CARMONA, Comentários ao art. 599 do CPC, in MARCATO (coord.), Código de Processo Civil Interpretado, p. 1961; ABDO, O Ato Atentatório à Dignidade da Justiça na Nova Execução Civil, p. 12.

${ }^{1255}$ Assis (Manual da Execução, § 71, p. 367) discorda desse entendimento. Para ele, mesmo quando o ato atentatório à dignidade da Justiça já esteja consumado, a advertência ao executado é útil porque visa a induzilo a se retratar, o que resulta em economia de tempo e esforços do Poder Judiciário.

${ }^{1256}$ Manual da Execução, § 71, p. 367.

${ }^{1257}$ Nesse sentido: BARBOSA MOREIRA, Comentários ao Código de Processo Civil, vol. V, pp. 572-573; LUCHI DEMO, Embargos de Declaração: aspectos processuais e procedimentais, p. 146; BONICIO, Proporcionalidade e Processo: a garantia constitucional da proporcionalidade, a legitimação do processo civil e o controle das decisões judiciais, p. 158.
} 
Por fim, cumpre tratar de mais uma particularidade da multa cominada a quem pratica ato atentatório à dignidade da Justiça. O parágrafo único do art. 601 do CPC estabelece que o magistrado tem o poder-dever de relevar a pena prevista no "caput" do mesmo dispositivo caso o devedor, cumulativamente: (a) comprometa-se a não praticar mais qualquer ato atentatório à dignidade da Justiça (art. 600 do CPC); e (d) ofereça fiador idôneo, que responda ao credor pela dívida principal, juros, despesas e honorários advocatícios. Essa fiança serve para garantir ao credor o sucesso de sua demanda executiva, já que ele pode voltar-se contra o fiador judicial, caso o devedor não liquide a dívida $^{1258}$. De acordo com Dinamarco ${ }^{1259}$, é a exigência do fiador responsável pelo valor integral da execução que garante a eficiência do art. 601, parágrafo único, do CPC ${ }^{1260}$.

\subsubsection{Destino do montante da multa}

O Código de Processo Civil de 1939, no art. 66, apenas estabelecia que as multas impostas às partes por atos de má-fé deviam ser contadas como custas, porém não informava em favor de quem. Isso acabou gerando controvérsias. As impostas aos procuradores e serventuários eram destinadas ao Estado ${ }^{1261}$.

$\mathrm{O}$ art. 35 do CPC atual, de maneira mais precisa, determina que as sanções impostas às partes em razão da prática de atos de má-fé sejam contadas como custas e sejam revertidas em benefício da parte contrária, compensando-se, assim, o litigante lesado pelo ato ímprobo ${ }^{1262}$.

Se a vítima do abuso processual for a Fazenda Pública, o montante da multa deve integrar-se ao patrimônio do ente federativo (União, Estado ou Município), tendo o mesmo destino dos honorários advocatícios. No caso de aplicação de multa no curso de ação civil pública, em favor do Ministério Público, seu valor deve ser destinado ao Fundo de Defesa de Direitos Difusos (art. 13 da Lei $n^{\circ} 7.347 / 85$ c/c Lei $\left.n^{\circ} 9.008 / 95\right)^{1263}$.

\footnotetext{
${ }^{1258}$ CARMONA, Comentários ao art. 601 do CPC, in MARCATO (coord.), Código de Processo Civil Interpretado, p. 1964.

${ }^{1259}$ Instituições de Direito Processual Civil, vol. II, § 529, p. 278.

${ }^{1260}$ No art. 733 do Código de Processo Civil projetado (Projeto de Lei $n^{\circ} 8.046 / 2010$ ), que versa sobre o ato atentatório à dignidade da Justiça, não há regra análoga à prevista no art. 601, parágrafo único, do CPC atual. ${ }_{1261}^{122}$ BARBI, Comentários ao Código de Processo Civil, vol. I, § 237, p. 171.

${ }^{1262}$ O Projeto de Lei $\mathrm{n}^{\circ} 8.046 / 2010$, em trâmite no Congresso Nacional, que versa sobre o novo Código de Processo Civil, simplesmente estatui que "o valor das sanções impostas aos litigantes de má-fé reverterão em benefício da parte contrária" (art. 98, $1^{\mathrm{a}}$ parte).

${ }^{1263}$ LUCHI DEMO, Embargos de Declaração: aspectos processuais e procedimentais, p. 146.
} 
Na hipótese de a parte oposta à que praticou o ato de má-fé ser formada por mais de uma pessoa, surgem três possibilidades ${ }^{1264}$ :

a) se o ato ímprobo foi dirigido contra todas, a quantia deve ser repartida entre elas, na proporção dos seus respectivos interesses na causa;

b) se apenas uma delas foi visada pelo ato de má-fé, somente ela deve ser beneficiada com o produto da sanção;

c) se o ato foi dirigido contra algumas pessoas do polo oposto, mas não contra todas, apenas as vitimadas devem receber a quantia, dividindo-a entre si na proporção dos seus respectivos interesses na causa.

O parágrafo único do art. 233 do CPC reitera a regra prevista no art. 35 do CPC, estatuindo que a multa prevista no "caput" reverterá em benefício do citando. Analogamente, os arts. 538, parágrafo único, e 557, § $2^{\circ}$, do CPC estabelecem que o valor das multas neles previstas deve ser revertido em favor do recorrido (embargado ou agravado), que é o prejudicado pela conduta abusiva. Da mesma forma, o parágrafo único do art. 740 e o "caput" do art. 601 do CPC determinam, respectivamente, que as multas em caso de oposição de embargos manifestamente protelatórios e de prática de ato atentatório à dignidade da Justiça devem favorecer o exequente. O art. 494 do CPC igualmente afirma que, se a ação rescisória for julgada inadmissível ou improcedente, em ambos os casos por unanimidade de votos, a multa prevista no art. 488, II, do CPC reverte em favor do réu.

Diversos doutrinadores - com os quais concordamos - criticam as normas supracitadas, alegando que são incoerentes com as consequências produzidas pelos atos processuais abusivos $^{1265}$. Sabe-se que o abuso processual é lesivo não só à parte contrária, mas principalmente ao Estado (item 1.6.4 "supra"). Como a contraparte já tem o direito de ter todos os seus prejuízos indenizados pelo autor da conduta ímproba lesiva (arts. 16 e 18 do CPC), o montante da multa deveria reverter para o Estado. O principal argumento a favor dessa tese refere-se aos casos em que o magistrado reconhece a prática de um comportamento abusivo antes mesmo de citar o réu. Imagine-se, por exemplo, uma demanda em que o pedido é juridicamente impossível; ou uma demanda que contrarie coisa julgada material anterior, ao arrepio do que dispõem os arts. 467 e 267, V, do CPC. Em ambas as hipóteses, uma vez constatado o vício, o magistrado deve proferir sentença terminativa, extinguindo o processo sem julgamento do mérito, e condenar o autor pela

${ }^{1264}$ BARBI, Comentários ao Código de Processo Civil, vol. I, § 238, p. 171.

1265 ABDO, O Ato Atentatório à Dignidade da Justiça na Nova Execução Civil, p. 12; ASSIS, Manual da Execução, § 72, p. 370; OLIVEIRA, Litigância de Má-Fé, p. 73; BARBOSA MOREIRA, Comentários ao Código de Processo Civil, vol. V, pp. 182 e 213. 
prática de litigância de má-fé (art. 17, I, do CPC), cominando-lhe multa de até $1 \%$ do valor da causa. De acordo com a lei, a multa deve beneficiar a pessoa indicada na petição inicial como ré, o que configura uma incongruência gritante, pois, nos casos em tela, ela não sofreu prejuízo algum em decorrência do ato abusivo, já que nem mesmo chegou a integrar a relação jurídica processual. Trata-se de hipóteses em que, logicamente, a quantia da multa deveria reverter para o Estado ${ }^{1266}$.

Os únicos dispositivos do Código de Processo Civil que contêm regras distintas da prevista no art. 35 são os arts. $701, \S 2^{\circ}$, e $746, \S 3^{\circ}$.

De acordo com o primeiro, se o pretendente à arrematação desistir de arrematar o imóvel pertencente ao executado incapaz, e outra pessoa que participe da praça não o arrematar, o juiz deve condená-lo a pagar multa no montante de $20 \%$ do valor da avaliação em favor do incapaz. Percebe-se que, nesse caso, o beneficiário da multa é a parte favorecida pelo abuso processual, ainda que indiretamente, já que o incapaz permanece com o bem em seu patrimônio durante o período de realização da praça infrutífera. Por causa disso, essa norma merece mais críticas que as anteriormente citadas. Se a lógica do art. 35 do CPC fosse mantida, o montante da multa deveria ser atribuído ao exequente, que foi a parte lesada pelo comportamento processual ímprobo (teve a satisfação do seu direito protelada, adiantou o pagamento das custas para a publicação do edital da praça etc. $)^{1267}$. Melhor ainda seria a reversão dessa multa para o Estado.

O segundo artigo estabelece que, se houver oposição de embargos à execução de segunda fase manifestamente protelatórios, o juiz deve impor multa ao embargante, não superior a $20 \%$ do valor da execução, em favor de quem houver desistido da aquisição. Se ele estivesse em consonância com o art. 35 do CPC, a multa seria revertida em benefício do embargado. Não obstante o art. 746, $\S 3^{\circ}$, do CPC se diferencie das regras supracitadas que reiteram o art. 35 do CPC, ele se mostra igualmente digno de crítica, pois o legislador houve por bem beneficiar com a multa um sujeito que não sofreu qualquer prejuízo com o abuso processual, já que o requerimento da desistência enseja a liberação imediata do depósito feito pelo adquirente (art. $746, \S \S 1^{\circ}$ e $2^{\circ}$, c/c art. $694, \S 1^{\circ}$, IV, do CPC), ao invés de conferi-la ao Estado.

\footnotetext{
${ }^{1266}$ Nesse sentido: OLIVEIRA, Litigância de Má-Fé, pp. 74-75.

${ }^{1267}$ Nesse sentido, entendendo que a multa prevista no $\S 2^{\circ}$ do art. 701 do CPC deveria ser destinada ao exequente, em razão dos prejuízos que o comportamento abusivo lhe causou: OLIVEIRA, Multa no Código de Processo Civil, pp. 119-120.
} 


\subsubsection{Cominação da multa e cobrança da quantia devida}

Em regra, a aplicação da multa em decorrência da prática de abuso processual deve constar de um capítulo do dispositivo da sentença ou do acórdão ${ }^{1268}$.

Ao impor a multa, o órgão jurisdicional deve sempre fundamentar sua decisão (art. 93, IX, da $\mathrm{CF})^{1269}$, esclarecendo em qual hipótese típica de abuso incorreu o sujeito processual no caso concreto. Se a sanção for do tipo que possui alíquota variável (até $1 \%$, até $10 \%$ do valor da causa, até $20 \%$ do valor atualizado do débito em execução etc.), deve também explicitar o critério de que se valeu para quantificar a multa, dentro do limite previsto na $\mathrm{lei}^{1270}$. Consoante os ensinamentos de Luchi Demo ${ }^{1271}$ acerca da dosimetria dessas multas, o "quantum debeatur" deve ser proporcional à dimensão da irregularidade do exercício da situação jurídica processual, levando em consideração elementos objetivos $^{1272} 1273$. No mesmo sentido, Carmona ${ }^{1274}$ afirma que o juiz deve fixar o montante da multa decorrente de ato atentatório à dignidade da Justiça com base: (a) na gravidade do ato praticado pelo devedor; e (b) no valor do débito, pois não é desejável que a multa represente valor irrisório, nem que arruíne o devedor. Não obstante este último autor trate especificamente da multa prevista no art. 601 do CPC, o seu conselho deve ser seguido na aplicação de qualquer norma que puna o abuso processual com multa dotada de alíquota variável $^{1275}$.

${ }^{1268}$ BONICIO, Análise do Sistema das Multas Previstas no Código de Processo Civil, in Revista de Processo, $\mathrm{n}^{\mathrm{o}} 118$, p. 32.

${ }^{1269}$ Nesse sentido: STJ, $1^{\text {a }}$ Turma, REsp 12.838/SP, Rel. Min. Milton Luiz Pereira, DJ 05/09/1994, p. 23035; STJ, $3^{\text {a }}$ Turma, REsp 605.088/MT, Rel ${ }^{a}$. Min ${ }^{a}$. Nancy Andrighi, DJ 03/10/2005, p. 243.

${ }^{1270}$ Nesse sentido, porém referindo-se apenas ao art. 538, parágrafo único, do CPC: BARBOSA MOREIRA, Comentários ao Código de Processo Civil, vol. V, p. 573.

${ }^{1271}$ Embargos de Declaração: aspectos processuais e procedimentais, pp. 141-142.

${ }^{1272} \mathrm{O}$ autor ilustra essa assertiva com o seguinte exemplo: merece punição mais rigorosa o sujeito processual que opõe reiterados embargos de declaração contra decisão judicial que versa sobre matéria já pacificada na jurisprudência, que aquele que tem a mesma conduta, porém com relação a uma decisão cujo conteúdo é complexo e inédito.

${ }^{1273}$ Essa orientação pode ser encontrada também na obra de Bonicio (Proporcionalidade e Processo: a garantia constitucional da proporcionalidade, a legitimação do processo civil e o controle das decisões judiciais, p. 157), no seguinte trecho, em que o autor disserta sobre as sanções previstas nos arts. 18 e 601 do CPC:

"Convém reparar que em todas as hipóteses a lei estabelece um limite para o valor a ser fixado e, portanto, deve o juiz verificar a gravidade dos atos praticados pelas partes e, proporcionalmente, fixar o valor da multa a ser paga".

1274 Comentários ao art. 601 do CPC, in MARCATO (coord.), Código de Processo Civil Interpretado, p. 1964.

${ }^{1275} \mathrm{Na}$ Espanha, o art. 247.3 da "Ley de Enjuiciamiento Civil" expressamente determina que o órgão jurisdicional deve respeitar o princípio da proporcionalidade ao determinar a quantia da multa aplicada em caso de violação das regras da boa-fé processual, a qual pode oscilar de 180 a 6.000 euros, desde que não ultrapasse a terça parte do valor da causa. Estatui também que, na determinação do montante da multa, o juízo deve levar em consideração as circunstâncias do caso concreto, bem como os prejuízos que a conduta 
Se a prática do abuso processual for reconhecida na sentença do juízo de primeiro grau e for mantida pelo Tribunal, os ministros do Superior Tribunal de Justiça entendem que eventual recurso especial contra o capítulo do acórdão versando sobre o pagamento de multa não pode ser conhecido porque sua apreciação implicaria o reexame do contexto fático-probatório, o que seria inviável ante o óbice da súmula $\mathrm{n}^{\mathrm{o}} 7$ do $\mathrm{STJ}^{1276}$. Apenas em casos excepcionais, quando a decisão do tribunal " a quo" a respeito da sanção por abuso do processo for manifestamente desarrazoada, é que se admite o cabimento do recurso especial (v.g., é admissível recurso especial contra acórdão que aplica as sanções previstas nos arts. 18 e 538, parágrafo único, do CPC à parte que opôs embargos de declaração com notório propósito de prequestionamento, ao arrepio da súmula $\mathrm{n}^{\circ} 98$ do $\mathrm{STJ}^{1277}$; o mesmo recurso é admissível contra acórdão que aplica a multa de até $10 \%$ prevista no art. $557, \S$ $2^{\circ}$, do CPC ao invés de aplicar a de até $1 \%$ prevista no art. $18 \mathrm{c} / \mathrm{c}$ art. 17, VII, do $\left.\mathrm{CPC}^{1278}\right)^{1279}$.

ímproba tenha causado ao procedimento ou à parte contrária. Uma norma com teor similar no ordenamento jurídico brasileiro seria de grande valia.

1276 Nesse sentido: STJ, $2^{\mathrm{a}}$ Turma, AgRg no REsp 1.302.461/DF, Rel. Min. Humberto Martins, DJe 02/10/2012; STJ, $4^{\text {a }}$ Turma, AgRg no AREsp 28.639/RS, Rel ${ }^{a}$. Min'a . Maria Isabel Gallotti, DJe 27/09/2012; STJ, $4^{a}$ Turma, AgRg no Ag 1.336.964/SP, Rel ${ }^{a}$. Min ${ }^{a}$. Maria Isabel Gallotti, DJe 27/08/2012; STJ, $2^{\mathrm{a}}$ Turma, AgRg nos EDcl no AREsp 51.988/RS, Rel. Min. Cesar Asfor Rocha, DJe 10/08/2012; STJ, $4^{\mathrm{a}}$ Turma, AgRg no AREsp 64.481/SP, Rel. Min. Luis Felipe Salomão, DJe 29/06/2012; STJ, $3^{a}$ Turma, AgRg no Ag 1.425.420/SC, Rel. Min. Sidnei Beneti, DJe 05/06/2012; STJ, $1^{\text {a }}$ Turma, AgRg no AREsp 7.598/RS, Rel. Min. Arnaldo Esteves Lima, DJe 12/12/2011; STJ, $4^{\text {a }}$ Turma, AgRg no Ag 1.306.184/SC, Rel. Min. Luis Felipe Salomão, DJe 04/11/2011; STJ, $4^{\text {a }}$ Turma, REsp 1.114.049/PE, Rel. Min. Luis Felipe Salomão, DJe 29/04/2011; STJ, $3^{\text {a }}$ Turma, AgRg nos EDcl no Ag 1.195.138/DF, Rel. Min. Sidnei Beneti, DJe 29/06/2010; STJ, $2^{\mathrm{a}}$ Turma, AgRg no Ag 1.259.714/SP, Rel ${ }^{\mathrm{a}}$. Min ${ }^{\mathrm{a}}$. Eliana Calmon, DJe 16/04/2010; STJ, $3^{\mathrm{a}}$ Turma, AgRg no REsp 1.066.938/SC, Rel. Min. Massami Uyeda, DJe 16/06/2009; STJ, $4^{a}$ Turma, AgRg no Ag 1.106.019/SP, Rel. Min. João Otávio de Noronha, DJe 18/05/2009; STJ, $3^{a}$ Turma, AgRg no Ag 739.156/SP, Rel. Min. Sidnei Beneti, DJe 28/08/2008; STJ, $2^{a}$ Turma, AgRg no Ag 552.437/RS, Rel. Min. João Otávio de

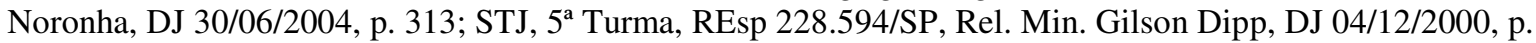
87; STJ, $5^{\text {a }}$ Turma, REsp 226.409/SP, Rel. Min. Jorge Scartezzini, DJ 16/10/2000, p. 326; STJ, $5^{\text {a Turma, }}$ REsp 193.504/RS, Rel. Min. Gilson Dipp, DJ 08/11/1999, p. 87.

${ }_{1277}$ Nesse sentido: STJ, $1^{\mathrm{a}}$ Turma, REsp 1.037.915/SP, Rel. Min. José Delgado, DJe 24/04/2008; STJ, ${ }^{\mathrm{a}}$ Turma, REsp 976.186/PR, Rel' ${ }^{\mathrm{a}}$. Min ${ }^{\mathrm{a}}$. Eliana Calmon, DJe 07/04/2008; STJ, ${ }^{\mathrm{a}}$ Turma, REsp 1.032.488/PB, Rel. Min. José Delgado, DJe 27/03/2008; STJ, $2^{a}$ Turma, REsp 613.184/RS, Rel. Min. João Otávio de Noronha, DJ 15/08/2007, p. 257; STJ, $1^{\text {a }}$ Turma, EDcl nos EDcl no AgRg no Ag 677.304/SP, Rel. Min. Luiz Fux, DJ 14/12/2006, p. 254; STJ, $2^{a}$ Turma, REsp 760.182/RJ, Rel. Min. João Otávio de Noronha, DJ 16/10/2006, p. 349; STJ, ${ }^{a}$ Turma, REsp 698.762/RS, Rela ${ }^{a}$. Mina . Eliana Calmon, DJ 03/10/2005, p. 209; STJ, 6a Turma, REsp 389.625/MG, Rel. Min. Fernando Gonçalves, DJ 07/04/2003, p. 347.

${ }_{1278}$ Nesse sentido: STJ, 4 ${ }^{a}$ Turma, REsp 241.109/BA, Rel. Min. Fernando Gonçalves, DJ 01/07/2004, p. 199.

${ }^{1279}$ A doutrina de Reis (Código de Processo Civil Anotado, vol. II, pp. 282-283) é nesse sentido. Ele entende que o Supremo Tribunal de Justiça português pode alterar decisão dos tribunais de instância a respeito de litigância de má-fé, posto que se trate de questão essencialmente fática. Mas, pondera que essa ingerência só é permitida em casos excepcionais, quando o julgamento do tribunal de instância for manifestamente injustificado. 
Pode-se promover a execução provisória (art. 475-O do CPC) do capítulo do acórdão que condena ao pagamento de multa pela prática de abuso do processo ${ }^{1280}$. Logicamente, uma vez transitado em julgado o capítulo da sentença ou do acórdão que condena o "improbus litigator" a pagar multa, ele pode ser executado definitivamente pela parte interessada ${ }^{1281}$.

O ordenamento jurídico processual brasileiro também admite a existência de decisão interlocutória de mérito que condena ao pagamento de multa por improbidade processual $^{1282}$. Nesse caso, uma vez precluso o poder de impugnar a decisão (em razão do decurso "in albis" do prazo para a interposição do último recurso cabível - preclusão temporal -; ou em razão da aquiescência à decisão ou da renúncia ao poder de interpor o último recurso cabível - preclusão lógica -; ou ainda em razão do efetivo julgamento do último recurso cabível - preclusão consumativa), o juiz precisa reiterar a condenação em um capítulo específico no dispositivo da sentença, em respeito ao princípio da concentração da decisão, segundo o qual devem-se concentrar na sentença o exame e o pronunciamento do juiz acerca de todas as questões de mérito, além da decisão pela procedência ou improcedência do pedido (art. 459 c/c art. 458, II e III, do CPC) ${ }^{1283}$. Entretanto, quando o abuso do processo ocorre em processo de execução ou na fase executiva, o juiz deve necessariamente cominar a multa em decisão interlocutória, já que a sentença proferida no processo de execução simplesmente reconhece a satisfação da dívida ou a renúncia do credor (art. 794 do CPC), não podendo constituir um novo título executivo ${ }^{1284}$. É possível promover a execução provisória (art. 475-O do CPC) dessa decisão interlocutória de mérito, já que o recurso de agravo não é dotado de efeito suspensivo. Uma vez precluso o poder de impugná-la, ela transita em julgado e pode ser executada definitivamente pela parte interessada ${ }^{1285} 1286$.

\footnotetext{
${ }^{1280}$ O capítulo da sentença que condena ao pagamento de multa pela prática de abuso processual não pode ser executado provisoriamente porque a apelação cabível nesse caso tem efeito devolutivo e suspensivo (art. 520 do CPC) (BONICIO, Análise do Sistema das Multas Previstas no Código de Processo Civil, in Revista de Processo, $\mathrm{n}^{\circ} 118$, pp. 32, 38).

${ }^{1281}$ IOCOHAMA, Litigância de Má-Fé e Lealdade Processual, p. 285; BONICIO, Análise do Sistema das Multas Previstas no Código de Processo Civil, in Revista de Processo, n⿳⺈ 118, p. 38.

${ }^{1282}$ BONICIO, Análise do Sistema das Multas Previstas no Código de Processo Civil, in Revista de Processo, $\mathrm{n}^{\mathrm{o}} 118$, p. 34.

1283 Acerca desse princípio, consultar: DINAMARCO, Ação Rescisória contra Decisão Interlocutória, in Nova Era do Processo Civil, pp. 285-286.

${ }^{1284}$ BONICIO, Análise do Sistema das Multas Previstas no Código de Processo Civil, in Revista de Processo, no 118 , p. 35.

Nesse sentido, com relação à multa prevista no art. 740, parágrafo único, do CPC: LUCON, Comentários ao art. 740 do CPC, in MARCATO (coord.), Código de Processo Civil Interpretado, p. 2345.

${ }^{1285}$ IOCOHAMA, Litigância de Má-Fé e Lealdade Processual, p. 285; BONICIO, Análise do Sistema das Multas Previstas no Código de Processo Civil, in Revista de Processo, nº 118, pp. 35-36, 38 e 39.
} 
A execução da decisão interlocutória de mérito, da sentença ou do acórdão que condena ao pagamento de multa por improbidade processual é regida pelas normas relativas ao cumprimento de sentença que reconhece obrigação de pagar quantia certa (art. 475-J e ss. do CPC) ${ }^{1287}$.

Se houver processo de execução ou fase executiva em curso, a cobrança da multa deve ser promovida no próprio processo em que ocorreu o abuso processual, como determina o art. 739-B do $\mathrm{CPC}^{1288}$. Nesse caso, a execução da decisão judicial que comina multa tem autonomia completa em relação à execução em curso, pois ocorre em autos apensos $^{1289}$. Incumbe à parte prejudicada pela conduta ímproba a extração das peças processuais necessárias para justificar a medida, as quais serão autuadas em apenso ao processo executivo em curso. Dentre essas peças, deve figurar a decisão que cominou a multa $^{1290}$.

Não obstante o referido artigo exija, expressamente, que a execução da multa seja realizada em autos apensos, Oliveira ${ }^{1291}$ tem razão ao admitir que ela seja efetivada conjuntamente com a execução principal, nos mesmos autos, desde que o sujeito beneficiado pela multa figure como exequente na execução em curso e que esta seja do tipo "execução por quantia certa"1292. Se o beneficiário da multa for o executado, ou então

\footnotetext{
${ }^{1286}$ A decisão interlocutória de mérito que condena ao pagamento de multa por abuso processual, uma vez transitada em julgado, pode ser objeto de ação rescisória (DINAMARCO, Ação Rescisória contra Decisão Interlocutória, in Nova Era do Processo Civil, pp. 289-292; BONICIO, Análise do Sistema das Multas Previstas no Código de Processo Civil, in Revista de Processo, n 118, pp. 35 e 36).

1287 LUCON, Comentários ao art. 739-B do CPC, in MARCATO (coord.), Código de Processo Civil Interpretado, p. 2337; LUCON, Comentários ao art. 740 do CPC, in MARCATO (coord.), Código de Processo Civil Interpretado, p. 2345; LUCON, Execução de Título Extrajudicial, p. 31; IOCOHAMA, Litigância de Má-Fé e Lealdade Processual, pp. 286-288.

${ }^{1288} \mathrm{O}$ enunciado do art. 739-B do CPC gera a impressão de que apenas a cobrança da multa e da indenização decorrentes da litigância de má-fé (arts. 17 e 18 do CPC) devem ser promovidas no próprio processo de execução, em autos apensos. Porém, Lucon (Comentários ao art. 739-B do CPC, in MARCATO (coord.), Código de Processo Civil Interpretado, pp. 2336-2337; Execução de Título Extrajudicial, p. 30) ensina que essa interpretação declaratória não é a mais correta. $\mathrm{O}$ autor afirma que a norma contida no referido dispositivo do Código de Processo Civil tem caráter geral e, por isso, deveria localizar-se na parte geral da execução. Ela diz respeito à cobrança de quaisquer multas ou indenizações fixadas em decisão judicial proferida no curso do processo, seja ele de conhecimento (tanto na fase cognitiva, quanto na fase executiva), ou de execução. Sua incidência abrange, então, não só a multa e o dever de reparar perdas e danos previstos no art. 18 do CPC, mas também as multas previstas nos arts. 30; 161; 196; 233; 461; 461-A; 601; 740, parágrafo único; e 746, $\S 3^{\circ}$, do CPC. No mesmo sentido: SCARPINELLA BUENO, A Nova Etapa da Reforma do Código de Processo Civil, vol. 3, pp. 285 e 289.

1289 LUCON, Comentários ao art. 739-B do CPC, in MARCATO (coord.), Código de Processo Civil Interpretado, p. 2337; LUCON, Execução de Título Extrajudicial, p. 31.

1290 LUCON, Comentários ao art. 739-B do CPC, in MARCATO (coord.), Código de Processo Civil Interpretado, p. 2337; LUCON, Execução de Título Extrajudicial, p. 30.

${ }_{1291}^{129}$ Multa no Código de Processo Civil, pp. 26-27.

1292 Assis (Manual da Execução, § 71, pp. 367-368) adota entendimento mais restritivo. Para ele, a possibilidade de se exigir o montante da multa na própria execução aplica-se somente à execução por quantia certa. Na execução de obrigação de fazer, por exemplo, não pode haver a execução também do valor da multa porque os ritos dessas duas espécies executivas são diferentes (art. 573 do CPC).
} 
se a execução principal for do tipo "execução para a entrega de coisa" ou "execução de obrigação de fazer" ou "de não fazer", a cobrança da multa decorrente de abuso processual deve ser promovida em autos apensos mesmo, como estatui o art. 739-B do CPC.

Caso a vítima do ato abusivo figure como executado no processo de execução ou na fase executiva em curso, ela pode requerer, nos autos apensos, a compensação entre o montante que deve para o exequente e o valor da multa a que tem direito ${ }^{1293}$.

\subsubsection{Peculiaridades da multa por abuso do processo da rescisória}

O Código de Processo Civil de 1973, com o intuito de impedir a utilização desmedida e infundada de ações rescisórias e de reprimir eventuais abusos, atribui ao autor o ônus de depositar a importância de $5 \%$ do valor da causa no momento do ajuizamento da petição inicial, a título de multa caso a ação venha a ser declarada inadmissível ou improcedente por unanimidade de votos (art. 488, II, do CPC) ${ }^{1294}$.

A efetuação do depósito é considerada um requisito necessário para que o relator profira despacho liminar de conteúdo positivo, deferindo a petição inicial ${ }^{1295}$. Consoante o inciso II do art. 490 do CPC, se faltar o depósito, a petição inicial deve ser indeferida liminarmente ${ }^{1296}$.

O montante do depósito, segundo o art. 488, II, do CPC, é de 5\% do valor da causa. Existem, porém, na doutrina e na jurisprudência, muitas dúvidas a respeito da base de cálculo dessa porcentagem, uma vez que o art. 259 do CPC, que versa sobre valor da causa, não prevê uma regra específica para a ação rescisória.

Alguns juristas estabelecem uma vinculação necessária entre o valor do processo no qual foi proferida a decisão rescindenda e o valor da rescisória. Afirmam que o valor

Entretanto, com o devido respeito, esse não parece ter sido o intuito do legislador, que determinou que a execução da decisão judicial que comina multa seja realizada em autos em apenso exatamente para assegurar a autonomia procedimental dela em relação à execução em curso.

${ }^{1293}$ LUCON, Comentários ao art. 739-B do CPC, in MARCATO (coord.), Código de Processo Civil Interpretado, p. 2337; LUCON, Execução de Título Extrajudicial, p. 30; OLIVEIRA, Multa no Código de Processo Civil, p. 27.

${ }^{1294}$ BARBOSA MOREIRA, Comentários ao Código de Processo Civil, vol. V, p. 182.

1295 BARBOSA MOREIRA, Comentários ao Código de Processo Civil, vol. V, pp. 183 e 189.

${ }^{1296}$ De acordo com Barbosa Moreira (Comentários ao Código de Processo Civil, vol. V, pp. 190-191), não se pode interpor o recurso previsto no art. 296 do CPC contra o indeferimento liminar da petição inicial da ação rescisória, pois parece violar a sistemática recursal brasileira sustentar o cabimento de apelação contra decisão que não seja oriunda de juízo de primeiro grau de jurisdição. Para o autor mostra-se mais correta do ponto de vista técnico a teoria de que o recurso cabível nesse caso é aquele previsto na lei de organização judiciária ou então no regimento interno do tribunal (e.g., no Supremo Tribunal Federal, utiliza-se o agravo regimental do art. 317 do RISTF). Aduz que, atualmente, o autor da rescisória pode fazer uso, por analogia, do agravo interno previsto no art. 557, $\S 1^{\circ}$, do CPC. 
desta é igual, do ponto de vista monetária, ao valor daquele, devendo a atualização ocorrer por meio da aplicação de índice de correção monetária ${ }^{1297}$.

Barbosa Moreira ${ }^{1298}$ discorda desse entendimento. Para o autor, três premissas devem ser levadas em consideração na determinação do valor da causa na ação rescisória: (a) o valor da causa é fixado basicamente com base no pedido; (b) a ação rescisória acarreta o surgimento de um processo distinto daquele no qual foi proferida a decisão rescindenda, com objeto próprio, que pode ser distinto do da outra causa (v.g., rescisória que impugna apenas o capítulo da sentença referente aos honorários advocatícios); (c) mesmo quando a ação rescisória acarreta o rejulgamento da causa, a pretensão deduzida pelo autor pode não coincidir, do ponto de vista econômico, com a apreciada no primeiro processo. Diante disso, o jurista sustenta que o dado essencial para se estabelecer o valor da ação rescisória é o seu pedido. Cita o seguinte exemplo: se a pretensão do autor é rescindir apenas o capítulo da sentença que fixou os honorários advocatícios abaixo do mínimo ou acima do máximo previstos no art. $20, \S 3^{\circ}$, do CPC, o valor da ação rescisória deve ser a diferença (para mais ou para menos) pleiteada.

Pode ser que a ação rescisória não tenha conteúdo econômico imediato, caso em que o autor deve indicar um valor estimativo, em respeito ao art. 258 do CPC. O mesmo se dá quando o autor da rescisória visa apenas à rescisão da sentença, sem pedir o rejulgamento $^{1299}$.

Se a rescisória impugnar duas ou mais sentenças, cumulando pedidos, incide o art. 259, II, do CPC (“O valor da causa constará sempre da petição inicial e será: [...] II havendo cumulação de pedidos, a quantia correspondente à soma dos valores de todos eles") ${ }^{1300}$.

No curso do processo rescisório, é possível que o valor da causa seja retificado, de ofício ou em decorrência de impugnação do réu. Nesse caso, o depósito precisa ser complementado. Se o autor deixar de complementar, o processo deve ser extinto sem julgamento do mérito com fundamento no art. 267, III, do $\mathrm{CPC}^{1301}$.

O Capítulo IV do Título IX do Livro I do Código de Processo Civil, que trata da ação rescisória, é silente acerca da forma como o depósito deve ser feito. O art. 490, II, do

\footnotetext{
${ }^{1297}$ Nesse sentido é a doutrina de Pontes de Miranda (Tratado da Ação Rescisória das Sentenças e de Outras Decisões, p. 513):

"O valor de uma ação rescisória não pode ser considerado maior do que o da sentença rescindenda, mas há a correção monetária".

${ }^{1298}$ Comentários ao Código de Processo Civil, vol. V, pp. 180-182.

1299 BARBOSA MOREIRA, Comentários ao Código de Processo Civil, vol. V, p. 182.

${ }^{1300}$ BARBOSA MOREIRA, Comentários ao Código de Processo Civil, vol. V, p. 182.

${ }^{1301}$ BARBOSA MOREIRA, Comentários ao Código de Processo Civil, vol. V, p. 184.
} 
CPC apenas estatui que o deferimento da petição inicial pressupõe o depósito, como já se afirmou anteriormente. Com base nessa exigência, Barbosa Moreira ${ }^{1302}$ propõe duas possíveis soluções procedimentais:

a) uma vez ajuizada a demanda rescisória, a petição inicial só é encaminhada ao relator depois de efetuado o depósito por meio de guia do juízo ou quando esgotado "in albis" o prazo para fazê-lo;

b) depois de distribuída (art. 548 do CPC), a petição inicial da ação rescisória vai imediatamente para o relator, o qual profere despacho determinando a expedição da guia de recolhimento. Efetuado o depósito, o relator pode deferir a petição ou não.

Para Barbosa Moreira, a solução "a" é a mais vantajosa do ponto de vista prático, porém, se adotada, ela raramente permitiria a observação do art. 549 do CPC, que fixa o prazo de 48 horas para que os autos subam à conclusão do relator após a distribuição. $\mathrm{O}$ jurista comenta que essa lacuna legal deve ser solucionada pelos próprios tribunais, por meio dos seus regimentos internos ${ }^{1303}$.

Outra questão polêmica diz respeito ao lapso temporal dentro do qual se deve efetuar o depósito. Parte da doutrina defende que esse prazo é de 10 dias, em consonância com o que dispõe o art. 284 do $\mathrm{CPC}^{1304}$. Porém, parece mais correto afirmar que, uma vez expedida a guia, o prazo para a realização do depósito é de 5 dias, com espeque no art. 185 do $\mathrm{CPC}^{1305}$.

No momento em que o tribunal julga a ação rescisória, ele deve pronunciar-se a respeito do depósito da importância de 5\% do valor da causa, feito nos termos do art. 488, II, do CPC. Da leitura do art. 494 c/c art. 488, II, do CPC é possível inferir duas possíveis soluções:

\footnotetext{
${ }^{1302}$ BARBOSA MOREIRA, Comentários ao Código de Processo Civil, vol. V, pp. 183-184 e 189.

${ }^{1303} \mathrm{O}$ Regimento Interno do TJ/SP é silente a respeito do tema. Em seu art. 232, ele apenas dispõe o seguinte: "Art. 232. Ajuizada a ação rescisória, a Secretaria, entre outras providências:

I - comunicará o fato ao distribuidor de primeira instância, em se cuidando de rescisória de sentença;

II - anotará a ocorrência nos assentamentos, com remissão ao processo em que foi proferida a decisão impugnada, na hipótese de rescisória de acórdão;

III - distribuirá o feito ao mesmo Grupo de Câmaras em que proferido o acórdão rescindendo, anotando o ato para futura compensação".

Já o Regimento Interno do TRF da $3^{\text {a }}$ Região parece ter adotado a solução "a" proposta por Barbosa Moreira, como se infere do seu art. 196:

"Art. 196 - Distribuída a inicial e preenchidos os requisitos legais, o Relator mandará citar o réu, assinando-lhe prazo nunca inferior a 15 (quinze) dias nem superior a 30 (trinta), para responder aos termos da ação.

Parágrafo único - A inicial deverá vir acompanhada de tantas cópias quantos forem os réus".

${ }^{1304}$ É o que defende Pontes de Miranda (Tratado da Ação Rescisória das Sentenças e de Outras Decisões, p. 498).

${ }^{1305}$ BARbOSA MOREIRA, Comentários ao Código de Processo Civil, vol. V, p. 184 e nt. 182.
} 
a) se a ação for unanimemente declarada inadmissível, ou se o pedido for julgado improcedente também de forma unânime, o autor perde a quantia depositada a título de multa para o réu. Para que isso ocorra, é irrelevante o comportamento da parte ré, podendo esta até mesmo ser considerada revel no processo ${ }^{1306}$. Havendo litisconsórcio passivo, os demandados devem ratear a importância depositada, a não ser que os pressupostos da perda do depósito sejam referentes a capítulo da sentença atinente a um só (ou a alguns) deles $^{1307}$;

b) se a ação for declarada inadmissível por maioria de votos, ou se o pedido for julgado improcedente por maioria de votos, ou ainda se a demanda for julgada procedente (independentemente de ser de forma unânime ou por maioria de votos), o tribunal deve determinar a restituição da importância depositada ao autor.

De acordo com a doutrina, o depósito deve ser restituído ao autor em outras duas situações não previstas expressamente no texto da lei: se houver o indeferimento liminar da petição inicial pelo relator (art. 490 do CPC) e em caso de desistência da ação ${ }^{1308} 1309$.

Na hipótese de haver sucumbência parcial recíproca (por exemplo, se o autor pediu a rescisão de dois capítulos da sentença, mas só obteve a de um deles), Barbosa Moreira ${ }^{1310}$ sustenta a aplicação, por analogia, do art. 21, “caput” e parágrafo único, do CPC ${ }^{1311}$.

Sabe-se que o julgamento da ação rescisória é realizado em três etapas sucessivas: (a) a verificação da admissibilidade da ação; (b) o exame do pedido de rescisão da sentença impugnada ("iudicium rescindens"); e (c) o rejulgamento da matéria que tinha sido decidida pela sentença impugnada ("iudicium rescissorium”). Tanto o "iudicium rescindens" quanto o "iudicium rescissorium" fazem parte do julgamento do mérito da ação rescisória ${ }^{1312}$. Porém, quando o legislador, no art. 494 do CPC, fala em julgar procedente ou improcedente a ação rescisória, ele está se referindo ao pedido de rescisão, ou seja, ao "iudicium rescindens". O resultado do "iudicium rescissorium" não influi na determinação do destino do depósito previsto no art. 488, II, do $\mathrm{CPC}^{1313}$.

\footnotetext{
${ }^{1306}$ BARBOSA MOREIRA, Comentários ao Código de Processo Civil, vol. V, p. 213.

${ }^{1307}$ BARBOSA MOREIRA, Comentários ao Código de Processo Civil, vol. V, p. 214.

${ }_{1308}$ Nesse sentido: STF, Tribunal Pleno, AR 1.031/SP, Rel. Min. Moreira Alves, DJ 01/09/1978, p. 06467.

${ }^{1309}$ BARBOSA MOREIRA, Comentários ao Código de Processo Civil, vol. V, pp. 212 e 213.

${ }^{1310}$ Comentários ao Código de Processo Civil, vol. V, p. 214.

1311 "Art. 21. Se cada litigante for em parte vencedor e vencido, serão recíproca e proporcionalmente distribuídos e compensados entre eles os honorários e as despesas.

Parágrafo único. Se um litigante decair de parte mínima do pedido, o outro responderá, por inteiro, pelas despesas e honorários"

${ }^{1312}$ BARBOSA MOREIRA, Comentários ao Código de Processo Civil, vol. V, pp. 205-206.

1313 BARBOSA MOREIRA, Comentários ao Código de Processo Civil, vol. V, p. 212.
} 
O pronunciamento a respeito do depósito deve ser realizado pelo tribunal de ofício, independentemente de pedido das partes. Se o acórdão for silente acerca desse tema, cabem embargos de declaração (art. 535, II, do CPC). Porém, mesmo se a parte interessada não opuser esse recurso, ela pode proceder ao levantamento da importância depositada, pois a lei a autoriza a fazê-lo ${ }^{1314}$.

Contra o acórdão proferido na rescisória é possível interpor três recursos, além dos embargos de declaração: embargos infringentes (art. 530 do CPC), recurso especial (art. 105, III, da CF) e recurso extraordinário (art. 102, III, da CF) $)^{1315}$. Se o órgão "ad quem" admite o recurso e passa à apreciação do mérito recursal, o destino do depósito é definido pelo que for fixado em sua decisão, a qual substitui o acórdão recorrido (art. 512 do CPC). Destarte, o autor da rescisória pode levantar o valor depositado se o juízo "ad quem" julgar procedente o pedido de rescisão, bem como se, por maioria de votos, declarar a ação inadmissível ou julgar improcedente o pedido; por outro lado, o montante beneficia o réu se for declarada a inadmissibilidade da ação ou a improcedência do pedido rescisório de forma unânime. Entretanto, se o recurso não for conhecido, o acórdão recorrido transita em julgado, restando definida a sorte do depósito de acordo com o seu conteúdo ${ }^{1316}$.

Para que se proceda ao levantamento do depósito, é necessário cumprir os seguintes requisitos ${ }^{1317}$ :

a) o acórdão deve ter transitado em julgado ou estar sujeito a recurso dotado apenas de efeito devolutivo. Nessa segunda hipótese, o requerente deve prestar caução, pois se aplica, por analogia, o art. 475-O, III, do CPC;

b) o autor ou o réu deve requerer a expedição de guia contra o estabelecimento bancário onde a quantia estiver depositada.

\subsection{Pagamento da multa como pressuposto objetivo de admissibilidade de recursos posteriores}

A aplicação da multa de até $10 \%$ do valor da causa em decorrência da prática de abuso do poder de recorrer - seja com fundamento no art. 538, parágrafo único, do CPC, seja com base no art. 557, § $2^{\circ}$, do CPC - tem por consequência uma segunda sanção: o

\footnotetext{
${ }^{1314}$ BARBOSA MOREIRA, Comentários ao Código de Processo Civil, vol. V, p. 212.

1315 Acerca dos recursos cabíveis contra o acórdão proferido no julgamento da rescisória, consultar: BARBOSA MOREIRA, Comentários ao Código de Processo Civil, vol. V, pp. 214-216.

${ }^{1316}$ BARBOSA MOREIRA, Comentários ao Código de Processo Civil, vol. V, pp. 213-214.

${ }^{1317}$ BARBOSA MOREIRA, Comentários ao Código de Processo Civil, vol. V, p. 214.
} 
pagamento dessa quantia constitui pressuposto objetivo de admissibilidade de eventuais recursos posteriores interpostos pelo "improbus litigator" ${ }^{1318}$. Abdo ${ }^{1319}$ classifica essa sanção na categoria das que importam "restrição de direitos".

O prévio depósito do montante da multa deve ser comprovado no ensejo da interposição do recurso ${ }^{1320}$ (mediante recibo de depósito ou certidão cartorária no sentido do cumprimento da norma processual $)^{1321}$.

Parte da doutrina alega que tal sanção prejudica os hipossuficientes econômicos, constituindo uma barreira à garantia constitucional da ampla defesa $\left(\operatorname{art.} 5^{\circ}, \mathrm{LV}, \text { da CF }\right)^{1322}$. No entanto, a questão da constitucionalidade do art. 557, § $2^{\circ}$, do CPC (e, consequentemente, também do art. 538, parágrafo único, do CPC) já se encontra superada no Supremo Tribunal Federal, que decidiu nos seguintes termos:

A exigência pertinente ao depósito prévio do valor da multa, longe de inviabilizar o acesso à tutela jurisdicional do Estado, visa a conferir real efetividade ao postulado da lealdade processual, em ordem a impedir que o processo judicial se transforme em instrumento de ilícita manipulação pela parte que atua em desconformidade com os padrões e critérios normativos que repelem atos atentatórios à dignidade da justiça (CPC, art. 600) e que repudiam comportamentos caracterizadores de litigância maliciosa, como aqueles que se traduzem na interposição de recurso com intuito manifestamente protelatório (CPC, art. 17, VII). A norma inscrita no art. 557, $\S 2^{\circ}$, do CPC, na redação dada pela Lei $\mathrm{n}^{\circ} 9.756 / 98$, especialmente quando analisada na perspectiva dos recursos manifestados perante o Supremo Tribunal Federal, não importa frustração do direito de acesso ao Poder Judiciário, mesmo porque a exigência de depósito prévio tem por única finalidade coibir os excessos, os abusos e os desvios de caráter ético-jurídico nos quais incidiu o improbus litigator (STF, $2^{\mathrm{a}}$ Turma, EDcl no AgRg no RE no 246.564-0/RS, Rel. Min. Celso de Mello, j. 19/10/1999, maioria de votos).

O que atualmente se discute acerca dos arts. 538, parágrafo único, e 557, $\S 2^{\circ}$, do CPC é a necessidade de a parte beneficiária da justiça gratuita depositar o montante da multa de até $10 \%$ do valor da causa para que outros recursos por ela interpostos sejam admitidos.

\footnotetext{
1318 O Projeto de Lei $\mathrm{n}^{\circ}$ 8.046/2010 (que institui o novo Código de Processo Civil) tem dispositivos semelhantes. Consoante os arts. $980, \S 6^{\circ}$, e $975, \S 2^{\circ}$, se a parte for condenada pela oposição de embargos de declaração manifestamente protelatórios ou pela interposição de agravo interno manifestamente inadmissível, a interposição de qualquer outro recurso fica condicionada ao depósito do valor da multa, ressalvados os beneficiários da gratuidade de justiça, que devem recolhê-la ao final.

${ }^{1319}$ O Abuso do Processo, p. 238.

${ }^{1320}$ BARBOSA MOREIRA, Comentários ao Código de Processo Civil, vol. V, pp. 573 e 680.

${ }^{1321}$ Nesse sentido: STJ, $2^{\mathrm{a}}$ Turma, AgRg no REsp 532.621/RJ, Rel. Min. Franciulli Netto, DJ 06/09/2004, p. 214; STJ, $5^{a}$ Turma, AgRg no Ag 473.040/RJ, Rel. Min. Gilson Dipp, DJ 10/02/2002, p. 232.

${ }^{1322}$ LUCON, Abuso do Exercício do Direito de Recorrer, in NERY JÚNIOR; ALVIM WAMBIER (coords.), Aspectos Polêmicos e Atuais dos Recursos Cíveis e de Outras Formas de Impugnação às Decisões Judiciais, pp. 892-893.
} 
Na opinião de Luchi Demo ${ }^{1323}$, essa sanção não se aplica ao beneficiário da justiça gratuita porque a multa de $10 \%$ do valor da causa tem natureza jurídica de custas processuais (art. 35 do CPC) e a sua isenção encontra espeque legal no art. $3^{\circ}$, I, da Lei $n^{\circ}$ $1.060 / 50^{1324}$.

Ao contrário, e com mais razão, Barbosa Moreira ${ }^{1325}$ entende que o art. $3^{\circ}$, II, da Lei $\mathrm{n}^{\mathrm{o}} 1.060 / 50^{1326}$ não abrange as custas que são revertidas em proveito da parte contrária, como ocorre com as multas previstas nos arts. 538, parágrafo único; e 557, $\S 2^{\circ}$, do $\mathrm{CPC}^{1327}$. Logo, os beneficiários da justiça gratuita devem, sim, pagar a multa para que possam interpor novo recurso.

Os ministros do Superior Tribunal de Justiça acompanham este segundo posicionamento, porém abrandam-no. Eles entendem que isentar o assistido pela justiça gratuita do pagamento de multa por litigância de má-fé constituiria uma permissão para que ele praticasse atos indevidos ou ilegais durante o trâmite processual sem sofrer qualquer punição por isso ${ }^{1328}$. Contudo, em virtude da concessão de gratuidade de justiça, o pagamento da multa fica suspenso ${ }^{1329} 1330$.

Resta sublinhar outro tema tormentoso para a doutrina dentro dessa matéria: tratase da submissão da Fazenda Pública à exigência de depósito prévio da multa de até $10 \%$ do

\footnotetext{
${ }^{1323}$ Embargos de Declaração: aspectos processuais e procedimentais, p. 145.

1324 "Art. 3". A assistência judiciária compreende as seguintes isenções:

I - das taxas judiciárias e dos selos".

${ }^{1325}$ Comentários ao Código de Processo Civil, vol. V, p. 572.

1326 "Art. $3^{\circ}$. A assistência judiciária compreende as seguintes isenções:

$[\ldots]$
}

II -dos emolumentos e custas devidos aos Juízes, órgãos do Ministério Público e serventuários da justiça".

${ }^{1327}$ No mesmo sentido: DORIA, A Litigância de Má-Fé e a Aplicação de Multas, in MARINONI (coord.), Estudos de Direito Processual Civil - homenagem ao professor Egas Dirceu Moniz de Aragão, p. 654.

${ }^{1328}$ Nesse sentido: STJ, Corte Especial, AgRg nos EREsp 228.139/SP, Rel. Min. Francisco Peçanha Martins, DJ 23/10/2006, p. 235; STJ, 4 ${ }^{\mathrm{a}}$ Turma, EDcl nos EDcl nos EDcl no REsp 795.849/MG, Rel. Min. Luís Felipe Salomão, DJe 24/08/2009; STJ, $4{ }^{\mathrm{a}}$ Turma, RMS 15.600/SP, Rel. Min. Aldir Passarinho Júnior, DJe 23/06/2008; STJ, 4 a Turma, EDcl no AgRg no Ag 1.134.291/DF, Rel. Min. João Otávio de Noronha, DJe 14/09/2009; STJ, 4 $4^{\text {a }}$ Turma, EDcl no AgRg no REsp 1.113.799/RS, Rel. Min. Aldir Passarinho Júnior, DJe $16 / 11 / 2009$.

${ }^{1329}$ Expressamente nesse sentido: STJ, $4^{\text {a }}$ Turma, EDcl no REsp n ${ }^{\mathbf{o}}$ 264.661/MG, Rel. Min. Ruy Rosado de Aguiar, DJ 10/11/03, p. 193; STJ, 3 a Turma, AgRg nos EDcl no AgRg no Ag 563.492/GO, Rel. Min. Carlos Alberto Menezes Direito, DJ 21/02/2005, p. 171.

${ }^{1330}$ Caso o projeto do novo Código de Processo Civil (Projeto de Lei $n^{\circ}$ 8.046/2010) seja aprovado nos termos atuais, esse entendimento jurisprudencial passará a ter espeque legal expresso no $\S 2^{\circ}$ do art. 975 e no $\S 6^{\circ}$ do art. 980 :

"§ $2^{\circ}$ Quando manifestamente inadmissivel o agravo interno, assim declarado em votação unânime, o tribunal condenará o agravante a pagar ao agravado multa fixada entre um e dez por cento do valor corrigido da causa, ficando a interposição de qualquer outro recurso condicionada ao depósito prévio do respectivo valor, ressalvados os beneficiários da gratuidade de justiça que, conforme a lei, farão o pagamento ao final';

"§ $6^{\circ}$ A interposição de qualquer outro recurso fica condicionada ao depósito do valor de cada multa, ressalvados os beneficiários da gratuidade de justiça que a recolherão ao final, conforme a lei" (destaques nossos). 
valor da causa para que outros recursos por ela interpostos sejam admitidos. Essa polêmica existe em razão do art. $1^{\circ}$-A da Lei $n^{\circ}$ 9.494/97, incluído pela MP $n^{\circ}$ 2.180-35/01, que estatui que as pessoas jurídicas de direito público federais, estaduais, distritais e municipais estão dispensadas de depósito prévio para interposição de recurso.

Verifica-se a existência de duas correntes contrapostas:

a) a primeira afirma que a vontade do legislador que elaborou a Lei $n^{\circ}$ 9.494/97 foi de isentar as pessoas jurídicas de direito público interno de qualquer depósito prévio, sem fazer ressalva alguma referente a multas ${ }^{1331}$. Para corroborar essa tese, Carneiro da Cunha $^{1332}$ alega que as multas dos arts. 538, parágrafo único, e 557, $\S 2^{\circ}$, do CPC são equiparadas a custas pelo art. 35 do $\mathrm{CPC}^{1333}$. Desse modo, uma vez condenada a Fazenda Pública a pagar a multa, essa sanção só deve ser executada ao final, caso o ente estatal seja vencido na causa (art. 27 do $\mathrm{CPC}^{1334}$ ). Barbosa Moreira ${ }^{1335}$ é outro autor que sustenta que o depósito de tais multas pela Fazenda Pública não constitui pressuposto de admissibilidade de recurso subsequente, dada a incidência do art. $1^{\text {o }}$-A da Lei n ${ }^{\circ}$ 9.494/97;

b) a segunda corrente - pela qual mostramos preferência - interpreta restritivamente a expressão "depósito prévio" contida no art. 1º-A da Lei no 9.494/97, entendendo que ela apenas se refere ao preparo recursal, ou seja, às custas, não abrangendo as multas previstas nos dois supramencionados dispositivos do Código de Processo Civil, que têm natureza sancionatória. Diante disso, sem a realização do depósito do valor da multa, não pode ser admitido qualquer recurso interposto pela Fazenda Pública ${ }^{1336}$. Segundo o Ministro Humberto Martins, a adoção de tese diversa configuraria, por vias transversas, verdadeira isenção ${ }^{1337}$. No mesmo sentido, o Ministro Felix Fischer ${ }^{1338}$ argumenta que confundir a isenção de depósito prévio (caução) com o depósito referente à multa esvaziaria o sentido do art. 557, $\S 2^{\circ}$, do CPC, que é evitar a interposição procrastinatória do agravo regimental. Além do mais, não parece correto sustentar a aplicação do art. 27 do CPC (segundo o qual as despesas dos atos processuais efetuados a

\footnotetext{
${ }^{1331}$ Nesse sentido é o voto do Ministro Menezes Direito como relator nos EREsp 695.001/RJ (STJ, Corte Especial, DJ 02/04/2007, p. 207).

${ }^{1332}$ A Fazenda Pública em Juízo, pp. 130-131.

1333 “Art. 35. As sanções impostas às partes em consequência de má-fé serão contadas como custas e reverterão em benefício da parte contrária; as impostas aos serventuários pertencerão ao Estado".

1334 "Art. 27. As despesas dos atos processuais, efetuados a requerimento do Ministério Público ou da Fazenda Pública, serão pagas a final pelo vencido".

${ }^{1335}$ Comentários ao Código de Processo Civil, vol. V, p. 680.

1336 Nesse sentido: DORIA, A Litigância de Má-Fé e a Aplicação de Multas, in MARINONI (coord.), Estudos de Direito Processual Civil - homenagem ao professor Egas Dirceu Moniz de Aragão, p. 654.

${ }^{1337}$ Voto como relator nos EDcl nos EREsp 511.144/DF (STJ, $1^{\text {a }}$ Seção, DJ 12/02/2007, p. 229).

${ }^{1338}$ Voto vencido nos EREsp 695.001/RJ (STJ, Corte Especial, Rel. Min. Carlos Alberto Menezes Direito, DJ 02/04/2007, p. 207).
} 
requerimento da Fazenda Pública serão pagas pelo vencido, ao final do processo) ao regime de pagamento das multas previstas nos arts. 538, parágrafo único, e $557, \S 2^{\circ}$, do CPC, como sustenta Carneiro da Cunha, uma vez que isso faria com que a Fazenda Pública só fosse considerada devedora dessas sanções pecuniárias quando perdesse a causa. Acontece que, como foi explicado no item 1.7 "supra", tanto a parte sucumbente, quanto a que tem a sua demanda julgada procedente, podem ser consideradas litigantes de má-fé e, consequentemente, ter de pagar a multa decorrente da improbidade processual perpetrada.

A jurisprudência do Superior Tribunal de Justiça sobre esse assunto encontra-se dividida: há decisões adotando a segunda tese ${ }^{1339}$, porém, existem também julgados que optam pela primeira corrente, dentre os quais estão os mais recentes ${ }^{1340}$.

\subsection{Obrigação de arcar com o custo do processo (despesas processuais e honorários advocatícios)}

Todo processo demanda o dispêndio de recursos financeiros, quer para o exercício da jurisdição pelo Estado, quer para a defesa dos interesses das partes. O custo financeiro do processo abrange as despesas processuais e os honorários advocatícios, cujo pagamento é arcado, em regra, pelas partes. De acordo com a doutrina, a gratuidade total do processo incentivaria a litigância irresponsável, a dano da jurisdição ${ }^{1341}$.

A expressão "despesas processuais" engloba os itens do custo do processo devidos a agentes estatais. São eles: (a) as taxas judiciárias, ou custas, as quais são devidas ao Estado para ressarci-lo de parte significativa das despesas gerais decorrentes do exercício da jurisdição (investimentos em imóveis, remunerações, material empregado etc.); (b) os emolumentos, que são devidos aos titulares de eventuais cartórios não-oficializados, em decorrência de investimentos feitos, remunerações pagas a auxiliares e serviços prestados; (c) o custo de certos atos e diligências (v.g., intimações e citações feitas por oficiais de

\footnotetext{
${ }^{1339}$ Nesse sentido: STJ, $2^{\text {a }}$ Turma, AgRg no REsp 532.621/RJ, Rel. Min. Franciulli Netto, DJ 06/09/2004, p. 214; STJ, $5^{\text {a }}$ Turma, REsp 592.132/RS, Rel. Min. José Arnaldo da Fonseca, DJ 16/05/2005, p. 383; STJ, $6^{\text {a }}$ Turma, AgRg no REsp 695.001/RJ, Rel. Min. Hamilton Carvalhido, DJ 01/07/2005, p. 687; STJ, $2^{\mathrm{a}}$ Turma, AgRg no Ag 803.298/SP, Rel. Min. João Otávio de Noronha, DJ 06/02/2007, p. 290; STJ, 1 ${ }^{a}$ Seção, EDcl nos EREsp 511.144/DF, Rel. Min. Humberto Martins, DJ 12/02/2007, p. 229; STJ, 6 ${ }^{a}$ Turma, AgRg no Ag 524.667/RS, Rel'. Min $^{\mathrm{a}}$. Maria Thereza de Assis Moura, DJ 26/03/2007, p. 303.

${ }^{1340}$ Nesse sentido: STJ, $1^{\text {a }}$ Turma, REsp 605.197/SP, Rel. Min. Luiz Fux, DJ 31/05/2004, p. 227; STJ, $1^{\text {a }}$ Turma, REsp 749.528/SP, Rel. Min. Teori Albino Zavascki, DJ 01/07/2005, p. 452; STJ, Corte Especial, EREsp 695.001/RJ, Rel. Min. Carlos Alberto Menezes Direito, DJ 02/04/2007, p. 207; STJ, $1^{a}$ Seção, Pet 3.843/SP, Rel. Min. Luiz Fux, DJe 20/02/2009; STJ, $1^{\text {a }}$ Turma, REsp 1.102.277/PR, Rel. Min. Benedito Gonçalves, DJe 31/08/2009; STJ, Corte Especial, EREsp 1.068.207/PR, Rel. p/ Acórdão Min. Arnaldo Esteves Lima, DJe 16/08/2012.

${ }^{1341}$ DINAMARCO, Instituições de Direito Processual Civil, vol. II, § 738, pp. 650-651.
} 
justiça; serviços do contador do juízo etc.), posto que realizados por auxiliares permanentes da Justiça; (d) a remuneração de auxiliares eventuais da Justiça, os quais não são servidores do Poder Judiciário e, consequentemente, não são remunerados pelo Estado (v.g., peritos, avaliadores, depositários, inventariantes dativos, administradores de falências ou recuperações judiciais, órgãos extravagantes, como os entes postais e a imprensa oficial, etc. $)^{1342}$. Consoante o $\S 2^{\circ}$ do art. 20 do CPC, as despesas abrangem também a indenização de viagem, diária de testemunha (art. 419, "caput", do CPC) e remuneração do assistente técnico.

"Honorários advocatícios", por sua vez, é a denominação da verba que uma parte (em regra, a vencida) deve pagar à outra para ressarci-la das despesas suportadas ao remunerar seu próprio advogado na causa ${ }^{1343}$. No arbitramento do seu valor, o juiz deve levar em consideração os parâmetros previstos nos $\S \S 3^{\circ}$ a $5^{\circ}$ do art. 20 do CPC. A obrigação de pagar os honorários advocatícios é legitimada, do ponto de vista ético, pelo fato de o sujeito ter dado causa ao processo, gerando a necessidade de a parte contrária contratar um advogado e pagá-lo ${ }^{1344}$. Ainda que a parte vencedora tenha atuado em causa própria, ela tem direito aos honorários advocatícios, pois o serviço que realizou para si mesma tem valor econômico e teve como causa a conduta da contraparte ${ }^{1345}$. Por outro lado, quando é proferida sentença de improcedência em julgamento liminar do mérito (art. 285-A do CPC), ou em julgamento antecipado do mérito fundado na revelia do demandado (art. 330, II, do CPC), o autor não é condenado a pagar honorários da sucumbência justamente porque, nesses casos, o réu não tem qualquer gasto com honorários advocatícios. Segundo o art. 23 da Lei no 8.906/94, os honorários da sucumbência são um direito do advogado da parte vencedora, e não da própria parte, tendo ele legitimidade " $a d$ causam" para promover a execução forçada relativa a tais honorários em nome próprio. Mas, em respeito à liberdade contratual, o advogado pode negociar a verba honorária de sucumbência com seu constituinte, pois se trata de direito disponível ${ }^{1346} 1347$.

\footnotetext{
1342 DINAMARCO, Instituições de Direito Processual Civil, vol. II, § 739, pp. 651-652.

${ }^{1343}$ DINAMARCO, Instituições de Direito Processual Civil, vol. II, § 739, p. 652.

${ }^{1344}$ DINAMARCO, Instituições de Direito Processual Civil, vol. II, § 739, p. 653.

1345 DINAMARCO, Instituições de Direito Processual Civil, vol. II, § 749, p. 667.

${ }^{1346}$ Nesse sentido: STF, Pleno, ADI n ${ }^{\circ}$ 1.194/DF, Rel ${ }^{\mathrm{a}}$. p/ acórdão Mina ${ }^{\text {a }}$ Cármen Lúcia, DJe-171 DIVULG 10-09-2009 PUBLIC 11-09-2009, em que se declarou a inconstitucionalidade do $\S 3^{\circ}$ do art. 24 da Lei $\mathrm{n}^{\circ}$ 8.906/94 ("É nula qualquer disposição, cláusula, regulamento ou convenção individual ou coletiva que retire do advogado o direito ao recebimento dos honorários de sucumbência").

${ }^{1347}$ De acordo com Dinamarco (Instituições de Direito Processual Civil, vol. II, § 739, p. 653; e $§ 763$, p. 693), somente é válido o ajuste celebrado entre o advogado e seu cliente para que o valor dos honorários da sucumbência fixado na sentença pertença a este, e não àquele, se os dois houverem previamente acordado que o advogado tem o direito de receber uma quantia pelo menos equivalente a título de honorários
} 
Existem normas que estabelecem a maneira como as partes devem satisfazer o custo financeiro do processo. De acordo com o ordenamento jurídico brasileiro, a responsabilidade pelo custo do processo é composta: (a) pelo ônus de adiantar despesas processuais em certos momentos do processo; e (b) pela obrigação de, ao final do processo, pagar as despesas ainda em aberto, reembolsar a parte contrária pelas despesas que adiantou e pagar os honorários sucumbenciais ${ }^{1348}$. Amaral Santos ${ }^{1349}$ fala em "responsabilidade provisória" e em "responsabilidade definitiva", respectivamente.

Atribui-se às partes o ônus de adiantar despesas processuais em certos momentos do processo (art. 19 do CPC) como requisito para que tenham eficácia determinados atos que elas praticam (v.g., ônus de preparar a demanda inicial - art. 257 do CPC; ônus de preparar o recurso - art. 511 do CPC), ou então para que elas obtenham a realização de certos atos por auxiliares da Justiça (e.g., ônus de adiantar os honorários provisórios ao perito - art. 33 do CPC $)^{1350}$. Essa responsabilidade provisória pelo pagamento das despesas do processo tem espeque na premissa do interesse: ao sujeito que pretende beneficiar-se de um ato deve-se atribuir o ônus de custeá-lo. Sua função é evitar a litigiosidade irresponsável, incentivando os possíveis demandantes a pensarem a respeito da viabilidade de suas pretensões ${ }^{1351}$.

A chamada "responsabilidade definitiva" pelos custos processuais consiste na obrigação de, ao final do processo, uma das partes (em regra, a vencida) pagar ao Estado ou aos auxiliares da Justiça as despesas ainda em aberto, reembolsar a parte contrária pelas despesas que adiantou e pagar também a esta os honorários advocatícios. Tem como premissa ética e econômica o fato de que seria injusto onerar o vencedor com despesas que foram necessárias para o reconhecimento do seu direito; em outras palavras, o vencedor da

contratuais. Se o cliente não for contratualmente obrigado a pagar qualquer remuneração ao seu advogado, o doutrinador defende que a integralidade do valor dos honorários da sucumbência deve-se destinar ao causídico.

${ }^{1348}$ DINAMARCO, Instituições de Direito Processual Civil, vol. II, § 741, p. 655; LIEBMAN, Manual de Direito Processual Civil, vol. I, §§ 61 e 62, pp. 126-130.

${ }_{1349}$ Primeiras Linhas de Direito Processual Civil, vol. 2, pp. 306-309.

${ }^{1350}$ Dinamarco (Instituições de Direito Processual Civil, vol. II, § 743, pp. 659-661) ensina que, no sistema do Código de Processo Civil brasileiro, existem apenas dois momentos cruciais de adiantar despesas: o da propositura da demanda inicial (art. 257 do CPC) e o da interposição dos recursos (art. 511 do CPC). O autor esclarece que as leis de organização judiciária é que repartem o valor das custas totais do processo, fixando o percentual a ser recolhido na propositura da demanda e o que se recolherá depois, seja ao recorrer, seja em outro momento por elas indicado. No que concerne aos atos praticados por auxiliares eventuais da Justiça (v.g., peritos, avaliadores, depositários, inventariantes dativos, administradores de falências ou recuperações judiciais, órgãos extravagantes em geral etc.), a parte interessada tem o ônus de antecipar o pagamento das despesas por ocasião de cada um desses atos (art. 19, "caput" e $\S 1^{\circ}$, do CPC), como requisito prévio para que se realizem.

${ }^{1351}$ DINAMARCO, Instituições de Direito Processual Civil, vol. II, § 741, pp. 655-656; e $\S \S 742$ e 743 , pp. 657-661. 
demanda deve obter a satisfação do seu direito integralmente, e não diminuído pelas despesas patrimoniais da causa ${ }^{1352}$. Rege-se pelo princípio da causalidade, segundo o qual responde pelo custo do processo o sujeito que houver dado causa a ele, seja ao propor demanda inadmissível ou improcedente, seja ao obrigar quem tem razão a vir a juízo para obter ou manter aquilo a que já tem direito.

Um excelente indicador dessa relação causal é a sucumbência, a qual está prevista no art. 20 do CPC: "A sentença condenará o vencido a pagar ao vencedor as despesas que antecipou e os honorários advocatícios" 1353 1354. Considera-se sucumbente a parte cujos pedidos não foram acolhidos pelo órgão jurisdicional, ainda que por motivos diferentes do mérito, bem como aquela que, não tendo formulado pedido algum, vê acolhidos os pedidos da parte contrária ${ }^{1355}$.

Em algumas situações, a sucumbência deixa de ser um indício do princípio da causalidade e não pode ser empregada como critério para a atribuição da obrigação pelo custo do processo. Isso acontece, por exemplo, quando uma pessoa ajuíza demanda cobrando algo e o devedor, logo depois de citado, reconhece o pedido e efetua o pagamento, demonstrando que sempre se dispôs a pagar. Quem deve arcar com o custo financeiro desse processo é o autor-vencedor, pois deu causa a ele sem necessidade, já que o réu-sucumbente não estava oferecendo resistência alguma à sua pretensão. Igualmente, quando, em ação de consignação em pagamento, o credor demandado demonstra que não incorreu em "mora accipiendi" (art. 896, I, do CPC), quem paga as custas do processo é o devedor que ajuizou a ação. Nesses casos, posto que se afaste o critério da sucumbência, mantém-se em vigor o princípio da causalidade ${ }^{1356}$.

Entretanto, certas normas do Código de Processo Civil tratam de situações extraordinárias em que a obrigação de pagar as despesas processuais e os honorários advocatícios ao final do processo não é regida pelo princípio da causalidade. Elas atribuem a um dos sujeitos do processo o dever de arcar com o custo processual em decorrência da

\footnotetext{
${ }^{1352}$ LIEBMAN, Manual de Direito Processual Civil, vol. I, § 62, p. 128.

${ }^{1353}$ Em atenção ao critério da sucumbência, nas situações em que mais de um sujeito deu causa ao processo e sucumbiu, a responsabilidade final pelo custo processual deve ser rateada entre as partes. É o que ocorre, por exemplo: nos casos de sucumbência recíproca, em que cada litigante é parcialmente vencedor e parcialmente vencido (art. 21 do CPC); em processos de jurisdição voluntária (art. 24 do CPC), pois se pressupõe que não há litigiosidade ou controvérsias em processos dessa espécie; nos processos divisórios em que inexista litígio entre as partes (art. 25 do CPC); nos processos em que há desistência parcial da ação ou reconhecimento parcial do pedido (art. 26, $\S 1^{\circ}$, do CPC); nos processos em que há transação entre as partes e elas tenham silenciado a respeito do rateio das despesas processuais no ato translativo (art. $26, \S 2^{\circ}$, do CPC) etc.

${ }^{1354}$ DINAMARCO, Instituições de Direito Processual Civil, vol. II, § 741, pp. 655, 656, 657; § 748, pp. 665667; e § 750, pp. 667-671.

${ }^{1355}$ LIEBMAN, Manual de Direito Processual Civil, vol. I, § 62, pp. 128-129.

${ }^{1356}$ DINAMARCO, Instituições de Direito Processual Civil, vol. II, § 748, p. 667.
} 
perpetração de algum comportamento abusivo. É o que se verifica nos arts. 18, "caput"; $22 ; 29 ; 31 ; 113, \S 1^{\text {o }}$; e 267, § $3^{\text {o }}$, do $\mathrm{CPC}^{135713581359}$.

${ }^{1357}$ Nesse sentido, porém tratando especificamente do art. 31 do CPC: BARBI, Comentários ao Código de Processo Civil, vol. I, § 227, p. 166.

1358 Diversos ordenamentos jurídicos contêm regras que cominam ao "improbus litigator" o dever de arcar com o custo financeiro do processo.

No Uruguai, o art. 56.1 do CPC c/c art. 688 do CC estatuem que, se a parte vencida litigou com alguma razão, ela pode não ser condenada ao pagamento das despesas processuais e honorários advocatícios. Se ela litigou com leviandade culpável, pode ser condenada ao pagamento das despesas processuais. Por fim, se litigou com malícia, merecendo ser considerada temerária, pode ser condenada ao pagamento das despesas processuais e dos honorários advocatícios (LANDONI SOSA, El Abuso de los Derechos Procesales, in BARBOSA MOREIRA (coord.), Abuso dos Direitos Processuais, p. 138).

De acordo com o $\S 1^{\circ}$ do art. 456 do CPC português, a parte litigante de má-fé deve ser condenada a indenizar a parte contrária, desde que esta o peça. Essa indenização pode consistir "no reembolso das despesas a que a má fé do litigante tenha obrigado a parte contrária, incluindo os honorários dos mandatários ou técnicos" (art. 457, § $1^{\circ}$, “a”, do CPC português). Se não houver elementos para se fixar logo na sentença a importância da indenização, o juiz deve ouvir as partes e fixar depois, com prudente arbítrio, o que parecer razoável, podendo reduzir aos justos limites as verbas de despesas e de honorários apresentadas pela parte (art. $457, \S 2^{\circ}$, do CPC português).

No Direito espanhol, vigora o princípio da sucumbência, de modo que a parte vencida é geralmente condenada ao pagamento do custo financeiro do processo. Essa regra possui algumas exceções, dentre as quais duas são relacionadas à prática do abuso do processo: (a) em caso de procedência parcial do pedido, cada parte deve arcar com suas próprias despesas processuais e com metade das despesas comuns, a não ser que haja motivos para impô-las a uma delas por haver litigado de modo temerário (art. 394.2 da "Ley de Enjuiciamiento Civil"); e (b) se o demandado reconhecer a procedência do pedido antes de impugná-lo, não deve pagar despesas processuais, exceto se o juízo entender que ele agiu de má-fé. Entende-se que existe máfé quando, antes de ajuizada a demanda, é formulado requerimento fidedigno e justificado de pagamento; quando é iniciado procedimento de mediação; bem como quando é dirigida contra o devedor demanda de conciliação (art. 395.1 da "Ley de Enjuiciamiento Civil") (MÉNDEZ, Abuse of Procedural Rights? Spain and Portugal, in TARUFFO (ed.), Abuse of Procedural Rights: comparative standards of procedural fairness, pp. 184-185)

$\mathrm{O}$ art. 91 do CPC italiano estatui que o juiz, ao proferir a sentença, condenará a parte sucumbente a reembolsar à outra as despesas feitas no processo, devendo liquidar o valor das mesmas juntamente com os honorários advocatícios. Uma das atenuações dessa regra geral consta da primeira parte do $\S 1^{\circ}$ do art. 92 do CPC italiano, consistindo no poder que o juiz tem de negar a repetição das despesas efetuadas pela parte vencedora quando as considerar excessivas ou supérfluas (v.g., gastos onerosos com viagens, despesas decorrentes de intervenções de terceiros infundadas, valer-se de testemunhos de peritos injustificadamente etc.). A excessividade e a superfluidade são avaliadas em relação a cada ato processual concreto, devendo o juiz levar em consideração: (a) a necessidade da despesa para o correto desenvolvimento do processo; e (b) a oportunidade. Se o ato processual puder ser eficazmente realizado sem a despesa, esta é considerada excessiva ou supérflua. Outra atenuação é a possibilidade de o juiz condenar uma das partes a reembolsar as despesas (inclusive as não-repetíveis) que ela tenha causado à parte contrária em razão de transgressão do dever de lealdade e probidade (art. $92, \S 1^{\circ}, 2^{\mathrm{a}}$ parte, do CPC italiano). Essa norma é aplicável toda vez que a parte realiza uma conduta processual objetivamente contrária à boa-fé (LIEBMAN, Manual de Direito Processual Civil, vol. I, § 62, pp. 128-130; DONDI, Abuse of Procedural Rights: regional report for Italy and France, in TARUFFO (ed.), Abuse of Procedural Rights: comparative standards of procedural fairness, pp. 116-117; CARPI; COLESANTI; TARUFFO, Commentario Breve al Codice di Procedura Civile, pp. 278279). Por fim, a $2^{\mathrm{a}}$ parte do $\S 1^{\mathrm{o}}$ do art. 91 do CPC italiano atribui aos litigantes o onus de avaliar diligentemente a possibilidade de solução conciliatória do litígio: "Se [o juiz] acolhe a demanda em medida não superior à eventual proposta conciliatória, condena a parte que recusou sem motivo justificado a proposta ao pagamento das despesas do processo advindas depois da formulação da proposta, salvo o disposto no segundo parágrafo do artigo 92" (tradução nossa) (FALCO, La Buona Fede e l'Abuso del Diritto: principi, fattispecie e casistica, pp. 523-524).

$\mathrm{Na}$ França, o art. 700 do "Code de Procédure Civile" prevê a possibilidade de o juiz condenar a parte vencida a pagar à vencedora não só as despesas processuais previstas em lei, mas também outras, a título de "gastos comprometidos e não incluídos nas despesas" ("frais exposés et non compris dans les dépens"). Segundo Dondi (Abuse of Procedural Rights: regional report for Italy and France, in TARUFFO (ed.), Abuse of Procedural Rights: comparative standards of procedural fairness, pp. 120-121), apesar de esse dispositivo 
$\mathrm{O}$ art. 18, "caput", do CPC prevê a condenação do litigante de má-fé a ressarcir a parte contrária dos honorários advocatícios e de todas as despesas processuais que houver realizado $^{1360}$.

A doutrina debate a seguinte questão acerca do dever de o litigante de má-fé arcar com o custo financeiro do processo: quando a sentença, além de ser totalmente desfavorável à parte, ainda a qualifica como “improbus litigator", ela deve pagar uma só vez os honorários advocatícios e as despesas processuais ou deve pagá-los duas vezes, uma com fundamento no art. 18 e outra com base no art. 20 do CPC?

não fazer menção a qualquer comportamento processual ímprobo, ele contém regra similar à dos arts. 92 e 96 do CPC italiano, permitindo que a parte lesada obtenha o ressarcimento das despesas que tenha sofrido em razão do abuso do processo.

Hazard Jr. (Abuse of Procedural Rights: a summary view of the Common Law systems, in TARUFFO (ed.), Abuse of Procedural Rights: comparative standards of procedural fairness, p. 39) afirma que, nos Estados Unidos da América, em regra, cada parte deve pagar as próprias despesas processuais e os honorários advocatícios, independentemente de ela ser vencedora ou vencida. Excepcionalmente, a responsabilidade por todo o custo do processo pode ser atribuída a uma das partes pela prática de abuso intencional ou reiterado. Mas, segundo o autor, essa exceção raramente ocorre na prática.

No ordenamento jurídico inglês, a regra geral é a atribuição da responsabilidade pelos custos processuais à parte vencida ("Rule" 44.3, (2), "a", das "Civil Procedure Rules"). Além da sucumbência, outro fator que interfere na distribuição do custo financeiro do processo é a conduta das partes. O órgão judicial avalia, por exemplo, se as alegações e questões suscitadas pelas partes foram razoáveis; a maneira como as partes defenderam suas pretensões ou sustentaram uma alegação ou questão particular; e se o demandante vitorioso, no todo ou em parte, exagerou no seu pedido ("Rule" 44.3, (4), "a", e (5), "b", "c" e "d", das "Civil Procedure Rules"). Logo, a parte que deduz em juízo pedido infundado, ou que faz alegações sem fundamento, ou ainda que provoca incidentes processuais com escopo ilegítimo (e.g., para protelar o julgamento do processo, para pressionar a parte contrária etc.), pode ser condenada a arcar com as custas processuais (FENTIMAN, Abuse of Procedural Rights: the position of English Law, in TARUFFO (ed.), Abuse of Procedural Rights: comparative standards of procedural fairness, p. 60; ANDREWS, Abuse of Process in English Civil Litigation, in TARUFFO (ed.), Abuse of Procedural Rights: comparative standards of procedural fairness, p. 72).

Segundo Hess (Abuse of Procedure in Germany and Austria, in TARUFFO (ed.), Abuse of Procedural Rights: comparative standards of procedural fairness, pp. 152, 156, 176-177 e 179), na Alemanha e na Áustria, a prática de atos processuais protelatórios, inúteis, frívolos ou manifestamente infundados ensejam a imposição de despesas processuais adicionais. Consoante o ordenamento jurídico austríaco, a parte que atrasa a apresentação de fatos ou de argumentos pode até ser obrigada a arcar com todas as despesas processuais.

${ }^{1359}$ No projeto do novo Código de Processo Civil (Projeto de Lei no $8.046 / 2010$ ), há dispositivos com textos similares aos dos arts. 18, "caput", e 29 do CPC atual:

"Art. 84. O juiz ou tribunal, de ofício ou a requerimento, condenará o litigante de má-fé a pagar multa que não deverá ser inferior a dois por cento, nem superior a dez por cento, do valor corrigido da causa e a indenizar a parte contrária dos prejuízos que esta sofreu, além de honorários advocatícios e de todas as despesas que efetuou";

"Art. 95. As despesas dos atos que forem adiados ou tiverem de repetir-se ficarão a cargo da parte, do serventuário, do órgão do Ministério Público ou do juiz que, sem justo motivo, houver dado causa ao adiamento ou à repetição".

Mas, o Código de Processo Civil projetado não prevê normas análogas às dos arts. 22; 31; 113, § 1º e 267, § $3^{\circ}$, do CPC em vigor.

${ }^{1360}$ A opinião de Bedaque (Comentários ao art. 18 do CPC, in MARCATO (coord.), Código de Processo Civil Interpretado, p. 64) a respeito da interpretação desse dispositivo legal destoa da dos demais doutrinadores. Ele afirma que o legislador, ao elaborar o art. 18, "caput", do CPC, não imaginou que a sanção por litigância de má-fé poderia ser imposta à parte vencedora. Por causa disso, entende que é mais adequada a interpretação de que apenas o litigante de má-fé vencido responde pelas verbas de sucumbência. Para ele, se o vencedor for considerado litigante de má-fé, apenas a multa e a obrigação de ressarcir os danos ser-lheão imputadas. 
De um lado, Stoco ${ }^{1361}$ diz que a leitura combinada dos arts. 18 e 20 do CPC leva à conclusão de que o litigante de má-fé deve responder por dupla verba honorária e duplas despesas. Responde uma vez por causa da perda da ação (princípio da sucumbência) e outra vez a título de sanção pela indigna atuação em juízo (princípios da reparabilidade e da punibilidade).

Do outro está Barbosa Moreira ${ }^{1362}$, que parte do pressuposto de que existe uma diferença quantitativa entre o reembolso decorrente da sucumbência (art. 20 do CPC) e a sanção por causa da má-fé (art. 18 do CPC). O primeiro abrange as custas dos atos do processo, a indenização de viagem, a diária de testemunha e a remuneração do assistente técnico (art. 20, § $2^{\circ}$, do CPC). Já a segunda inclui esses gastos e também outras despesas, desde que relacionadas ao processo e que não sejam supérfluas, como os gastos com a obtenção de certidões ou outros documentos necessários à instrução da causa, com a extração de fotocópias, com a tradução de documentos redigidos em língua estrangeira, com pareceres de jurisconsultos etc. Diante disso, Barbosa Moreira discorda que o litigante de má-fé deva responder por dupla verba honorária e duplas despesas. Com razão, o jurista entende que, se o litigante de má-fé perder a causa, ele é condenado a pagar ao vencedor as despesas que este antecipou e os honorários de seu advogado (art. 20, "caput", do CPC) e mais as outras despesas não-supérfluas relacionadas ao processo (art. 18 do CPC).

No art. 22 do CPC, o legislador impõe duas sanções ao réu que deixa de arguir em contestação a existência de fato impeditivo, modificativo ou extintivo do direito do autor, mas comparece em outro momento com a defesa omitida, dilatando o julgamento da demanda: (a) a condenação ao pagamento das custas incidentes a partir do saneamento do processo, ainda quando vencedor na causa; e (b) a perda do direito de receber honorários da sucumbência, na hipótese de ser vencedor na causa.

Na prática, a aplicação desse dispositivo no que concerne às despesas processuais é bastante difícil, uma vez que, como observa Dinamarco ${ }^{1363}$, os regimentos de custas não costumam dividir as custas ou a taxa judiciária pelas fases do procedimento.

Nota-se que, quando é a parte vencedora que pratica alguma das condutas previstas no art. 17 ou no art. 22 do CPC, não somente ela é sancionada, mas também o seu advogado, que perde o direito aos honorários advocatícios (art. 23 da Lei $\left.n^{\circ} 8.906 / 94\right)^{1364}$.

\footnotetext{
${ }^{1361}$ Abuso do Direito e Má-Fé Processual - aspectos doutrinários, p. 98.

1362 A Responsabilidade das Partes por Dano Processual no Direito Brasileiro, in Temas de Direito Processual, p. 34.

${ }^{1363}$ DINAMARCO, Instituições de Direito Processual Civil, vol. II, § 752, p. 675.
} 
Consoante o art. 29 do CPC, a parte, o serventuário, o órgão do Ministério Público ou o juiz que der causa a adiamento ou a repetição de atos sem justo motivo deve arcar com as respectivas despesas ${ }^{1365}$.

Deve-se salientar que a responsabilidade pelas despesas dos atos adiados ou repetidos ocorre apenas se o adiamento ou a repetição ocorrer "sem justo motivo". De acordo com Barbi ${ }^{1366}$, é comum o adiamento em razão de um motivo justo. Já a repetição de um ato raramente acontece por motivo justo, pois ela decorre, via de regra, de algum defeito na prática do ato.

$\mathrm{O}$ art. 31 do CPC estatui que as "despesas dos atos manifestamente protelatórios, impertinentes ou supérfluos serão pagas pela parte que os tiver promovido ou praticado, quando impugnados pela outra".

Considera-se protelatório o ato que se destina a atrasar o normal andamento do processo. Impertinente é o ato do autor ou do réu estranho às questões versadas na causa. Sua prática, em regra, decorre de um erro do advogado, que não percebe a falta de relação entre o ato e a causa. Por fim, é supérfluo o ato que tem pertinência à causa, mas se mostra desnecessário (v.g., promover a citação do réu depois de ele ter comparecido espontaneamente, na forma do art. $214, \S 1^{\circ}$, do CPC). Também é causado por uma visão defeituosa do advogado, que não atenta para a sua inutilidade ${ }^{1367}$.

A incidência dessa norma depende do preenchimento de duas condições ${ }^{1368}$ : (a) a finalidade protelatória, a impertinência ou a superfluidade deve ser manifesta; e (b) a parte

\footnotetext{
${ }^{1364}$ No Direito inglês, o advogado (seja ele um "barrister" ou um "solicitor") que realiza conduta processual (ação ou omissão) imprópria, desarrazoada ou negligente (v.g., apoiar o uso desnecessário do processo; sustentar em juízo um pedido manifestamente indefensável ou mal fundamentado etc.) fica sujeito a uma "wasted cost order" ("Rule" 48.7 das "Civil Procedure Rules" c/c seção 51 (6) e (7) do "Supreme Court Act" de 1981), que implica a perda total ou parcial do seu direito aos honorários advocatícios ou a obrigação de pagar as custas da parte contrária, integral ou parcialmente (FENTIMAN, Abuse of Procedural Rights: the position of English Law, in TARUFFO (ed.), Abuse of Procedural Rights: comparative standards of procedural fairness, p. 59; ANDREWS, Abuse of Process in English Civil Litigation, in TARUFFO (ed.), Abuse of Procedural Rights: comparative standards of procedural fairness, pp. 70, 73-74 e 84-89; NORMAND, Final Report: the two approaches to the abuse of procedural rights, in TARUFFO (ed.), Abuse of Procedural Rights: comparative standards of procedural fairness, p. 246).

${ }^{1365}$ No Código de Processo Civil de 1939, apenas as partes e os serventuários podiam ser responsabilizados pelas despesas decorrentes de adiamento ou de repetição de atos processuais (art. 62 do CPC39). O Código de 1973 inovou ao estabelecer que também podem ser responsabilizados pelas despesas o representante do Ministério Público e o juiz.

Barbi (Comentários ao Código de Processo Civil, vol. I, § 218, p. 162) mostra preferência pela regra de 1939, pois não concorda com a inclusão do juiz no rol de possíveis responsáveis pelas despesas decorrentes do adiamento ou da repetição de atos processuais. Na sua opinião, configura uma violência impor ao magistrado o dever de condenar-se a si mesmo ao pagamento das custas.

${ }^{1366}$ Comentários ao Código de Processo Civil, vol. I, § 218, p. 162.

${ }^{1367}$ BARBI, Comentários ao Código de Processo Civil, vol. I, §§ 223-225, p. 165.

${ }^{1368}$ BARBI, Comentários ao Código de Processo Civil, vol. I, § 226, pp. 165-166.
} 
interessada deve ter impugnado o ato em algum momento (antes ou depois da sua realização).

Segundo o art. 113, $\S 1^{\circ}$, do CPC, se o demandado não alegar eventual incompetência absoluta do órgão jurisdicional no prazo da contestação, ou na primeira oportunidade em que lhe couber falar nos autos, ele responderá integralmente pelas custas.

Por fim, o art. 267, $\S 3^{\circ}$, do CPC estabelece que, se o demandado não alegar eventual ausência de algum pressuposto de constituição ou de desenvolvimento válido e regular do processo, ou de qualquer das condições da ação, ou eventual ocorrência de perempção, de litispendência ou de coisa julgada, na primeira oportunidade em que lhe couber falar nos autos, ele deve responder pelas custas de retardamento do processo.

Vale para esse dispositivo legal a mesma observação feita anteriormente a respeito do art. 22 do CPC: na prática, sua aplicação é muito dificultada pelo fato de os regimentos de custas, em regra, não dividirem as custas ou a taxa judiciária pelas fases do procedimento.

Constata-se que, nas situações excepcionais regidas pelos dispositivos supracitados, a "responsabilidade definitiva" pelas despesas processuais e honorários advocatícios não se subordina ao princípio da causalidade, funcionando, na verdade, como uma sanção imposta ao sujeito que violou o princípio da lealdade processual ${ }^{1369}$.

No processo de conhecimento, a sentença, qualquer que seja a sua natureza (meramente declaratória, constitutiva ou condenatória), ou o seu conteúdo (extinção sem julgamento do mérito, procedência ou improcedência do pedido), deve conter capítulo atribuindo o custo do processo a uma das $\operatorname{partes}^{1370}$, ainda que não haja pedido explícito nesse sentido ${ }^{1371}{ }^{1372}$. Dinamarco ${ }^{1373}$ recomenda que o autor requeira a condenação na petição inicial e o réu, na contestação, porém ensina que constitui dever do juiz incluir capítulo específico na sentença acerca da atribuição, fundamentada, das despesas processuais e dos honorários advocatícios (dever esse inferido da locução "a sentença condenarâ", contida no art. 20 do CPC). O mesmo vale para os arts. $18 ; 22 ; 29 ; 31 ; 113, \S$ $1^{\text {o}}$; e $267, \S 3^{\circ}$, do CPC, cuja incidência pode-se dar de ofício, independentemente de requerimento da parte lesada pela conduta abusiva. Quanto ao art. 31 do CPC, apenas se

1369 IOCOHAMA, Litigância de Má-Fé e Lealdade Processual, pp. 247-249; AMARAL SANTOS, Primeiras Linhas de Direito Processual Civil, vol. 2, p. 309.

${ }^{1370}$ DINAMARCO, Instituições de Direito Processual Civil, vol. II, § 753, pp. 675-676.

${ }^{1371}$ AMARAL SANTOS, Primeiras Linhas de Direito Processual Civil, vol. 2, p. 305.

${ }^{1372}$ Nesse sentido é o teor da súmula $\mathrm{n}^{\circ} 256$ do STF: "É dispensável pedido expresso para condenação do réu em honorários, com fundamento nos arts. 63 ou 64 do Código de Processo Civil".

${ }^{1373}$ Instituições de Direito Processual Civil, vol. II, § 755, pp. 678-679. 
exige que a parte prejudicada impugne os atos manifestamente protelatórios, impertinentes ou supérfluos praticados pela contraparte, mas não é preciso pedir expressamente a condenação ao pagamento das respectivas despesas.

Cumpre lembrar que a condenação pelo custo do processo não ocorre só em primeiro grau de jurisdição; ela também pode acontecer em segundo grau de jurisdição. $O$ Tribunal pode manter a condenação imposta quanto ao custo do processo, caso profira acórdão que confirme o que o juiz de primeiro grau decidiu a respeito do mérito do processo. Pode também inverter os encargos da sucumbência, atribuindo-os à parte que fora vencedora em primeiro grau, caso dê provimento ao recurso que impugnou o julgamento do "meritum causae". O tribunal pode ainda simplesmente ajustar o capítulo da sentença que contém a condenação pelo custo do processo, reduzindo ou elevando o seu valor, se isso houver sido pedido no recurso ${ }^{1374} 1375$.

\subsection{Antecipação de tutela (art. 273, II, do CPC)}

A técnica da antecipação de tutela visa a oferecer à parte, antes do julgamento final da causa, a coisa ou situação da vida pleiteada ou algum benefício que a obtenção da coisa poderá lhe proporcionar ${ }^{1376}$.

O art. 273 do CPC é considerado uma abertura para o poder geral de antecipação de tutela. Esse dispositivo legal generaliza o poder de antecipar a tutela, estabelecendo que o juiz pode conceder a antecipação nas seguintes hipóteses ${ }^{1377}$ :

a) em casos de situação de urgência, ou "periculum in mora" (art. 273, I, do CPC);

b) como sanção ao demandado que procura maliciosamente retardar o fim do processo (art. 273, II, do CPC);

c) quando inexiste controvérsia sobre alguns dos fatos constitutivos do direito do autor, autorizando-se a antecipação parcial da tutela, na medida do direito decorrente dos fatos incontroversos (art. 273, $\S 6^{\circ}$, do CPC).

A doutrina chama a hipótese prevista no art. 273, II, do CPC de "tutela antecipada sancionatória", pois a técnica da antecipação provisória mediante cognição sumária é

\footnotetext{
${ }^{1374}$ Só não pode haver condenação pelo custo do processo em segundo grau de jurisdição quando o tribunal se limita a anular a sentença para que o juiz de primeiro grau venha a proferir outra, uma vez que o processo não se extingue com esse julgamento, não havendo ainda um vencedor e um vencido.

${ }^{1375}$ DINAMARCO, Instituições de Direito Processual Civil, vol. II, § 756, p. 679.

${ }^{1376}$ DINAMARCO, O Regime Jurídico das Medidas Urgentes, in Nova Era do Processo Civil, pp. 63, 64, 68 e 80.

${ }^{1377}$ DINAMARCO, O Regime Jurídico das Medidas Urgentes, in Nova Era do Processo Civil, pp. 82-83.
} 
utilizada, nesse caso, como um instrumento para punir a conduta processual desleal ${ }^{1378}$. Contra o abuso da defesa e o intuito protelatório do réu, o legislador prevê a concessão da tutela antecipada a favor do autor, punindo o demandado e eliminando o risco de incremento do dano marginal do processo, que poderia comprometer a integralidade do direito pleiteado em juízo e, consequentemente, o resultado útil da atividade jurisdicional do Estado ${ }^{1379}$.

Mas, não se trata propriamente de uma sanção. De acordo com Marinoni ${ }^{1380}$, a antecipação de tutela fundada em abuso do direito de defesa visa a impedir que o demandante que tem razão tenha a satisfação do seu direito substancial retardada pelo tempo que o demandado utilizará para tentar demonstrar seus argumentos defensivos infundados. Trata-se, então, de uma técnica de distribuição ou até de inversão do ônus do tempo do processo, ante a conduta desleal do demandado ${ }^{1381}$.

O texto do art. 273, II, do CPC estatui o seguinte:

O juiz poderá, a requerimento da parte, antecipar, total ou parcialmente, os efeitos da tutela pretendida no pedido inicial, desde que, existindo prova inequívoca, se convença da verossimilhança da alegação e: [...] II - fique caracterizado o abuso de direito de defesa ou o manifesto propósito protelatório do réu ${ }^{1382}$.

Cumpre analisar detalhadamente os requisitos necessários para a incidência dessa norma jurídica processual.

A maioria dos juristas brasileiros afirma que a antecipação de tutela somente pode ser concedida se houver requerimento da parte a ser beneficiada pela medida, em respeito

${ }^{1378}$ CARRILHO LOPES, Tutela Antecipada Sancionatória (art. 273, inc. II, do Código de Processo Civil), pp. 55-56; OLIVEIRA, Litigância de Má-Fé, p. 41; BEDAQUE, Tutela Cautelar e Tutela Antecipada Tutelas Sumárias e de Urgência (Tentativa de Sistematização), p. 357.

${ }^{1379}$ BEDAQUE, Tutela Cautelar e Tutela Antecipada - Tutelas Sumárias e de Urgência (Tentativa de Sistematização), pp. 359-360.

${ }^{1380}$ Abuso de Defesa e Parte Incontroversa da Demanda, pp. 53-59, 111-121 e 124-127.

${ }^{1381}$ Por não se tratar de uma sanção, a antecipação de tutela fundada no inciso II do art. 273 do CPC pode ser aplicada em conjunto com as punições previstas no art. 18, ou no art. 538, parágrafo único, ou no art. 557, § $2^{\circ}$, ou ainda no art. 601 do CPC, sem que se configure "bis in idem".

Em sentido contrário, entendendo que a hipótese de antecipação de tutela prevista no art. 273, II, do CPC tem caráter punitivo e, por causa disso, afasta a incidência das multas previstas nos arts. 18; 538, parágrafo único; 557, $\S 2^{\circ}$; e 601 do CPC: CARRILHO LOPES, Tutela Antecipada Sancionatória (art. 273, inc. II, do Código de Processo Civil), pp. 132 e 133-134.

${ }^{1382}$ Se o Projeto de Lei $n^{\circ}$ 8.046/2010 for aprovado, sancionado e publicado com sua redação atual, a chamada "tutela antecipada sancionatória" constará do art. 278, I, do novo Código de Processo Civil:

"Art. 278. A tutela da evidência será concedida, independentemente da demonstração de risco de dano irreparável ou de difícil reparação, quando:

I - ficar caracterizado o abuso de direito de defesa ou o manifesto propósito protelatório do requerido". 
ao disposto no "caput" do art. 273 do CPC e ao princípio da demanda (arts. $2^{\circ}$ e 262 do (CPC) $)^{1383}$.

No entanto, Carrilho Lopes ${ }^{1384}$ sustenta a possibilidade de a "tutela antecipada sancionatória" ser concedida de ofício, em razão dos seguintes argumentos:

a) da mesma forma como o juiz pode sancionar o litigante de má-fé de ofício ou a requerimento da parte, com base no art. 18, "caput", do CPC, ele também pode antecipar a tutela com fundamento no art. 273, II, do CPC de ofício ou a requerimento da parte. A "ratio" é a mesma, pois ambos os dispositivos visam a punir quem abusa do processo;

b) o art. 125, II e III, do CPC prevê o poder-dever do juiz de "velar pela rápida solução do litígio" e "prevenir ou reprimir qualquer ato contrário à dignidade da Justiça".

Ocorre que, se a efetivação da antecipação de tutela causar prejuízo ao réu e, ao final, o juiz julgar a demanda improcedente, o autor deve responder objetivamente pelos danos, não sendo necessário provar dolo ou culpa (art. 273, § 3º c/c art. 475-O, I, do CPC; ou art. 811 do CPC, por analogia) ${ }^{1385}$. Essa circunstância abala a tese de Carrilho Lopes, pois seria ilegítimo imputar ao autor a responsabilidade por eventuais prejuízos decorrentes de uma antecipação de tutela que ele não requereu, caso o magistrado profira sentença de improcedência do seu pedido no final do processo ${ }^{1386}$.

${ }^{1383}$ Assis (A Antecipação da Tutela (à Luz da Garantia Constitucional do Devido Processo Legal), pp. 153154) admite que o "caput" do art. 273 do CPC claramente veda a antecipação de tutela "ex officio", prevalecendo o princípio da demanda (arts. $2^{\circ}$ e 262 do CPC). Todavia, "de lege ferenda", sugere uma ampliação do instituto da antecipação de tutela, permitindo que a hipótese do inciso II do art. 273 do CPC seja concedida "ex officio", uma vez que a atitude protelatória ou abusiva que motiva a tutela antecipatória ofende a própria seriedade da atividade jurisdicional. O autor lembra que, desde 1994, quando a Lei $\mathrm{n}^{\circ} 8.952$ alterou o texto do art. 18 do CPC, o legislador reconhece expressamente a possibilidade de o magistrado declarar de ofício a litigância de má-fé, que é um dos parâmetros para a incidência do inciso II do art. 273 do CPC.

${ }^{1384}$ Tutela Antecipada Sancionatória (art. 273, inc. II, do Código de Processo Civil), pp. 90-91.

1385 DINAMARCO, O Regime Jurídico das Medidas Urgentes, in Nova Era do Processo Civil, pp. 97-98.

${ }^{1386}$ Em sua monografia, Carrilho Lopes (Tutela Antecipada Sancionatória (art. 273, inc. II, do Código de Processo Civil), p. 91) aborda esse argumento. Para ele, se o juiz conceder a antecipação de tutela de ofício e a demanda for, ao final, julgada em desfavor do autor, não existe responsabilidade objetiva pelos danos eventualmente sofridos pelo réu porque a antecipação ocorreu em razão da conduta desleal deste. O que o doutrinador quer dizer, em outras palavras, é que o réu deve-se conformar com os danos sofridos em razão da efetivação da antecipação da tutela, como uma forma de punição por sua conduta processual desleal.

Esse entendimento, com o devido respeito, não merece ser adotado porque viola o princípio da legalidade. $\mathrm{O}$ $\S 3^{\circ}$ do art. 273 do CPC estatui, expressamente, que a efetivação da tutela antecipada deve observar, no que couber, a norma prevista no art. 588 do CPC, que, atualmente, encontra-se no art. 475-O do CPC. O inciso I do art. 475-O do CPC, por sua vez, estabelece que o litigante que promove a execução provisória obriga-se, em caso de reforma da decisão, a reparar os danos que o executado tenha sofrido. O legislador não mencionou qualquer exceção aplicável a essa regra. Logo, nenhuma norma do ordenamento jurídico brasileiro atual prevê a sanção consistente na aceitação dos danos decorrentes da efetivação da tutela antecipada fundada no art. 273, II, do CPC.

Carrilho Lopes (Tutela Antecipada Sancionatória (art. 273, inc. II, do Código de Processo Civil), pp. 102103) assevera que, em contrapartida, no caso de ter ocorrido requerimento para a aplicação do art. 273, II, do CPC, o requerente deve devolver ao réu os benefícios efetivamente recebidos e indenizar integralmente os prejuízos por ele sofridos. Mas, nesse caso, a responsabilidade pelo ressarcimento dos danos não é objetiva, 
Logo, o requerimento da parte a ser beneficiada pela medida é, sim, uma condição necessária para a concessão da "tutela antecipada sancionatória".

A esse requisito somam-se outros dois ${ }^{1387}$ :

a) prova inequívoca da verossimilhança das alegações do autor. É necessário que haja nos autos elementos probatórios suficientemente fortes para que o juiz se convença a respeito da existência do direito afirmado pelo autor;

b) resposta do réu despida de seriedade, seja em razão da dedução de argumentos inaplicáveis ao caso concreto, seja por causa do uso do processo como instrumento para protelar a solução final. Bedaque ${ }^{1388}$ esquiva-se de definir o conteúdo da expressão "abuso de direito de defesa ou o manifesto propósito protelatório do réu”, contida no art. 273, II, do CPC. Ele se limita a afirmar que o abuso do direito de defesa e o intuito protelatório são manifestações concretas de litigância de má-fé, de modo que os arts. 16 a 18 do CPC devem servir como parâmetros interpretativos. Aduz que, como as expressões utilizadas pelo legislador são vagas, de difícil delimitação objetiva, cabe ao intérprete buscar o significado do vocábulo com base em elementos jurídicos e metajurídicos. A doutrina de Bedaque é suplementada pelo magistério de Marinoni e de Costa Machado. O primeiro autor ensina que a técnica da tutela antecipatória fundada em abuso do direito de defesa é viável em duas situações: (1) quando o réu deduzir defesa de mérito indireta (alegação de fatos extintivos, modificativos ou impeditivos) que exija dilação probatória (produção de prova pericial ou testemunhal) e o juiz se convencer da falta de verossimilhança dessas alegações defensivas, quer dizer, da provável falta de fundamento da defesa indireta; e (2) quando o réu deduzir defesa de mérito direta (negação dos fatos constitutivos) que exija dilação probatória, mas que não tenha fundamento capaz de abalar a convicção do juiz

na opinião do doutrinador, mas sim subjetiva, dependente de demonstração de culpa ou dolo do requerente (arts. 186, 187 e 927 do CC), pois: (a) o art. 811 do CPC, pertinente à disciplina das medidas cautelares, não pode ser aplicado à tutela antecipada sancionatória, uma vez que esta não é uma medida urgente, ou seja, não tem como pressuposto o "periculum in mora", como ocorre no caso do art. 273, I, do CPC; (b) o art. 475-O do CPC somente se aplica à antecipação de tutela "no que couber e conforme sua natureza" (art. $273, \S 3^{\circ}$, do CPC) e, segundo o autor, a natureza da tutela antecipada sancionatória e as razões que a justificam não são compatíveis com a responsabilidade objetiva. O doutrinador complementa que, diante da complexidade da apuração da responsabilidade subjetiva do requerente, esta deve ser pleiteada em demanda autônoma (CARRILHO LOPES, Tutela Antecipada Sancionatória (art. 273, inc. II, do Código de Processo Civil), p. 103).

Novamente, Carrilho Lopes parece se enganar porque não existe qualquer dispositivo no Código de Processo Civil que exclua os danos decorrentes da efetivação da tutela antecipada sancionatória (art. 273, II, do CPC) do âmbito da responsabilidade objetiva prevista nos arts. 273 , § $3^{\circ}$, e 475-O, I, do CPC.

1387 BEDAQUE, Tutela Cautelar e Tutela Antecipada - Tutelas Sumárias e de Urgência (Tentativa de Sistematização), p. 357.

${ }^{1388}$ Tutela Cautelar e Tutela Antecipada - Tutelas Sumárias e de Urgência (Tentativa de Sistematização), p. 356 e p. 357, nt. 111. 
formada pelas provas documentais ou emprestadas já produzidas pelo autor ${ }^{1389} 1390$. Analogamente, Costa Machado ${ }^{1391}$ sustenta que as atitudes do polo passivo da demanda que podem caracterizar o "abuso de direito de defesa" a que alude o inciso II do art. 273 do CPC são: (1) a dedução de defesa contra texto expresso de lei ou fato incontroverso (art. 17 , I, do CPC) $)^{1392}$; (2) a dedução de defesa que altera a verdade dos fatos (art. 17, II, do CPC); e (3) a dedução de defesa de mérito indireta sem fundamento fático ou jurídico ${ }^{1393}$. Além desses comportamentos ímprobos, que configuram abuso do direito de defesa, também pode dar ensejo à antecipação da tutela a prática de ato que denote o "manifesto propósito protelatório" do réu (v.g., a interposição de recurso manifestamente protelatório $^{1394}$; a provocação reiterada de incidentes manifestamente infundados; a prática

${ }^{1389}$ MARINONI, Abuso de Defesa e Parte Incontroversa da Demanda, pp. 56-58, 64-79, 82-85, 102-104, $106-111$ e 129.

${ }^{1390}$ O Projeto de Lei ${ }^{\circ}$ 8.046/2010, em trâmite no Congresso Nacional, que versa sobre o novo Código de Processo Civil, trata dessa circunstância como sendo mais uma hipótese de tutela de evidência, ao lado do abuso do direito de defesa e do manifesto propósito protelatório do requerido:

“Art. 278. A tutela da evidência será concedida, independentemente da demonstração de risco de dano irreparável ou de difícil reparação, quando:

I - ficar caracterizado o abuso de direito de defesa ou o manifesto propósito protelatório do requerido;

$[\ldots]$

III - a inicial for instruída com prova documental irrefutável do direito alegado pelo autor a que o réu não oponha prova inequívoca".

${ }^{1391}$ Tutela Antecipada, pp. 424-428.

${ }^{1392}$ Também nesse sentido, defendendo que a dedução de defesa contra texto expresso de lei (art. 17, I, do CPC) autoriza a concessão de tutela antecipada, com fulcro no art. 273, II, do CPC, desde que haja prova inequívoca e convencimento do juiz da verossimilhança das alegações: OLIVEIRA, Litigância de Má-Fé, p. 41.

${ }^{1393}$ Para Bedaque (Tutela Cautelar e Tutela Antecipada - Tutelas Sumárias e de Urgência (Tentativa de Sistematização), p. 361), a conduta consistente em deduzir na contestação razões completamente infundadas não autoriza, por si só, a antecipação. O autor sustenta que a antecipação dos efeitos da tutela final deve ser concedida apenas quando for imprescindível para assegurar a efetividade do processo. Diante disso, afirma que a incidência do art. 273, II, do CPC somente pode ocorrer se o comportamento abusivo do réu causar atraso indevido na entrega da tutela.

Com razão, Carrilho Lopes (Tutela Antecipada Sancionatória (art. 273, inc. II, do Código de Processo Civil), pp. 127-128) discorda expressamente dessa tese. Argumenta que a conduta processual desleal do réu, consistente no abuso do direito de defesa ou na prática de ato com manifesto propósito protelatório, mesmo quando não produz efetivamente o resultado ilícito visado, é lesiva à correta administração da justiça e constitui fundamento bastante para a antecipação da tutela. Além disso, assevera que, dentre as duas causas de concessão da "tutela antecipada sancionatória", apenas o "manifesto propósito protelatório do réu" depende necessariamente do intento do demandado de procrastinar a concessão da tutela jurisdicional; o "abuso de direito de defesa" não exige retardamento.

${ }^{1394}$ Há precedente do Superior Tribunal de Justiça concedendo tutela antecipada com fundamento no abuso do poder de recorrer:

"PROCESSO CIVIL. TUTELA ANTECIPADA. REAJUSTE DE VENCIMENTOS DE SERVIDORES PÚBLICOS. 28,86\%. RECONHECIMENTO ADMINISTRATIVO DO DIREITO. MEDIDA PROVISÓRIA N 1.704-3/97. RECURSO ESPECIAL. PREQUESTIONAMENTO.

$O$ direito ao reajuste de vencimentos dos servidores públicos em 28,86\%, está pacificado no âmbito do Supremo Tribunal Federal e do Superior Tribunal de Justiça.

O reconhecimento administrativo desse direito, através da Medida Provisória 1.704-3/97, conjugado com a intenção de efetuar o pagamento dos valores correspondentes a todos os servidores públicos, mesmo que não tenham ingressado em juízo, torna inequívoco o direito dos recorridos à concessão de antecipação de tutela. 
reiterada de atos temerários ou de atos de resistência injustificada ao andamento do processo $\left.^{1395}\right)^{1396}$.

Nota-se que um requisito complementa o outro, já que a ausência de seriedade da resposta do réu confirma que a existência do direito do autor é provável ${ }^{1397}$. Costa Machado ${ }^{1398}$ chega a afirmar que a tutela antecipada do inciso II do art. 273 do CPC exige "fumus boni juris" dobrado para ser outorgada. Explica que, enquanto a tutela antecipada cautelar do inciso I do art. 273 do CPC tem como requisitos cumulativos o "fumus boni juris" e o "periculum in mora", a do inciso II tem como pressupostos a "prova inequívoca", que representa sempre o "fumus boni juris", e o comportamento reprovável do réu, que reforça a probabilidade da existência do direito material do autor aos olhos da lei e do magistrado, e que configura também o "fumus boni juris".

\footnotetext{
Na hipótese, a insistência da União em recorrer caracteriza abuso do direito de defesa e manifesto propósito protelatório, (art. 273, II, do CPC).

A ausência de manifestação do acórdão quanto ao tema versado no recurso especial, impede seu conhecimento, por faltar-lhe o requisito do prequestionamento.

Precedente da Corte Especial.

Recurso especial não conhecido" (destaques nossos)

(STJ, $5^{\text {a }}$ Turma, REsp 194.193/CE, Rel. Min. Gilson Dipp, DJ 19/04/1999 p. 166).

${ }^{1395}$ Conforme foi dito nos itens $2.11 .2,2.14$ e 2.16 "supra", a prática de apenas um ato processual manifestamente infundado não quer dizer, necessariamente, que a parte tenha o intuito de procrastinar. O fim protelatório só fica evidente com a execução reiterada de atos processuais infundados (ou seja, apenas a partir do segundo ato processual manifestamente infundado é que se pode caracterizar o intuito manifestamente protelatório). $\mathrm{O}$ mesmo raciocínio vale para comportamentos que configurem resistência injustificada ao andamento do processo e temeridade (art. 17, IV e V, do CPC): apenas a sua reiteração demonstra que o litigante tem o escopo de dilatar indevidamente o tempo do processo.

Por causa disso, não parece totalmente correto o entendimento de Costa Machado (Tutela Antecipada, pp. 425 e 429-430) no sentido de que os comportamentos do réu que demonstram o "manifesto propósito protelatório" previsto no inciso II do art. 273 do CPC são: (a) a reiteração de atos que configurem resistência injustificada ao andamento do processo (art. 17, IV, do CPC); (b) a provocação de incidentes manifestamente infundados (art. 17, VI, do CPC); (c) a atuação de modo temerário em qualquer incidente ou ato do processo (art. 17, V, do CPC).

${ }^{1396}$ A antecipação de tutela com espeque no inciso II do art. 273 do CPC guarda semelhanças com o "référé provision", do Direito francês, e com a "condanna con riserva", do Direito italiano (MARINONI, Antecipação da Tutela, pp. 275 e 278-279; MARINONI, Abuso de Defesa e Parte Incontroversa da Demanda, pp. 62-64 e p. 127, nt. 91).

Consoante o art. 771, $\mathrm{n}^{\circ} 3$, e o art. 809, $\S 2^{\circ}$, do "Code de Procédure Civile" francês, o "référé provision" permite a antecipação da tutela quando a existência da obrigação não for seriamente contestável. A execução da decisão antecipatória da tutela pode ser subordinada à constituição de uma garantia (real ou pessoal) suficiente para ressarcir todos os eventuais danos.

Quanto à condenação com reserva, Pisani (Lezioni di Diritto Processuale Civile, pp. 608-609) explica que, com base nessa técnica preventiva do abuso do direito de defesa, o juiz italiano emite um provimento jurisdicional de mérito depois de conhecer somente os fatos constitutivos do direito do autor, contanto que eles estejam plenamente provados ou não tenham sido impugnados, adiando para uma fase processual sucessiva a cognição das exceções do demandado aparentemente infundadas e não provadas documentalmente. O provimento jurisdicional é imediatamente executivo, mas sua eficácia é resolutivamente condicionada ao acolhimento das exceções.

${ }^{1397}$ BEDAQUE, Tutela Cautelar e Tutela Antecipada - Tutelas Sumárias e de Urgência (Tentativa de Sistematização), p. 356; PUOLI, Os Poderes do Juiz e as Reformas da Lei Processual Civil Brasileira, p. 166.

${ }^{1398}$ Tutela Antecipada, pp. 387-388 e 420-421.
} 
Percebe-se, outrossim, que o diferencial da hipótese de antecipação de tutela prevista no art. 273, II, do CPC reside no fato de ela não ser vinculada à demonstração do perigo concreto de dano à efetividade da tutela jurisdicional ("periculum in mora") ${ }^{1399}$. Por causa disso, a doutrina nega que ela tenha natureza de medida de urgência ${ }^{1400} 1401$.

É consabido que a antecipação da tutela nos processos que versam sobre cumprimento de obrigação de fazer, de não-fazer e de entregar coisa é regida especificamente pelos $\S \S 3^{\circ}$ e $4^{\circ}$ do art. 461 do CPC. Acontece que tais dispositivos não mencionam a "tutela antecipada sancionatória", nem fazem remissão expressa ao inciso II do art. 273 do CPC. Apesar disso, seria ilógico não admitir essa hipótese de antecipação da tutela nas ações voltadas à imposição de obrigação de fazer, de não-fazer ou de entregar coisa, contanto que haja prova inequívoca da verossimilhança das alegações do autor e o réu abuse do direito de defesa ou se comporte com manifesto propósito procrastinatório $^{1402}$.

Quando há litisconsórcio passivo no processo, e todos os demandados agem com abuso do direito de defesa ou manifesto propósito protelatório, não há dúvida a respeito da possibilidade de antecipação da tutela. Mas, o que ocorre se apenas um dos litisconsortes agir de forma desleal? Consoante Carrilho Lopes ${ }^{1403}$, se o litisconsórcio for comum, o juiz deve conceder a antecipação da tutela em face apenas do demandado ímprobo. Mas, se o litisconsórcio for unitário, não se deve conceder a antecipação. $\mathrm{O}$ autor argumenta que não é lícito punir um litigante que não violou dever processual algum e pondera que, no litisconsórcio unitário, é impossível conceder a antecipação da tutela perante um dos litisconsortes sem prejudicar os demais.

Como um dos requisitos da "tutela antecipada sancionatória" é a apresentação de defesa infundada ou inverídica ou o manifesto propósito protelatório do réu, ela não pode

1399 BEDAQUE, Tutela Cautelar e Tutela Antecipada - Tutelas Sumárias e de Urgência (Tentativa de Sistematização), pp. 356, 359 e 360.

${ }^{1400}$ Nesse sentido: DINAMARCO, O Regime Jurídico das Medidas Urgentes, in Nova Era do Processo Civil, pp. 72-73; CARRILHO LOPES, Tutela Antecipada Sancionatória (art. 273, inc. II, do Código de Processo Civil), pp. 49-51.

${ }^{1401} \mathrm{O}$ tempo é tido como um fator de corrosão dos direitos e pode ser nocivo ao processo de três maneiras: (a) ele faz com que o provimento de mérito seja emitido quando o mal temido já se consumou, inutilizando a tutela jurisdicional; (b) quando a tutela jurisdicional de mérito é tempestiva, porém demorada, causa sofrimento e privações ao titular do direito; e (c) o tempo também faz com que o processo fique desprovido dos meios externos indispensáveis para a sua correta e útil realização, impossibilitando a oferta de uma tutela justa à parte que tem razão (DINAMARCO, O Regime Jurídico das Medidas Urgentes, in Nova Era do Processo Civil, pp. 65 e 66-67).

Os remédios processuais destinados a neutralizar os males do tempo-inimigo denominam-se "medidas de urgência", tendo como espécies as medidas cautelares e as antecipatórias (DINAMARCO, O Regime Jurídico das Medidas Urgentes, in Nova Era do Processo Civil, pp. 59 e 69).

${ }_{1402}$ Nesse sentido: MARINONI, Abuso de Defesa e Parte Incontroversa da Demanda, pp. 104-106.

${ }^{1403}$ Tutela Antecipada Sancionatória (art. 273, inc. II, do Código de Processo Civil), p. 136. 
ser concedida "in limine litis", antes de o demandado integrar o contraditório ${ }^{1404}$. Alguns doutrinadores sustentam que o pedido liminar de antecipação de tutela fundado no inciso II do art. 273 do CPC é admissível se o abuso do direito de defesa ou o manifesto propósito protelatório for constatado antes do início do processo (e.g., se houver prova suficiente de que o réu foi notificado várias vezes para cumprir a obrigação, mas apresentou evasivas e respostas pedindo prazo para o adimplemento) ${ }^{1405}$. Acontece que o réu somente passa a ter direito de defesa, do qual pode abusar, a partir do ajuizamento da demanda. Também não se pode cogitar de intuito protelatório do provimento jurisdicional antes da existência do próprio processo. Portanto, parece correta a seguinte lição de Costa Machado ${ }^{1406}$ : “Antecipa-se a tutela pelo art. 273, inciso II, para sancionar conduta processual reprovável e não a extraprocessual; sanciona-se a defesa abusiva e não a contranotificação abusiva; sanciona-se o propósito protelatório perante o juiz e não perante o credor" (destaques no original).

A decisão que concede a tutela antecipatória embasada no inciso II do art. 273 do CPC decorre de cognição sumária e, por causa disso, é provisória e suscetível de modificação ou revogação no final do processo (art. $273, \S 4^{\circ}$, do CPC) ${ }^{1407}$.

O recurso cabível contra a decisão interlocutória que concede a tutela antecipada é o agravo de instrumento (art. 522 do CPC). A interposição desse recurso não impede a efetivação da tutela antecipada (art. 273, § $3^{\circ}$, c/c art. 475-O do CPC), a não ser que o recorrente peça a atribuição de efeito suspensivo ou a concessão da antecipação da tutela recursal e o relator do agravo defira esse pedido (art. 527, III; e art. 558 do CPC) ${ }^{1408}$.

A doutrina sustenta que a "tutela antecipada sancionatória" pode ser concedida em segundo grau, desde que verificados os pressupostos previstos no art. 273 do CPC. Afirmase que a parte interessada tem o poder de encaminhar petição ao relator ou ao Presidente do Tribunal, pleiteando a concessão da medida antecipatória, com espeque na patente falta de fundamento do recurso ${ }^{1409}$ ou então no intuito manifestamente protelatório do recorrente.

\footnotetext{
${ }^{1404}$ Nesse sentido, afirmando que a hipótese de tutela antecipada prevista no inciso II do art. 273 do CPC somente pode ocorrer após a apresentação da defesa pelo réu: BEDAQUE, Comentários ao art. 273 do CPC, in MARCATO (coord.), Código de Processo Civil Interpretado, p. 841.

${ }^{1405}$ Nesse sentido: NERY JÚNIOR, Atualidades sobre o Processo Civil: a reforma do Código de Processo Civil brasileiro de 1994 e de 1995, p. 70; CARRILHO LOPES, Tutela Antecipada Sancionatória (art. 273, inc. II, do Código de Processo Civil), pp. 123-124.

1406 Tutela Antecipada, p. 434, nt. 701.

${ }^{1407}$ MARINONI, Abuso de Defesa e Parte Incontroversa da Demanda, p. 131.

${ }^{1408}$ MARINONI, Abuso de Defesa e Parte Incontroversa da Demanda, pp. 131-133 e nt. 96; MARINONI, Antecipação da Tutela, pp. 294 e 295.

1409 De acordo com Carrilho Lopes (Tutela Antecipada Sancionatória (art. 273, inc. II, do Código de Processo Civil), p. 122), se o recurso de apelação incidir em uma das hipóteses do "caput" do art. 557 do
} 
Se o pedido for deferido em favor do apelado, a sentença que estava com sua eficácia suspensa passa a ser eficaz imediatamente ${ }^{1410}$.

Deve-se salientar que o abuso do direito de defesa pode gerar não só a antecipação dos efeitos da sentença (art. 273, II, do CPC), mas também o julgamento antecipado do pedido. Isso porque o magistrado tem o poder de indeferir as provas eventualmente requeridas pelo réu que apresentou defesa abusiva ou protelatória (art. 130 do CPC) e, com base apenas nos elementos de convicção trazidos pelo autor com a inicial, julgar o mérito antecipadamente (art. 330, I, do CPC) ${ }^{1411}$.

Consoante os ensinamentos de Bedaque ${ }^{1412}$, na prática, os juízes normalmente julgam antecipadamente a lide com base na prova inequívoca trazida pelo autor e, na própria sentença, concedem a antecipação da tutela regulada pelo art. 273, II, do CPC, o que torna o provimento judicial imediatamente eficaz e retira o efeito suspensivo de eventual apelação ${ }^{1413}$.

CPC - ou seja, se ele for manifestamente inadmissível, improcedente, prejudicado ou estiver em contraste com súmula ou com jurisprudência dominante do Tribunal, do Supremo Tribunal Federal, ou de Tribunal Superior -, deve ser antecipada a tutela jurisdicional com base no inciso II do art. 273 do CPC. Para o jurista, essa é a única forma de neutralizar o tempo necessário para o julgamento do recurso nas hipóteses do art. 557 do CPC, o qual é suportado injustamente pelo recorrido.

${ }^{1410}$ Nesse sentido: BEDAQUE, Comentários ao art. 273 do CPC, in MARCATO (coord.), Código de Processo Civil Interpretado, p. 841; COSTA MACHADO, Tutela Antecipada, pp. 437-439.

1411 BEDAQUE, Tutela Cautelar e Tutela Antecipada - Tutelas Sumárias e de Urgência (Tentativa de Sistematização), p. 357.

${ }^{1412}$ Tutela Cautelar e Tutela Antecipada - Tutelas Sumárias e de Urgência (Tentativa de Sistematização), pp. 357 e 360 .

${ }^{1413} \mathrm{Na}$ opinião de Bedaque (Comentários ao art. 273 do CPC, in MARCATO (coord.), Código de Processo Civil Interpretado, pp. 841-843), se o magistrado verificar, no momento de sentenciar, que estão presentes os requisitos necessários para conceder a tutela antecipada, ele deve acolher definitivamente a pretensão e antecipar os efeitos do provimento, fundado em cognição plena. O jurista também sustenta que a norma prevista no art. 520, VII, do CPC (“Art. 520. A apelação será recebida em seu efeito devolutivo e suspensivo. Será, no entanto, recebida só no efeito devolutivo, quando interposta de sentença que: [...] VII - confirmar a antecipação dos efeitos da tutela") incide não apenas quando o juiz confirma antecipação anterior na sentença, mas também quando ele concede a antecipação da tutela na própria sentença.

Contudo, esses entendimentos não são unânimes na doutrina. É o que se infere a partir do seguinte excerto da obra de Costa Machado (Tutela Antecipada, p. 442):

"Com efeito, se frente à prova produzida, o magistrado já está convicto da procedência do pedido deduzido, não há de se cogitar de antecipação do que está prestes a ser concedido de forma definitiva: ao invés de decisão interlocutória, o juiz profere sentença. Note-se, em relação a tal argumento, que embora ele pareça equivocado sob o ponto de vista das providências cautelares - lembremos que o periculum é enxergado pelo juiz na perspectiva da demora de uma decisão exequível e não na perspectiva da sentença que pode ser atacada por apelação com efeito suspensivo, que é a regra no nosso sistema (art. 520) - nele não há equívoco algum porque a tutela antecipada que fosse concedida por meio de uma sentença ficaria desprovida de eficácia imediata, justamente por integrar o conteúdo decisório de ato sentencial. Não nos esqueçamos que nossos tribunais não admitem separação das decisões que compõem uma mesma sentença para a atribuição de efeito suspensivo para uma parte e não suspensivo para outra. A sentença é um todo e como um todo, incluindo a antecipação da tutela, não seria executada se o apelo interponível não se enquadrasse nas excepcionais hipóteses dos incisos do art. 520". 


\subsection{Prolação de sentença que obste ao objetivo das partes de praticar ato simulado ou de conseguir fim ilícito por meio do processo (art. 129 do CPC)}

Uma vez reconhecido o uso do processo como instrumento para praticar simulação ou para obter objetivo contra a lei, o magistrado deve aplicar o disposto no art. 129 do CPC e "proferir sentença que obste aos objetivos das partes"1414 1415. Apesar de estar inserido no Livro I do Código de Processo Civil, que rege o processo de conhecimento, esse artigo incide também no processo de execução ${ }^{1416} 1417$.

A doutrina diverge a respeito da natureza da "sentença que obste aos objetivos das partes". De acordo com Greco Filho ${ }^{1418}$, essa sentença é extintiva do processo sem julgamento do mérito e deve conter providências complementares e até punitivas visando a obstar a intenção maliciosa das partes. Barbosa Moreira ${ }^{1419}$ afirma, com base em juristas lusitanos $^{1420}$, que a decisão que o juiz deve proferir para obstar ao objetivo das partes é a de anulação do processo. Já Barbi ${ }^{1421}$ entende que o juiz pode proferir sentença extintiva do processo sem julgamento do mérito ou com julgamento do mérito. Como exemplo desta segunda hipótese, ele menciona o caso da mãe que, como representante de seu filho, ajuíza demanda declaratória de paternidade, mas deliberadamente a conduz mal, com o intuito de perdê-la, pois recebeu compensação pecuniária do pai ou de seus herdeiros. Nesse caso, se o juiz constatar a prática da simulação e tiver elementos de convicção suficientes, ele pode

\footnotetext{
${ }^{1414}$ O art. 665 do CPC português, que trata do "uso anormal do processo", contém norma similar:

"Quando a conduta das partes ou quaisquer circunstâncias da causa produzam a convicção segura de que o autor e o réu se serviram do processo para praticar um ato simulado ou para conseguir um fim proibido por lei, a decisão deve obstar ao objetivo anormal prosseguido pelas partes".

${ }^{1415}$ Caso o projeto do novo Código de Processo Civil (Projeto de Lei $n^{\circ}$ 8.046/2010) seja aprovado nos termos atuais, essa norma constará do art. 122:

"Art. 122. Convencendo-se, pelas circunstâncias da causa, de que autor e réu se serviram do processo para praticar ato simulado ou conseguir fim vedado por lei, o juiz proferirá sentença que obste aos objetivos das partes, aplicando, de ofício, as penalidades da litigância de má-fé".

${ }^{1416}$ Yarshell (Simulação e Processo de Execução, in ALVIM WAMBIER (coord.), Processo de Execução e Assuntos Afins, p. 232) explica que o Livro I funciona como uma espécie de "parte geral" do Código de Processo Civil, sendo, por isso, o art. 129 aplicável também ao processo de execução. Esse entendimento é amparado pelo art. 598 do CPC ("Aplicam-se subsidiariamente à execução as disposições que regem o processo de conhecimento").

${ }^{1417}$ Reis (Código de Processo Civil Anotado, vol. V, p. 112) não compartilha desse entendimento. Para ele, o art. 665 do CPC português (que contém norma similar à prevista no art. 129 do CPC nacional) foi elaborado tendo em vista o processo de conhecimento. Logo, na sua opinião, ele só se aplica ao processo de execução se neste houver a oposição de embargos, que têm natureza de ação de conhecimento. Aduz que, fora desse caso, apenas por meio de analogia muito duvidosa se pode sustentar a incidência do dispositivo em comento na execução.

${ }_{1418}$ Direito Processual Civil Brasileiro, vol. I, p. 225.

${ }^{1419}$ Comentários ao Código de Processo Civil, vol. V, p. 127.

${ }^{1420}$ REIS, Código de Processo Civil Anotado, vol. V, p. 103; ANTUNES VARELA; BEZERRA; SAMPAIO E NORA, Manual de Processo Civil, pp. 696-697.

${ }^{1421}$ Comentários ao Código de Processo Civil, vol. I, § 695, p. 407.
} 
e deve prolatar sentença de mérito declarando a paternidade. Para Yarshell ${ }^{1422}$, no processo de conhecimento, pode-se cogitar de julgamento do mérito para impedir a utilização do processo como instrumento para a prática de simulação, mas, tratando-se de execução, o juiz só pode extinguir o processo sem julgamento do mérito, ainda que o executado tenha oposto embargos.

Não há dúvida de que, na maioria dos casos, a sentença que o juiz deve prolatar ao aplicar o art. 129 do CPC é extintiva do processo sem julgamento do mérito. No entanto, existem situações em que a prolação de uma sentença de mérito contrária ao intuito ilícito das partes é a melhor maneira de obstar a utilização do processo como instrumento de consumação da simulação, como no exemplo citado por Barbi. Apenas no processo ou fase executiva é que a sentença deve, necessariamente, ser terminativa, sem a satisfação do credor, já que nunca há julgamento do mérito na execução ${ }^{1423}$. Em hipóteses excepcionais, a sentença que aplica o art. 129 do CPC também pode ter carga eficacial desconstitutiva (por exemplo, se no processo já se tiver operado a expropriação, o desapossamento ou a transformação, é necessário anular $\mathrm{o}$ ato que consubstanciou a expropriação, o desapossamento ou a transformação para retornar ao "status quo ante").

A aplicação do dispositivo em comento é bastante simples quando há apenas um demandante e um demandado no processo, estando ambos unidos em conluio, ou se há mais de uma pessoa no polo ativo, ou no polo passivo, ou em ambos, e todos fazem parte da simulação. Mas, como o magistrado deve proceder se, em um dos polos da relação jurídica processual, houver apenas um litigante, que atua de forma abusiva, e, no outro, houver pluralidade de litigantes, sendo que apenas um ou alguns dos litisconsortes estão conluiados com a parte contrária? E se houver litisconsórcio bilateral (ativo e passivo) e apenas alguns dos litigantes do polo ativo estiverem em conluio igualmente com parcela dos litigantes do polo passivo?

$\mathrm{Na}$ primeira situação, a incidência do art. 129 do CPC implica a extinção do processo sem julgamento do mérito e, eventualmente, a anulação de atos processuais, atingindo todos os litigantes, necessariamente, inclusive os que atuam de boa-fé. Não faria

\footnotetext{
${ }^{1422}$ Simulação e Processo de Execução, in ALVIM WAMBIER (coord.), Processo de Execução e Assuntos Afins, p. 242.

${ }^{1423}$ É o que ensina Dinamarco (Instituições de Direito Processual Civil, vol. IV, § 1.849, p. 931):

"Com referência ao processo ou fase executiva não é adequado estabelecer uma contraposição entre os conceitos de extinção com ou sem julgamento do mérito, que são próprios do processo de conhecimento, sabendo-se que na execução o mérito jamais é julgado (ou seja, a pretensão do exequente). É mais adequado falar em extinção da execução com ou sem a satisfação do credor, porque é nessa satisfação que consiste a tutela jurisdicional executiva - tanto quanto no processo cognitivo a tutela jurisdicional é outorgada pela sentença de mérito" (destaques no original).
} 
sentido excluir apenas os litigantes ímprobos e manter o processo em relação aos sujeitos de boa-fé, já que a relação jurídica processual só pode subsistir se houver duas partes contrapostas e, no caso em tela, um dos polos da relação seria necessariamente extirpado porque é composto somente por um litigante e ele está envolvido no comportamento $\operatorname{abusivo}^{1424}$.

Já na segunda situação, a solução do problema depende da espécie de litisconsórcio existente, se unitário ou comum. Se houver litisconsórcio unitário no polo ativo, ou no passivo, ou em ambos, a aplicação do art. 129 do CPC acarreta a extinção do processo sem julgamento do mérito e, eventualmente, a anulação de atos processuais em relação a todas as partes, inclusive as que estão de boa-fé. Isso deve ocorrer por duas razões: (a) primeiro, porque o litisconsórcio unitário caracteriza-se pela homogeneidade no tratamento de todos os litisconsortes, sendo impossível endereçar a cada um deles um julgamento diferente; (b) segundo, porque a extinção do processo sem julgamento do mérito relativamente aos litigantes que estão no polo em que há litisconsórcio unitário torna inviável a continuação do processo para os demais, uma vez que, insta repetir, a relação jurídica processual só subsiste se houver duas partes contrapostas. Por outro lado, se houver litisconsórcio comum em ambos os polos da relação jurídica processual, a decisão do juiz fundada no art. 129 do CPC deve ser seletiva, obstando ao prosseguimento do processo unicamente quanto aos litigantes ímprobos, demandantes e demandados ${ }^{1425}$. Opera-se, assim, uma redução ou até extinção dos litisconsórcios ativo e passivo. A relação jurídica processual que, originalmente, tinha mais sujeitos em seus polos, agora passa a ter menos. $\mathrm{O}$ ato judicial que exclui os litisconsortes é considerado, pela doutrina e pela jurisprudência, decisão interlocutória, e não sentença, podendo ser impugnado por meio de agravo de instrumento $^{1426}$.

Contanto que se convença, pelas circunstâncias da causa, de que o demandante e o demandado estão se servindo do processo para praticar ato simulado ou conseguir fim proibido por lei, qualquer juízo pode e deve fazer uso do poder previsto no art. 129 do CPC, seja ele um órgão judicial de primeira instância, de segunda instância, o Superior Tribunal de Justiça ou o Supremo Tribunal Federal.

Entretanto, se os juízos de primeiro e de segundo grau já houverem decidido a respeito da incidência do dispositivo em comento no caso concreto, eventual recurso

\footnotetext{
${ }^{1424}$ LUSO SOARES, A Responsabilidade Processual Civil, pp. 281 e 282.

${ }^{1425}$ LUSO SOARES, A Responsabilidade Processual Civil, pp. 283-284.

${ }^{1426}$ DINAMARCO, Instituições de Direito Processual Civil, vol. II, § 570, p. 352.
} 
especial contra o capítulo do acórdão que aplica, ou não, o art. 129 do CPC não poderá ser conhecido pelo Superior Tribunal de Justiça porque sua apreciação implicaria o reexame do contexto fático-probatório, o que é vedado pela súmula $\mathrm{n}^{\circ} 7$ do STJ ("A pretensão de simples reexame de prova não enseja recurso especial") ${ }^{1427}$.

Como o exercício do poder outorgado pelo art. 129 do CPC de alguma forma impede a efetivação da garantia prevista no art. $5^{\circ}, \mathrm{XXXV}$, da $\mathrm{CF}$, o magistrado que o emprega deve motivar adequadamente sua decisão, indicando quais elementos objetivos o convenceram de que as partes se serviram do processo para praticar ato simulado ou conseguir fim proibido por lei ${ }^{1428}$.

\subsection{Cabimento de ação rescisória}

A ação rescisória é descrita pela doutrina processual nacional como uma ação impugnativa autônoma por meio da qual se pleiteia: (a) a desconstituição de sentença de mérito $^{1429}$ que já transitou em julgado materialmente; e, (b) eventualmente, em seguida, o rejulgamento, da matéria nela julgada ${ }^{1430}$. Possui natureza jurídica desconstitutiva (constitutiva negativa) e, dependendo do pedido a ser rejulgado no "iudicium rescissorium", também pode ter natureza declaratória, constitutiva, condenatória, executiva ou mandamental (arts. 488, I, e 494 do CPC) ${ }^{1431}$.

A sentença rescindível, nos termos do art. 485 do CPC, não se confunde com a inexistente, nem com a nula. Não há dúvida de que ela existe, pois não se desconstitui aquilo que não existe. Além disso, ela é válida e apta a produzir todos os efeitos que

\footnotetext{
${ }^{1427}$ Contra, entendendo que, em Portugal, o poder outorgado pelo art. 665 do CPC português (análogo ao art. 129 do CPC nacional) pode ser exercido pelo Supremo Tribunal de Justiça diretamente ou indiretamente, por meio da apreciação do uso que dele tenha feito o tribunal "a quo": REIS, Código de Processo Civil Anotado, vol. V, pp. 107 e 109.

1428 YARSHELL, Simulação e Processo de Execução, in ALVIM WAMBIER (coord.), Processo de Execução e Assuntos Afins, p. 242.

${ }^{1429}$ Deve-se salientar que o legislador emprega a locução "sentença de mérito", no art. 485 do CPC, em sentido amplo, compreendendo as decisões sobre o "meritum causae". Logo, são rescindíveis não só as sentenças, mas também as decisões, interlocutórias e finais, e acórdãos que apreciem o mérito da causa (BARBOSA MOREIRA, Comentários ao Código de Processo Civil, vol. V, pp. 113 e 116; SCARPINELLA BUENO, Comentários ao art. 485 do CPC, in MARCATO (coord.), Código de Processo Civil Interpretado, p. 1664; DINAMARCO, Ação Rescisória contra Decisão Interlocutória, in Nova Era do Processo Civil, pp. 289-292).

${ }^{1430}$ Nesse sentido: BARBOSA MOREIRA, Comentários ao Código de Processo Civil, vol. V, p. 100.

1431 SCARPINELLA BUENO, Comentários ao art. 485 do CPC, in MARCATO (coord.), Código de Processo Civil Interpretado, p. 1663.
} 
normalmente produziria caso não tivesse vício algum, sendo, inclusive, exequível ${ }^{1432}$. Ainda que tenha ocorrido alguma nulidade ao longo do processo e os sujeitos processuais não a tenham alegado, a autoridade da coisa julgada material tem a aptidão de convalidá-la, razão pela qual é considerada a "sanatória geral das invalidades". Em regra, depois do trânsito em julgado, a nulidade se transforma em simples rescindibilidade. Segundo Barbosa Moreira ${ }^{1433}$, a sentença rescindível se assemelha ao ato anulável, pois, uma vez reconhecido judicialmente o seu vício, ela é desconstituída ${ }^{1434}$.

Os pressupostos da ação de rescisão podem ser didaticamente classificados em ${ }^{1435}$ :

a) genérico, que é o trânsito em julgado da decisão de mérito rescindenda. Considera-se transitada em julgado materialmente a sentença de mérito que não possa mais ser impugnada mediante qualquer recurso, ordinário ou extraordinário (art. 467 do CPC), e que não esteja sujeita ao reexame necessário (art. 475 do $\mathrm{CPC}$ ). $\mathrm{O}$ fato de as partes não terem utilizado todos os recursos eventualmente cabíveis para impugnar a decisão que se pretende rescindir é irrelevante para o ajuizamento da ação rescisória ${ }^{1436}$. Igualmente não são óbices para o cabimento da rescisória: a aceitação da sentença, a renúncia ao poder de recorrer, a desistência de recurso já interposto, nem o fato de o recurso ter ficado deserto;

b) específicos, que são os possíveis fundamentos do pedido de rescisão previstos nos incisos do art. 485 do CPC. Cada um deles corresponde a uma causa de pedir da demanda e podem, dependendo da circunstância, ser cumulados numa mesma ação rescisória. Nada impede também a propositura sucessiva de ações rescisórias, desde que fundadas em diversas causas de pedir e respeitado o prazo decadencial de 2 anos (art. 495 do CPC).

Dentre as hipóteses de cabimento da ação rescisória previstas no Código de Processo Civil, algumas delas só podem decorrer da prática de abuso processual. Trata-se daquelas enunciadas no inciso III do art. 485 do CPC: “A sentença de mérito, transitada

${ }^{1432}$ É o que se infere do texto do art. 489 do CPC: "O ajuizamento da ação rescisória não impede o cumprimento da sentença ou acórdão rescindendo, ressalvada a concessão, caso imprescindíveis e sob os pressupostos previstos em lei, de medidas de natureza cautelar ou antecipatória de tutela".

${ }_{1433}$ Comentários ao Código de Processo Civil, vol. V, pp. 106-109.

${ }^{1434}$ Essa parece ser também a opinião de Bueno Vidigal (Comentários ao Código de Processo Civil, vol. 6, pp. 39-40 e 96).

Em sentido contrário, atribuindo às decisões de mérito sujeitas à ação rescisória o regime jurídico das decisões absolutamente nulas, exceto na hipótese do inciso VII do art. 485 do CPC: SCARPINELLA BUENO, Comentários ao art. 485 do CPC, in MARCATO (coord.), Código de Processo Civil Interpretado, pp. 1662-1663.

1435 BARBOSA MOREIRA, Comentários ao Código de Processo Civil, vol. V, pp. 117-121; SCARPINELLA BUENO, Comentários ao art. 485 do CPC, in MARCATO (coord.), Código de Processo Civil Interpretado, pp. 1663-1664.

${ }^{1436}$ É o que estatui a súmula $\mathrm{n}^{\circ} 514$ do STF: "Admite-se ação rescisória contra sentença transitada em julgado, ainda que contra ela não se tenha esgotado todos os recursos". 
em julgado, pode ser rescindida quando: [...] III - resultar de dolo da parte vencedora em detrimento da parte vencida, ou de colusão entre as partes, a fim de fraudar a lei"1437 1438 . Segundo Barbosa Moreira ${ }^{1439}$, a causa de pedir enunciada na primeira parte do inciso III do art. 485 do CPC ("dolo da parte vencedora em detrimento da parte vencida") ocorre sempre que, ao arrepio do art. 14, II, do CPC, a parte vencedora tenha impedido ou dificultado a atividade processual da contraparte, ou tenha influenciado o juízo do magistrado, afastando-o da verdade.

Sendo assim, podem, por exemplo, dar ensejo à propositura da ação rescisória fundada no art. 485, III, do CPC as condutas abusivas consistentes em alterar a verdade dos fatos (art. 17, II, do CPC) e em requerer a citação por edital alegando dolosamente os requisitos do art. 231 do CPC (art. 233 do CPC), desde que o "improbus litigator" seja o vencedor da causa em razão do seu comportamento desleal.

$\mathrm{Na}$ opinião de Bueno Vidigal ${ }^{1440}$, a dedução de pretensão ou de defesa manifestamente infundada (art. 17, I, do CPC) também pode levar à rescisão da sentença

${ }^{1437}$ A alínea "g" do art. 771 do CPC português prevê uma hipótese de desconsideração da coisa julgada material bastante parecida com a prevista no inciso III do art. 485 do CPC:

"A decisão transitada em julgado só pode ser objeto de revisão quando:

$[\ldots]$

g) O litígio assente sobre ato simulado das partes e o tribunal não tenha feito uso do poder que lhe confere o artigo $665 .^{\circ}$, por se não ter apercebido da fraude".

Barbosa Moreira (Comentários ao Código de Processo Civil, vol. V, p. 102, nt. 8) esclarece que, no moderno Direito português, vícios semelhantes aos que, no Brasil, fundamentam a ação rescisória são denunciáveis por meio da "revisão", que é um recurso, embora interponível contra decisão já transitada em julgado.

Analogamente, no Uruguai, o recurso de "revisión" é cabível contra sentenças definitivas ou interlocutórias firmes, que ponham fim ao processo, e que decorram de atividade dolosa do tribunal, declarada por sentença firme, ou de colusão ou outra manobra fraudulenta das partes que tenha causado prejuízo ao recorrente ou à ordem pública (art. 283, 5 e 6, do CPC uruguaio). Esse recurso visa a anular os atos processuais praticados mediante dolo, fraude, ou colusão. Pode ser interposto pela pessoa que tenha sido lesada pelo dolo, fraude, ou colusão, podendo ser parte ou terceiro (arts. 114 e 115.2 do CPC uruguaio).

$\mathrm{O}$ art. 510.4 da "Ley de Enjuiciamiento Civil" espanhola estatui que é cabível a demanda de "revisión" contra sentença transitada em julgado decorrente de maquinação fraudulenta. De acordo com a doutrina, o exemplo mais expressivo de "maquinação fraudulenta" que enseja a incidência dessa norma é a citação ou intimação do réu em um local fictício, apesar de o autor conhecer o seu verdadeiro endereço, com o intuito de impedi-lo de se defender no processo e de facilitar a obtenção de uma sentença final de procedência do pedido (MÉNDEZ, Abuse of Procedural Rights? Spain and Portugal, in TARUFFO (ed.), Abuse of Procedural Rights: comparative standards of procedural fairness, p. 185).

No Direito alemão, a coisa julgada também pode ser desconsiderada em casos de abuso do processo. Segundo Hess (Abuse of Procedure in Germany and Austria, in TARUFFO (ed.), Abuse of Procedural Rights: comparative standards of procedural fairness, pp. 152 e 171-174), se a sentença transitada em julgado foi obtida mediante dolo ou fraude processual, ela pode ser desconstituída por meio de uma ação de restituição, fundada nas seções 578 e 580 da ZPO, ou então de uma ação baseada na responsabilidade extracontratual ("action based on tort"), com espeque na seção 826 do BGB.

${ }^{1438}$ No Projeto de Lei no 8.046/2010, que institui o novo Código de Processo Civil, as mesmas hipóteses de cabimento da ação rescisória estão previstas no art. 919, III.

${ }_{1439}$ Comentários ao Código de Processo Civil, vol. V, p. 124.

${ }^{1440}$ Comentários ao Código de Processo Civil, vol. 6, pp. 80-81. 
com espeque no inciso III do art. 485 do CPC. Contudo, parece que essa hipótese de improbidade processual se enquadra melhor na figura do inciso V do art. 485 do CPC.

No julgamento do REsp 656.103/DF (STJ, Rel. Min. Jorge Scartezzini, DJ 26/02/2007, p. 595), a $4^{\text {a }}$ Turma do Superior Tribunal de Justiça aplicou o dispositivo em comento a uma hipótese bastante rara de abuso processual. A autora e o réu do processo originário celebraram acordo extrajudicial em que a primeira se comprometia a desistir da ação em curso, desde que o segundo doasse um bem imóvel a uma terceira pessoa, convenção essa que foi devidamente registrada em Cartório de Títulos e Documentos. Acontece que, uma vez efetuada a doação, a demandante não fez o pedido de desistência da ação e o demandado, acreditando que a primeira estivesse cumprindo sua parte no acordo, deixou de apresentar contestação, sendo declarado revel. O juízo de primeiro grau prolatou sentença de procedência, a qual transitou em julgado, pois não foi interposto qualquer recurso. O demandado ajuizou ação rescisória, a qual chegou ao Superior Tribunal de Justiça por meio de Recurso Especial. Os Ministros do STJ consideraram que a conduta da autora violou os deveres de lealdade processual e de boa-fé (art. 14, II, do CPC) e dificultou sobremaneira o desempenho do direito à ampla defesa e ao contraditório pelo réu, acarretando a prolação de sentença de procedência dos pedidos integrantes da petição inicial. Diante disso, decidiram que ficou caracterizado o dolo da parte vencedora em detrimento da parte vencida (art. 485, III, do CPC) e rescindiram a sentença de mérito.

Como o texto legal prevê o cabimento da rescisória quando a sentença de mérito "resultar de dolo da parte vencedora" (destaque nosso), a doutrina considera necessária a constatação de nexo de causalidade entre o comportamento doloso e o pronunciamento do órgão jurisdicional. Desse modo, para que a sentença seja rescindível, exige-se que o seu teor pudesse ser diferente, caso não tivesse sido praticada a conduta ímproba. Se os atos dolosos não tiverem influenciado o resultado da ação, é descabida a rescisória por esse fundamento $^{1441}$.

Barbosa Moreira ${ }^{1442}$ observa que, se houver litisconsórcio, basta o dolo de um dos sujeitos integrantes da parte vitoriosa para que a sentença seja rescindível com espeque no art. 485, III, do CPC. Mas, se a sentença tiver capítulos autônomos, referentes a cada um

${ }^{1441}$ SCARPINELLA BUENO, Comentários ao art. 485 do CPC, in MARCATO (coord.), Código de Processo Civil Interpretado, pp. 1666-1667; BUENO VIDIGAL, Comentários ao Código de Processo Civil, vol. 6, p. 81; BARBOSA MOREIRA, Comentários ao Código de Processo Civil, vol. V, p. 126.

${ }^{1442}$ Comentários ao Código de Processo Civil, vol. V, p. 126. 
dos litisconsortes, a rescindibilidade limita-se ao capítulo relativo ao sujeito que se comportou dolosamente ${ }^{1443}$.

O segundo motivo de rescisão enunciado no inciso III do art. 485 do CPC consiste em "resultar [a decisão de mérito] de colusão entre as partes, a fim de fraudar a lei".

A “colusão entre as partes”, mencionada nesse dispositivo, relaciona-se com o comportamento abusivo previsto no art. 129 do CPC: "Convencendo-se, pelas circunstâncias da causa, de que autor e réu se serviram do processo para praticar ato simulado ou conseguir fim proibido por lei, o juiz proferirá sentença que obste aos objetivos das partes". Logo, a rescisória só é cabível se o juiz não tiver percebido o intuito ímprobo das partes e, consequentemente, não houver prolatado sentença capaz de obstar a consecução do escopo ilícito ${ }^{1444}$. Na opinião de Barbosa Moreira ${ }^{1445}$, a hipótese de incidência do art. 485, III, $2^{\mathrm{a}}$ parte, do CPC coincide apenas parcialmente com a do art. 129 do CPC, uma vez que a causa de pedir da ação rescisória refere-se exclusivamente ao processo fraudulento, e não ao processo simulado. Já Bueno Vidigal ${ }^{1446}$ entende que essa hipótese de cabimento da rescisória nada mais é do que um desdobramento, levado às últimas consequências, do art. 129 do CPC. Em abono desta tese, Yarshell ${ }^{1447}$ argumenta $^{2}$ que, no mais das vezes, a simulação configura um meio para fraudar.

Um exemplo de conduta que enseja a incidência do art. 485, III, $2^{\mathrm{a}}$ parte, do CPC é a omissão do réu em impugnar fato inverídico alegado pelo autor, tendo ambos acertado essa atuação conjunta previamente, com o intuito de fraudar a lei ${ }^{1448}$.

Como a causa de pedir prevista na segunda parte do art. 485, III, do CPC pressupõe o conluio entre as partes do processo em que foi proferida a sentença rescindenda, o legislador preocupou-se em legitimar expressamente o Ministério Público para propor a ação rescisória (art. 487, III, “ $b ”$, do CPC) ${ }^{1449}$. O Ministério Público pode ajuizar a ação rescisória fundada na "colusão entre as partes, a fim de fraudar a lei" tanto na posição de parte do processo anterior, quanto na de fiscal da lei ${ }^{1450}$. Pelo mesmo motivo (existência de conluio entre as partes do processo em que a decisão rescindenda foi prolatada), o

\footnotetext{
${ }^{1443}$ Nesse mesmo sentido: BUENO VIDIGAL, Comentários ao Código de Processo Civil, vol. 6, p. 83.

1444 SCARPINELLA BUENO, Comentários ao art. 485 do CPC, in MARCATO (coord.), Código de Processo Civil Interpretado, p. 1667.

${ }^{1445}$ Comentários ao Código de Processo Civil, vol. V, p. 127.

${ }^{1446}$ Comentários ao Código de Processo Civil, vol. 6, pp. 82-83.

1447 Simulação e Processo de Execução, in ALVIM WAMBIER (coord.), Processo de Execução e Assuntos Afins, p. 232, nt. 19.

1448 BARBOSA MOREIRA, Comentários ao Código de Processo Civil, vol. V, p. 128.

1449 SCARPINELLA BUENO, Comentários ao art. 485 do CPC, in MARCATO (coord.), Código de Processo Civil Interpretado, p. 1667.

${ }^{1450}$ BARBOSA MOREIRA, Comentários ao Código de Processo Civil, vol. V, pp. 171 e 173.
} 
"terceiro juridicamente interessado" em denunciar a simulação processual também consta do rol de legitimados à propositura da ação rescisória (art. 487, II, do CPC).

$\mathrm{Na}$ rescisória proposta pelo Ministério Público ou pelo terceiro juridicamente interessado, devem figurar no polo passivo todas as pessoas que, no momento da decisão rescindenda, figuravam como partes no processo anterior. Se algum (ou alguns) dos citados tiver interesse coincidente com o do autor da rescisória na desconstituição da sentença, ele pode tornar-se litisconsorte ativo, em vez de assumir a condição de réu ${ }^{1451}$ (v.g., no caso de algum sujeito parcial do processo não se ter envolvido no conluio formado entre os demais litigantes).

Cumpre destacar que são inconfundíveis as hipóteses de cabimento da ação rescisória previstas na primeira e na segunda parte do inciso III do art. 485, uma vez que o dolo é unilateral, enquanto a colusão é bilateral, pressupondo entendimento prévio entre os sujeitos imbuídos do propósito fraudatório ${ }^{1452}$.

Engana-se quem entende que apenas os motivos de rescisão mencionados no inciso III do art. 485 do CPC relacionam-se com o abuso do processo. Os previstos nos incisos I, IV, V e VI desse dispositivo legal também podem decorrer de comportamentos processuais ímprobos.

O inciso I do art. 485 do CPC estabelece que é rescindível a decisão de mérito que “foi dada por prevaricação, concussão ou corrupção do juiz".

De acordo com a doutrina, para que seja cabível a ação rescisória fundada nessa causa de pedir é necessário que o comportamento do magistrado no caso concreto corresponda a um dos tipos penais mencionados no texto legal ${ }^{1453}$. Ou seja, é necessário que ele tenha praticado:

a) prevaricação, cuja conduta típica está descrita no art. 319 do CP: “Retardar ou deixar de praticar, indevidamente, ato de ofício, ou praticá-lo contra disposição expressa de lei, para satisfazer interesse ou sentimento pessoal"; ou

b) concussão, que nada mais é do que "exigir, para si ou para outrem, direta ou indiretamente, ainda que fora da função ou antes de assumi-la, mas em razão dela, vantagem indevida" (art. 316, "caput”, do CP); ou

${ }^{1451}$ BARBOSA MOREIRA, Comentários ao Código de Processo Civil, vol. V, p. 175.

${ }^{1452}$ BARBOSA MOREIRA, Comentários ao Código de Processo Civil, vol. V, p. 128.

${ }^{1453}$ BARBOSA MOREIRA, Comentários ao Código de Processo Civil, vol. V, p. 121; SCARPINELLA BUENO, Comentários ao art. 485 do CPC, in MARCATO (coord.), Código de Processo Civil Interpretado, p. 1665. 
c) corrupção passiva, que é o fato de "solicitar ou receber, para si ou para outrem, direta ou indiretamente, ainda que fora da função ou antes de assumi-la, mas em razão dela, vantagem indevida, ou aceitar promessa de tal vantagem" (art. 317, “caput”, do CP).

Não obstante o texto do inciso I do art. 485 do CPC mencione apenas o juiz, também é possível rescindir decisões emanadas de órgãos colegiados com espeque nessa causa de pedir. Para que isso ocorra, basta que um dos integrantes do órgão colegiado, que tenha efetivamente participado do julgamento, tenha praticado ato definido como prevaricação, concussão ou corrupção passiva ${ }^{1454}$. Com razão, Barbosa Moreira ${ }^{1455}$ afirma que, além da participação do juiz infrator no julgamento, é necessário que seu voto tenha concorrido para a formação da maioria ou da unanimidade. Se o seu voto foi vencido, o acórdão não pode ser considerado rescindível, uma vez que o ato de prevaricação, concussão ou corrupção passiva foi inócuo para o processo.

O motivo de rescisão previsto no art. 485, I, do CPC pode, eventualmente, ser um corolário do comportamento ímprobo do órgão jurisdicional. O magistrado comete abuso do processo sempre que exercita algum de seus poderes-deveres com desvio de finalidade, para atingir escopo ilícito ou ilegítimo. Quando o desvio de finalidade for decorrente da prática de prevaricação, concussão ou corrupção passiva, uma das consequências do ato processual abusivo é o cabimento da ação rescisória. É o caso, por exemplo, do juiz que prolata sentença acolhendo pretensão manifestamente infundada ou inverídica, depois de ter exigido da parte que se sagrou vencedora uma vantagem patrimonial (concussão).

No entanto, existem situações em que a incidência do dispositivo legal em análise não decorre de conduta ímproba alguma. É necessário lembrar o ensinamento de Bueno Vidigal $^{1456}$, segundo o qual, se o autor da rescisória alegar e provar que o juiz solicitou, recebeu ou exigiu vantagem indevida, o julgado é rescindível, ainda que não se demonstre a injustiça da sentença ou a ilegalidade de qualquer outro ato judicial. De acordo com o jurista, a decisão de mérito prolatada por juiz peitado é nula, seja ela justa ou injusta, legal ou ilegal. É como se fosse proferida por pessoa desprovida de jurisdição. Diante disso, não se pode dizer que essa causa de pedir da ação rescisória seja sempre uma consequência do cometimento de abuso processual na atividade jurisdicional. Por exemplo: se o juiz, em um primeiro momento, exige vantagem econômica de uma das partes, oferecendo, em

\footnotetext{
${ }^{1454}$ BUENO VIDIGAL, Comentários ao Código de Processo Civil, vol. 6, p. 60; SCARPINELLA BUENO, Comentários ao art. 485 do CPC, in MARCATO (coord.), Código de Processo Civil Interpretado, p. 16651666.

${ }^{1455}$ Comentários ao Código de Processo Civil, vol. V, p. 123.

${ }^{1456}$ Comentários ao Código de Processo Civil, vol. 6, pp. 55 e 59.
} 
contrapartida, o acolhimento de sua pretensão manifestamente infundada ou inverídica e, em seguida, prolata uma sentença justa, favorável à parte contrária, a decisão de mérito é rescindível, em razão da concussão consumada, embora não tenha ocorrido qualquer abuso de situação jurídica processual.

Para que seja rescindível a sentença, não é necessária a prévia condenação criminal do magistrado infrator, nem mesmo a pendência de processo criminal para apurar o delito por ele praticado. A verificação da ocorrência de prevaricação, concussão ou corrupção passiva incumbe ao próprio órgão julgador da rescisória. Mas, se existir um processo penal pendente, pode-se determinar o sobrestamento do processo rescisório até que o juízo criminal se pronuncie definitivamente sobre a prática criminosa, por decisão transitada em julgado (art. 110 do CPC) ${ }^{1457}$.

Se, porventura, houver uma sentença penal, já transitada em julgado, condenando o magistrado pela prática de prevaricação, concussão ou corrupção passiva, o órgão julgador da rescisória não pode rejeitar o pedido de rescisão sob a alegação de que não houve qualquer infração criminal, sob pena de ofensa à "res iudicata". Por outro lado, se o juízo criminal houver proferido sentença absolutória, declarando a inexistência material do fato (art. 386, I, do CPP), fica pré-excluída a possibilidade de acolher-se o pedido da rescisória, uma vez que essa sentença penal faz coisa julgada no âmbito civil (art. 66 do $\left.\mathrm{CPP}^{1458}\right)^{1459}$.

Consoante o art. 485, IV, do CPC, a sentença de mérito que ofende a coisa julgada, uma vez transitada em julgado, pode ser objeto de ação rescisória.

1457 BUENO VIDIGAL, Comentários ao Código de Processo Civil, vol. 6, pp. 56-57; SCARPINELLA BUENO, Comentários ao art. 485 do CPC, in MARCATO (coord.), Código de Processo Civil Interpretado, p. 1665; BARBOSA MOREIRA, Comentários ao Código de Processo Civil, vol. V, pp. 121 e 122.

${ }^{1458} \mathrm{O}$ art. 66 do CPP estabelece que a sentença absolutória no juízo criminal só faz coisa julgada no âmbito civil se reconhecer a inexistência material do fato, em tese, típico.

Nucci (Código de Processo Penal Comentado, p. 183, nt. 15) ensina que algumas sentenças criminais não produzem coisa julgada no cível porque, nelas, o juiz criminal: (a) não decide se o fato existiu ou não; (b) não afasta, por completo, a autoria em relação a determinada pessoa; e (c) também não afirma, expressamente, que a conduta é lícita. São elas:

1) a absolvição por não estar provada a existência do fato (art. 386, II, do CPP), sendo possível produzir tal prova no âmbito civil;

2) a absolvição por não constituir infração penal o fato (art. 386, III, do CPP), o que não quer dizer que não se trate de ato ilícito civil;

3) a absolvição por não existir prova suficiente de ter o réu concorrido para a infração penal (art. 386, IV, do $\mathrm{CPP}$ ), restando a possibilidade de provar tal fato no processo civil de conhecimento;

4) a absolvição por insuficiência de provas (arts. 67, III, e 386, VI, do CPP), as quais podem ser apresentadas na esfera civil;

5) a absolvição por excludentes de culpabilidade e algumas de ilicitude (art. 386, V, do CPP), o que não significa que o ato é lícito;

6) a decisão de arquivamento de inquérito policial ou de peças de informação (art. 67, I, do CPP), restando aberta a possibilidade de o fato ser um ilícito civil; e

7) a decisão de extinção da punibilidade (art. 67, II, do CPP), o que apenas afasta a pretensão punitiva do Estado, mas não o direito à indenização da vítima.

${ }^{1459}$ BARBOSA MOREIRA, Comentários ao Código de Processo Civil, vol. V, p. 122. 
A coisa julgada consiste na imutabilidade da sentença ${ }^{1460}$ e de seus efeitos, a qual somente ocorre quando já estiver precluso o poder de impugnação da decisão. Ela possui duas facetas ${ }^{1461}$ :

a) a coisa julgada formal, que é a imutabilidade da sentença como ato jurídico processual, decorrente das preclusões do poder de impugná-la e do poder do tribunal de decidir novamente a causa (art. 475 do CPC) ${ }^{1462}$. Trata-se de um fenômeno puramente processual, que impede qualquer outro órgão jurisdicional de introduzir naquele mesmo processo outro ato que substitua a sentença irrecorrível (art. 467 do CPC). Consoante o ordenamento jurídico brasileiro atual, toda e qualquer sentença que encerre a relação jurídica processual é apta a receber a coisa julgada formal, seja ela terminativa ou de mérito (arts. 162, § 1²; 267; e 269 do CPC), de procedência ou de improcedência, prolatada em procedimento de jurisdição contenciosa ou de jurisdição voluntária; e

b) a coisa julgada material, que é a imutabilidade dos efeitos substanciais da sentença de mérito, seja ela meramente declaratória, constitutiva, condenatória ou de improcedência. A sentença terminativa não é suscetível de coisa julgada material, uma vez que ela não passa de uma decisão sobre o processo, exaurindo neste a sua eficácia. De fato, quando a sentença determina a extinção do processo sem julgamento do mérito, ela simplesmente põe fim à fase cognitiva ou à relação processual, continuando as partes com o poder de ajuizar novamente a mesma demanda no futuro (art. 268 do CPC). Não produz qualquer efeito externo, que afete as relações interpessoais que as partes mantêm fora do processo. Além das sentenças terminativas, a coisa julgada material também não incide

\footnotetext{
${ }^{1460}$ Menciona-se apenas a sentença por mera comodidade de linguagem. Dinamarco (Instituições de Direito Processual Civil, vol. III, § 953, p. 303, nt. 2) esclarece que a coisa julgada atinge também os acórdãos dos tribunais e as decisões monocráticas dos relatores que dão ou negam provimento a recursos, notadamente no Supremo Tribunal Federal ou no Superior Tribunal de Justiça (art. 544, § $3^{\circ}$, do CPC).

${ }_{1461}$ DINAMARCO, Instituições de Direito Processual Civil, vol. III, § 952, pp. 300-302; § 953, pp. 303-304; $\S 955$, pp. 307-308; § 956, pp. 309-310; § 958, pp. 311-314; DINAMARCO, Relativizar a Coisa Julgada Material, in Nova Era do Processo Civil, § 111, pp. 217-218; § 112, pp. 221-223.

${ }_{1462}$ Parte da doutrina se refere à coisa julgada formal como sendo a preclusão máxima ("praeclusio maxima"), uma vez que ela resulta da "irrecorribilidade", ou seja, da preclusão de todo e qualquer poder de provocar ou emitir novo julgamento sobre a causa no mesmo processo (DINAMARCO, Instituições de Direito Processual Civil, vol. III, § 953, p. 304; DINAMARCO, Relativizar a Coisa Julgada Material, in Nova Era do Processo Civil, § 112, p. 223).

Baptista da Silva (Coisa Julgada e Efeitos da Sentença, in BAPTISTA DA SILVA; GOMES, Teoria Geral do Processo Civil, p. 322) chega a afirmar que a chamada "coisa julgada formal" não é uma verdadeira coisa julgada, mas sim uma forma de preclusão que incide sobre a sentença irrecorrível.

$\mathrm{Na}$ verdade, como esclarece Grinover em suas notas relativas à obra "Eficácia e Autoridade da Sentença e Outros Escritos sobre a Coisa Julgada", de Liebman, a preclusão e a coisa julgada formal são institutos diversos, embora ligados entre si por uma relação lógica de antecedente-consequente. De acordo com a referida jurista, a primeira é, subjetivamente, a perda de uma faculdade processual e, objetivamente, um fato impeditivo. Já a segunda é a qualidade da decisão, ou seja, sua imutabilidade, dentro do processo (LIEBMAN, Eficácia e Autoridade da Sentença e Outros Escritos sobre a Coisa Julgada (com aditamentos relativos ao direito brasileiro), p. 68).
} 
sobre os efeitos das sentenças proferidas em processo de jurisdição voluntária (art. 1.111 do CPC), em processo cautelar (arts. 807; 808, III; e 810 do CPC), em processo executivo $^{1463}$, nem sobre os efeitos das medidas antecipatórias de tutela jurisdicional (art. $273, \S 4^{\circ}$, do CPC).

A autoridade da coisa julgada impede o órgão jurisdicional de emitir novo pronunciamento acerca da matéria já decidida. Em alguns casos, essa impossibilidade só prevalece no mesmo processo em que foi prolatada a decisão (coisa julgada formal); em outros, prevalece em qualquer processo (coisa julgada material) ${ }^{1464}$. De acordo com parte da doutrina, ao impedir novo julgamento do mérito, entre as mesmas partes e com base na mesma causa de pedir, a coisa julgada material extingue o direito de ação. Logo, se a demanda judicial for reiterada, ela carecerá de base jurídica, devendo ser extinto o processo sem julgamento do mérito (art. $267, \mathrm{~V}$, do CPC) ${ }^{1465}$.

Caso o órgão jurisdicional não reconheça a existência de coisa julgada (art. 301, VI e $\S 4^{\circ}$, do CPC), cabe ação rescisória para impugnar a decisão que julgar novamente o mérito, entre as mesmas partes e com base na mesma causa de pedir (art. 485, IV, do $\mathrm{CPC})^{1466}$. O mesmo pode acontecer quando o órgão jurisdicional aprecia pedido que, apesar de não ser idêntico à demanda já decidida definitivamente, tem solução logicamente subordinada ao resultado do primeiro processo. Por exemplo: uma vez transitada em julgado a sentença declarando que "A" é filho de "B", se "A" ajuizar demanda de alimentos em face de "B", o órgão jurisdicional não pode julgá-la improcedente com

\footnotetext{
${ }^{1463}$ Nesse sentido: BAPTISTA DA SILVA, Coisa Julgada e Efeitos da Sentença, in BAPTISTA DA SILVA; GOMES, Teoria Geral do Processo Civil, p. 323.

${ }^{1464}$ BARBOSA MOREIRA, Comentários ao Código de Processo Civil, vol. V, p. 128.

${ }^{1465}$ DINAMARCO, Instituições de Direito Processual Civil, vol. III, § 955, p. 308; BARBOSA MOREIRA, Considerações sobre a Chamada "Relativização da Coisa Julgada Material", in Revista Síntese de Direito Civil e Processual Civil, $\mathrm{n}^{\circ} 33$, p. 14.

${ }^{1466}$ Na opinião de Yarshell (Ação Rescisória: juízos rescindente e rescisório, pp. 320-321, nt. 69), se houver a repropositura de uma demanda que já foi anteriormente julgada, o órgão jurisdicional deve-se abster de julgar o mérito, proferindo sentença terminativa. Mas, se ele proferir novo julgamento, não existe interesse processual para a ação rescisória se o seu teor coincidir com o da sentença anterior já transitada em julgado. Segundo ele, excepcionalmente, só haveria utilidade no ajuizamento da ação rescisória para cassar a segunda decisão se fosse para excluir uma segunda condenação ao pagamento de verba honorária ou outra condenação decorrente do julgamento.

Já Barbosa Moreira (Comentários ao Código de Processo Civil, vol. V, p. 128) entende que a ofensa à coisa julgada existe tanto na hipótese de o novo pronunciamento judicial ser conforme ao primeiro, quanto na de ser desconforme. De acordo com o jurista, a autoridade da coisa julgada não obriga o órgão jurisdicional a rejulgar a matéria no mesmo sentido. Na verdade, ela o impede até mesmo de rejulgar.

A razão parece estar com o segundo doutrinador, uma vez que o inciso V do art. 267 do CPC prevê o acolhimento da alegação de coisa julgada como causa de extinção do processo sem resolução do mérito. Caso o juiz estivesse autorizado a emitir novo julgamento, desde que em consonância com a sentença anterior, o acolhimento da alegação de coisa julgada estaria inserido no rol do art. 269 do CPC, que trata dos casos de extinção do processo com julgamento do mérito.
} 
fundamento na inexistência da referida relação de filiação, sob pena de ofensa à "res iudicata" e possível invocação do art. 485, IV, do $\mathrm{CPC}^{1467}$.

Como já se afirmou no item 2.2 "supra", o ajuizamento de demanda que já foi anteriormente apreciada em sentença de mérito transitada em julgado formal e materialmente subsume-se ao inciso I do art. 17 do CPC, uma vez que se trata de dedução de pretensão contrária ao texto expresso dos arts. 467 (“Denomina-se coisa julgada material a eficácia, que torna imutável e indiscutivel a sentença, não mais sujeita a recurso ordinário ou extraordinário" - destaque nosso) e 267, V, do CPC (“Extingue-se o processo, sem resolução do mérito: [...] V-quando o juiz acolher a alegação [...] de coisa julgada" - destaque nosso). Logo, a hipótese de rescindibilidade prevista no inciso IV do art. 485 do CPC também deve ser considerada uma consequência da prática de abuso do processo.

Cumpre, por fim, observar que não constitui obstáculo ao ajuizamento da ação rescisória fundada no art. 485, IV, do CPC, nem impede o acolhimento do respectivo pedido de rescisão, o fato de uma eventual preliminar acerca da coisa julgada ter sido oposta e rejeitada no processo em que se proferiu a sentença rescindenda. Nesse ponto, o ordenamento jurídico brasileiro é diferente do italiano, que exige, como requisito de admissibilidade da "revocazione" (recurso que se aproxima da ação rescisória brasileira), a inexistência de qualquer pronunciamento judicial sobre a alegação de coisa julgada na sentença impugnada (art. 395, $\mathrm{n}^{\circ} 5$, do CPC italiano) ${ }^{1468}$.

De acordo com o inciso $\mathrm{V}$ do art. 485 do CPC, a sentença de mérito transitada em julgado pode ser rescindida quando "violar literal disposição de lei", ou seja, quando afrontar uma norma que integre o ordenamento jurídico nacional ${ }^{1469}$.

Essa norma pode estar prevista na Constituição Federal, em lei (complementar, ordinária ou delegada), em medida provisória, em decreto legislativo, em resolução, em decreto emanado do Executivo, ou até em ato normativo emanado de órgão do Poder Judiciário. Pode ser até uma norma jurídica estrangeira, se for o caso de aplicar à espécie o Direito de outro país (por exemplo, nas hipóteses regidas pelos arts. $7^{\circ}$ a 11 e 13 do Decreto-Lei $n^{\circ} 4.657 / 42$ ). É irrelevante o fato de o seu conteúdo integrar a competência

\footnotetext{
${ }^{1467}$ BARBOSA MOREIRA, Comentários ao Código de Processo Civil, vol. V, pp. 128-129.

1468 BUENO VIDIGAL, Comentários ao Código de Processo Civil, vol. 6, pp. 86-87; SCARPINELLA BUENO, Comentários ao art. 485 do CPC, in MARCATO (coord.), Código de Processo Civil Interpretado, p. 1667; BARBOSA MOREIRA, Comentários ao Código de Processo Civil, vol. V, p. 130.

${ }_{1469}$ Contra, entendendo que é rescindível apenas a sentença de mérito que contrarie o texto escrito da lei: BUENO VIDIGAL, Comentários ao Código de Processo Civil, vol. 6, pp. 109-112.
} 
legislativa da União, dos Estados ou dos Municípios. Também não importa se a norma versa sobre direito substancial ou processual ${ }^{1470} 1471$.

A violação à norma jurídica precisa ser "literal", ou seja, inequívoca, flagrante, evidente, de modo que qualquer um que analise o julgamento possa constatá-la. Assim sendo, não é rescindível a decisão de mérito se houver controvérsia nos tribunais acerca da correta interpretação da norma jurídica que a embasou. Nesse sentido é a súmula no 343 do STF: "Não cabe ação rescisória por ofensa a literal disposição de lei, quando a decisão rescindenda se tiver baseado em texto legal de interpretação controvertida nos tribunais". Nesse caso, é irrelevante que, após o trânsito em julgado da decisão que se quer impugnar, os tribunais tenham uniformizado sua jurisprudência, adotando entendimento oposto ao que prevaleceu no caso concreto ${ }^{1472}{ }^{1473}$. De acordo com Barbosa Moreira ${ }^{1474}$, a decisão que se afasta da jurisprudência não pode ser vista, só por isso, como necessariamente violadora da lei, ainda que ela contrarie entendimento consagrado em súmula do Superior Tribunal de Justiça ou do Supremo Tribunal Federal. O jurista argumenta que é possível até que a agressão à norma jurídica esteja no próprio teor da súmula, e não na decisão que se afasta do entendimento sumulado.

Ainda a respeito da súmula $\mathrm{n}^{\circ} 343$ do STF, Barbosa Moreira ${ }^{1475}$ comenta que a tese nela prevista deve ser adotada "cum grano salis", uma vez que não se pode afastar a

${ }^{1470}$ BARBOSA MOREIRA, Comentários ao Código de Processo Civil, vol. V, p. 131; SCARPINELLA BUENO, Comentários ao art. 485 do CPC, in MARCATO (coord.), Código de Processo Civil Interpretado, pp. $1667-1668$.

1471 Bueno Vidigal (Comentários ao Código de Processo Civil, vol. 6, pp. 100-103) restringe a rescindibilidade da sentença de mérito que "violar literal disposição de lei" aos casos de "error in judicando". Comenta que, se o art. 485, V, do CPC abrangesse também os erros "in procedendo" cometidos pelo magistrado, os demais incisos do mesmo dispositivo legal seriam ociosos, já que eles também versam, implícita ou explicitamente, sobre hipóteses de violação de disposição literal de lei.

Porém, a razão parece estar com a corrente doutrinária contrária, encabeçada por Barbosa Moreira (Comentários ao Código de Processo Civil, vol. V, p. 131), que defende a incidência do art. 485, V, do CPC tanto nos casos de violação de norma de direito material, quanto nos de transgressão a norma de direito processual. O jurista cita como exemplo a rescindibilidade da sentença que julga "ultra petita" ou "extra petita", que não pode ser fundada em nenhum outro inciso do art. 485 do CPC que não o quinto, em razão da ofensa ao art. 128 do CPC.

1472 SCARPINELLA BUENO, Comentários ao art. 485 do CPC, in MARCATO (coord.), Código de Processo Civil Interpretado, p. 1668.

${ }^{1473}$ A única situação em que os tribunais não aplicam a súmula no 343 do STF é no caso de ofensa a norma constitucional. Considera-se rescindível a sentença de mérito fundada em norma cuja constitucionalidade seja controvertida nos tribunais, notadamente nas situações em que, após a prolação da decisão rescindenda, o Supremo Tribunal Federal tenha declarado inconstitucional a norma que a embasava, em sede de controle difuso ou concentrado de constitucionalidade (SCARPINELLA BUENO, Comentários ao art. 485 do CPC, in MARCATO (coord.), Código de Processo Civil Interpretado, pp. 1668-1669).

Nesse sentido é a súmula no 63 do TRF da $4^{\text {a }}$ Região: "Não é aplicável a súmula 343 do Supremo Tribunal Federal nas ações rescisórias versando matéria constitucional".

${ }^{1474}$ Comentários ao Código de Processo Civil, vol. V, p. 133.

${ }^{1475}$ Comentários ao Código de Processo Civil, vol. V, p. 132. 
incidência do art. 485, V, do CPC apenas porque dois ou três acórdãos tenham adotado uma interpretação absurda do texto legal.

A causa de pedir prevista no inciso V do art. 485 do CPC deve ser considerada um corolário eventual da litigância de má-fé porque, em regra, a prolação de uma sentença de mérito que contraria inequivocamente determinada norma jurídica é uma decorrência do ajuizamento de uma demanda, ou da dedução de uma defesa, que também contraria o texto expresso da lei (art. 17, I, do CPC). Entretanto, como o sistema processual civil brasileiro adota o sistema da substanciação, pelo qual os fatos narrados pelas partes influem na delimitação objetiva da demanda e da sentença (art. 128 do CPC) e os fundamentos jurídicos invocados por elas não passam de mera sugestão endereçada ao juiz ("narra mihi factum dabo tibi jus" ${ }^{1476}$, pode ser que a sentença seja embasada em um argumento jurídico flagrantemente contrário à lei que jamais foi mencionado pelo autor ou pelo réu. Nesse caso, logicamente, o cabimento da ação rescisória fundada no art. 485, V, do CPC não é uma consequência do abuso processual das partes.

O autor da ação rescisória pode alegar que a decisão rescindenda contrariou mais de uma norma. Nesse caso, cada suposta violação constitui uma causa de pedir diferente. Se o órgão julgador constatar que nenhuma delas ocorreu, deve julgar o pedido improcedente, ainda que verifique o desrespeito a uma norma não indicada pelo autor.

É pacífica a dispensabilidade do "prequestionamento" na ação rescisória, ou seja, não é necessário demonstrar que a norma supostamente violada foi expressamente invocada no processo em que se prolatou a decisão rescindenda ${ }^{1477}$.

Por fim, a hipótese de rescindibilidade prevista no art. 485, VI, do CPC consiste em "se fundar [a decisão de mérito] em prova, cuja falsidade tenha sido apurada em processo criminal ou seja provada na própria ação rescisória".

A lei não distingue entre falsidade material e falsidade ideológica. Exige-se apenas que a prova falsa tenha sido o sustentáculo da decisão, sem o qual ela teria um conteúdo diverso. Se a decisão judicial tiver outro fundamento suficiente e bastante que não a prova falsa, ela não é rescindível ${ }^{1478}$.

Trata-se de outro motivo de rescisão que pode, eventualmente, decorrer da prática de litigância de má-fé. Isso porque a parte que altera a verdade dos fatos (art. 17, II, do

${ }_{1476}$ DINAMARCO, Instituições de Direito Processual Civil, vol. II, § 450, p. 132.

1477 BARBOSA MOREIRA, Comentários ao Código de Processo Civil, vol. V, p. 133.

1478 SCARPINELLA BUENO, Comentários ao art. 485 do CPC, in MARCATO (coord.), Código de Processo Civil Interpretado, p. 1669; BARBOSA MOREIRA, Comentários ao Código de Processo Civil, vol. V, pp. 126 e 133-134; BUENO VIDIGAL, Comentários ao Código de Processo Civil, vol. 6, pp. 128 e 129. 
CPC) precisa valer-se de provas para convencer o juiz e, assim, obter um provimento jurisdicional favorável. Como os acontecimentos alegados jamais ocorreram ou, se ocorreram, não foi da maneira narrada, as provas apresentadas a seu respeito precisam ser, no mínimo, ideologicamente falsas e, se o juiz se fiar apenas nelas para formar seu convencimento, a sentença de mérito é rescindível com espeque no art. 485, VI, do CPC.

Contudo, há situações em que esse motivo de rescisão não é consequência de conduta ímproba alguma. Basta imaginar o caso da parte que narra fatos verídicos, mas apresenta provas formalmente falsas para demonstrá-los, as quais o magistrado utiliza como fundamento na motivação da sentença. Sendo assim, é incorreto afirmar que o art. 485, VI, do CPC é sempre um corolário do abuso processual.

É possível que a apuração da falsidade da prova seja feita em processo criminal que analisa a prática de ato ilícito penal (v.g., as condutas penais típicas previstas nos arts. 297, 298 e 299 do CP), ou em processo de revisão criminal ou de "habeas corpus". A decisão criminal que reconhece a falsidade da prova, uma vez transitada em julgado, é apta a servir de fundamento à rescisória. Nesse caso, provada a materialidade e a autoria do crime de falsidade no juízo criminal, não se pode mais discutir essas questões no juízo cível. A defesa do réu na ação rescisória fica, então, restrita à afirmação de que a sentença rescindenda teve outro fundamento suficiente que não a prova ilícita, visto que a existência da falsidade é indiscutível. Por outro lado, se o juízo criminal proferir sentença absolutória, declarando que está provada a inexistência de falsidade (art. 386, I, do CPP), fica préexcluído o cabimento de ação rescisória com base no art. 485, VI, do CPC, uma vez que essa sentença penal faz coisa julgada no âmbito civil (art. 66 do CPP) ${ }^{1479}$.

Embora seja possível a apuração da falsidade da prova em processo criminal, isso não é um requisito essencial para o ajuizamento da rescisória. Não havendo sentença penal transitada em julgado, a falsidade da prova pode ser apurada no próprio processo da rescisória $^{1480}$.

A doutrina diverge a respeito da possibilidade de apuração da falsidade na esfera cível fora da rescisória. De um lado, Scarpinella Bueno ${ }^{1481}$ defende que a falsidade da prova pode ser reconhecida em eventual ação declaratória ajuizada para tal finalidade (art.

1479 BARBOSA MOREIRA, Comentários ao Código de Processo Civil, vol. V, pp. 135-136; BUENO VIDIGAL, Comentários ao Código de Processo Civil, vol. 6, pp. 126-127.

1480 SCARPINELla BUENO, Comentários ao art. 485 do CPC, in MARCATO (coord.), Código de Processo Civil Interpretado, p. 1669; BARBOSA MOREIRA, Comentários ao Código de Processo Civil, vol. V, p. 136.

${ }^{1481}$ Comentários ao art. 485 do CPC, in MARCATO (coord.), Código de Processo Civil Interpretado, p. 1669. 
$4^{\circ}$, II, do CPC) ou em incidente de falsidade, nos termos dos arts. 390 e ss. do CPC. Do outro, Barbosa Moreira ${ }^{1482}$ nega expressamente que constitua fundamento bastante da rescisão fundada no art. 485, VI, do CPC a existência de uma sentença civil já transitada em julgado que declara a falsidade da prova, proferida em processo autônomo de ação declaratória (art. $4^{\circ}$, II, do CPC), ou em processo de incidente de falsidade. Segundo o jurista, nesse caso, é necessário produzir a prova da falsidade no processo da rescisória porque a "auctoritas rei iudicatae" da sentença civil declaratória não vincula o órgão julgador da rescisória. A sentença civil declaratória serve apenas como elemento de prova, a ser avaliado pelo órgão julgador da rescisória segundo a regra do livre convencimento motivado. No entanto, Barbosa Moreira explica que, se for prolatada sentença em incidente de falsidade documental declarando a autenticidade do documento (art. 395 do CPC), a decisão sobre o mérito da causa principal fundada nessa mesma prova não pode ser impugnada mediante ação rescisória com fundamento no art. 485, VI, do CPC, pois isso contrariaria a "auctoritas rei iudicatae" da decisão proferida no incidente de falsidade.

\subsection{Relativização da coisa julgada material}

O legislador, ao elaborar as normas jurídicas processuais, e o operador do direito, ao lidar com o ordenamento processual brasileiro, precisam equilibrar adequadamente duas exigências conflitantes ${ }^{1483}$ :

a) a celeridade, pois o processo civil deve ser realizado no menor tempo possível, com o intuito de definir o quanto antes as relações existentes entre os litigantes, favorecendo a segurança e a certeza nas relações jurídicas e, consequentemente, cumprindo o escopo de pacificar as pessoas; e

b) a ponderação, que se destina à produção de resultados justos. No Estado de Direito, a justiça é um valor a ser perseguido no exercício da atividade jurisdicional ${ }^{1484}$. Não basta que a decisão judicial tenha legitimidade processual, ou seja, tenha sido

\footnotetext{
${ }^{1482}$ Comentários ao Código de Processo Civil, vol. V, pp. 134 e 136.

1483 DINAMARCO, Relativizar a Coisa Julgada Material, in Nova Era do Processo Civil, § 111, pp. 218-219.

${ }^{1484}$ Segundo Theodoro Júnior e Faria (A Coisa Julgada Inconstitucional e os Instrumentos Processuais para seu Controle, in Revista dos Tribunais, $\mathrm{n}^{\mathbf{0}}$ 795, p. 33), isso pode ser inferido do preâmbulo da Constituição Federal:

"Nós, representantes do povo brasileiro, reunidos em Assembleia Nacional Constituinte para instituir um Estado Democrático, destinado a assegurar o exercício dos direitos sociais e individuais, a liberdade, a segurança, o bem-estar, o desenvolvimento, a igualdade e a justiça como valores supremos de uma sociedade fraterna, pluralista e sem preconceitos, fundada na harmonia social e comprometida, na ordem interna e internacional, com a solução pacífica das controvérsias, promulgamos, sob a proteção de Deus, a seguinte CONSTITUIÇÃO DA REPÚBLICA FEDERATIVA DO BRASIL” (destaques nossos).
} 
prolatada pelo órgão estatal competente e na forma da lei; ela deve, ainda, ser justa do ponto de vista material, isto é, ser consentânea com o Direito objetivo. Em suma: " $a$ legitimidade processual deve andar lado a lado com a sindicância material" ${ }^{1485}$. Para que o processo civil alcance resultados justos, as partes precisam ter meios adequados e eficientes para poderem buscar resultados favoráveis, segundo o Direito e a justiça, bem como o juiz deve ter conhecimento integral dos elementos da causa para conseguir julgar bem e fazer justiça.

Ligam-se à busca do primeiro desses objetivos: os prazos preclusivos impostos às partes, as preclusões de toda ordem e a coisa julgada material. Dentre outros institutos, favorecem o valor do justo: as garantias constitucionais do contraditório, da igualdade, da ampla defesa, do devido processo legal, do juiz natural, os recursos e a ação rescisória.

De acordo com Dinamarco ${ }^{1486}$, a coisa julgada consiste na imutabilidade da sentença e de seus efeitos. Ela possui dois aspectos: (a) a coisa julgada formal, que é a imutabilidade da sentença como ato jurídico processual, decorrente das preclusões do poder de impugná-la e do poder do tribunal de decidir novamente a causa ("preclusão máxima"); e (b) a coisa julgada material, que é a imutabilidade dos efeitos substanciais da sentença de mérito, seja ela meramente declaratória, constitutiva, condenatória ou de improcedência $^{1487}$.

\footnotetext{
${ }^{1485}$ MENEZES CORDEIRO, Litigância de Má-Fé, Abuso do Direito de Ação e Culpa “in Agendo", p. 34. ${ }^{1486}$ Instituições de Direito Processual Civil, vol. III, § 952, p. 300; § 953, pp. 303-304; § 955, pp. 307-308; Relativizar a Coisa Julgada Material, in Nova Era do Processo Civil, § 112, pp. 221-223.

${ }^{1487}$ Diversos doutrinadores tentam conceituar o que substancialmente seja a coisa julgada material, o que faz com que esse seja um dos temas mais polêmicos do Direito processual civil.

No presente trabalho, adota-se o conceito de "coisa julgada material" proposto por Dinamarco, que, por sua vez, se inspirou no conceito de Liebman.

De acordo com Liebman (Eficácia e Autoridade da Sentença e Outros Escritos sobre a Coisa Julgada (com aditamentos relativos ao direito brasileiro), pp. 54 e 60), a coisa julgada material é uma qualidade que torna imutável o conteúdo da sentença e principalmente os seus efeitos.

Essa concepção é expressamente encampada, no Brasil, por Dinamarco (Instituições de Direito Processual Civil, vol. III, § 955, p. 307; e § 957, p. 310; Relativizar a Coisa Julgada Material, in Nova Era do Processo Civil, § 111, p. 218; § 112, pp. 221-222; § 127, p. 245), que conceitua a coisa julgada material como a imutabilidade dos efeitos substanciais da sentença de mérito, tenha esta conteúdo meramente declaratório (o que abrange a sentença de improcedência), condenatório ou constitutivo. $\mathrm{O}$ autor nega peremptoriamente que a coisa julgada material seja um efeito da sentença, reforçando que ela incide sobre os efeitos da sentença de mérito, imunizando-os (DINAMARCO, Instituições de Direito Processual Civil, vol. III, § 956, p. 309; DINAMARCO, Relativizar a Coisa Julgada Material, in Nova Era do Processo Civil, § 112, p. 221).

No entanto, diversos doutrinadores nacionais criticam a concepção liebmaniana de coisa julgada material. Afirma-se que o autor italiano não leva em consideração o fato de alguns dos efeitos da sentença de mérito serem mutáveis mesmo depois de ultrapassados todos os meios de impugnação com que as partes podem atacar a decisão. Tendo isso em vista, Baptista da Silva (Coisa Julgada e Efeitos da Sentença, in BAPTISTA DA SILVA; GOMES, Teoria Geral do Processo Civil, pp. 325-327) conceitua a coisa julgada material como a qualidade que torna imutável apenas o efeito declaratório da sentença irrecorrível. Na opinião do autor, os demais efeitos da sentença de mérito são mutáveis, a não ser que a sua alteração acarrete nova discussão da declaração anterior, o que fica vedado pela eficácia preclusiva da coisa julgada.
} 
A sentença de mérito oferece uma solução final destinada a eliminar o conflito e, por isso, interfere na vida das pessoas, produzindo efeitos internos e também externos ao processo. Consequentemente, quando se dá a preclusão do poder das partes de impugná-la e do poder do tribunal de decidir novamente a causa (art. 475 do CPC), é necessário não só preservá-la contra possíveis futuros questionamentos no mesmo processo em que foi proferida (coisa julgada formal), mas também assegurar a estabilidade dos efeitos que ela projeta para fora do processo, fazendo com que o julgamento daquela pretensão, entre aquelas pessoas e por aquele fundamento não possa ser novamente discutido em outro processo (coisa julgada material) ${ }^{1488}$. Constata-se que a coisa julgada é um instituto jurídico com finalidade essencialmente prática: ela visa a conferir estabilidade à tutela jurisdicional que foi prestada e também segurança às relações jurídicas atingidas pelos efeitos da sentença de mérito, imunizando o resultado final do processo contra futuras contestações $^{1489}$.

A autoridade da coisa julgada tem espeque constitucional. Estatui o art. $5^{\circ}$, XXXVI, da CF que "a lei não prejudicará o direito adquirido, o ato jurídico perfeito e a coisa julgada". Apesar do texto constitucional, a imunidade que o constituinte de 1.988 outorgou à coisa julgada não se refere apenas a eventuais leis tendentes a afrontá-la, mas também a

No mesmo sentido, Barbosa Moreira (Eficácia da Sentença e Autoridade da Coisa Julgada, in Temas de Direito Processual - terceira série, pp. 107-110; Coisa Julgada e Declaração, in Temas de Direito Processual - primeira série, p. 89) entende que, uma vez ocorrido o trânsito em julgado, o que se torna indiscutível não são os efeitos da sentença, mas sim o próprio conteúdo dela, ou seja, a norma jurídica concreta que deve disciplinar a situação submetida à cognição judicial. Mas, em explícita divergência à opinião de Baptista da Silva, o jurista esclarece que a imutabilidade decorrente do trânsito em julgado reveste todo o conteúdo decisório da sentença de mérito, não se limitando ao elemento declaratório da norma jurídica concreta (BARBOSA MOREIRA, Eficácia da Sentença e Autoridade da Coisa Julgada, in Temas de Direito Processual - terceira série, p. 107, nt. 19, e p. 112; BARBOSA MOREIRA, Coisa Julgada e Declaração, in Temas de Direito Processual - primeira série, pp. 85 e 86).

Respondendo a tais críticas, Dinamarco (Instituições de Direito Processual Civil, vol. III, § 955, p. 308) reconhece que, se a sentença de mérito versar sobre direitos ou situações jurídicas disponíveis, as partes podem, depois do trânsito em julgado, acordar direitos e obrigações de modo distinto do julgado. Trata-se da eficácia "rebus sic stantibus" da coisa julgada material. O autor explica, porém, que esse poder das partes não elide a asserção de que a coisa julgada incide sobre os efeitos da sentença, uma vez que a autoridade da coisa julgada apenas garante, à parte vencedora, segurança jurídica com relação aos bens, direitos ou situações jurídicas que lhe foram concedidos ou que foram negados à parte contrária na sentença não mais sujeita a recurso. Esse estado de segurança jurídica gerado pela coisa julgada não implica a impossibilidade de dispor de direitos, pois isso contrariaria a garantia constitucional da liberdade e da autonomia da vontade. Na verdade, o que a autoridade da coisa julgada impede é apenas que o vencido, ou qualquer outra pessoa, negue a situação jurídica criada ou declarada na sentença, ou então se comporte contrariamente ao decidido. Em contrapartida, no que concerne às sentenças que tratam de direitos indisponíveis, Dinamarco estatui que o consenso das partes não pode alterar a situação jurídica criada ou declarada pela sentença de mérito transitada em julgado formal e materialmente.

1488 DINAMARCO, Instituições de Direito Processual Civil, vol. III, § 956, p. 309.

1489 BARBOSA MOREIRA, Coisa Julgada e Declaração, in Temas de Direito Processual - primeira série, p. 83; DINAMARCO, Relativizar a Coisa Julgada Material, in Nova Era do Processo Civil, § 111, p. 218; § 112 , p. 221. 
qualquer outro ato, estatal ou não, que possa desestabilizar a sua autoridade. Com efeito, o referido dispositivo constitucional assegura ao vencedor da causa que a segurança jurídica obtida por meio da sentença de mérito passada em julgado fique imune a novos questionamentos do juiz, do legislador, do administrador e também do vencido. Em outras palavras, a situação jurídica concreta regrada em sentença já irrecorrível não pode ser contrariada pelos sujeitos do processo, nem por outro juiz, nem mesmo pelo próprio legislador $^{1490}$.

Contudo, não se pode afirmar que o valor da coisa julgada material seja absoluto. No ordenamento jurídico brasileiro, ele é relativizado por dois remédios processuais civis destinados a infringir as sentenças de mérito transitadas em julgado. São eles ${ }^{1491}$ :

a) a ação rescisória, fundamentada em algum dos incisos do art. 485 do CPC; e

b) os embargos à execução ou a impugnação, cabíveis na hipótese em que não tenha ocorrido a citação do demandado na fase de conhecimento, ou a sua citação tenha sido nula, e ele tenha-se mantido revel (arts. 475-L, I; e 741, I, do CPC) ${ }^{1492}$.

Diante disso, Barbosa Moreira ${ }^{1493}$ adverte, com todo o acerto, que a imutabilidade não é conatural à sentença de mérito irrecorrível. Uma vez formada a "res iudicata", a sentença normalmente se torna imutável, mas pode ainda ser alterada em casos excepcionais e de suma gravidade, taxativamente previstos na lei.

Alguns doutrinadores não se contentam com essas hipóteses de relativização da coisa julgada material previstas na lei e propõem uma ampliação dos seus limites ${ }^{1494}$, com

${ }^{1490}$ DINAMARCO, Instituições de Direito Processual Civil, vol. III, § 952-A, pp. 302-303; § 955, pp. 307308; § 956, p. 309; DINAMARCO, Relativizar a Coisa Julgada Material, in Nova Era do Processo Civil, § 125 , pp. 241-242.

${ }^{1491}$ DINAMARCO, Relativizar a Coisa Julgada Material, in Nova Era do Processo Civil, § 125, pp. 242-243. 1492 Além desses remédios, o art. 463, I, do CPC abre mais uma oportunidade para a revisão de sentenças passadas em julgado. De acordo com esse dispositivo legal, uma vez publicada a sentença, remanesce o poder do magistrado de corrigir inexatidões materiais ou de retificar erros de cálculo, de ofício ou após requerimento da parte interessada. No entanto, os tribunais vêm entendendo que "inexatidões materiais" e "erros de cálculo" só podem justificar a revisão de sentença se consistirem em simples equívocos no modo de expressar a opinião do julgador. Se o juiz houver adotado conscientemente um determinado critério, ou tiver chegado intencionalmente a um resultado aritmético, principalmente se as partes tiverem discutido o tema, não incide o art. 463, I, do CPC (DINAMARCO, Relativizar a Coisa Julgada Material, in Nova Era do Processo Civil, § 125, p. 243).

1493 BARBOSA MOREIRA, Eficácia da Sentença e Autoridade da Coisa Julgada, in Temas de Direito Processual - terceira série, pp. 102 e 103.

${ }^{1494}$ É oportuno citar a observação terminológica feita por Barbosa Moreira (Considerações sobre a Chamada "Relativização da Coisa Julgada Material”, in Revista Síntese de Direito Civil e Processual Civil, n” 33, pp. 5-6) a respeito da expressão "relativização da coisa julgada material":

“[...] quando se afirma que algo deve ser 'relativizado', logicamente se dá a entender que se está enxergando nesse algo um absoluto: não faz sentido que se pretenda 'relativizar' o que já é relativo. Ora, até a mais superficial mirada ao ordenamento jurídico brasileiro mostra que nele está longe de ser absoluto o valor da ciosa julgada material: para nos cingirmos, de caso pensado, aos dois exemplos mais ostensivos, eis aí, no campo civil, a ação rescisória e, no penal, a revisão criminal, ambas destinadas, primariamente, à 
o intuito de corrigir situações de injustiça grave e flagrante. Eles se dividem em dois $\operatorname{grupos}^{1495}$ :

a) alguns autores defendem que a coisa julgada pode ser desconsiderada em razão de vício grave que inquine a sentença de mérito;

b) outros negam a própria existência da coisa julgada material em casos excepcionais de injustiça grave, apesar da preclusão total das vias de impugnação utilizáveis no mesmo processo.

Dentre os integrantes da primeira corrente doutrinária estão os doutrinadores que sustentam a chamada teoria da "coisa julgada inconstitucional"1496.

Com razão, Barbosa Moreira ${ }^{1497}$ critica a expressão “coisa julgada inconstitucional", pois o que pode ser incompatível com a Constituição Federal é a própria sentença, e não a imutabilidade desta e de seus efeitos, alcançada com o trânsito em julgado.

A referida teoria é embasada em dois argumentos principais:

a) no ordenamento jurídico brasileiro, o princípio da intangibilidade da coisa julgada não tem "status" constitucional. O que a Constituição Federal brasileira garante aos jurisdicionados, no art. $5^{\circ}$, XXXVI, é a imunidade da coisa julgada contra os efeitos de lei nova que contemple regra diversa da contida na sentença judicial irrecorrível. Trata-se de norma de direito intertemporal, destinada ao legislador ordinário, que protege a coisa julgada do efeito retroativo de lei nova. A imutabilidade e a indiscutibilidade da coisa julgada estão previstas apenas em lei ordinária ${ }^{1498}$;

b) no Estado Democrático de Direito, o princípio da constitucionalidade - segundo o qual a validade de um ato depende sempre de sua conformidade com a Constituição aplica-se a todos os atos emanados do Poder Público, inclusive aos atos do Poder Judiciário. Por causa disso, as decisões judiciais que violem diretamente a Constituição são nulas $^{1499}$.

eliminação da coisa julgada. O que se pode querer - e é o que no fundo se quer, com dicção imperfeita - é a ampliação do terreno 'relativizado', o alargamento dos limites da 'relativização"' (destaques no original).

${ }_{1495}$ BARBOSA MOREIRA, Considerações sobre a Chamada "Relativização da Coisa Julgada Material", in Revista Sintese de Direito Civil e Processual Civil, nº 33, pp. 7-8 e 16.

${ }^{1496}$ É o que afirma Barbosa Moreira (Considerações sobre a Chamada "Relativização da Coisa Julgada Material", in Revista Síntese de Direito Civil e Processual Civil, no 33, p. 7, nt. 5).

${ }_{1497}$ Considerações sobre a Chamada "Relativização da Coisa Julgada Material", in Revista Síntese de Direito Civil e Processual Civil, $\mathrm{n}^{\circ}$ 33, pp. 6-7 e 19.

${ }^{1498}$ THEODORO JÚNIOR; FARIA, A Coisa Julgada Inconstitucional e os Instrumentos Processuais para seu Controle, in Revista dos Tribunais, $\mathrm{n}^{\circ}$ 795, pp. 30 e 31, nt. 39.

${ }_{1499}$ THEODORO JÚNIOR; FARIA, A Coisa Julgada Inconstitucional e os Instrumentos Processuais para seu Controle, in Revista dos Tribunais, $\mathrm{n}^{\circ} 795$, pp. 24, 25-26 e 30. 
Segundo os partidários dessa teoria, como o princípio da intangibilidade da coisa julgada está previsto apenas em lei ordinária, ele deve-se subordinar ao princípio da constitucionalidade. Disso se infere que a coisa julgada só pode ser considerada intangível se estiver em conformidade com a Constituição. Destarte, se uma sentença já coberta pelo manto da "res iudicata" houver dirimido o litígio aplicando lei posteriormente declarada inconstitucional, ou tiver deixado de aplicar determinada norma constitucional por entendê-a inconstitucional, ou ainda tiver, de alguma maneira, contrariado regra ou princípio diretamente contemplado na Constituição, ela deve ser considerada nula, assim como o caso julgado dela resultante, e pode ser submetida a controle da mesma forma como os atos legislativos inconstitucionais ${ }^{1500}$.

Quanto ao segundo grupo de defensores da maior flexibilização da coisa julgada material (aqueles que sustentam a inexistência da coisa julgada material em casos excepcionais de injustiça), um dos seus membros parece ser Dinamarco.

A tese relativizadora desse autor é embasada em duas premissas ${ }^{1501}$ :

a) a coisa julgada material consiste na imutabilidade dos efeitos substanciais da sentença de mérito, razão pela qual ela não tem dimensões próprias, mas sim as dimensões que tiverem os efeitos a serem imunizados;

b) o valor segurança das relações jurídicas, tutelado por meio da garantia da coisa julgada, não é absoluto no sistema jurídico processual brasileiro porque ele deve conviver com outro valor de grandeza similar, que é a justiça das decisões judiciárias. Este último valor encontra espeque constitucional na garantia do acesso à justiça (art. 5, XXXV, da $\mathrm{CF}$ ), uma vez que o objetivo mais nobre de todo o sistema processual consiste na eliminação de conflitos mediante critérios justos. Dinamarco infere, então, a relatividade da garantia constitucional da coisa julgada da existência de outros valores com grandeza similar ou superior à da coisa julgada e da necessidade de harmonizá-los com esta.

Visto que - na opinião de Dinamarco - a autoridade da coisa julgada incide sobre os efeitos substanciais da sentença de mérito, ela não pode existir onde esses efeitos também inexistam. É o que ocorre, por exemplo, com as sentenças terminativas, que apenas transitam em julgado formalmente, e não materialmente. De acordo com o jurista,

${ }^{1500}$ THEODORO JÚNIOR; FARIA, A Coisa Julgada Inconstitucional e os Instrumentos Processuais para seu Controle, in Revista dos Tribunais, $\mathrm{n}^{\circ}$ 795, pp. 31-32 e 34.

${ }^{1501}$ DINAMARCO, Relativizar a Coisa Julgada Material, in Nova Era do Processo Civil, § 111, pp. 217-220; $\S 112$, p. 224; § 113, pp. 224-225; § 124, p. 240. 
sucede o mesmo com as seguintes sentenças de mérito, as quais não são dotadas de uma "imperatividade possível"1502:

a) as sentenças que enunciam, em seu decisório, resultados materialmente impossíveis. O autor dá como exemplo a sentença que manda alguém caminhar a pé sobre as águas do Rio Tietê, sem qualquer embarcação e sem a ajuda de qualquer instrumento ou apoio. Uma decisão como essa não pode transitar em julgado materialmente porque os seus efeitos jamais poderiam ser produzidos por algum ser humano;

b) as sentenças que ditam preceitos impossíveis do ponto de vista jurídicoconstitucional, uma vez que colidem com valores éticos, humanos, sociais ou políticos que são garantidos pela Constituição Federal e que possuem relevância igual ou superior à da “auctoritas rei judicatae"1503. São exemplos disso: a sentença que declara o recesso de algum Estado federado brasileiro, dispensando-o de continuar fazendo parte da República Federativa do Brasil, ao arrepio do art. $1^{\circ}$ da CF; a sentença que condena uma pessoa a dar a outrem determinado peso de sua própria carne, em cumprimento de uma dívida contratual não honrada, contrariando os arts. $1^{\circ}$, III, e $5^{\circ}$ da CF; a sentença que determina o cumprimento de um contrato por meio do qual um tatuado vendeu a própria pele para entrega "post mortem"; a sentença que condena alguém a casar com outrem; a decisão judiciária que contém determinação do valor indenizatório muito além ou muito aquém do valor de mercado da coisa, transgredindo a garantia constitucional da justa indenização (art. $5^{\circ}, \mathrm{XXIV}$, da $\mathrm{CF}$ ) e também a moralidade administrativa ou o direito de propriedade,

${ }^{1502}$ DINAMARCO, Instituições de Direito Processual Civil, vol. III, § 958-A, pp. 314-315; DINAMARCO, Relativizar a Coisa Julgada Material, in Nova Era do Processo Civil, §§ 127-130, pp. 245-253; § 136, pp. 263-264.

${ }^{1503}$ Insta deixar claro que não é toda e qualquer pretensa injustiça ou desarmonia com a ordem jurídica, contida na sentença, que causa a sua inexistência. É necessário que haja ofensa a valor ou princípio muito elevado e constitucionalmente protegido.

Barbosa Moreira (Considerações sobre a Chamada "Relativização da Coisa Julgada Material", in Revista Síntese de Direito Civil e Processual Civil, $\mathrm{n}^{\circ} 33$, p. 16) adverte que a mera injustiça contida na sentença passada em julgado não é suficiente para justificar a ampliação das hipóteses de relativização da coisa julgada material, sob pena de se fazer tábula rasa do próprio instituto da coisa julgada, uma vez que dificilmente a parte vencida se convence de que sua derrota foi justa.

Segundo Dinamarco (Relativizar a Coisa Julgada Material, in Nova Era do Processo Civil, § 123, pp. 238239; § 131, pp. 253-254; § 136, pp. 268-269), a inconstitucionalidade da sentença irrecorrível, isoladamente, não é suficiente para autorizar a flexibilização ou a relativização da autoridade da coisa julgada. É necessário que, no caso concreto, a decisão transitada em julgado tenha violado um valor constitucional que tenha maior significado social, político, econômico ou humano que a segurança jurídica, colidindo ao menos com a garantia constitucional do acesso à justiça (art. $5^{\circ}, \mathrm{XXXV}$, da $\mathrm{CF}$ ).

Nesse aspecto reside a grande diferença entre a tese desse jurista e a teoria da "coisa julgada inconstitucional", que parte do pressuposto de que o princípio da intangibilidade da coisa julgada deve-se subordinar sempre ao princípio da constitucionalidade (a validade de um ato depende de sua conformidade com a Constituição Federal), uma vez que está previsto apenas em lei ordinária (THEODORO JÚNIOR; FARIA, A Coisa Julgada Inconstitucional e os Instrumentos Processuais para seu Controle, in Revista dos Tribunais, $\mathrm{n}^{\mathrm{o}}$ 795, pp. 31-32 e 34). 
igualmente garantidos constitucionalmente etc. Elas não ficam imunizadas porque o valor "segurança jurídica", que é tutelado pelo instituto da coisa julgada material, não pode implicar desprezo a outros valores constitucionais como o da unidade federativa, o da dignidade humana, o da intangibilidade do corpo, o da justa e prévia indenização, dentre outros de igual ou superior relevância. Apesar de aparentemente elas produzirem os efeitos substanciais programados, na verdade, tais sentenças são desprovidas de eficácia exatamente porque os seus efeitos são juridicamente impossíveis e, consequentemente, elas não são aptas a produzir resultado algum. Nas palavras de Dinamarco ${ }^{1504}$, "não se legitima que, para evitar a perenização de conflitos, perenizem inconstitucionalidades de extrema gravidade ou injustiças insuportáveis e manifestas" (destaques no original).

A tese desse jurista pode ser resumida em um raciocínio silogístico que tem como premissa maior a assertiva de que a "auctoritas rei iudicatae" incide sobre os efeitos substanciais da sentença de mérito e como premissa menor a proposição de que as sentenças que contrariam valores éticos, humanos, sociais ou políticos assegurados constitucionalmente são desprovidas de eficácia, chegando à conclusão de que tais sentenças que ditam preceitos impossíveis do ponto de vista jurídico-constitucional não transitam em julgado materialmente.

Cumpre dar destaque para o alerta de Dinamarco ${ }^{1505}$ no sentido de que a tese de flexibilizar a garantia da coisa julgada deve ser aplicada apenas em situações excepcionais, em razão da insegurança que ela gera. Enfatiza o jurista que a flexibilização só pode ocorrer em casos extremos, devendo o magistrado se recusar a efetivá-la quando o caso concreto "não seja portador de absurdos, injustiças graves, transgressões constitucionais etc." ${ }^{1506}$. Caso contrário, se a infringência da coisa julgada se tornasse regra geral, o sistema processual perderia utilidade e confiabilidade. Além disso, haveria um risco muito grande de aumentar a carga de trabalho e, consequentemente, as despesas do Poder Judiciário, pois os litigantes insatisfeitos com a tutela jurisdicional prestada poderiam se sentir incentivados a "descobrir" inconstitucionalidades ou injustiças intoleráveis nas sentenças com o fim de impugná-las sempre ${ }^{1507}$.

Dentre os exemplos de situações nas quais sua teoria pode ser aplicada, Dinamarco alude a duas hipóteses de abuso processual.

\footnotetext{
${ }^{1504}$ Instituições de Direito Processual Civil, vol. III, § 958-A, p. 315.

${ }^{1505}$ Relativizar a Coisa Julgada Material, in Nova Era do Processo Civil, § 124, p. 241; § 135, p. 262.

${ }^{1506}$ DINAMARCO, Relativizar a Coisa Julgada Material, in Nova Era do Processo Civil, § 132, p. 255.

1507 Esse risco decorrente da ampliação das hipóteses de relativização da coisa julgada material foi identificado por Barbosa Moreira (Considerações sobre a Chamada "Relativização da Coisa Julgada Material”, in Revista Síntese de Direito Civil e Processual Civil, no 33, pp. 25-26).
} 
Ele menciona o caso do processo simulado de investigação de paternidade promovido em nome do filho de um rico fazendeiro, com o fim de obter sentença favorável a este, narrado por Couture ${ }^{1508}$. O fazendeiro teve um filho com uma pessoa de seu serviço, com a qual não era casado, e não queria ter de arcar com as consequências jurídicas e econômicas da paternidade. Então, induziu a mãe de seu filho a constituir um certo indivíduo como procurador da criança, com poderes para promover a ação de investigação de paternidade. Nesse processo, uma vez citado, o rico fazendeiro negou todos os fatos narrados na petição inicial e o advogado da parte autora, que agia em conluio com o réu, não produziu prova alguma, o que ensejou a improcedência total da demanda. Muitos anos depois que a sentença de improcedência havia transitado em julgado, quando o filho do fazendeiro completou a maioridade, ele ajuizou nova ação de investigação de paternidade. Em sua defesa, o fazendeiro opôs a exceção de coisa julgada e o seu filho, em contrapartida, alegou a prática de fraude no processo anterior. Logo depois, foi prolatada decisão interlocutória rechaçando a exceção de coisa julgada. Porém, o Poder Judiciário não chegou a se pronunciar definitivamente a respeito da relativização da coisa julgada nesse caso, pois as partes celebraram um acordo em sede recursal ${ }^{1509} 1510$.

Dinamarco $^{1511}$ cita também uma situação narrada por Mazzilli ${ }^{1512}$, que consiste em mais uma hipótese de abuso do processo apta a ensejar a relativização da coisa julgada material. O Ministério Público ajuíza ação civil pública em face de uma fábrica, cuja chaminé emite resíduos na atmosfera considerados prejudiciais ao meio ambiente. O magistrado defere a realização de perícia, que conclui pela toxicidade dos resíduos. Porém, na sentença, o juiz entende que os resíduos são inócuos para o homem e decide pela

\footnotetext{
${ }^{1508}$ Revocación de los Actos Procesales Fraudulentos, in Estudios de Derecho Procesal Civil, t. III, pp. 388389.

${ }^{1509}$ DINAMARCO, Instituições de Direito Processual Civil, vol. III, § 958-A, pp. 315-316; DINAMARCO, Relativizar a Coisa Julgada Material, in Nova Era do Processo Civil, § 117, pp. 229-230, e § 132, p. 254.

${ }^{1510}$ Nery Júnior (Coisa julgada e o Estado Democrático de Direito, in Revista Forense, vol. 375, pp. 157-158) discorda do exemplo citado por Dinamarco, alegando que Couture jamais insinuou, em sua obra, que a coisa julgada deveria ser desconsiderada. O "Príncipe dos processualistas latino-americanos" teria apenas afirmado que o ordenamento jurídico pode prever e determinar meios de combater a fraude processual, como a "tierce opposition" do Direito francês, a "opposizione di terzo" do Direito italiano, e as ações autônomas de impugnação, como a ação rescisória do Direito brasileiro.

Porém, a razão parece estar com Dinamarco. Em sua obra, Couture (Revocación de los Actos Procesales Fraudulentos, in Estudios de Derecho Procesal Civil, t. III, pp. 409-411 e 414-416) sustenta que o filho do fazendeiro pode ajuizar demanda tendente a revogar a coisa julgada fraudulenta que lhe é desfavorável, independentemente de essa ação revocatória ter previsão legal expressa ou não. Além de realizar uma interpretação histórica para defender essa tese, o jurista uruguaio argumenta que o cabimento da ação revocatória nesse caso nada mais é do que uma extensão dos princípios da ação pauliana ao campo do direito processual, justificada pelo fato de existirem apenas diferenças de forma, e não de fundo, entre o processo fraudulento e o negócio jurídico fraudulento.

${ }^{1511}$ Relativizar a Coisa Julgada Material, in Nova Era do Processo Civil, § 119, pp. 231-233.

${ }^{1512}$ A Defesa dos Interesses Difusos em Juízo, pp. 624-625.
} 
improcedência da demanda. Uma vez formada a coisa julgada com eficácia "erga omnes", e decorrido o prazo decadencial de 2 anos para o ajuizamento da ação rescisória, verificase que a sentença foi dada por corrupção do magistrado. Segundo Mazzilli, nesse caso, deve-se mitigar a regra da imutabilidade da coisa julgada, pois não se pode admitir coisa julgada ou direito adquirido contra direitos fundamentais da humanidade, como é o caso do meio ambiente (art. 225 da CF), em detrimento até mesmo das gerações futuras.

Não obstante existam julgados do Supremo Tribunal Federal e do Superior Tribunal de Justiça mitigando os rigores da coisa julgada material ${ }^{1513}$, é necessário sublinhar que não existe consenso doutrinário a respeito da possibilidade de se relativizar a coisa julgada material fora dos casos previstos expressamente na lei. Alguns juristas brasileiros mostram-se contrários a isso, deduzindo diversos argumentos desfavoráveis à aceitação tanto da teoria da "coisa julgada inconstitucional", quanto da tese de Dinamarco $^{1514}$.

Foge do escopo do presente trabalho analisar, pormenorizadamente, os argumentos favoráveis e contrários ao alargamento das hipóteses de relativização. O importante é notar que, para os juristas que defendem a maior flexibilização da coisa julgada material, a prática do abuso processual é uma das situações que podem ensejar esse fenômeno.

Por fim, é conveniente tratar dos instrumentos adequados à relativização da coisa julgada material. A doutrina nacional menciona diversos remédios processuais de que os

${ }^{1513}$ Recentemente, o Supremo Tribunal Federal fixou o entendimento de que deve ser relativizada a coisa julgada estabelecida em ação de investigação de paternidade em que não foi possível determinar a efetiva existência de vínculo genético entre as partes, em decorrência da não-realização do exame de DNA (STF, Pleno, RE 363.889/DF, Rel. Min. Dias Toffoli, DJe-238 DIVULG 15-12-2011 PUBLIC 16-12-2011).

A jurisprudência do Superior Tribunal de Justiça era no sentido da impossibilidade de se repropor ação de investigação de paternidade quando anterior demanda idêntica tivesse sido julgada improcedente por falta de provas, em respeito à segurança jurídica (nesse sentido: STJ, $3^{\text {a }}$ Turma, AgRg no REsp 899.981/MG, Rel. Min. Vasco Della Giustina, DJe 01/09/2010; STJ, $3^{\text {a }}$ Turma, AgRg no REsp 895.545/MG, Rel. Min. Sidnei Beneti, DJe 07/06/2010; STJ, 4 a Turma, AgRg no REsp 363.558/DF, Rel. Min. Luis Felipe Salomão, DJe 22/02/2010; STJ, 4 $4^{\text {a }}$ Turma, REsp 960.805/RS, Rel. Min. Aldir Passarinho Júnior, DJe 18/05/2009; STJ, $2^{\text {a }}$ Seção, REsp 706.987/SP, Rel. p/ Acórdão Min. Ari Pargendler, DJe 10/10/2008). Contudo, é possível encontrar julgados recentes desse Tribunal Superior que acolhem o recente entendimento do STF e admitem o ajuizamento de nova ação de investigação de paternidade, relativizando a coisa julgada (por exemplo: STJ, $3^{\mathrm{a}}$ Turma, EDcl na MC 18.265/SP, Rel. Min. Paulo de Tarso Sanseverino, DJe 19/06/2012; STJ, $4^{\mathrm{a}}$ Turma, REsp 876.434/RS, Rel. para Acórdão Min. Marco Buzzi, DJe 01/02/2012 ).

${ }^{1514}$ Nesse sentido, por todos: BARBOSA MOREIRA, Considerações sobre a Chamada "Relativização da Coisa Julgada Material", in Revista Síntese de Direito Civil e Processual Civil, no 33, pp. 5-28, "passim"; NERY JÚNIOR, Coisa julgada e o Estado Democrático de Direito, in Revista Forense, vol. 375, pp. 141159, "passim", notadamente pp. 142-144, 150-151 e 153. 
litigantes podem-se valer para obter a infringência da coisa julgada em cada caso concreto $^{1515}$ :

a) o ajuizamento de nova demanda igual à primeira, desconsiderada a coisa julgada;

b) a resistência à execução, mediante embargos, impugnação ou exceção de préexecutividade;

c) a ação declaratória da nulidade absoluta e insanável da sentença ${ }^{1516}$;

d) a alegação "incidenter tantum" em processo para cujo desfecho seja relevante a “auctoritas rei iudicatae" da sentença em foco, inclusive em peças defensivas ${ }^{1517}$;

e) a ação rescisória, o que pressupõe uma flexibilização das suas hipóteses de admissibilidade (art. 485 do CPC) ${ }^{1518}$, bem como da exigência de que o ajuizamento se dê dentro do biênio decadencial ${ }^{1519}$. Logicamente, os autores que fundamentam a relativização na inexistência da coisa julgada não podem elencar a ação rescisória entre os possíveis

1515 DINAMARCO, Relativizar a Coisa Julgada Material, in Nova Era do Processo Civil, §§ 133-134, pp. 257-260; THEODORO JÚNIOR; FARIA, A Coisa Julgada Inconstitucional e os Instrumentos Processuais para seu Controle, in Revista dos Tribunais, no 795, pp. 34-37 e 39-40.

${ }^{1516}$ Barbosa Moreira (Considerações sobre a Chamada "Relativização da Coisa Julgada Material", in Revista Síntese de Direito Civil e Processual Civil, no 33, p. 24) identifica um problema de competência na utilização desse remédio processual para obter a relativização da coisa julgada. De acordo com o autor, haveria uma subversão da hierarquia do Poder Judiciário se se admitisse que um juízo de primeiro grau reexaminasse, no mérito, uma decisão prolatada por tribunal (eventualmente, até mesmo pelo STF). O autor também observa que a ação de declaração de nulidade não poderia ser ajuizada diretamente no juízo de hierarquia superior que prolatou a decisão impugnada, como ocorre na ação rescisória, pois as hipóteses de competência originária dos tribunais estão previstas na Constituição Federal em róis taxativos (art. 102, I; 105, I, da CF) e em nenhum deles está previsto esse tipo de demanda.

${ }^{1517}$ O problema de competência identificado por Barbosa Moreira no uso da ação declaratória como meio de se obter a relativização da coisa julgada (nota 1516 "supra") é repetido pelo autor com relação à utilização deste outro remédio processual para o mesmo fim (BARBOSA MOREIRA, Considerações sobre a Chamada "Relativização da Coisa Julgada Material", in Revista Síntese de Direito Civil e Processual Civil, no 33, p. 25).

${ }^{1518}$ É possível encontrar julgados do Superior Tribunal de Justiça que admitem a utilização de laudo de exame de DNA, obtido depois de extinto o processo de investigação de paternidade, para fundamentar ação rescisória, flexibilizando o conceito de "documento novo" contido no art. 485, VII, do CPC (BARBOSA MOREIRA, Considerações sobre a Chamada "Relativização da Coisa Julgada Material", in Revista Síntese de Direito Civil e Processual Civil, no 33, pp. 22-23 e nt. 50 e p. 28). Entende-se que a prova do parentesco já existia quando a sentença rescindenda foi prolatada, pois estava no interior das células, mas a sua obtenção somente se tornou possível quando a evolução científica concebeu o exame intracitológico. Nesse sentido: STJ, 4ª Turma, REsp 653.942/MG, Rel. Min. Honildo Amaral de Mello Castro, DJe 28/09/2009; STJ, $2^{\text {a }}$ Seção, REsp 300.084/GO, Rel. Min. Humberto Gomes de Barros, DJ 06/09/2004, p. 161; STJ, $4^{\text {a }}$ Turma, REsp 189.306/MG, Rel. p/ Acórdão Min. Cesar Asfor Rocha, DJ 14/10/2002, p. 231.

${ }^{1519}$ Segundo Theodoro Júnior e Faria (A Coisa Julgada Inconstitucional e os Instrumentos Processuais para seu Controle, in Revista dos Tribunais, $\mathrm{n}^{\circ} 795$, pp. 35-37 e 40), como a coisa julgada inconstitucional é maculada de nulidade absoluta e insanável, ela pode ser conhecida e declarada a qualquer tempo, em qualquer procedimento e em qualquer juízo ou grau de jurisdição, inclusive de ofício (art. 146 do CC). Logo, o ajuizamento da rescisória além do prazo de dois anos (art. 495 do CPC) não implica a impossibilidade de se conhecer do vício da inconstitucionalidade da coisa julgada.

Os referidos autores afirmam que não seria necessário o uso da rescisória para obter a relativização da coisa julgada inconstitucional, mas reconhecem que essa ação impugnativa autônoma tem sido utilizada para esse fim com base nos princípios da instrumentalidade e da economicidade (THEODORO JÚNIOR; FARIA, A Coisa Julgada Inconstitucional e os Instrumentos Processuais para seu Controle, in Revista dos Tribunais, $\mathrm{n}^{\circ}$ 795, pp. 35-36). 
remédios processuais, uma vez que um dos requisitos de admissibilidade dessa ação é a existência de sentença de mérito revestida da autoridade de coisa julgada material ${ }^{1520}$.

\subsection{Nulidade do ato processual}

No Brasil, vigora a garantia do devido processo legal (art. $5^{\circ}$, LIV, da CF), de modo que todo o processo é regido por regras preestabelecidas. Algumas delas prescrevem requisitos para a perfeição do ato jurídico processual, os quais se classificam em duas categorias $^{1521}$ :

a) formais: são requisitos extrínsecos ao ato processual, que dizem respeito ao modo, ao tempo e ao lugar de sua prática;

b) não-formais: exigem que (1) o autor do ato seja pessoa a quem o Direito atribuiu qualidade para realizá-lo; (2) o autor tenha manifestado a vontade de produzir os resultados do ato; (3) os resultados visados sejam materialmente possíveis; (4) os resultados visados sejam admitidos pelo Direito; e (5) o ato seja juridicamente adequado à produção dos resultados pretendidos.

Em tese, apenas os atos processuais perfeitos, que cumprem todos esses requisitos, têm aptidão para produzir os efeitos que a lei lhes atribui, alcançando o seu escopo ${ }^{1522}$. As consequências da imperfeição do ato processual, ou seja, da falta de algum requisito, dependem da natureza e da gravidade do defeito e também da natureza do próprio ato. Elas vão desde a mera irregularidade (imperfeição processualmente irrelevante) até a inexistência do ato jurídico, passando pela invalidade (nulidade), pela ineficácia e pela impossibilidade ou retardo do julgamento do mérito da causa ${ }^{1523}$. Dentre tais consequências, a que interessa ao estudo do abuso processual é a invalidade.

Considera-se inválido o ato processual que não observa os requisitos de forma exigidos pela lei (modo, lugar e tempo $)^{1524}$. De acordo com a gravidade do defeito, o sistema processual distingue as nulidades em absolutas e relativas, dando um tratamento mais severo àquelas que a estas. A nulidade absoluta decorre da infração a exigências estabelecidas com o fim de preservar o interesse público da justiça. Elas devem ser

\footnotetext{
${ }^{1520}$ BARBOSA MOREIRA, Considerações sobre a Chamada "Relativização da Coisa Julgada Material", in Revista Síntese de Direito Civil e Processual Civil, n 33, p. 8.

${ }^{1521}$ DINAMARCO, Instituições de Direito Processual Civil, vol. II, § 703, p. 597.

1522 CINTRA; DINAMARCO; GRINOVER, Teoria Geral do Processo, p. 349; DINAMARCO, Instituições de Direito Processual Civil, vol. II, § 702, pp. 596-597.

${ }^{1523}$ DINAMARCO, Instituições de Direito Processual Civil, vol. II, § 705, p. 599.

${ }^{1524}$ DINAMARCO, Instituições de Direito Processual Civil, vol. II, § 708, p. 605.
} 
reconhecidas pelo juiz de ofício e as partes podem alegá-las a todo tempo e em qualquer grau jurisdicional ordinário $^{1525}$ (art. 245, parágrafo único, do CPC). As nulidades relativas resultam do desrespeito a exigências que tutelam apenas interesses das partes, sem atingir a ordem pública. O juiz não as pode conhecer de ofício. A parte inocente prejudicada tem o ônus de alegá-las na primeira oportunidade que tiver para se manifestar no processo (arts. 243 e 245 do CPC), desde que tenha interesse processual no seu reconhecimento, ou seja, que tenha algum benefício (art. 249, $\S 2^{\circ}$, do CPC). Se restar inerte, ocorre preclusão lógica e a nulidade relativa desaparece. As nulidades também se classificam em: (a) cominadas, que são aquelas previstas expressamente pelo legislador; e (b) não-cominadas (ou sistemáticas), que não são expressamente previstas na lei, decorrendo de duas operações: (1) constatação de que o ato processual concreto não cumpre os requisitos legais; e (2) nãoprodução do resultado desejado ${ }^{1526}$.

$\mathrm{O}$ art. 247 do CPC prevê uma hipótese de nulidade absoluta e cominada. Ele estatui que as citações feitas sem observância das prescrições legais são nulas. O que importa ressaltar é que a incidência desse dispositivo legal pode ser causada por uma das "fattispecies" abusivas previstas no Código de Processo Civil brasileiro, qual seja, o requerimento de citação por edital fundado na alegação mentirosa de que o demandado é pessoa desconhecida ou incerta ou de que o lugar em que ele se encontra é ignorado, incerto ou inacessível (art. 233 do CPC) ${ }^{15271528}$.

Não se pode perder de vista que o sistema de nulidades é regido pelo princípio da instrumentalidade das formas, segundo o qual é possível desconsiderar qualquer tipo de vício decorrente do desrespeito de exigência formal, independentemente de sua gravidade (nulidade relativa, nulidade absoluta, inexistência fática ou inexistência jurídica), desde que não seja comprometido o fim visado pelo legislador para o ato ou para o processo como um todo e que não haja prejuízo para as partes (arts. $244 ; 249, \S \S 1^{\circ}$ e $2^{\circ}$; e 250 ,

${ }^{1525}$ Em recurso especial e recurso extraordinário, as nulidades anteriores à prolação da decisão recorrida só podem ser conhecidas se já houverem sido prequestionadas, ou seja, se já tiverem sido aventadas e expressamente repelidas pelo órgão jurisdicional "a quo" (súmulas n ${ }^{\text {os }} 282$ e 356 do STF).

${ }^{1526}$ DINAMARCO, Instituições de Direito Processual Civil, vol. II, §§ 710-713, pp. 608-615 e § 717, p. 621; CINTRA; DINAMARCO; GRINOVER, Teoria Geral do Processo, pp. 353-354.

${ }^{1527}$ Constata-se que não é apenas no Brasil que a nulidade é uma das consequências do abuso processual. O mesmo se dá nos Estados Unidos da América (HAZARD JR., Abuse of Procedural Rights: regional report for the United States, in TARUFFO (ed.), Abuse of Procedural Rights: comparative standards of procedural fairness, p. 48).

${ }^{1528}$ O projeto do novo Código de Processo Civil (Projeto de Lei $\mathrm{n}^{\mathrm{o}}$ 8.046/2010) trata do mesmo assunto nos arts. 255 e 227:

"Art. 255. As citações e as intimações serão nulas quando feitas sem observância das prescrições legais";

"Art. 227. A parte que requerer a citação por edital, alegando dolosamente os requisitos para a sua realização, incorrerá em multa de cinco vezes o salário mínimo.

Parágrafo único. A multa reverterá em benefício do citando". 
parágrafo único, do $\mathrm{CPC})^{1529}$. Sendo assim, a nulidade da citação feita dolosamente por edital deve ser desconsiderada se o demandado houver apresentado contestação regular, já que a finalidade desse ato processual é levar ao conhecimento do réu a existência da demanda justamente para que ele possa exercitar o direito de defesa (art. 213 do CPC). O mesmo deve ocorrer se ficar comprovado que a citação por edital fundada em alegação mentirosa foi capaz de levar ao conhecimento do réu a existência do litígio, e que este, deslealmente, optou por permanecer revel e alegar o suposto vício apenas na fase recursal, depois de ter ciência da sentença de mérito desfavoráve ${ }^{1530}$. Cumpre esclarecer que o fato de o vício formal ser superado não exime o demandante da obrigação de pagar a multa no valor de 5 vezes o salário mínimo em benefício do demandado (art. 233 do CPC). Por outro lado, se o réu realmente for privado da oportunidade de apresentar resposta e, no plano material, não puder obter tutela jurisdicional favorável, a nulidade da citação é insanável, pois o vício formal obstou a realização do escopo do ato de comunicação processual, comprometendo o contraditório e a ampla defesa.

Diferentemente do que ocorre no Direito privado, o ato processual nulo produz seus efeitos normais até que uma decisão judicial declare sua invalidade ${ }^{1531}$. Sendo assim, é necessário que o órgão jurisdicional anule a citação por edital decorrente de alegação desleal do autor para que sua eficácia seja subtraída. O reconhecimento da invalidade da citação leva à contaminação também dos atos que a sucedem e que lhe são dependentes, comprometendo todo o processo a partir do ato celebrado com imperfeição (trata-se do chamado "efeito expansivo das nulidades" ou "princípio da causalidade", previsto no art. 248 do CPC) ${ }^{1532}$.

Caso o vício não seja reconhecido pelo órgão julgador até a prolação da decisão final, a nulidade da citação fica neutralizada com o trânsito em julgado da sentença ou do acórdão. A coisa julgada é considerada a sanatória geral das nulidades porque tem uma eficácia preclusiva que impede novos pronunciamentos do juiz acerca das questões inerentes ao processo, bem como a alegação de novas razões por qualquer das partes (arts. 471 e 474 do CPC). Excepcionalmente, é possível suscitar essa nulidade absoluta na

1529 CINTRA; DINAMARCO; GRINOVER, Teoria Geral do Processo, pp. 330 e 352; DINAMARCO, Instituições de Direito Processual Civil, vol. II, § 710, p. 610; § 712, p. 612; e § 714, pp. 615-617; BEDAQUE, Efetividade do Processo e Técnica Processual, pp. 412-413; 416; 418-422; 424-426; e 428-460. ${ }^{1530}$ Segundo Picó i Junoy (El Principio de la Buena Fe Procesal y su Fundamento Constitucional, in Revista de Processo, $\mathrm{n}^{\circ}$ 196, p. 155), esse é o entendimento do Tribunal Constitucional espanhol.

1531 CINTRA; DINAMARCO; GRINOVER, Teoria Geral do Processo, pp. 350-351; DINAMARCO, Instituições de Direito Processual Civil, vol. II, § 708, pp. 605-606; e § 709, pp. 607-608.

${ }^{1532}$ DINAMARCO, Instituições de Direito Processual Civil, vol. II, §§ 715 e 716, pp. 617-620; CINTRA; DINAMARCO; GRINOVER, Teoria Geral do Processo, p. 352. 
impugnação (art. 475-L, I, do CPC), em embargos à execução contra a Fazenda Pública (art. 741, I, do CPC) e em ação rescisória (art. 485, V, do CPC). Porém, se a parte lesada não fizer uso desses remédios impugnativos tempestivamente, ou se eles forem julgados improcedentes, o convalescimento é definitivo ${ }^{1533}$.

\subsection{Remoção do inventariante}

O inventariante é a pessoa que o juiz nomeia para administrar e representar o espólio, ativa e passivamente, em juízo e fora dele, até a homologação da partilha (arts. 12, V; e 991, I e II, do CPC e art. 1.991 do CC). A inventariança é um encargo pessoal, pois gera responsabilidade própria do indivíduo que a exerce; e de investidura isolada, visto que não pode ser exercida por duas ou mais pessoas, ainda que no inventário haja mais de um espólio $^{1534}$.

A doutrina reconhece três modalidades de inventariança ${ }^{1535}$ :

a) a inventariança legítima, que pode ser conferida às seguintes pessoas: (1) ao cônjuge ou ao companheiro sobrevivente, desde que estivesse convivendo com a pessoa falecida ao tempo da morte desta; (2) ao herdeiro que se achar na posse e administração do espólio, se não houver cônjuge ou companheiro sobrevivente ou este não puder ser nomeado; (3) a qualquer herdeiro, se nenhum estiver na posse e administração do espólio; (4) ao testamenteiro, se lhe foi confiada a administração do espólio ou se toda a herança estiver distribuída em legados (art. 990, I a IV, do CPC);

b) a inventariança judicial, que ocorre nos casos em que não existe qualquer das pessoas indicadas nos incisos I a IV do art. 990 do CPC ou, se existe, não é idônea, ou foi removida da inventariança (art. 995 do CPC), ou tem motivo comprovadamente justo para não poder se desincumbir do encargo de inventariante; e

c) a inventariança dativa, que é desempenhada por pessoa estranha idônea a exercer a função de inventariante, nos casos em que falta inventariante judicial ou ele é impedido.

Tanto o inventariante dativo, quanto o testamentário e o legal (art. 990 do CPC) são auxiliares eventuais da justiça, sendo a sua atividade complementar à do juiz ${ }^{1536}$.

\footnotetext{
${ }^{1533}$ DINAMARCO, Instituições de Direito Processual Civil, vol. II, § 712, p. 613; § 717, p. 621; CINTRA; DINAMARCO; GRINOVER, Teoria Geral do Processo, p. 355.

${ }^{1534}$ MARCATO, Procedimentos Especiais, p. 215; DINIZ, Curso de Direito Civil Brasileiro, vol. 6, pp. 382383.

${ }^{1535}$ MARCATO, Procedimentos Especiais, pp. 215-216.

${ }^{1536}$ DINAMARCO, Instituições de Direito Processual Civil, vol. I, § 358, pp. 685-686.
} 
Uma vez intimado de sua nomeação, o inventariante deve prestar, no prazo de 5 dias, o compromisso de desempenhar bem e fielmente o cargo (art. 990, parágrafo único, do CPC). Em seguida, dentro de 20 dias contados da prestação do compromisso, ele deve fazer as primeiras declarações (art. 993 do CPC), as quais constituem a base do processo de divisão da herança ${ }^{1537}$.

$\mathrm{O}$ art. 995 do CPC prevê as causas que ensejam a remoção do inventariante. Tratase de comportamentos omissivos ou comissivos praticados dentro do processo ou fora dele, mas sempre relacionados à causa em curso ${ }^{1538}$. Dentre eles, há duas condutas processuais abusivas: "O inventariante será removido: [...] II - se não der ao inventário andamento regular, suscitando dúvidas infundadas ou praticando atos meramente protelatórios"; e "VI - se sonegar, ocultar ou desviar bens do espólio",1539.

A causa de remoção prevista no inciso II do art. 995 do CPC relaciona-se tanto com o dever de não formular pretensão, nem alegar defesa, ciente de que é destituída de fundamento (art. 14, III, do CPC), quanto com o dever de utilidade, que veda a protelação do curso do processo mediante o emprego de artifícios dilatórios ou outros, com o intuito de lesar a parte contrária (art. 14, IV, do CPC).

Já o inciso VI do art. 995 do CPC se refere à prática da sonegação, que é a ocultação dolosa de bens do espólio que devam ser inventariados ou levados à colação ${ }^{1540}$. Mostra-se, assim, intimamente ligado com o dever de veracidade, que proíbe o sujeito processual de afirmar um fato que sabe ser falso, de impugnar fato que sabe ser verdadeiro, e também de descrever fato existente, mas sem correspondência exata com a realidade. A caracterização da sonegação requer a presença de dois elementos ${ }^{1541}$ : (a) um objetivo, que consiste na omissão de conferir, de declarar ou de restituir bens do acervo hereditário; e (b) um subjetivo, que é a intenção maliciosa de subtrair bens do inventário, visando a prejudicar alguém. Sendo assim, considera-se sonegador o inventariante que, dolosamente, não inclui ou omite bens do espólio em suas declarações ou que, sendo herdeiro, deixa de

\footnotetext{
${ }^{1537}$ DINIZ, Curso de Direito Civil Brasileiro, vol. 6, p. 386.

${ }^{1538}$ MARCATO, Procedimentos Especiais, p. 218.

${ }^{1539}$ No Código de Processo Civil projetado (Projeto de Lei no 8.046/2010), esses comportamentos ímprobos também ensejam a remoção do inventariante:

"Art. 608. O inventariante será removido:

$[\ldots]$

II - se não der ao inventário andamento regular, suscitar dúvidas infundadas ou praticar atos meramente protelatórios;

$[\ldots]$

VI - se sonegar, ocultar ou desviar bens do espólio".

${ }^{1540}$ DINIZ, Curso de Direito Civil Brasileiro, vol. 6, p. 410.

${ }^{1541}$ DINIZ, Curso de Direito Civil Brasileiro, vol. 6, pp. 410-411.
} 
trazer à colação as doações que porventura recebeu em vida do "de cujus". De acordo com o art. 994 do CPC e o art. 1.996 do CC, a sonegação só se caracteriza depois de encerrada a descrição dos bens, com a lavratura do termo de últimas declarações (termo que põe fim à fase de inventário e que deve, consequentemente, retratar a realidade do acervo hereditário, declarando o inventariante que não existem outros bens por inventariar), pois, até esse instante, podem-se aditar as primeiras declarações (art. 1.011 do CPC), nelas incluindo bens omitidos ou até então ignorados ${ }^{1542}$.

O procedimento da remoção pode ser instaurado de ofício pelo juiz ou a requerimento de qualquer interessado (herdeiro, legatário, meeiro, credor, representante do Ministério Público ou da Fazenda Pública), com a indicação de uma das causas previstas no art. 995 do CPC. O incidente da remoção é processado em apenso aos autos do inventário (art. 996, parágrafo único, do CPC), sem suspensão do curso deste ${ }^{1543}$.

Uma vez requerida a remoção, o inventariante é intimado para, no prazo de 5 dias, defender-se e produzir provas (art. 996, “caput”, do CPC). Findo esse prazo, com a defesa do inventariante ou sem ela, o juiz deve julgar o incidente. Se decidir pela remoção do inventariante, precisa nomear outro, observada a ordem estabelecida no art. 990 do CPC (art. 997 do CPC). Como se trata de decisão interlocutória, o recurso adequado contra o julgamento da remoção é o agravo ${ }^{1544}$.

Além de perder o cargo e continuar responsável pelos atos de administração até então praticados, o inventariante removido deve entregar imediatamente ao substituto os bens do espólio ${ }^{1545}$. Se deixar de fazê-lo, será compelido a tanto pelo órgão jurisdicional mediante mandado de busca e apreensão ou de imissão na posse, conforme se tratar de bem móvel ou imóvel (art. 998 do CPC) ${ }^{1546}$.

\subsection{Questões referentes à aplicação das sanções}

1542 MARCATO, Procedimentos Especiais, pp. 226 e 231; DINIZ, Curso de Direito Civil Brasileiro, vol. 6, p. 392.

${ }_{1543}$ MARCATO, Procedimentos Especiais, p. 218.

1544 MARCATO, Procedimentos Especiais, pp. 218-219.

${ }^{1545}$ MARCATO, Procedimentos Especiais, p. 219.

1546 O Código de Processo Civil projetado (Projeto de Lei $\mathrm{n}^{\circ}$ 8.046/2010) prevê, ainda, uma punição pecuniária ao inventariante removido:

"Art. 611. O inventariante removido entregará imediatamente ao substituto os bens do espólio; deixando de fazê-lo, será compelido mediante mandado de busca e apreensão ou de imissão na posse, conforme se tratar de bem móvel ou imóvel, sem prejuizo da multa a ser fixada pelo juiz em montante não superior a três por cento do valor dos bens inventariados" (destaque nosso). 


\subsubsection{Necessidade de respeito ao contraditório}

As sanções decorrentes da prática de atos abusivos podem ser aplicadas "ex officio" pelo órgão jurisdicional ${ }^{1547}$. Com relação à litigância de má-fé, por exemplo, isso ficou patente a partir de 1994, quando a Lei $\mathrm{n}^{\mathrm{o}} 8.952$ alterou o teor do art. 18 do CPC e estabeleceu expressamente que o juiz tem o dever de condenar o litigante ímprobo de ofício.

Questionou-se se a aplicação "ex officio" não se daria ao arrepio do princípio dispositivo. Porém, essa dúvida foi logo superada pelo fato de que essas punições são imputadas no interesse, não só da parte, mas também do Estado, que sofre prejuízos com o abuso do processo ${ }^{1548}$ (como se observou no item 1.6.4 "supra"). Compreende-se, assim, a incidência dessas sanções como um pedido implícito, ou seja, uma exceção à proibição de se conceder tutela que extrapole o pedido feito pelo autor (arts. 128 e 460 do CPC) ${ }^{1549}$.

Entretanto, esse poder do juiz de aplicar as sanções de ofício não é irrestrito. De acordo com a doutrina, ele deve ser interpretado à luz das garantias constitucionais do contraditório e da ampla defesa (art. 5, $\mathrm{LV}$, da CF).

Abdo $^{1550}$ ressalta que a imposição de sanções a condutas abusivas não pode ser feita de maneira imprudente. É necessário que haja respeito às garantias do contraditório, de acesso à justiça e de ampla defesa. Ademais, a sanção deve ser sempre embasada em prova da ocorrência da conduta abusiva.

1547 ABDO, O Abuso do Processo, pp. 233-234; LUCON, Abuso do Exercício do Direito de Recorrer, in NERY JÚNIOR; ALVIM WAMBIER (coords.), Aspectos Polêmicos e Atuais dos Recursos Cíveis e de Outras Formas de Impugnação às Decisões Judiciais, p. 893; BARBOSA MOREIRA, Comentários ao Código de Processo Civil, vol. V, p. 572.

${ }^{1548}$ LUCHI DEMO, Embargos de Declaração: aspectos processuais e procedimentais, p. 141; LUCON, Abuso do Exercício do Direito de Recorrer, in NERY JÚNIOR; ALVIM WAMBIER (coords.), Aspectos Polêmicos e Atuais dos Recursos Cíveis e de Outras Formas de Impugnação às Decisões Judiciais, p. 893.

${ }^{1549}$ OLIVEIRA, Litigância de Má-Fé, p. 68; TORNAGHI, Comentários ao Código de Processo Civil, vol. I, p. 150 .

Dinamarco (Instituições de Direito Processual Civil, vol. II, § 455, pp. 142-143) ensina que a expressão "pedido implícito" não é conceitualmente correta, pois gera a falsa impressão de que a lei presume que o pedido foi feito. $\mathrm{Na}$ verdade, as hipóteses de "pedido implícito" são mais que exceções à regra da interpretação estrita (art. 293 do CPC); são ressalvas à vedação de conceder tutela que vá além do pedido feito (arts. 128 e 460 do CPC). Nessas situações excepcionais, o sistema processual confere poder ao juiz para se pronunciar independentemente de pedido do autor (v.g., no que concerne a juros, correção monetária, "astreintes").

${ }^{1550}$ O Abuso do Processo, p. 228. 
Tratando especificamente do art. 18 do CPC, Barbosa Moreira ${ }^{1551}$ diz que, antes de se impor a punição, é necessária a oitiva daquele cuja condenação por litigância de má-fé está sendo pleiteada.

Essa mesma orientação é adotada por Stoco ${ }^{1552}$, que propõe que o art. 18 do CPC seja interpretado conforme o art. $5^{\circ}, \mathrm{LV}$, da $\mathrm{CF}$, de modo que, quando o magistrado vislumbrar a possibilidade de aplicar alguma sanção, ele deve abrir prazo para que a parte acusada de litigância de má-fé se manifeste e apresente os esclarecimentos acerca de sua conduta. Somente após essa defesa, ou o decurso "in albis" do prazo estabelecido, é que o juiz pode tomar a decisão que julgar cabível.

Em Portugal, Menezes Cordeiro ${ }^{1553}$ defende essa mesma ideia, pregando que, mesmo em caso de condenação de ofício pela prática de litigância de má-fé, a parte precisa ser previamente ouvida. O autor cita julgado do Supremo Tribunal de Justiça português que endossa a tese.

Esses autores estão certos ao afirmar que a aplicação de sanção por abuso de situação jurídica processual precisa respeitar a garantia constitucional do contraditório (art. $5^{\circ}, \mathrm{LV}$, da CF). Com efeito, é necessário oferecer oportunidade de manifestação nos autos à parte que supostamente atuou em juízo de má-fé, antes de puni-la.

No entanto, Nery Júnior e Andrade Nery ${ }^{1554}$ afirmam que, nos casos em que a máfé é evidente, é inócuo permitir que a parte acusada de abusar de situação jurídica processual se pronuncie sobre o assunto. Argumentam que permitir a manifestação nessas circunstâncias geraria mais atraso na prestação jurisdicional, aumentando ainda mais o prejuízo da vítima do abuso.

Analogamente, em matéria de embargos de declaração protelatórios, Luchi Demo $^{1555}$ assevera que não é necessário oportunizar defesa ao embargante porque o art. 538, parágrafo único, do CPC só incide quando o recurso for manifestamente protelatório. $\mathrm{Na}$ sua opinião, a notoriedade do intuito protelatório torna desnecessária qualquer manifestação do embargante ímprobo.

Esses doutrinadores parecem pecar por seu radicalismo. Sendo a condenação ao ressarcimento de perdas e danos uma das consequências do abuso processual, deve-se oportunizar a defesa ao litigante ímprobo para que ele possa, por exemplo, reduzir aos

1551 A Responsabilidade das Partes por Dano Processual no Direito Brasileiro, in Temas de Direito Processual, p. 31.

${ }^{1552}$ Abuso do Direito e Má-Fé Processual - aspectos doutrinários, pp. 100-102.

${ }^{1553}$ Litigância de Má-Fé, Abuso do Direito de Ação e Culpa "in Agendo", p. 57, nt. 82.

${ }^{1554}$ Código de Processo Civil Comentado e Legislação Extravagante, p. 213.

${ }^{1555}$ Embargos de Declaração: aspectos processuais e procedimentais, p. 141. 
justos limites os prejuízos de que a parte contrária se inculca vítima ${ }^{1556}$. Nos casos em que se comina multa com alíquota variável (até $1 \%$, até $10 \%$ do valor da causa, até $20 \%$ do valor atualizado do débito em execução etc.), é necessário que a parte tenha a oportunidade de se defender, procurando justificar sua conduta abusiva, de modo a reduzir a sanção ao mínimo legal. No que concerne à aplicação do art. 538, parágrafo único, do CPC, não se pode desconsiderar que existem situações cinzentas, em que o juiz fica indeciso se deve ou não considerar protelatórios os embargos. Nesses casos, também é salutar que ele dê oportunidade para que o embargante se manifeste, com o fim de sanar sua dúvida. Portanto, ainda que a má-fé do litigante seja evidente, ou que o abuso do processo seja patente, é necessário abrir prazo para que o "improbus litigator" se manifeste nos autos e apresente os esclarecimentos acerca de sua conduta ímproba, em atenção às garantias do contraditório e da ampla defesa (art. $5^{\circ}, \mathrm{LV}$, da CF).

\subsubsection{Aplicação de sanções por tribunal e respeito ao duplo grau de jurisdição}

Algumas sanções pelo cometimento de abuso de situações jurídicas processuais podem ser aplicadas de ofício pelos Tribunais de segunda instância (v.g., Tribunais de Justiça dos Estados, Tribunais Regionais Federais) e superiores (e.g., Superior Tribunal de Justiça, Supremo Tribunal Federal). São exemplos: a multa e o dever de reparar o dano causado pela litigância de má-fé (art. 18 do CPC), a multa pela oposição de embargos manifestamente protelatórios (art. 538, parágrafo único, do CPC) e a multa pela interposição de agravo manifestamente inadmissível ou infundado (art. 557, § $2^{\circ}$, do CPC).

A imposição dessas sanções pelo tribunal pode ser atacada tão somente por meio de recursos extraordinários (recurso especial e, excepcionalmente, recurso extraordinário), sendo, em alguns casos, até irrecorrível (por exemplo, se a sanção for imposta pelo próprio STF). Diante dessa situação, poder-se-ia alegar que esses dispositivos do Código de Processo Civil são inconstitucionais por violarem o princípio do duplo grau de jurisdição?

A resposta há de ser negativa ${ }^{1557}$.

O princípio do duplo grau de jurisdição estabelece que as demandas devem ser submetidas a exames judiciais sucessivos, com o fim de garantir uma boa solução. Dele decorre a necessidade de se permitir que, após uma primeira decisão, a causa seja reapreciada por um órgão situado em nível superior na hierarquia judiciária, por meio da

\footnotetext{
${ }^{1556}$ Nesse sentido: REIS, Código de Processo Civil Anotado, vol. II, p. 280.

${ }^{1557}$ Nesse sentido: OLIVEIRA, Litigância de Má-Fé, p. 78.
} 
interposição de recurso ou de expediente análogo (v.g., art. 475 do CPC $)^{15581559}$. O recurso devolve ao órgão jurisdicional superior toda a causa já decidida pelo inferior e todas as questões relevantes para seu julgamento, abrangendo questões de fato e de direito, substanciais e processuais, constitucionais e infraconstitucionais etc $^{1560}$.

Esse princípio estava expressamente contido na Constituição do Império, de $1824^{1561}$, mas não na atual Constituição Federal brasileira. Não obstante a falta de previsão expressa, os processualistas inferem a sua existência do fato de a Constituição Federal estabelecer o cabimento de recursos aos tribunais de superposição (recurso extraordinário ao STF; recurso especial ao STJ; e recurso ordinário a ambos) e aos tribunais integrantes da Justiça da União (Superior Tribunal Militar, Tribunal Superior do Trabalho, Tribunal Superior Eleitoral e Tribunais Regionais Federais), bem como da referência aos órgãos inferiores e superiores das Justiças Estaduais ${ }^{1562}$. Parte da doutrina também afirma que ele decorre dos princípios do devido processo legal ${ }^{1563}$ e da ampla defesa ${ }^{1564}$. O princípio do duplo grau de jurisdição ganhou mais um fundamento quando, em 1992, o Brasil aderiu à Convenção Americana sobre Direitos Humanos (Pacto de São José da Costa Rica), que prevê o direito de recorrer da sentença para juiz ou tribunal superior (artigo $8^{\circ}, 2$, alínea "h") ${ }^{1565}$.

\footnotetext{
${ }^{1558}$ BARBOSA MOREIRA, Comentários ao Código de Processo Civil, vol. V, pp. 237 e 238-239.

${ }^{1559}$ Marinoni (Garantia da Tempestividade da Tutela Jurisdicional e Duplo Grau de Jurisdição, in CRUZ E TUCCI (coord.), Garantias Constitucionais do Processo Civil - homenagem aos 10 anos da Constituição Federal de 1988, p. 208) explica que, em princípio, o duplo grau de jurisdição quer dizer que dois órgãos jurisdicionais devem realizar juízo sobre o mérito. Contudo, o autor afirma que esse conceito é mais bem definido como simplesmente um duplo juízo sobre o mérito, uma vez que o segundo juízo sobre o mérito pode ser realizado por órgãos colegiados compostos por juízes de primeiro grau de jurisdição, como ocorre nos Juizados Especiais Cíveis (art. 41, § 2º da Lei 9.099/95).

${ }^{1560}$ DINAMARCO, Instituições de Direito Processual Civil, vol. I, § 92, pp. 243-244.

${ }^{1561}$ A garantia do duplo grau de jurisdição estava inscrita no art. 158 da Constituição Política do Império do Brasil:

"Art. 158. Para julgar as Causas em segunda, e última instância haverá nas Províncias do Império as Relações, que forem necessárias para comodidade dos Povos".

${ }_{1562}^{1563}$ DINAMARCO, Instituições de Direito Processual Civil, vol. I, § 92, p. 242.

${ }^{1563}$ MENEZES MARCATO, O Princípio do Duplo Grau de Jurisdição e a Reforma do Código de Processo Civil, p. 28.

${ }^{1564}$ MARINONI, Garantia da Tempestividade da Tutela Jurisdicional e Duplo Grau de Jurisdição, in CRUZ E TUCCI (coord.), Garantias Constitucionais do Processo Civil - homenagem aos 10 anos da Constituição Federal de 1988, pp. 215-216.

${ }^{1565}$ Para Nery Júnior (Princípios do Processo Civil na Constituição Federal, p. 214), o artigo 8, 2, alínea " $h$ ", da Convenção Americana sobre Direitos Humanos indica a adoção da garantia do duplo grau de jurisdição em matéria penal, não alcançando o Direito processual como um todo.

Menezes Marcato (O Princípio do Duplo Grau de Jurisdição e a Reforma do Código de Processo Civil, p. 32) também sustenta que esse dispositivo só se aplica ao processo penal. A autora defende que, em razão dessa norma internacional, combinada com o art. $5^{\circ}, \S 3^{\circ}$, da $\mathrm{CF}$, o duplo grau de jurisdição é uma garantia constitucional no âmbito do processo penal.
} 
Portanto, não parece correto afirmar que o ordenamento jurídico brasileiro não adota o princípio do duplo grau de jurisdição ${ }^{1566}$, apesar de alguns doutrinadores ainda se mostrarem contrários a ele $\mathrm{e}^{1567}$.

Não obstante o reconhecimento de sua vigência no ordenamento jurídico nacional, não é possível afirmar que esse princípio seja uma garantia constitucional. Isso porque o próprio texto constitucional prevê três situações em que a jurisdição é exercida em grau único, sem possibilidade de recurso ${ }^{1568}$ :

a) casos de competência originária dos Tribunais Regionais Federais e dos Tribunais de Justiça dos Estados;

b) casos de competência originária do Superior Tribunal de Justiça e do Supremo Tribunal de Justiça; e

c) as sentenças proferidas pelos Juizados Especiais Cíveis, que apenas são suscetíveis de recurso a um colegiado formado por juízes de primeiro grau (art. 98, I, da CF) ${ }^{1569}$.

Existem também dispositivos infraconstitucionais prevendo exceções ao princípio do duplo grau de jurisdição. São exemplos:

a) o art. 34 da Lei de Execuções Fiscais (Lei n 6.830/80) exclui o acesso a órgãos recursais em causas abaixo de determinado valor econômico, prevendo recursos (embargos infringentes e de declaração) apenas para o próprio órgão prolator da sentença ${ }^{1570} 1571$;

b) o art. 515, $\S 3^{\circ}$, do CPC prevê que, nos casos de extinção do processo sem julgamento do mérito, o tribunal pode julgar desde logo a lide se a causa versar sobre questão exclusivamente de direito e estiver em condições de imediato julgamento. Neste

\footnotetext{
1566 Para reforçar esse entendimento, cabe informar que há julgados no Superior Tribunal de Justiça reconhecendo que o duplo grau de jurisdição é um princípio constitucional implícito: STJ, $4^{\mathrm{a}}$ Turma, REsp

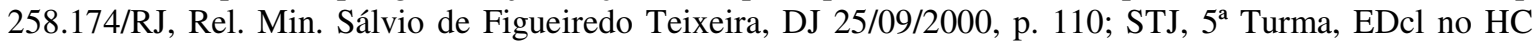
17.081/SP, Rel. Min. Edson Vidigal, DJ 25/02/2002, p. 416; STJ, $5^{\text {a }}$ Turma, HC 25.640/GO, Rel. Min. Felix Fischer, DJ 12/08/2003, p. 249; STJ, $1^{a}$ Turma, AgRg no REsp 650.217/RJ, Rel. Min. Francisco Falcão, DJ 16/05/2005, p. 249.

${ }^{1567}$ É o caso de Marinoni (Garantia da Tempestividade da Tutela Jurisdicional e Duplo Grau de Jurisdição, in CRUZ E TUCCI (coord.), Garantias Constitucionais do Processo Civil - homenagem aos 10 anos da Constituição Federal de 1988, pp. 209-222), que tece pesadas críticas ao princípio do duplo grau de jurisdição.

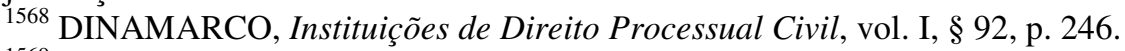

${ }^{1569}$ Cintra, Dinamarco e Grinover (Teoria Geral do Processo, p. 78) entendem que o duplo grau de jurisdição é preservado neste caso, pois esse princípio não exige que a causa seja reexaminada por órgão da chamada "jurisdição superior".

${ }_{1570}$ Nesse sentido: MENEZES MARCATO, O Princípio do Duplo Grau de Jurisdição e a Reforma do Código de Processo Civil, p. 32.

${ }^{1571}$ Na opinião de Cintra, Dinamarco e Grinover (Teoria Geral do Processo, p. 78), trata-se de disposição de constitucionalidade duvidosa.
} 
caso, Dinamarco ${ }^{1572}$ entende que a supressão de um grau jurisdicional é legitimada constitucionalmente pelo empenho em acelerar a oferta da tutela jurisdicional;

c) o art. 518, § $1^{\circ}$, do CPC estatui que o juízo "a quo" não deve receber a apelação quando a sentença recorrida tenha sido prolatada em conformidade com súmula do STJ ou do STF (súmula impeditiva de recurso).

Dado que a Constituição Federal e a legislação ordinária preveem restrições ao duplo grau de jurisdição, constata-se que não se trata de uma garantia dos cidadãos contra o Estado ${ }^{1573}$. Também não se trata de uma mera regra, uma vez que, se o fosse, já teria sido revogada pelos atos normativos supramencionados.

A conclusão a que se chega é que o duplo grau de jurisdição é um princípio, pois apenas os princípios têm a característica de conviverem pacificamente com regras e outros princípios que os contrariam, sem serem excluídos do ordenamento jurídico. No caso do princípio do duplo grau de jurisdição, ele sofre mitigações tanto em razão da organização constitucional do Poder Judiciário (por exemplo, as ações que são da competência originária do Superior Tribunal de Justiça e do Supremo Tribunal Federal), quanto por causa da garantia do acesso à tutela jurisdicional efetiva e tempestiva, decorrente do art. $5^{\circ}$, XXXV e LXXVIII, da CF (v.g., as normas contidas nos arts. 515, $\S 3^{\circ}$; e $518, \S 1^{\text {o}}$, do $\mathrm{CPC}$, que primam pela celeridade da tutela jurisdicional, em detrimento do duplo grau de jurisdição).

Entre estas últimas exceções (com fundamento na garantia de um processo efetivo e tempestivo) devem-se incluir também as hipóteses de imposição, pelos tribunais, de penalidades em decorrência da prática de abuso de situações jurídicas processuais.

Em suma, quando um juízo condena a parte que praticou abuso do processo, sem a possibilidade de reexame, isso se dá ao arrepio do princípio do duplo grau de jurisdição. Porém, não se trata de um ato inconstitucional, uma vez que encontra supedâneo na garantia constitucional do acesso à tutela jurisdicional efetiva e tempestiva (art. $5^{\circ}, \mathrm{XXXV}$ e LXXVIII, da CF).

\subsubsection{Possibilidade de cumulação e "non bis in idem"}

\footnotetext{
1572 Instituições de Direito Processual Civil, vol. I, § 92, p. 247.

${ }^{1573}$ Nesse sentido: DINAMARCO, Instituições de Direito Processual Civil, vol. I, § 92, p. 246; MENEZES MARCATO, O Princípio do Duplo Grau de Jurisdição e a Reforma do Código de Processo Civil, pp. 32 e 33; NERY JÚNIOR, Princípios do Processo Civil na Constituição Federal, pp. 211-212.
} 
É possível cumular sanções de espécies diferentes referentes a um mesmo ato processual abusivo. Por exemplo, é lícito cumular a multa sancionatória prevista no art. 18, “caput", do CPC com a reparação de perdas e danos regulada pelo mesmo dispositivo. Da mesma forma, é possível aplicar a multa do art. 538, parágrafo único, ou a do art. 601, ou ainda a do art. 740, parágrafo único, do CPC juntamente com o dever de indenizar previsto nos arts. 16 e 18 do $\mathrm{CPC}^{1574}$.

Porém, é vedado somar penas de natureza idêntica com relação a um mesmo fato, pois configuraria "bis in idem"1575. Nesse caso, a pena mais específica prevalece sobre a geral (v.g., se forem opostos embargos de declaração manifestamente protelatórios, como não se pode cumular a multa do art. 538, parágrafo único, do CPC com a do art. $18 \mathrm{c} / \mathrm{c}$ art. 17, VII, do CPC, aquela - que versa especificamente sobre esse recurso - deve prevalecer sobre esta; se o executado pratica um ato atentatório à dignidade da Justiça, ele deve ser apenado com a multa do art. 601, e não com a do art. 18 do CPC; quem opõe embargos do devedor manifestamente protelatórios deve ser condenado a pagar a multa prevista no art. 740, parágrafo único, e não a do art. 18 do CPC).

Abdo ${ }^{1576}$ denuncia a existência de jurisprudência da $1^{\text {a }}$ Turma do Superior Tribunal de Justiça cumulando a multa prevista no art. 18 do CPC com a do art. 538, parágrafo único, do $\mathrm{CPC}^{1577}$. Todavia, ela foi superada por um entendimento mais recente dos

${ }^{1574}$ Nesse sentido é o enunciado cível no 36 do TJSP, dirigido aos Juizados Especiais: “É admissível a cumulação das sanções previstas nos arts. 18 caput e parágrafo $2^{\circ}$ e 538 , parágrafo único, do Código de Processo Civil, nos embargos de declaração manifestamente protelatórios".

${ }^{1575}$ Nesse sentido: ABDO, O Abuso do Processo, p. 236; BARBOSA MOREIRA, Comentários ao Código de Processo Civil, vol. V, p. 574; BARBOSA MOREIRA, A Responsabilidade das Partes por Dano Processual no Direito Brasileiro, in Temas de Direito Processual, p. 17; LUCHI DEMO, Embargos de Declaração: aspectos processuais e procedimentais, p. 143; LUCON, Abuso do Exercício do Direito de Recorrer, in NERY JÚNIOR; ALVIM WAMBIER (coords.), Aspectos Polêmicos e Atuais dos Recursos Cíveis e de Outras Formas de Impugnação às Decisões Judiciais, p. 892; CARMONA, Comentários ao art. 601 do CPC, in MARCATO (coord.), Código de Processo Civil Interpretado, p. 1964; OLIVEIRA, Litigância de Má-Fé, pp. 51-52; LUCON, Comentários ao art. 740 do CPC, in MARCATO (coord.), Código de Processo Civil Interpretado, p. 2345; NEGRÃO; GOUVÊA; BONDIOLI; FONSECA, Código de Processo Civil e Legislação Processual em Vigor, pp. 137-138, art. 18, nt. 9.

${ }^{1576}$ O Abuso do Processo, pp. 236-237.

1577 "PROCESSUAL CIVIL. EMBARGOS DE DECLARAÇÃO. INEXISTÊNCIA DE IRREGULARIDADES NO ACÓRDÃO. INTENÇÃO PROCRASTINATÓRIA. DESOBEDIÊNCIA AOS DITAMES DO ART. 535, DO CPC. CARÁTER MERAMENTE PROTELATÓRIO. LITIGÂNCIA DE MÁ-FÉ. MULTA. ARTS. 16, 17, IV E VII, E 18, DO CPC. LEI No 9.668/1998. MULTA. PARÁGRAFO ÚNICO, DO ART. 538, DO CPC.

1. Inocorrência de irregularidades no acórdão quando a matéria que serviu de base à interposição do recurso foi devidamente apreciada no aresto atacado, com fundamentos claros e nítidos, enfrentando as questões suscitadas ao longo da instrução, tudo em perfeita consonância com os ditames da legislação e jurisprudência consolidada.

2. Prequestionamento dos artigos de lei invocados como violados perfeitamente realizado e divergência jurisprudencial devidamente comprova, com indicação, de maneira clara, dos repositórios em que se encontram publicados os acórdãos paradigmas, nos termos das alíneas “a” $e$ "c", respectivamente, do permissivo constitucional. 
ministros do STJ, no sentido da impossibilidade de cumulação de multas sancionatórias com relação a um mesmo fato ${ }^{1578}$.

\subsubsection{Dever de motivação das decisões que reprimem condutas processuais abusivas e impossibilidade de punição fora dos limites permitidos pela lei}

O princípio da legalidade estatui que nenhuma pessoa pode receber uma sanção estatal sem que esta tenha espeque legal expresso ("nulla poena sine lege"). De acordo com a doutrina, esse princípio é aplicável a todas as categorias de sanções, inclusive às penas irrogáveis no âmbito processual ${ }^{1579}$.

Segundo Greco ${ }^{1580}$, o exercício da jurisdição, por ser uma atividade pública, está genericamente subordinado ao princípio da legalidade, no sentido de que é a lei que fixa os

3. Indicando-se a interposição do recurso especial pelo art. 104, III, “a” $e$ " $b$ ”, da CF/88, não se tem como inválido o conhecimento do apelo, por se verificar que a citada indicação foi assim feita por erro na digitação, ademais se toda a fundamentação das razões recursais encontra-se fincada na alíneas " $a$ " $e$ "c", do inciso III, do art. 105, da Carta Magna, inclusive com referência expressa a este último dispositivo.

4. Recurso que revela sua patente intenção de procrastinar o feito, dificultando a solução da lide ao tentar esgotar todas as instâncias e impedindo, com isso, o aceleramento das questões postas a julgamento ao insistir com uma mesma tese, quando esta Corte já pacificou seu entendimento sobre a matéria. Ocorrência de litigância de má-fé, por "opor resistência injustificada ao andamento do processo" (art. 17, IV, do CPC), ao "interpor recurso com intuito manifestamente protelatório" (art. 17, VII, do CPC - Lei no 9.668/1998).

5. Inteligência dos arts. 16, 17, IV e VII, e 18, do CPC. Multa de 1\% (um por cento) sobre o valor da causa, corrigida monetariamente até seu efetivo pagamento, caracterizadora da litigância de má-fé da embargante, mais honorários advocatícios no patamar de $20 \%$ sobre o valor da condenação, assim como a devolução de todas as despesas efetuadas pela parte contrária, devidamente atualizadas.

6. Aplicação da multa de $1 \%$ (um por cento) sobre o valor da causa, em favor da parte embargada, nos termos do parágrafo único, do art. 538, do CPC.

7. Embargos rejeitados" (destaques nossos).

(STJ, $1^{\text {a }}$ Turma, EDcl no REsp 511.378/DF, Rel. Min. José Delgado, DJ 02/02/2004, p. 277).

1578 "EMBARGOS DE DIVERGENCIA EM RECURSO ESPECIAL. PROCESSUAL CIVIL. EMBARGOS

DECLARATÓRIOS E LITIGÂNCIA DE MÁ-FÉ. IMPOSIÇ̃̃O DE DUAS MULTAS (ART. 18 E ART. 538 DO CPC). CARÁTER PROCRASTINATÓRIO DOS EMBARGOS. DIVERGÊNCIA NÃO CONFIGURADA. CUMULAÇÃO DAS DUAS MULTAS. INVIABILIDADE. HONORÁRIOS ADVOCATÍCIOS. VENCIDA A FAZENDA PÚBLICA. CONDENAÇÃO INFERIOR AOS 10\%. ART. 20, $\$ \S 3^{o} E^{\circ} \quad 4^{o}$ DO CPC. POSSIBILIDADE.

Não se configura como paradigma a decisão trazida com vistas a afastar a condenação das multas dos retrocitados artigos do CPC, pois o aresto citado entendeu não serem protelatórios os embargos, enquanto que o acórdão ora embargado rejeitou os declaratórios, afirmando, sem qualquer dúvida, que os mesmos cuidavam de uma tentativa de rediscutir a controvérsia.

Não deve prevalecer a imposição cumulativa das multas do art. 18 e do art. 538 do CPC em razão do mesmo fato (oposição de embargos declaratórios com efeito procrastinatório), devendo subsistir, na hipótese, esta última.

Não conhecimento quanto à fixação da verba honorária em percentual inferior ao limite mínimo de $10 \%$, porquanto o dissenso é entre Turmas da mesma Seção, remetendo-se-lhe os autos para deliberar sobre esse ponto.

Embargos conhecidos parcialmente e, nesta extensão, providos" (grifo nosso).

(STJ, Corte Especial, EREsp 511.378/DF, Rel. Min. José Arnaldo da Fonseca, DJ 21/02/2005, p. 99).

${ }^{1579}$ COMOGLIO, Abuso del Processo e Garanzie Costituzionali, in Rivista di Diritto Processuale, Ano 63, $\mathrm{n}^{\circ} 2$, p. 345.

${ }^{1580}$ Garantias Fundamentais do Processo: o processo justo, p. 29. 
poderes do juiz e os limites da sua atuação. A legalidade a que o órgão jurisdicional está sujeito costuma ser flexível (por exemplo, em matéria probatória, o magistrado pode utilizar todos os meios idôneos para formar a sua convicção, ainda que não previstos em lei). Mas, quando se trata do poder de coerção no processo, a legalidade imposta é estrita, uma vez que o juiz não pode impor coações ou sanções às partes ou terceiros a não ser nos termos e nos limites permitidos pela lei. As sanções ou coações indeterminadas são consideradas incompatíveis com o Estado de Direito.

Em razão disso, ao impor penalidades por atos processuais abusivos, o juiz deve motivar sua decisão (art. 93, IX, da CF e art. 458, II, do CPC) por meio da indicação do ato processual concreto a ser sancionado e da espécie de infração cometida, reportando-se ao tipo legal ao qual aquele se subsume (v.g., alguma das condutas abusivas previstas nos incisos do art. 17 do CPC) $)^{1581} 1582$.

Contrariariam o supracitado princípio, bem como a garantia do "due process of law" (art. 5, LIV, da CF), as seguintes atitudes do órgão jurisdicional:

a) imposição de sanção prevista no ordenamento jurídico, mas com motivação deficiente, sem descrição razoavelmente precisa das condutas abusivas cometidas em concreto e das hipóteses de abuso típicas nas quais haja incorrido a parte ou seu advogado;

b) cominação de sanção prevista no ordenamento jurídico, mas fora das hipóteses de incidência descritas na lei ${ }^{1583}$;

\footnotetext{
${ }^{1581}$ DINAMARCO, Instituições de Direito Processual Civil, vol. II, § 529-A, p. 278. ${ }_{1582}$ Nesse sentido: STJ, 2 ${ }^{\mathrm{a}}$ Turma, REsp 1.035.604/RS, Rel ${ }^{\mathrm{a}}$. Min ${ }^{\mathrm{a}}$. Eliana Calmon, DJe 26/02/2009.

${ }^{1583}$ Não obstante Dinamarco (Instituições de Direito Processual Civil, vol. II, § 528-A, pp. 273-274; § 529A, p. 278) sustente a observância do princípio da legalidade no processo, ele defende a possibilidade de punição de condutas abusivas não tipificadas em dispositivo legal algum, desde que o juiz indique em que consistiu tal abuso e demonstre sua gravidade.

"Data venia", desta vez não parece correto seguir a opinião do autor porque a imposição de determinada sanção em razão da prática de uma certa conduta exige que ambas estejam previstas no ordenamento jurídico. Especificamente, a última deve estar inserida, em abstrato, no suporte fático de uma norma (ou hipótese de incidência) e a primeira, no consequente da mesma (ou preceito, ou disposição da norma jurídica). Contraria o princípio da legalidade aplicar uma sanção - ainda que prevista no ordenamento jurídico - a determinada conduta que a lei não estabeleça, em abstrato, como hipótese de incidência daquela.

Saliente-se que o tema aqui analisado não se confunde com a questão da necessidade de se interpretar conceitos indeterminados contidos na lei como suportes fáticos de normas repressivas do abuso processual. Como se observou no capítulo 2 "supra" e no presente capítulo, diversos dispositivos legais que preveem e punem condutas processuais abusivas contêm conceitos jurídicos indeterminados, que demandam atividade interpretativa para que sejam efetivados. No momento de aplicar essas normas, cabe ao magistrado definir se, no caso concreto, a conduta do sujeito processual está abrangida, ou não, pelo conceito indeterminado contido no texto legal. Percebe-se que a utilização desses conceitos vagos nas normas sancionatórias traduzem uma opção legislativa de fortalecer os poderes do juiz, que fica incumbido de definir concretamente as condutas abusivas (PUOLI, Os Poderes do Juiz e as Reformas da Lei Processual Civil Brasileira, pp. 192 e 194), porém sempre subsumindo-as a alguma das hipóteses de incidência previstas no ordenamento jurídico. Assim, diferentemente do que propõe Dinamarco, punem-se apenas condutas tipificadas como abusivas pelo legislador.
} 
c) punição de atos processuais abusivos mediante outros instrumentos que não as sanções consignadas na lei. Dois exemplos merecem destaque:

\section{a) não constitui pena imponível à oposição de embargos de declaração manifestamente protelatórios a negativa de seu efeito interruptivo do prazo para a interposição de outros recursos}

Na vigência do Código de Processo Civil de 1939, o art. 862, § 5º em sua redação original, estabelecia que os embargos de declaração que não tivessem apoio legal, opostos com o objetivo exclusivo de atrasar a marcha do processo, não interrompiam os prazos para interpor outros recursos. Posteriormente, o Dec.-lei $\mathrm{n}^{\circ}$ 8.570/46 alterou o texto legal, prescrevendo que a oposição dos embargos declaratórios suspendia o prazo de outros recursos, salvo se, na decisão que os rejeitasse, eles fossem declarados manifestamente protelatórios.

O Código de Processo Civil de 1973, desde o início, abandonou essa sanção de não-interrupção (ou não-suspensão) do prazo de outros recursos, preferindo a cominação de multa nos casos de oposição de embargos de declaração manifestamente protelatórios (art. 538, parágrafo único, do CPC). Essa alteração na técnica sancionatória foi celebrada pela doutrina por inspirar no embargante maior segurança quanto à fluência dos prazos de outros recursos ${ }^{1584}$.

Não obstante a não-previsão, no Código de Processo Civil ora em vigor, da sanção de exclusão do efeito interruptivo do prazo de outros recursos, alguns juristas brasileiros insistem em defender a sua aplicação.

Em sede doutrinária, Luchi Demo ${ }^{1585}$ sustenta que, se a parte já foi sancionada pela multa de $10 \%$ do valor da causa e, novamente, opõe embargos de declaração manifestamente protelatórios, a única sanção cabível consiste em considerar inadmissível esse último recurso por falta de interesse recursal e, com fundamento no art. 125 do CPC, negar o seu efeito interruptivo do prazo de outros recursos. Alega o autor que essa tese se justifica porque o art. 538, parágrafo único, do CPC limita o valor da sanção ao máximo de $10 \%$ do valor da causa. Assim, se, no caso concreto, o tribunal fixa a multa máxima de $10 \%$, os recursos manifestamente protelatórios apresentados em seguida ficam isentos de pena, dada a ausência de previsão normativa específica. Segundo o autor, isso é injusto

\footnotetext{
1584 BARBOSA MOREIRA, Comentários ao Código de Processo Civil, vol. V, p. 572.
}

${ }^{1585}$ Embargos de Declaração: aspectos processuais e procedimentais, pp. 146-151. 
porque, a cada recurso protelatório interposto, a conduta do "improbus litigator" torna-se mais danosa, de modo que a sanção deve progredir proporcionalmente ao incremento do prejuízo.

O magistério de Didier Junior ${ }^{1586}$ também coaduna com esse entendimento. O autor defende que o Direito brasileiro nem mesmo admite que a parte oponha embargos de declaração protelatórios por três vezes sucessivas. Para ele, a segunda oposição abusiva gera a perda do direito de embargar pela terceira vez. Trata-se, na sua opinião, de uma preclusão por ato ilícito. Cita, em defesa de sua teoria, a decisão tomada pela $2^{\text {a }}$ Turma do Supremo Tribunal Federal no julgamento dos Embargos de Declaração nos Embargos de Declaração nos Embargos de Declaração nos Embargos de Declaração no Agravo Regimental no Agravo de Instrumento no 587.285/RJ, no sentido de que se deve determinar a imediata devolução dos autos ao juízo de origem, independentemente da publicação de acórdão, a partir dos segundos embargos de declaração julgados improcedentes e procrastinatórios $^{1587}$.

Apesar de essa tese estar em consonância com o princípio da lealdade processual, ela não deve ser aceita. Em primeiro lugar, porque parte de um pressuposto errado, visto que o parágrafo único do art. 538 do CPC não deve ser interpretado como se sancionasse múltiplas reiterações de embargos de declaração procrastinatórios com apenas uma única multa de até $10 \%$ do valor da causa. Na verdade, cada reiteração deve ser sancionada com uma multa de até um décimo do valor da causa (item 2.11.3.1 "supra"). Em segundo lugar, porque prevê uma sanção que não consta expressamente do ordenamento jurídico brasileiro, qual seja, a rejeição do efeito dos embargos declaratórios de interromper o prazo para a interposição de outros recursos, violando o princípio da legalidade, que tem primazia em relação a qualquer outro no que concerne a sanções por abuso do processo ${ }^{1588}$.

\footnotetext{
${ }^{1586}$ Editorial 22, p. 1; Editorial 122, p. 1.

1587 "QUARTOS EMBARGOS DE DECLARAÇÃO - DECISÃO MONOCRÁTICA DO RELATOR CONHECIMENTO COMO RECURSO DE AGRAVO - CONFIGURAÇÃO, NA ESPÉCIE, DE INTUITO MANIFESTAMENTE PROCRASTINATÓRIO - INADMISSIBILIDADE - ABUSO DO DIREITO DE RECORRER - PRÉVIA IMPOSIÇÃO DE MULTA - FUNÇÃO INIBITÓRIA DESSA SANÇÃO PROCESSUAL - DEVOLUCÃO IMEDIATA DOS AUTOS, INDEPENDENTEMENTE DA PUBLICAÇ̃̃O DO ACÓRDÃ O CONSUBSTANCIADOR DO PRESENTE JULGAMENTO - RECURSO DE AGRAVO IMPROVIDO” (destaques nossos).

(STF, 2 ${ }^{\text {a }}$ Turma, AI 587.285 AgR-ED-ED-ED-ED/RJ, Rel. Min. Celso de Mello, DJe-189 DIVULG 30-092011 PUBLIC 03-10-2011).

${ }^{1588}$ No Brasil, só é legítima a aplicação dessa sanção nos processos em curso na Justiça Eleitoral, uma vez que o art. 275, $\S 4^{\circ}$, da Lei $\mathrm{n}^{\circ} 4.737 / 65$ (Código Eleitoral) estatui que: “Os embargos de declaração suspendem o prazo para a interposição de outros recursos, salvo se manifestamente protelatórios e assim declarados na decisão que os rejeitar".
} 
Quando é incitado a se pronunciar acerca dessa prática, o Superior Tribunal de Justiça sempre a repudia. Os Ministros afirmam que os embargos de declaração tempestivamente apresentados interrompem o prazo para a interposição de outros recursos, ainda que considerados procrastinatórios. Aduzem que a pena para os embargos protelatórios não é a negação do seu efeito de interromper o prazo para a interposição de outros recursos, mas, sim, a multa de $1 \%$ a até $10 \%$ do valor da causa (art. 538, parágrafo único, do CPC) e a punição por litigância de má-fé (art. 18 do CPC) ${ }^{1589}$.

\section{b) não se podem utilizar os honorários advocatícios para sancionar a prática de atos processuais abusivos}

Esse entendimento foi fixado pelo Superior Tribunal de Justiça no julgamento de um recurso especial interposto contra acórdão proferido pelo Tribunal de Justiça do Estado de São Paulo (TJSP) e serve muito bem para ilustrar a aplicação do princípio da legalidade no âmbito das sanções contra o abuso do processo.

Tratava-se de uma ação de execução de título executivo judicial que tinha sido ajuizada em face do Município de Santo André/SP. O executado apresentou embargos à execução, os quais foram julgados improcedentes pelo juízo de primeira instância.

Como não houve qualquer notícia de recurso por parte da Fazenda Pública, o processo foi encaminhado para o TJSP reexaminar a questão (art. 475, I, do CPC), decidindo também pela improcedência dos embargos à execução.

Ocorre que o Município de Santo André havia interposto apelação tempestiva, mas o procurador do município, no instrumento da petição de interposição, tinha-se enganado e inserido número errado do processo, de modo que os funcionários do Judiciário paulista não perceberam a sua existência antes da apreciação do reexame necessário. Quando

\footnotetext{
1589 Nesse sentido: STJ, $1^{\text {a }}$ Turma, REsp 1.213.153/SC, Rel. Min. Napoleão Nunes Maia Filho, DJe 10/10/2011; STJ, $4^{\mathrm{a}}$ Turma, REsp 1.171.682/GO, Rel. Min. Luis Felipe Salomão, DJe 07/10/2011; STJ, $4^{\mathrm{a}}$ Turma, AgRg no REsp 1.099.875/MG, Rel Min. Raul Araújo, DJe 01/08/2011; STJ, $4{ }^{\text {a }}$ Turma, REsp 1119820 / PI, Rel. Min. Luis Felipe Salomão, DJe 01/03/2011; STJ, ${ }^{a}$ Seção, AgRg nos EREsp 962.800/SC, Rel. Min. Humberto Martins, DJe 18/12/2009; STJ, 6a Turma, AgRg no Ag 876.449/SP, Rel ${ }^{\mathrm{a}}$. Min ${ }^{\mathrm{a}}$. Maria Thereza de Assis Moura, DJe 22/06/2009; STJ, $1^{\text {a }}$ Turma, REsp 1.074.334/PR, Rel. Min. Luiz Fux, DJe 20/04/2009; STJ, 4 ${ }^{\text {a }}$ Turma, REsp 771.818/SP, Rel. Min. Aldir Passarinho Junior, DJ 05/03/2007, p. 292; STJ, $4^{\text {a }}$ Turma, REsp 334.972/MG, Rel. Min. Aldir Passarinho Junior, DJ 15/04/2002, p. 225; STJ, $3^{\text {a Turma, }}$ REsp 171.146/RJ, Rel. Min. Ari Pargendler, DJ 05/11/2001, p. 107; STJ, $3^{\text {a } ~ T u r m a, ~ R E s p ~ 187.525 / S P, ~ R e l . ~}$ Min. Waldemar Zveiter, DJ 03/04/2000, p. 146; STJ, $3^{\text {a }}$ Turma, REsp 174.193/SP, Rel. Min. Carlos Alberto Menezes Direito, DJ 18/10/1999, p. 229; STJ, 3 ${ }^{\text {a }}$ Turma, REsp 153.462/RS, Rel. Min. Eduardo Ribeiro, DJ 09/03/1998, p. 106; STJ, $4^{\text {a }}$ Turma, REsp 2.087/DF, Rel. Min. Fontes de Alencar, DJ 07/05/1990, p. 3833.
} 
notaram o erro, procedeu-se à juntada do instrumento do recurso, que foi regularmente processado e os autos do processo retornaram para o TJSP.

Os desembargadores paulistas decidiram julgar o recurso voluntário, a despeito de já terem efetuado o reexame necessário. No mérito, reiteraram o conteúdo do acórdão anterior e, em razão do erro cometido pelo procurador do município, somado a outras circunstâncias, reconheceram que houve litigância de má-fé por parte do Município de Santo André. Porém, os desembargadores optaram por não aplicar as sanções previstas no art. 18 do CPC. Eles decidiram incutir a sanção a título de litigância de má-fé no valor dos honorários advocatícios devidos à outra parte (art. 20 do CPC), agravando-os. Argumentaram que a "fixação da honorária em termos ínfimos só incentiva as práticas como a presente, onde os remédios processuais são usados com intuito meramente protelatórios" $" 1590$.

Inconformada com o teor do acórdão, a Procuradoria do Município de Santo André interpôs recurso especial, que foi regularmente admitido e que teve como relator o Ministro Luiz Fux. No julgamento do recurso, os ministros da $1^{\text {a }}$ Turma do Superior Tribunal de Justiça explicaram que os honorários advocatícios são regidos pelo principio da mera sucumbência (o qual estabelece o dever de a parte vencida reembolsar a vencedora em razão simplesmente do fato da derrota ${ }^{1591}$ ), não devendo ser excessivamente fixados com o escopo de punir o litigante em decorrência de atos protelatórios que porventura tenha praticado no decorrer do processo. Advertiram que existem penas específicas para tais atos, previstas no art. 18 do CPC. Diante disso, cassaram o capítulo do acórdão recorrido referente aos honorários advocatícios e determinaram o retorno dos autos à origem para que o TJSP decidisse novamente a respeito da verba honorária, tendo, agora, em consideração apenas os parâmetros previstos no art. $20, \S \S 3^{\circ}$ e $4^{\circ}$, do $\mathrm{CPC}^{1592}$.

O que se infere desse julgamento é o evidente repúdio, por parte do STJ, à aplicação de sanções contra o abuso do processo não previstas expressamente em lei, consagrando, assim, nessa seara, o brocardo latino "nulla poena sine lege".

1590 TJSP, $3^{\text {a }}$ Câmara de Direito Público, Apelação cível com revisão n $624.313-5 / 7-00$, Rel. Des. Laerte Sampaio, Data de registro: 20/06/2008.

${ }^{1591}$ BARBOSA MOREIRA, A Responsabilidade das Partes por Dano Processual no Direito Brasileiro, in Temas de Direito Processual, p. 20.

${ }^{1592}$ STJ, $1^{\text {a }}$ Turma, REsp n ${ }^{\circ} 1.164 .543 /$ SP, Rel. Min. Luiz Fux, DJe 15/03/2010. 


\subsubsection{Da condenação do advogado ao ressarcimento das perdas e danos e ao pagamento de multa}

A aplicação de sanções diretamente ao advogado em razão da prática de comportamentos processuais ímprobos não é um assunto muito estudado e discutido no Brasil. Mas, há algum tempo, os doutrinadores e órgãos jurisdicionais vêm dando atenção a ele porque constataram que, em diversas ocasiões, o abuso do processo é imputável exclusivamente ao causídico, e não à parte sua cliente ${ }^{1593}$.

Quando da vigência do Código de Processo Civil de 1939, se houvesse dolo, fraude, violência ou simulação no processo, apenas a parte era condenada, não o seu advogado, desde que este tivesse atuado de acordo com o mandato. É o que se infere da leitura do $\S 3^{\circ}$ do art. 63 do CPC39, que tratava dos casos em que a temeridade ou a malícia fosse imputável ao procurador. Esse dispositivo estatuía que o juiz devia levar o caso ao conhecimento do Conselho local da Ordem dos Advogados, sem prejuízo da condenação da parte, prevista no $\S 2^{\circ}$ do mesmo artigo de lei ${ }^{1594}$. A responsabilidade da parte somente era excluída se o advogado realizasse atos que extrapolassem os poderes a ele concedidos e não houvesse uma posterior ratificação expressa ou tácita do mandante ${ }^{1595}$.

Americano $^{1596}$ entende que essa regra presente no Código de Processo Civil de 1939 era justa. Em defesa de sua correção, ele aduz os seguintes argumentos:

a) o fato de o constituinte não revogar a procuração mesmo tendo conhecimento do uso irregular do processo, aliado ao benefício que ele espera tirar da conduta processual ímproba executada em detrimento da parte adversária, denotam uma ratificação tácita do ato processual abusivo do advogado praticado fora dos limites do mandato (art. 1.296, parágrafo único, do CC16), justificando a responsabilidade da parte-mandante. Caso o mandante não tenha sido cientificado dos atos ímprobos praticados pelo mandatário

\footnotetext{
1593 Taruffo (General Report, in TARUFFO (ed.), Abuse of Procedural Rights: comparative standards of procedural fairness, p. 20) assevera que "muito frequentemente, o verdadeiro autor do ato ou do comportamento abusivo é o advogado em vez do cliente" (tradução nossa).

O seguinte trecho do voto do Desembargador Torres de Carvalho, integrante da Câmara Especial de Meio Ambiente do Tribunal de Justiça de São Paulo, no julgamento da Apelação nº 897.737-5/9-00 (julgamento dia 26/11/2009), retrata bem a tomada de consciência dessa realidade:

"Sancionar a parte sem sancionar o patrono é conduta que a nada leva: pune quem nada fez e protege quem fez, mas não devia ter feito; e deixa no julgador um sabor de injustiça, por saber que a parte o mais das vezes desconhece o que se faz em seu nome e acaba pagando com dinheiro próprio o malfeito do outro". ${ }^{1594}$ CASTRO FILHO, Abuso do Direito no Processo Civil, p. 148.

1595 AMERICANO, Do Abuso do Direito no Exercício da Demanda, § 26, pp. 57-58.

${ }^{1596}$ Do Abuso do Direito no Exercício da Demanda, §§ 26 e 27, pp. 57-60.
} 
durante a lide, forçosamente ele toma ciência deles no momento em que é intimado para cumprir o disposto na decisão (sentença ou acórdão) transitada em julgado. O silêncio do mandante nesse instante, aliado à manutenção do procurador, tornam inequívoca a ratificação dos atos deste;

b) o legislador pressupôs que: (1) quem quer constituir um procurador age com razoável vigilância e atenção na escolha da pessoa do mandatário; e que (2) uma pessoa somente é mantida como mandatária enquanto procede corretamente. Logo, se o mandatário comete abuso do processo, a responsabilidade do constituinte decorre de culpa "in eligendo" e "in vigilando". No Código Civil de 1916, o ônus da prova era da vítima, que podia demonstrar a ocorrência da culpa "in eligendo" por meio das circunstâncias que circundavam o fato da escolha do procurador (v.g., a notória má-reputação do advogado; o fato de o mandante ter consultado anteriormente outros advogados que lhe recusaram o patrocínio da causa em razão da manifesta ausência de direito etc.).

À época, algumas vozes se levantaram contra esse entendimento, sustentando que a representação processual não advinha de uma relação entre mandatário e mandante. Dentre os juristas que assim pensavam estava Sebastião de Sousa ${ }^{1597}$. De acordo com esse autor, o advogado não recebe instruções da parte a respeito do modo de conduzir a demanda. A parte não diz ao seu advogado: "promova esta ou aquela ação, fundamente desta ou daquela maneira a inicial, interponha este ou aquele recurso". O patrono atua no processo de acordo com seus próprios conhecimentos jurídicos, caso contrário a sua intervenção seria perfeitamente dispensável. Como a parte técnica do processo é da competência exclusiva do causídico, dotado de título de habilitação conferido pela Ordem dos Advogados do Brasil, ele age em seu próprio nome, e não em nome da parte que é sua cliente, a qual não pode ser responsabilizada pelos atos abusivos por ele praticados.

Em resposta a esse argumento, Castro Filho ${ }^{1598}$ afirma que, independentemente da natureza jurídica da representação processual (mandato ${ }^{1599}$; mandato e locação de serviços ${ }^{1600}$; contrato de locação de serviços ${ }^{1601}$; função de caráter público ${ }^{1602}$ ), a parte

\footnotetext{
${ }^{1597}$ Honorários de Advogado, § 30, pp. 165-166.

${ }^{1598}$ Abuso do Direito no Processo Civil, p. 151.

${ }^{1599}$ É a opinião de Fraga (Instituições do Processo Civil do Brasil, tomo II, § CCX, pp. 119-123).

${ }^{1600}$ Essa teoria híbrida sustenta que o mandato judicial (ou seja, a procuração) não é um contrato, mas sim o instrumento pelo qual se executa o contrato de locação de serviços celebrado entre o advogado e o cliente. É o mandato judicial que habilita o causídico a prestar seus serviços de natureza jurídica ao cliente. Essa tese é acolhida por Bevilaqua (Código Civil dos Estados Unidos do Brasil Comentado, vol. 5, p. 58) e por Sebastião de Souza (Honorários de Advogado, § 17, pp. 90-97).

${ }^{1601}$ É o que sustenta Carnelutti (Sistema de Derecho Procesal Civil, vol. II, pp. 150 e 151), apesar de o autor afirmar também que o patrocínio serve a um interesse público.

${ }^{1602}$ Nesse sentido: GUIMARÃES DE SOUZA, O Advogado, pp. 137-142.
} 
deve responder pelos atos do seu advogado porque destes sempre podem resultar-lhe vantagens e, em razão disso, ela há de suportar os incômodos da utilização de tais serviços. Além disso, o doutrinador recorda que, tradicionalmente, o mandante responde pelas obrigações contraídas pelo mandatário (art. 1.313 do CC16) e o comitente, pelos atos dos prepostos (art. 1.521, III, do CC16), devendo o mesmo raciocínio ser aplicado ao advogado, apesar de ele ser uma figura diferente do mandatário e dos empregados, serviçais e prepostos. Por fim, o jurista argumenta que responsabilizar sempre a parte pelas condutas processuais ímprobas não pode ser considerada uma regra injusta, pois a pessoa que não tenha concorrido para o desvirtuamento do processo tem direito regressivo contra seu advogado que exorbitou os poderes (art. 1.300 do CC16). Assim, ela pode ressarcir-se integralmente dos danos que o comportamento desleal de seu defensor lhe tenha causado $^{1603}$.

Em regra, o ordenamento jurídico hodierno atribui capacidade postulatória plena apenas aos advogados, ou seja, aos profissionais inscritos nos quadros da Ordem dos Advogados do Brasil (art. 36 do CPC c/c art. 3', "caput", da Lei no 8.906/94). Logo, na grande maioria dos casos, uma pessoa que seja parte em um litígio só pode praticar, pessoalmente, atos de postulação perante o Poder Judiciário (v.g., demanda, contestação, recurso etc. ${ }^{1604}$ ) se for habilitada na OAB. Caso contrário, precisa de um procurador que o seja, sob pena de os atos postulatórios serem considerados ineficazes ${ }^{1605}$. O mandato judicial celebrado entre o litigante e o seu advogado é considerado uma subespécie do mandato em geral, sendo regido pela legislação processual e, supletivamente, pelas normas

Consta da obra de Sebastião de Souza (Honorários de Advogado, § 19, pp. 101-106) uma análise crítica dessa teoria.

${ }^{1603}$ CASTRO FILHO, Abuso do Direito no Processo Civil, pp. 150 e 151-152.

${ }^{1604}$ Atos personalíssimos não são considerados atos postulatórios (v.g., depoimento pessoal e participação em tentativa de conciliação), logo podem ser realizados pela própria parte, sem que o seu advogado esteja presente.

${ }^{1605}$ De acordo com o art. $1^{\circ}$, I, da Lei no 8.906/94, "São atividades privativas de advocacia: I-a postulação a qualquer órgão do Poder Judiciário e aos juizados especiais". Mas, no julgamento da ADI 1.127-8, a maioria dos Ministros do Supremo Tribunal Federal declararam inconstitucional a palavra "qualquer" presente nesse dispositivo legal. Justificaram que, apesar de o art. 133 da CF declarar que o advogado é indispensável à administração da justiça, sua presença pode ser dispensada pela lei em certos atos jurisdicionais, notadamente: (a) na postulação na Justiça do Trabalho (art. 791 da CLT); (b) no ajuizamento de demanda com valor de até 20 salários mínimos nos Juizados Especiais Estaduais, desde que não haja a interposição de recurso (art. $9^{\circ}$ e art. 41, § $2^{\circ}$, da Lei n ${ }^{\circ}$ 9.099/95; STF, Tribunal Pleno, ADI 1.539/UF, Rel. Min. Maurício Corrêa, DJ 05/12/2003, pp. 00017); (c) na postulação nos Juizados Especiais Federais, desde

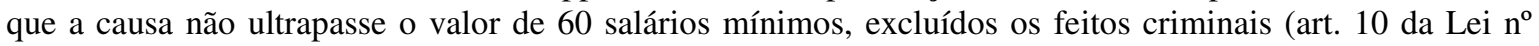
10.259/01; STF, Tribunal Pleno, ADI 3168/DF, Rel. Min. Joaquim Barbosa, DJe-072 DIVULG 02-08-2007 PUBLIC 03-08-2007); (d) na impetração de "habeas corpus" (art. $1^{\text {o }}$, § $1^{\circ}$, da Lei n n $^{\circ} .906 / 94$; art. 654, “caput”, do CPP; STF, Tribunal Pleno, HC 67.390/PR, Rel. Min. Moreira Alves, DJ 06/04/1990, pp. 0262); e (e) no ajuizamento de revisão criminal (art. 623 do CPP; STF, $1^{\text {a }}$ Turma, HC 72.981, Rel. Min. Moreira Alves, DJ 09/02/1996, pp. 02075). 
do Código Civil referentes ao contrato de mandato (art. 692 do CC). É por meio da procuração "ad judicia" que o advogado é habilitado aos atos do processo ${ }^{1606}$, em representação da parte constituinte (art. 37 do CPC) ${ }^{1607}$.

A outorga da procuração faz com que os atos privativos que o defensor pratique sejam considerados atos da própria parte, já que esta o habilitou a atuar por ela no processo $^{1608}$. Consequentemente, quando o advogado comete um ato processual abusivo, é sobre a parte patrocinada por ele em juízo que recaem as sanções ${ }^{1609}$, sendo inócua eventual alegação desta de que suas instruções foram contrariadas (arts. 116 e 679 do CC) ${ }^{1610}$.

Isso só não ocorre em duas situações excepcionais: (a) quando o advogado atua em seu próprio nome (advocacia em causa própria), hipótese em que ele mesmo sofre as consequências da prática da improbidade processual, uma vez que figura como parte na demanda; e (b) quando o causídico postula sem procuração, pois, nesse caso, o legislador lhe atribui a responsabilidade pessoal pelos danos decorrentes das condutas praticadas em juízo (art. 37, parágrafo único, do CPC; e arts. 32 e 34, VI, da Lei no 8.906/94) ${ }^{1611}$.

Se a parte que foi punida pelo abuso do processo não houver nem mesmo concorrido para a sua prática, ou seja, se o advogado tiver adotado um comportamento processual ímprobo por conta própria, sem a anuência do seu cliente, o ordenamento jurídico garante a este o direito regressivo contra aquele. Trata-se de responsabilidade subjetiva, que depende da prova de que o procurador procedeu com culpa ou dolo (arts. 667 e 679, $2^{\mathrm{a}}$ parte, do CC; arts. 17 e 32, “caput”, da Lei no 8.906/94; e, para alguns juristas, art. $14, \S 4^{\circ}$, da Lei $n^{\circ} 8.078 / 90^{1612}$; com relação aos advogados públicos, ou seja,

${ }^{1606}$ A procuração "ad judicia" investe o advogado para todos os atos do processo, exceto os mencionados no art. 38, "caput", do CPC, que requerem a outorga de poderes especiais pelo constituinte ( $\operatorname{art} .5^{\circ}$, § $2^{\circ}$ da Lei 8.906/94) (DINAMARCO, Instituições de Direito Processual Civil, vol. II, § 537, p. 295, nt. 48, e p. 296).

${ }^{1607}$ DINAMARCO, Instituições de Direito Processual Civil, vol. II, § 537, pp. 294 e 295.

${ }^{1608}$ OLIVEIRA, Litigância de Má-Fé, p. 71; DINAMARCO, Instituições de Direito Processual Civil, vol. II, § 536, pp. 291-292.

${ }_{1609}$ MILMAN, Improbidade Processual: comportamento das partes e de seus procuradores no processo civil, pp. 71-72; STOCO, Abuso do Direito e Má-Fé Processual - aspectos doutrinários, p. 92.

${ }^{1610}$ DINAMARCO, Instituições de Direito Processual Civil, vol. II, § 528-A, p. 271.

${ }^{1611}$ DINAMARCO, Instituições de Direito Processual Civil, vol. II, § 439, p. 120; e § 528-A, p. 271.

${ }^{1612}$ Parte da doutrina nacional sustenta que a relação entre o advogado e seu cliente é uma relação de consumo. Nesse sentido: DENARI, Da Qualidade de Produtos e Serviços, da Prevenção e da Reparação dos Danos (arts. $8^{\circ}$ a 28 do CDC), in GRINOVER "et alii", Código de Defesa do Consumidor: comentado pelos autores do anteprojeto, pp. 205-206; NETTO LÔBO, Comentários ao Estatuto da Advocacia e da OAB, pp. 172-173 e 177; OLIVEIRA, Litigância de Má-Fé, p. 71; MILMAN, Improbidade Processual: comportamento das partes e de seus procuradores no processo civil, pp. 69-70 e 75-77.

Entretanto, a jurisprudência do Superior Tribunal de Justiça é no sentido de que tal relação contratual é regida pelo Estatuto da OAB (Lei n. 8.906/94), a ela não se aplicando o Código de Defesa do Consumidor. Nesse sentido: STJ, $3^{\mathrm{a}}$ Turma, REsp 1.228.104/PR, Rel. Min. Sidnei Beneti, DJe 10/04/2012; STJ, $4^{\mathrm{a}}$ Turma, REsp 1.123.422/PR, Rel. Min. João Otávio de Noronha, DJe 15/08/2011; STJ, $3^{\text {a }}$ Turma, AgRg no Ag 
Defensores Públicos, Advogados da União, Procuradores do Estado etc., tem aplicação o art. $37, \S 6^{\circ}, 2^{\mathrm{a}}$ parte, da $\left.\mathrm{CF}^{1613}\right)$.

Essa regra potencializa a necessidade de o advogado orientar e aconselhar seu cliente sobre as possíveis consequências da prática de certos atos processuais que possam ser considerados abusivos pelo órgão judicial, dando ensejo a sanções. Desde que a parte receba prévia orientação técnica de seu patrono acerca dos riscos de receber uma penalidade, e que haja um amplo debate entre eles a respeito da conduta processual a ser tomada, eventual multa ou condenação a indenizar decorrente da prática de abuso do processo não gerará responsabilidade civil do defensor perante seu cliente, salvo casos patológicos de grave erro na orientação ${ }^{1614}$.

Já no caso de a parte punida ter participado, de alguma forma, na prática do comportamento processual ímprobo, atuando em conluio com seu advogado para lesar a parte contrária, o Estatuto da Advocacia prevê a possibilidade de os dois serem responsabilizados solidariamente, em demanda autônoma (art. 32, parágrafo único, da Lei $\left.\mathrm{n}^{\mathrm{o}} 8.906 / 94\right)^{1615}$.

1.380.692/SC, Rel ${ }^{\mathrm{a}}$. Min ${ }^{\mathrm{a}}$. Nancy Andrighi, DJe 30/05/2011; STJ, 3ª Turma, REsp 1.155.200/DF, Rel ${ }^{\mathrm{a}}$. p/ Acórdão Mina ${ }^{a}$ Nancy Andrighi, DJe 02/03/2011; STJ, $3^{\mathrm{a}}$ Turma, REsp 1.117.137/RS, Rel ${ }^{\mathrm{a}}$. Min ${ }^{\mathrm{a}}$. Nancy Andrighi, DJe 30/06/2010; STJ, $4^{\text {a }}$ Turma, REsp 1.134.889/PE, Rel. Min. Honildo Amaral de Mello Castro (Desembargador convocado do TJ/AP), DJe 08/04/2010; STJ, $4^{\text {a }}$ Turma, REsp 914.105/GO, Rel. Min. Fernando Gonçalves, DJe 22/09/2008; STJ, $4^{\text {a }}$ Turma, AgRg no Ag 815.998/BA, Rel. Min. Fernando Gonçalves, DJ 03/12/2007, p. 317; STJ, $3^{\text {a }}$ Turma, REsp 757.867/RS, Rel. Min. Humberto Gomes de Barrros, DJ 09/10/2006, p. 291; STJ, 4a Turma, REsp 539.077/MS, Rel. Min. Aldir Passarinho Júnior, DJ 30/05/2005, p. 383.

${ }^{1613}$ MILMAN, Improbidade Processual: comportamento das partes e de seus procuradores no processo civil, p. 71.

${ }^{1614}$ PUOLI, Os Limites ao Direito de Recorrer e a Responsabilidade Civil do Advogado Perante o Cliente, in COSTA; RIBEIRO; DINAMARCO (coords.), Linhas Mestras do Processo Civil, pp. 346-347, 349 e 350; PEYRANO, Abuso de los Derechos Procesales, in BARBOSA MOREIRA (coord.), Abuso dos Direitos Processuais, p. 77.

Esses doutrinadores aconselham os advogados a obter, previamente, um documento escrito por seus clientes contendo a decisão de adotar uma determinada opção técnica nos casos concretos, apesar da advertência a respeito da possibilidade de incorrerem em abuso processual. Fazendo isso, os profissionais têm uma prova concreta a seu favor, resguardando-se contra possível ação de regresso. Nesse mesmo sentido: MILMAN, Improbidade Processual: comportamento das partes e de seus procuradores no processo civil, p. 75.

${ }_{1615}$ Os ordenamentos jurídicos norte-americano, argentino e uruguaio, diferentemente do brasileiro, permitem expressamente que o magistrado sancione o advogado diretamente, e não a parte sua cliente.

A "Rule" 11, "b", das "Federal Rules of Civil Procedure" estatui que, ao apresentar em juízo um pedido, um requerimento escrito ou qualquer petição, o advogado certifica que, ao que ele saiba, tenha informação e acredita, depois de uma investigação razoável diante das circunstâncias: (1) não se está litigando por qualquer propósito inadequado, tais como: para incomodar, causar atraso desnecessário ou aumentar desnecessariamente as despesas do litígio; (2) os pedidos, as defesas e outras alegações são justificados por normas vigentes ou por argumentos não-frívolos para ampliar a abrangência, modificar ou revogar normas vigentes ou para estabelecer novas normas; (3) as alegações fáticas têm suporte probatório ou provavelmente terão suporte probatório depois de oportunidade razoável de ulterior investigação ou "discovery"; e (4) as impugnações de alegações fáticas são fundamentadas em provas ou são razoavelmente baseadas em convicção ou falta de informação. Se o advogado violar essa regra, o órgão judicial pode puni-lo (em alguns casos, juntamente com o escritório de advocacia a que pertence) por meio de: sanções não-monetárias, 
Alguns juristas discordam desse regramento. Existem diversos precedentes, emanados de órgãos jurisdicionais de segunda instância e até do Superior Tribunal de Justiça, condenando o advogado ao pagamento de multa e ao ressarcimento de perdas e danos, isoladamente ou em solidariedade com a parte por ele representada, no mesmo processo no qual a conduta abusiva foi praticada ${ }^{1616}$. São evocados, em defesa dessa tese, os dispositivos legais que atribuem ao advogado os deveres de veracidade, de lealdade, de boa-fé, de não formular pretensão ou defesa conscientemente infundada e de não praticar atos processuais inúteis ou desnecessários (art. 14, I a IV, do CPC; arts. $2^{\circ}$, parágrafo único, II e VIII, " $d$ ”; e $6^{\circ}$ do Código de Ética e Disciplina da OAB c/c art. 33 da Lei no 8.906/94; e art. 34, VI, XIV e XVII, da Lei nº 8.906/94). Argumenta-se também que o advogado exerce sua função com independência (art. 31, § $1^{\circ}$, da Lei $n^{\circ} 8.906 / 94$ ) e é o único responsável pela estratégia processual e pelas manifestações trazidas aos autos. Diante disso, ele não pode eximir-se da responsabilidade pessoal pelos rumos dados ao processo, notadamente do ponto de vista da técnica processual, e, consequentemente, deve ser condenado pela improbidade processual.

imposição de multa ou condenação ao pagamento dos honorários advocatícios e das despesas que a parte contrária houver suportado em decorrência do comportamento processual ilícito. Ao estipular a sanção a ser imposta ao causídico, o órgão judicial deve-se limitar àquilo que for suficiente para dissuadir outras pessoas de repetirem a conduta ou comportamento análogo ("Rule" 11, "c", (1) e (4), das "Federal Rules of Civil Procedure"). A "Rule" 37, "a", (5); "b", (2), (C); “d”, (3); e "f”, das "Federal Rules of Civil Procedure" também prevê a possibilidade de o magistrado condenar o advogado ao pagamento dos honorários advocatícios e das despesas da parte contrária em casos de abuso no procedimento da "discovery" (DONDI, Cultura dell'Abuso e Riforma del Processo Civile Negli Stati Uniti, in Rivista di Diritto Processuale, Ano 50, nº 3, pp. 794 e 797).

De acordo com o art. 45 do CPC da Argentina, quando o juiz se convencer de que a parte vencida, total ou parcialmente, teve conduta maliciosa ou temerária, ele pode impor multa a ela, ou ao seu advogado, ou a ambos conjuntamente, dependendo das circunstâncias do caso concreto.

O art. 24, (10), do CPC uruguaio e os arts. 149, (3), e 150 da Lei Orgânica da Judicatura e de Organização dos Tribunais do Uruguai (Lei $n^{\circ} 15.750$ ) atribuem ao Tribunal a faculdade de impor aos advogados multas disciplinares de até 30.000 novos pesos nos casos previstos na lei. Dentre as condutas que podem ser corrigidas disciplinariamente estão duas hipóteses de abuso processual: a alegação de fatos cuja falsidade seja provada nos autos e a dedução de recursos expressamente proibidos pela lei (art. 148, (4), da Lei $\left.{ }^{\circ} 15.750\right)$.

1616 Nesse sentido: TJSP, 10 $0^{\text {a }}$ Câmara de Direito Público, Apelação no 766.370.5/2-00, Rel. Des. Torres de Carvalho, julgamento dia 08/02/2010; TJSP, $37^{\mathrm{a}}$ Câmara de Direito Privado, Embargos de Declaração $\mathrm{n}^{\mathrm{o}}$ 0600363-51.2008.8.26.0003/50000, Rel. Des. Dimas Carneiro, julgamento dia 09/02/2012 ; TJSP, 4 Grupo de Direito Privado, Embargos de Declaração nº 0262311-63.2011.8.26.0000/50000, Rel. Des. Miguel Brandi, julgamento dia 08/02/2012; TJSP, 5ª Câmara de Direito Privado, Apelação no 994.09.271173-9, Rel. Des. James Siano, julgamento dia 16/02/2011; TJSP, 7 a Câmara de Direito Privado, Apelação no 990.10.329925-6, Rel. Des. Miguel Brandi, julgamento dia 06/10/2010; TJSP, 2a Câmara de Direito Público, Apelação $n^{\circ}$ 641.122-5/0-00, Rel. Des. José Luiz Germano, julgamento dia 06/04/2010; TJSP, 21ª Câmara de Direito Privado, Embargos de Declaração no 7279526-5/02, Rel. Des. Souza Lopes, julgamento dia 02/09/2009; TJSP, $11^{a}$ Câmara de Direito Privado, Agravo de Instrumento no 7384378-6, Rel. Des. Moura Ribeiro, julgamento dia 13/08/2009; TJSP, Câmara Especial do Meio Ambiente, Agravo Regimental no 578369-5/401, Rel. Des. Torres de Carvalho, julgamento dia 30/11/2009; STJ, $2^{\text {a }}$ Turma, EDcl nos EDcl no AgRg no REsp 494.021/SC, Rel ${ }^{a}$. Min ${ }^{a}$. Eliana Calmon, DJ 13/09/2004, p. 204; STJ, $2^{\text {a }}$ Turma, EDcl no AgRg nos EDcl no Ag 438.554/SC, Rel ${ }^{a}$. Min ${ }^{a}$. Eliana Calmon, DJ 17/03/2003, p. 220; STJ, $2^{\mathrm{a}}$ Turma, EDcl no AgRg no REsp 427.839/RS, Rel ${ }^{a}$. Mina. Eliana Calmon, DJ 18/11/2002, p. 205; STJ, 6 a Turma, EDcl no AgRg no Ag 421.626/SP, Rel. Min. Nilson Naves, DJ 07/03/2005, p. 352. 
Nota-se que esse raciocínio lembra muito os supramencionados argumentos utilizados por Sebastião de Sousa para defender a responsabilidade do advogado, e não da parte sua cliente, pelos atos processuais abusivos, ao arrepio do art. $63, \S 3^{\circ}$, do CPC39. Ocorre que os mesmos motivos que levaram Americano e Castro Filho a rechaçarem a tese desse jurista, quando o Código de Processo Civil de 1939 ainda era vigente, podem ser utilizados, hoje, para descartar a possibilidade de o advogado ser sancionado pela prática de um comportamento ímprobo, no mesmo processo em que este foi constatado:

a) as sanções decorrentes do abuso do processo praticado pelo advogado recaem no cliente em razão da sua culpa "in eligendo", já que escolheu mal seu procurador ${ }^{1617}$;

b) a responsabilidade da parte também é um reflexo da culpa "in vigilando", pois, se o cliente não revoga a procuração ao ter conhecimento de que seu advogado realizou algum ato processual abusivo, presume-se que ele aquiesceu à prática ímproba após conjecturar os benefícios que esse comportamento poderia lhe render em prol da vitória na demanda;

c) outro fundamento para a responsabilidade do litigante pelo comportamento processual abusivo e lesivo do seu advogado é a própria relação contratual existente entre eles, uma vez que o art. $679,1^{\mathrm{a}}$ parte, do CC estatui que o mandante fica obrigado para com aqueles com quem o seu mandatário contratou, ainda que este contrarie as suas instruções, desde que não exceda os limites do mandato ${ }^{1618}$; e

d) reiterando o que se mencionou anteriormente, o ordenamento jurídico protege a parte que não tenha concorrido para o ato processual ímprobo, assegurando-lhe direito regressivo contra o advogado que tenha agido com dolo ou culpa (arts. 667 e 679, $2^{\mathrm{a}}$ parte, do CC c/c arts. 17 e 32, "caput", da Lei n ${ }^{\circ} 8.906 / 94$; ou art. 37, $\S 6^{\circ}, 2^{\text {a }}$ parte, da CF, no caso dos advogados públicos).

Alega-se, outrossim, que a punição do advogado, em solidariedade com o seu cliente, no mesmo processo em que houve a conduta abusiva, é amparada legalmente no parágrafo único do art. 32 da Lei no 8.906/94.

Essa interpretação, contudo, não condiz com o texto da lei. De fato, o dispositivo do Estatuto da Advocacia em comento prevê a responsabilidade solidária do advogado com o seu cliente, desde que o órgão jurisdicional se convença da coligação dos dois para lesar

\footnotetext{
${ }^{1617}$ MILMAN, Improbidade Processual: comportamento das partes e de seus procuradores no processo civil, p. 72.

${ }^{1618}$ Esse argumento não se aplica aos advogados públicos (Advogados da União, Procuradores do Município, Procuradores do Estado etc.) porque os vínculos que possuem com os entes públicos que representam não têm natureza contratual.
} 
a parte contrária. Porém, a apuração desse conluio é expressamente reservada, pelo legislador, para um processo diverso, devendo ser ajuizada uma demanda autônoma a respeito desse ponto. Veda-se, assim, a cominação de sanção ao advogado no mesmo processo em que o comportamento ímprobo foi constatado ${ }^{1619} 1620$.

Além do mais, ignorar o texto expresso do parágrafo único do art. 32 da Lei $\mathrm{n}^{\circ}$ 8.906/94 e condenar solidariamente o advogado e a parte que é sua cliente equivale a admitir um chamamento ao processo, especificamente a hipótese descrita no inciso III do art. 77 do CPC (Art. 77. É admissível o chamamento ao processo: [...] III - de todos os devedores solidários, quando o credor exigir de um ou de alguns deles, parcial ou totalmente, a dívida comum). Como o art. 18 do CPC autoriza o magistrado a aplicar as sanções por litigância de má-fé independentemente de qualquer requerimento da parte lesada, o chamamento da pessoa do advogado ao processo ocorreria de ofício. Todavia, isso contraria o art. 78 do CPC, que atribui apenas ao réu o poder e a faculdade de chamar terceiro ao processo.

Verifica-se, igualmente, uma tentativa de alicerçar na garantia constitucional da duração razoável do processo (art. 5\%, LXXVIII, da CF) e nos princípios da celeridade e da economia processual a condenação, no mesmo processo, do advogado e do seu cliente pela prática de abuso processual $^{1621}$.

Entretanto, quem alega isso desconsidera que, uma vez condenado, o advogado inevitavelmente impugnaria o capítulo da sentença que lhe causou prejuízo, deduzindo pretensão recursal que poderia até mesmo ser contrária à do seu próprio cliente, o que postergaria ainda mais a efetiva tutela jurisdicional. Imagine-se, por exemplo, a situação do

${ }^{1619}$ NETTO LÔBO, Comentários ao Estatuto da Advocacia e da OAB, p. 177; OLIVEIRA, Litigância de Má-Fé, p. 71; MILMAN, Improbidade Processual: comportamento das partes e de seus procuradores no processo civil, p. 78.

${ }^{1620}$ É possível encontrar diversos julgados do Superior Tribunal de Justiça nesse sentido, dentre os quais se encontram os mais recentes acerca desse tema: STJ, $4^{\mathrm{a}}$ Turma, REsp 1.173.848/RS, Rel. Min. Luis Felipe Salomão, DJe 10/05/2010; STJ, $3^{\text {a }}$ Turma, AgRg nos EDcl no Ag 918.228/RS, Rel. Min. Paulo de Tarso Sanseverino, DJe 22/09/2010; STJ, $3^{\mathrm{a}}$ Turma, EDcl no RMS 31.708/RS, Rel ${ }^{\mathrm{a}}$. Min ${ }^{\mathrm{a}}$. Nancy Andrighi, DJe 20/08/2010; STJ, $3^{\text {a }}$ Turma, EDcl no AgRg no REsp 1.128.584/MG, Rel. Min. Massami Uyeda, DJe 02/03/2010; STJ, $4^{\text {a }}$ Turma, REsp 14.0578/SP, Rel. Min. Luis Felipe Salomão, DJe 15/12/2008; STJ, $3^{\text {a }}$ Turma, REsp 22.027 / RS, Rel. Min. Nilson Naves, DJ 14/09/1992, p. 14970.

${ }^{1621}$ Nesse sentido, no âmbito doutrinário: ESTEVAN FERNANDES, Condenação Solidária de Advogado com Cliente em Lide Temerária e o Projeto de Lei $n^{\circ}$ 4.074/08, "passim"; ESTEVAN FERNANDES, Litigância de Má-Fé: razoável duração do processo que decorre da responsabilização de quem dela se vale, pp. 8-9, para quem a parte final do parágrafo único do art. 32 da Lei $n^{\circ}$ 8.906/94 é inconstitucional por ser incompatível com o art. $5^{\circ}$, LXXVIII, da CF.

Nesse mesmo sentido são os seguintes julgados do Tribunal Regional do Trabalho da $3^{\text {a }}$ Região: TRT da $3^{\text {a }}$ Região,1 ${ }^{\mathrm{a}}$ Turma, PROCESSO nº 00658-2002-044-03-00-0, Rel. Juíza Maria Auxiliadora Machado Lima, Publicação dia 29/11/2002; TRT da $3^{\text {a }}$ Região, $2^{\text {a }}$ Turma, RO n ${ }^{\circ} 18433 / 96$, Rel. Juiz José Roberto Freire Pimenta, Publicação dia 27/06/1997. 
advogado que é condenado solidariamente com a parte por ter mencionado fatos falsos dentre as causas de pedir da demanda. Em sede recursal, o causídico pode alegar que não houve conluio entre ele e seu cliente, uma vez que este não lhe havia confidenciado a falsidade dos fatos, e que não teria como ele apurar a verdade por conta própria, obstando a incidência do parágrafo único do art. 32 da Lei $n^{\circ}$ 8.906/94. Nesse caso hipotético, a solução da questão referente à responsabilização do advogado pelo comportamento ímprobo com certeza atrasaria a entrega da tutela jurisdicional a quem tivesse o direito, causando um aumento anormal do dano marginal do processo e, consequentemente, agravando ainda mais os danos que a conduta abusiva originalmente gerou para o Estado e para a parte contrária. Além do mais, essa modalidade anômala de intervenção de terceiro no processo causaria uma série de questionamentos processuais, que tumultuariam muito o feito. Apenas a título exemplificativo, é suficiente mencionar a seguinte dúvida que surgiria nessa situação: a parte que também foi condenada pela improbidade processual teria que contratar um outro advogado para defendê-la, já que o seu antigo procurador passaria a ter interesses conflitantes com os dela a partir da prolação da sentença?

Em razão de tudo isso, conclui-se que responsabilizar a parte e o seu procurador, solidariamente, no mesmo processo em que se praticou o abuso do processo, contribui, na realidade, para fazer tábula rasa da garantia da duração razoável do processo (art. $5^{\circ}$, LXXVIII, da CF) e dos princípios da celeridade e da economia processual.

A ideia de condenar não somente a parte ímproba, mas também o seu advogado, ao pagamento de multa e ao ressarcimento de perdas e danos, no mesmo processo no qual o abuso foi praticado, tem adeptos também no Congresso Nacional. O Projeto de Lei $\mathrm{n}^{\circ}$ 4.074/2008, de autoria do Deputado Juvenil Alves Ferreira Filho, propõe a alteração do "caput" do art. 18 do CPC para majorar o "quantum" da multa de $1 \%$ para $5 \%$ do valor da causa e para permitir que as sanções aplicáveis à parte litigante de má-fé recaiam também sobre o advogado ${ }^{1622}$. Se esse Projeto de Lei for aprovado, estará superado o obstáculo que o parágrafo único do art. 32 da Lei $n^{\circ}$ 8.906/94 atualmente oferece à condenação solidária do advogado pela prática do abuso processual. No entanto, essa nova regra seria digna de críticas, pois, como já se explicou, a responsabilização solidária da parte e do seu procurador, no mesmo processo em que se praticou o abuso, geraria questionamentos

\footnotetext{
${ }^{1622}$ O Projeto de Lei n ${ }^{\circ} 4.074 / 2008$ propõe que o "caput" do art. 18 do CPC passe a ter a seguinte redação: “Art. 18. O juiz ou tribunal, de ofício ou a requerimento, condenará o litigante de má-fé e seu advogado a pagar multa não excedente a 5\% (um por cento) sobre o valor da causa e a indenizar a parte contrária dos prejuizos que esta sofreu, mais os honorários advocatícios e todas as despesas que efetuou".
} 
processuais que tumultuariam o feito e atrasariam a prestação da tutela jurisdicional, potencializando o efeito nocivo do comportamento ímprobo ${ }^{1623}$.

Em suma, de acordo com o ordenamento jurídico atual, sempre que um dos advogados que atuam no processo cometer abuso, o magistrado deve penalizar apenas a parte patrocinada por ele. Cabe a esta, em um segundo momento, depois de já ter sido condenada ao pagamento da multa e ao ressarcimento das perdas e danos, ajuizar: (a) demanda regressiva, pleiteando o ressarcimento de todo o prejuízo que sofreu em razão da improbidade processual dolosa ou culposa do causídico, desde que não tenha nem mesmo concorrido para a prática do comportamento abusivo; ou (b) demanda pleiteando a responsabilidade solidária do seu procurador, caso tenha-se unido em conluio com este para praticar a conduta processual ímproba.

${ }^{1623}$ Em outros países, também se cogita ou já se cogitou a criação de norma jurídica expressa autorizando a condenação do advogado pelo abuso do processo, e não a parte sua cliente.

Dondi e Giussani (Appunti sul Problema dell' Abuso del Processo Civile nella Prospettiva de Iure Condendo, in Rivista Trimestrale di Diritto e Procedura Civile, vol. 61, $\mathrm{n}^{\circ}$ 1, pp. 195-196 e 197) entendem que os advogados são os verdadeiros responsáveis pelas condutas processuais abusivas e, por causa disso, sugerem a inserção de normas no ordenamento jurídico italiano que autorizem o órgão judicial a puni-los diretamente, ao invés das partes. Falco (La Buona Fede e l'Abuso del Diritto: principi, fattispecie e casistica, pp. 518-519) faz coro com esses juristas e também defende a atribuição da responsabilidade pelo abuso do processo aos advogados.

Segundo Reis (Código de Processo Civil Anotado, vol. II, pp. 273-274), originalmente, o art. 609 do Projeto do Código de Processo Civil português tinha a seguinte redação: "Se o juiz reconhecer que o advogado ou solicitador da parte teve responsabilidade pessoal e directa nos actos pelos quais se revelou a má fé no litígio, condená-lo-á na quota parte das custas e indemnização que lhe parecer justa e dará conhecimento do facto à Ordem dos Advogados ou à Câmara dos Solicitadores". Esse texto dividiu a opinião dos integrantes da Comissão Revisora: os Doutores Pinheiro Chagas, Sá Carneiro, Barbosa de Magalhães e Botelho de Sousa foram contra o dispositivo; enquanto os Doutores Manuel Rodrigues (então Ministro da Justiça português), Henriques Góis, Ulisses Cortês, Heitor Martins e Silva e Sousa apoiaram-no. O debate prosseguiu e a maioria acabou aceitando o princípio da responsabilidade pessoal do mandatário, contanto que a apreciação do fato e a aplicação das sanções fossem da competência da Ordem dos Advogados e da Câmara dos Solicitadores. O dispositivo finalmente aprovado estatuía que: "Quando se reconhecer que o mandatário da parte teve responsabilidade pessoal e directa nos actos pelos quais se revelou a má fé na causa, dar-se-á conhecimento do facto à Ordem dos Advogados ou à Câmara dos Solicitadores, para que estas possam aplicar as sanções respectivas e condenar o mandatário na quota parte das custas, multa e indemnização que lhes parecer justa" (art. 468 do CPC português de 1939). Trata-se, praticamente, da mesma norma contida no art. 459 do CPC português atual.

Na Bélgica, também se cogitou uma alteração do "Code Judiciaire" para prever a responsabilidade do advogado pelo ressarcimento das perdas e danos e das despesas processuais decorrentes dos comportamentos abusivos cometidos pela parte no processo. Entretanto, os órgãos que representam os advogados daquele país opuseram-se apaixonadamente a essa projeto e, segundo Taelman (Abuse of Procedural Rights: regional report for Belgium-The Netherlands, in TARUFFO (ed.), Abuse of Procedural Rights: comparative standards of procedural fairness, pp. 136 e 144), a chance de ele se tornar lei algum dia são muito pequenas.

Até 1964, o art. 102 da ZPO alemã permitia que o órgão jurisdicional condenasse o advogado a pagar as despesas adicionais causadas por seu comportamento gravemente culposo no processo (v.g., interposição de recurso manifestamente infundado ou vexatório). Mas, os advogados protestaram contra essa regra, alegando que ela interferia indevidamente na sua posição de "órgãos da administração da justiça", e ela foi revogada. Analogamente, na Áustria, também houve a revogação dos dispositivos legais que permitiam a imposição de multa ao advogado que atrasasse o processo por culpa grave (HESS, Abuse of Procedure in Germany and Austria, in TARUFFO (ed.), Abuse of Procedural Rights: comparative standards of procedural fairness, $\mathrm{p}$. 175). 
As únicas providências que o magistrado que preside o processo em que se deu o comportamento abusivo pode (e deve) tomar com relação ao profissional ímprobo são: (a) determinar a perda do direito aos honorários advocatícios, se tiver praticado alguma das condutas previstas no art. 17 ou no art. 22 do CPC, contanto que a parte sua cliente tenhase consagrado vencedora na causa (arts. 18, “caput”, e 22 do CPC) ${ }^{1624}$; e (b) oficiar à Ordem dos Advogados do Brasil, comunicando os fatos ${ }^{1625}$.

A representação que o magistrado elabora, contendo a narrativa do ato de improbidade processual do advogado, e encaminha à $\mathrm{OAB}$ dá ensejo a um processo disciplinar perante o Tribunal de Ética e Disciplina do Conselho Seccional em cuja base territorial tenha ocorrido a infração (art. 70, “caput” e $\S 1^{\circ}$, da Lei $n^{\circ} 8.906 / 94$ ). Ao fim do processo, que tem tramitação sigilosa (art. 72, "caput" e $\S 3^{\circ}$, da Lei n 8.906/94), as seguintes sanções disciplinares podem ser cominadas: (a) censura (v.g., nas hipóteses

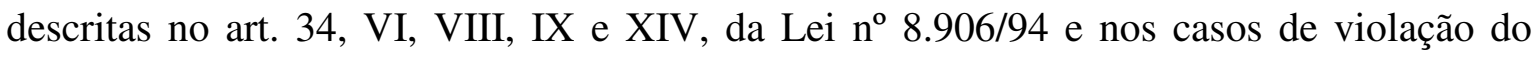
disposto nos arts. $2^{\circ}$, parágrafo único, II; VII; VIII, “ $d$ ” e " $e$ "; $6^{\circ}$ e $8^{\circ}$ do Código de Ética e Disciplina da OAB - art. 36 da Lei $n^{\circ}$ 8.906/94), a qual pode ser convertida em advertência, quando presente alguma das circunstâncias atenuantes previstas nos incisos do “caput” do art. 40 da Lei no 8.906/94 (art. 36, parágrafo único, da Lei no 8.906/94); (b) suspensão (e.g., para os comportamentos previstos nos incisos XVII, XIX e XXIV do art. 34 da Lei $n^{\circ} 8.906 / 94$, bem como para os casos de reincidência em infração disciplinar art. 37 da Lei $n^{\circ}$ 8.906/94); (c) exclusão (se o advogado for punido, por três vezes, com suspensão - art. 38, I, da Lei $\mathrm{n}^{\circ}$ 8.906/94); (d) multa variável entre o mínimo correspondente ao valor de uma anuidade e o máximo de seu décuplo (aplicável cumulativamente com a censura ou a suspensão, considerando as circunstâncias descritas no parágrafo único do art. 40 da Lei no 8.906/94 - art. 39 c/c art. 40, parágrafo único, " $a$ ", da Lei $n^{\circ}$ 8.906/94). O profissional sancionado com suspensão ou exclusão fica impedido de exercer o mandato (art. 42 da Lei ${ }^{\circ}$ 8.906/94). Da decisão condenatória proferida pelo Tribunal de Ética e Disciplina cabe recurso ao Conselho Seccional (art. 76 da Lei ${ }^{\circ}$ 8.906/94). A decisão definitiva deste órgão da OAB também é impugnável mediante recurso para o Conselho Federal, desde que não tenha sido unânime ou, sendo unânime, tenha contrariado a Lei ${ }^{\circ}$ 8.906/94, decisão do Conselho Federal ou de outro Conselho Seccional e, ainda, o Regulamento Geral, o Código de Ética e Disciplina e os Provimentos

${ }^{1624}$ Acerca da perda do direito aos honorários advocatícios, consultar o item 3.4 "supra".

${ }^{1625}$ Oliveira (Litigância de Má-Fé, p. 70) menciona a última providência, mas não reconhece a primeira. 
(art. 75, “caput", da Lei $\mathrm{n}^{\mathrm{o}}$ 8.906/94). Em regra, tais recursos são dotados de efeito suspensivo (art. 77, “caput”, da Lei no 8.906/94). 


\section{MECANISMOS DE PREVENÇÃO DO ABUSO DO PROCESSO}

Nos capítulos anteriores, foram analisadas as hipóteses de abuso do processo expressamente previstas no Código de Processo Civil brasileiro (capítulo 2 "supra"), bem como as consequências jurídicas que a prática dessas condutas acarreta (capítulo 3 "supra").

Sabe-se que a própria previsão de sanções às condutas abusivas já é considerada um método preventivo, dado o seu efeito psicológico dissuasivo: diante da possibilidade de sofrer a incidência da norma punitiva, a pessoa prefere não praticar a conduta sancionada ${ }^{1626}$. A existência de um sistema eficaz de repressão do abuso do processo acaba servindo como um contrapeso, que torna a improbidade processual não convidativa, principalmente em termos patrimoniais ${ }^{1627}$.

No entanto, isso não é suficiente para que os sujeitos do processo deixem totalmente de lado as práticas processuais ímprobas. Logo, para tornar mais escasso o abuso do processo, mostra-se necessária também a existência de medidas processuais preventivas, destinadas precipuamente a evitar a efetivação de atos abusivos ou, caso isso não seja possível, pelo menos diminuir os efeitos nocivos da improbidade processual.

Os ordenamentos jurídicos atuais estão repletos de remédios processuais preventivos do abuso do processo, os quais são classificados em dois grandes grupos ${ }^{1628}$ :

a) os remédios preventivos explícitos: aqueles cuja finalidade de prevenir alguma das hipóteses de abuso do processo já se encontra explícita no texto legal; e

b) os remédios preventivos implícitos: aqueles cujo escopo principal não é a prevenção do abuso, mas que, indiretamente, auxiliam a impedir a efetivação do abuso processual ou a reduzir a eficácia deletéria das condutas processuais ímprobas já praticadas.

No Código de Processo Civil brasileiro, é possível encontrar os seguintes remédios preventivos explícitos:

\footnotetext{
${ }^{1626}$ Nesse sentido: ABDO, O Abuso do Processo, p. 228; ABDO, O Ato Atentatório à Dignidade da Justiça na Nova Execução Civil, p. 11; BARBOSA MOREIRA, A Responsabilidade das Partes por Dano Processual no Direito Brasileiro, in Temas de Direito Processual, p. 18; YARSHELL, Antecipação da Prova sem o Requisito da Urgência e Direito Autônomo à Prova, p. 150; e TARUFFO, General Report, in TARUFFO (ed.), Abuse of Procedural Rights: comparative standards of procedural fairness, p. 22; NORMAND, Final Report: the two approaches to the abuse of procedural rights, in TARUFFO (ed.), Abuse of Procedural Rights: comparative standards of procedural fairness, p. 239.

${ }^{1627}$ MENEZES CORDEIRO, Litigância de Má-Fé, Abuso do Direito de Ação e Culpa “in Agendo”, p. 28.

1628 Acerca dessa classificação, consultar: LUSO SOARES, A Responsabilidade Processual Civil, p. 205.
} 
a) os poderes-deveres genéricos do juiz de: (1) velar pela rápida solução da lide, impedindo qualquer manobra procrastinatória; (2) prevenir qualquer ato contrário à dignidade da Justiça (art. 125, II e III, do CPC ${ }^{1629}$ ); (3) advertir o devedor de que o seu procedimento constitui ato atentatório à dignidade da Justiça (art. 599, II, do CPC); (4) indeferir diligências inúteis ou meramente procrastinatórias (art. 130 do $\mathrm{CPC}$ ) ${ }^{1630}$; (5) proferir sentença que obste aos objetivos das partes, caso se convença de que se trata de processo simulado ou fraudulento (art. 129) ${ }^{1631} 1632$;

b) os poderes-deveres que o magistrado possui para verificar se os litigantes não estão respeitando o dever de veracidade, tais como: (1) o poder de determinar, até mesmo de ofício, o comparecimento pessoal das partes para serem interrogadas em juízo sobre os fatos da causa (art. 342 do CPC); (2) o poder de ordenar, até mesmo de ofício, que as partes exibam parcialmente livros e documentos (art. 382 do CPC); (3) o poder de requisitar às repartições públicas certidões necessárias à prova das alegações das partes (art. 399, I, do CPC); (4) o poder de inspecionar pessoas ou coisas, de ofício ou a requerimento da parte, a fim de esclarecer fato que interesse à decisão da causa (art. 440 do CPC) ${ }^{1633}$;

c) o poder-dever do membro do Ministério Público de, na função de físcal da lei, juntar documentos e certidões, produzir prova em audiência e requerer medidas ou diligências necessárias ao descobrimento da verdade (art. 83, II, do CPC) ${ }^{1634}$;

${ }^{1629} \mathrm{O}$ art. 34, 5, “ $d$ ”, do CPC argentino estabelece que é dever dos juizes dirigir o procedimento, prevenindo e sancionando, dentro dos limites expressamente estabelecidos pela lei, todo ato contrário ao dever de lealdade, probidade e boa-fé.

O "Codigo Procesal Civil Modelo para Iberoamerica" também tem dispositivo semelhante:

"[...] O Tribunal deverá impedir a fraude processual, a colusão e qualquer outra conduta ilícita ou dilatória" $\left(\operatorname{art} .5^{\circ}\right)$.

${ }^{1630}$ Greco Filho (Direito Processual Civil Brasileiro, vol. I, p. 228) adverte que, no exercício desse poder, o juiz deve ter cuidado para não interferir na livre discussão da causa pelos litigantes, ou seja, para não cercear as atividades essenciais das partes na defesa de seus direitos.

${ }^{1631}$ Theodoro Júnior (Abuso de Direito Processual no Ordenamento Jurídico Brasileiro, in Revista Forense, v. 344, p. 57) e Abdo (O Abuso do Processo, pp. 238-239; O Ato Atentatório à Dignidade da Justiça na Nova Execução Civil, p. 11) fazem menção a esses instrumentos, porém sem a especificação de que se tratam de remédios preventivos explícitos.

${ }^{1632}$ Se o Projeto de Lei no 8.046/2010 for aprovado, sancionado e publicado com sua redação atual, esses remédios preventivos explícitos constarão, respectivamente, dos arts. 118, I e II; 731, II; 354, parágrafo único; e 122 do novo Código de Processo Civil.

${ }^{1633}$ No Projeto de Lei $n^{\circ} 8.046 / 2010$, que versa sobre o novo Código de Processo Civil, esses poderesdeveres do juiz estão previstos nos arts. 118, VIII; 409; 424, I; e 468.

${ }^{1634}$ Caso o projeto do novo Código de Processo Civil (Projeto de Lei no 8.046/2010) seja aprovado nos termos atuais, o referido poder-dever do representante do Ministério Público terá como fundamento legal o art. 157, II. 
d) o ônus de depositar a importância de 5\% do valor da causa no momento do ajuizamento da petição inicial da ação rescisória (art. 488, II, do CPC), sob pena de indeferimento liminar desta (art. 490, II, do CPC) ${ }^{16351636}$;

e) o poder-dever do juiz de antecipar a tutela, total ou parcialmente, desde que (1) haja requerimento da parte interessada; (2) exista prova inequívoca da verossimilhança das alegações do autor; e (3) o réu abuse do direito de defesa ou se comporte com manifesto propósito protelatório (art. 273, II, do CPC) $)^{16371638 .}$

Cumpre observar que, na prática, as sanções são mais usuais que a aplicação dessas medidas preventivas, pois a aparência de legalidade do ato ímprobo muitas vezes faz com que o seu caráter abusivo só seja revelado ao magistrado após a produção do resultado danoso $^{1639}$.

Quanto aos remédios preventivos implícitos, eles estão espalhados por todo o Código de Processo Civil. Sem ter a pretensão de fazer um rol exauriente, destacam-se:

a) os arts. $8^{\circ}$ (determina que as pessoas absolutamente incapazes devem ser representadas no processo por seus pais, tutores ou curadores e que as relativamente incapazes devem ser assistidas por seus pais, tutores ou curadores) e 38, "caput", do CPC (estatui que a procuração geral para o foro habilita o advogado a praticar todos os atos do processo, salvo receber citação inicial, confessar, reconhecer a procedência do pedido, transigir, desistir, renunciar ao direito sobre que se funda a ação, receber, dar quitação e firmar compromisso), que asseguram, ambos, a correta formação e manifestação das vontades dos sujeitos do processo, o que dificulta a prática de atos processuais simulados ou fraudulentos;

b) os arts. 134 a 138 do CPC, que tratam das causas de impedimento e de suspeição de magistrados, órgãos do Ministério Público e auxiliares da justiça, bem como os arts. 131, 165 e 458, II, do CPC, que preveem o dever de o juiz indicar, na decisão, os motivos

\footnotetext{
${ }^{1635}$ Nesse sentido: THEODORO JÚNIOR, Abuso de Direito Processual no Ordenamento Jurídico Brasileiro, in Revista Forense, v. 344, p. 57, mas sem especificar que se trata de um remédio preventivo explícito.

${ }^{1636}$ O Projeto de Lei no 8.046/2010 (que institui o novo Código de Processo Civil) prevê regras similares no art. 921 , II e $\S 2^{\circ}$.

${ }^{1637}$ Nesse sentido, porém sem esclarecer que se trata de remédio preventivo explícito: MARINONI, Abuso de Defesa e Parte Incontroversa da Demanda, pp. 123-124 e 130. Esse jurista sustenta que a técnica antecipatória prevista no art. 273, II, do CPC inibe o exercício abusivo do direito de defesa porque ela distribui e até de inverte o ônus do tempo do processo e, desse modo, impede que o réu utilize a demora do processo para arrancar vantagens do autor. Em outras palavras, ela impossibilita que o tempo do processo seja utilizado como "moeda de troca" em favor do réu ímprobo.

${ }^{1638}$ No projeto do novo Código de Processo Civil (Projeto de Lei no $8.046 / 2010$ ), o poder de conceder a chamada "tutela antecipada sancionatória" está previsto no art. 278, I.

${ }_{1639}$ ABDO, O Abuso do Processo, p. 227; ABDO, O Ato Atentatório à Dignidade da Justiça na Nova Execução Civil, p. 11.
} 
que formaram o seu convencimento, visam a manter a independência e a liberdade de consciência desses sujeitos processuais no exercício de suas funções e, desse modo, previnem a prática de condutas abusivas;

c) os arts. 405 (proíbe pessoas incapazes, impedidas e suspeitas de deporem como testemunhas), 413 (proíbe que uma testemunha ouça o depoimento das outras), 414 (permite a contradita de testemunha incapaz, impedida ou suspeita), 415 (prevê o compromisso de dizer a verdade da testemunha) e 418, II, do CPC (prevê a possibilidade de se realizar a acareação de duas ou mais testemunhas ou de alguma delas com a parte quando suas declarações divergirem a respeito de fato determinado e relevante para o julgamento da demanda), que têm por fim garantir que as testemunhas transmitam fatos verdadeiros;

d) certos dispositivos do Código de Processo Civil que promovem a celeridade e a pontualidade, evitando os atos processuais procrastinatórios, como, por exemplo, os arts. 60 (permite que o juiz suspenda o andamento do processo por no máximo 90 dias para julgá-lo juntamente com a oposição); 193-194 e 198-199 (preveem regras de verificação do cumprimento de prazos processuais pelos auxiliares da justiça e pelos órgãos judiciais); 203 (estatui que, em toda carta de ordem, carta precatória e carta rogatória, o juiz precisa fixar o prazo dentro do qual ela deva ser cumprida) ${ }^{1640} ; 338$ (estatui que a carta precatória e a carta rogatória somente suspendem o processo, com fundamento no art. 265 , IV, " $b$ ", do CPC, se tiverem sido requeridas antes da decisão de saneamento e a prova nelas solicitada apresentar-se imprescindível para o julgamento da demanda); 400, 2ª parte (autoriza o juiz a indeferir a inquirição de testemunhas sobre fatos já provados por documento ou confissão da parte ou que só possam ser provados por meio de documento ou exame pericial); 407, parágrafo único (estatui que cada parte pode oferecer, no máximo, 10 testemunhas e permite que o juiz ouça apenas três testemunhas para provar cada fato, dispensando as eventuais restantes); 421, "caput", c/c 432 (estabelece que, ao nomear o perito, o juiz deve fixar imediatamente o prazo para que ele entregue o laudo, o qual pode ser prorrogado uma vez, motivadamente); 453 (autoriza o adiamento da audiência apenas em duas circunstâncias: em razão de convenção das partes, uma única vez; ou se o perito, as partes, as testemunhas ou os advogados não puderem comparecer por motivo justificado) etc.;

${ }^{1640}$ Esse dispositivo é citado também por Theodoro Júnior (Abuso de Direito Processual no Ordenamento Jurídico Brasileiro, in Revista Forense, v. 344, p. 57) como sendo integrante do sistema preventivo do abuso do processo. 
e) os dispositivos que garantem a regularidade da distribuição aleatória de processos, frustrando eventual intuito preconcebido da parte de fazer a sua demanda ser processada e julgada em primeiro grau por um órgão judicial determinado. Dentre eles, destacam-se os incisos II e III do art. 263 do CPC, que determinam a distribuição por dependência ao juízo prevento nas hipóteses: (1) de reiteração de pedido formulado em processo anterior extinto sem julgamento do mérito (art. 267 do CPC), independentemente de se ter estabelecido litisconsórcio com outros autores ou de terem sido parcialmente alterados os réus na nova demanda ${ }^{1641} 1^{1642}$; e (2) de ajuizamento de ações idênticas. Essa norma previne a prática abusiva consistente no ajuizamento simultâneo ou sucessivo de várias demandas idênticas ou bastante similares (apenas com o acréscimo de novos litisconsortes ou com pequenas alterações na causa de pedir) seguido da desistência ou do abandono unilateral por mais de trinta dias daquelas nas quais não foi concedida medida liminar ou que foram distribuídas para juízos que têm entendimento jurídico divergente do postulado na petição inicial ${ }^{1643}$. O juiz que percebe o estratagema do demandante deve pronunciar a própria incompetência de ofício, a qualquer tempo, e determinar a remessa do processo ao juízo prevento, visto que essa competência é funcional e, consequentemente, absoluta. Essa decisão interlocutória é impugnável por meio de agravo de instrumento ${ }^{1644}$. Cumpre esclarecer que a aplicação do art. 263, II e III, do CPC independe do "animus" do autor da demanda ${ }^{1645}$;

f) o art. $499, \S 1^{\circ}$, do CPC, que atribui legitimidade ao terceiro prejudicado para interpor recurso, ajudando a evitar que processos simulados sejam bem sucedidos;

\footnotetext{
${ }^{1641}$ Originalmente, quando o inciso II foi acrescentado ao art. 253 do CPC pela Lei ${ }^{\circ} 10.358 / 01$, ele impunha a prevenção do juízo apenas em casos de desistência da ação. Depois, a Lei ${ }^{\circ}$ 11.280/06 alterou novamente esse dispositivo, conferindo a ele a redação atual, que ampliou sua área de incidência.

${ }^{1642}$ Dinamarco (A Reforma da Reforma, § 32, p. 75) observa que essa regra não incide nos casos em que o demandante houver desistido de demanda proposta perante Justiça ou juízo absolutamente incompetente, uma vez que jamais se tem por prevento o juízo absolutamente incompetente. Se a incompetência do primeiro juízo for somente de foro, que é relativa, o jurista distingue três hipóteses: (1) se a desistência ocorrer antes do momento da resposta, ou seja, antes de o juízo poder pronunciar-se em eventual exceção de incompetência, ele está prevento e, no segundo processo, terá que decidir a respeito, caso a exceção seja proposta; (2) se a desistência ocorrer depois da rejeição da exceção de incompetência, o juízo está prevento e a exceção não será admissível no segundo processo; (3) se a desistência ocorrer depois do acolhimento da exceção de incompetência, o juízo não está prevento para o segundo processo.

${ }^{1643}$ CRUZ E TUCCI, Lineamentos da Nova Reforma do CPC, pp. 37-39; SILVA DINAMARCO, Comentários ao art. 253 do CPC, in MARCATO (coord.), Código de Processo Civil Interpretado, pp. $752-$ 753; DINAMARCO, A Reforma da Reforma, § 31, pp. 73-74; § 33, pp. 75-76; DINAMARCO, Instituições de Direito Processual Civil, vol. I, § 326, p. 642.

${ }^{1644}$ DINAMARCO, A Reforma da Reforma, $\S 32$, p. 75.

1645 DINAMARCO, A Reforma da Reforma, $\$ 33$, p. 76.
} 
g) os arts. 355 e ss. do CPC, que tratam da exibição de documento ou coisa e garantem a apresentação tempestiva de documentos, assegurando o dever de lealdade ${ }^{1646}$;

h) os arts. 295 e 330 do CPC, que autorizam o juiz, respectivamente, a indeferir a petição inicial e a julgar o mérito do processo sem que haja audiência, caso o autor ou o réu tenha deduzido pretensão manifestamente infundada, limitando os efeitos deletérios desse comportamento ímprobo ${ }^{1647}$. O art. 285-A do CPC também previne implicitamente essa hipótese de abuso do processo em sentido estrito ao permitir que o juiz rejeite o pedido do autor antes mesmo da citação do réu, desde que a matéria objeto do processo seja unicamente de direito e que no juízo já tenha sido proferida sentença de total improcedência em outros casos idênticos ${ }^{1648}$;

1646 Os remédios preventivos implícitos mencionados nas alíneas "a" a "g" constam da obra de Luso Soares (A Responsabilidade Processual Civil, pp. 206-207), mas, obviamente, esse autor faz referência a dispositivos e institutos do Direito português.

${ }^{1647}$ É o que defende Theodoro Júnior (Abuso de Direito Processual no Ordenamento Jurídico Brasileiro, in Revista Forense, v. 344, p. 57).

${ }^{1648}$ Existem normas similares a essas em diversos ordenamentos jurídicos.

Consoante a "Rule" 3.4, (2), "a" e "b", das "Civil Procedure Rules" inglesas c/c "Practice Direction" 3A, 1.4 a 1.6, o juízo pode rejeitar, no todo ou em parte, um pedido do autor ou uma defesa do réu que (ANDREWS, Abuse of Process in English Civil Litigation, in TARUFFO (ed.), Abuse of Procedural Rights: comparative standards of procedural fairness, pp. 74 e 79-84):

a) não tenha embasamento razoável (v.g., se o litigante não indicar fatos suficientes para a identificação do pedido; se a narração dos fatos for incoerente e sem sentido; se o réu simplesmente negar os fatos alegados pelo autor; se não for possível deduzir da narrativa fática qualquer pedido contra o réu ou defesa contra o autor);

b) consista em abuso processual (e.g., se o pedido for vexatório, isto é, se for feito com o intuito de incomodar o réu, sem qualquer perspectiva de sucesso; ou se for grosseiro; ou se for obviamente mal fundamentado; ou ainda se o intuito do autor do pedido não for levar o caso a julgamento, mas sim enervar e molestar o réu, ou talvez lhe infligir dano colateral); ou

(c) seja capaz de obstruir o bom andamento dos trabalhos judiciais (v.g., se a demanda ofender a garantia da coisa julgada).

Segundo Fentiman (Abuse of Procedural Rights: the position of English Law, in TARUFFO (ed.), Abuse of Procedural Rights: comparative standards of procedural fairness, p. 59), os órgãos judiciais ingleses aplicam essa regra com bastante cautela, já que ela priva o litigante do direito de acesso efetivo ao Judiciário. Normand (Final Report: the two approaches to the abuse of procedural rights, in TARUFFO (ed.), Abuse of Procedural Rights: comparative standards of procedural fairness, p. 246) afirma que a existência de uma norma como essa pressupõe uma extraordinária confiança na honestidade e perspicácia do juiz inglês e observa que, em outros países, ela poderia dar ensejo a abusos por parte dos próprios juízes, que tentariam utilizá-la para diminuir ilegitimamente o volume do seu trabalho.

Na Austrália, as demandas escandalosas, frívolas, vexatórias ou infundadas também são rejeitadas pelo órgão jurisdicional (BEAUMONT, Report on Abuse of Procedural Rights for Australia, in TARUFFO (ed.), Abuse of Procedural Rights: comparative standards of procedural fairness, pp. 101 e 105).

Analogamente, na Alemanha e na Áustria, as demandas ajuizadas com o intuito de atingir um objetivo dissimulado ou irrelevante, bem como as destinadas a impedir ou frustrar procedimentos podem ser rejeitadas por falta de legítimo interesse pela proteção legal (HESS, Abuse of Procedure in Germany and Austria, in TARUFFO (ed.), Abuse of Procedural Rights: comparative standards of procedural fairness, pp. 156-159).

$\mathrm{O}$ art. 11.2 da "Ley Orgánica del Poder Judicial" e o art. 247.2 da "Ley de Enjuiciamiento Civil" da Espanha estatuem que os juízos e tribunais devem rechaçar fundadamente as petições, as exceções e os incidentes que sejam formulados com manifesto abuso de direito ou que se dediquem à fraude da lei ou do processo. Para Lozano (La Buena Fe Procesal y el Ejercicio de la Abogacía, in CONRADI (coord.), El Abuso del Proceso: mala fe y fraude de ley procesal, p. 110), essas normas parecem ser dirigidas a uma inadmissão "a limine", que sempre deve ser motivada, seja no manifesto abuso de direito, seja na fraude processual, caso contrário o 
i) a atribuição do custo financeiro do processo às partes, notadamente àquela que deu causa a ele, que consiste em um modo eficiente de inibir a propositura de demandas destituídas de embasamento legal ou fático e a prática de atos processuais protelatórios ou ímprobos, além de evitar a excessiva oneração dos cofres públicos ${ }^{1649}$;

j) a execução provisória da decisão (art. 475-O do CPC), que desestimula a interposição de recursos manifestamente infundados e protelatórios, pois o início da execução faz com que a parte vencida somente recorra se realmente entender que tem razão ${ }^{1650}$;

órgão jurisdicional incorreria em uma violação do direito à tutela judicial efetiva previsto no art. 24 da Constituição espanhola.

${ }^{1649}$ CAHALI, Honorários Advocatícios, § 1º pp. 21-22; CARRILHO LOPES, Honorários Advocatícios no Processo Civil, pp. 4-5; FENTIMAN, Abuse of Procedural Rights: the position of English Law, in TARUFFO (ed.), Abuse of Procedural Rights: comparative standards of procedural fairness, pp. 56 e 60; ANDREWS, Abuse of Process in English Civil Litigation, in TARUFFO (ed.), Abuse of Procedural Rights: comparative standards of procedural fairness, pp. 74-75; HESS, Abuse of Procedure in Germany and Austria, in TARUFFO (ed.), Abuse of Procedural Rights: comparative standards of procedural fairness, p. 157.

${ }^{1650}$ Nesse sentido: ASSIS, Cumprimento da Sentença, p. 139; TAELMAN, Abuse of Procedural Rights: regional report for Belgium-The Netherlands, in TARUFFO (ed.), Abuse of Procedural Rights: comparative standards of procedural fairness, p. 140.

Três teorias explicam por que a execução provisória torna menos frequente a prática do abuso do poder de recorrer (RAMOS ROMEU, ¿Reduce Realmente la Ejecución Provisional la Interposición de Recursos Injustificados?, in Indret - Revista para el Análisis del Derecho, ${ }^{\circ}$ 385, pp. 6-7):

a) teoria da insolvência (ou do "periculum in mora"): se inexistir execução provisória, a parte condenada, mesmo sabendo que não tem razão, interpõe o recurso com o fim de ganhar tempo para dilapidar seu patrimônio e frustrar a futura execução definitiva. Com a execução provisória, a parte condenada tem seu patrimônio imediatamente diminuído, perdendo a motivação para recorrer;

b) teoria da rentabilidade: sem a execução provisória, a parte condenada continua com o dinheiro em suas mãos durante o trâmite recursal, podendo aplicá-lo e obter dele algum lucro até o fim do processo. Como a execução provisória retira do patrimônio do condenado, desde logo, o valor que ele utilizaria em seus investimentos, o interesse em recorrer é dissipado;

c) teoria da acomodação: parte do pressuposto de que o tribunal que conhece do recurso se mostra menos favorável a revogar a sentença de primeiro grau se esta já estiver executada provisoriamente. Segundo Ramos Romeu (¿Reduce Realmente la Ejecución Provisional la Interposición de Recursos Injustificados?, in Indret Revista para el Análisis del Derecho, $\mathrm{n}^{\circ} 385, \mathrm{p}$. 7), isso ocorre porque os desembargadores levam em consideração os gastos extras que a Administração da Justiça teria para revogar a execução provisória, bem como a possível responsabilidade pessoal do juiz e do Estado pelos danos que o condenado possivelmente teria sofrido injustamente (quanto a este último aspecto, ele não se aplica integralmente ao ordenamento jurídico brasileiro porque o art. 475-O, I, CPC responsabiliza o exequente pelos danos que a execução provisória causar ao executado, não o Estado). Diante da pouca probabilidade de que eventual recurso prospere, quando o devedor condenado sabe que a sentença será executada provisoriamente, ele desiste de recorrer, pois as custas recursais seriam pagas a esmo.

Mas, nem toda a doutrina concorda com isso. Álvarez (La Ejecución Provisional de las Sentencias, in Revista de Derecho de la Pontificia Universidad Católica de Valparaíso, $\mathrm{n}^{\circ}$ 31, pp. 380-381 e 399-400), por exemplo, menciona três argumentos que põem em dúvida essa suposta capacidade da execução provisória de reduzir a prática do abuso do poder de recorrer:

a) diante da possibilidade de ocorrer a execução provisória, o devedor tem mais um incentivo para impugnar a sentença definitiva;

b) é legitimamente discutível o afã de reduzir o número de recursos, uma vez que eles melhoram a qualidade da jurisprudência, permitindo que as decisões se aproximem mais da realidade. Nesse ponto, o autor se contradiz, pois, momentos antes, ele menciona dados estatísticos da "Corporación Administrativa del Poder Judicial", do Chile, no sentido de que poucos recursos são julgados procedentes e, a partir disso, conclui que o teor da maioria das sentenças de primeiro grau não merece reprovação, sendo repetido em segunda 
k) o instituto da preclusão, que consiste na perda de um poder ou de uma faculdade em decorrência de uma das seguintes circunstâncias: (1) o decurso "in albis" do prazo para praticar o ato que a parte tinha o poder ou a faculdade de realizar (preclusão temporal); (2) a prática de um ato incompatível com a vontade de exercer o poder ou a faculdade (preclusão lógica); (3) o exercício válido do próprio poder ou da faculdade (preclusão consumativa); ou (4) a falta do exercício do poder ou da faculdade no momento oportuno, quando a ordem legalmente estabelecida para a sucessão das atividades processuais importar nessa grave consequência (preclusão "mista"1651) ${ }^{1652}$. Trata-se de um instituto essencial para que o processo tenha um desenvolvimento ordenado, coerente e regular, pois assegura a certeza e a estabilidade das situações jurídicas processuais e, com isso, garante a ordem sequencial de realização dos atos processuais, enfatiza a separação temporal entre as fases do procedimento e impede o retrocesso do processo a fases já superadas ${ }^{1653}$. Desse modo, a preclusão previne comportamentos abusivos que impliquem retroceder desnecessariamente a marcha processual, causando tumulto e atraso na entrega da prestação jurisdicional ${ }^{1654}$. Pode-se afirmar que ela impede o "venire contra factum

instância (ÁLVAREZ, La Ejecución Provisional de las Sentencias, in Revista de Derecho de la Pontificia Universidad Católica de Valparaíso, no 31 , pp. 378-379);

c) na Espanha, onde a "Ley de Enjuiciamiento Civil", de 2000, facilitou a execução provisória, pois retirou a necessidade de a parte prestar caução para requerê-la, houve uma redução significativa do número de apelações. Por outro lado, a porcentagem de acórdãos que negam provimento aos recursos aumentou. Então, estatisticamente, a facilitação da execução provisória nesse país não teria diminuído os recursos injustificados; pelo contrário, tê-los-ia aumentado. Na verdade, a doutrina conclui que essas alterações nos dados estatísticos decorreram de outras causas que não a facilitação da execução provisória e que este instituto processual tem um efeito neutro sobre a interposição de apelações contra sentenças.

$\mathrm{O}$ autor baseou esse último argumento em um estudo realizado por Ramos Romeu acerca dos efeitos que a introdução ou a facilitação da execução provisória gera sobre a interposição de recursos, notadamente de recursos injustificados e protelatórios. A conclusão a que ele chegou foi a seguinte:

"[...] contrariamente ao que se crê com frequência, a introdução ou facilitação da execução provisória não tem qualquer efeito, ou não tem qualquer efeito prático importante, fora algum caso marginal, sobre os incentivos que um demandado derrotado tenha para interpor um recurso. O motivo principal que está por trás dessa conclusão é que o recurso é o único mecanismo que um demandado tem em suas mãos para minimizar o revés que tenha sofrido pela sentença proferida. Basta que a probabilidade de que o recurso prospere seja muito pequena para que o recurso seja rentável" (tradução nossa) (RAMOS ROMEU, ¿Reduce Realmente la Ejecución Provisional la Interposición de Recursos Injustificados?, in Indret - Revista para el Análisis del Derecho, $\mathrm{n}^{\circ} 385$, p. 26).

${ }^{1651}$ Essa espécie de preclusão é denominada "mista" porque exige dois requisitos cumulativos para se concretizar: o decurso do tempo e o prosseguimento do processo. Exemplo: mesmo que o autor não se manifeste sobre os fatos novos alegados ou os documentos exibidos pelo réu dentro do prazo previsto nos arts. 326, 327 e 398 do CPC, ele ainda tem a faculdade de fazê-lo até a designação da audiência preliminar ou o saneamento do processo (art. 331 do CPC). Mas, esgotado o prazo e designada a audiência preliminar ou saneado o processo, essa faculdade é considerada preclusa.

${ }_{1652}$ LIEBMAN, Manual de Direito Processual Civil, vol. I, § 107, pp. 235-236; DINAMARCO, Instituições de Direito Processual Civil, vol. II, § 633, pp. 466-467.

${ }^{1653}$ MARCATO, Preclusões: limitação ao contraditório?, in Revista de Processo, $\mathrm{n}^{\circ}$ 17, pp. 105-106.

${ }^{1654}$ Nesse sentido: NEVES, Preclusões para o Juiz: preclusão pro iudicato e preclusão judicial no processo civil, p. 30; BEDAQUE, Efetividade do Processo e Técnica Processual, pp. 131-132; ABDO, O Abuso do 
proprium" no processo, ou seja, a prática de um ato que contrarie comportamento anterior do sujeito processual ${ }^{1655}$;

1) o art. 620 do CPC, que prevê o princípio da execução menos onerosa possível ao executado: "Quando por vários meios o credor puder promover a execução, o juiz mandará que se faça pelo modo menos gravoso para o devedor". Essa norma de sobredireito $^{1656}$ impede a execução desnecessariamente onerosa, abusiva, em que o credor se vale do meio executivo mais danoso ao executado sem ter qualquer vantagem, contrariando o princípio da boa-fé processual ${ }^{1657}{ }^{1658}$. Traduz a ideia de execução equilibrada, que, de um lado, deve ser realizada do modo mais efetivo possível, satisfazendo o direito do credor, mas, de outro, deve-se desenvolver do modo menos gravoso possível ao executado, que não pode ter o seu patrimônio sacrificado além do

Processo, pp. 207-208; THEODORO JÚNIOR, Abuso de Direito Processual no Ordenamento Jurídico Brasileiro, in Revista Forense, v. 344, p. 60; CASTRO FILHO, Abuso do Direito no Processo Civil, p. 154.

${ }^{1655}$ É por isso que Mitidiero (Colaboração no Processo Civil: pressupostos sociais, lógicos e éticos, p. 96, nt. 5) arrola a preclusão lógica entre as manifestações da boa-fé objetiva no processo civil brasileiro.

Acerca do "venire contra factum proprium", consultar o item 1.1 "supra".

${ }^{1656}$ De acordo com Zavascki (Comentários ao Código de Processo Civil, vol. 8, p. 400), o art. 620 do CPC é uma "típica regra de sobredireito, cuja função não é a de disciplinar situação concreta, e sim a de orientar a aplicação das demais normas do processo de execução, com a nítida finalidade de evitar atos executivos desnecessariamente onerosos ao devedor".

${ }^{1657}$ DIDIER JUNIOR, Contribuição para o Entendimento do Art. 620 do CPC (Cláusula Geral de Proteção contra o Abuso do Direito pelo Exequente), pp. 1 e 2.

${ }^{1658}$ Por exemplo, os ministros do Superior Tribunal de Justiça invocaram o art. 620 do CPC para impedir que o mesmo credor ajuizasse, concomitantemente, duas execuções distintas, sendo uma contra o devedor principal, fundamentada no instrumento contratual, e outra contra o avalista, com base em nota promissória dada em garantia:

"PROCESSO CIVIL. EXECUÇÃO SIMULTANEA DE UMA MESMA DIVIDA EM PROCESSOS DISTINTOS. INADMISSIBILIDADE. ART. 620, CPC. CAPITALIZAÇÃO DE JUROS. CORREÇÃO MONETARIA. ENUNCIADOS 5 E 7 DA SUMULA/STJ. RECURSO PARCIALMENTE ACOLHIDO.

I - NÃO PODE O CREDOR, DE FORMA CONCOMITANTE, AJUIZAR DUAS EXECUÇÕES DISTINTAS (UMA CONTRA A DEVEDORA PRINCIPAL, APARELHADA COM O INSTRUMENTO DE CONTRATO, E OUTRA, COM BASE EM PROMISSORIA DADA EM GARANTIA, CONTRA OS AVALISTAS) BUSCANDO HAVER UM MESMO CREDITO.

II - CONDUTA QUE AFRONTA O ART. 620, CPC, E O PRINCIPIO QUE VEDA A UTILIZAÇÃO SIMULTANEA DE DUAS VIAS PROCESSUAIS QUE VISEM A TUTELAS IDENTICAS OU EQUIVALENTES EM SEUS EFEITOS (ELECTA UNA VIA NON DATUR REGRESSUS AD ALTERAM). III - ADMISSIVEL, EM CASOS TAIS, A PROPOSITURA DE UMA UNICA EXECUÇÃO CONTRA AVALIZADA E AVALISTAS, INSTRUMENTALIZADA COM AMBOS OS TITULOS - INSTRUMENTO CONTRATUAL E PROMISSORIA - (ENUNCIADO N. 27 DA SUMULA/STJ), O QUE SE VIABILIZA MESMO QUANDO NÃO FIGUREM OS REFERIDOS AVALISTAS COMO GARANTES SOLIDARIOS NO CONTRATO OU QUANDO O VALOR EXIGIDO COM BASE NESTE SEJA SUPERIOR AO RECLAMADO COM BASE NA CAMBIAL.

IV - A CORREÇÃO MONETARIA SOBRE O VALOR CONSIGNADO NA PROMISSORIA COM VENCIMENTO A VISTA FLUI, COMO REGRA, A PARTIR DO AJUIZAMENTO DA EXECUÇÃO (RESP 32.627-1-RS). NÃO ASSIM, POREM, QUANDO ESTIPULADA EXPRESSAMENTE NA CARTULA SUA INCIDENCIA DESDE A DATA DA EMISSÃO.

$V$ - RESSALVADAS AS HIPOTESES EM QUE ADMITIDO POR LEGISLAÇÃO ESPECIFICA, A EXEMPLO DA QUE DISCIPLINA OS MUTUOS RURAL, INDUSTRIAL E COMERCIAL, O ANATOCISMO É VEDADO"

(STJ, 4 ${ }^{a}$ Turma, REsp 24.242/RS, Rel. Min. Sálvio de Figueiredo Teixeira, DJ 02/10/1995, p. 32364). 
necessário $^{1659}$. A incidência desse dispositivo pressupõe a existência de vários meios executivos, admitidos pela lei ou pelo contrato ${ }^{1660}$, que sejam todos aptos a tutelar adequada e efetivamente o direito de crédito ${ }^{1661}$. É irrelevante a existência, ou não, de culpa do exequente ${ }^{1662}$. De acordo com Pontes de Miranda ${ }^{1663}$, na análise de qual meio executivo é menos prejudicial para o devedor, o juiz deve levar em consideração as dimensões econômica, jurídica e moral, dentre outras (v.g., se o devedor é colecionador de obras de arte, seus quadros e esculturas somente serão penhorados se faltarem outros bens penhoráveis). Se, no caso concreto, não houver um meio mais ameno para o executado, capaz de conduzir à satisfação do exequente, o juiz não tem outra opção que não seja a aplicação do meio severo, pois prevalece o interesse da pessoa que tem um crédito a receber e pode contar apenas com as providências do Poder Judiciário ${ }^{1664}$. Esse dispositivo aplica-se em qualquer execução, seja ela fundada em título judicial ou extrajudicial, qualquer que seja a prestação executada (fazer, não-fazer, dar ou pagar quantia) ${ }^{1665}$. O juiz pode aplicá-lo de ofício ou após requerimento do executado ${ }^{1666}$;

m) de acordo com Yarshell ${ }^{1667}$, a antecipação de prova (ou mecanismos de instrução preliminares) auxilia na prevenção do abuso processual porque permite aos litigantes a ciência prévia de fatos relevantes relacionados à situação substancial controvertida, inibindo, assim, o ajuizamento de demandas fundadas em fatos inverídicos, bem como a resistência a determinada pretensão embasada na negativa da ocorrência de fatos que realmente aconteceram. Em suma, evita-se principalmente a conduta abusiva consistente em violar o dever de veracidade (arts. 14, I; e 17, II, do CPC);

n) os arts. 557, “caput" e $\S 1^{\circ}$-A; e 518, $\S 1^{\circ}$, do CPC, que foram concebidos com o intuito de diminuir a demora na prestação jurisdicional, mas que, de maneira indireta, também servem para evitar o abuso do poder de recorrer, ou, pelo menos, diminuir seus efeitos deletérios (notadamente o aumento do dano marginal). O art. 557, "caput", do CPC,

1659 LUCON, Comentários ao art. 620 do CPC, in MARCATO (coord.), Código de Processo Civil Interpretado, p. 2047; DINAMARCO, Instituições de Direito Processual Civil, vol. IV, § 1.338, p. 64.

${ }_{1660}$ PONTES DE MIRANDA, Comentários ao Código de Processo Civil, tomo X, p. 43.

${ }^{1661}$ BARBOSA MOREIRA, Tendências na Execução de Sentenças e Ordens Judiciais, in Temas de Direito Processual - quarta série, p. 221; DIDIER JUNIOR, Contribuição para o Entendimento do Art. 620 do CPC (Cláusula Geral de Proteção contra o Abuso do Direito pelo Exequente), p. 1.

${ }_{1662}$ PONTES DE MIRANDA, Comentários ao Código de Processo Civil, tomo X, p. 43.

${ }^{1663}$ Comentários ao Código de Processo Civil, tomo X, p. 42.

${ }^{1664}$ DINAMARCO, Instituições de Direito Processual Civil, vol. IV, § 1.338, pp. 63 e 64.

1665 DIDIER JUNIOR, Contribuição para o Entendimento do Art. 620 do CPC (Cláusula Geral de Proteção contra o Abuso do Direito pelo Exequente), p. 2.

1666 PONTES DE MIRANDA, Comentários ao Código de Processo Civil, tomo X, p. 43; LUCON, Comentários ao art. 620 do CPC, in MARCATO (coord.), Código de Processo Civil Interpretado, p. 2047.

${ }^{1667}$ Antecipação da Prova sem o Requisito da Urgência e Direito Autônomo à Prova, pp. 180-181, 157-158 e 205-206. 
após ser alterado pela Lei $\mathrm{n}^{\circ} 9.756 / 98$, passou a estabelecer que o relator tem a faculdade de negar seguimento a recurso manifestamente inadmissível, improcedente, prejudicado ou em contraste com súmula ou com jurisprudência dominante do respectivo tribunal, do Supremo Tribunal Federal, ou de Tribunal Superior. Analogamente, se a decisão recorrida estiver em manifesto contraste com súmula ou com jurisprudência dominante do Supremo Tribunal Federal, ou de Tribunal Superior, o relator pode dar provimento ao recurso, com espeque no $\S 1^{\circ}$-A do art. 557 do CPC, inserido pela mesma Lei $\mathrm{n}^{\circ}$ 9.756/98. O art. 518, $\S$ $1^{\circ}$, acrescentado pela Lei $n^{\circ} 11.276 / 06$, estatui que o juiz não deve receber o recurso de apelação quando a sentença estiver em conformidade com súmula do STJ ou do $\mathrm{STF}^{1668}$;

o) o parágrafo único do art. 134 do CPC, que proíbe o advogado de exercer sua função em processo que já se encontre em andamento, no qual seu cônjuge ou parente atue como juiz. Esse dispositivo impede o causídico de criar dolosamente a hipótese de impedimento do juiz prevista no inciso IV do art. 134 do CPC, com o escopo de obter a suspensão do andamento do processo até o julgamento da exceção (art. 306 do CPC) e, com isso, atrasar o provimento da tutela jurisdicional;

p) o art. 39 do CPC, que obriga o advogado e a parte que postula em causa própria a declararem, na petição inicial ou na contestação, o endereço em que pretendem receber as intimações e a comunicarem ao escrivão qualquer alteração de endereço, sob pena de indeferimento da petição inicial (em caso de descumprimento do primeiro dever, seguido da inércia em suprir a omissão no prazo de 48 horas) e de serem consideradas válidas as intimações enviadas, em carta registrada, para o endereço constante dos autos (na hipótese de violação do segundo dever). Essa norma evita que o litigante dificulte a efetivação da intimação pessoal do advogado, com o fim de opor resistência injustificada ao andamento do processo (art. 17, IV, do CPC);

q) o art. $40, \S 2^{\circ}$ (estatui que, na hipótese de prazo comum às partes, os advogados só podem retirar os autos do processo do cartório ou da secretaria em conjunto ou mediante prévio acordo) e o art. 180, $1^{\mathrm{a}}$ parte, do CPC (prevê a suspensão do curso do prazo em caso de obstáculo criado por uma das partes e a restituição do prazo à parte prejudicada por tempo igual ao que faltava para sua integralização), que garantem que uma parte não crie embaraços para que a outra exerça tempestivamente suas situações jurídicas processuais;

${ }^{1668}$ Segundo Abdo (O Abuso do Processo, pp. 203 e 238-239), esses poderes que os arts. 557 e 518 , $\S 1^{\circ}$, do CPC atribuem ao relator destinam-se a inibir ou reprimir a conduta abusiva dos litigantes.

Similarmente, Marinoni (Antecipação da Tutela, p. 297) afirma que a decisão do relator fundada no art. 557, "caput", do CPC certamente pode desestimular a interposição de recursos abusivos. 
r) o art. 310 do CPC, que atribui ao juiz o poder de indeferir a petição inicial da exceção de incompetência quando a improcedência for manifesta, evitando que a provocação de um incidente manifestamente infundado (art. 17, VI, do CPC) prejudique ainda mais a efetiva prestação da tutela jurisdicional ${ }^{1669}$;

s) os incisos II e III do art. 739 do CPC, que obstam que o abuso do poder de opor embargos do devedor produza mais danos, pois estatuem que o juiz deve rejeitar os embargos quando a petição inicial for inepta, o que inclui a formulação de pedido juridicamente impossível (e, consequentemente, manifestamente infundado); e quando forem manifestamente protelatórios. A rejeição é uma medida preliminar e unilateral, que o magistrado adota de plano, independentemente de contraditório ou oitiva do credor embargado. Trata-se de uma forma de indeferimento da petição inicial ${ }^{1670}$, com força de sentença. Logo, o recurso cabível é o de apelação, nos termos dos arts. 513 e 296 do $\mathrm{CPC}^{1671}$.

Por fim, deve-se mencionar uma espécie singular de normas que previnem implicitamente o abuso do processo, as quais alcançam o seu desiderato por meio da oferta de benefícios à parte que adota um comportamento probo. São elas:

a) o $\S 1^{\circ}$ do art. 1.102-C do CPC, que isenta de custas e de honorários advocatícios o réu que cumpre voluntariamente o mandado monitório, o que configura um estímulo à não-oposição de embargos infundados ou protelatórios ${ }^{1672 ~ 1673 ; ~ e ~}$

\footnotetext{
${ }^{1669} \mathrm{Na}$ Itália, a Lei $\mathrm{n}^{\circ}$ 353/90 alterou a redação do art. 367 do CPC italiano, retirando o efeito suspensivo imediato do exercício do poder de apresentar o "regolamento di giurisdizione". Atualmente, a atribuição dessa eficácia suspensiva é condicionada a uma avaliação discricionária do juízo "a quo" acerca da ausência de manifesta inadmissibilidade ou de manifesta falta de fundamentação do instrumento processual, o que impede o seu uso abusivo para fim procrastinatório do processo (CARPI; COLESANTI; TARUFFO, Commentario Breve al Codice di Procedura Civile, pp. 267 e 287).

${ }^{1670}$ Na opinião de Dinamarco (Instituições de Direito Processual Civil, vol. IV, § 1.783, p. 828), quando o juiz rejeita os embargos em razão de eles serem manifestamente protelatórios, ele pode, conforme o caso: (a) negar sua admissibilidade; ou (b) proferir sentença liminar pela improcedência.

Contudo, "data venia", o art. 739 do CPC não parece fazer qualquer alusão ao julgamento liminar do mérito dos embargos. A única hipótese de julgamento do mérito "initio litis" admitida pelo ordenamento jurídico brasileiro consta do art. 285-A do CPC, cuja incidência em sede de embargos do devedor é admitida por parte da doutrina (SCARPINELLA BUENO, A Nova Etapa da Reforma do Código de Processo Civil, vol. 3, p. 267).

${ }^{1671}$ THEODORO JÚNIOR, Os Embargos do Devedor Após as Reformas do CPC Efetuadas pelas Leis ${ }^{\text {os }}$ 11.232 e 11.382, in Revista Forense, vol. 391, p. 125; THEODORO JÚNIOR, Curso de Direito Processual Civil, vol. II, p. 439; LUCON, Comentários ao art. 739 do CPC, in MARCATO (coord.), Código de Processo Civil Interpretado, p. 2329; ASSIS, Manual da Execução, § 513.2, p. 1242; SCARPINELLA BUENO, A Nova Etapa da Reforma do Código de Processo Civil, vol. 3, p. 267.

${ }^{1672}$ Nesse sentido: MARCATO, O Processo Monitório Brasileiro, p. 83; MARCATO, Procedimentos Especiais, pp. 307-308.

${ }^{1673}$ O Código de Processo Civil projetado (Projeto de Lei no 8.046/2010) não contém norma análoga, pois não prevê o procedimento especial da ação monitória.
} 
b) o parágrafo único do art. 652-A do CPC, que estatui que o pagamento integral do débito nas execuções fundadas em título executivo extrajudicial, feito no prazo de três dias, autoriza a redução "pela metade" da verba honorária inicialmente fixada ${ }^{1674}$, estimulando, igualmente, a não-oposição de embargos do devedor infundados ou protelatórios ${ }^{1675}$.

1674 YARSHELL, Antecipação da Prova sem o Requisito da Urgência e Direito Autônomo à Prova, pp. 201202.

${ }^{1675}$ Se o Projeto de Lei $n^{\circ} 8.046 / 2010$ for aprovado, sancionado e publicado com sua redação atual, essa regra constará do art. 784, $\S 1^{\circ}$, do novo Código de Processo Civil. 


\section{CONCLUSÃO}

As normas de prevenção e repressão da improbidade processual já existiam no Direito romano, no Direito intermédio e abundavam no processo das Ordenações do Reino. No entanto, tratava-se de normas pontuais, que versavam sobre hipóteses específicas de abuso do processo, sem qualquer sistematização. A verdadeira teoria do abuso do processo surgiu como uma derivação da teoria do abuso do direito, oriunda do Direito privado, a qual foi concebida na França e na Bélgica, entre meados do século XIX e o princípio do século XX. Apenas com a adoção desta é que a ciência processual civil passou a ter o cabedal dogmático necessário para ordenar as condutas processuais ímprobas há muito tempo previstas no ordenamento jurídico e reconhecidas pela jurisprudência.

O processo de incorporação da teoria do abuso do direito mostra-se bastante complexo, pois envolve: (a) a identificação das garantias e princípios inerentes ao Direito processual que lhe dão espeque; (b) a adaptação dessa teoria às peculiaridades da relação jurídica processual; e (c) a identificação dos elementos essenciais do abuso do processo.

No ordenamento jurídico brasileiro, a farta previsão legislativa de medidas preventivas e de sanções ao abuso do processo encontra sete ordens de fundamentos:

a) o princípio da inafastabilidade do controle jurisdicional (art. $5^{\circ}, \mathrm{XXXV}$, da $\mathrm{CF}$ );

b) a garantia da razoável duração do processo (art. $5^{\circ}$, LXXVIII, da CF);

c) as garantias da igualdade e da ampla defesa (art. 5', "caput" e LV, da CF);

d) o respeito às finalidades institucionais do processo (os escopos sociais, políticos e jurídico aventados pela doutrina processual instrumentalista);

e) o princípio da boa-fé (art. 14, II, do CPC), que, em sua faceta objetiva, gera o dever de as partes agirem em juízo com lealdade e cooperarem entre si e com o juiz no exercício justo da atividade jurisdicional, servindo de fundamento para a prevenção e a repressão do abuso do processo; e, em sua faceta subjetiva, cria a presunção relativa de que os litigantes atuam no processo com lealdade e probidade, garantindo que o magistrado não exerça com excesso de autoridade sua função preventiva e repressiva de condutas processuais abusivas;

f) o princípio da cooperação, que implica a atribuição de diversos deveres comportamentais aos sujeitos do processo: (1) às partes, os deveres de esclarecimento, de lealdade e de proteção; (2) ao juiz, os deveres de lealdade, de esclarecimento, de prevenção, de consulta e de auxílio; (3) aos auxiliares da justiça, os deveres de não praticar 
atos inúteis, de cumprir os prazos previstos na lei ou fixados pelo juiz, de executar as decisões judiciais e de realizar as diligências necessárias a tal fim, de praticar oficiosamente os atos de que a lei os encarrega diretamente, dentre outros. Excepcionalmente, o legislador atenua o dever de colaboração dos sujeitos processuais, em respeito à defesa legítima da esfera privada, de certos valores morais e de outros interesses relevantes (arts. 347, 363 e 406 do CPC);

g) os deveres gerais dos sujeitos processuais, quais sejam:

1) o dever de veracidade (art. 14, I, do CPC): proíbe a parte de afirmar em juízo fato que sabe ser falso, de impugnar fato que sabe ser verdadeiro e de descrever fato existente, porém sem correspondência exata com a realidade (verdade fática subjetiva). Veda, outrossim, declarações mentirosas sobre certas circunstâncias jurídicas (e.g., a mentira a respeito do teor ou da vigência de norma de Direito municipal, estadual, estrangeiro ou consuetudinário; a citação de precedente judicial inverídico). No Brasil, ele não abrange o dever de completude, ou seja, a obrigação de a parte mencionar não só os elementos fáticos que lhe são favoráveis, mas também aqueles que podem trazer consequências desfavoráveis à sua pretensão. Em regra, somente contraria esse preceito a mentira praticada com dolo. No entanto, quando a parte tem o poder e o dever de investigar determinadas circunstâncias fáticas antes de ajuizar a demanda, a inverdade embasada em imprudência ou em negligência inescusável também contraria o dever de veracidade. Deve-se salientar que o referido dever não é considerado absoluto, uma vez que a mentira é tolerada nos casos em que a declaração da verdade põe em perigo interesses de altíssimo valor (v.g., a vida, a saúde, a liberdade etc.);

2) o dever de lealdade (art. 14, II, do CPC): impõe aos sujeitos processuais a moralidade e a probidade indispensáveis para a consecução das finalidades sócio-políticas do processo e, consequentemente, refreia a sua habilidade e astúcia;

3) o dever de prontidão: determina que as partes exponham suas razões em juízo e proponham suas provas na primeira oportunidade que tiverem para falar nos autos, ou o quanto antes possível, evitando que um dos litigantes surpreenda o outro com lances que este não espera. Trata-se do aspecto temporal do dever de lealdade. Ele é inferido dos ônus estabelecidos pelos arts. 282, III e VI; 283; 300-302; e 396 do CPC, os quais são amainados pela lei (arts. 264, 462, 303 e 397 do CPC), pela doutrina e pela jurisprudência nacionais; e

4) o dever de utilidade: veda o atraso da marcha do processo mediante o emprego de artifícios protelatórios, com o fim de lesar a parte contrária. Ele inspira diversos 
dispositivos do Código de Processo Civil brasileiro, como os arts. 14, IV; 17, I, IV, VI e VII c/c arts. 16 e 18; 29; 31; 130; 400, I e II; 407, parágrafo único; 420, parágrafo único; 426, I; 427; 416, § 1º $453, \S 3^{\text {o }}$; 538, parágrafo único; e 557, § $2^{\circ}$, que impõem aos sujeitos processuais o dever de praticar apenas atos úteis e necessários à declaração ou defesa de suas pretensões e preveem consequências jurídicas negativas para quem o contraria em certas circunstâncias.

Algumas peculiaridades da relação jurídica processual fazem com que o abuso do processo tenha características próprias, que o distinguem do abuso do direito regido pelo Direito civil:

a) o objeto mínimo do abuso do processo são as situações jurídicas subjetivas processuais. Como alguns comportamentos regulados pelo Código de Processo Civil não pressupõem o exercício de qualquer situação jurídica processual, eles não podem ser considerados hipóteses de abuso do processo (v.g., art. 600, I, c/c arts. 593 e 615-A, § 3º; e art. 615-A, $\S 4^{\circ}$ ). Cumpre destacar que a prática do abuso do processo somente pode ocorrer no exercício de situações jurídicas ativas (faculdades e poderes) ou de situação jurídica passiva necessariamente acompanhada de uma situação ativa (exercício concomitante de situações jurídicas);

b) podem praticar abuso do processo apenas os sujeitos da relação jurídica processual, tanto os parciais (partes, litisconsortes, terceiros intervenientes, advogados e membros do Ministério Público, quando ajuízam demandas), quanto os imparciais (juízes, auxiliares da justiça e membros do Ministério Público, quando exercem a atividade de fiscais da lei).

Para que um ato processual seja qualificado como abusivo, é necessário o preenchimento de quatro requisitos cumulativos:

a) aparência de legalidade. Em razão desse requisito, uma conduta processual que viole um dever de maneira patente (por exemplo, as condutas descritas nos seguintes dispositivos do Código de Processo Civil: art. 15 c/c art. 446, III; art. 161; arts. 195, 196 e 197; art. 690-A, parágrafo único; art. 695; arts. 879 a 881), ou que implique o descumprimento de um provimento judicial, de natureza antecipatória ou final (e.g., art. 14, V e parágrafo único; art. 362; arts. 461, §§ $4^{\circ}$ a $6^{\circ} ; 461-A, 475-J$ e 645; e art. 600, III e IV, do CPC), não pode ser considerada hipótese de abuso do processo, pois lhe falta a aparência de licitude;

b) exercício da situação jurídica processual com desvio de finalidade, para atingir escopo ilícito ou ilegítimo. Para que haja abuso do processo, é indispensável que o 
instrumento processual seja utilizado para a obtenção de um fim: (1) distinto do seu escopo típico; e (2) ilícito ou ilegítimo (v.g., consoante os arts. 14; 17; 125, II e III; 129; 538, parágrafo único; $557, \S 2^{\circ}$; e 600 , II, do CPC, as pessoas não podem utilizar o processo para violar os deveres de veracidade, de lealdade ou de boa-fé; para deduzir pretensão ou defesa destituída de fundamentação séria; para praticar ato inútil ou desnecessário à declaração ou defesa de direito; para conseguir objetivo ilegal; para praticar ato simulado; nem para protelar a entrega da tutela jurisdicional ou se opor injustificadamente a ela). Sendo assim, não é correto afirmar que os arts. 475-O, I e II; e 811 do CPC versam sobre abuso processual, uma vez que a produção de danos na esfera jurídica da parte contrária decorre naturalmente do exercício legítimo do poder de promover a execução provisória e do poder de ajuizar a demanda cautelar, inexitindo utilização do remédio processual com desvio de finalidade;

c) eventualmente, o dolo ou a culpa. O elemento subjetivo (dolo ou culpa) só é relevante para caracterizar o abuso do processo quando o legislador expressamente exige do sujeito processual uma atitude psicológica (v.g., arts. 17, VII; e 233 do CPC). Quando a lei silencia a respeito do "animus" (e.g., arts. 17, I; 69, I; 267, § 3º do CPC), o sujeito pode ser punido pela simples prática da conduta abusiva descrita no tipo legal;

d) o dano, que deve ser considerado mais uma consequência natural do abuso do processo que um requisito para sua ocorrência. O comportamento processual abusivo é um ilícito pluriofensivo, uma vez que causa, sempre, dano ao Estado e, eventualmente, lesa o âmbito patrimonial ou o extrapatrimonial da esfera jurídica da parte contrária.

Por outro lado, não são considerados elementos essenciais do ato processual abusivo:

a) o julgamento de improcedência da demanda, já que o indivíduo que tem razão no âmbito do direito substancial pode também cometer uma conduta processual abusiva, hipótese em que não fica imune às sanções previstas na lei;

b) a imperfeição (formal ou não-formal) dos atos processuais. A constatação do desrespeito a algum requisito para a perfeição do ato jurídico processual é apenas um indício de improbidade. Para que se afirme que alguém cometeu uma conduta processual abusiva é forçoso que um ato processual de sua autoria tenha materializado todos os elementos que constituem o suporte fático hipotético de alguma norma que previne ou sanciona expressamente o abuso do processo, acarretando a sua incidência. Caso contrário, a imperfeição (formal ou não-formal) do ato jurídico processual configura apenas um 
vício, que pode ensejar a irregularidade, a ineficácia, a nulidade ou a inexistência do ato jurídico processual, ou ainda impossibilitar ou retardar o julgamento do mérito da causa.

Na classificação dos fatos jurídicos, o lugar certo dos atos processuais abusivos é no grupo dos fatos jurídicos processuais "lato sensu" ilícitos, uma vez que eles vão de encontro a diversas garantias individuais, princípios processuais e deveres gerais dos sujeitos do processo previstos expressamente na Constituição Federal e no Código de Processo Civil, além de desrespeitarem as finalidades institucionais do processo. Ademais, o Código Civil de 2002 considera, expressamente, o ato abusivo como ilícito (art. 187 do $\mathrm{CC})$.

Levando em consideração os supramencionados elementos caracterizadores do abuso do processo, é possível identificar as seguintes hipóteses abusivas previstas no Código de Processo Civil brasileiro, as quais são divididas, didaticamente, de acordo com as situações jurídicas processuais que constituem o objeto do abuso:

a) abuso do processo ou de poder processual mediante a dedução de pretensão ou de defesa contra texto expresso de lei ou fato incontroverso (art. 17, I, do CPC);

b) utilização do processo para conseguir objetivo ilegal (art. 17, III, do CPC);

c) utilização do processo como instrumento para simulação (art. 129 do CPC);

d) violação do dever de veracidade (arts. 17, II; e 233 do CPC);

e) violação do dever de prontidão (arts. $22 ; 113, \S 1^{\circ}$; e $267, \S 2^{\circ}$, do CPC);

f) abuso do poder de nomear à autoria (art. 69 do CPC);

g) utilização de poderes e faculdades processuais para opor resistência injustificada ao andamento do processo (art. 17, IV, do CPC);

h) utilização de poderes e faculdades processuais de modo temerário (art. 17, V, do CPC);

i) abuso do poder de provocar incidentes no processo (art. 17, VI, do CPC);

j) abuso do poder de recorrer (arts. 17, VII; 538, parágrafo único; e 557, § $2^{\circ}$, do CPC);

k) abuso do processo da rescisória (art. 488, II, do CPC);

1) utilização de poderes e faculdades processuais para opor-se maliciosamente à execução (art. 600, II, do CPC);

m) abuso do poder de opor embargos do devedor (art. 740, parágrafo único, do CPC);

n) abuso do poder de se arrepender da arrematação de bem imóvel de incapaz (art. $701, \S 2^{\circ}$, do CPC); 
o) abuso do poder de opor embargos à execução de segunda fase (art. 746, § $3^{\circ}$, do CPC);

p) abuso de poder-dever por magistrado; e

q) abuso de poder-dever por auxiliar da justiça.

Durante a análise dessas "fattispecies" abusivas, constatou-se que parte da doutrina e alguns órgãos jurisdicionais encontram certa dificuldade no reconhecimento dos comportamentos abusivos que configuram atos manifestamente protelatórios (arts. 17, VII; 740, parágrafo único; e 746, $\S 3^{\circ}$, do CPC), confundindo-os, muitas vezes, com os atos que são manifestamente infundados. Mas, para que o intuito manifestamente protelatório fique caracterizado, não basta a manifesta falta de fundamentação jurídica ou fática do ato. É necessário que a esse elemento seja adicionado: (a) o efeito suspensivo do ato ímprobo (seja o efeito de suspender o curso do processo, seja o de suspender a eficácia imediata da decisão recorrida), protelando a tutela jurisdicional efetiva; ou (b) o fato de a parte já ter praticado, anteriormente, no mesmo processo, algum ato manifestamente protelatório (v.g., art. 17, VII; ou art. 538, parágrafo único, do CPC), ou manifestamente infundado (art. 17, VI, do CPC), ou temerário (art. 17, V, do CPC), ou de resistência injustificada ao andamento do processo (art. 17, IV, do CPC).

Consoante a legislação brasileira, a prática do abuso de situações jurídicas processuais acarreta as seguintes consequências jurídicas:

a) reparação de perdas e danos (arts. 16 e 18; 69; 133; 144, II; 147; 150; e 153 do CPC);

b) multa (arts. 18; 233; 488, II; 538, parágrafo único; 557, § 2o ; 601; 701, § 2º 740 , parágrafo único; e $746, \S 3^{\circ}$, do $\mathrm{CPC}$ );

c) pagamento da multa como pressuposto objetivo de admissibilidade de recursos posteriores (art. 538, parágrafo único; e art. 557, § 2º do CPC);

d) obrigação de arcar com o custo do processo (arts. $18 ; 22 ; 29 ; 31 ; 113, \S 1^{\text {o }}$; e $267, \S 3^{\circ}$, do CPC);

e) antecipação de tutela (art. 273, II, do CPC);

f) prolação de sentença que obste ao objetivo das partes de praticar ato simulado ou de conseguir fim ilícito por meio do processo (art. 129 do CPC);

g) cabimento de ação rescisória, com fundamento nos incisos III, IV e, eventualmente, I, V e VI do art. 485 do CPC;

h) relativização da coisa julgada;

i) nulidade do ato processual (v.g., art. $247 \mathrm{c} / \mathrm{c}$ art. 233 do CPC); e 
j) remoção do inventariante (art. 995, II e VI, do CPC).

As normas sancionatórias do abuso do processo podem ser aplicadas de ofício pelo órgão jurisdicional. Porém, antes de fazê-lo, o juízo deve oferecer oportunidade de manifestação nos autos à parte acusada de atuar de maneira ímproba, ainda que a má-fé seja evidente, ou que o abuso do processo seja patente, respeitando, assim, a garantia constitucional do contraditório (art. 5 ${ }^{\circ}, \mathrm{LV}$, da CF).

Constata-se que algumas sanções pelo cometimento de abuso de situações jurídicas processuais são aplicadas de ofício pelos Tribunais de segunda instância e superiores, e que as decisões que as cominam só podem ser atacadas por meio de recursos extraordinários (recurso especial e, excepcionalmente, recurso extraordinário), sendo, em alguns casos, até irrecorríveis (por exemplo, se a sanção for imposta pelo próprio Supremo Tribunal Federal). Isso ocorre ao arrepio do princípio do duplo grau de jurisdição. Porém, não se trata de um ato inconstitucional, uma vez que tem espeque na garantia constitucional do acesso à tutela jurisdicional efetiva e tempestiva (art. $5^{\circ}, \mathrm{XXXV}$ e LXXVIII, da CF).

É lícita a aplicação de sanções de espécies diferentes para punir a prática de um mesmo ato processual abusivo (e.g., a multa do art. 538, parágrafo único, do CPC e o dever de indenizar dos arts. 16 e 18 do CPC). Porém, veda-se a soma de penas de natureza idêntica, pois configuraria "bis in idem". Nesse caso, a pena específica prevalece sobre a genérica (v.g., se forem opostos embargos de declaração manifestamente protelatórios, deve-se aplicar apenas a multa do art. 538, parágrafo único, do CPC, não incidindo a do art. $18 \mathrm{c} / \mathrm{c}$ art. 17, VII, do CPC).

Em respeito ao princípio da legalidade e à garantia do "due process of law" (art. 50, LIV, da CF), o órgão jurisdicional não pode:

a) impor sanção prevista no ordenamento jurídico sem qualquer fundamentação ou com motivação deficiente (art. 93, IX, da CF e art. 458, II, do CPC), ou seja, sem indicar: (1) o ato processual concreto a ser punido; e (2) a hipótese de abuso típica na qual haja incorrido o sujeito processual;

b) cominar sanção prevista no ordenamento jurídico, mas fora das hipóteses de incidência descritas na lei;

c) punir atos processuais abusivos mediante outros instrumentos que não as sanções consignadas na lei (v.g., reprimir a oposição de embargos de declaração manifestamente protelatórios por meio da negativa de seu efeito interruptivo do prazo para a interposição de outros recursos; utilizar os honorários advocatícios como sanção à prática de atos processuais abusivos). 
De acordo com o ordenamento jurídico atual, quando o advogado que postula com procuração comete um ato processual abusivo, é sobre a parte patrocinada por ele em juízo que recaem as sanções. Cabe a esta, em um segundo momento, depois de já ter sido condenada ao pagamento da multa e ao ressarcimento das perdas e danos, ajuizar:

a) demanda regressiva, pleiteando o ressarcimento de todo o prejuízo que sofreu em razão da improbidade processual dolosa ou culposa do causídico, desde que não tenha nem mesmo concorrido para a prática do comportamento abusivo (arts. 17 e 32, "caput", da Lei $\mathrm{n}^{\mathrm{o}} 8.906 / 94$ e, para alguns doutrinadores, art. $14, \S 4^{\circ}$, da Lei $\mathrm{n}^{\circ} 8.078 / 90$; ou art. $37, \S 6^{\circ}$, $2^{\mathrm{a}}$ parte, da CF, no caso dos advogados públicos); ou

b) demanda pleiteando a responsabilidade solidária do seu procurador, caso tenhase unido em conluio com este para praticar a conduta processual ímproba (art. 32, parágrafo único, da Lei no $8.906 / 94)$.

Não é correto condenar o advogado ao pagamento de multa e ao ressarcimento de perdas e danos, isoladamente ou em solidariedade com a parte por ele representada, no mesmo processo no qual a conduta abusiva foi praticada. As únicas providências que o órgão jurisdicional pode (e deve) tomar com relação ao profissional ímprobo são: (a) determinar a perda do direito aos honorários advocatícios, se tiver praticado alguma das condutas previstas no art. 17 ou no art. 22 do CPC, contanto que a parte sua cliente tenhase consagrado vencedora na causa (arts. 18, “caput”, e 22 do CPC); e (b) oficiar à Ordem dos Advogados do Brasil, comunicando os fatos.

Dado que a mera cominação de sanções não se mostra suficiente para que os sujeitos do processo deixem de abusar de situações jurídicas processuais, o ordenamento jurídico prevê também medidas processuais preventivas, cuja principal função é evitar a efetivação de atos abusivos ou, pelo menos, diminuir os efeitos nocivos da improbidade processual. Elas são classificadas em dois grandes grupos:

a) os remédios preventivos explícitos, que constam dos arts. 125, II e III; 599, II; 130; 129; 342; 382; 399, I; 440; 83, II; 488, II, c/c 490, II; e 273, II, do CPC; e

b) os remédios preventivos implícitos, como a atribuição do custo financeiro do processo às partes, os institutos da execução provisória (art. 475-O do CPC), da preclusão e da antecipação de prova, além das normas previstas nos arts. $8^{\circ}$ e 38, "caput"; 134 a 138; 131, 165 e 458, II; 405, 413-415 e 418, II; 60, 193-194, 198-199, 338, 400, 407, parágrafo único, 421, “caput”, c/c 432, e 453; 263, II e III; 499, § 1; 355 e ss.; 295, 330, I, e 285-A; 620; 557, “caput” e $\S 1^{\circ}$-A, e $518, \S 1^{\text {o }} ; 134$, parágrafo único; 39; 40, § 2º e 180; 310; 739, II e III, do CPC etc. Dentre esses mecanismos implícitos, merecem destaque as normas 
processuais que previnem o abuso mediante a oferta de benefícios à parte que adota um comportamento probo (v.g., os arts. 1.102-C, $\S 1^{\text {o }}$; e 652-A, parágrafo único, do CPC).

Ante o exposto, resta aguardar que todos os indivíduos que figuram como partes e advogados em processos se conscientizem da necessidade de proceder em juízo de maneira proba, cooperando entre si e com o juiz no exercício justo da atividade jurisdicional. Espera-se também que o Estado-juiz utilize os instrumentos processuais que ele já tem à sua disposição para combater e prevenir eventuais condutas abusivas que essas pessoas venham a praticar, mas sempre sem menosprezar as garantias do contraditório e da ampla defesa.

Quando todos os litigantes cumprirem os deveres de lealdade e boa-fé processual, e todos os magistrados estiverem cientes da relevância do seu papel na repressão e prevenção do abuso de situações jurídicas processuais, o Poder Judiciário brasileiro terá melhores condições para conceder tutelas jurisdicionais efetivas e tempestivas às demandas que lhe são apresentadas, concretizando, assim, as garantias constitucionais da inafastabilidade do controle jurisdicional (art. $5^{\circ}, \mathrm{XXXV}$, da $\mathrm{CF}$ ) e da duração razoável do processo (art. $5^{\circ}$, LXXVIII, da CF). 


\section{REFERÊNCIAS BIBLIOGRÁFICAS}

ABDO, Helena Najjar. O Abuso do Processo. São Paulo: Revista dos Tribunais, 2007.

O Ato Atentatório à Dignidade da Justiça na Nova Execução Civil. Disponível em: <http://www.marcatoadvogados.com.br/sdi/paginas/imagens/arquivo 40.pdf>. Acesso em: 15/03/2011.

AFONSO DA SILVA, José. Curso de Direito Constitucional Positivo. $24^{\mathrm{a}}$ ed. São Paulo: Malheiros, 2005.

ALBUQUERQUE, Pedro de. Responsabilidade Processual por Litigância de Má Fé, Abuso de Direito e Responsabilidade Civil em Virtude de Actos Praticados no Processo. Coimbra: Almedina, 2006.

ALENCAR RODRIGUES, Douglas. A Litigância de Má-Fé e o Direito do Trabalho. Disponível em: <http://www.buscalegis.ufsc.br/revistas/files/anexos/22767-22769-1PB.htm>. Acesso em: 15/11/2012.

ÁLVAREZ, Óscar Silva. La Ejecución Provisional de las Sentencias. In Revista de Derecho de la Pontificia Universidad Católica de Valparaíso, no 31, pp. 369-402, $2^{\circ}$ sem. 2008.

ALVARO DE OLIVEIRA, Carlos Alberto. Poderes do Juiz e Visão Cooperativa do Processo. In Revista da AJURIS, nº 90, pp. 55-84, jun. 2003.

ALVIM, Arruda. Tratado de Direito Processual Civil. vol. 2. $2^{\mathrm{a}}$ ed. São Paulo: Revista dos Tribunais, 1996.

ALVIM WAMBIER, Teresa Arruda (coord.). Aspectos Polêmicos da Nova Execução - 3: de títulos judiciais - Lei 11.232/2005. São Paulo: Revista dos Tribunais, 2006.

AMERICANO, Jorge. Do Abuso do Direito no Exercício da Demanda. $2^{\mathrm{a}}$ ed. São Paulo: Saraiva e Cia., 1932.

AMIRANTE, Luigi. Giuramento (Diritto Romano). In Novissimo Digesto Italiano. vol. VII. Torino: Tipografia Sociale Torinese, 1961, pp. 937-942.

. Giuramento (Diritto Intermedio). In Novissimo Digesto Italiano. vol. VII.

Torino: Tipografia Sociale Torinese, 1961, pp. 942-943.

AMORIM SILVA, Luiz Antonio Miranda. O Contempt of Court no Direito Processual Civil Brasileiro. In Revista de Processo, nº 191, pp. 83-123, jan. 2011.

ANDREWS, Neil. Abuse of Process in English Civil Litigation. In TARUFFO, Michele (ed.). Abuse of Procedural Rights: comparative standards of procedural fairness. The Hague; London; Boston: Kluwer Law International, 1999, pp. 65-99.

ANTUNES VARELA, João de Matos; BEZERRA, José Miguel; SAMPAIO E NORA. Manual de Processo Civil. $2^{\mathrm{a}}$ ed. Coimbra: Coimbra, 1985. 
ASCENSÃO, José de Oliveira. A Desconstrução do Abuso do Direito. In Revista de Direito do Tribunal de Justiça do Estado do Rio de Janeiro, n ${ }^{\circ}$ 66, pp. 60-82, jan./fev./mar. 2006.

ASSIS, Araken de. Cumprimento da Sentença. Rio de Janeiro: Forense, 2006.

. Manual da Execução. 12a ed. São Paulo: Revista dos Tribunais, 2009.

O Contempt of Court no Direito Brasileiro. Disponível em: <http://www. abdpc.org.br/abdpc/artigos/Araken\%20de\%20Assis\%284\%29\%20-\%20formatado.pdf>. Acesso em: 16/09/2012.

ASSIS, Carlos Augusto de. A Antecipação da Tutela (à Luz da Garantia Constitucional do Devido Processo Legal). São Paulo: Malheiros, 2001.

AZEVEDO, Luiz Carlos de; TUCCI, José Rogério Cruz e. Lições de História do Processo Civil Romano. São Paulo: Revista dos Tribunais, 1996.

Paulo: Revista dos Tribunais, 2009.

Lições de História do Processo Civil Lusitano. São

BAPTISTA DA SILVA, Ovídio Araújo. Comentários ao Código de Processo Civil. vol. 1. $2^{\text {a }}$ ed. São Paulo: Revista dos Tribunais, 2005.

. Coisa Julgada e Efeitos da Sentença. In BAPTISTA DA SILVA, Ovídio A.; GOMES, Fábio. Teoria Geral do Processo Civil. $2^{\mathrm{a}}$ ed. São Paulo: Revista dos Tribunais, 2000, pp. 322-332.

; GOMES, Fábio Luiz. Teoria Geral do Processo Civil. $4^{\mathrm{a}}$ ed. São Paulo: Revista dos Tribunais, 2006.

BARBI, Celso Agrícola. Comentários ao Código de Processo Civil. vol. I. 14 a ed. Rio de Janeiro: Forense, 2010.

BARBOSA MOREIRA, José Carlos. O Juízo de Admissibilidade no Sistema dos Recursos Civis. Rio de Janeiro: S.N., 1968.

. A Responsabilidade das Partes por Dano Processual no Direito Brasileiro. In Temas de Direito Processual. São Paulo: Saraiva, 1977, pp. 16-35.

Convenções das Partes sobre Matéria Processual. In Temas de Direito Processual - terceira série. São Paulo: Saraiva, 1984, pp. 87-98.

. Eficácia da Sentença e Autoridade da Coisa Julgada. In Temas de Direito Processual - terceira série. São Paulo: Saraiva, 1984, pp. 99-113.

Coisa Julgada e Declaração. In Temas de Direito Processual - primeira série. $2^{a}$ ed. São Paulo: Saraiva, 1988, pp. 81-89. 
. Tendências na Execução de Sentenças e Ordens Judiciais. In Temas de Direito Processual - quarta série. São Paulo: Saraiva, 1989, pp. 215-241.

110, jan./mar. 2003.

. Abuso do Direito. In Revista Trimestral de Direito Civil. vol. 13, pp. 97-

- Considerações sobre a Chamada "Relativização da Coisa Julgada Material”. In Revista Síntese de Direito Civil e Processual Civil, no 33, pp. 5-28, jan./fev. 2005.

Forense, 2006.

. Comentários ao Código de Processo Civil. vol. V. 13ª ed. Rio de Janeiro:

O Novo Processo Civil Brasileiro. 26 a ed. Rio de Janeiro: Forense, 2008.

BARRETO, Cunha. O Dirigismo na Vida dos Contratos. In Revista Forense, vol. 77, pp. 252-256, fev. 1939.

BARRoS, Marco Antonio de. A Busca da Verdade no Processo Penal. $2^{\mathrm{a}}$ ed. São Paulo: Revista dos Tribunais, 2010.

BEAUMONT, Bryan. Report on Abuse of Procedural Rights for Australia. In TARUFFO, Michele (ed.). Abuse of Procedural Rights: comparative standards of procedural fairness. The Hague; London; Boston: Kluwer Law International, 1999, pp. 101-107.

BEDAQUE, José Roberto dos Santos. Os Elementos Objetivos da Demanda Examinados à Luz do Contraditório. In CRUZ E TUCCI, José Rogério; BEDAQUE, José Roberto dos Santos. Causa de Pedir e Pedido no Processo Civil: questões polêmicas. São Paulo: Revista dos Tribunais, 2002, pp. 13-52.

. Efetividade do Processo e Técnica Processual. São Paulo: Malheiros,

2006 .

. Comentários ao art. 18 do CPC. In MARCATO, Antonio Carlos (coord.). Código de Processo Civil Interpretado. $3^{\mathrm{a}}$ ed. São Paulo: Atlas, 2008, pp. 63-65.

. Comentários ao art. 69 do CPC. In MARCATO, Antonio Carlos (coord.). Código de Processo Civil Interpretado. $3^{\mathrm{a}}$ ed. São Paulo: Atlas, 2008, p. 146.

. Comentários ao art. 85 do CPC. In MARCATO, Antonio Carlos (coord.). Código de Processo Civil Interpretado. $3^{\mathrm{a}}$ ed. São Paulo: Atlas, 2008, p. 188.

- Comentários ao art. 133 do CPC. In MARCATO, Antonio Carlos (coord.). Código de Processo Civil Interpretado. $3^{\text {a }}$ ed. São Paulo: Atlas, 2008, p. 392.

Comentários ao art. 273 do CPC. In MARCATO, Antonio Carlos (coord.). Código de Processo Civil Interpretado. $3^{\mathrm{a}}$ ed. São Paulo: Atlas, 2008, pp. 824849 . 
Tutela Cautelar e Tutela Antecipada - Tutelas Sumárias e de Urgência (Tentativa de Sistematização). $5^{\text {a }}$ ed. São Paulo: Malheiros, 2009.

2009.

. Poderes Instrutórios do Juiz. $4^{\mathrm{a}}$ ed. São Paulo: Revista dos Tribunais,

BERALDO, Maria Carolina Silveira. O Comportamento dos Sujeitos Processuais como Obstáculo à Razoável Duração do Processo. 2010. Dissertação (Mestrado) - Faculdade de Direito, Universidade de São Paulo, São Paulo.

O Dever de Cooperação no Processo Civil. In Revista de Processo, $\mathrm{n}^{\circ}$ 198, pp. 455-462, ago. 2011.

BEVILAQUA, Clóvis. Código Civil dos Estados Unidos do Brasil Comentado. vol. 5. 9a ed. Rio de Janeiro: Francisco Alves, 1954.

. Código Civil dos Estados Unidos do Brasil Comentado. vol. 1. 12 $12^{\mathrm{a}} \mathrm{ed}$. Rio de Janeiro: Francisco Alves, 1959.

BONICIO, Marcelo José Magalhães. Análise do Sistema das Multas Previstas no Código de Processo Civil. In Revista de Processo, n 118, pp. 29-40, nov./dez. 2004.

- Proporcionalidade e Processo: a garantia constitucional da proporcionalidade, a legitimação do processo civil e o controle das decisões judiciais. São Paulo: Atlas S.A., 2006.

. Introdução ao Processo Civil Moderno. São Paulo: Lex, 2009.

. Ensaio sobre o Dever de Colaboração das Partes Previsto no Projeto do Novo Código de Processo Civil Brasileiro. In Revista de Processo, n 190, pp. 210-230, dez. 2010.

BONIFACIO, Franco. Infitiatio. In Novissimo Digesto Italiano. vol. VIII. Torino: Tipografia Sociale Torinese, 1962, pp. 655-656.

. Revocatio in Duplum. In Novissimo Digesto Italiano. vol. XV. Torino: Tipografia Sociale Torinese, 1968, pp. 820-821.

BOUlos, Daniel Martins. Abuso do Direito no Novo Código Civil. São Paulo: Método, 2006.

BRAGA, Paula Sarno. Primeiras Reflexões sobre uma Teoria do Fato Jurídico Processual - plano de existência. In DIDIER JÚNIOR, Fredie; EHRHARDT JÚNIOR, Marcos (coords.). Revisitando a Teoria do Fato Jurídico: homenagem a Marcos Bernardes de Mello. São Paulo: Saraiva, 2010, pp. 445-474.

BRAGA NETTO, Felipe Peixoto. Teoria dos Ilícitos Civis. Belo Horizonte: Del Rey, 2003. 
BRASIELLO, Ugo. Infamia (Diritto Romano). In Novissimo Digesto Italiano. vol. VIII. Torino: Tipografia Sociale Torinese, 1962, pp. 641-643.

BUENO, Júlio César. Contribuição ao Estudo do Contempt of Court e seus Reflexos no Processo Civil Brasileiro. 2001. Tese (Doutorado) - Faculdade de Direito, Universidade de São Paulo, São Paulo.

BUENO VIDIGAL, Luís Eulálio de. Comentários ao Código de Processo Civil. vol. 6. $2^{\mathrm{a}}$ ed. São Paulo: Revista dos Tribunais, 1976.

BUZAID, Alfredo. Do Agravo de Petição no Sistema do Código de Processo Civil. $2^{\mathrm{a}}$ ed. São Paulo: Saraiva, 1956.

pp. 92-99, jul./set. 1987.

Processo e Verdade no Direito Brasileiro. In Revista de Processo, n 47 ,

BUZZACCHI, Chiara. L'Abuso del Processo nel Diritto Romano. Milano: Giuffrè, 2002.

CAHALI, Yussef Said. Honorários Advocatícios. $2^{a}$ ed. São Paulo: Revista dos Tribunais, 1990.

CALAMANDREI, Piero. Instituciones de Derecho Procesal Civil: según el nuevo código. Buenos Aires: Editorial Depalma, 1943.

. Sul Progetto Preliminare Solmi. In Opere Giuridiche. vol. I. Napoli: Morano, 1965, pp. 295-385.

. Verità e Verosimiglianza nel Processo Civile. In Opere Giuridiche. vol. V. Napoli: Morano, 1972, pp. 615-640.

CALOGERO, Guido. Probità, Lealtà, Veridicità nel Processo Civile. In Rivista di Diritto Processuale Civile, vol. XVI, parte I, pp. 129-153, 1939.

CAPPELlETTI, Mauro. La Testimonianza della Parte nel Sistema dell'Oralità. vol. I. Milano: Dott. A. Giuffrè, 1962.

. El Principio Dispositivo y sus Principales Manifestaciones. In El Proceso Civil en el Derecho Comparado. Buenos Aires: Ediciones Juridicas Europa-America, 1973, pp. 1-39.

; GARTH, Bryant. Acesso à Justiça. Porto Alegre: Fabris, 1988.

CARMONA, Carlos Alberto. Comentários ao art. 599 do CPC. In MARCATO, Antonio Carlos (coord.). Código de Processo Civil Interpretado. $3^{\mathrm{a}}$ ed. São Paulo: Atlas, 2008, pp. 1960-1961.

Comentários ao art. 600 do CPC. In MARCATO, Antonio Carlos (coord.). Código de Processo Civil Interpretado. $3^{\mathrm{a}}$ ed. São Paulo: Atlas, 2008, pp. 19611963. 
Comentários ao art. 601 do CPC. In MARCATO, Antonio Carlos (coord.). Código de Processo Civil Interpretado. $3^{\mathrm{a}}$ ed. São Paulo: Atlas, 2008, pp. 19631965.

CARNEIRO DA CUNHA, Leonardo José. A Fazenda Pública em Juízo. $3^{\text {a }}$ ed. São Paulo: Dialética, 2005.

CARNELUTTI, Francesco. Contro il Processo Fraudolento. In Studi di Diritto Processuale. vol. II. Padova: CEDAM, 1928, pp. 23-36.

. Sistema di Diritto Processuale Civile. vol. I. Padova: CEDAM, 1936.

Argentina, 1944.

. Sistema de Derecho Procesal Civil. vol. II. Buenos Aires: UTEHA

1971.

. Derecho y Proceso. Buenos Aires: Ediciones Jurídicas Europa-América,

CARPI, Federico; COLESANTI, Vittorio; TARUFFO, Michele. Commentario Breve al Codice di Procedura Civile. $4^{\mathrm{a}}$ ed. Padova: CEDAM, 2002.

CARRILHO LOPES, Bruno Vasconcelos. Tutela Antecipada Sancionatória (art. 273, inc. II, do Código de Processo Civil). São Paulo: Malheiros, 2006.

. Honorários Advocatícios no Processo Civil. São Paulo: Saraiva, 2008.

CARVAlHO FILHO, José dos Santos. Manual de Direito Administrativo. $21^{\mathrm{a}}$ ed. Rio de Janeiro: Lumen Juris, 2009.

CASTRO FILHO, José Olímpio de. Abuso do Direito no Processo Civil. $2^{\mathrm{a}}$ ed. Rio de Janeiro: Forense, 1960.

CATALANO, Elena Maria. L’Abuso del Processo. Milano: Giuffrè, 2004.

CHIOVENDA, Giuseppe. La Condanna nelle Spese Giudiziali. 2a ed. Roma: Società Editrice del "Foro Italiano", 1935.

. Principios de Derecho Procesal Civil. tomo II. Madrid: REUS, 2000.

Bookseller, 2000.

Instituições de Direito Processual Civil. vol. I. $2^{\mathrm{a}}$ ed . Campinas:

CINTRA, Antônio Carlos de Araújo; DINAMARCO, Cândido Rangel; GRINOVER, Ada Pellegrini. Teoria Geral do Processo. 21 a ed. São Paulo: Malheiros, 2005.

COMOGLIO, Luigi Paolo. Abuso del Processo e Garanzie Costituzionali. In Rivista di Diritto Processuale, Ano 63, nº 2, pp. 319-354, mar./abr. 2008.

; FERRI, Corrado; TARUFFO, Michele. Lezioni sul Processo Civile. $2^{\mathrm{a}}$ ed. Bologna: Il Mulino, 1998. 
CONRADI, Faustino Gutiérrez-Alviz (coord.). El Abuso del Proceso: mala fe y fraude de ley procesal. Madrid: Consejo General del Poder Judicial, 2006.

CORDOPATRI, Francesco. L'Abuso del Processo e la Condanna alle Spese. In Rivista Trimestrale di Diritto e Procedura Civile, v. 59, nº 1, pp. 249-280, mar. 2005.

COSTA MACHADO, Antônio Cláudio da. Tutela Antecipada. São Paulo: Oliveira Mendes, 1998.

COUTURE, Eduardo Juan. Fundamentos do Direito Processual Civil. São Paulo: Saraiva, 1946.

Revocación de los Actos Procesales Fraudulentos. In Estudios de

Derecho Procesal Civil. t. III. Buenos Aires: Ediciones Depalma, 1978, pp. 385-416.

CRETElla JR., J.; CRETELlA, Agnes. Institutas do Imperador Justiniano. $2^{\text {a }}$ ed. São Paulo: Revista dos Tribunais, 2005.

CRUZ E TUCCI, José Rogério. Lineamentos da Nova Reforma do CPC. $2^{\mathrm{a}}$ ed. São Paulo: Revista dos Tribunais, 2002.

. Duração Razoável do Processo (Art. 5, LXXVIII, da Constituição Federal). In MARTINS, Ives Gandra da Silva; JOBIM, Eduardo (coords.). O Processo na Constituição. São Paulo: Quartier Latin, 2008, pp. 321-342.

Lex, 2010.

(coord.). Direito Processual Civil Americano Contemporâneo. São Paulo:

CUNHA, Oscar da. O Dolo e o Direito Judiciário Civil. Rio de Janeiro: Jornal do Commercio, 1936.

CUNHA DE SÁ, Fernando Augusto. Abuso do Direito. Lisboa: Centro de Estudos Fiscais da Direcção-Geral das Contribuições e Impostos, Ministério das Finanças, 1973.

DALL'AGNOL JUNIOR, Antonio Janyr. O Princípio Dispositivo no Pensamento de Mauro Cappelletti. In Lex - Jurisprudência dos Tribunais de Alçada Civil de São Paulo, vol. 119, pp. 11-26, jan./fev. 1990.

DENARI, Zelmo. Da Qualidade de Produtos e Serviços, da Prevenção e da Reparação dos Danos (arts. $8^{\circ}$ a 28 do CDC). In GRINOVER, Ada Pellegrini "et alii". Código de Defesa do Consumidor: comentado pelos autores do anteprojeto. $9^{\mathrm{a}}$ ed. Rio de Janeiro: Forense Universitária, 2007, pp. 171-250.

DENTI, Vittorio. Negozio Processuale. In Enciclopedia del Diritto. vol. XXVIII. Milano: Giuffrè, 1978, pp. 138-145.

DIDIER JUNIOR, Fredie. O Princípio da Cooperação: uma apresentação. In Revista de Processo, $\mathrm{n}^{\circ}$ 127, pp. 75-79, set. 2005. 
; EHRHARDT JÚNIOR, Marcos (coords.). Revisitando a Teoria do Fato Jurídico: homenagem a Marcos Bernardes de Mello. São Paulo: Saraiva, 2010.

; NOGUEIRA, Pedro Henrique Pedrosa. Teoria dos Fatos Jurídicos Processuais. Salvador: JusPODIVM, 2011.

- Os Três Modelos de Direito Processual: inquisitivo, dispositivo e cooperativo. In Revista de Processo, no 198, pp. 213-225, ago. 2011.

Contribuição para o Entendimento do Art. 620 do CPC (Cláusula Geral de Proteção contra o Abuso do Direito pelo Exequente). Disponível em: <http://www. frediedidier.com.br/wp-content/uploads/2012/09/Contribuição-para-o-entendimento-doart.-620-do-CPC-cláusula-geral-de-proteção-contra-o-abuso-do-direito-peloexequente ${ }^{1}$.pdf $>$. Acesso em: 15/10/2012.

. Editorial 22. Disponível em: <http://www.frediedidier.com.br/editorial/ editorial-22/>. Acesso em: 28/09/2012.

. Editorial 122. Disponível em: <http://www.frediedidier.com.br/editorial/ editorial-122/>. Acesso em: 26/09/2012.

DINAMARCO, Cândido Rangel. A Execução na Teoria Geral do Direito Processual Civil. 1972. Tese (Livre-docência) - Faculdade de Direito, Universidade de São Paulo, São Paulo.

. A Reforma da Reforma. $6^{\mathrm{a}}$ ed. São Paulo: Malheiros, 2003.

. O Regime Jurídico das Medidas Urgentes. In Nova Era do Processo Civil. $2^{\text {a }}$ ed. São Paulo: Malheiros, 2007, pp. 58-113.

. Relativizar a Coisa Julgada Material. In Nova Era do Processo Civil. $2^{\mathrm{a}}$ ed. São Paulo: Malheiros, 2007, pp. 217-270.

. Ação Rescisória contra Decisão Interlocutória. In Nova Era do Processo Civil. 2a ed. São Paulo: Malheiros, 2007, pp. 284-293.

$\overline{\text { Malheiros, } 2009 .}$

Instituições de Direito Processual Civil. vol. I. $6^{\text {a }}$ ed. São Paulo:

Malheiros, 2009.

Instituições de Direito Processual Civil. vol. II. 6 ${ }^{\text {a }}$ ed. São Paulo:

$\overline{\text { Malheiros, } 2009 .}$

Instituições de Direito Processual Civil. vol. III. 6 $6^{\text {a }}$ ed. São Paulo:

Instituições de Direito Processual Civil. vol. IV. $3^{\mathrm{a}}$ ed. São Paulo:

$\overline{\text { Malheiros, } 2009 .}$

. A Instrumentalidade do Processo. 14 ${ }^{\mathrm{a}}$ ed. São Paulo: Malheiros, 2009. 
DONDI, Angelo. Effettività dei Provvedimenti Istruttori del Giudice Civile. Padova: CEDAM, 1985.

. Cultura dell' Abuso e Riforma del Processo Civile Negli Stati Uniti. In Rivista di Diritto Processuale, Ano 50, no 3, pp. 787-808, jul./set. 1995.

Abuse of Procedural Rights: regional report for Italy and France. In TARUFFO, Michele (ed.). Abuse of Procedural Rights: comparative standards of procedural fairness. The Hague; London; Boston: Kluwer Law International, 1999, pp. 109-124.

; GIUSSANI, Andrea. Appunti sul Problema dell'Abuso del Processo Civile nella Prospettiva de Iure Condendo. In Rivista Trimestrale di Diritto e Procedura Civile, vol. 61, nº 1, pp. 193-198, mar. 2007.

DONDINA, Mario. Atti Processuali (civili e penali). In Novissimo Digesto Italiano. vol. I. t. II. Torino: Tipografia Sociale Torinese, 1958, pp. 1515-1521.

DORIA, Rogéria Dotti. A Litigância de Má-Fé e a Aplicação de Multas. In MARINONI, Luiz Guilherme (coord.). Estudos de Direito Processual Civil - homenagem ao professor Egas Dirceu Moniz de Aragão. São Paulo: Revista dos Tribunais, 2005, pp. 648-655.

ENCINAS, Emilio Eiranova; MÍGUEZ, Miguel Lourido. Código Procesal Civil Alemán. Madrid: Marcial Pons, 2001.

ESTEVAN FERNANDES, Márcio. Condenação Solidária de Advogado com Cliente em Lide Temerária e o Projeto de Lei $n^{o}$ 4.074/08. Disponível em: <http://www.epm.tjsp.jus. br/Internas/ArtigosView.aspx?ID=2934>. Acesso em: 21/08/2012.

Litigância de Má-Fé: razoável duração do processo que decorre da responsabilização de quem dela se vale. Disponível em: <http://www.amb.com.br/portal/ docs/artigos/litigancia-de-ma-fe.pdf $>$. Acesso em: 21/08/2012.

FALCO, Gianluca. La Buona Fede e l'Abuso del Diritto: principi, fattispecie e casistica. Milano: Dott. A. Giuffrè, 2010.

FAZZALARI, Elio. Instituições de Direito Processual. Campinas: Bookseller, 2006.

FENTIMAN, Richard. Abuse of Procedural Rights: the position of English Law. In TARUFFO, Michele (ed.). Abuse of Procedural Rights: comparative standards of procedural fairness. The Hague; London; Boston: Kluwer Law International, 1999, pp. 5364.

FERNANDES DE SOUZA, Luiz Sergio. Abuso de Direito Processual - uma teoria pragmática. São Paulo: Revista dos Tribunais, 2005.

FIDELIS, Andressa Lin. Sham Litigation e o Sistema Brasileiro de Defesa da Concorrência. Disponível em: <http://www.sbdp.org.br/artigos_ver.php?idConteudo=80>. Acesso em: 30/05/2011. 
FRAGA, Affonso. Instituições do Processo Civil do Brasil. tomo II. São Paulo: Saraiva e Cia., 1940.

GERALDES, António Santos Abrantes. Temas da Reforma do Processo Civil. vol. I. $2^{\text {a }}$ ed. Coimbra: Almedina, 1998.

GOLDSCHMIDT, James. Teoría General del Proceso. Barcelona - Madrid - Buenos Aires - Rio de Janeiro: Editorial Labor S.A., 1936.

GOMES, Orlando. Introdução ao Direito Civil. 20ª ed. Rio de Janeiro: Forense, 2010.

GRASSO, Eduardo. La Collaborazione nel Processo Civile. In Rivista di Diritto Processuale, vol. XXI, pp. 580-609, 1966.

GRECO, Leonardo. Garantias Fundamentais do Processo: o processo justo. Disponível em : <http://www.mundojuridico.adv.br/cgi-bin/upload/texto165(1).doc>. Acesso em: 01/07/2012.

GRECO FILHO, Vicente. Direito Processual Civil Brasileiro. vol. I. 17 ${ }^{\text {a }}$ ed. São Paulo: Saraiva, 2003.

. Direito Processual Civil Brasileiro. vol. II. 20ª ed. São Paulo: Saraiva,

2009.

2009.

. Direito Processual Civil Brasileiro. vol. III. 20ª ed. São Paulo: Saraiva,

GREIF, Jaime. El Abuso del Derecho y la Responsabilidad Civil Emergente en el Derecho Uruguayo. In BARBOSA MOREIRA, José Carlos (coord.). Abuso dos Direitos Processuais. Rio de Janeiro: Forense, 2000, pp. 153-170.

GRINOVER, Ada Pellegrini. Abuso do Processo e Resistência às Ordens Judiciárias: o contempt of court. In A Marcha do Processo. Rio de Janeiro: Forense Universitária, 2000, pp. 62-69.

; "et alii". Código de Defesa do Consumidor: comentado pelos autores do anteprojeto. $9^{\text {a }}$ ed. Rio de Janeiro: Forense Universitária, 2007.

; SCARANCE FERNANDES, Antonio; GOMES FILHO, Antonio Magalhães. As Nulidades no Processo Penal. $12^{\mathrm{a}}$ ed. São Paulo: Revista dos Tribunais, 2011.

GROSSMANN, Kaethe. O Dever de Veracidade no Processo Civil (exposição de direito comparado). In Revista Forense, vol. 101, pp. 279-290, fev. 1945.

GROSSMANN, Kaethe. O Dever de Veracidade das Partes Litigantes no Processo Civil (aspecto doutrinário). In Revista Forense, vol. 101, pp. 476-483, mar. 1945.

GUIMARÃES DE SOUZA, Mario. O Advogado. Recife: S.N., 1935. 
HAZARD JR., Geoffrey C.; TARUFFO, Michele. American Civil Procedure: an introduction. New Haven; London: Yale University Press, 1993.

Abuse of Procedural Rights: a summary view of the Common Law systems. In TARUFFO, Michele (ed.). Abuse of Procedural Rights: comparative standards of procedural fairness. The Hague; London; Boston: Kluwer Law International, 1999, pp. $35-40$.

Abuse of Procedural Rights: regional report for the United States. In TARUFFO, Michele (ed.). Abuse of Procedural Rights: comparative standards of procedural fairness. The Hague; London; Boston: Kluwer Law International, 1999, pp. 4352.

HERCULANO, Alexandre. História de Portugal: desde o começo da monarchia até o fim do reinado de Affonso III. tomo IV. $3^{\mathrm{a}}$ ed. Lisboa: Em Casa da Viúva Bertrand E.C. ${ }^{\text {a }}, 1874$.

HESS, Burkhard. Abuse of Procedure in Germany and Austria. In TARUFFO, Michele (ed.). Abuse of Procedural Rights: comparative standards of procedural fairness. The Hague; London; Boston: Kluwer Law International, 1999, pp. 151-179.

IOCOHAMA, Celso Hiroshi. Litigância de Má-Fé e Lealdade Processual. $1^{\mathrm{a}}$ ed. $3^{\mathrm{a}}$ reimpr. Curitiba: Juruá, 2011.

JOSSERAND, Louis. De l'Esprit des Droits et de leur Relativité - théorie dite de l'abus des droits. Paris: Dalloz, 1927.

Relatividad y Abuso de los Derechos. In Del Abuso de los Derechos y Otros Ensayos. Colombia: Temis S.A., 1999, pp. 1-27.

KANE, Mary Kay. Civil Procedure in a Nutshell. $4^{\mathrm{a}}$ ed. St. Paul, Minn.: West. Pub. Co., 1996.

LANDONI SOSA, Angel. El Abuso de los Derechos Procesales. In BARBOSA MOREIRA, José Carlos (coord.). Abuso dos Direitos Processuais. Rio de Janeiro: Forense, 2000, pp. 131-151.

LASPRO, Oreste Nestor de Souza. A Responsabilidade Civil do Juiz. São Paulo: Revista dos Tribunais, 2000.

LAUTENSCHLÄGER, Milton Flávio de Almeida Camargo. Abuso do Direito. São Paulo: Atlas S.A., 2007.

LENT, Friedrich. Diritto Processuale Civile Tedesco. $1^{\text {a }}$ parte. Napoli: Morano, 1962.

LIEBMAN, Enrico Tullio. Fondamento del Principio Dispositivo. In Problemi del Processo Civile. Napoli: Morano, 1962, pp. 3-17.

1984.

. Manual de Direito Processual Civil. vol. I. Rio de Janeiro: Forense, 
Eficácia e Autoridade da Sentença e Outros Escritos sobre a Coisa Julgada (com aditamentos relativos ao direito brasileiro). $3^{\text {a }}$ ed. Rio de Janeiro: Forense, 1984.

LIMONGI FRANÇA, Rubens. Responsabilidade Civil e Abuso de Direito. In Revista do Advogado, no 19, pp. 40-45, out. 1985.

LOBÃO, Manuel de Almeida e Sousa de. Segundas Linhas sobre o Processo Civil. Parte I. Lisboa: Imprensa Nacional, 1855

Collecção de Dissertações e Tractados Varios em Supplemento ás Segundas Linhas sobre o Processo Civil e ás Notas a Elles Relativas. Lisboa: Imprensa Nacional, 1855.

LOBO DA COSTA, Moacyr. O Agravo no Direito Lusitano. In AZEVEDO, Luiz Carlos de; LOBO DA COSTA, Moacyr. Estudos de História do Processo: recursos. Osasco: FIEO, 1996, pp. 131-158.

LOIS ESTÉVEZ, José. Teoria del Fraude en el Proceso Civil. Disponível em: $<$ http://www.horagar.com/Publicaciones/Libros/TeoriadelFraude.pdf $>$. Acesso em: $14 / 06 / 2011$.

LONGO, Giovanni Elio. Esecuzione Forzata (Diritto Romano). In Novissimo Digesto Italiano. vol. VI. Torino: Tipografia Sociale Torinese, 1960, pp. 713-722.

LOZANO, David Arias. La Buena Fe Procesal y el Ejercicio de la Abogacía. In CONRADI, Faustino Gutiérrez-Alviz (coord.). El Abuso del Proceso: mala fe y fraude de ley procesal. Madrid: Consejo General del Poder Judicial, 2006, pp. 103-120.

LUCAS SOSA, Gualberto. Abuso de Derechos Procesales. In BARBOSA MOREIRA, José Carlos (coord.). Abuso dos Direitos Processuais. Rio de Janeiro: Forense, 2000, pp. 33-68.

LUCHI DEMO, Roberto Luís. Embargos de Declaração: aspectos processuais e procedimentais. Rio de Janeiro: Forense, 2003.

LUCON, Paulo Henrique dos Santos. Abuso do Exercício do Direito de Recorrer. In NERY JÚNIOR, Nelson; ALVIM WAMBIER, Teresa Arruda (coords.). Aspectos Polêmicos e Atuais dos Recursos Cíveis e de Outras Formas de Impugnação às Decisões Judiciais. São Paulo: Revista dos Tribunais, 2001, pp. 873-904.

Comentários ao art. 620 do CPC. In MARCATO, Antonio Carlos (coord.). Código de Processo Civil Interpretado. $3^{\mathrm{a}}$ ed. São Paulo: Atlas, 2008, pp. 20472049.

Comentários ao art. 736 do CPC. In MARCATO, Antonio Carlos (coord.). Código de Processo Civil Interpretado. $3^{\mathrm{a}}$ ed. São Paulo: Atlas, 2008, pp. 23122323. 
Comentários ao art. 739 do CPC. In MARCATO, Antonio Carlos (coord.). Código de Processo Civil Interpretado. $3^{\mathrm{a}}$ ed. São Paulo: Atlas, 2008, pp. 23272330 .

. Comentários ao art. 739-A do CPC. In MARCATO, Antonio Carlos (coord.). Código de Processo Civil Interpretado. $3^{\mathrm{a}}$ ed. São Paulo: Atlas, 2008, pp. 23302336.

Comentários ao art. 740 do CPC. In MARCATO, Antonio Carlos (coord.). Código de Processo Civil Interpretado. $3^{\text {a }}$ ed. São Paulo: Atlas, 2008, pp. 23382345.

Comentários ao art. 746 do CPC. In MARCATO, Antonio Carlos (coord.). Código de Processo Civil Interpretado. $3^{\mathrm{a}}$ ed. São Paulo: Atlas, 2008, pp. 23712376 .

LUSO SOARES, Fernando Augusto de Freitas Motta. A Responsabilidade Processual Civil. Coimbra: Livraria Almedina, 1987.

MACHADO GUIMARÃES, Luiz. Processo Autoritário e Regime Liberal. In Revista Forense, vol. 82, pp. 243-248, mai. 1940.

MALATESTA, Nicola Framarino dei. A Lógica das Provas em Matéria Ciminal. vol. I. São Paulo: Saraiva, 1960.

MARCATO, Antonio Carlos. Preclusões: limitação ao contraditório? In Revista de Processo, $\mathrm{n}^{\circ}$ 17, pp. 105-114, jan./mar. 1980.

. Breves Considerações sobre Jurisdição e Competência. In Revista de Processo, no 66, pp. 25-43, abr./jun. 1992.

. O Processo Monitório Brasileiro. São Paulo: Malheiros, 1998.

Procedimentos Especiais. 13a ed. São Paulo: Atlas, 2007.

(coord.). Código de Processo Civil Interpretado. $3^{\mathrm{a}}$ ed. São Paulo: Atlas,

2008.

Comentários ao art. 301 do CPC. In MARCATO, Antonio Carlos (coord.). Código de Processo Civil Interpretado. $3^{\text {a }}$ ed. São Paulo: Atlas, 2008, pp. 989993.

MARINONI, Luiz Guilherme. Garantia da Tempestividade da Tutela Jurisdicional e Duplo Grau de Jurisdição. In CRUZ E TUCCI, José Rogério (coord.). Garantias Constitucionais do Processo Civil - homenagem aos 10 anos da Constituição Federal de 1988. São Paulo: Revista dos Tribunais, 1999, pp. 207-233.

. Antecipação da Tutela. 11 $1^{\mathrm{a}}$ ed. São Paulo: Revista dos Tribunais, 2009. 
; MITIDIERO, Daniel. O Projeto do CPC: crítica e propostas. São Paulo: Revista dos Tribunais, 2010.

. Abuso de Defesa e Parte Incontroversa da Demanda. $2^{\mathrm{a}}$ ed. São Paulo: Revista dos Tribunais, 2011.

MARQUES, José Frederico. Manual de Direito Processual Civil. vol. 2. $9^{a}$ ed. São Paulo: Saraiva, 1987.

Instituições de Direito Processual Civil. vol. 1. Campinas: Millennium,

1999.

Instituições de Direito Processual Civil. vol. 3. Campinas: Millennium,

1999.

MARTINS-COSTA, Judith. A Boa-Fé no Direito Privado: sistema e tópica no processo obrigacional. $1^{\text {a }}$ ed. $2^{\mathrm{a}}$ tir. São Paulo: Revista dos Tribunais, 2000.

- A Ilicitude Derivada do Exercício Contraditório de um Direito: o renascer do venire contra factum proprium. In Revista Forense, vol. 376, pp. 109-129, nov./dez. 2004.

MAZZACANE, Aldo. Infamia (Diritto Romano e Intermedio). In Enciclopedia del Diritto. vol. XXI. Milano: Giuffrè, 1971, pp. 382-387.

MAZZILLI, Hugo Nigro. A Defesa dos Interesses Difusos em Juízo. 25 a ed. São Paulo: Saraiva, 2012.

MELlO, Marcos Bernardes de. Teoria do Fato Jurídico: plano da existência. $12^{\mathrm{a}}$ ed. São Paulo: Saraiva, 2003.

MÉNDEZ, Francisco Ramos. Abuse of Procedural Rights? Spain and Portugal. In TARUFFO, Michele (ed.). Abuse of Procedural Rights: comparative standards of procedural fairness. The Hague; London; Boston: Kluwer Law International, 1999, pp. 181-190.

MENEZES CORDEIRO, Antonio Manuel da Rocha e. Da Boa Fé do Direito Civil. Coimbra: Almedina, 1984.

Do Abuso do Direito: estado das questões e perspectivas. In Revista da Ordem dos Advogados, vol. 65, nº 02, pp. 327-385, set. 2005.

. Litigância de Má-Fé, Abuso do Direito de Ação e Culpa “in Agendo". $2^{\mathrm{a}}$ ed. Coimbra: Almedina, 2011.

MENEZES MARCATO, Ana Cândida. O Princípio do Duplo Grau de Jurisdição e a Reforma do Código de Processo Civil. São Paulo: Atlas S.A., 2006.

MERÊA, Manuel Paulo. Resumo de História do Direito Português. Coimbra: Coimbra Editora Lda., 1925. 
MICHELI, Gian Antonio. Corso di Diritto Processuale Civile. vol. I. Milano: Dott. A. Giuffrè, 1959.

MILMAN, Fabio. Improbidade Processual: comportamento das partes e de seus procuradores no processo civil. $2^{\mathrm{a}}$ ed. Rio de Janeiro: Forense, 2009.

MIRAGEM, Bruno. Abuso do Direito: ilicitude objetiva no direito privado brasileiro. In Revista dos Tribunais, vol. 842, pp. 11-44, dez. 2005.

MIRANDA, Gilson Delgado; PIZZOL, Patrícia Miranda. Novos Rumos da Execução por Quantia Certa Contra Devedor Insolvente: o cumprimento de sentença. In ALVIM WAMBIER, Teresa Arruda (coord.). Aspectos Polêmicos da Nova Execução - 3: de títulos judiciais - Lei 11.232/2005. São Paulo: Revista dos Tribunais, 2006, pp. 179-222.

MITIDIERO, Daniel. Colaboração no Processo Civil: pressupostos sociais, lógicos e éticos. São Paulo: Revista dos Tribunais, 2009.

Colaboração no Processo Civil como Prêt-à-Porter? Um Convite ao Diálogo para Lenio Streck. In Revista de Processo, nº 194, pp. 55-68, abr. 2011.

MONTERO AROCA, Juan. Ideología y Proceso Civil. Su Reflejo en la "Buena Fe Procesal". In CONRADI, Faustino Gutiérrez-Alviz (coord.). El Abuso del Proceso: mala fe y fraude de ley procesal. Madrid: Consejo General del Poder Judicial, 2006, pp. 251-319.

MOREIRA ALVES, José Carlos. Direito Romano. vol. 1. 13 a ed. Rio de Janeiro: Forense, 2003.

NEGRÃO, Theotonio; GOUVÊA, José Roberto Ferreira; BONDIOLI, Luis Guilherme Aidar; FONSECA, João Francisco Naves da. Código de Processo Civil e Legislação Processual em Vigor. 44 ed. São Paulo: Saraiva, 2012.

NERY JÚNIOR, Nelson. Atualidades sobre o Processo Civil: a reforma do Código de Processo Civil brasileiro de 1994 e de 1995. $2^{a}$ ed. São Paulo: Revista dos Tribunais, 1996.

; ALVIM WAMBIER, Teresa Arruda (coords.). Aspectos Polêmicos e Atuais dos Recursos Cíveis e de Outras Formas de Impugnação às Decisões Judiciais. São Paulo: Revista dos Tribunais, 2001.

. Princípios do Processo Civil na Constituição Federal. $8^{\mathrm{a}}$ ed. São Paulo: Revista dos Tribunais, 2004.

. Coisa julgada e o Estado Democrático de Direito. In Revista Forense, vol. 375, pp. 141-159, set./out. 2004.

; ANDRADE NERY, Rosa Maria de. Código de Processo Civil Comentado e Legislação Extravagante. 10ª ed. São Paulo: RT, 2007.

. Princípios do Processo na Constituição Federal: processo civil, penal e administrativo. $9^{\text {a }}$ ed. São Paulo: Revista dos Tribunais, 2009. 
NETTO LÔBO, Paulo Luiz. Comentários ao Estatuto da Advocacia e da OAB. $3^{\mathrm{a}}$ ed. São Paulo: Saraiva, 2002.

NEVES, Daniel Amorim Assumpção. Preclusões para o Juiz: preclusão pro iudicato e preclusão judicial no processo civil. São Paulo: Método, 2004.

NORMAND, Jacques. Final Report: the two approaches to the abuse of procedural rights. In TARUFFO, Michele (ed.). Abuse of Procedural Rights: comparative standards of procedural fairness. The Hague; London; Boston: Kluwer Law International, 1999, pp. 237-248.

Nouveau Code de Procédure Civile. 97ª ed. Paris: Dalloz, 2005.

NUCCI, Guilherme de Souza. Código de Processo Penal Comentado. $8^{\mathrm{a}}$ ed. São Paulo: Revista dos Tribunais, 2008.

OLIVEIRA, Ana Lúcia Iucker Meirelles de. Litigância de Má-Fé. São Paulo: Revista dos Tribunais, 2000.

OLIVEIRA, Evandro Carlos de. Multa no Código de Processo Civil. São Paulo: Saraiva, 2011.

OLIVEIRA BARBOSA, Adriana Villa-Forte de; LIMA NETO, Francisco Vieira. Anotações Acerca do Contempt of Court no Direito Norte-Americano. In Revista de Processo, no 192, pp. 129-165, fev. 2011.

OTEIZA, Eduardo. Abuso de los Derechos Procesales en América Latina. In BARBOSA MOREIRA, José Carlos (coord.). Abuso dos Direitos Processuais. Rio de Janeiro: Forense, 2000, pp. 7-31.

PABST, Haroldo. Natureza Jurídica dos Embargos do Devedor. São Paulo: Revista dos Tribunais, 1986.

PEREIRA E SOUSA, Joaquim José Caetano. Primeiras Linhas sobre o Processo Civil. tomo I. Coimbra: Imprensa Litteraria, 1872.

PEYRANO, Jorge W. Abuso de los Derechos Procesales. In BARBOSA MOREIRA, José Carlos (coord.). Abuso dos Direitos Processuais. Rio de Janeiro: Forense, 2000, pp. 69-78.

PICÓ I JUNOY, Joan. El Principio de la Buena Fe Procesal y su Fundamento Constitucional. In Revista de Processo, nº 196, pp. 131-162, jun. 2011.

PISANI, Andrea Proto. Lezioni di Diritto Processuale Civile. $3^{\mathrm{a}}$ ed. Napoli: Dott. Eugenio Jovene, 1999.

PLANIOL, Marcel. Traité Élémentaire de Droit Civil. $2^{\circ}$ tomo. $3^{\mathrm{a}}$ ed. Paris: Librairie Générale de Droit \& de Jurisprudence, 1905. 
PONTES DE MIRANDA, Francisco Cavalcanti. Tratado de Direito Privado. t. I. Rio de Janeiro: Borsoi, 1954.

. Tratado de Direito Privado. t. LIII. $2^{\mathrm{a}}$ ed. Rio de Janeiro: Borsoi, 1966.

. Comentários ao Código de Processo Civil. tomo I. Rio de Janeiro: Forense; Brasília: INL, 1973.

. Comentários ao Código de Processo Civil. tomo II. Rio de Janeiro: Forense; Brasília: INL, 1973.

. Comentários ao Código de Processo Civil. tomo X. Rio de Janeiro:

Forense, 1976.

Forense, 1976.

. Comentários ao Código de Processo Civil. tomo XII. Rio de Janeiro:

. Tratado da Ação Rescisória das Sentenças e de Outras Decisões. $5^{\mathrm{a}}$ ed. Rio de Janeiro: Forense, 1976.

Comentários ao Código de Processo Civil. tomo IV. $2^{\mathrm{a}}$ ed. Rio de

Janeiro: Forense, 1979.

PORTANOVA, Rui. Princípios do Processo Civil. Porto Alegre: Livraria do Advogado, 1995.

PROCURADORIA REGIONAL DO TRABALHO DA $2^{\mathrm{a}}$ REGIÃO. Trabalhador - você conhece seus direitos?. Disponível em: <http://www.prt2.mpt.gov.br/img/slides/slide_03 _g.jpg>. Acesso em: 08/07/2012.

PROCURADORIA REGIONAL DO TRABALHO DA 5 $5^{\mathrm{a}}$ REGIÃO. Combate à Lide Simulada: como agir legalmente no momento da extinção do contrato de trabalho. Disponível em: <http://www.prt5.mpt.gov.br/cartilhas/lidesimulada.pdf>. Acesso em: 08/07/2012.

PUOLI, José Carlos Baptista. Os Poderes do Juiz e as Reformas da Lei Processual Civil Brasileira. 2000. Dissertação (Mestrado) - Faculdade de Direito, Universidade de São Paulo, São Paulo.

Os Limites ao Direito de Recorrer e a Responsabilidade Civil do Advogado Perante o Cliente. In COSTA, Hélio Rubens Batista Ribeiro; RIBEIRO, José Horácio Halfeld Rezende; DINAMARCO, Pedro da Silva (coords.). Linhas Mestras do Processo Civil. São Paulo: Atlas, 2004, pp. 332-352.

- Comentários ao art. 668 do CPC. In MARCATO, Antonio Carlos (coord.). Código de Processo Civil Interpretado. $3^{\mathrm{a}}$ ed. São Paulo: Atlas, 2008, pp. 21402144.

RAMALHO, Joaquim Ignácio. Praxe Brasileira. São Paulo: Ypiranga, 1869. 
RAMOS ROMEU, Francisco. ¿Reduce Realmente la Ejecución Provisional la Interposición de Recursos Injustificados? In Indret - Revista para el Análisis del Derecho, $\mathrm{n}^{\mathrm{o}}$ 385, pp. 1-30, out. 2006. Disponível em: <http://www.indret.com/pdf/385_es.pdf>. Acesso em: 07/06/2010.

REDENTI, Enrico; VELLANI, Mario. Diritto Processuale Civile. vol. 1. $5^{\text {a }}$ ed. Milano: Giuffrè, 2000.

REIS, José Alberto dos. Código de Processo Civil Anotado. vol. II. $3^{\mathrm{a}}$ ed. Coimbra: Coimbra, 1981.

Código de Processo Civil Anotado. vol. V. Coimbra: Coimbra, 1984.

RIBAS, Antonio Joaquim. Consolidação das Leis do Processo Civil Commentada pelo Conselheiro Dr. Antonio Joaquim Ribas com a Colloboração de seu Filho Dr. Julio A. Ribas. vol. I. Rio de Janeiro: Dias da Silva Júnior, 1879.

RIBEIRO, Darci Guimarães. O Sobreprincípio da Boa-Fé Processual como Decorrência do Comportamento da Parte em Juízo. In Revista Forense, vol. 381, pp. 57-70, set./out. 2005.

RICCOBONO, Salvatore; RICCOBONO JR., Salvatore. Emulazione (Diritto Romano). In Novissimo Digesto Italiano. vol. VI. Torino: Unione Tipográfico-Editrice Torinese, 1957, pp. 519-521.

ROCHA, José de Albuquerque. Nomeação à Autoria. São Paulo: Saraiva, 1983.

ROSENBERG, Leo. Tratado de Derecho Procesal Civil. tomo I. Buenos Aires: Ediciones Jurídicas Europa-América, 1955.

SATTA, Salvatore. Diritto Processuale Civile. 9a ed. Padova: CEDAM, 1981.

SCARPINELla BUENO, Cassio. A Nova Etapa da Reforma do Código de Processo Civil. vol. 3. São Paulo: Saraiva, 2007.

. Comentários ao art. 485 do CPC. In MARCATO, Antonio Carlos (coord.). Código de Processo Civil Interpretado. $3^{\mathrm{a}}$ ed. São Paulo: Atlas, 2008, pp. 16621677.

Comentários ao art. 686 do CPC. In MARCATO, Antonio Carlos (coord.). Código de Processo Civil Interpretado. $3^{\mathrm{a}}$ ed. São Paulo: Atlas, 2008, pp. 21782189.

Comentários ao art. 701 do CPC. In MARCATO, Antonio Carlos (coord.). Código de Processo Civil Interpretado. $3^{\mathrm{a}}$ ed. São Paulo: Atlas, 2008, p. 2226.

SCIALOJA, Vittorio. Procedimiento Civil Romano. Buenos Aires: Ediciones Jurídicas Europa-América, 1954. 
SILVA DINAMARCO, Pedro da. Comentários ao art. 233 do CPC. In MARCATO, Antonio Carlos (coord.). Código de Processo Civil Interpretado. $3^{\text {a }}$ ed. São Paulo: Atlas, 2008, pp. 666-667.

Comentários ao art. 253 do CPC. In MARCATO, Antonio Carlos (coord.). Código de Processo Civil Interpretado. $3^{\mathrm{a}}$ ed. São Paulo: Atlas, 2008, pp. 749757.

SOBRINHO, Elicio de Cresci. Dever de Veracidade das Partes no Processo Civil. São Paulo: Livraria Jurid Vellenich, 1975.

SOHM, Rodolfo. Instituciones de Derecho Privado Romano: historia y sistema. $17^{\mathrm{a}}$ ed. Madrid: Tipografia Artística: 1928.

SOUZA, Sebastião de. Honorários de Advogado. $2^{\mathrm{a}}$ ed. São Paulo: Saraiva, 1952.

STOCO, Rui. Abuso do Direito e Má-Fé Processual - aspectos doutrinários. São Paulo: Revista dos Tribunais, 2002.

TABOSA PESSOA, Fábio Guidi. Comentários ao art. 339 do CPC. In MARCATO, Antonio Carlos (coord.). Código de Processo Civil Interpretado. $3^{\mathrm{a}}$ ed. São Paulo: Atlas, 2008, pp. 1082-1083.

- Comentários ao art. 340 do CPC. In MARCATO, Antonio Carlos (coord.). Código de Processo Civil Interpretado. $3^{\mathrm{a}}$ ed. São Paulo: Atlas, 2008, pp. 10841087.

Comentários ao art. 341 do CPC. In MARCATO, Antonio Carlos (coord.). Código de Processo Civil Interpretado. $3^{\mathrm{a}}$ ed. São Paulo: Atlas, 2008, pp. 10871090 .

Comentários ao art. 342 do CPC. In MARCATO, Antonio Carlos (coord.). Código de Processo Civil Interpretado. $3^{\mathrm{a}}$ ed. São Paulo: Atlas, 2008, pp. 10901093.

. Comentários ao art. 347 do CPC. In MARCATO, Antonio Carlos (coord.). Código de Processo Civil Interpretado. $3^{\mathrm{a}}$ ed. São Paulo: Atlas, 2008, pp. 11071111 .

Comentários ao art. 363 do CPC. In MARCATO, Antonio Carlos (coord.). Código de Processo Civil Interpretado. $3^{\text {a }}$ ed. São Paulo: Atlas, 2008, pp. 11641169.

. Comentários ao art. 406 do CPC. In MARCATO, Antonio Carlos (coord.). Código de Processo Civil Interpretado. $3^{\mathrm{a}}$ ed. São Paulo: Atlas, 2008, pp. 13061310 .

TAELMAN, Piet. Abuse of Procedural Rights: regional report for Belgium-The Netherlands. In TARUFFO, Michele (ed.). Abuse of Procedural Rights: comparative 
standards of procedural fairness. The Hague; London; Boston: Kluwer Law International, 1999, pp. 125-149.

TARTUCE, Flávio. A Polêmica do Bem de Família Ofertado. Disponível em : $<$ http://www.flaviotartuce.adv.br/artigos/Tartuce_bfAMOFER.doc>. Acesso em: 02/07/2012.

TARUFFO, Michele. Elementi per una Definizione di "Abuso del Processo". In AA.VV. Studi in Onore di Pietro Rescigno. vol. V. Milano: Giuffrè, 1998, pp. 1117-1135.

(ed.). Abuse of Procedural Rights: comparative standards of procedural fairness. The Hague; London; Boston: Kluwer Law International, 1999.

. General Report. In TARUFFO, Michele (ed.). Abuse of Procedural Rights: comparative standards of procedural fairness. The Hague; London; Boston: Kluwer Law International, 1999, pp. 03-29.

TEIXEIRA, Sálvio de Figueiredo. Código de Processo Civil Anotado. $4^{\mathrm{a}}$ ed. São Paulo: Saraiva, 1992.

TEIXEIRA DE FREITAS, Augusto. Código Civil: esboço. Brasília: Ministério da Justiça, Departamento de Imprensa Nacional; Universidade de Brasília, 1983.

THEODORO JÚNIOR, Humberto. Abuso de Direito Processual no Ordenamento Jurídico Brasileiro. In Revista Forense, v. 344, pp. 43-65, out./dez. 1998.

; FARIA, Juliana Cordeiro de. A Coisa Julgada Inconstitucional e os Instrumentos Processuais para seu Controle. In Revista dos Tribunais, $\mathrm{n}^{\mathbf{0}}$ 795, pp. 21-40, jan. 2002.

Boa-Fé e Processo: princípios éticos na repressão à litigância de má-fé papel do juiz. In MARINONI, Luiz Guilherme (coord.). Estudos de Direito Processual Civil - homenagem ao professor Egas Dirceu Moniz de Aragão. São Paulo: Revista dos Tribunais, 2005, pp. 636-647.

. Os Embargos do Devedor Após as Reformas do CPC Efetuadas pelas Leis ${ }^{\text {os }} 11.232$ e 11.382. In Revista Forense, vol. 391, pp. 111-129, mai./jun. 2007.

Forense, 2007.

. Curso de Direito Processual Civil. vol. II. $41^{\mathrm{a}}$ ed. Rio de Janeiro:

. Comentários ao Novo Código Civil. vol. III. t. II. $4^{\mathrm{a}}$ ed. Rio de Janeiro:

Forense, 2008.

. Direito Fundamental à Duração Razoável do Processo. Disponível em: <www.anima-opet.com.br/segunda_edicao/Humberto_Theodoro_Junior.pdf $>$. Acesso em: 18/04/2011.

TORNAGHI, Hélio. Comentários ao Código de Processo Civil. vol. I. São Paulo: Revista dos Tribunais, 1974. 
VENOSA, Silvio de Salvo. Abuso de Direito. In Revista da Faculdade de Direito das Faculdades Metropolitanas Unidas de São Paulo, v. 2, nº 2, pp. 251-270, mar. 1988.

VINCENZI, Brunela Vieira de. A Boa-Fé no Processo Civil. São Paulo: Atlas, 2003.

VOCI, Pasquale. Esecuzione Forzata (Diritto Romano). In Enciclopedia del Diritto. vol. XV. Milano: Giuffrè, 1966, pp. 422-431.

WAMBIER, Luiz Rodrigues; ALVIM WAMBIER, Teresa Arruda; MEDINA, José Miguel Garcia. Breves Comentários à Nova Sistemática Processual Civil 2. São Paulo: Revista dos Tribunais, 2006.

YARSHELL, Flávio Luiz. Simulação e Processo de Execução. In ALVIM WAMBIER, Teresa Arruda (coord.). Processo de Execução e Assuntos Afins. São Paulo: Revista dos Tribunais, 1998, pp. 226-245.

2005. . Ação Rescisória: juízos rescindente e rescisório. São Paulo: Malheiros, . Antecipação da Prova sem o Requisito da Urgência e Direito Autônomo à Prova. São Paulo: Malheiros, 2009.

ZACLIS, Lionel. Direito Processual Civil Estadunidense. In CRUZ E TUCCI, José Rogério (coord.). Direito Processual Civil Americano Contemporâneo. São Paulo: Lex, 2010, pp. 165-210.

ZANZUCCHI, Marco Tullio. Diritto Processuale Civile. vol. I. 6 ${ }^{\mathrm{a}}$ ed. Milano: Giuffrè, 1964.

ZAVASCKI, Teori Albino. Comentários ao Código de Processo Civil. vol. 8. $2^{\mathrm{a}}$ ed. São Paulo: Revista dos Tribunais, 2003. 